\title{
Cognitieve strategieen van borstkankerpatienten en de relatie met aanpassing: een longitudinale studie
}

Citation for published version (APA):

Oosterwijk, M. H. (2004). Cognitieve strategieen van borstkankerpatienten en de relatie met aanpassing: een longitudinale studie. [Doctoral Thesis, Maastricht University]. Universiteit Maastricht. https://doi.org/10.26481/dis.20040312mo

Document status and date:

Published: 01/01/2004

DOI:

10.26481/dis.20040312mo

Document Version:

Publisher's PDF, also known as Version of record

\section{Please check the document version of this publication:}

- A submitted manuscript is the version of the article upon submission and before peer-review. There can be important differences between the submitted version and the official published version of record.

People interested in the research are advised to contact the author for the final version of the publication, or visit the DOI to the publisher's website.

- The final author version and the galley proof are versions of the publication after peer review.

- The final published version features the final layout of the paper including the volume, issue and page numbers.

Link to publication

\footnotetext{
General rights rights.

- You may freely distribute the URL identifying the publication in the public portal. please follow below link for the End User Agreement:

www.umlib.nl/taverne-license

Take down policy

If you believe that this document breaches copyright please contact us at:

repository@maastrichtuniversity.nl

providing details and we will investigate your claim.
}

Copyright and moral rights for the publications made accessible in the public portal are retained by the authors and/or other copyright owners and it is a condition of accessing publications that users recognise and abide by the legal requirements associated with these

- Users may download and print one copy of any publication from the public portal for the purpose of private study or research.

- You may not further distribute the material or use it for any profit-making activity or commercial gain

If the publication is distributed under the terms of Article $25 \mathrm{fa}$ of the Dutch Copyright Act, indicated by the "Taverne" license above, 


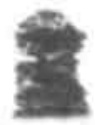

COGNITIEVE STRATEGIEËN VAN BORSTKANKERPATIËNTEN EN DE RELATIE MET AANPASSING: EEN LONGITUDINALE STUDIE 
ISBN

90-9017573-3

Druk PrintPartners Ipskamp B.V., Enschede

Ontwerp kaft Anne Detrueille

Lay-out Herman ter Reegen

Copyright 0 M.H.Oosterwijk, Nieuwolda, 2004

Deze studie werd mede mogelijk gemaakt door een subsidie van NWO (projectnr, UU 900-559-033) 


\title{
COGNITIEVE STRATEGIEËN VAN BORSTKANKERPATIËNTEN EN DE RELATIE MET AANPASSING: EEN LONGITUDINALE STUDIE
}

\author{
COGNITIVE STRATEGIES OF BREAST CANCER PATIENTS IN RELATION \\ TO THEIR ADAPTATION PROCESS: A LONGITUDINAL STUDY \\ (with a summary in English)
}

\section{PROEFSCHRIFT}

ter verkrijging van de graad van doctor aan de Universiteit Maastricht,

op gezag van de Rector Magnificus, Prof. Mr. G.P.M.F. Mols

volgens het besluit van het College van Decanen, in het openbaar te verdedigen op vrijdag 12 maart 2004 om 16.00 uur

door Maria Hyacintha Oosterwijk 


\section{Promotor:}

Prof. dr. A.P.W.M. Appels

\section{Co-promotor:}

Dr. H.F.J. ten Kroode (Universiteit Utrecht)

\section{Beoordelingscommissie:}

Prof. dr. B. van den Borne (voorzitter)

Prof. dr. J.J. Batterman (Universiteit Utrecht)

Prof. dr. G.J. Dinant

Prof. dr. M.F. von Meyenfeldt

Prof. dr. R. Sanderman (Rijksuniversiteit Groningen) 


\section{DANKWOORD}

Dit project had niet volbracht kunnen worden zonder de steun en belangstelling van vooral mijn partner Hans, maar ook mijn ouders, familie, vrienden, collega's en achtereenvolgende werkgevers.

Mijn promotor, Ad Appels, ben ik veel dank verschuldigd. Zijn vertrouwen in mij, zijn wijsheid, humor en relativeringsvermogen waren onontbeerlijk. Ik heb veel van hem geleerd.

Herman ten Kroode heeft als co-promotor een belangrijke bijdrage geleverd. Niet alleen was hij voortdurend zeer betrokken en heeft hij het manuscript steeds van deskundig commentaar voorzien, ook heeft hij mij, samen met David van Maanen, geholpen met het interviewen. Gedrieën hebben we de interviews uitgewerkt en de uitspraken beoordeeld en ingedeeld. De vele sessies waarin we probeerden te begrijpen hoe de puzzel in elkaar stak, waren inspirerend, prikkelend én uitermate plezierig. Ook mijn paranimfen Frans Pouwer en Frans Grosveld, indertijd collega's op de afdeling Medische Psychologie, hebben hieraan hun bijdrage geleverd.

Jan Batterman, hoogleraar radiotherapie aan het Universitair Medisch Centrum Utrecht, bood mij de ruimte patiënten van zijn afdeling te benaderen en heeft met een 'medische bril' de onderzoeksopzet bekeken.

Mijn vader maakte 'de schuif' en heeft geholpen bij het uittypen van de interviews. Fijn dat hij de eerste versie van het manuscript nog heeft kunnen zien.

Het zal de lezer niet ontgaan dat in het methodologie-hoofdstuk de naam van Han Bonarius regelmatig wordt genoemd. Tijdens mijn studie was hij mijn leermeester en heeft mij mede gevormd als psycholoog en onderzoeker. Zijn indirecte invloed op dit proefschrift is dan ook groot.

Speciale dank gaat uit naar de patiënten die ons hun vertrouwen schonken en hun ervaringen zo openhartig met ons hebben gedeeld. Hun verhalen vormen de basis van dit proefschrift. Door deze verhalen te ontleden, de elementen te hergroeperen en te vertalen naar 'psychologen-constructen', ben ik weer een stap dichter bij het antwoord op de vraag 'wat doen mensen nu precies wanneer zij geconfronteerd worden met een levensbedreigende ziekte?'

Tijdens het schrijven van dit boek en de bijbehorende cognitieve arbeid vormden de werkzaamheden in onze prachtige tuin een heilzaam tegenwicht. De houtwal en houtstapels op de kaft en in het boek zijn 'constructen' die deze tuinarbeid heeft opgeleverd. Herman ter Reegen gebruikte deze bij de lay-out. Mijn vriendin Dorenda van Seumeren begeleidde het drukwerk.

ledereen bedankt! 


\section{INHOUD}

INLEIDING

1. Aanleiding 10

2. Onderzoeksvragen 10

3. Leeswijzer

I OVerzicht VAN de literatuur $\quad 13$

1. Problemen als gevolg van kanker 13

1. 1- Gevolgen van kanker in het algemeen 13

1.2. Gevolgen van borstkanker 16

1.3-Samenvatting en conclusies 22

2. Omgaan met kanker: coping 24

2-1. Historische achtergrond 24

$2-2$ - Enkele theoretische modellen 26

2-2-1. De theorie van de rechtvaandige wereld en zijn slachtoffers 26

$2 \cdot 2 \cdot 2$. Sociale vergelijkingstheorieèn $\quad 27$

2.2-3-Attributietheorie $\quad 29$

$2-2 \cdot 4$ - Coping volgens Lazarus en collega's $\quad 36$

2-2.5. De ral van afweermechanismen en illusies $\quad 46$

2 -3-Samenhang tussen de verschillende theorieèn 49

2 - 4 - Enkele methodologische kwesties rond het begrip coping 50

2 - 5 - Samenvatting en conclusies 55

II OpZet VAN het ONDERzoeK $\quad 57$

1. Onderzoeksvragen en meetmomenten 57

2- Methode en gegevensverzameling 57

$\begin{array}{lr}2-1 \text { - Overwegingen } & 57\end{array}$

2-2-Soort interview $\quad 59$

2-3- Inhoud van het interview en werkwijze 61

$2 \cdot 3-1$ - Cognitieve strategieèn $\quad 61$

2-3-2-Aanpassing $\quad 62$

2- 4 - Afname van de interviews 66

3- De onderzoeksgroep 66

3- 1-Criteria voor deelname 66

3-2-Behandeling $\quad 67$

3-3-Werving en selectie 68

3-4-Beschrijving van de onderzoeksgroep 68 


\section{DEFINIËRING VAN dE COGNITIEVE STRATEGIEËN EN ORDENING VAN DE} PATIËNTENUITSPRAKEN

1- De aanvankelijke definities 71

2- Categoriseringsproblemen 73

3- De dubbelstrategie $\quad 74$

4- De uiteindelijke definities 76

5- Samenvatting en conclusies $\quad 91$

IV COGNITIEVE STRATEGIEËN VAN BORSTKANKERPATIËNTEN 95

1. Onderwerpen van de cognitieve strategieën 95

2 - Welke vragen roepen welke cognitieve strategieèn op? 124

3 - De mate waarin de cognitieve strategieèn zijn aangetroffen 128

$3-1$ - Indices voor de mate van strategiegebruik $\quad 128$

3-2-Resultaten 129

4- Veranderingen in het gebruik van de cognitieve strategieèn op de drie meetmomenten 133

5. Stabiliteit van de cognitieve strategieën 136

6- Samenhang tussen de cognitieve strategieën 138

6-1-Directe koppeling tussen de cognitieve strategiein 138

6 - 2 - Correlaties tussen de cognitieve strategieen 153

7. Strategiegebruik door verschillende subgroepen respondenten 156

$\begin{array}{ll}\text { 8- Samenvatting en conclusies } & 159\end{array}$

$\begin{array}{lrr}V & \text { AANPASSING AAN BORSTKANKER } & 161\end{array}$

$\begin{array}{ll}1 \text { - Operationalisering van aanpassing } & 161\end{array}$

2- De drie aanpassingsschalen 165

2 - 1 - Samenhang tussen de schalen 165

$2-2$ - Het verloop van de aanpassing $\quad 166$

3 - Eigen invloed en schaamte 170

4. Nogmaals verandering in aanpassing: rekenkundige verschillen versus patiëntenoordelen 172

5 - Aanpassing bij verschillende subgroepen 177

6- Ervaren steun en aanpassing 179

6 - 1 - Operationalisering van het begrip en de mate van steun 179

$6-1$ - 1 - Steun van de omgeving $\quad 180$

6-1-2 - Steun vanuit het ziekenhuis 182

6 - 2 - Relatie tussen steun en aanpassing 183

7. Discrepantie tussen verhaal en score 184

8- Samenvatting en conclusies 186 
VI Relaties tuSSEN COGNITIEVE StrategieËN EN AANPASSING

1- De eerste vijf onderzoeksvragen: relaties tussen de cognitieve strategieên en de aanpassingsindices

1. 1- Werkwijze, analyses en beslisregel

1-2-Resultaten

$1-2-1$-Verbanden tussen afzonderlijke strategieèn en danpassingsindice

1-2 - 2 - Vertaling naar de onderzoeksvragen

2- De onderzoeksvragen zes tot en met acht

3 - Discrepantie tussen verhaal en score (vraag 9)

4. Samenvatting en conclusies

\section{VAN ONDERZOEK NAAR THEORIE EN VAN THEORIE NAAR PRAKTIIK}

1. Probleemstelling en onderzoeksvragen

2. Methodologische reflecties

2-1-Onderzocksmethode

2-1 - I-Inventarisatie en definiering van de cognitieve strategieên

2.1-2-Operationalisering van aanpassing en hoe scoren mensen?

2 - 2 - Selectiebias en andere invloeden

3. Theoretische reflecties en belangriikste resultaten

4 . Rexultatero, ner alipnassingsindex

3-2. Wat is er gevonden over cognitieve coping?

3. 3 - Hoe verhouden de resultaten zich tot de overige aanpassingstheorieen?

3-4-Zijn er verschillen tussen subgroepen van patiénten?

\section{SAMENVATIING}

\section{BIJLAGEN}

Bijlage A: Onderwerpen uit het interview

Bijlage B: Vragen uit het interview met de aantallen patiênten die met een bepaalde strategie hebben geantwoord. Tabellen behorend bij hoofdstuk IV paragraaf 2

Bijlage C: Het gebruik van de strategieèn door verschillende subgroepen respondenten. Tabellen behorend bij hootdstuk IV paragraaf 7

Bijlage D: De mate van aanpassing bij verschillende subgroepen respondenten. Tabellen behorend bij hoofdstuk $V$ paragraaf 5 
NLEIDING

\section{INLEIDING}

\section{1 - AANLeiding}

Dat kankerpatiènten op héél verschillende manieren met hun ziekte en behandeling omgaan was me in mijn werkzaamheden als radiotherapeutisch laborant al opgevallen. Die observatie op de bestralingsafdeling van de toenmalige Daniël den Hoed kliniek in Rotterdam was één van de redenen om psychologie te gaan studeren. Middels die studie hoopte ik onder andere antwoord te vinden op de vragen 'wat doen mensen nu precies wanneer zij geconfronteerd worden met een levensbedreigende ziekte?' en 'wat maakt dat sommige mensen in staat zijn daar adequaat mee om te gaan en anderen niet?'.

Natuurlijk leverde de studie psychologie, die ik aan de Universiteit Utrecht volgde, een aantal belangrijke inzichten op maar een helemaal bevredigend antwoord vond ik er nog niet. Na mijn studie kreeg ik de kans mee te werken aan het onderzoek van Herman ten Kroode dat uitmondde in de dissertatie 'Het verhaal van kankerpatiënten: oorzaakstoekenning en betekenisverlening' met als ondertitel: een onderzoek naar het verband tussen attributies en zelfrespect (Ten Kroode 1990). Daarin werden de oorzaken waaraan kankerpatiënten hun ziekte toeschreven vergeleken met de oorzaken die hartinfarctpatiënten en patiënten met multiple sclerose (MS) voor hun ziekte hadden gevonden, en is onderzocht wat deze verklaringen bijdroegen aan de aanpassing aan hun ziekte. Uit de diepte-interviews bleek dat denken over oorzaak en zin een belangrijk plaats inneemt bij verwerking en aanpassing aan ziekte. Voor mij was er weer een stukje van de puzzel ingevuld. Tegelijkertijd werd uit de interviews duidelijk dat cognitieve arbeid gericht op het integreren van de ziekte in het (nieuwe) leven van de patiënten zich niet beperkt tot attributies alleen. Er gebeurde cognitief nog veel meer. Dat laatste werd bevestigd in mijn klinische werk bij patiënten van de afdelingen radiotherapie en oncologie van wat toen nog het Academisch Ziekenhuis Utrecht (AZU) heette. Ook tijdens die therapie-gesprekken bleek duidelijk dat cognities (wat denkt de patiënt over zijn ziekte) en cognitieve strategieën (hoe gaat hij of zij er mentaal mee om) van groot belang zijn voor aanpassing. Het zijn dan ook vaak de aangrijpingspunten voor de psychologische begeleiding.

Opnieuw drong de vraag zich op 'wat doen kankerpatiēnten nu precies?' en 'wat helpt wel en wat niet?' De tijd was rijp dit systematisch te gaan onderzoeken. 


\section{2- Onderzoeksvragen}

Met behulp van een subsidie van NWO zijn tussen 1991 en 1994 zesenvijttig vrouwen met borstkanker gedurende ongeveer twee jaar na hun diagnose gevolgd. Hun openhartige verhalen vormen de basis van dit proefschrift.

In de komende hoofdstukken wordt gezocht naar het antwoord op de vraag: wat is de relatie tussen cognitieve strategieĕn, ook wel cognitieve coping genoemd, en aanpassing aan borstkanker? Deze vraag is opgesplitst in de volgende onderzoeksvragen:

- Welke cognitieve strategieěn gebruiken borstkankerpatiënten gedurende de eerste twee jaar na hun behandeling?

- Treden er in de loop van de tijd veranderingen op in het strategiegebruik?

- Wat is de relatie tussen de cognitieve strategieèn en aanpassing?

- Is de deze relatie afhankelijk van de tijd die sinds de diagnose is verstreken? Met andere woorden, is de relatie tussen cognitieve strategie en aanpassing op de verschillende meetmomenten dezelife?

\section{3- LEEWIIZER}

Om deze vragen te beantwoorden is allereerst de literatuur over cognitieve coping en aanpassing bestudeerd, met name die over cognitieve coping en aanpassing aan borstkanker. Hiervan wordt in hoofdstuk I verslag gedaan. Vervolgens wordt in hoofdstuk II de opzet van het onderzoek beschreven en wordt aandacht besteed aan enkele methodologische kwesties bij het onderzoeken van complexe, emotioneel geladen onderwerpen. De lezer wordt in hoofdstuk III deelgenoot gemaakt van de afwegingen die hebben geleid tot de definitieve keuze en de definitie van de onderzochte strategieën; het bleek overigens niet eenvoudig de cognitieve strategieën eenduidig te omschrijven en goed van elkaar af te baken.

In hoofdstuk IV komt aan de orde op welke aspecten van ziekte en behandeling de onderzochte cognitieve strategieën precies betrekking hebben. Naast deze kwalitatieve resultaten worden frequenties, onderlinge samenhang en verschuivingen in de tijd besproken. Tenslotte wordt in dit hoofdstuk aandacht besteed aan mogelijke verschillen in strategiegebruik tussen subgroepen van respondenten. Hoofdstuk $V$ heeft de aanpassing van de borstkankerpatiènten uit dit onderzoek tot onderwerp. Allereerst wordt beschreven op welke wijze dit begrip is geoperationaliseerd en hoe de aanpassing gedurende de twee jaar na behandeling verloopt. In hoofdstuk VI wordt ingegaan op de centrale vraag van dit onderzoek: 'wat is er te zeggen over de relatie 
tussen cognitieve strategieèn en aanpassing aan borstkanker?'. Tenslotte worden in hoofdstuk VII werkwijze en resultaten afgezet tegen de bevindingen uit de literatuur en wordt er ingegaan op de klinische relevantie van hetgeen deze studie heeft opgeleverd. 


\section{OVERZICHT VAN DE LITERATUUR}

De centrale vraag van dit proefschrift luidt: Wat is de relatie tussen cognitiene strategieèn en aampassing aan borstkanker?'. In dit hoofdstuk komt aan de orde wat daarover in de literatuur bekend is. In het eerste deel wordt besproken waaraan borstkankerpatiënten zich moeten aanpassen. Het tweede deel gaat over het aanpassingsproces zelf, ook wel coping genoemd. Verschillende theorieěn die elk met hun eigen accenten een deel van het aanpassingsproces beschrijven, passeren de revue en de rol die cognitieve strategieẻn daarin spelen wordt belicht.

\section{1 - Problemen als gevolg van kanker}

\section{1 - 1 - Gevolgen van kanker in het algemeen}

Omgaan met kanker betekent omgaan met een scala aan problemen en gevoelens (Dunkel-Schetter 1992, Somerfield \& Curbow 1992, Schrameijer \& Brunenberg 1992).

\section{Dreiging en onzekerheid}

De psychosociale belasting van kanker vloeit in de eerste plaats voort uit het levensbedreigende karakter van deze ziekte. Twee van de drie mannen en één van de twee vrouwen is vijf jaar na de diagnose overleden. Veel kankerpatiënten zijn relatief jong: ongeveer eenderde van de overleden kankerpatiënten is nog geen zestig jaar (Schrameijer \& Brunenberg 1992). Naast de doodsdreiging veroorzaakt de behandeling een belangrijk deel van de ziektelast. De behandeling is er immers op gericht het aangedane lichaamsweefsel radicaal te verwijderen (door chirurgie) of te vernietigen (door bestraling of chemotherapie).Vaak worden daarmee ook gezond weefsel en gezonde functies aangetast of uitgeschakeld. Vanwege dit agressieve karakter gaat de behandeling dikwijls gepaard met zeer ernstige bijverschijnselen en is daarom zowel lichamelijk als psychisch een zware belasting voor de patiënt en diens familie. Door de hoge incidentie van kanker en het hoge sterftecijfer heeft vrijwel iedere nieuwe kankerpatiènt van dichtbij al eens meegemaakt hoe dramatisch de ziekte kán verlopen. Dit maakt dat de meeste kankerpatiënten bij het horen van de diagnose worden overvallen door de negatieve beelden over de ziekte (Schrameijer \& Brunenberg 1992); de confrontatie met de diagnose roept gedachten op aan ingrijpende behandelingen, aftakeling en dood (Ten Kroode 1990). Dat er ook mensen van kanker genezen, wordt op dat moment vaak niet beseft. 
Een bijkomende belasting ligt in het feit dat de oorzaken van kanker grotendeels onbekend en in nog grotere mate onbeheersbaar zijn, zeker vanaf het moment dat de diagnose is gesteld. Het aanpassen van de eigen leefgewoonten kan na het stellen van de diagnose wel belangrijk zijn maar zal het verloop van het ziekteproces in veel gevallen niet of nauwelijks beïnvloeden. Aan genetische oorzaken kan het individu zich al helemaal niet onttrekken.

Kanker is dus onlosmakelijk verbonden met onzekerheid en angst. Dit gedt zowel in de periode van het ontdekken van de symptomen alsook in de pericden van diagnostiek en behandeling. Maar, ook nog lang daarna dringen vragen zich op als: 'hoe zal het verder gaan?' en 'komt het terug?'. In het geval van kanker kan op zulke vragen meestal geen afdoende antwoord worden gegeven. Deze blijvende onzekerheid is vervolgens een voortdurende bron voor angst, depressie en andere regatieve gevoelens (Van den Borne \& Pruyn 1987).

Butts (1988) ondervroeg 371 studenten. De ene helft werd gevraagd zich in te leven in de situatie van een hartpatiènt, de andere helft in die van een kankerpatiènt. De groep die zich met kankerpatiēnten moest identificeren, maakte zich meer zorgen over hoe zij zich naar de buitenwereld moeten opstellen en over interacties met anderen. Ook vreesden zij vaker dan de 'ingebeelde hartpatiënten' dat ze te maken zouden krijgen met een stigma dat aan de ziekte kleeft. Hoewel dit onderzoek al weer enige tijd geleden is uitgevoerd, lijkt het nog steeds geldigheid te bezitten. Ook Ten Kroode (1990) vond in zijn vergetijkend onderzoek tussien dankerpatiänter, MS- en hartinfarctpatiënten dat deze laatste twee groepen blij waren dat ze geen kankerpatiënt waren, terwijl de kankerpatiënten, met uitzondering van AIDS, geen ziekte noemden die zij erger vonden dan hun eigen ziekte. Dit alles geeft aan dat kanker geassocieerd is met zeer negatieve beelden.

\section{Gevolgen van kanker}

Verscheidene auteurs beschouwen het begin van een chronische ziekte als een breuk in de autobiografie. De ziekte is een aanslag, niet alleen op het fysieke zelf, maar ook op de identiteit en het gevoel van eigenwaarde. Door de ziekte ontstaat verlies van vertrouwen in het lichaam, dat gepaard gaat met verlies van vertrouwen in sociale relaties en interacties. Dit roept vragen op als 'wie ben ik?', 'wat is mijn rol?', 'wat verwachten ze van me?', 'hoe kijken ze tegen me aan?' (Ten Kroode 1990, Bury 1991). Taylor, Wood en Lichtman (1983) vatten de gevolgen van kanker als volgt samen. Eerst zijn er persoonlijke gevolgen zoals tijdelijk of permanent verlies van fysieke capaciteiten, onzekerheid over het verloop van de ziekte, verlies van controle over lijf en leven en verlies van het gevoel van eigenwaarde (self-esteem). Dan zijn er sociale gevolgen zoals verlies van werk of rol, isolatie en afwijzing ten gevolge van 
secundaire victimisatie. Dit laatste heeft betrekking op het verschijnsel dat anderen het maar moeilijk vinden met 'slachtoffers' (in dit geval kankerpatiënten) om te gaan. Het gevolg is dat zij vaak onhandig met de patiènt omgaan en hem op die manier opnieuw 'slachtoffer' maken. Deze secundaire victimisatie kan het gevoel van eigenwaarde aantasten.

Uit het grootschalig Nederlandse onderzoek van Schrameijer en Brunenberg (1992) wordt duidelijk hoe breed de problematiek als gevolg van kanker eigenlijk is. De 188 respondenten die zij ondervroegen noemen samen in totaal 805 problemen, waaronder ruim 100 verschillende. Deze problemen zijn in vijf categorieén onder te verdelen: psychisch, somatische, relationele, praktische/financiële en problemen als gevolg van de gezondheidszorg. Verreweg de meeste patiënten $(87 \%)$ noemden één of meer problemen van psychische aard, die meestal te maken hebben met het levensbedreigende karakter van kanker (71\%). Ook een aanzienlijk deel noemde één of meer lichamelijke problemen $(60 \%)$. De helft $(48 \%)$ noemde problemen in de relationele sfeer: bij $17 \%$ betrof het de partner, de rest had problemen met andere naasten. Een op de tien patiënten had seksuele problemen ten gevolge van de ziekte. Praktische en financiële problemen werden minder genoemd (door 20\%). Een groter deel $(40 \%)$ noemde één of meer problemen die met de gezondheidszorg hadden te maken. Vooral ging het daarbij om het pijnlijke of langdurige karakter van de behandeling $(19 \%)$ maar ook over wachtlijsten, wachttijden en andere organisatorische problemen (10\%). Tenslotte vond $9 \%$ zich niet voldoende geinformeerd of onvoldoende voorbereid op de behandeling en noemde $6 \%$ problemen in de artspatiënt relatie.

\section{Fasen in het ziekteproces}

De psychosociale problemen van kankerpatiënten zijn het beste te typeren als een hele reeks crisissituaties. De crises treden op wanneer doodsdreiging actueel is, of wanneer er sprake is van medisch ingrijpen dat verminking of ernstige bijwerking tot gevolg heeft. Weisman (1977, in Boer et al 1992) onderscheidde vier fasen in het ziekteproces, die nog steeds gehanteerd worden bij het beschrijven van de problemen van kankerpatiënten. De eerste fase is die van diagnosestelling en behandeling. Zij betekent een aanslag op het bestaan en brengt de patiënt in een existentiéle crisis. Kenmerkend zijn gevoelens als verdoving, onrust, verwarring, boosheid en verdriet. De tweede fase is er een van aanpassing. De behandeling is beëindigd of in intensiteit verminderd. Het alledaagse leven wordt weer opgepakt, eventueel op aangepaste wijze. De derde fase treedt in wanneer de ziekte terugkeert of zich uitzaaiingen elders in het lichaam manifesteren. Door de reële doodsverwachting treedt er opnieuw een existentiële crisis op, met de daarbij horende gevoelens. De vierde fase is de terminale 
fase. De patiênt bereidt zich voor op het einde en heeft zorgen om zijn nabstaanden. Soms worden de fasen twee en drie overgeslagen omdat het meteen al slecit gaat met de patiënt. Wanneer echter de patiënt na de behandeling 'kankervrij' blijft, lomen fase drie en vier niet aan de orde. Couzijn et al (1986) merkten terecht op da Weisman geen fase na de genezing heeft opgenomen. $\mathrm{Zij}$ vermoedden dat patiërten na de mededeling dat ze genezen zijn, toch nog problemen ervaren. Vooral de migelijkheid dat de ziekte, ondanks de behandeling, zal terugkomen, zou daaraan debet ijn.

\section{Ernst en duur}

Gezien het voorgaande is het niet verwonderlijk dat de meeste auteurs iet er over eens zijn dat kanker, meer dan de meeste andere ziekten, al met het meddelen van de diagnose het psychisch evenwicht ontregelt. Er is echter geen eenduidgheid over ernst en duur van de problematiek.

Filipp et al (1990) vonden in een onderzoek onder 332 kankerpatiênen dat zij significant meer emotionele problemen hadden dan een algemene groep ensignificant minder dan een groep psychiatrische patiënten. Greer et al (1992) ieden een grootschalig onderzoek bij kankerpatiënten die sinds kort hun diagnce wisten. Aanvankelijk voldeed $23 \%$ aan psychiatrische criteria voor angst of depressiviteit. Ruim een jaar later was ruim $40 \%$ van hen (9\% van de totale groep) nog teeds zeer angstig, en meer dan $20 \%$ (5\% van de totale groep) nog steeds depresief. Jarrett (1992) komt op grond van literatuuronderzoek tot dè conciusie dát ongeveer een kwan van de kankerpatiënten klinisch relevante, aanhoudende problemen heeft op het gebied van angst en depressie. Volgens Razavi (1994) zou ongeveer $47 \%$ van de kankerpatiënten voldoen aan één van de criteria voor psychiatrische aandoeningen zoals beschreven in de DSM III. Hij baseert zich op een omvangrijke Europese studie. Dit percentage zou tweemaal zo hoog zijn als die bij somatische patiënten in het algemeen en driemaal zo hoog als voor de algemene bevolking. Het grootste deel $(68 \%)$ komt voor rekening van de aanpassingstoornissen. Bij $85 \%$ van de patiënten die aan de DSM III-criteria voldeden, was angst of depressie het belangrijkste symptoom. Mendelsohn (1990) vond daarentegen weinig echte psychopathologie. Zij zijn van mening dat het grootste deel van de patiënten zich verrassend snel aanpast. Toch bleek ook uit hun onderzoek dat een kwart van de onderzoekspopulatie zowel psychische als sociale problemen had. Bovendien had nog eens een kwart van de patiënten, ondanks dat zij zich sociaal goed hadden aangepast, te kampen met psychische problemen, met name angst voor terugkeer van de ziekte. In feite was de helft van hun onderzoeksgroep niet vrij van problemen, hoewel deze niet als psychopathologie konden worden gekenmerkt. Deze auteurs vatten hun resultaten als volgt samen: The patients did report that they were deeply disturbed at the time of the 
diagnosis and primary treatment. It is also evident that worries about a recurrence and, in many cases, a continuing sense of loss or disfigurement persisted even in those patients who were several years beyond primary treatment. But generally, the trauma was successfully mastered with a surprising rapidity'. Schroevers (2002) komt tot een soortgelijke conclusie.

\section{Soort kanker en aard van de behandeling}

Door de algemene problematiek van kankerpatiënten en door de invloed van de maatschappelijke beelden over kanker zouden de problemen van kankerpatiënten eerder voortvloeien uit het feit dat men kanker heeft, dan uit specifieke gevolgen van een bepaalde soort kanker. Zo vinden Edgar et al (1992) bij de 205 door hen onderzochte kankerpatiënten geen relatie tussen de aard van de kanker, ziektestadium en psychosociale gevolgen. Dezelfde bevinding rapporteerden Taylor $\boldsymbol{e}$ al (1985), Ell $\boldsymbol{t}$ al (1989) en Mendelsohn (1990). Taylor verwoordde het als volgt: the objective diagnostic stage may be less meaningful psychologically for patients than are other subjective aspects of the illness experience'. Deze bevindingen zijn in lijn met onderzoeken waaruit blijkt dat, tegen de verwachting in, patiënten die borstsparend zijn behandeld voor hun borstkanker, er psychologisch gezien niet anders aan toe zijn dan patiënten die een borstamputatie hebben ondergaan. Fallowfield en Hall (1991) kwamen in een overzichtsartikel tot de conclusie dat de verwachting dat vrouwen door de mogelijkheid van een borstsparende behandeling minder last zouden hebben van psychische problemen, niet is bewaarheid. $\mathrm{Er}$ is weliswaar verschil in lichaamsbeeld (body image), maar niet of nauwelijks in psychiatrische morbiditeit en seksuele disfunctie, Zij schreef: 'Whatever the primary therapy, women still have to confront the fact that they have had cancer, a life-threatening disease which may recur'. Onderzoek van Goldberg et al (1992) en van Omne-Ponten et al (1994) bevestigen dat amputatie-patiënten in psychisch opzicht niet slechter af zijn dan patiënten bij wie alleen de tumor is verwijderd. Wel blijken beide groepen kankerpatiënten meer psychische problemen te hebben dan patiënten met een goedaardige aandoening in de borst. Dit zou er volgens de auteurs op wijzen dat het vooral om de impact van kanker gaat.

\section{1 - 2 - Gevolgen van borstkanker}

$\mathrm{Er}$ is veel onderzoek verricht onder borstkankerpatiënten. Dit komt mede omdat de incidentie zo hoog is. In Nederland krijgt ongeveer één op de tien vrouwen deze ziekte. In de meeste andere Westerse landen liggen de incidenties ongeveer op hetzelfde niveau. Circa $20 \%$ van alle sterfte ten gevolge van kanker wordt veroorzaakt 
door borstkanker. Daarmee staat borstkanker de laatste tientallen jaren op de eerste plaats wat betreft sterfte aan kanker bij vrouwen (Boer et al 1992).

Het onderzoek dat specifiek betrekking heeft op vrouwen met borstkanier levert, evenals het onderzoek bij kankerpatiènten in het algemeen, geen eenduidigbeeld op. Hierna worden de belangrijkste bevindingen besproken. Tabel 1.1 geeft eei schematisch overzicht van de literatuur.

\section{Periode rond de diagnose}

De periode rond de diagnosestelling wordt door de meeste patiëntei als zeer spannend ervaren. Benedict et al (1994) vroegen een grote groep vrouwen, bj wie was gebleken dat een verdacht knobbeltje in hun borst goedaardig was, hoe zij te periode van de onderzoeken hadden ervaren. Slechts $10 \%$ vond de periode tussen intdekken en uiteindelijke diagnose niet zo angstig. Ruim eenderde had het behoorlik angstig gevonden en een ruime meerderheid (58\%) zelfs zeer angstig. Epping e:al (1999) constateerden bij $40 \%$ van de door hen onderzochte vrouwen, veertien daen nadat de diagnose borstkanker was gesteld, klinisch relevante scores voor angst en bij 33\% klinisch relevante scores voor depressie. Deze resultaten zijn ongeveer gelik aan die van Goldberg et al (1992).

\section{Periode van behandeling}

Atfiankelijk van hiet stadium van dè zièkte zıjin er verscrililènuè deriandielvormen voor borstkanker. In de meeste gevallen vindt er eerst een operatie plaats: óf alleen de tumor wordt verwijderd (lumpectomie) of amputatie van de borst is noodzakelijk (mastectomie). In de vorige paragraaf kwam al aan de orde dat de psychosociale consequenties van beide behandelingen niet van elkaar verschillen. Uitzondering is het lichaamsbeeld, dat in geval van een amputatie meer beschadigd zou zijn (Fallowfield \& Hall 1991). Na lumpectomie volgt bijna altijd bestraling van de borst en soms ook van de nabijgelegen gebieden met lymfeklieren. De meest genoemde gevolgen van deze behandeling zijn een pijnlijke tot zeer pijnlijke huid in het bestraalde gebied en vaak ook vermoeidheid. Ook kunnen er klachten van keel en slokdarm ontstaan, als de Iymfeklieren achter het borstbeen zijn bestraald. Indien er kankercellen in de dichtstbijzijnde lymfeklieren zijn aangetroffen en nog niet elders in het lichaam, volgt er in de regel nog een aanvullende behandeling: adjuvante therapie. Deze heeft tot doel uitzaaingen in de toekomst te vermijden en kan bestaan uit chemotherapie of hormonale therapie. Veel voorkomende bijwerkingen van chemotherapie zijn: misselijkheid, haarverlies, pijnlijke slijmvliezen (bijvoorbeeld in de mond), onvruchtbaarheid, vervroegde menopauze en algehele malaise. Over het algemeen worden er niet zoveel bijwerkingen van de hormonale therapie gemeld. Zijn er echter uitzaaiingen buiten de lymfeklieren dan is de behandeling vaak nog uitgebreider en agressiever. 


\begin{tabular}{|c|c|c|c|c|}
\hline Metimomint & AUMEUR + ONDERZOCHII GROEP & ANast & Dererssen & ANDEES + OEMEREINGEN \\
\hline fond diagnose & $\begin{array}{l}\text { Goldberg of al (1992) } \\
\text { gernengde groep BK } n=166 \\
\text { Benedict ef all (1994) } \\
\text { bleek na diagnose goedaardig n=238 } \\
\text { Epping ef af (1999) } \\
\text { gemerngde groep BK } n=B 0\end{array}$ & $\begin{array}{l}51 \% \\
32 \% \text { tamelijk } \\
58 \% \text { zeer } \\
40 \%\end{array}$ & 325 & 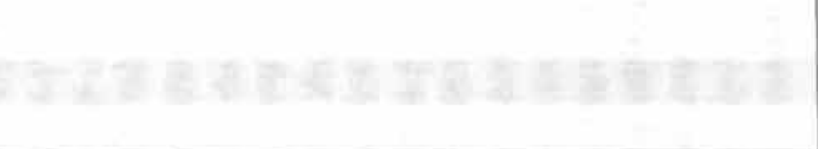 \\
\hline $\begin{array}{l}\text { tijdens of vlak } \\
\text { na behandeling }\end{array}$ & $\begin{array}{l}\text { Watson d al (1991) } \\
\text { lumpectomietradiotherapie } n=380 \\
\text { Boet ef d' (1992) } \\
\text { gemengde groep BK } n=56 \\
\text { Spiege (1997) } \\
\text { citeert anderen } \\
\text { Epping \& d (1999) } \\
\text { gemengde groep BK n=80 }\end{array}$ & $\begin{array}{l}16 \% \\
18 \%\end{array}$ & $\begin{array}{r}6 \% \\
298 \\
-29\end{array}$ & 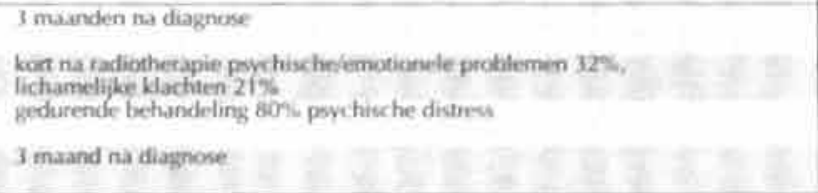 \\
\hline $\begin{array}{l}6 \text { maanden na } \\
\text { diagnoses }\end{array}$ & $\begin{array}{l}\text { Goldberg ef al (19921 } \\
\text { gemengde groep BK } n=166 \\
\text { Epping ef al }(1999) \\
\text { gemengde groep BK } n=80\end{array}$ & $\begin{array}{l}29 \% \\
21 \%\end{array}$ & $\begin{array}{l}24 \% \\
26 \%\end{array}$ & eksuele problemen $40 \%$, lichamelipe problemen $30 \%$ \\
\hline $\begin{array}{l}\text { tot l jaar na } \\
\text { diagnose }\end{array}$ & 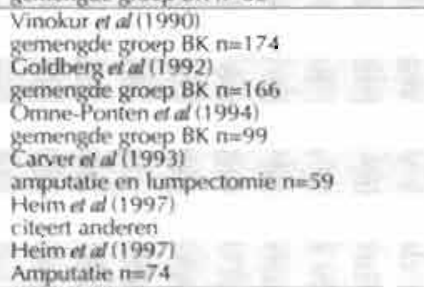 & $27 \%$ & 215 & 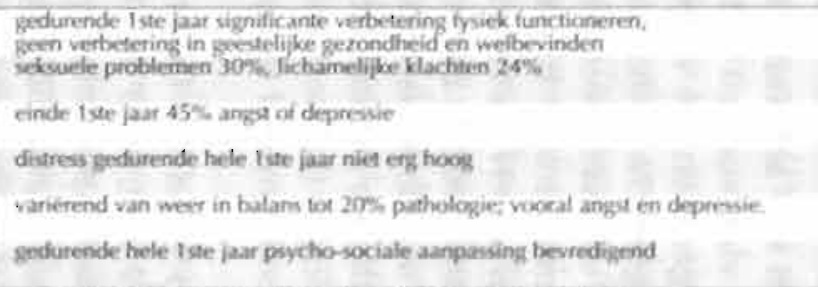 \\
\hline $\begin{array}{l}\text { I tot } 5 \text { ja.t } \\
\text { na diagnose }\end{array}$ & 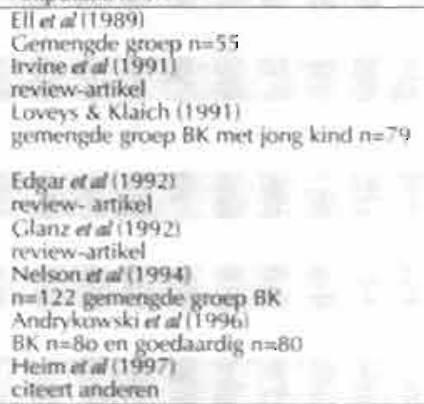 & & & 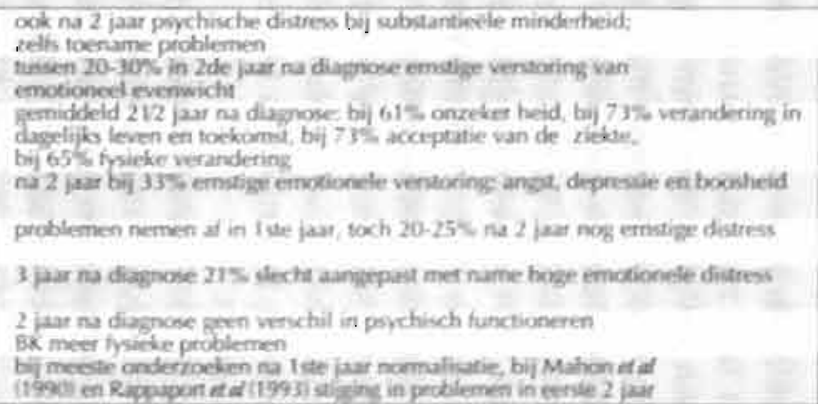 \\
\hline $\begin{array}{l}5 \text { f sar of meer } \\
\text { nal diagnose }\end{array}$ & 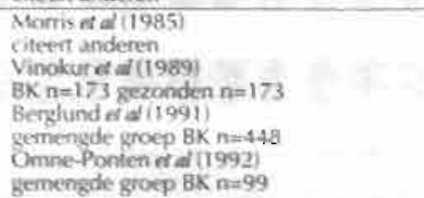 & $27-33=$ & f & 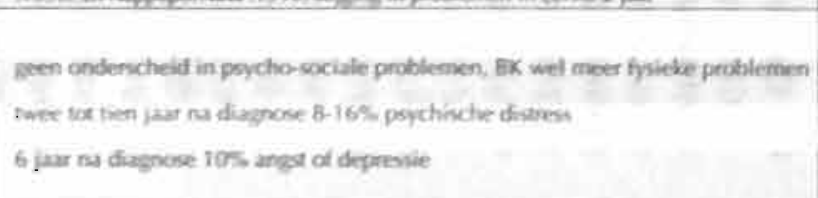 \\
\hline
\end{tabular}


De literatuur over de gevolgen van adjuvante chemotherapie bij bostkankerpatiënten laat zien dat vrouwen vlak voor en tijdens de kuren meer pychische problemen ervaren dan hun lotgenoten die ongeveer even lang geleden voor borstkanker zijn geopereerd, maar geen chemotherapie ondergingen. Ook r.pporteren de met chemotherapie behandelde vrouwen meer lichamelijke klachten. Ecter, enige tijd na beëindiging van de chemotherapie blijken die verschillen virdwenen (Wainstock 1991 review, Berglund et al 1991 Carver et al 1993, Nelson et al 194, Hürny et al 1996, Budin 1998). Volgens Hürny geeft dit aan dat de extra belasting dor chemotherapie tijdelijk is en vergeleken met de impact van de diagnose relatiefklein. De bevindingen lijken in zekere zin dus op die uit onderzoek naar de invloed van de verschillende chirurgische behandelingen (lumpectomie versus amputatie). $\mathrm{D}$. aard van de behandeling lijkt niet van blijvende invloed te zijn op het psychisch wetbevinden van de vrouwen.

Spiegel (1997) concludeerde op grond van literatuuronderzoek dat, onfhankelijk van wat de behandeling precies inhoudt, rond de $80 \%$ van de borstkankerpatiénten aanzienlijke psychische problemen rapporteren gedurende de periodt van hun behandeling. Boer et al (1992) komen naar aanleiding van wat 56 vrouwennet na de bestralingsperiode vertelden, tot een achttal probleemgebieden. Het meest genoemd werden psychische of emotionele problemen (32\%), lichamelijke klachten $(21 \%)$ en zorgen over wat het allemaal betekent voor partner en kinderen (22\%). Dric maanden na diagnose vonden Watson et al (1991) en Epping et al (1999) dat respectievelijk 16\% en $18 \%$ van hun onderzoeksgroep angstig was. Deze percentage liggen dicht bij elkaar. De mate waarin zij in hun onderzoeksgroep depressie constateerden liep wel uiteen (respectievelijk $6 \%$ en $29 \%$ ).

\section{Ontwikkeling gedurende het eerste jaar na diagnose}

Volgens Budin (1998) begint er drie à vier maanden na chirurgie een periode die als zeer stressvol wordt ervaren. Rond die tijd is voor een deel van de patiënten de behandeling achter de rug; zij zijn bezig met hun fysieke herstel. Anderen zijn ver gevorderd met hun therapie. De aandacht richt zich langzaam op het reorganiseren van het leven en het weer oppakken van vroegere activiteiten en rollen.

Carver et al (1993) vonden gedurende het eerste jaar een significante daling in angst en depressie, waarbij zij opmerkten dat de niveaus op geen van de meetmomenten eigenlijk bijzonder hoog waren. Deze laatste bevinding wordt gesteund door Heim et al (1997). Ook in de onderzoeksgroep van Goldberg et al (1992) daalden de niveaus van angst en depressie significant. Maar deze onderzoekers troffen aan het einde van het eerste jaar toch nog bij een substantieel deel van de vrouwen klinisch relevante niveaus van angst $(27 \%)$ of depressie $(21 \%)$ aan. Deze percentages komen overeen 
met de percentages die door Epping et al (1999) en Omne-Ponten et al (1992) aan het eind van het eerste jaar zijn gevonden.

Vinokur et al (1990) daarentegen kon geen significante verandering aantonen in geestelijke gezondheid en welbevinden, ondanks significante afname in de ervaren dreiging ten gevolge van de ziekte: 'This suggests that although women perceived their breast cancer as now being less threatening and more predictable and controllable, their general mental health and well-being did not improve'. Wel was er een significante en consistente verbetering in fysiek functioneren.

Goldberg et al (1992) vermeldden dat in hun onderzoekgroep na een jaar nog $24 \%$ van de vrouwen lichamelijke klachten had en 30\% seksuele problemen ten gevolge van ziekte of behandeling.

\section{Beloop op de lange termijn}

Ook over de lange termijn gevolgen van borstkanker bestaat weinig overeenstemming. Verschillende onderzoekers vonden dat tussen de $20 \%$ en $30 \%$ van de vrouwen met borstkanker twee tot drie jaar na diagnose nog steeds psychische problemen hebben (Irvine $e t$ al 1991, Edgar et al 1992, Glanz \& Lerman 1992, Nelson ot al 1994). Anderen, zoals Andrykowski et al (1996) konden na twee jaar geen verschillen meer aantonen tussen (ex-)borstkankerpatiënten en vrouwen zonder gezondheidsproblemen. Hoewel over het algemeen de indruk bestaat dat in de loop van de tijd de problemen afnemen, meldden zowel Mendelsohn (1990) als Nelson et al (1994) dat zij in hun onderzoeksgroep geen relatie konden vinden tussen de tijd sinds diagnose en de mate van aanpassing. Met andere woorden, de tijd sinds diagnose had geen aantoonbare invloed op de problemen. Onderzoek van Ell et al (1989) liet zelfs zien dat de problemen in de loop van de eerste twee jaar juist waren toegenomen. Ook Mahon et al (1990) en Rappaport et al (1993) maakten melding van een toename van problemen (in Heim et al 1997).

Moyer en Salovey (1996) bevestigen in een review-artikel dit diverse beeld. Zij komen tot de conclusie dat uit een groot aantal onderzoeken blijkt, dat vrouwen met borstkanker gedurende lange tijd veel problemen ervaren, maar dat er eveneens veel onderzoeken zijn die erop wijzen dat de gevolgen ofwel meevallen ofwel na één jaar zijn verdwenen. Wel zouden de recentere onderzoeken over het algemeen minder problemen na borstkanker laten zien dan onderzoeken uit de jaren zeventig. Dit laatste wordt bevestigd door Carver et al (1993) die eveneens constateren dat de wat oudere literatuur aangeeft dat reacties als depressie, angst en boosheid de norm waren. Echter, de meer recente studies zouden laten zien dat vrouwen zonder psychiatrische voorgeschiedenis eigenlijk geen grote kans lopen ernstige psychologische symptomen te ontwikkelen. Maar, zo merkten ook zij op, dit neemt niet weg dat sommige vrouwen minder goed reageren op de diagnose dan anderen. 
Het lijkt erop dat een deel van de verwarring samenhangt met de definitie van 'psychische problemen'. Zo merken Nelson et al (1994) op dat er subgroepen van patiénten zijn aan te wijzen, die ondanks een 'normale' psychische aanpassing toch op een aantal gebieden problemen ervaren. Deze patiënten zouden moeilijk zichtbaar worden in onderzoek. Loveys en Klaich (1991) deden een poging om met behulp van interviews de problemen van 79 vrouwen met borstkanker te inventariseren. De vrouwen uit het onderzoek hadden maximaal $2 \frac{1}{2}$ jaar daarvoor de diagnose gekregen. De auteurs kwamen tot de conclusie dat $73 \%$ problemen had met veranderingen in het dagelijks leven en met veranderingen in toekomstverwachtingen. Eveneens $73 \%$ van de vrouwen had moeite de ziekte te accepteren, $65 \%$ had fysieke problemen, $61 \%$ voelde zich onzeker en $69 \%$ was emotioneel labiel. In tegenstelling tot deze hoge percentages vrouwen met problemen scoorde in de onderzoeksgroep van Berglund et al (1991) slechts een klein deel (8-16\%) hoog op verschillende maten van psychische distress. De onderzoekers verklaren deze relatief lage percentages uit het feit dat hun onderzoeksgroep voor een groot deel bestond uit vrouwen bij wie de diagnose al lang geleden was gesteld ( 2 tot 10 jaar na diagnose). Ook Omne-Ponten et al (1992) vonden soortgelijke percentages (10\% angst en depressie) bij een follow-up na zes jaar. Vinokur (1989) ontdekte dat er een breekpunt ligt rond vijf jaar na diagnose. Vrouwen bij wie de diagnose borstkanker minder dan vijf jaar geleden was gesteld, rapporteerden meer problemen dan een controlegroep van 'gezonde' vrouwen, maar vrouwen bij wie het al vijf jaar of langer geleden was verschilden niet van die controlegroep.

\section{1 - 3 - Samenvatting en conclusies}

Schrameijer en Brunenberg (1992) stelden zich de vraag of de psychosociale problemen van kankerpatiënten een eigen karakter hebben. Ze kwamen tot de conclusie dat wanneer men alle aspecten van de ziekte afzonderlijk neemt, dit niet het geval is: er zijn telkens wel andere ziekten te vinden waarvoor hetzelfde geldt. Het bijzondere aan kanker zou nu juist zijn dat er een aantal dingen samenkomt: het onbeheersbare van de ziekte, de angst die kanker de patiënt en anderen inboezemt en die mede aanleiding is tot vooroordelen, het agressieve karakter van de ingrepen waarmee getracht wordt de ziekte te bestrijden en de onzekerheid over het uiteindelijke effect daarvan. Deze combinatie maakt dat de meeste auteurs het er over eens zijn dat kanker, méér dan de meeste andere ziekten, vanaf de aanvang het psychisch evenwicht ontregelt. Bovendien is men het er over eens dat de specifieke gevolgen van de verschillende soorten kanker minder bepalend zijn dan het feit dat men kanker heeft. 
In de literatuur worden uiteenlopende negatieve gevoelens en reacties ten gevolge van kanker genoemd: angst, depressie, boosheid, gevoel van verlatenheid, negatieve veranderingen van het zelfbeeld, controleverlies, onzekerheid, gevoelens van hulpeloosheid en hopeloosheid en verlies van zelfwaardering.

Desondanks komt uit een groot deel van de literatuur het beeld naar voren dat kankerpatiënten er psychologisch en vooral psychiatrisch niet slechter aan toe lijken dan gezonden. Deze bevindingen contrasteren met de alledaagse ervaringen van artsen, verpleegkundigen en andere hulpverleners en met studies waarin diepgaande interviews zijn gebruikt (Breedveld \& Van Dam 1991). Volgens Schrameijer en Brunenberg doen veel van deze bevindingen geen recht aan de werkelijkheid en is er zelfs sprake van onderrapportage van psychische problematiek. Spiegel (1997) merkt in dit verband op dat het van belang is hoe de onderzochte problematiek precies is gedefinieerd. Zo vonden Nelson et al (1994) dat er subgroepen van kankerpatiënten zijn die naast een normale psychische aanpassing toch problemen ervaren. Dit zou uit veel onderzoek moeilijk zichtbaar worden, aangezien door standaard vragenlijsten naar algemene kenmerken van angst en depressie, de specifiek aan kanker gerelateerde problemen niet zichtbaar zouden worden. Deze bewering wordt bevestigd door onderzoek van Northouse en Swain (1987) en Northouse (1989). Zij maakte onderscheid tussen stemming en kankerspecifieke distress en toonde aan dat in de eerste 18 maanden na de diagnose wel de stemming verbeterde (geoperationaliseerd als angst en depressie gemeten met de Hospital Anxiety and Depression Scale) maar de kankerspecifieke distress niet. Onder dit laatste verstond zij 'zorgen en spanningen', waarvoor zij kankerspecifieke vragen had opgesteld.

De resultaten uit onderzoek onder vrouwen met borstkanker lopen nogal uiteen. Zij variëren van: 'na ongeveer een jaar zijn de meeste vrouwen weer in balans en hebben de belangrijkste gevolgen van hun borstkanker overwonnen' tot 'een belangrijke minderheid ( $20 \%$ tot $30 \%$ ) kampt na enkele jaren nog steeds met problemen'.

Bij het vaststellen van de mate van problematiek lijkt het uitermate belangrijk hoe de problemen zijn gedefinieerd en op welke wijze ze zijn onderzocht. Ook lijkt het van belang een onderscheid te maken tussen korte termijn gevolgen, gevolgen tot vijf jaar na diagnose, en gevolgen later dan die vijf jaar (Vinokur 1989). 


\section{2 - OMGAAN MET KANKER: COPING}

De term 'coping' betekent zoveel als 'het hoofd bieden aan', 'opgewaen zijn tegen' of 'om kunnen gaan met'. Wordt iemand ernstig ziek, dan vraą̧dit inspanningen, zoals het reduceren van de bedreigende situatie en het bevorderevan de kans op herstel. Maar ook het verdragen van of het zich aanpassen aan de gatieve gevolgen van de ziekte, het handhaven van een positief zelfbeeld, het handven of herstellen van het emotioneel evenwicht en het vasthouden van bevredigendsociale relaties (Baider \& Sarell 1983). Hoe mensen dit doen is onderwerp van helopingonderzoek.

\section{2-1 - Historische achtergrond}

Verschillende theoretische stromingen hebben een bijdrage geleverdan het copingdebat. De interesse in 'coping' gaat terug tot de eerste psycho-an/tische beschrijvingen van het begrip. Sindsdien werden theorievorming en onderzoekarallel aan de ontwikkelingen in de psychologie, vooral gevoed door inzichten vuit de leertheorie, de sociale en de cognitieve psychologie (zie voor een historisch erzicht Kessler $\boldsymbol{e t}$ al 1985, Somerfield \& Curbow 1992 en Muris \& Merckelbach 1997).

In de psycho-analytische traditie was coping synoniem aan afweer; cop3 werd uaánn ais een onbewuste reactie op een intra-psychisch contlict beschouwd. Het onderzoek naar coping met kanker gebeurde aanvankelijk vanuit deze psychoanalytische traditie, meestal door consultatief psychiaters. Zij kwamen tot de conclusie dat kankerpatiènten een scala aan afweermechanismen ontwikkelden om zich aan hun situatie aan te passen. Daarbij werd verondersteld dat het voor een goede geestelijke gezondheid nodig is de realiteit onder ogen te zien. Het gebruik van afweermechanismen werd aanvankelijk opgevat als geestelijk ongezond en onrijp.

Sindsdien is het coping-onderzoek uitgebreid naar terreinen buiten het psychoanalytische kader. Daarmee verschoof de aandacht van interne psychische conflicten naar coping met externe factoren. Dit onderzoek speelde zich aanvankelijk af in een laboratoriumsetting. Vanaf het midden van de jaren zeventig ging men, vooral onder invloed van sociaal-psychologen, de in het laboratorium opgedane inzichten toetsen aan gebeurtenissen in de buitenwereld. Een belangrijke vraag werd in welke mate coping in het geval van een levenscrisis, zoals een ziekte, psychosociale aanpassing faciliteert.

Attributie-onderzoekers, met Heider (1958) als grondlegger en Kelley (1971) als een van zijn belangrijkste navolgers, benadrukten dat wanneer er iets naars gebeurt, mensen op zoek gaan naar een oorzaak (in Ten Kroode 1990). Deze causale attributies zouden er vooral voor dienen weer controle over de situatie te krijgen. Vanuit de 
sociale leertheorieèn kwam het inzicht dat een persoon niet alleen als actor optreedt, maar dat persoon en (sociale) omgeving elkaar wederzijds beïnvloeden (Bandura 1977, Mischel 1977 in Kessler et al 1985). Onderzoeken gebaseerd op de sociale vergelijkingstheorie lieten zien dat onder dreigende omstandigheden mensen geneigd zijn zich te vergelijken met anderen om zo de stressvolle situatie te evalueren en met de gevolgen ervan om te gaan (Taylor et al 1984, Buunk et al 1990).

De cognitieve gedragstherapie tenslotte, leverde belangrijke inzichten over de rol van cognitieve processen en hoe deze kennis gebruikt kan worden in een therapeutische setting. Bij al deze bijdragen ligt, anders dan bij de psycho-analytische inzichten, de nadruk op de actieve, bewuste rol die het individu speelt bij zowel het construeren van zijn psychische wereld, als bij het inzetten van de hem ter beschikking staande middelen om de stressvolle gebeurtenis het hoofd te bieden. Dit blijkt ook uit de term copingstrategie, een term die halverwege de jaren zeventig opduikt' ${ }^{1}$ en verwijst naar het actieve, strategische karakter van het copingproces.

Uitermate belangrijk voor de ontwikkeling van het begrip 'coping' zijn de publicaties van de groep rond Lazarus, Cohen en Folkman evenals die rond Pearlin en Scooler. Zij deden onderzoek naar coping en stress (Cohen \& Lazarus 1979, Lazarus \& Folkman 1984 en Pearlin \& Scooler 1978). Met name Lazarus vestigde de aandacht op de invloed van wat hij 'cognitive appraisals' noemde. Hiermee bedoelde hij de inschattingen en mentale representaties, die een persoon maakt van de situatie waarin hij verkeert. Volgens Lazarus zijn deze inschattingen bepalend voor wat daarna volgt. Hij noemt appraisals het sturend mechanisme van het copingproces (Lazarus \& Launier 1978).

De inzichten die deze en verwante onderzoekers voortbrachten, leidden tot een definitie van coping die, met hier en daar een kleine wijziging of accentverschil, expliciet maar vaak ook impliciet, de basis vormt voor veel van het coping-onderzoek sindsdien. Onderstaande definitie is een synthese van die van Pearlin en Scooler (1978), Cohen \& Lazarus (1979), Weisman (1979), Lazarus en Folkman (1984), Kessler et al (1985), Somerfield en Curbow (1992). Zij geeft de essentie weer van wat onder coping moet worden verstaan.

COPING IS DE COGNITIEVE EN GEDRAGSMATIGE INSPANNING DIE EEN PERSOON LEVERT OM HET HOOFD TE BIEDEN AAN EISEN DIE DOOR ANDEREN, DE SITUATIE OF ZICHZELF AAN HEM WORDEN GESTELD, EN WAARVAN HII INSCHAT DAT DEZE ZIIN VERMOGENS OP DE PROEF

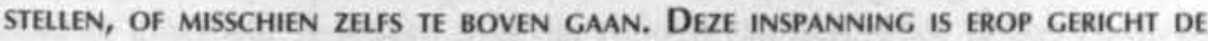
STRESSVOLLE SITUATIE TE BEHEERSEN, OP TE HEFFEN, TE REDUCEREN OF TE TOLEREREN.

1 Het oudste artikel waarin de term copingstrategie is aangetroffen, althans binnen de literatuur die voor deze studie is onderzocht, stamt uit $1976 \mathrm{en}$ is van de hand van Weisman en Worden. 


\section{2 - 2 - Enkele theoretische modellen}

Er zijn dus meerdere theoretische modellen van waaruit (een deel van) het copingproces kan worden begrepen, elk met eigen accenten en begrippen. Achtereenvolgens worden enkele modellen uitgewerkt die van belang zijn voor 'omgaan met kanker'. Nadat ze afzonderlijk zijn besproken worden ze in paragraaf 1-2-3 in hun onderlinge samenhang belicht.

\section{2-2 - 1 - De theorie van de rechtvaardige wereld en zijn slachtoffers}

Onderzoek naar de gevolgen van een ernstige gebeurtenis laat zien dat bij de slachtoffers een aantal belangrijke aannames over zichzelf en de wereld om hen heen onder vuur zijn komen te liggen ${ }^{2}$. Veel mensen geloven dat de wereld recbtvaardig, betekenisvol en begrijpelijk in elkaar zit. In een rechtvaardige wereld krijgt ieder wat hij verdient en verdient ieder wat hij krijgt $^{3}$ (Lerner 1971). Ook leven de meeste mensen impliciet vanuit een gevoel van persoonlijke onaantastbaarheid, met daaraan gekoppeld de ontkenning tan de eigen sterfelijkbeid. Bovendien beoordelen mensen zichzelf over het algemeen als waardevol, integer en betrouwbaar. Deze fundamentele veronderstellingen over de wereld en onszelf, worden in de cognitieve psychologie 'basale schemata' of 'core beliefs' genoemd (Mc Cann et al 1988). Door een rampzalige gebeurtenis storten de veilige kaders in en worden de illusies van veiligheid, rechtvaardigheid, onaantastbaarheid en voorspelbaarheid op de proef gesteld of teniet gedaan. Ook kan een negatief zelfbeeld worden geactiveerd wanneer 'slachtoffers' zichzelf gaan zien als minderwaardig, afwijkend, zwak of schuldig aan de gebeurtenis (Janoff-Bulman \&Wortman 1977, Kleber 2000).

Het copingproces is erop gericht de ervaring slachtoffer te zijn te integreren in de opvattingen die men heeft. Dit kan ofwel door de gebeurtenis cognitief te manipuleren, zodat deze past in de oude schema's, ofwel door de vroegere opvattingen aan te passen aan de nieuwe werkelijkheid (Festinger 1957 in Gleitman 1986, Janoff-Bulmann 1983 en 1992). Een van de mogelijkheden die men daarvoor heeft is betekenis te vinden in de onzinnige gebeurtenis, waardoor het lijden tenminste zin heeft gekregen (Frankl 1963 in Ten Kroode 1990). Meer dan de helft van de mensen geeft na afloop van allerlei intense crises aan dat er op de een of andere wijze ook positieve dingen uit voort zijn gekomen (Schaefer \& Moos 1998, Kleber 2000). Voorbeelden die worden genoemd zijn: een toename in de waardering voor relaties met de directe omgeving; een positieve verandering in het perspectief op het eigen

\footnotetext{
2 Onderzoek bij slachtoffers van een ernstig ongeluk en van verkrachting door Janoff-Bulman (1983 en 1992), onderzoek bij slachtoffers van levensbedreigende ziekten waaronder kanker door Taylor et al (1983) en onderzoek bij slachtoffers van rampen door Kleber (2000).

3 In de Angelsaksische literatuur is deze theorie bekend onder de naam: 'The just world theory'.
} 
leven omdat men beseft dat het leven met grote zorg moet worden gekoesterd of 'persoonlijke groei' tengevolge van de gebeurtenis.

Naast betekenisverlening kan het slachtoffer een poging ondernemen de gebeurtenis te begrijpen om daarmee het gevoel van willekeur op te heffen. Begrijpen hoe het zo is gekomen biedt mogelijk aangrijpingspunten om herhaling te voorkomen en zich voor de toekomst veilig te stellen. Dit thema van begrijpen en voorspellen is onderwerp van de attributietheorie (zie paragraaf 2-2-3).

Het zelfbeeld tenslotte kan worden hersteld door een antwoord te vinden op de schuldvraag of door zich in positieve zin te vergelijken met anderen. Taylor, Wood en Lichtman onderscheidden in hun artikel 'It could be worse: selective evaluation as a response to victimisation' (1983) een vijftal copingstrategieën waarmee de door hen onderzochte kankerpatiënten poogden het zelfbeeld 'hoog' te houden en schuldgevoel en slachtofferschap te minimaliseren: (1) selectieve vergelijkingen met mensen die slechter af zijn, (2) zich selectief richten op dimensies waarin men bevoordeeld lijkt ten opzichte van andere slachtoffers, zoals bijvoorbeeld: 'gelukkig heb ik een man die me opvangt', (3) bedenken van hypothetische, slechtere senario's, zodat de gebeurtenis relatief meevalt, (4) bedenken dat de negatieve gebeurtenis toch positieve kanten heeft gehad, i.e. de zingeving zoals hiervoor beschreven, (5) van oordeel zijn dat men zich uitzonderlijk goed aan de situatie heeft aangepast. Deze vijf selectieve evaluaties zijn cognitieve manipulaties van de situatie en op te vatten als cognitieve copingstrategieën. De wijze waarop mensen zich met anderen vergelijken en de motieven die daaraan ten grondslag liggen zijn veelvuldig onderwerp van onderzoek geweest. In de volgende paragraaf wordt hier nader op ingegaan.

\section{2 - 2 - 2 - Sociale vergelijkingstheorieën}

Sociale vergelijkingen werden aanvankelijk gezien als middel tot zelfevaluatie. Door vergelijking, bij voorkeur met personen die als ongeveer gelijkwaardig of als iets beter worden beschouwd, kan men zich immers een oordeel vormen over eigen vaardigheden, kenmerken, emoties en opvattingen (Festinger 1954 en Schachter 1959 in Wills 1991). Later onderzoek maakte duidelijk dat sociale vergelijkingen ook andere functies vervullen, zoals versterking van het zelfbeeld (self-enhancement) of als motief de eigen situatie te verbeteren (Taylor et al 1983, Taylor \& Lobel 1989). Zo noemen Affleck en Tennen (1991) een drietal redenen waarom ernstig zieke mensen sociale vergelijkingen maken. $\mathrm{Zij}$ zouden dit doen omdat (1) zij meestal niet in staat zijn eenduidige informatie te krijgen over het verloop van hun ziekte of hoe zij de ziekte onder controle kunnen krijgen, (2) hun zelfwaardering en sociale positie bedreigd worden door de ziekte en (3) zij perioden ervaren van emotionele ontregeling, die niet verzacht kunnen worden door copingstrategieën gericht op probleemoplossing. 
In deze opsomming vinden we twee verschillende functies van sociale vergelijkingen terug, namelijk objectieve, accurate zelf-evaluatie ten behoeve van de informatievoorziening en 'zelfversterkende' vergelijkingen ten behoeve van de bedreigde zelfwaardering en tegen emotionele ontregeling. Beide functies zouden elkaar in principe niet in de weg staan. Er zijn echter aanwijzingen dat vergelijkingsactiviteiten onder bepaalde omstandigheden divergeren. Taylor en haar onderzoeksgroep toonden namelijk aan dat onder dreiging, bijvoorbeeld ten gevolge van kanker, men zich bij voorkeur niet vergelijkt met gelijken of met personen die beter af zijn, zoals gebruikelijk is bij zelf-evaluatie, maar juist met personen met wie het slechter gaat. In tegenstelling tot de opvattingen tot dan toe hebben deze neerwaartse vergelijkingen meestal een positieve uitwerking; zij geven de persoon in kwestie het prettige gevoel dat hij nog boft en het zo gek nog niet heeft gedaan. Met andere woorden, ze verstekten het zelfbeeld (Taylor 1983, Taylor \& Lobel 1989, Buunk et al 1990, Wheeler 1991, Helgeson \& Taylor 1993, Hagopagian 1994). Om zo'n positief gevoel te krijgen kiest iemand niet alleen de personen uit waarmee hij zich in positieve zin vergelijkt, maar ook de dimensies waarop hij positief afsteekt (Taylor, Wood \& Lichtman 1983). Volgens Taylor en Brown (1988 en 1994) komt dit omdat mensen lang niet altijd de behoefte hebben hun eigen situatie of handelen objectier in te schalen, Lods Festinger en Schachter meenden, maar dat zij, zeker onder bedreigende omstandigheden, eerder de behoefte hebben te geloven dat ze het onder de gegeven omstandigheden goed doen c.q. goed af zijn. Daartoe kiezen ze informatie die daarbij het best aansluit en maken ze gebruik van cognitieve strategieën waarmee informatie wordt gefilterd en vervormd.

Buunk et al (1990) toonden aan dat opwaartse en neerwaartse vergelijkingen zowel een positief als een negatief gevoel kunnen veroorzaken ${ }^{4}$, maar dat beide soorten vergelijkingen aanzienlijk vaker een positief dan een negatief gevoel uitlokken. Blijkbaar zijn mensen in staat een positieve selectie te maken. Ze kiezen er voor om ten opzichte van personen die slechter af zijn zichzelf in positieve zin als verschillend te ervaren. Ten opzichte van mensen die beter af zijn, zien zichzelf juist als gelijke. Daarbij houden zij zich voor dat ook zijzelf in staat zijn die betere situatie te bereiken (zie ook Van der Zee 1996). Personen met relatief weinig gevoel van controle (Buunk et al 1990) of met een hoge score op neuroticisme (Van der Zee 1996) blijken het meest geneigd tot negatieve neerwaartse vergelijkingen en dus niet goed in staat een voor hen gunstige selectie te maken.

\footnotetext{
4 Een opwaartse vergelijking levert een positief gevoel op wanneer men zich optrekt aan de persoon die beter af is, en een negatief gevoel wanneer men zich ten opzichte van die ander benadeeld voelt. De neerwaartse vergelijking met mensen die slechter af zijn levert een positief gevoel op wanneer dit tot de conclusie leidt dat men er nog goed vanaf komt, en een negatief gevoel wanneer men beseft dat het nog erger kan worden: "dat is mijn voorland".
} 
Onderzoek dat zich specifiek richt op de informatiebehoefte van kankerpatiénten en de behoefte aan lotgenotencontact (Molleman et al 1986, Van den Borne \& Pruyn 1987) laat zien dat patiënten voor het verkrijgen van informatie zich bij voorkeur juist wel vergeleken met anderen die in dezelfde situatie verkeren, aangezien dit hun de beste informatie opleverde. De vergelijking betrof niet alleen de eigen situatie, maar ook hoe normaal de eigen gevoelens en reacties waren. Lotgenoten die in een slechtere conditie verkeerden werden daarentegen juist vermeden, omdat zij als bedreigend werden ervaren. De behoefte aan vergelijking bleek afhankelijk van de mate waarin de kankerpatiënten in staat waren hun onzekerheid te reduceren via objectieve informatie; het betrof vooral vragen waarop geen (eenduidig) medisch antwoord mogelijk was. De relatie verliep volgens een omgekeerde $\mathrm{U}$. Bij toenemende onzekerheid nam aanvankelijk de behoefte aan vergelijking en contact met gelijken toe, bij hoge angst namen deze behoeftes weer af.

Concluderend blijkt dat 'zelfversterking' enerzijds en het verkrijgen van informatie over de eigen situatie anderzijds bij kankerpatiënten verschillende soorten sociale vergelijkingen vragen die met elkaar kunnen conflicteren. Voor het verkrijgen van informatie zijn accurate zelfevaluaties nodig, waarbij de vergelijking met anderen die slechter af zijn angst kan oproepen en om die reden vaak wordt vermeden. Onderzoek dat niet specifiek op de informatiebehoefte is toegespitst laat juist zien dat kankerpatiënten vooral neerwaartse vergelijkingen maken en dat doen op een manier die positief uitpakt voor hun zelfbeeld. Daarbij zouden zij dikwijls de werkelijkheid vertekenen. Welk van de twee de overhand heeft lijkt afhankelijk van de behoefte aan informatie (Molleman et al 1986, Van den Borne \& Pruyn 1987), de mate van angst (Molleman et al 1986, Van den Borne \& Pruyn 1987), het gevoel van controle (Buunk et al 1990), de mate van neuroticisme (Van der Zee 1996) en de bedreiging van zelfbeeld en zelfrespect (Taylor \& Lobel 1989).

\section{2 - 2 - 3 - Attributietheorie}

Mensen hebben de behoefte te begrijpen hoe de wereld om hen heen in elkaar zit. Zij maken in allerlei situaties inschattingen over oorzaak en gevolg en stellen zich daarbij vragen over het 'wat', 'hoe' en 'waarom'. De antwoorden worden causale attributies genoemd. Heider als grondlegger van de attributietheorie en Kelley als een van zijn belangrijkste navolgers waren van mening dat attributies voornamelijk dienen om controle over de omgeving te krijgen of te behouden. Door te begrijpen hoe een gebeurtenis verloopt ontstaat immers de mogelijkheid de afloop te voorspellen en eventueel te beïnvloeden. 
Toen ook 'real life' gebeurtenissen onderwerp van studie werden, bleek dat bij zoiets als een ziekte de betrokkenen niet alleen naar een oorzaak zoeken, zoals het geval was bij de experimentele onderzoeken in een psychologisch laboratorium, maar dat zij zich tevens de vraag stellen 'wat betekent deze ziekte in mijn leven?'. Deze vraag is meer filosofisch en gaat in feite over zingeving. Naast controle en zingeving bleken ook emotiebeheersing en handhaving van het zelfbeeld belangrijke functies van attributies te zijn (zie voor een overzicht Ten Kroode 1990).

In 1956 schreven Bard en Dyk over de psycho-dynamische werking van de oorzakelijke verklaring en kwamen tot de conclusie dat: 'When confronted with serious illness, individuals must establish a belief explaining the event. The more serious the disease (..) the more necessary the belief.' (in Ten Kroode 1990). Deze opvatting wordt onderschreven door Sensky (1997) die in zijn overzichtsartikel 'Causal attributions in physical illness' concludeert dat $70 \%$ tot $90 \%$ van de patiënten een causale attributie heeft over het ontstaan van de ziekte. De hoogste frequentie aan attributies werd inderdaad aangetroffen onder de ernstiger zieken. Onderzoek specifiek bij kankerpatiènten levert vergelijkbare percentages op. Taylor et al (1984) vonden dat 95\% van een groep borstkankerpatiënten een attributie voor de oorzaak had. Ten Kroode (1990) komt bij een gemengde groep kanikerpatiemten tor eenzéfút percentage. Er bestaat onder onderzoekers dan ook een brede consensus dat negatieve en onverwachte gebeurtenissen zoals ziekte een zoektocht naar oorzaken oproepen en dat deze zoektocht dwingender wordt naar name de situatie meer onzekerheid in zich bergt. Over de invloed van attributies op aanpassing zijn de meningen verdeeld (Sensky 1997).

\section{Verschillende attributies; conceptuele verwarring rond het begrip}

Door het onderzoek van 'real life-gebeurtenissen' kreeg zingeving een plaats binnen de attributietheorie, echter de terminologie werd niet aangepast. Dit heeft als gevolg dat verschillende soorten attributies onder de noemer 'causale attributies' worden geschaard. Zo vat Janoff-Bulman (1983) de vraag naar 'bet waarom' op als een vraag naar de oorzaak en omschrijft deze als volgt: the perceptions of how it had occurred as well as the broad, philosophical perspective in which they placed the victimisation.' Hiermee verwijst zij naar twee verschillende vormen van betekenisverlening. Beide noemt ze causale attributies. Taylor et al (1983 en 1984) doen iets dergelijks. Zij deden onderzoek bij vrouwen met borstkanker en merkten dat de vrouwen op tenminste twee manieren probeerden betekenis te verlenen aan wat hen was overkomen. Ook hier betrof het op de eerste plaats een oorzakelijke analyse. Daarnaast was er op grote schaal sprake van betekenisverlening die bij meer dan $60 \%$ van de patiènten tot een heroverweging van levenshouding en prioriteiten leidde. Dit 
laatste fenomeen noemden Taylor et al 'construing benefit out of the worse', omdat uit de negatieve gebeurtenis positieve gevolgen werden benoemd, zoals het verdiepen van relaties, het vermeerderen van zelfkennis en 'groei'. De auteurs concludeerden dat het aanpassingsproces aan kanker zich centreert rond drie thema's: (1) 'a search for meaning', (2) 'an attempt to regain mastery' en (3) 'an effort to restore self-esteem'. Causale attributies zouden een bijdrage leveren aan elk van deze thema's. Echter hoe het begrip 'construing benefit out of the worse' zich tot causale attributies verhoudt en of beide begrippen (ten dele) samenvallen, wordt niet duidelijk.

Tot op de dag van vandaag, in ieder geval in onderzoek onder patiénten met een ernstige ziekte, worden maar zelden expliciet verschillende soorten attributies onderscheiden. Een uitzondering vormt het onderzoek van Ten Kroode (1990). Hij onderscheidt antwoorden op de vraag naar de oorzaak van de ziekte hoe kom ik hier aan?' en de antwoorden op de vraag 'waarom ik, waarom moet mij dit overkomen?' Antwoorden op de 'boe-traag' vat hij op als causale attributies en die op de 'uaarom-vraag' noemt hij betekenisterlenende attributies. Bovendien viel het hem op dat in het proces van oorzaaktoekenning en betekenisverlening ook de vragen 'hoe komt het niet? of 'waaraan heeft het niet gelegen?' van belang zijn. Bespiegelingen over oorzaken waarbij wordt aangegeven dat ze niet van toepassing zijn, noemt ten Kroode ontkennende attributies. Oorzaken die wel van toepassing zijn maar door de patiënt als oorzaak worden afgewezen, noemt hij ontlastende attributies. Met deze laatste vorm van attributies zou schuld worden afgewezen. Volgens Ten Kroode zijn de termen ontkennende en ontlastende attributies niet eerder in de literatuur aangetroffen, althans hij heeft ze niet kunnen vinden. Op zich is dit vreemd, omdat het thema 'schuld' veelvuldig aan de orde komt binnen de attributietheorie. Wanneer er in de causale attributie sprake is van zelfbeschuldiging zou dit aangrijpingspunten bieden voor verandering en daarmee het gevoel van controle bevorderen. De meningen hierover zijn trouwens enigszins verdeeld, maar daarover later meer. Hier is van belang dat het thema schuld binnen de attributietheorie vooral is onderzocht in relatie tot controle en veel minder in relatie tot emotieregulering en handhaving van het zelfrespect. Dit zou kunnen verklaren waarom een begrip als ontlastende attributie niet voorkomt. Wel merken bijvoorbeeld Janoff-Bulman en Wortman (1977) op dat het verlangen van het slachtoffer om zichzelf tegen gevoelens van schuld te beschermen' van belang is in het proces van aanpassing (zie ook paragraaf 2-2-1). Zij verwijzen naar Shaver (1970) die van mening is dat 'people assign causality in order to maintain or enhance their selfesteem in their desire to avoid blame'. Shaver gebruikt daarvoor de term 'defensive attribution'. Hij verstaat hieronder klaarblijkelijk alle attributies die er voor zorgen dat men geen schuldgevoel hoeft te hebben want hij schaart ook kansattributies onder dit begrip. Ten Kroode (1990) gaat verder en reserveert de term ontlastende attributies 
voor het expliciet afwijzen van een (vermeende) oorzaak, die wel degelijk op de betreffende persoon van toepassing is, zoals ' $/ \mathrm{k}$ beb wel gerookt maar bet is absoluut niet zeker dat bet daar nan komt. Ik ken mensen... (enz) : In zijn onderzoek bleken kankerpatiënten meer van dergelijke ontlastende attributies te hebben dan patiënten die recent een hartinfarct hadden doormaakt of die aan multiple sclerose leden.

De term causale attributie wordt dus gebruikt voor zowel inschattingen van oorzaak-gevolg relaties als voor attributies die betrekking hebben op thema's als zingeving en schuld. Daarnaast heeft er nog een andere uitbereiding van het begrip plaatsgevonden. Zo wijst Van Rooij (1986) er bijvoorbeeld op dat onder attributies soms causale oordelen worden verstaan, soms labelingsprocessen en soms oordelen over karakteristieken van personen. De laatste twee zijn geen causale oordelen maar behoren tot de sociale afleidingen. Kortom het begrip causale attributies is in feite een containerbegrip geworden voor allerhande afleidingen.

\section{Attributies, controle en zelfbeschuldiging}

Causale attributies zouden er onder andere voor dienen om cognitieve controle te krijgen of te behouden over omgeving en gebeurtenissen. Het begrip controle wordt over het algemeen opgevat zoals Thompson (1981) dat verwoordde: 'Perceived control is the belief that one has a strategy available that can influence or change the intensity, duration, or outcome of a threatening event'. De woorden 'perceived' en 'belief' zijn in dit verband van belang omdat het gat over de controle zoals de persoon die ervaart. Wanneer iemand controle ervaart zou dat positief zijn voor aanpassing.

Vrijwel vanaf het begin van het attributieonderzoek worden de volgende dimensies aan attributies onderscheiden: (1) intern versus extern: zoekt de persoon de oorzaak binnen zichzelf of legt hij deze daarbuiten?, (2) globaal versus specifiek: heeft de attributie algemene geldigheid of alleen voor een bepaalde situatie?, (3) stabiel versus instabiel: hanteert de persoon steeds dezelfde of telkens een andere attributie? Interne, globale, stabiele attributies, zoals 'ik ben mu eenmaal iemand die altijd door zijn zenuven de boel in de soep gooit', zouden tot de minste aanpassing en zelfs tot depressie en aangeleerde hulpeloosheid leiden. Met het laatste wordt bedoeld dat iemand er bij voorbaat vanuit gaat dat hij toch geen invloed heeft en 'hulpeloos' de situatie ondergaat. Abramson et al (1978) onderscheiden twee soorten hulpeloosheid namelijk persoonlijke bulpeloosbeid wanneer iemand de attributie maakt dat bij in bet bijzonder deze situatie niet kan controleren - deze vorm van hulpeloosheid is vaak het gevolg van interne attributies - en unitersele bulpeloosbeid wanneer de attributie de strekking heeft dat niemand in een dergelijke situatie controle zou hebben, over het algemeen zijn dit externe attributies. Persoonlijke hulpeloosheid zou sterker correleren met depressie en vaker samengaan met een laag gevoel van eigenwaarde dan universele hulpeloosheid. 
Of iemand al dan niet controle ervaart, hoeft overigens niet per se het gevolg te zijn van een causale attributie. Andersom leidt een causale attributie niet per definitie tot controle. Wat vervolgens de relatie is tussen controle en aanpassing ligt zo mogelijk nog ingewikkelder.

Tompson (1981) onderscheidt vier soorten controle: (1) cognitieve controle, door er anders over te gaan denken, (2) informatie als middel tot controle, door er bijvoorbeeld over te lezen, (3) gedragscontrole, door iets aan de situatie te veranderen middels directe actie en (4) retrospectieve controle, door te leren van de gebeurtenis zodat iets dergelijks in de toekomst kan worden voorkomen. In de literatuur worden retrospectieve controle en controle in de toekomst vaak op een hoop gegooid. Sensky (1997) merkt in dit verband op dat causale attributies - als bron voor retrospectieve controle - en locus of control - daar waar de persoon meent dat de controle over de situatie ligt - vaak ten onrechte met elkaar worden verbonden. Voor een ziekte als kanker geldt in ieder geval dat een opvatting over de (vermeende) oorzaak meestal geen aanknopingspunten biedt voor controle over symptomen of gevolgen van de ziekte. Onderzoek van Lowery et al (1993) bevestigt dit. Bij de 195 borstkankerpatiènten die zij onderzochten, bleek 'perceived loss of control' een belangrijke negatieve voorspeller voor de mate van aanpassing aan de ziekte $(12 \%$ verklaarde variantie op een totale variantie van $22 \%$ ). Maar er bleek geen verband tussen deze vorm van controleverlies en de attributies van de vrouwen over het ontstaan van de ziekte. Ook Taylor et al (1984) vonden dat vrouwen met borstkanker die meer controle rapporteerden, beter scoorden op allerlei aanpassingsmaten. Het maakte daarbij niet uit of ze het gevoel hadden zelf controle te hebben (interne locus of control), of dat ze vonden dat de arts de controle heeft (externe locus of control). Of er een relatie is tussen dit soort controle en de causale attributies voor de ziekte wordt niet duidelijk. Berckman en Austin (1993) tenslotte komen tot een tegengestelde bevinding; zij vonden geen relatie tussen gevoel van controle en aanpassing. Het maakte niet uit of de patiënt interne of externe attributies had.

Een van de mogelijkheden om vanuit het verleden invloed te hebben op de toekomst zou lopen via attributies waarin sprake is van zelfbeschuldiging. Als iemand zichzelf beschuldigt heeft hij immers ook de mogelijkheid tot verandering en daarmee de controle in eigen hand. Zelfbeschuldiging is onder te verdelen in gedragsmatige en karakterologische zelfbeschuldiging (Janoff-Bulman1979). De gedragsmatige variant heeft betrekking op gedrag in het verleden, dat als oorzaak van de gebeurtenis wordt gezien; deze biedt de meeste mogelijkheden tot verandering. De karakterologische variant slaat op de persoonlijkheid, welke moeilijker is te veranderen. Kans-attributies zouden de minste aanknoping voor controle bieden en derhalve vermeden worden (Janoff-Bulman \& Wortman 1977). Taylor et al (1984) vonden bij vrouwen met 
borstkanker inderdaad een gematigd positieve correlatie tussen zelfbeschuldiging en aanpassing en vonden bovendien dat, wanneer anderen werden beschuldigd, dit samenging met minder aanpassing. In onderzoek van Timko en Janoff-Bulman (1985) bleken vrouwen die het feit dat ze kanker hadden eerder aan hun gedrag dan aan hun karakter toeschreven, meer vertrouwen te hebben dat zij in de toekomst de terugkeer van de kanker konden voorkomen. Recenter vonden Malcamer en Compas (1990) eveneens een significante correlatie tussen gedragsmatige zelibeschuldiging en het gevoel van controle over het verloop van de ziekte (zie Beckmann \& Austin 1993). Burgess et al (1988) daarentegen vonden juist dat kankerpatiënten met attributies waarin zij zichzelf beschuldigen, significant hoger scoorden op depressie, en Houldin et al (1996) dat hogere niveaus van zelfbeschuldiging samengingen met lagere scores op aanpassing.

Over de rol van schuld in relatie tot controle en aanpassing bestaat dus niet veel overeenstemming. In paragraaf 2-2-1 kwam reeds aan de orde dat het copingproces de volgende drijfveren kent: (1) het verlangen het geloof in de 'rechtvaardige wereld' vast te houden,(2) het verlangen zichzelf tegen gevoelens van schuld te beschermen en (3) het verlangen een gevoel van controle te behouden (Janoff-Bulman \&Wortman 1977). Het is niet onwaarschijnlijk dat deze drie drijfveren verschillende en misschien zelfs conflicterende manieren vereisen voor het omgaan met de schuldvraag. Zo vonden Chodoff, Friedman en Hamburg (1964) dat ouders van kinderen met leukemie het een geruststellender idee vonden dat zij er zelf schuldig aan waren dan dat er geen oorzaak bekend was, en vond Wortman (1983) dat slachtoffers van verkrachting paradoxaal genoeg soms hun eigen causale rol - en daar mee hun schuld - groter maakten dan reëel was. Wortman merkte daarbij op dat 'blaming oneself may be more tolerable than the conclusion that no one knows who is to blame and/or that the person is living in a meaningless chaotic world where events occur at random'. In deze voorbeelden zijn klaarblijkelijk het behoud van het geloof in de rechtvaardige wereld en het behoud van een gevoel van controle zo belangrijk dat ze ten koste gaan van het verlangen zichzelf tegen gevoelens van schuld te beschermen. Daarentegen zijn er ook aanwijzingen, dat slachtoffers van negatieve gebeurtenissen juist beter af zijn wanneer ze geloven dat ze niet verantwoordelijk zijn voor de gebeurtenis (Brickman et al 1982) of zelfs helemaal niet naar een oorzaak zoeken (Gotay 1985, Lowery 1993).Veel kankerpatiënten lijken overigens hun ziekte toe te schrijven aan oncontroleerbare factoren, waaraan ze geen schuld hebben (Buddeberg et al 1991 , Wolf et al 1995, Lavery et al 1996). Tegelijkertijd komt - zoals eerder in deze paragraaf is beschreven - het verschijnsel schuldontlastende attributie veel voor bij kankerpatiënten.

In dit verband is het interessant dat verschillende onderzoekers hebben geconstateerd dat mensen gemakkelijk meerdere oorzaken voor hun kanker naast elkaar kunnen hebben (Taylor \& Brown 1994, Wolf et al 1995 en Sensky 1997). De meest 
simpele lekenmodellen over ziekte en behandeling bestaan uit complexe ketens van attributies die met elkaar verbonden zijn, maar tevens ook omkleed zijn met ambivalentie en twijfel. Twijfel biedt de mogelijkheid tussen alternatieven te switchen, naar gelang de situatie er om vraagt (Taylor \& Brown 1994 en Sensky 1997). Het zou dan ook niet zo van belang zijn welke specifieke attributies de 'denkarbeid' oplevert maar het denkproces zelf zou al helpen bij de verwerking (Taylor 1983, Wolf et al 1995).

De kwestie hoe attributies, controle en aanpassing zich tot elkaar verhouden kent ook een situationele component. Glanz et al (1992) wijzen er op dat de behoefte aan controle niet in alle situaties tot aanpassing leidt. Zij verwijzen naar Lerman et al (1990) die vonden dat een monitoring copingstijl - dat wil zeggen alles in de gaten houden en controle willen hebben - tijdens de periode van chemotherapie samenging met hogere angstniveaus en meer misselijkheid, terwijl afleiding zoeken geassocieerd was met lagere angst en depressie en minder misselijkheid. In het begin van de ziekte, vlak na de diagnose, bleek behoefte aan controle in de vorm van informatie zoeken en willen weten wat de ziekte inhoud en controle bij de planning van de behandeling wel tot betere aanpassing te leiden. Janoff-Bulman en Wortman (1977) verwoordden het als volgt: 'Although exaggerated feelings of personal control may generally be adaptive, they can be maladaptive when the individual is confronted with a permanent, non-modifiable outcome'. Dit laatste is dikwijls het geval bij kanker.

Samenvattend kan worden geconcludeerd dat tussen de $70 \%$ en $95 \%$ van de mensen die leiden aan een ernstige ziekte, een causale attributie heeft over het ontstaan. Er is echter weinig consensus over de aanpassende waarde. Dit is gedeeltelijk terug te voeren tot het feit dat er weinig consensus bestaat over de precieze functie van causale attributies (Sensky 1997). Uit de literatuur blijkt dat causale attributies niet alleen dienen om controle over de situatie te verkrijgen, maar ook een rol spelen bij betekenisverlening in meer filosofische zin en bij schuldontlasting. Mogelijk zijn dit conflicterende functies waardoor er geen eenduidigheid is over de aanpassende waarde in het algemeen. Daarbij komt dat er slechts zelden onderscheid wordt gemaakt in soorten causale attributies. Het begrip wordt gebruikt voor zowel oorzaak-gevolg relaties, schuldontlasting, betekenisverlening, labelingsprocessen en sociale afleidingen. Ook dit maakt het moeilijk de relatie tussen causale attributies en aanpassing eenduidig vast te stellen. Tenslotte wordt het begrip causale attributie - als bron voor retrospectieve controle - valk ten onrechte verbonden met het begrip Tocus of control'; i.e. daar waar de persoon meent dat de controle over de situatie ligt. Voor een ziekte als kanker geldt in ieder geval dat een opvatting over de (vermeende) oorzaak meestal geen aanknopingspunten biedt voor controle over symptomen of gevolgen van de ziekte. 


\section{2 - 2 - 4 - Coping volgens Lazarus en collega's}

\section{Het theoretisch model}

De groep rond Lazarus, Cohen en Folkman ontwikkelde een model voor coping, waarin vier stappen worden onderscheiden (Lazarus \& Launier 1978, Cohen \& Lazarus 1979, Lazarus \& Folkman 1984, Lazarus 1991 en Lazarus 1993). (1) Het copingproces start met de eerste, fundamentele inschattingen die een persoon maakt in een nieuwe situatie, de zogenaamde primary appraisals. Het zijn inschattingen of de situatie gevaar oplevert en of er iets op het spel staat. (2) Daarna volgen secondary appraisals. Dit zijn opnieuw inschattingen maar ditmaal gaan ze over de mogelijkheden die het individu zichzelf toedicht. $\mathrm{Hij}$ schat als het ware zijn eigen copingarsenaal in. Er zijn drie gebieden waarop deze secundaire inschattingen zich richten. Het eerste betreft verantwoordelijkheid en invloed. Hierbij horen vragen als 'wie of wat is verantwoordelijk voor de situatier', 'in welke mate heeft die instantie de controle?' en 'wat zijn mijn eigen mogelijkheden om invloed uit te oefenen?' Het tweede terrein van de secundaire appraisals is dat van de eigen vaardigheden: 'wat kan ik?' en 'is dat voldoende in deze situatie?'. Ten slotte zijn er secundaire appraisals over de toekomst. Zij gaan over de afloop, maar ook over toekomstige copingmogelijkheden zoals: 'hoe zal het uitpakken?', 'zal ik het volhouden?', 'hoe moet het dan verder?'. (3) Na de inschattingen volgt de coping-inspaming in een poging het hoofd te bieden aan de situatie. (4) Tenslotte volgt de evaluatie van de eenmaal ingezette copingacties. Met vragen als hoe gaat het?', 'bereik ik mijn doel?', 'hoe doe ik het ten opzicht van anderen?' en dergelijke wordt het effect van de coping beoordeeld en eventueel bijgesteld. De evaluatie behoort eveneens tot de secundaire inschatting. Daarmee is de cirkel rond. Op grond van de evaluatie volgen nieuwe copingacties, waarmee een nieuwe cyclus in gang wordt gezet.

Essentieel in het model zijn de appraisals. Deze nemen een centrale plaats in en sturen het copingproces. Dit betekent dat de beoordeling door het individu en de manier waarop hij kan omgaan met de ervaren bedreiging - coping dus - een cruciale rol spelen bij de uitkomst. De gevolgen van een situatie zijn derhalve niet zonder meer toe te schrijven aan de objectieve aspecten van die situatie. Onderzoek naar psychosociale gevolgen van kanker en andere ernstige ziekten ondersteunt deze opvatting. Bij herhaling is gebleken dat verschillen in aanpassing, psychisch welbevinden en kwaliteit van leven eerder zijn toe te schrijven aan de subjectieve inschattingen over de ziekte, de gevolgen en de eigen mogelijkheden dan aan de objectieve biomedische factoren van die ziekte (Jenkins \& Pargament 1988, Ell et al 1989. Filipp et al 1990, De Haes et al 1991, Dunkel-Schetter et al 1992, Boer et al 1992, Edgar et al 1992, Glanz \& Lerman 1992, Carver et al 1993, Heyink 1993, Sensky 1997 en vele anderen). 


\section{Verschillende soorten coping}

Er zijn verschillende manieren om een situatie het hoofd te bieden. Op de eerste plaats is er een onderscheid tussen probleem-georiênteende en emotie-georiènteerde coping. Hiermee wordt aangegeven waarop de coping zich richt. Probleem-georiēnteerde coping is direct gericht op de verstoorde relatie tussen de persoon en zijn omgeving. Het doel is deze te veranderen van problematisch naar niet of minder problematisch. Emotie-georiënteerde coping richt zich niet op de situatie zelf, maar is ofwel gericht op de beleving ofwel op de emotionele gevolgen. Wanneer een patiènt bijvoorbeeld aanvankelijk kanker ziet 'als een dodelijke ziekte waar geen kruid tegen is gewassen' kan hij door voorlichting of vergelijking met lotgenoten zijn mening bijstellen tot 'kanker is weliswaar een ernstige ziekte, maar met een goede behandeling en wat geluk kun je ervan genezen'. In feite is er niets aan zijn objectieve situatie veranderd, maar de kans is groot dat hij zich door verandering in de beleving minder verdrietig, angstig of boos zal voelen. Bovendien bestaat de kans dat hij vanuit die veranderde houding gemotiveerder de ingrijpende behandelingen kan en wil ondergaan.

Ook is er het onderscheid tussen gedragsmatige en cognitiete coping. Gedragsmatige coping is 'iets doen', cognitieve coping is 'iets bedenken'. Gedragsmatige coping richt zich er meestal op daadwerkelijk iets aan de situatie te veranderen. Cognitieve coping daarentegen heeft over het algemeen als doel de betekenis van de situatie te veranderen of de emotionele gevolgen hanteerbaar te maken. De indeling gedragsmatige versus cognitieve coping loopt derhalve voor een groot deel parallel aan die tussen probleem- versus emotie-georiënteerde coping, maar valt er niet helemaal mee samen. Afleiding zoeken door te gaan sporten is een voorbeeld van 'iets doen' zonder dat dit de situatie verandert. Deze actie is vooral gericht op de emotionele consequenties: even vergeten, even afstand nemen. Hetzelfde geldt voor alcoholgebruik.

De meeste onderzoekers zijn het er over eens dat omgaan met kanker en andere ernstige ziekten vooral bestaat uit emotie-gerichte coping en dus uit de cognitieve component van het copingproces. Volgens Morris, Blake en Buckley (1985) beperken de copingmogelijkheden van een kankerpatiënt zich tot wat zij noemen: the manipulation of meaning of the experience in order to tolerate the anxiety caused by the essentially ambiguous nature of the stress, and the handling of the painful emotions which remain after such manipulation of meaning'. Aangezien tegen aantasting of bedreiging van de gezondheid maar tot op zekere hoogte actie kan worden ondernomen, zal er veeleer een vorm van psychologische beheersing moeten plaatsvinden (Taylor, Wood \& Lichtman 1983, Lazarus 1993). Probleem-oplossend gedrag zou, in situaties waarin niets zinnigs kan worden gedaan om de situatie te veranderen, zelfs contraproductief zijn (Burgess et al 1988, Lazarus 1993, Filipp et al 1990). 
Van der Hart (1991) geeft de volgende indeling van cognitieve strategieén: (1) het vinden van een oorzaak, (2) het vergelijken van de eigen ervaring met die van anderen, (3) isolatie, dat wil zeggen het inperken van de betekenis van de gebeurtenis en (4) het herordenen van het bestaan. De functie van deze cognitieve strategieèn is de ervaren machteloosheid en ontwrichting zoveel mogelijk te minimaliseren.

\section{Van theorie naar factoranalyse}

Een aantal onderzoekers heeft het copingmodel van Lazarus en collega's vertaald naar coping met ernstige ziekte. Greer, Moorey en Watson (1989) blijven heel dicht bij het oorspronkelijke model. Zij definièren aanpassing aan kanker als 'the cognitive and behavioural responses made by an individual to the diagnosis of cancer'. Zij vervolgen: 'Mental adjustment comprises appraisal i.e. how the patient perceives the implications of cancer, and the ensuing reactions i.e. what the patient thinks and does to reduce the treat imposed by the disease'. Op basis van klinische ervaring en interviews met kankerpatiēnten benoemen zij vier manieren waarop coping met kanker zou plaats vinden (Greer\& Silberfarb1982): (1) vechtlust, (2) ontkenning/ vermijding, (3) hulpeloosheid/hopeloosheid, (4) fatalisme/stö̈cijnse acceptatie. Later voegen zij daar nog een vijfde manier aan toe: (5) angstige preoccupatie (Greer et al 1989).

Anderen uit dezelfde onderzoeksgroep hebben geprobeerd de afzonderlijke responsen waaruit de eerste vier copingwijzen zijn opgebouwd te identificeren (Morris et al 1985 en 1986, Burgess et al 1988). Uitgebreide analyses van interviews met kankerpatiënten leverden een gedetailleerde beschrijving op van tien verschillende soorten 'appraisal responses', uitspraken die betrekking hebben op de evaluatie van de diagnose en die gericht zijn op de notie dat men kanker heeft. Verder werden er negen 'palliative responses' geïdentificeerd, waarmee de patiënt gedachten over de kanker manipuleert om de psychische consequenties te verkleinen. Tenslotte waren er nog zes 'confrontive responses': manieren om positief te denken over de gebeurtenis. Naast deze drie groepen van cognitieve responsen werden er nog negenentwintig gedragsmatige responsen benoemd. Op een gedetailleerder niveau bleek coping dus heel divers te zijn. Met behulp van factoranalyse is nagegaan of deze responsen inderdaad factoren opleverden die correspondeerden met de vier door Greer et al benoemde manieren van omgaan met kanker. Dat bleek in eerste instantie niet het geval. Vervolgens zijn de responsen tezamen met totaalscores van een aantal vragenlijstmetingen voor psychologische aanpassing bij elkaar in een pool gestopt en opnieuw aan factoranalyse onderworpen. Dit leverde uiteindelijk een viertal factoren op die niet helemaal precies samenvielen met de door Greer et al gepostuleerde copingwijzen, maar er volgens de onderzoekers wel veel verwantschap mee vertoonden. 
Conceptueel is het niet fraai om coping en aanpassing op één hoop te gooien. Dit gebeurde niet alleen bij de factoranalyses, maar ook de begrippen zelf werden niet van elkaar gescheiden, zoals blijkt uit het volgende citaat: 'several broad categories of adjustment to cancer have been delineated clinically. These coping styles .....' (Greer, Moorey \& Watson 1989; cursief M.O.). In dit geval was dat niet zo bezwaarlijk, aangezien de onderzoeken gericht waren op de relatie tussen copingstijl en overlevingsduur en niet zozeer op de relatie tussen coping en aanpassing. Wat wel te denken geeft is dat op grond van de hierboven beschreven reeks onderzoeken een vragenlijst is ontwikkeld waarin zowel copingstrategieën als aanpassingsmaten zijn opgenomen $^{5}$. Deze lijst is sindsdien veelvuldig als copingvragenlijst gebruikt, ook in onderzoek waar de relatie tussen coping en aanpassing juist wel het onderwerp van onderzoek was, zoals bijvoorbeeld bij Lavery en Clarke (1996) en Classen et al (1996). De scheidslijn tussen aanpassing (de uitkomst) en coping (de weg waarlangs) is in het algemeen lastig te trekken. In paragraaf 2-4, waar enkele conceptuele en methodologische aspecten van het coping-onderzoek aan de orde komen, zal hier nader op in worden gegaan.

Velen hebben, vaak impliciet, de ideeën van Lazarus et al als uitgangspunt genomen om copingstrategieën van kankerpatiënten te identificeren en deze op een of andere manier aan een maat voor aanpassing te koppelen. Bijna al dit onderzoek berust op factoranalyses. Op deze wijze is er een woud aan factoranalytisch gegroepeerde items en uitkomstmaten ontstaan. Deze factoren die vervolgens copingswijzen worden genoemd, komen gedeeltelijk overeen, overlappen elkaar of zijn met enige fantasie in elkaar te vertalen. Dit laatste is niet altijd gemakkelijk, omdat het dikwijls aan definities ontbreekt en ook omdat het regelmatig voorkomt dat één en hetzelfde item bij verschillende onderzoekers in een verschillende factor terecht is gekomen.

Ook Folkman en Lazarus (1988) ontwierpen een copingvragenlijst, de Ways of Coping Scale (WCS), die de volgende acht factoren bevat: (1) confrontive coping, (2) distancing, (3) self-controlling, (4) seeking social support, (5) accepting responsibility, (6) escape-avoidance, (7) planful problem solving en (8) positive reappraisal. Deze vragenlijst is vaak gebruikt, ook in kankeronderzoek. Een aantal onderzoekers is echter van mening dat de lijst niet alle copingreacties meet die voorkomen in situaties die gerelateerd zijn aan ziekte. Om die reden hebben bijvoorbeeld Felton et al (1984) enkele ziekte-specifieke items aan de WCS toegevoegd. Na factoranalyse kwamen zij tot zes factoren. Carver et al (1993) ontwikkelden om dezelfde reden een eigen copinglijst, de COPE, die twaalf verschillende copingschalen bevat. Heim et al (1987, 1993 en 1997) kwamen zelfs tot 26 verschillende categorieën in hun BFO (Bernese Coping Modes).

\footnotetext{
${ }^{5}$ De MAC: Mental Adjustment to Cancer (Watson et al 1989)
} 
Om zicht te krijgen op wat er nu zoal aan copingstrategieën wordt genoemd, zijn de publicaties van een tiental onderzoeksgroepen geinventariseerd, die zich op coping met kanker hebben gericht. De door hen onderzochte copingstrategieèn zijn op een rij gezet. Het overzicht is weergegeven in onderstaand overzicht. Strategieẽn die op elkaar lijken zijn bij elkaar geplaatst en van een gemeenschappelijke noemer voorzien. Wanneer er onder één noemer meerdere strategieën van dezelf́de auteur staan vermeld, wil dat zeggen dat deze ze afzonderlijk heeft benoemd. Sommige strategieèn bevatten elementen die bij verschillende noemers horen en zijn dan ook onder meerdere noemers geplaatst.

\section{Overzicht van coping bij kanker}

1) Afleiding zoeken:

2) Vermijden:

3) Ontkennen:

4) Onverschilligheid:

5) Wensdenken:

6) Aistand nemen:
Irying to stay physically busy and mentally occupied (Benedict ef al 1994), thought as diversion (Heim et al 1987, 1993 en 1997), self-distraction (Carver et al 1993 en 1994), behavioural escape-avoidance (Dunkel-Schetter $e t$ al 1992) activity as diversion (Heim $\boldsymbol{e}$ al 1987,1993 en 1997; bevat ook elementen van positief herwaarderen, zoals 'ik neem nu meer tijd voot mijzelf' en 'ik weet nu hoe betrekkelijk alles is?), planning positive actions and events (Morris of al 1985 en 1986, Burgess et al 1988; met daarin ook elementen van positief denken) avoidance (Greer et al 1982), active avoidance (Heim et al 1987, 1993 en 1997). patient claims not to have considered outcome (larrett et al 1992), blocking i.e. trying to expunge from the mind thoughts of the event (Morris et al 1985 en 1986, Burgess et al 1988. Benedict et al 1994), escape avoidance (Folkman \& Lazarus1988; bevat ook wishful thinking), cognitive escape-avoidance (Jarrett $e t$ al 1992, Dunkel-Schetter ot al 1992; bevat ook wishful thinking), avoidance of relevant information (Jarrett $\boldsymbol{c}_{\text {al }}$ 1992), active attempts to return to normal (Jarrett et al 1992; lijkt op actieve coping maar heeft ook elementen van vermijden)

denial (Greer ef al 1982, Carver ot al 1993 en 1994; bevat items variërend van echte ontkenning tot wishful thinking), dissimulation (Heim et al 1987, 1993 en 1997: bevat denying en ignoring maar ook minimisation), threat minimisation (Filipp et at 1990 ; i.e. het besluit dat men niet in de ziekte wil zwelgen maar dat men gedachten opzij wil zetten. Bevat naast verkleinen van de dreiging ook elementen van vermijiden!

lacks concern about the event (Morris et al 1985 en 1986, Burgess et al 1988) wishful-fulfilling fantasy (Felton et al 1984), compensation (Heim et al 1987. 1993 en 1997; items zijn op te vaten als wishful thinking), escape avoidance (Folkman \& Lazarus 1988; bevat wishful thinking)

distancing (Folkman \& Lazarus1988; bevat ook items die op ontkennen en op vermijiden lijken, idem bij Dunkel-Schetter et al 1992), dissociation (Morris $\alpha$ al 1985 en 1986. Burgess et al 1988; wordt omschreven als 'sense of detachment from the event) 
7) Opknippen:

8) Dreiging reduceren:

9) Positief denken:

10) Positief herwaarderen:

11) Compenseren:

12) Befekenisverlening:

13) Religie en bidden:

14) Steun zoeken: partializing (Morris ef al 1985 en 1986, Burgess of al 1988; wordt omschreven als concentrating on limited aspects of event rather than broad view)

threat minimisation (Felton et al 1984, Filipp ef al 1990; i.e. besluit dat men niet in de ziekte wil zwelgen maar dat men gedachten eraan opzij wil zetten. Bevat elementen van vermijden), dissimulation (Heim et al 1987, 1993 en 1997; bevat minimisation maar ook denying en ignoring), believes will suffer no adverse consequences Jarrett et al 1992. Morris ef al 1985 en 1986. Burgess et al 1988), finds seriousness of event unreal (Morris et at 1985 en 1986, Burgess of al 1988), claims more pressing concern(s) than that of the event (Morris ef al 1985 en 1986, Burgess et al 1988)

fighting spirit (Greer el al 1982), hopeful (Benedict 1994), optimism (Heim et al 1987. 1993 en 1997), adopting a positive approach (Morris ef al 1985 en 1986, Burgess of at 1988). sees event as a challenge (Morris et al 1985 en 1986. Bungess ot al 1988). focussing on the positive (Dunkel-Schetter et al 1992; bevat ook elementen van positief herwaarderen), planning positive actions and events (Morris el al 1985 en 1986, Burgess et al 1988; bevat ook afleiding zoeken), behaviour to aid recovery (Jarretl $t$ al 1992; bevat veel elementen van positief denken, daamaast ook onderdelen van iets aan de situatie doen)

positive reappraisal (Folkman \& Lazarus1988), positive reframing (Carver ef al 1993 en 1994), focussing on the positive (Dunkel-Schefter el al 1992; bevat eveneens elementen van optimisme en positief denken), cognitive restructuring (felton $e t a l$ 1984), constructive activity (Heim et al 1987, 1993 en 1997), positive reappraisal of illness and life (Jarrett et al 1992), changing perception of life in ways subject believes will of benefit (Morris et al 1985 en 1986, Burgess et al 1988), valorisation (Heim et al 1987, 1993 en 1997)

counterbalancing positive aspects of life with stress of events (Morris of al 1985 en 1986, Burgess et al 1988)

giving meaning (Heim et al 1987, 1993 en 1997)

religion (Carver et al 1993 en 1994), religiousness (Heim et al 1987, 1993 en 1997), using religion (Morris ot al 1985 en 1986, Burgess ot al 1988), search for meaning in religion (Filipp et al 1990), religion and prayer (Jarrett et al 1992); using prayer (Morris et al 1985 en 1986, Burgess et al 1988), prayer (Benedict et al 1994)

seeking social support (Folkman \& Lazarus1988, Dunkel-Schetter 1992 en farrett et al 1992), seeking reassurance and information through sharing and talking with others (Benedict1994), using social support (Carver et al 1993 en 1994), search for affiliation (Filipp et al 1990), attention and care (Heim ef al 1987, 1993 en 1997)

15) Zich er bij neerleggen: fatalistic and passive acceptance (Jarrett et al1992), fatalism (Greer ot al 1982). patient passively accepts the event (Morris of al 1985 en 1986, Burgess of al 1988), passive co-operation (Heim et al,1987, 1993 en 1997)

stoic acceptance (Greer et al 1982), acceptance (Carver et al 1993 en 1994), acceptation-stoicism (Heim et al 1987, 1993 en 1997), realistic acceptance (Jarrett et al 1992), persevering composure (Heim et al 1987, 1993 en 1997) 
17) Zich terugtrekken/ opgeven:

19) Onderdrukken van gevoel:

20) Humor:

21) Relativeren:

22) Angstige gedachten:

23) Oorzaakstoekenning:

24) Plannen:

25) Verantwoordelijkheid nemen/zeltbeschuldiging; helplessnesshopelessness (Greer ef al 1982), restraint (Carver af al 1993 en 1994). resignation (Heim of al 1987, 1993 en 1997) (social) withdrawal (Heim ef al 1987, 1993 en 1997), social avoidance (Jarrett et al 1992), behavioural disengagement (Carver et al 1993 en 1994)

expressing of emotional strain such as getting angry or joking about the illness (felton et al 1984), emotional release (Heim ef al 1987, 1993 en 1997), release of anger (Heim ef al 1987, 1993 en 1997), rebelling (Heim ef al 1987, 1993 en 1997), anget (Jarrett ef al 1992). directing anger (Morris et al 1985 en 1986, Burgess et al 1988). rehearsing emotions anticipated in response to event and consequences (Morris $a t$ ' 1985 en 1986, Burgess $\alpha$ al 1988) confrontive coping (Folkman \& Lazarus 1988; bevat ook elementen van expressie van emotie, met name boosheid)

self-controlling (Folkman \& Lazarus1988), isolation-suppression (Heim ef al 1987. 1993 en 1997)

use of humour (Carver ef a/ 1993 en 1994, larrett ef al 1992, Morris et al 1985 en 1986, Burgess et al 1988)

relativizing (Heim ef al 1987, 1993 en 1997)

anxious preoccupation (Greer ef al 1982), fear of diagnoses Uarrett ef al 1992), patient expresses fear in relation to the event and its possible development (Morris et al 1985 en 1986, Burgess et at 1988), fear of treatment (farrett et al 1992), uncentainty whether will suifer adverse consequences (Jarrett et al 1992), believes probably/certainly will suffer adverse consequences (Jarrett et al 1992), sees event as a severe threat to value aspects of life (Morris et at 1985 en 1986, Burgess et al 1988), believes has little/no control (Jarrett et al 1992), thought intrusion (Carver ef al 1994), rumination (Filipp et al 1990, Heim et al 1987, 1993 en 1997)

attributes event to a specific lactor (Morris et al 1985 en 1986, Burgess et al 1988)

planful problem solving (Folkman \& Lazarus1988), planning (Carver et al 1993 en 1994), problem analysis (Heim et al 1987, 1993 en 1997)

accepting responsibility (Folkman \& Lazarus1988; bevat ook elementen van zelfbeschuldiging), self-blame (Felton et al 1984), self-accusation (Heim et al 1987, 1993 en 1997 )

26) De situatie onder ogen zien en proberen er iets an te doen:

27) Informatie zoeken: confrontive coping (Folkman \& Lazarus 1988; bevat ook elementen van expressie van emotie met name boosheid), active coping (Carver et al 1993 en 1994), active attempts to return to normal (Jarrett et al 1992; lijkt op actieve coping maar heeft ook elementen van vermijiden), behaviour to aid recovery (Jarrett ef al 1992), tackling (Heim et al 1987, 1993 en 1997), fighting spirit (Greer et al 1982)

information seeking (Felton et al 1984, Filipp et al 1990, larrett et al 1992), tackling (Heim et al 1987, 1993 en 1997; hieronder wordt verstaan actief met de ziekte bezig zijn, informatie zoeken maakt hier onderdeel van uit)

28) Geloof in eigen invloed: believes can have some control over outcome (Jarrett ot al 1992), exerting imaginative control over outcome (Morris ef al 1985 en 1986, Burgess ef al 1988)

29) Geloof in exteme asigning control to others, God, or other external tactors (Morris at al 1985 en 1986. invloed: Burgess ef al 1988) 
Uit het overzicht blijkt de diversiteit in naamgeving en definities, evenals de geringe consensus over de vraag welke copingstrategieën kankerpatiënten nu precies gebruiken. Daarbij komt dat veel auteurs strategieèn tot clusters hebben samengevoegd. De clusters bevatten dikwijls gedeeltelijk dezelfde strategieën, vaak net in een andere combinatie. Een van de vele voorbeelden die ter illustratie verder wordt uitgewerkt, is het onderzoek van Shapiro et al (1997). De auteurs komen tot de volgende clusters van karakteristieken van kankerpatiënten: (1) confrontive: de patiënten zijn optimistisch over de toekomst, zoeken informatie, willen betrokken worden bij beslissingen, gaan gesprekken over kanker niet uit de weg, doen niet aan cognitieve vermijding en zoeken geen afleiding, (2) avoidant-confrontive: de patiènten zoeken informatie, zijn optimistisch over de toekomst, willen betrokken worden bij beslissingen, spreken niet met vrienden over de ziekte, doen aan cognitieve vermijding en zoeken afleiding, (3) avoidant-resigned: patiënten zijn optimistisch over de toekomst, willen niet betrokken worden bij beslissingen, doen aan cognitieve vermijding, spreken niet met vrienden over de ziekte en zoeken afleiding en (4) resigned: de patiënten zijn pessimistisch over de toekomst, willen niet betrokken worden bij beslissingen, zoeken geen informatie, praten wel met vrienden over de ziekte, zoeken geen afleiding en doen niet aan cognitieve vermijding. Dergelijke clusters zijn niet in het overzicht ondergebracht. In feite is het woud aan strategieën nog ondoorzichtiger dan het overzicht al doet vermoeden (zie ook Coyne 2000).

Hoewel er weinig overeenstemming bestaat over de precieze inhoud en naamgeving, zijn bijna alle auteurs het er wel over eens dat, analoog aan Lazarus, copingstrategieën zijn in te delen in strategieën die (1) het probleem direct aanpakken, (2) de betekenis van het probleem beïnvloeden en (3) zich richten op de emotionele gevolgen van het probleem. Deze drie groepen sluiten elkaar niet uit. Soms dient eenzelfde actie meerdere van deze doelen, soms ook vragen verschillende doelen juist tegengestelde acties.

\section{Coping en aanpassing aan kanker}

Het is vaak onduidelijk of strategieën met (ongeveer) dezelfde naam ook inhoudelijk gelijk zijn. Dit maakt het moeilijk algemene uitspraken te doen over het effect van een strategie. Toch zijn er trends aan te geven. Tabel 1.2 op pagina $\$ 5$ is een samenvatting van een aantal artikelen over dit onderwerp. Strategieèn die een negatief effect lijken te hebben zijn: 'thought intrusion', 'social withdrawal', 'emotional ventilation', 'anger' en 'wishful thinking'. Andere zoals 'fighting response', 'optimism', 'positive reframing' en 'focussing on the positive' lijken positief uit te werken. Daarnaast zijn er strategieën waarvoor geen eenduidige resultaten zijn gevonden. 
Er is een aantal verklaringen voor deze tegenstrijdige bevindingen. Het kan zijn dat onder dezelfde noemer inhoudelijk verschillende strategieën zijn onderzocht, waardoor verschillende uitkomsten zijn gevonden. In dat geval zijn tegenstrijdige bevindingen terug te voeren tot het definitieprobleem. Verder kan het effect van een strategie afhangen van de specifieke eisen die de situatie stelt of van de fase van het ziekteproces waarin de patiènt verkeert. Een strategie die tijdens chemotherapie een gunstig effect heeft, hoeft niet positief uit te pakken wanneer de ziekte in rustiger vaarwater is, of andersom (Lerman et al 1990, Heim et al 1997). Dit kan paradoxale bevindingen opleveren, waardoor enerzijds vermijding en afleiding en anderzijds juist probleemoplossing en actieve coping gunstige strategieèn lijken te zijn (Suls 1985 in Glanz en Lerman 1992). Overigens is er weinig bekend over specifieke coping in verschillende stadia van het ziekteproces (Carver et al 1993 en 1994).

Een andere verklaring is dat een bepaalde copingstrategie verschillende uitkomstmaten verschillend beïnvloedt. Escape-avoidance zou bijvoorbeeld positief zijn voor distress, maar negatief voor sociaal functioneren. En Manne et al (1994) toonden bijvoorbeeld aan dat, wanneer het algemene begrip 'stemming' wordt opgesplitst in positief en negatief affect, sommige copingstrategieèn op de ene pool wel en op de andere pool geen effect hebben. Aan de vraag of een copingstrategie een gunstige uitwerking heeft, zou volgens Lazarus (1993) dan ook moeten worden toegevoegd: 'gunstig waarvoor?'.

Tenslotte blijken maar weinig strategieën een unieke bijdrage aan aanpassing te leveren. Veel van de variantie zou het gevolg zijn van een combinatie van strategieën (Carver et al 1993 en 1994). Tegenstrijdige uitkomsten kunnen berusten op verschillen in de onderzochte combinaties. Dat de meeste patiënten inderdaad meerdere strategieèn gebruiken, blijkt uit de vele verwijzingen op dit punt in het overzichtsartikel van Glanz en Lerman (1992). In de literatuur is dan ook veel evidentie voor de adaptieve waarde van een breed coping-repertoire (Jarrett et al 1992). Volgens Heim et al (1987) gebruikt een kankerpatiënt er gemiddeld zelfs tien.

Een aantal copingstrategieèn zoals denial, avoidance, selective ignoring, threat minimisation, dissimulation en dergelijke behoort tot de afweermechanismen. $\mathrm{Er}$ is veel over deze strategieën geschreven, ook in relatie tot omgaan met kanker. $\mathrm{Ze}$ worden daarom in de volgende paragraaf apart besproken. 


\begin{tabular}{|c|c|c|c|}
\hline STRATEGIE & POSIIIFF EFIECT & GEEN EFFECT & NEGATIE HFEC \\
\hline $\begin{array}{l}\text { denigl } \\
\text { avoidance/ } \\
\text { escape-avoidance }\end{array}$ & 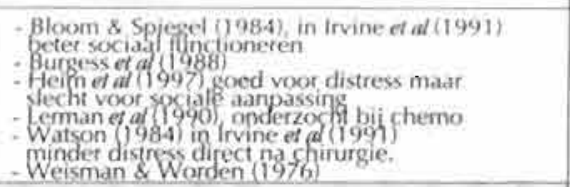 & $\begin{array}{l}\text { - Classen ef al (1996) } \\
\text { Aetson ef af } 1994 \text { ) } \\
\text { Geen eenduidig elfer }\end{array}$ & 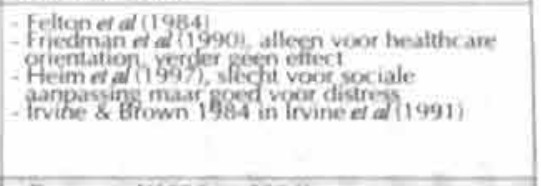 \\
\hline wishful thinking & 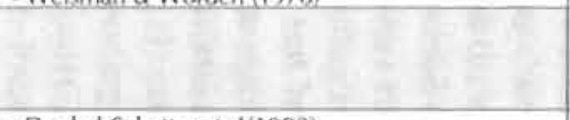 & - & 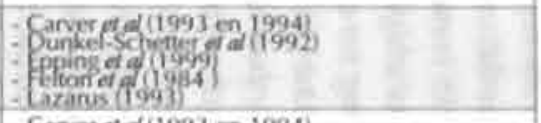 \\
\hline $\begin{array}{l}\text { distancing/ } \\
\text { disengagement }\end{array}$ & 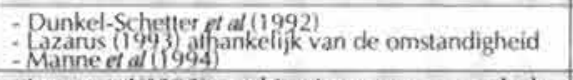 & & $\begin{array}{l}\text { - Carver ef } 6 \text { (f } 1993 \text { en } 1994) \\
\text { - Lazarus } 1993 \text { athankelijkan de camstandigheid }\end{array}$ \\
\hline selective ignoring & 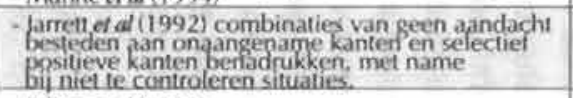 & & \\
\hline $\begin{array}{l}\text { threat minimisation/ } \\
\text { dissimulation }\end{array}$ & $\begin{array}{l}\text { Filipp fod (1990) } \\
\text { Orim \& Meyer (1990) }\end{array}$ & & \\
\hline $\begin{array}{l}\text { thought intrusion } \\
\text { rumination }\end{array}$ & 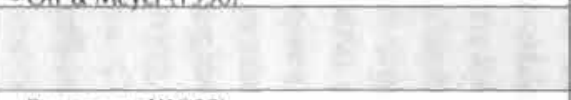 & - & 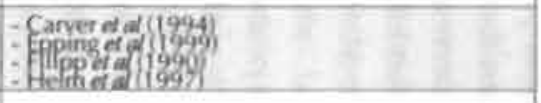 \\
\hline fighting response & $\begin{array}{l}\text { Burgess et al (1988) } \\
\text { Cyasen et dil } 996) \\
\text { Friedman ed }(1990)\end{array}$ & & 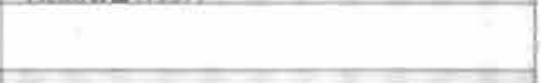 \\
\hline optimism & 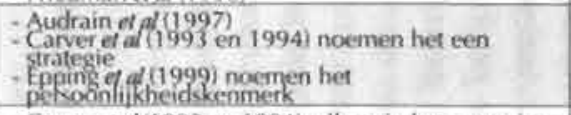 & & \\
\hline $\begin{array}{l}\text { positive reframing/, } \\
\text { postive reappraisal } \\
\text { cognutive nemaming } \\
\text { redefinition }\end{array}$ & 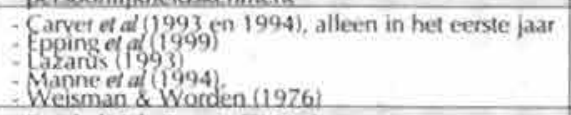 & & \\
\hline focussing on the positive & Dunkel-Schetter ef al (1992) & +2 & \\
\hline (stoic) acceptance & $\begin{array}{l}\text { Burgess ef id (1983) } \\
\text { Carver ef ad } 1993 \text { en 1994) } \\
\text { Heim ei dat }(997)\end{array}$ & & - Weisman \& Worden (1976) \\
\hline fatalism & 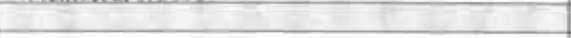 & - Classen ef al (1996) & \\
\hline resignation & & & - Heim et del (1997) \\
\hline $\begin{array}{l}\text { conironting/ } \\
\text { active coping }\end{array}$ & $\begin{array}{l}\text { - Burgess et al }(1988) \\
\text { Shapiro ef d } 1997) \\
\text { Weisman \& Worden }(1976)\end{array}$ & - Carver el al (1993 en 1994) & - Lazanus (1993) \\
\hline problem solving & $\begin{array}{l}\text { - Bruder-Mattson \& Hovanitz (1990) } \\
\text { - Epping ft d (1999) } \\
\text { - Heim ed d }(1997) \\
\text { - Lezarus }(1993)\end{array}$ & & \\
\hline $\begin{array}{l}\text { information seeking } \\
\text { monitoring }\end{array}$ & - Felton ef al (1984) & $\begin{array}{l}\text { - Filippet af }(1990) \\
\text { - Hoppins } 1994 \text { in } \\
\text { inineet al (1991) }\end{array}$ & $\begin{array}{l}\text { - Audrain ef do (1997) } \\
\text { - Lermun ef d (1990), onderzocht bif shemo }\end{array}$ \\
\hline $\begin{array}{l}\text { seeking/ } \\
\text { using voial support }\end{array}$ & $\begin{array}{l}\text { - Dunkel-Schetter of al (1992) } \\
\text { - Heim of all (1997) }\end{array}$ & - Carvet ef al (1993 en 1994) & - Epping ed (1999) \\
\hline social withdrawal & & & $\begin{array}{l}\text { - Epring ef d (1999) } \\
\text { - Hemifogi) }\end{array}$ \\
\hline seli-controlling & - Munned el (1994) & & \\
\hline $\begin{array}{l}\text { emotional control } \\
\text { emotional ventilation }\end{array}$ & Heim (1991) & & 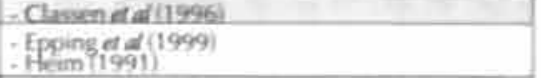 \\
\hline anger & & & - Heimef d (1997) \\
\hline religion & - Filipp ef al (1990) & & \\
\hline
\end{tabular}


Samenvattend blijkt dat veel van het coping-onderzoek berust op factoranalyses. Op deze wijze is er een woud aan copingvragenlijsten ontstaan, bestaande uit factoranalytisch gegroepeerde items die tezamen een factor vormen, welke vervolgens wordt opgevat als een manier van coping. De factoren afkomstig uit de verschillende onderzoeken komen gedeeltelijk overeen, overlappen elkaar of zijn met enige fantasie in elkaar te vertalen. Er bestaat dus een enorme diversiteit in naamgeving en definities. Wel zijn bijna alle auteurs het er over eens dat, analoog aan Lazarus, copingstrategieèn zijn in te delen in strategieën die (1) het probleem direct aanpakken, (2) de betekenis van het probleem beinvloeden en (3) zich richten op de emotionele gevolgen van het probleem.

Er wordt onderscheid gemaakt tussen probleem-georiënteerde en emotiegeoriènteerde coping, en tussen gedragsmatige en cognitieve coping. Beide indelingen lopen voor een groot deel parallel omdat gedragsmatige coping meestal gericht is op het daadwerkelijk veranderen van de situatie en cognitieve coping op het veranderen van de betekenis, dan wel op het hanteerbaar maken van de emotionele gevolgen van de situatie. De meeste onderzoekers zijn van mening dat omgaan met kanker en andere ernstige ziekten vooral bestaat uit emotie-gerichte coping en dus uit de cognitieve component van het copingproces.

Aangezien het dikwijls onduidelijk is wat er precies onder een bepaalde copingstrategie wordt verstaan, is het moeilijk iets met zekerheid te zeggen over het effect van een strategie. Strategieën die vooral een negatief effect lijken te hebben op de aanpassing aan kanker zijn 'social withdrawal', 'emotional ventilation', 'anger', 'thought intrusion', en 'wishtul thinking'. Anderen zoals 'fighting response', 'optimism', 'positive reframing' en 'focussing on the positive' lijken vooral positief uit te werken. Daarnaast zijn er strategieèn waarover geen eenduidigheid bestaat. Soms is dat te verklaren uit het feit dat de werking van de strategie is onderzocht in verschillende periodes na de diagnose, of omdat er verschillende uitkomstmaten zijn gebruikt. Ook is vaak onvoldoende gespecificeerd op welk aanpassingsgebied het effect is onderzocht. Tenslotte blijken maar weinig strategieën een unieke bijdrage te leveren. Veel van de variantie in aanpassing zou het gevolg zijn van een combinatie van strategieèn.

\section{2 - 2 - 5 - De rol van afweermechanismen en illusies}

De uitwerking van het begrip 'afweer' voert terug tot Anna Freud (1946, zie Hackett \& Cassem 1974). Dit geschiedde vanuit een psycho-analytisch denkkader waarbij er vooral aandacht was voor de relatie tussen afweer en intrapsychische conflicten. Afweer, en daarvan vooral de ontkenning, werd in dit verband opgevat als een 
psychopathologisch verschijnsel. Inmiddels is men daar, zeker als het gaat over op de realiteit gebaseerde problemen zoals kanker, anders over gaan denken. Ontkenning bij ziekte wordt nu vooral gezien als een normale en adequate vorm van coping (Hackett $\&$ Cassem 1974). Immers, een voortdurend besef van de realiteit, gepaard aan de onmogelijkheid zichzelf af te leiden van de gedachte aan de ziekte en de gevolgen ervan, levert een ongezond hoog niveau aan distress op (Mages \& Mendelsohn 1979). Volgens Beisser (1979) hoort het begrip ontkenning, in relatie tot ziekte, vooral bij het referentiekader van de behandelaar en niet bij het perspectief van de patiënt. De behandelaar legt het accent op de behandeling van ziekte, de patiènt zou zich op de eerste plaats bezig houden met datgene wat zijn leven (nog) de moeite waard maakt. Beisser voegt daaraan toe dat 'preference for focus on one aspect of reality does not necessarily imply that a person is closed to others'. Leventhal et al (1986) sluiten hierbij aan. $\mathrm{Zij}$ maken onderscheid in de rollen die de patiènt heeft en zijn van mening dat in de rol van patiènt ontkenning weliswaar een negatieve invloed kan hebben op het ondergaan van de adequate therapieèn of op het omgaan met bijwerkingen, maar zo menen zij, op het werk of in het gezin kan het heel nuttig zijn om niet te veel stil te staan bij het feit dat men patiënt is. Ontkenning zou derhalve ten opzichte van verschillende rollen een verschillend effect kunnen hebben.

Weinstein en Kahn (1954, in Hackett \& Cassem 1974) maken in het geval van ernstige ziekten onderscheid tussen 'expliciete ontkenning', waarbij er sprake is van ontkenning van de aandoening, en 'impliciete ontkenning', waarbij de aandoening wel wordt erkend maar men er niet over wil praten. Cohen en Lazarus (1979) deden iets soortgelijks en onderscheidden ontkenning (denial) en vermijding (avoidance). Ontkenning is in hun definitie een poging het probleem of de situatie te negeren, terwijl er bij vermijding wel degelijk sprake is van acceptatie van de realiteit. Onder vermijding verstaan zij een weloverwogen poging niet aan die realiteit te denken. Meyerowitz (1983) introduceert de term kankerspecifieke ontkenning en definieert deze als een 'variety of cognitive coping strategies that minimise patients awareness of either stressful information or upsetting emotional responses'.

Greer (1992) is van mening dat er drie soorten ontkenning zijn te onderscheiden, namelijk (1) complete ontkenning, (2) ontkenning van de gevolgen van de diagnose en (3) ontkenning van de distress. Orr (1986) maakt onderscheid tussen 'first-order' en 'second-order' denial. First-order denial is het ontkennen van feiten en het uit de weg gaan van informatie. Deze vorm van ontkenning zou slecht zijn voor aanpassing. Second-order denial is het ontkennen van negatieve gevoelens en de weigering zichzelf als ziek te beschouwen. De strategieën die erbij horen zijn afleiding zoeken en vermijding van angstoproepende zaken zoals het uitspreken van het woord kanker. Wanneer een situatie erg veel angst oproept zou het gunstig zijn de angst via 'secondorder denial' te reduceren. 
Minimalisatie van de kankerdreiging lijkt geen invloed te hebben op therapietrouw (Meyerowitz 1983) of het tijdig zoeken van medische hulp (Watson et al 1984). Morris, Blake en Buckley (1985) vatten afweermechanismen op als een vorm van cognitieve herstructurering en noemen het 'defensive reappraisal'. Hierbij wordt een situatie die aanvankelijk als bedreigend is gepercipieerd als het ware geherdefinieerd, waardoor de dreiging afneemt (zie ook Lazarus 1993). Deze vorm van reappraisal wordt door hen gezien als een onderdeel van het normale waarnemingsproces, dat voortdurend onderhevig is aan een opeenvolging van appraisals en reappraisals. In deze opvatting zijn afweermechanismen in feite onderdeel van het normale copingproces. Meestal is het niet de bedoeling de ziekte te ontkennen. 'Defensive reappraisal' zou veeleer een poging zijn om belangrijke waarden en het zelfbeeld in stand te houden. Ook dient het ervoor om onder de gegeven omstandigheden hoop te kunnen houden.

Het algemene beeld is dan ook dat bij ernstige ziekten, waarbij het niet mogelijk is iets aan de situatie te veranderen, allerlei vormen van ontkennen en verdringen 6 positief zijn voor aanpassing (Cohen \& Lazarus 1979, Meyerowitz 1983, Watson et al 1984, Orr \& Meyer 1990, Peterson 1991, Greer 1992, Heytink 1993). Dit is zeker zo wanneer het geen volledige ontkenning van de ziekte betreft. Van volledige ontkenning is echter slechts zelden sprake.

Het is tamelijk lastig het begrip afweer goed af te bakenen (Lazarus 1993). Zoals al eerder aan de orde kwam zijn veel kankerpatiënten van mening dat zij er beter vanaf komen dan allerlei anderen. Een dergelijke sociale vergelijking kan een vertekening van de realiteit in zich houden en kan opgevat worden als een vorm van afweer. Taylor en Brown (1988) besteedt aandacht aan deze kwestie en introduceert het onderscheid tussen afweermechanismen en positieve illusies. In haar opinie is afweer het afhouden van bedreigende informatie, terwijl positieve illusies een antwoord zouden zijn op de bedreigende omstandigheden. Daarmee bedoelt ze dat veel kankerpatiënten zich goed bewust zijn van hun omstandigheden; er is nauwelijks sprake van afweer, aangezien deze patiënten klaarblijkelijk de informatie over hun ziekte niet hebben afgehouden. Zij geven echter een dusdanige draai aan hun situatie dat die vaak positiever lijkt dan op grond van de objectieve omstandigheden is gerechtvaardigd. Zij bedenken bijvoorbeeld dat zij beter af zijn dan anderen of richten zich op de positieve gevolgen van hun situatie. Hiermee proberen zij de bedreigende omstandigheden in de hand te houden situatie. Deze mechanismen worden door Taylor positieve illusies genoemd.

6 Naast de reeds genoemde vormen van afweer bij kanker, zoals denial, cancer-specific denial, first en second order denial, selective denial, defensive reappraisal en avoidance, treffen we in de literatuur een aantal verwante begrippen aan, zoals distancing, cognitive distortion, defence, negation, repression, selective ignoring, threat minimalisation, dissumulation, etc. 
De aanpassende waarde van positieve illusies is groot (Taylor \& Brown 1988, Taylor \& Brown 1994) maar niet specifiek voor kankerpatiènten. In zijn algemeenheid lijken mensen die (1) zichzelf in onrealistische positieve termen zien, (2) rooskleuriger tegen hun toekomst aankijken dan volgens kansberekening is te verwachten en (3) meer controle denken te hebben over hun omgeving en gebeurtenissen dan werkelijk zo is, zich beter te voelen dan mensen met accurate inschattingen (Taylor \& Brown 1994, Otten 1998).

Er is echter een groep theoretici die zich afvraagt of illusies op de lange duur hun aanpassende waarde behouden (Colvin en Block 1994). Zij zijn van mening dat, wanneer de illusies geen stand kunnen houden, bijvoorbeeld wanneer de kanker ondanks de illusie dat men invloed heeft op zijn genezing toch terugkomt, mensen extra bedrogen uitkomen en des te meer met lege handen staan. Taylor en Brown (1994) pareren dit argument met een reeks aan voorbeelden waaruit de flexibiliteit van de menselijke geest blijkt. Ook bij tegenslagen blijken mensen over een arsenaal aan cognitieve copingstrategieẽn te beschikken. De achterhaalde illusie wordt gewoon vervangen door een voor dat moment meer passende.

\section{2 - 3 - Samenhang tussen de verschillende theorieën}

Aan het eind van paragraaf 1-2-1 is de volgende definitie van coping geformuleerd:

\section{COPING IS DE COGNITIEVE EN GEDRAGSMATIGE INSPANNING DIE EEN PERSOON LEVERT OM HET HOOFD TE BIEDEN AAN EISEN DIE DOOR ANDEREN, DE SITUATIE OF ZICHZELF AAN HEM WORDEN GESTELD, EN WAARVAN HIJ INSCHAT DAT DEZE ZIIN VERMOGENS OP DE PROEF STELLEN, OF MISSCHIEN ZELFS TE BOVEN GAAN. DEZE INSPANNINGEN ZIJN EROP GERICHT DE STRESSVOLLE SITUATIE TE BEHEERSEN, OP TE HEFFEN, TE REDUCEREN OF TE TOLEREREN.}

In feite zijn alle theorieën die in dit hoofdstuk zijn besproken onder deze definitie te plaatsen.

De uitwerking die Lazarus en zijn collega's aan de stappen in het copingproces hebben gegeven (zie paragraaf 2-2-4) biedt een kapstok waaraan de theorieën nog wat specifieker zijn op te hangen. Volgens dat model start het copingproces met de inschatting of de situatie gevaar oplevert en of er iets op het spel staat. Dit wordt ruim opgevat en kan zowel fysieke, materiële als emotionele zaken betreffen: de zogenaamde primary appraisals. De 'Just world theory' kan hier worden geplaatst met haar notie dat slachtoffers van een ingrijpende gebeurtenis, naast een mogelijke fysieke aanslag, ook een aanslag ervaren op hun vaste schema's en opvattingen. 
De illusie dat de wereld betekenistol, begrijpbaar en recbttaardig in elkaar zit, het getoel van persoonlijke onaantastbaarbeid en de illusie van controle komen onder vuur te liggen. Vervolgens kunnen afweermechanismen en positieve illusies worden ingezet om de omvang van de gebeurtenis te vertekenen of te verdringen, zodat de impact ervan al bij de eerste inschatting wordt gereduceerd.

Daarna volgen de 'secondary appraisals'. Er zijn drie gebieden waarop deze secundaire inschattingen van toepassing zijn. Het eerste betreft verantwoordelijkheid en invloed. Hierbij horen vragen als 'wie of wat is er verantwoordelijk voor de situatie?', 'in welke mate heeft die instantie de controle?' en 'wat zijn mijn eigen mogelijkheden om invloed uit te oefenen?' Verschillende soorten attributies en sociale vergelijkingen helpen hierop een antwoord te vinden. Het zoekproces kan tevens gestuurd worden door positieve illusies en afweer. Het tweede gebied van de secundaire appraisals is dat van de eigen vaardigheden: 'wat kan ik?' en 'is dat voldoende in deze situatie?' Als derde zijn er de secundaire appraisals over de toekomst. Beide terreinen lenen zich voor sociale vergelijkingen, attributies en positieve illusies.

$\mathrm{Na}$ de inschattingen volgt de coping-inspanning: de poging de situatie het hoofd te bieden 7 . In het overzicht op pagina 40 staat een lijst van copingacties die zijn aangetroffen in de onderzoeksliteratuur over coping met kanker. Ook in deze lijst treffen we begrippen die passen bij verschillende theorieën. Zo vinden we er bijvoorbeeld 'betekenisverlening', verantwoordelijkheid nemen, zelfbeschuldiging, geloof in eigen invloed en geloof in externe invloed. Dit zijn sleutelbegrippen in zowel de attributietheorie als in de 'Just world theory'. Daarnaast treffen we er ook copingstrategieën die berusten op verdringing, positieve illusies of sociale vergelijkingen.

Samenvattend kan worden geconcludeerd dat de 'Just world theory', sociale vergelijkingstheorieën, attributietheorieën, theorieën over afweer, en de copingtheorie van Lazarus en collega's elkaar gedeeltelijk overlappen en aanvullen. Tezamen geven ze een brede kijk op hoe mensen omgaan met bedreigende situaties. De copingtheorie van Lazarus et al biedt een goede mogelijkheid de verschillende theorieën te integreren.

\footnotetext{
7 De scheidslijn tussen appraisals en coping-inspanning is overigens niet altijd helder. In de volgende paragraat, waar enkele conceptuele en methodologische aspecten van het coping-onderzoek aan de orde komen, zal hier nader op in worden gegaan.
} 


\section{2 - 4 - Enkele methodologische kwesties rond het begrip coping}

Er zijn tenminste drie onderling verbonden thema's die van belang zijn voor het onderzoek naar coping. (1) Is het copinggedrag van een individu consistent over verschillende situaties? Met andere woorden, is er sprake van een voor het individu specifieke copingstijl of van een flexibel copingproces? Deze kwestie heeft consequenties voor de vraag hoe specifiek op de situatie toegesneden de verzamelde gegevens over het copinggedrag moeten zijn. (2) In hoeverre is een individu zich bewust van zijn copinggedrag en in staat daarover te rapporteren? Dit heeft consequenties voor de vraag of met zelfrapportage verstaan kan worden. (3) Wat is goede coping, en is de uitkomst ervan wel te scheiden van het copingproces zelf? Het antwoord op deze laatste vraag is van belang voor de definitie en operationalisatie van de afhankelijke en onafhankelijke variabelen in het coping-onderzoek.

Bovenstaande thema's worden achtereenvolgens uitgewerkt.

\section{Copingstijl versus flexibel copingproces}

De term 'copingstijl' zou rond 1970 door Lipowski zijn geintroduceerd (zie Morris et al 1985). Deze term impliceert een min of meer vaste manier waarop een persoon nieuwe of stressvolle situaties te lijf gaat. Er is discussie over de vraag in hoeverre iemands copingpatroon vast ligt. Sommige onderzoekers veronderstellen dat het copingproces wordt beïnvloed door min of meer stabiele persoonlijkheidskenmerken. Een bepaalde persoonlijkheidstrek zou een specifiek, min of meer vast copingpatroon genereren (zie Peterson (1991) over de invloed van optimisme op coping, De Haes (1991) over de invloed van zelfwaardering op kwaliteit van leven bij kanker en Van der Zee (1996) over de invloed van neuroticisme op sociale vergelijking). Anderen, zoals Pearlin en Scooler (1978) constateerden dat individuen in verschillende situaties en in verschillende sociale rollen verschillende strategieèn gebruiken.

Volgens Dunkels-Schetter et al (1992) betekent de confrontatie met een ziekte als kanker dat er oplossingen gevonden moeten worden voor een heel scala aan problemen. Patiënten moeten leren omgaan met pijn, onzekerheid en verdriet, maar hebben vaak ook praktische problemen te overwinnen. Verschillende probleemgebieden zouden logischerwijs om verschillende strategieèn vragen. Dit geldt niet alleen voor de verschillende aspecten van een gebeurtenis maar ook voor de verschillende fasen in het aanpassingsproces (Cohen \& Lazarus 1979, Bury 1991). Deze argumenten pleiten ertegen dat aanpassing geschiedt middels een vaste copingstijl (Heim 1991, Dunkel-Schetter et al 1992, Glanz \& Lerman 1992).

Folkman en Lazarus (1981) bieden een oplossing voor dit dilemma. Volgens hen is consistentie in coping een kwestie van het abstractieniveau waarop het begrip wordt 
gedefinieerd (in Morris et al 1985). Het zou niet mogelijk zijn om iemands stijl te beschrijven op grond van specifieke gedachten, gevoelens en acties, omdat die nogal zullen verschillen, afhankelijk van de context waarin ze plaatsvinden. Een stijl wordt door hen opgevat als 'een manier van in het leven staan'. Deze zal het copingproces natuurlijk beïnvloeden, maar staat tegelijkertijd zo ver van de concrete eisen van de directe sociale context, dat ze daaruit niet zonder meer is af te lezen. Mages en Mendelsohn (1979) suggereerden dat een succesvolle aanpassing aan een complexe situatie, zoals kanker is, afhangt van het vermogen van het individu de voor hem gebruikelijke strategieèn te evalueren op effect, en zonodig nieuwe te ontwikkelen. Meerdere auteurs noemen flexibiliteit in coping een belangrijke factor voor een succesvolle aanpassing (Taylor 1983, Heim 1991, Taylor \& Brown 1994).

De kwestie copingstijl versus flexibele coping heeft consequenties voor de vraag hoe specifiek er gemeten moet worden om iets zinnigs over het copinggedrag te kunnen zeggen. Immers wanneer er sprake is van een consistente copingstijl volstaan algemene vragen over coping. Veel auteurs zijn van mening dat dit niet voldoende is. Zij vinden het belangrijk om vast te stellen in welk domein het effect van coping wordt onderzocht, en om de vragen aan deze context aan te passen (Somerfield \& Curbow 1992, Dunkel-Schetter et al 1992, Lazarus 1993). Volgens Lazarus (1991) is niet alleen het domein van belang, maar kunnen individuele verschillen in stress en emoties niet worden begrepen wanneer daarbij geen rekening wordt gehouden met de specifieke betekenis die de onderzochte persoon eraan geeft. Hiermee sluit hij aan bij Kelly die al in 1955 bij de introductie van zijn 'personal construct theory' het belang van de persoonlijke beleving centraal stelt (in Bonarius 1988). Daarmee wordt mogelijk verklaard waarom de Ways of Coping Scale (WCS) - een copingvragenlijst die door Lazarus en Folkman is ontwikkeld (Folkman \& Lazarus 1988) - geen eenduidige resultaten oplevert. Uit een overzichtsartikel van Somerfield en Curbow (1992) blijkt dat de WCS - die volgens Folkman en Lazarus acht manieren van coping zou meten in verschillende studies tussen de twee en achtentwintig factoren oplevert. Ook Leventhal en Nerenz (1985) merkten op dat er problemen rijzen wanneer standaardvragenlijsten niet de 'key coping strategies' bevatten die relevant zijn voor de te onderzoeken situatie (in Somerfield \& Curbow 1992). Het is daarom aan te raden om coping te meten in een welomschreven context, met vragen die aansluiten bij de specifieke situatie en bij de beleving van de onderzochte. 


\section{Bewuste versus onbewuste copingstrategieën}

Een tweede belangrijk thema voor het meten van coping hangt samen met de vraag in hoeverre iemand zich bewust is van zijn copinggedrag en derhalve in hoeverre hij daarover kan rapporteren.

Moris et al (1986) - zich baserend op een overzichtsartikel van Cohen en Lazarus uit 1980 - wijzen erop dat er geen of slechts zwakke correlaties zijn gevonden tussen wat mensen zeggen dat zij in het algemeen doen en het werkelijk geobserveerde gedrag. Daar zijn verschillende verklaringen voor te geven. Zoals in paragraaf 1-2-1 reeds is beschreven werd coping aanvankelijk, onder invloed van psychoanalytici, vooral opgevat als een onbewust proces. Theoretici met een sociaal-psychologische achtergrond daarentegen veronderstelden dat een individu een actief en bewust aandeel heeft in hoe hij omgaat met de situatie waarin hij verkeert. De waarheid ligt waarschijnlijk in het midden. Cohen en Lazarus bespraken deze kwestie in een artikel uit 1979. Zijzelf maken geen onderscheid tussen afweer en coping, omdat deze begrippen zodanig met elkaar zijn verweven dat ze volgens hen eenvoudigweg niet van elkaar zijn te onderscheiden. Ook Leventhal et al (1986) delen de mening dat onderdelen van het copingproces zowel automatisch gebeuren als na rijp beraad. Aanpassing zou het gevolg zijn van een hoeveelheid individuele beslissingen, automatische reacties en onbewuste of slechts ten dele tot het bewustzijn doorgedrongen percepties en doelen (Mages \& Mendelsohn 1979, Bury 1991). Greer et al (1989) kwamen tot de conclusie dat de vragenlijst die door hen was ontworpen om coping en aanpassing bij kankerpatiënten te onderzoeken, niet goed in staat bleek om verdringing (denial) te meten. Ook zij vragen zich af in hoeverre verdringing überhaupt door zelfrapportage kan worden gedetecteerd.

Jarrett et al (1992) brengen nog een ander element in. Volgens hen kan er bij zelfrapportage van coping, los van afweermechanismen, vertekening optreden omdat mensen geneigd zijn niet weer te geven wat ze werkelijk hebben gedacht en gedaan, maar eerder wat ze hadden willen denken of doen. Zij geven sociaal wenselijke antwoorden. In de visie van Lazarus (1993) ligt het motief voor de niet-accurate rapportage er niet zozeer in dat mensen sociaal wenselijk willen antwoorden, maar gaat het er eerder om het gevoel van eigenwaarde te beschermen of het zelfbeeld in stand te houden. Hij noemt dit een 'self-esteem' verhogende manier van rapporteren (zie ook Ten Kroode 1990).

Op grond van het bovenstaande zijn verschillende auteurs dan ook van mening dat indirecte bepaling van coping, al dan niet naast zelfrapportage, noodzakelijk is (Kessler et al 1985, Greer et al 1989, Shedler 1993). Lazarus (1993) stelt voor om precies te beschrijven wat een persoon denkt en doet in zijn poging aan een situatie het hoofd te bieden, om vervolgens door een 'professional observer' te laten benoemen van welke copingstrategie er sprake is (zie ook Bonarius 1988). 


\section{Coping versus aanpassing}

Tenslotte is nog een derde thema van belang, namelijk kan de uitkomst van het copingproces worden gescheiden van het proces zelf? Volgens Coyne $(2000)$ zijn veel van de problemen in het onderzoeksgebied terug te voeren op de moeilijkheid de kernbegrippen goed en eenduidig te definiëren en van elkaar af te bakenen.

Zo is het bijvoorbeeld niet op voorhand duidelijk of overmatig alcoholgebruik en verdringing copingstrategieën zijn om de impact van een stressvolle situatie te reduceren, of dat zij moeten worden opgevat als een symptoom van slechte aanpassing. Lazarus (1991) legt in een artikel waarin hij terugblikt uit, dat hij in zijn model coping doelbewust heeft opgevat als een inspanning (effort) die onafhankelijk is van de uitkomst ervan. Daardoor wordt het mogelijk de effectiviteit van een copingstrategie te onderzoeken, zonder dat coping wordt verward met haar resultaat. Echter in de realiteit zijn een copingstrategie, het doel van de strategie en de uitkomst ervan - ook volgens Lazarus - meer met elkaar vervlochten dan het theoretische model impliceert.

Hetzelfde geldt voor de afbakening tussen de fasen in het copingproces. Theoretisch zijn de primaire en secundaire inschattingen (appraisals) en de daarop volgende coping-actie goed van elkaar te scheiden. Door deze scheiding geeft het model inzicht in het copingproces. Echter het is de vraag of bijvoorbeeld een inschatting dat de ernst van de situatie wel meevalt, een appraisal is, of tegelijkertijd al een cognitieve copingactie? Ray et al (1982) introduceren de term 'defensive reappraisal': een situatie die aanvankelijk is gepercipieerd als bedreigend, wordt zodanig geherdefinieerd dat de dreiging wordt afgezwakt, met als doel de emotionele distress te verminderen. Voor hen is deze 'reappraisal' synoniem aan cognitieve coping.

Een ander probleem dat in dit verband opdoemt is de vraag: wat is een goede aanpassing? Met andere woorden, wanneer is coping effectief? Mages en Mendelsohn (1979) zijn van mening dat de termen 'goede' en 'slechte' coping veel te globaal zijn. Volgens hem is het nodig om een strategie te bezien in relatie tot de doelen waarvoor deze wordt ingezet. Dit laatste is niet alleen van de situatie afhankelijk, maar ook van de intentie en de behoeften van het individu. Bovendien hoeft wat op de korte termijn effectief is niet noodzakelijkerwijs ook op de langere termijn effectief te zijn. Ook Lazarus concludeert dat er waarschijnlijk geen absolute, universele vorm van goede of slechte coping bestaat. Hij voegt daar wel aan toe dat sommige vormen vaker adaptief zullen zijn en andere vaker maladaptief. Het effect van coping zou altijd moet worden bezien in relatie tot het specifieke doel. Aan de vraag of een copingstrategie een gunstige uitwerking heeft, zou dan ook moeten worden toegevoegd: 'gunstig waarvoor?' (Lazarus 1993). 
Samenvattend kan worden opgemerkt dat een drietal kwesties van belang is voor de vraag hoe coping gemeten kan worden. Op de eerste plaats lijkt een individu weliswaar over zoiets als een copingstijl te beschikken, maar deze is niet zonder meer af te leiden uit specifieke gedachten, gevoelens en acties, aangezien die nogal zullen wisselen afhankelijk van de context waarin ze plaatsvinden Ten tweede is een individu zich maar ten dele bewust van zijn copinggedrag. Daarenboven is hij om redenen van sociale wenselijkheid, of uit behoefte het zelfbeeld te beschermen, niet altijd in staat of van zins accuraat te rapporteren over zijn eigen copinggedrag. Tenslotte blijkt het in de praktijk moeilijk de theoretische concepten van het copingmodel goed van elkaar te onderscheiden. Dit alles vraagt een aantal maatregelen in het coping-onderzoek. Zo is het van belang om coping te meten in een welomschreven context, met vragen die aansluiten bij de specifieke situatie. Voorts moet coping ook op indirecte wijze worden vastgesteld, al dan niet naast zelfrapportage. En tenslotte - gezien de conceptuele verwarring binnen het copingdebat - verdient het extra aanbeveling veel aandacht te besteden aan de definities van de gehanteerde concepten.

\section{2 - 5 - Samenvatting en conclusies}

Vanuit verschillende theoretische modellen, elk met eigen accenten en begrippen, is beschreven hoe mensen omgaan met ernstige gebeurtenissen. De inzichten die hieruit volgen zijn samen te vatten onder het begrip coping. Uit de verschillende definities die al dan niet impliciet worden gehanteerd, is de volgende werkdefinitie geformuleerd: coping is de cognitieve en gedragsmatige inspanning die een persoon levert om het hoofd te bieden aan eisen die door anderen, de situatie of zichzelf aan hem worden gesteld, en waarvan hij inschat dat deze zijn vermogens op de proef stellen, of misschien zelfs te boven gaan. Deze inspanning is erop gericht de stressvolle situatie te beheersen, op te heffen, te reduceren of te toleren.

De meeste onderzoekers zijn het er over eens dat omgaan met kanker en andere ernstige ziekten vooral bestaat uit de cognitieve component van het copingproces, aangezien directe actie meestal onmogelijk is (Taylor, Lichtman \& Wood 1983, Burgess et al 1988, Filipp et al 1990, Lazarus 1993). De inschattingen van de persoon (de appraisals) nemen daarbij een centrale plaats in en sturen het copingproces: bij herhaling is gebleken dat verschillen in aanpassing, psychisch welbevinden en kwaliteit van leven eerder zijn toe te schrijven aan de subjectieve inschattingen aangaande de ziekte, de gevolgen ervan en de eigen mogelijkheden dan aan objectieve biomedische factoren (Jenkins \& Pargament 1988, Ell et al 1989, Filipp et al 1990, De Haes 1991, Dunkel-Schetter 1992, Boer et al 1992, Edgar et al 1992, Glanz \& Lerman 1992, Carver et al 1993, Heyink 1993, Sensky 1997 en vele anderen). 
Een van de problemen die zich voordoen in het copingonderzoek is het gebrek aan (goede) definities. Daardoor is het niet goed mogelijk te overzien in hoeverre de begrippen uit de verschillende theorieèn elkaar overlappen of aanvullen. Dit maakt het lastig de samenhang tussen theorieèn te ontdekken. Ook binnen één theorie is er dikwijls sprake van conceptuele verwarring (Sensky 1997, Coyne 2000). Mede hierdoor is er weinig consensus over de aanpassingswaarde van verschillende manieren van omgaan met kanker. Daarbij komt dat er onvoldoende inzicht is in de functie van een bepaalde copingstrategie. Er zijn aanwijzingen dat deze mede afhangt van de specifieke eisen die de situatie stelt (Buunk et al 1990, Lazarus 1991, Taylor \& Brown 1994), of van de fase van het ziekteproces waarin de patiënt verkeert (Lerman $e t$ al 1990, Heim et al 1997, Glanz \& Lerman 1992, Carver et al 1993 en 1994). Volgens Lazarus (1991) zijn de termen 'goede' en 'slechte' coping dan ook veel te globaal en moet het effect van een copingstrategie worden bezien in relatie tot de doelen waarvoor deze wordt ingezet. De intenties en de behoeften van het individu, almede de specifieke betekenis die de onderzochte persoon aan de situatie geeft, spelen daarbij een rol. Bovendien hoeft het effect op de korte termijn niet altijd gelijk te zijn aan het effect op de langere termijn. Op grond van dit alles is het noodzakelijk de gehanteerde concepten zo helder mogelijk te definitiëren. Ook moet van tevoren worden vastgesteld in welk domein het effect van coping wordt onderzocht en om welke fase van het aanpassingsproces het gaat. Vervolgens is het van belang de vragen aan te passen aan deze context en geen standaard copingvragenlijsten te gebruiken (Somerfield \& Curbow 1992, Dunkel-Schetter et al 1992, Lazarus 1993).

Een ander probleem bij het onderzoek naar coping is in hoeverre iemand zich bewust is van zijn denken en doen. Ook is hij om redenen van sociale wenselijkheid of uit behoefte het zelfbeeld te beschermen niet altijd in staat of van zins hierover accuraat te rapporteren. Verschillende auteurs zijn dan ook van mening dat indirecte bepaling van coping, al dan niet naast zelfrapportage, noodzakelijk is (Kessler et al 1985, Greer et al 1989, Shedler et al 1993). Lazarus (1993) stelt voor om precies te beschrijven wat een persoon denkt en wat hij doet in zijn poging aan een situatie het hoofd te bieden, om vervolgens door een 'professional observer' te laten benoemen van welke copingstrategie er sprake is (zie ook Bonarius 1988).

Wanneer aan al deze aspecten aandacht wordt besteed, lijkt het begrip cognitieve coping een bruikbaar concept om de aanpassing van patiënten aan borstkanker te onderzoeken. 


\section{OPZET VAN HET ONDERZOEK}

\section{1 - ONderzoeksVRAGeN EN MEetMOMENTEN}

De vragen waarop een antwoord wordt gezocht zijn:

- Welke cognitieve strategieèn gebruiken borstkankerpatiënten gedurende de eerste twee jaar na hun behandeling?

- In welke mate komen deze cognitieve strategieèn op drie achtereenvolgende meetmomenten voor?

- Wat is de relatie tussen de cognitieve strategieèn en aanpassing?

- Is deze relatie afhankelijk van de tijd die sinds de diagnose is verstreken? Met andere woorden, is de relatie tussen cognitieve strategieèn en aanpassing op de verschillende momenten dezelfde?

Om deze vragen te beantwoorden is een longitudinaal onderzoek opgezet. Op drie momenten zijn gegevens verzameld. De eerste keer $\left(T_{1}\right)$ was gemiddeld zeven weken na het beèindigen van de bestraling' (standaarddeviatie: 2,5 week), de tweede keer $\left(\mathrm{T}_{2}\right)$ was ongeveer acht maanden later, gemiddeld 35 weken na $\mathrm{T}_{1}$ (standaarddeviatie: 4 weken) en de derde keer $\left(\mathrm{T}_{3}\right)$ was een jaar na $\mathrm{T}_{2}$ (standaarddeviatie: 9 weken). Dit betekent dat $\mathrm{T}_{3}$ ongeveer twee jaar na de diagnose plaatsvond.

\section{2 - Methode VAN GegeVenSVerzameling}

De gegevens over het proces van aanpassing aan de borstkanker en over de cognitieve strategieèn die de patiënten daarbij gebruikt hebben, zijn met interviews verkregen. In deze paragraaf wordt ingegaan op de overwegingen die aan deze keuze ten grondslag liggen. Ook zal het interview zelf en de methode van afname worden besproken.

\section{2 - 1 - Overwegingen}

In Hoofdstuk I is vermeld dat bij onderzoek met vragenlijsten, kankerpatiënten over het algemeen geen lagere kwaliteit van leven rapporteren dan gezonde respondenten, en dat dit in tegenspraak is met de resultaten van studies gebaseerd op interviews, als ook met de dagelijkse ervaring van artsen, verpleegkundigen en andere

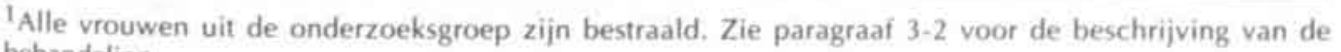
behandeling.
} 
hulpverleners (Breetvelt \& Van Dam 1991 en Schrameijer \& Brunenberg 1992). Deze 'onderrapportage' in de zelfrapportage zou vooral optreden als het gaat om emoties en attitudes en minder bij lichamelijke symptomen (zie ook Heyink \& Tijmstra 1991). Een mogelijke verklaring wordt door Hofstee (1965) gegeven:

'De vragenlijstsituatie betekent een tweeslachtig appèl, waarin het persoonlijke en het onpersoonlijke op een merkwaardige manier verweven zijn (...) het antwoord is vórgedrukt, dat wil zeggen privé-antwoorden worden niet op prijs gesteld. Qua volgorde zit er bijzonder weinig verband tussen de vragen: het is alsof iemand quasibelangstellend doet en intussen vragen afvuurt zonder naar het antwoord te luisteren.' Vragenlijsten sporen volgens Hofstee proefpersonen aan op de vlakte te blijven. Analoog aan de verre kennis die de standaardvraag 'Hoe gaat bet met je?' beantwoord krijgt met een 'Nou goed, boor', nodigt een vragenlijst niet uit tot persoonlijke bekentenissen. Met vragenlijsten kan geen inzicht worden verkregen in de individuele beleving van ernstig zieke mensen, omdat de persoonlijke zingeving van de ervaring van de onderzochte in zulke lijsten niet kan worden uitgedrukt (Bonarius 1988). Indien het gaat om de individuele definiëring en subjectieve beleving, is een meer kwalitatieve werkwijze de methodiek die daarop beter aansluit (Heyink \& Tijmstra 1991, Van Zuuren 1995). Voor het verkrijgen van gegevens over aanpassing aan kanker lijkt een interview derhalve de meest geëigende methode.

Wanneer iemand iets ernstigs overkomt, komt een proces van oorzaakstoekenning en betekenisverlening op gang; er ontstaat een verhaal waarmee de gebeurtenis een plek krijgt in de autobiografie (Ten Kroode 1990). Op deze manier wordt de gebeurtenis verhalend gereconstrueerd en her(ver)vormd. In de Engelstalige literatuur wordt dit fenomeen 'narrative reconstruction' genoemd (Williams 1984). Deze reconstructie geschiedt met behulp van cognitieve strategieën. Om deze strategieën te bestuderen is het dan ook noodzakelijk het verhaal als uitgangspunt te nemen (zie ook Bonarius 1988 en Affleck \& Tennen 1991). Ook volgens Lazarus (1991) kunnen individuele verschillen in coping niet worden begrepen wanneer daarbij geen rekening wordt gehouden met de specifieke betekenis die de onderzochte persoon geeft aan de stressor.

Nog een ander argument voor het inventariseren van cognitieve strategieën door middel van het interview is te vinden in Hoofdstuk I paragraaf 2-4, waar is uitgewerkt dat er verschillende dimensies aan het copingproces zijn te onderscheiden. Eén daarvan is de dimensie 'bewust' versus 'onbewust'. Het is dan ook de vraag in hoeverre mensen zich bewust zijn van al hun cognitieve strategieën en dus ook in hoeverre zij in staat zijn daarover te rapporteren. Het interview biedt kans om naast gegevens die gebaseerd zijn op zelfrapportage door de patiënt, ook gegevens te verzamelen die zich voordoen in het actuele, verbale gedrag waarvan de patiënt zich niet bewust hoeft te 
zijn (zie ook Morris et al 1985). Bijvoorbeeld, wanneer iemand voortdurend bagatelliserend of met verkleinwoorden over zijn ziekte spreekt.

Op grond van het bovenstaande is besloten zowel de gegevens over aanpassing als die over de gebruikte cognitieve strategieën met behulp van interviews te onderzoeken.

Er kleven ook nadelen aan de interviewmethode. Zowel afname als scoring zijn uitermate tijdrovend. Bovendien bestaat het gevaar van beinnloeding door de interviewer. Deze is immers direct betrokken bij het proces van afweging en rapportage door de ondervraagde. Ook is de kans op interpretatie door de onderzoeker groter, omdat uitspraken die gedaan worden in een interview vaak minder eenduidig zijn dan de omcirkelde antwoordcategorieèn van een vragenlijst. Derhalve is het bij interviews lastiger de eisen van objectiviteit en betrouwbaarheid te waarborgen; deze zijn minder vanzelf onderdeel van de methode dan het geval is bij vragenlijstonderzoek. Ondanks deze bezwaren hebben de argumenten voor de interviewmethode toch de doorslag geven. Bij de verdere beschrijving van onderzoek en resultaten zal steeds worden weergeven op welke wijze er is gestreefd naar een zo groot mogelijke betrouwbaarheid.

\section{2 - 2 - Soort interview}

Bij een diepte-interview bepaalt de geïnterviewde min of meer zelf de volgorde en onderwerpen van het interview. Het voordeel is dat bij een goede interviewtechniek de beleving van deze ene persoon optimaal tot uitdrukking komt, het nadeel dat het soms moeilijk wordt interviews te vergelijken die met verschillende proefpersonen zijn gehouden. Wanneer een onderwerp niet aan de orde is gekomen, zijn er met betrekking tot die proefpersoon geen gegevens. De kans op zogenaamde 'missing values' is dus groot.

Bij een semi-gestructureerde interview wordt dit nadeel ondervangen: alle door de onderzoeker als relevant beschouwde onderwerpen worden systematisch aan de orde gesteld. Het gevaar is dat de onderzochte een referentiekader wordt opgedrongen en op initiatief van de onderzoeker diverse malen van spoor moet veranderen, zodat al gauw oppervlakkige, door de directe context bepaalde antwoorden worden verkregen (zie ook Van Zuuren 1995). Bij een semi-gestructureerd interview vindt als het ware structurering vooraf plaats. De interviewer bepaalt de structuur van het gesprek, de volgorde van de onderwerpen, de formulering van de vragen en daarmee soms ook de formulering van de antwoorden.

De techniek die is gebruikt bij de interviews voor dit onderzoek, is afgeleid van Bonarius (1988) en is een combinatie van een diepte-interview en een semigestructureerd interview. De interviewer bepaalt van te voren welke onderwerpen in 
ieder geval aan de orde moeten komen, maar probeert door de geïnterviewde in zijn verhaal te volgen en deze zo min mogelijk te sturen optimaal aan te sluiten bij diens persoonlijke beleving: zijn persoonlijke constructen (Kelly 1955 in Bonarius 1988). Het is de geinterviewde die de structuur van het gesprek, de volgorde van de onderwerpen en de formulering in grote mate zelf bepaalt. Op deze wijze is het verhaal niet alleen onderzoeksobject maar ook methode van onderzoek.

Praktisch is als volgt te werk gegaan. De openingsvraag voor het eerste interview Was steeds: 'Kunt $u$ mij in bet kort uw ziektegescbiedenis tertellen, dat wil zeggen: boe beeft $u$ bet ontdekt, en boe is bet verder gegaam?' En voor de vervolginterviews was het: 'Kunt $u$ mij in bet kort vertellen boe bet $u$ is vergaan sinds bet torige interview ?' Wanneer er na zo'n vraag spontaan onderwerpen aan de orde kwamen, die de interviewer verderop in het interview zou aansnijden, dan volgde deze de patiënt en niet de volgorde van het interviewprotocol. De bijbehorende vraag werd dan zelfs niet meer gesteld om het verhaal van de patiēnt niet te onderbreken. De volgorde van de vragen lag dus tevoren niet vast, maar werd door het verhaal van de patiënt bepaald. Wanneer een nieuw onderwerp door de interviewer werd geĩntroduceerd, gebeurde dat met een open vraag die uitlokt het eigen verhaal te vertellen. Bijvoorbeeld: 'Toekomst ...., uat meet dat waard wu by y gap' Moesten er asnvullende vragen worden gesteld dan werd de formulering van de vragen aangepast aan de taal van de patiënt, variërend van 'Bent $u$ daar nu beel erg ontevreden over, of juist erg tevreden?' tot 'Baal je dan als een stekker of zeg je, dat vind ik eigenlijk prima zo?"

Voor een dergelijke werkwijze is het noodzakelijk dat de interviewer goed in de onderwerpen van het interview is ingevoerd, flexibel is en - ter voorkoming van ontbrekende gegevens - er nauwgezet op toeziet dat alle onderwerpen inderdaad aan de orde komen.

De vragen zijn vooral aandachtspunten voor de interviewer. Alle relevante tekst, ongeacht waar in het interview aan de orde gekomen, is bij het uitwerken gegroepeerd rond de vragen die gesteld (zouden) zijn. Dit betekent, dat wanneer er in het vervolg van dit proefschrift wordt geschreven over 'vragen uit het interview', het dan meestal geen letterlijk gestelde vragen zijn, maar onderwerpen die in het interview aan de orde zijn geweest. 


\section{2 - 3 - Inhoud van het interview en werkwijze}

Zoals eerder vermeld is het interview samengesteld om de cognitieve strategieèn van de patiènten te inventariseren, alsmede de mate van aanpassing aan de ziekte vast te stellen. Het zijn respectievelijk de onafhankelijke en afhankelijke variabele van dit onderzoek. Met het interview zijn ook de benodigde demografische gegevens verzameld. Tevens is de ziektegeschiedenis zoals verteld door de patiènt opgetekend. De objectieve ziektegegevens zijn uit het medisch dossier overgenomen.

\section{$2-3-1$ - Cognitieve strategieën}

Op grond van de inventarisatie van de literatuur en de ervaringen uit het onderzoek van Ten Kroode (1990) is een lijst opgesteld van te onderzoeken cognitieve copingstrategieèn met hun voorlopige definities. Deze worden in hoofdstuk III besproken. De interviews zijn geanalyseerd op de aanwezigheid van deze strategieèn. Daartoe is als volgt te werk gegaan.

Het interview bevat allerlei vragen die uitlokken over de ziekte en haar gevolgen te vertellen (zie bijlage A). De interviews zijn integraal op band opgenomen. De banden zijn door de interviewer afgeluisterd en de stukken tekst die betrekking hebben op één van de vragen, zijn verbatim uitgeschreven. Er waren drie interviewers bij dit onderzoek betrokken. Steekproefsgewijs is ongeveer een kwart van de banden door één van de andere twee afgeluisterd; per meetmoment steeds twaalf, van elk van de interviewers vier. Zo vond er afstemming plaats of inderdaad de relevante stukken tekst zijn uitgeschreven en is er naar gestreefd individuele verschillen tussen de interviewers te minimaliseren. Vervolgens zijn de uitgeschreven delen van de interviews steeds gezamenlijk door twee van de drie interviewers gescreend op de aanwezigheid van letterlijke uitspraken die onder één van de te onderzoeken cognitieve strategieèn zijn te plaatsen. De tweetallen wisselden steeds, ook weer om er voor te zorgen dat er voortdurend afstemming plaatsvond. Per strategie zijn alle uitspraken die aan de definitie voldeden op lijsten gezet. Deze lijsten zijn vervolgens door de drie onderzoekers doorgenomen op interne consistentie. Er bleek zich een aantal problemen voor te doen bij de indeling. In hoofdstuk III wordt hierop verder in gegaan. Nadat hier oplossingen voor waren gevonden, zijn de uitgeschreven interviews opnieuw gescreend en de uitspraken nogmaals volgens de aangepaste definities en de aangescherpte scoringsafspraken ingedeeld.

Bij de codering van de uitspraken uit de interviews van het tweede en derde meetmoment is dezelfde werkwijze gevolgd. Er bleken geen verdere aanpassingen nodig. Zo diende de scoring van de interviews van het tweede en derde meetmoment als het ware als een validering van de definities en scoringsafspraken. 


\section{2 - 3 - 2 - Aanpassing}

In hoofdstuk I is gebleken dat het begrip 'aanpassing aan kanker' op nogal verschillende manieren is geoperationaliseerd. Ook kwam aan de orde dat het gebrek aan eenduidigheid in de bevindingen mogelijk is terug te voeren op de definitie van aanpassing en de methode van onderzoek. Over de methode die voor dit onderzoek is gekozen, is al het een en ander uiteengezet. Wat de uitwerking van het begrip aanpassing betreft, dit vindt eveneens zijn wortels in eerder onderzoek (Ten Kroode, Oosterwijk \& Bonarius 1988 en Ten Kroode 1990). Indertijd is als uitgangspunt voor aanpassing de mate van zelfrespect gekozen. Zelfrespect is toen geoperationaliseerd als opgebouwd uit een vijftal conceptueel te onderscheiden maar met elkaar samenhangende dimensies namelijk (1) toekomstperspectief, (2) zelfbeeld, (3) schaamte, (4) gevoel van controle en (5) ervaren respect van anderen.

Een ernstige gebeurtenis, zoals het horen van de diagnose kanker, is een aanslag op het zelfrespect. Er is sprake van aanpassing c.q. herstel van zelfrespect als iemand er in slaagt die aanslag te pareren. Dat wil zeggen: in staat is zich een (nieuw) toekomstperspectief te scheppen, hoe beperkt die toekomst misschien ook zijn moge; een positief zelfbeeld te handhaven of te herkrijgen; niet te lijden onder gevoelens van schaamte: controle over zijn of haar leven te ervaren en zich gerespecteerd te voelen door anderen.

Op dit moment is nog onvoldoende onderzocht of het begrip zelfrespect werkelijk samenvalt met de genoemde vijf dimensies. Een dergelijk onderzoek valt echter buiten het kader van deze studie. Derhalve wordt in het midden gelaten in hoeverre het begrip zelfrespect samenvalt met deze dimensies. De dimensies worden in ieder geval wel gezien als indicatoren voor aanpassing, aangezien ze goed lijken aan te sluiten bij de literatuur over de gevolgen van kanker. Een uitzondering vormt 'ervaren respect van anderen'. In tegenstelling tot eerder, wordt 'ervaren respect van anderen' beschouwd als een moderatorvariabele voor aanpassing en niet als onderdeel ervan. Hierin wordt de literatuur over sociale ondersteuning of 'social support' gevolgd (zie Dunkel-Schetter \& Bennet 1990, Ros 1989 en Komproe et al 1997).

Dat betekent dat de volgende vier indicatoren voor aanpassing zijn onderzocht:

\section{INDICATOREN VOOR AANPASSING}

- toekomstPerspectief

- zeLFBeEld

- schumite

- gevoel van controle 
Over deze onderwerpen zijn in het interview vragen opgenomen. In hoofdstuk IV wordt nader ingegaan op de wijze waarop aanpassing precies is geoperationaliseerd.

Om veranderingen in aanpassing niet alleen kwalitatief maar ook kwantitatief te kunnen beschrijven zijn in het interview meetmomenten met Visueel Analoge Schalen (VAS) ingevoerd. Een VAS is een lijn van tien centimeter met aan beide uiteinden een uitspraak. Deze uitspraken zijn de uitersten van een antwoord op een stelling die bij de VAS hoort. Bijvoorbeeld over 'toekomst' is er een VAS met als uitersten 'Oner de toekomst ben ik beel eng optimistiscb' en 'Over de toekomst ben ik beel erg pessimistiscb'. De ondervraagde kan door middel van een kruisje op de lijn aangeven hoe zij zichzelf of haar situatie met betrekking tot deze stelling beoordeelt. De afstand vanaf één uiteinde, uitgedrukt in centimeters, is de score.

De keuze is gevallen op de VAS in tegenstelling tot items met een Likertschaalscoring, omdat een VAS gevoeliger zou zijn om verandering in de tijd aan te geven (Aitken 1969, Scott \& Huskinson 1976 en Cella \& Perry 1986). Bij een Likertschaal wordt net als bij een VAS gevraagd om aan te geven in hoeverre een uitspraak betrekking heeft op de ondervraagde. Het verschil is dat een aantal vaste antwoordcategorieën wordt gegeven en daaruit moet worden gekozen. Neem het voorbeeld over de toekomst: bij een Likertschaal moet de ondervraagde bij de uitspraak ' $\mid k$ zie de toekomst pessimistiscb' een keuze maken uit de volgende antwoordmogelijkheden: 'belemaal mee eens', 'enigszins mee eens', 'neutraal', 'enigszins oneens', 'belemaal mee oneens'. In dit geval is sprake van een vijfpuntsschaal.

De grotere gevoeligheid van de VAS-schaal berust er waarschijnlijk op dat in de beleving van mensen allerlei gebeurtenissen en verschijnselen eerder continue zijn of glijdend, en daardoor niet precies passen in elkaar uitsluitende categorieën. De VAS is gevoeliger, want geeft een grotere variantie aan scores (Pfennings et al 1995). Wanneer bijvoorbeeld op twee verschillende momenten een Likertschaal wordt afgenomen, dan kan een verandering voor de ene persoon aanleiding zijn een andere antwoordcategorie te kiezen - hij koos aanvankelijk 'enigszins' en kiest ten gevolge van die verandering nu 'veel' -, terwijl voor iemand anders dezelfde verandering zich binnen de grenzen van één categorie afspeelt - ondanks de verandering houdt hij het op beide momenten bij 'enigszins'. Het scoren op een continue lijn als van de VAS ondervangt dit probleem; het sluit beter aan bij de beleving van de onderzochte die niet gedwongen wordt voor een bepaalde categorie te kiezen (zie ook Aitkin 1969. Andrews \& McKennell 1980). In verschillende onderzoeken wordt de VAS een betrouwbaar instrument genoemd; met name de test-hertest betrouwbaarheid zou hoog zijn (o.a. Luria 1975 en Cella \& Perry 1986). 


\section{De 'schuif': het VAS-apparaat}

Om de verzameling van de benodigde kwantitatieve gegevens niet los van het 'verhaal' van de patiènt te laten plaatsvinden, is naar een methode gezocht om het scoren op de VAS met het interview te verweven. De 'VAS-vragen' zijn dus niet als een soort vragenlijst achteraf aangeboden, maar zijn in het interview geintegreerd en steeds aansluitend op het onderwerp waarop ze betrekking hebben, gesteld. Bovendien was het daarbij belangrijk de woorden van de patiënt te gebruiken en geen standaardtermen aan de uiteinden van de VAS aan te bieden. Immers, niet het begrippenstelsel van de onderzoeker maar dat van de onderzochte stond centraal.

Tussen interviewer en patiènt was een apparaat geplaatst dat speciaal voor dit onderzoek is ontworpen (zie de afbeelding hiernaast). Aan de voorkant bevindt zich een horizontale lijn van tien centimeter, die aan de uit-

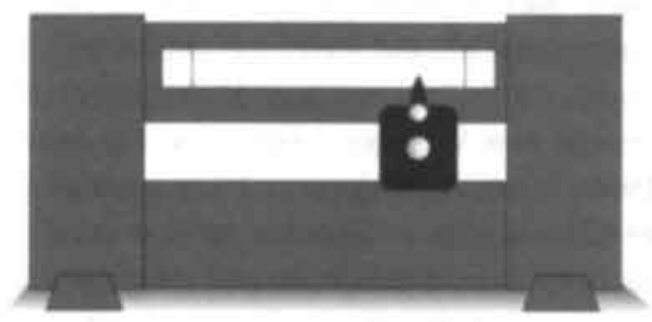
einden is gemarkeerd door twee verticale strepen.

Aan de achterkant is een centimeter-indeling opgeplakt die correspondeert met de lengte van de lijn aan de voorkant. Aan beide zijden zit een wijzertje, bevestigd aan een schuifje.

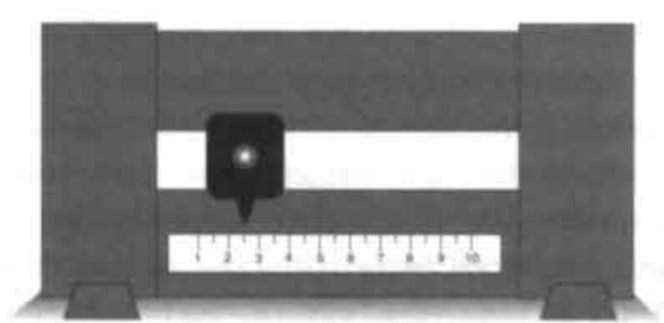

De geinterviewde wordt gevraagd het wijzertje te verschuiven naar de positie tussen de twee uiteinden, die voor haar van toepassing is. Het wijzertje aan de achterkant geeft dan de afstand in centimeters aan. De score werd door de interviewer genoteerd in de daarvoor bestemde ruimte van het interviewprotocol. Om elke vorm van geheimzinnigheid te vermijden is voor aanvang van het interview de werking van de 'schuif' uitgelegd. Daarbij werd de patiënt ook de achterkant met de centimeterindeling getoond.

$\mathrm{Er}$ is haar verteld dat de interviewer de getallen kan zien en zij niet. Ook is verteld dat uit onderzoek is gebleken dat, wanneer de geinterviewden de getallen kunnen zien, zij in het algemeen geneigd zijn rapportcijfers te geven, waarbij de 9 en de 10 niet zo vaak worden gebruikt, evenals de 0 en de andere lage cijfers, en dat het juist de bedoeling is dat, indien van toepassing, de hele lijn voor scoring wordt benut. Dat de uiteinden ook inderdaad gebruikt werden was vaak te horen. De interviews zijn 
integraal op cassetteband opgenomen. Regelmatig werd de scoring kracht bijgezet door de schuif met een klap tegen een uiteinde te laten stuiten.

\section{Van persoonlijke naar psychologenconstructen}

De 'schuif' stond tussen interviewer en patiënt in. Telkens wanneer de patiënt iets over een van de gebieden van aanpassing had verteld, werd haar gevraagd de bijbehorende VAS-vragen te scoren. Op deze wijze is de kwantitatieve gegevensverzameling als vanzelfsprekend in het interview geïntegreerd. De interviewer wees de beide uiteinden van de lijn aan en legde daabij duidelijk uit wat die uiteinden in dat geval betekenden. Bij de benoeming van de uiteinden gebruikte de interviewer zoveel mogelijk de termen of constructen van de patiënt zelf en lette daarbij zorgvuldig op dat de strekking van de VAS, zoals weergegeven in het interviewprotocol, bewaard bleef.

Een voorbeeld. Eén van de VAS-scores was bedoeld om meting te doen van het verschijnsel dat veel patiënten, nadat hen is meegedeeld dat zij borstkanker hebben, anders gaan reageren op 'normale' lichaamsensaties zoals kramp of lichte pijn en op 'normale' vlekjes en pukkeltjes op de huid. Geprobeerd is een score te krijgen die aangaf of de patiènt 'absoluut niet angstiger uas dan daarvoor' of daarentegen juist 'bét veel angstiger was geworden'. Wanneer de patiënt zelf de term 'angstig' had gebruikt, werd deze ook genoemd bij het beschrijven van de uiteinden. $\mathrm{Er}$ was echter een patiënt die weigerde de term 'angstig' voor zichzelf te gebruiken, omdat ze aangaf absoluut niet angstig te zijn maar eerder 'bezorgd'. In dit geval werden de uiteinden van de VAS benoemd als 'dan maak ik mij absoluut niet meer zorgen dan vnoeger' en 'dan maak ik mij beel veel meer zorgen dan vroeger'. Wanneer op een voorgedrukte vragenlijst de term angstig had gestaan, dan zou deze vrouw de extreme lage kant hebben gekozen ('absoluut niet angstig'), terwijl ze, nu het benoemd kon worden als 'bezorgd', ver naar de hoge kant ging. Dit laatste klopte met haar verhaal. Ze vertelde dat haar bezorgdheid zover ging, dat ze haar man elke avond haar ruggewervels liet bekloppen. Dat deed de arts immers ook altijd tijdens de controles. Blijkbaar was het niet goed wanneer je daar iets voelde. Haar score voor 'bezorgdheid' is dan ook opgevat als een score voor angst.

Zo'n voorbeeld geeft aan dat het belangrijk is aan te sluiten bij de woorden en begrippen die iemand zelf gebruikt: de 'persoonlijke constructen' van de ondervraagde (Bonarius 1986 en 1988 en Lazarus 1993). Door scoringsmomenten met de VAS door het interview heen te vlechten kan steeds optimaal bij deze persoonlijke constructen worden aangesloten. Het is vervolgens de taak van de onderzoeker deze achteraf te vertalen in psychologenconstructen.

De VAS-vragen die bij de uiteindelijke analyses hebben gediend als een indicatie voor aanpassing worden in hoofdstuk V gepresenteerd.

In een drietal proefinterviews met drie willekeurige borstkankerpatiënten is het protocol van het eerste interview en het gebruik van de VAS-schuif getest. 
Met de geinterviewden is nabesproken of alle voor hen relevante onderwerpen ook werkelijk in het protocol als aandachtspunt aan de orde waren gekomen, en omgekeerd of alle aandachtspunten ook relevant waren. Dit bleek in hoge mate het geval. Ook de 'schuif' bleek goed bruikbaar. Deze werd tijdens het interview door de drie patiènten niet als storend ervaren en werkte niet remmend bij het vertellen van hun verhaal.

\section{2-4-Afname van de interviews}

Het interview kon naar keuze van de patiènt bij haar thuis of op de afdeling Medische Psychologie worden gehouden. Twee patiènten voelden zich vrijer wanneer zij naar de afdeling kwamen; dit vanwege kinderen en de echtgenoot thuis. De overige patiènten stelden het zeer op prijs dat zij thuis werden bezocht.

De interviews zijn door drie ervaren psychologen afgenomen. Alle drie waren ook betrokken bij het onderzoek van Ten Kroode (1990) en dus goed in de materie ingevoerd. Elke interviewer volgde een eigen groep patiënten, zodat elke patiënt steeds met dezelfde interviewer te maken kreeg.

\section{3 - DE ONDERZoeksGroep}

\section{3-1 - Criteria voor deelname}

Uit methodologische overwegingen is voor een zo homogeen mogelijke onderzoeksgroep gekozen. Vanwege het longitudinale karakter van het onderzoek was het nodig dat de levensverwachting van de groep goed was, zodat er om medische redenen niet te veel uitval zou zijn. Daarom is de keuze gevallen op vrouwen met borstkanker in een gunstig stadium. Uitgegaan is van de stagering $\mathrm{T}_{1},{ }_{2} \mathrm{No}_{0-2} \mathrm{Mo}^{*}$. Het onderzoek is beperkt tot vrouwen die borstsparend zijn behandeld en dus geen borstamputatie hebben ondergaan. In de literatuur zijn er weliswaar aanwijzingen dat er geen of slechts kleine verschillen in aanpassing zijn te verwachten tussen beide groepen vrouwen. Echter één van de punten waarop ze wel zouden verschillen is het

\footnotetext{
* De T staat voor staat voor tumorgrootte. Hoe hoger het getal achter de T, des te groter de turnor. Tr.2 betekent dat de tumor relatief klein is en dat een borstamputatie meestal niet nodig is. De $\mathrm{N}$ staat voor 'nodes', het Engelse woord voor lymfeklieren. No-2 betekent dan dat er ofwel geen kankercellen in de lymfeklieren zijn aangetoond ( $\mathrm{No}$ ) of dat ze alleen gevonden zijn in de twee eerste klierstations, namelijk die welke het dichtst bij de tumor liggen (N1 et N2). Een hoger getal achter N geeft aan dat er ook uitzaaiingen zijn gevonden in de klierstations die op grotere afstand van de tumor liggen. Een hogere $\mathrm{N}$ betekent een ongunstiger prognose. $M$ verwijst naar metastasen en geeft aan of er vitzaaiingen zijn gevonden op andere plaatsen in het lichaam, zoals bijvoorbeeld in de botten, hersenen, lever of longen. Mo geeft aan dat dergelijke metastasen niet zijn gevonden, $\mathrm{Er}$ is dan sprake van een gunstiger prognose.
} 
zelfbeeld, één van de vier indicatoren van aanpassing in dit onderzoek. De overige exclusie-criteria waren: ernstige, bijkomende ziekten en een leeftijd boven 60 jaar. Deze bovengrens is aangehouden, omdat werd ingeschat dat toekomstverwachting en beperkingen ten gevolge van ziekte en behandeling bij oudere vrouwen een andere betekenis kunnen hebben dan bij jongere vrouwen. Voorts moesten alle deelnemende vrouwen de Nederlandse taal beheersen en een Westerse culturele achtergrond hebben, omdat ziektebeleving en reactie op ziekte bij vrouwen uit een andere cultuur verschillend zijn.

\section{3 - 2 - Behandeling}

Alle vrouwen hebben een borstsparende behandeling ondergaan. Dit betekent dat de tumor chirurgisch uit de borst is verwijderd. Vervolgens zijn vooral om diagnostische overwegingen aan de kant van de aangedane borst de lymfeklieren uit de oksel verwijderd, het zogenaamde 'okselkliertoilet'. Deze klieren zijn op aanwezigheid van tumorcellen onderzocht. Wanneer geen tumorcellen werden aangetroffen, bestond de verdere behandeling uit bestraling van de borst. Waren er wel positieve klieren, dan is naast de bestraling aanvullende therapie gegeven, omdat anders de kans groot is dat, soms jaren later, elders in het lichaam alsnog uitzaaiingen ontstaan. Vrouwen die nog niet aan de menopauze voorbij zijn, kregen profylactische chemotherapie, ook wel adjuvante chemotherapie genoemd. Zo is de kans op uitzaaiing-op-termijn aanzienlijk kleiner. Vrouwen na de menopauze kregen met hetzelfde doel hormonen toegediend.

De chemotherapie bestond uit zes zogenaamde CMF-kuren, waarbij de C staat voor cyclofosfamide, de $\mathrm{M}$ voor Methotrexaat en de $\mathrm{F}$ voor 5 -FU. Elke kuur bestond uit tweemaal een infuus dat poliklinisch werd toegediend en een serie tabletten die thuis werd ingenomen.

\section{CMF SCHEMA}

CrCLOFOSFAMIDE

METHOTREXAAT

$5-\mathrm{FU}$
TABLETTEN

INFUUS

INFUUS
DAG $1 \mathrm{~T} / \mathrm{M} 14$

DAG 1 EN 8

DAG 1 EN 8

Op dag 29 startte de volgende kuur en zo verder tot zes kuren. De bijwerkingen van deze kuren kunnen bestaan uit misselijkheid en braken, vermoeidheid, haaruitval en vervroegd intreden van de overgang. De hormoonkuur bestond uit het gedurende ten minste twee jaar dagelijks innemen van een tamoxifentablet. Over het algemeen worden daarvan weinig bijwerkingen gemeld. 


\section{3-3 - Werving en selectie}

Gedurende ongeveer een jaar zijn de dossiers van borstkankerpatiènten die op de afdeling Radiotherapie van het Universitair Medisch Centrum Utrecht werden bestraald, gescreend op patiènten die aan de selectiecriteria voldeden. Bij 79 patiënten was dat het geval, 307 voldeden er niet aan, merendeels vanwege een te hoge leeftijd.

Aan de 79 geselecteerde patienten is door de bestralingslaborant een informatiebrief met antwoordstrook meegegeven, waarin werd gevraagd of de onderzoeker een afspraak mocht maken voor verdere uitleg. Patiènten die daarin toestemden, werden voor een afspraak benaderd. Steeds is gevraagd om in geval van weigering anoniem de reden daarvan op de antwoordstrook in te vullen en terug te sturen.

Van deze 79 vrouwen die in aanmerking kwamen, hebben 56 aan het onderzoek meegewerkt $(71 \%)$. Er waren 23 weigeringen $(29 \%)$. Ongeveer de helift hiervan (elf vrouwen) heeft geen reden voor weigering opgegeven. Van de andere twaalf gaf, op één na, ieder aan dat ze na de bestraling liever niet meer over de ziekte wilden spreken en alles zo gauw mogelijk wilden afsluiten. Ze zagen met name op tegen het longitudinale karakter van de studie. Hiermee is mogelijk een selectie opgetreden en hebben de meest 'vermijdende' vrouwen niet aan het onderzoek meegedaan.

\section{3 - 4 - Beschrijving van de onderzoeksgroep}

\section{Uitval}

Er zijn drie interviews gehouden. Het aantal deelneemsters aan het eerste interview bedroeg 56, aan het tweede interview 53. Van de drie vrouwen die tussen het eerste en het tweede interview zijn uitgevallen, was er één aan haar borstkanker overleden, een ander zag vanwege een heupoperatie van verdere deelname af en een derde was verhuisd en niet meer op te sporen. Aan het derde interview namen 48 vrouwen deel. Tussen het tweede en derde interview zijn drié vrouwen aan hun borstkanker overleden en weer was er één verhuisd en niet meer op te sporen. Tenslotte was van één vrouw in die tussentijd de echtgenoot aan kanker overleden. Er is wel een interview gehouden, maar dat was zo gekleurd door de dood van haar man, dat het interview buiten de analyses is gehouden.

Bij de analyses zijn uiteindelijk 46 borstkankerpatiënten betrokken. De gegevens van nog eens twee vrouwen zijn weggelaten. Bij één ontbreekt een deel van de gegevens, omdat achteraf bleek dat het opname-apparaat niet had gewerkt. De ander wilde wel meewerken, maar stond niet toe dat het interview werd opgenomen. $\mathrm{Er}$ is geprobeerd om zoveel mogelijk tijdens het interview op te schrijven. Omdat de indeling van de strategieèn is gebaseerd op letterlijke uitspraken van de patiènten leek het bij nader inzien toch beter ook deze respondent buiten de analyses te houden. 


\section{Demografische gegevens en gegevens over de ziekte}

De gemiddelde leeftijd van de 46 vrouwen was op het eerste meetmoment 46,9 jaar (standaarddeviatie 8,0 jaar); de jongste was 29 en de oudste zestig. Op grond van de tumorgrootte hebben 25 van hen de stagering $T_{1}$ en 21 de stagering $T_{2}$ gekregen. Bij twaalf vrouwen werden geen tumorcellen in de okselklieren aangetroffen $\left(N_{0}\right)$, bij 34 vrouwen wel $\left(N_{1}\right.$ of $\left.N_{2}\right)$.

Alle vrouwen zijn geopereerd en bestraald. Voor de twaalf met negatieve okselklieren was dit de volledige behandeling. Eén vrouw, die wel positieve klieren had, heeft de chemotherapie geweigerd en is alleen bestraald. Daardoor komt het aantal vrouwen dat na chirurgie alleen is bestraald op dertien.

Bij de overigen met positieve okselklieren bestond bij 23 vrouwen die nog voor de menopauze waren de aanvullende behandeling uit chemotherapie en bij de tien vrouwen voorbij de menopauze uit hormoontherapie.

\section{StaGering}

TUMORGROOTE

$T_{1} \quad n=25$

$T_{2} \quad n=21$

\section{OKSELKLIEREN}

$\mathrm{N}_{0} \quad \mathrm{n}=12$

$N_{1,2} n=34$

\section{BEHANDELING}

ALLEN CHIRURGIE + BESTRALING $\mathrm{n}=13$

+ CHEMOTHERAPIE

$\mathrm{n}=23$

+ HORMONALE THERAPIE

Vier vrouwen zijn gedurende de onderzoeksperiode aan hun borstkanker overleden. Bij nog eens zes vrouwen is tussen het tweede en het derde interview de kanker teruggekeerd, zij kregen metastasen. Deze zes vrouwen maken deel uit van de groep van 46 waarover in dit proefschrift verslag wordt gedaan.

Ten tijde van het eerste interview woonden acht vrouwen alléén en 38 waren samenwonend of gehuwd. Achttien vrouwen bevonden zich op het niveau van een lagere beroepsopleiding, dertien op middelbaar niveau, elf hadden een hogere beroepsopleiding en vier een universitaire. Negen vrouwen werkten ten tijde van het eerste interview alweer (gedeeltelijk) in een betaalde baan, zeventien waren in de ziektewet, drie waren om andere redenen dan de borstkanker afgekeurd en zeventien waren zonder betaald werk. 


\section{DEFINIËRING VAN DE COGNITIEVE STRATEGIEËN EN ORDENING VAN DE PATIËNTENUITSPRAKEN}

\section{1 - De aAnVankelijke definities}

De interviews ten behoeve van het onderzoek van Ten Kroode (1990), lieten zien dat kankerpatiënten bij hun aanpassingsproces een scala aan cognitieve strategieën gebruiken. Analyse van enkele interviews, samen met inzichten uit de literatuur over cognitieve coping bij kanker, leverde veertien cognitieve strategieèn op die nader zijn onderzocht. Hierna volgt een opsomming van de aanvankelijke definities van de veertien cognitieve strategieën, waarmee de uitspraken van de borstkankerpatiènten in eerste instantie zijn ingedeeld. Maar eerst nog twee opmerkingen over het begrip 'cognitieve strategie'.

In het model van Lazarus et al wordt een aantal fasen onderscheiden. Het copingproces zou beginnen bij de inschattingen over de situatie, de zogenaamde primary appraisals. Op grond hiervan volgt de copingstrategie, waarna het resultaat wordt geëvalueerd: de secondary appraisals. Echter, sommige inschattingen zijn eigenlijk tegelijk een strategie. Immers, wanneer de situatie te licht wordt ingeschat, is de coping al begonnen, en wordt er meteen al gebagatelliseerd. Wanneer vervolgens het resultaat van de actie wordt geèvalueerd en er wordt bijvoorbeeld de conclusie getrokken dat men het in vergelijking met anderen nog niet zo slecht heeft gedaan, is er sprake van een sociale vergelijking. Ook dan lopen appraisals en coping door elkaar. Het bleek in de praktijk dan ook niet mogelijk appraisals en strategieën goed van elkaar te scheiden. Er is dan ook geen onderscheid gemaakt tussen appraisals en cognitieve coping.

De term 'strategie' impliceert dat het een bewuste, intentionele actie betreft. Dit is niet altijd het geval. De strategieën zijn te plaatsen in een continuüm, waarbij zichzelf toespreken het meest bewust gebeurt, en een aantal vormen van cognitieve vermijding en bagatelliseren het minst bewust plaatsvinden. Met het begrip 'cognitieve strategie' wordt alle cognitieve arbeid bedoeld, die een vrouw verricht bij de aanpassing aan haar borstkanker. Ook de minder strategische cognitieve arbeid is cognitieve 'strategie' genoemd.

\section{- Causale attributie (CA)}

Verwijst naar een concrete gebeurtenis of periode die de patiènt als - mogelijke oorzaak van haar ziekte noemt. 


\section{- OntKenNende atTRiButie (OKA)}

De patiënt noemt een concrete oorzaak die niet op haarzelf van toepassing is en die dus nooit een verklaring voor haar ziekte kán zijn. Er is sprake van het neutraal wegstrepen van een eventuele verklaring.

\section{- Schuldontlastende attributie (OLA)}

De patiènt noemt een oorzaak die wel op haarzelf van toepassing is, maar die ze als verklaring voor de ziekte afwijst.

\section{- Betekenisverlenende attributie (BA)}

Een globale, existentiêle beschouwing die de vraag naar een concrete oorzaak overstijgt, maar wel betrekking heeft op het denken over een oorzaak. Het is vaak een beschouwing over de zin van de ziekte.

\section{- VerlegGen van prioriteiten (VPR)}

De patiént geeft te kennen dat zij dankzij de ziekte andere dingen belangrijk is gaan vinden, of dat er dankzij de ziekte positieve veranderingen zijn opgetreden.

\section{- Sociale vergelijkingen (SV)}

De patiënt vergelijkt zich expliciet met anderen en verbindt daaraan conclusies over haar eigen situatie. Vijf soorten van sociale vergelijking worden onderscheiden:

- positief naar boven: zich vergelijken met anderen met wie het beter gaat en zich daaraan optrekken $\left(\mathrm{S}^{++}\right)$

- positief naar beneden: zich vergelijken met anderen met wie het slechter gaat en tot de conclusie komen dat men zelf beter af is ( $\mathrm{S}^{*-}$ )

- negatief naar boven: zich vergelijken met anderen met wie het beter gaat en tot de conclusie komen dat men zelf slechter af is $\left(\mathrm{S}^{-+}\right)$

- negatief naar beneden: zich vergelijken met anderen met wie het slechter gaat en hun situatie als voorland zien ( $\mathrm{S}^{--}$)

- gelijkwaardige vergelijking: zich vergelijken met anderen en tot de conclusie komen dat men zelf niet anders is ( $\left.\mathrm{S}^{*}\right)$

\section{- ERger bedenken (EB)}

De patiènt houdt zichzelf voor dat haar situatie nog erger had kunnen zijn en dat ze relatief gezien nog boft.

\section{- Bagateluiseren (BAG)}

De patiènt maakt de ernst van haar ziekte of de gevolgen ervan kleiner. 


\section{- OntKenNing (OK)}

De patiënt denkt of zegt dat ze niet aan kanker lijdt.

\section{- Vermijden van gedachten (VG)}

De patiēnt gaat cognities die met de ziekte te maken hebben uit de weg.

\section{- In PRotest Komen (PR)}

De patiënt komt in opstand tegen het feit dat zij kanker heeft, of tegen de gevolgen van de ziekte of behandeling.

\section{- Berusten (BR)}

De patiènt legt zich erbij neer dat zij kanker heeft omdat het nu eenmaal niet anders is, maar zit niet bij de pakken neer.

\section{- Aggraveren (AGG)}

De patiènt houdt er bewust rekening mee dat het wel eens slecht kan aflopen, zodat het in ieder geval niet kan tegenvallen.

\section{- ZichZelf tOESPREKen (ZT)}

De patiënt roept zichzelf tot de orde, zegt letterlijk of figuurlijk iets tegen zichzelf, of houdt zichzelf iets voor.

\section{2 - CATEgoriseringsproblemen}

Alle uitspraken die aan één van deze veertien definities leken te voldoen, zijn als zodanig gecategoriseerd. De zo ontstane lijsten zijn beoordeeld op interne consistentie en onderlinge overlapping. Er is gekeken of soortgelijke uitspraken inderdaad maar op één lijst voorkwamen (dus steeds hetzelfde waren gecategoriseerd), en of de uitspraken voldeden aan de definitie van de strategie. Het resultaat was niet vrij van problemen. Ondanks de interbeoordeling bleek eenduidig categoriseren niet overal mogelijk. Om een indruk te geven van deze problemen volgen hier enkele voorbeelden.

- 'Dan denk je wel eens boe kom ik eraan? Maar ja, dan zie je zoveel mensen die bet bebben en dan denk je: bet is domme pech.'

Deze uitspraak bevat zowel elementen van een sociale vergelijking (SV) (zoveel mensen die het hebben), als elementen van een causale attributie (CA) (zoeken naar de oorzaak: pech), van berusten (BR) (het is pech, het is niet anders, ik ben niet anders dan een ander) en van een betekenisverlenende attributie (BA). Wat de laatste betreft, het citaat kan worden opgevat als een existentiële beschouwing over de oorzaak: 
mensen kunnen kanker krijgen, ik ben niet anders dan een ander, dus waarom ik niet?

- 'Dan ben ik nog blij dat bet borstsparend kon, omdat bet maar een béel klein tumortje was.'

Deze uitspraak valt in de categorie 'erger bedenken' (EB). De bijna identieke uitspraak 'Als ik dan die vriendin zie die een borstamputatie beeft gebad, dan kom ik er nog goed af met $m i j n$ kleine tumortje' is definitorisch gezien een sociale vergelijking ( ${ }^{-*}$ ); de patiënt vergelijkt zich met iemand met wie het minder goed gaat en houdt daar een goed gevoel aan over. Beide uitspraken bevatten bovendien elementen van bagatelliseren (BAG): 'klein tumortje'.

- 'Als één op de tien trouuen borstkanker krigt, waanom ik dan niet?'

Een dergelijke uitspraak zou een sociale vergelijking (SV) aangaande de oorzaak kunnen worden genoemd, maar omgekeerd ook een causale attributie (CA) in de vorm van een sociale vergelijking. De uitspraak is niet op te delen in een deel dat de SV vertegenwoordigt en een deel dat de CA aangeeft.

- 'Soms denk ik er uel aan, maar dan zeg ik meteen tegen mijzelf : daar moet je niet oter denken, stop ermee, dat is niet goed woor je!"

Deze uitspraak is op te vatten als zichzelf toespreken (ZT) om daardoor gedachten aan de ziekte te vermijden, maar ook als vermijden van gedachten (VG) over de ziekte door zichzelf toe te spreken. Ook deze uitspraak is niet op te delen.

De problemen met de categorisering lijken terug te voeren op een vijftal oorzaken: 1. niet alle werkdefinities waren 'spits' genoeg en daardoor was de afbakening tussen de strategieën niet altijd duidelijk;

2. dezelfde uitspraken zijn bij verschillende strategieën ondergebracht, waarbij dikwijls de uitlokkende vraag richting gaf aan de categorisering en niet de uitspraak zelf;

3. de indeling was meer gebaseerd op een interpretatie dan op een observatie van de letterlijke tekst;

4. een stuk tekst dat inhoudelijk een eenheid vormt, bevat vaak meerdere strategieën die elkaar als het ware opvolgen. Hier is niet altijd hetzelfde mee omgegaan. Soms zijn de strategieèn afzonderlijk gecategoriseerd, andere keren is het hele tekstfragment ondergebracht bij één van de strategieën;

5. er zijn uitspraken die niet zijn op te delen en toch als twee verschillende strategieën zijn op te vatten. Dergelijke uitspraken zijn willekeurig bij één van de twee ingedeeld.

Voor de eerste vier problemen was relatief makkelijk een oplossing te vinden. De werkdefinities zijn toegespitst, er is een eenduidiger benaming voor sommige strategieën gekozen, andere strategieèn zijn - gedeeltelijk - samengevoegd en er zijn enkele nieuwe strategieèn toegevoegd. Ook is besloten dezelfde uitspraken steeds hetzelfde te benoemen, ongeacht door welke vraag ze zijn uitgelokt. Interpretatie is zoveel mogelijk vermeden, zodat de indeling is geschied op grond van de geobser- 
veerde uitspraak zelf. In die gevallen waarin er sprake was van een opeenvolging van strategieën, zijn de te onderscheiden delen afzonderlijk benoemd. In paragraaf 4 staat beschreven wat dit voor de aanvankelijke definities betekent.

\section{3 - De dubbelstrategie}

Het vijfde probleem, uitspraken die niet zijn op te delen en toch als verschillende strategieën zijn op te vatten, bleek moeilijker op te lossen en is ook fundamenteler van aard. Een van de redenen voor het samenvallen van strategieèn, of voor de gedeeltelijke onderlinge overlapping ervan, is dat ze voortkomen uit verschillende theoretische tradities. In hoofdstuk I is beschreven dat de sociale vergelijkingen stammen uit de sociale psychologie, de attributies uit de attributietheorie en de afweerstrategieën uit psycho-analytische theorieèn. Vanuit elke theorie is met de eigen, niet altijd even expliciete definities segmentarisch de werkelijkheid beschreven. Wanneer er breder naar cognitieve strategieèn wordt gekeken, zonder op één theorie terug te vallen, blijkt dat een en dezelfde uitspraak vanuit de verschillende theorieen bezien anders wordt benoemd (zie ook Van Rooij 1986).

Van Zuuren (1995) merkt in dit verband op dat men vanuit de kwantificerende benadering het liefst ziet dat een en het zelfde fragment eenduidig kan worden ingedeeld. Als maat hiervoor geldt dan de interbeoordelaarsbetrouwbaarheid. $\mathrm{Zij}$ betoogt dat een dergelijke aanpak geen recht doet aan het verzamelde kwalitatieve materiaal. Zo zou het soms onmogelijk zijn om een hoge betrouwbaarheid te krijgen, omdat een en hetzelfde fragment potentieel twee elementen in zich kan bergen, waardoor twee beoordelaars tot een verschillende categorisering kunnen komen. Volgens haar doet dit geen afbreuk aan het bestaansrecht en de betrouwbaarheid van beide afzonderlijke categorieën, zolang er ook fragmenten bestaan die voor slechts één van beide categorieën representatief zijn en als zodanig door de beoordelaars worden herkend. Psychische verschijnselen zouden nu eenmaal meervoudig gedetermineerd zijn en ook diverse functies tegelijk vervullen.

Hoewel hier een kern van waarheid inzit, is het uit wetenschappelijk oogpunt toch noodzakelijk naar eenduidigheid en herhaalbaarheid te streven en de categorisering niet te laten sturen door de voorkeur van de beoordelaar. Bovendien zijn de uitspraken wél eenduidig in te delen, namelijk door te onderkennen dat een bepaalde uitspraak twee aspecten tegelijkertijd bevat. Dit kan vervolgens in de categorisering tot uitdrukking worden gebracht. Immers, wanneer er overeenstemming over bestaat dat een bepaalde uitspraak een 'dubbele functie' heeft en dit ook expliciet wordt weergegeven, is er sprake van eenduidigheid. Daarom wordt in dit onderzoek de term dubbelstrategie geïntroduceerd. 
EEN DUBBELSTRATEGIE IS EEN UITSPRAAK DIE TWEE VERSCHILLENDE STRATEGIEËN TEGELIJK BEVAT EN NIET IS OP TE DELEN ZONDER DAT DE BETEKENIS ERVAN VERDWIJNT.

Een dubbelstrategie is steeds bij beide strategieèn waar de uitspraak onder zou kunnen vallen, gecategoriseerd. Overigens viel op dat in een dubbelstrategie altijd een sociale vergelijking of de strategie zichzelf toespreken voorkomt. De tweede strategie is gebaseerd op die vergelijking of zelfinstructie, of wordt in die vorm geuit. Zo zijn er veel causale attributies gebaseerd op een sociale vergelijking: 'bet zal wel erfelijk zijn want mijn zus beeft bet ook'. Ook wordt soms het protest of het bagatelliseren aan de vergelijking opgehangen of vormt de vergelijking de bron van het doemdenken. Voorbeelden worden geven in de volgende paragraaf. Cognitief vermijden en berusten gebeurt dikwijls in de vorm van een zelf-instructie ' $/ k$ moet me er bij neerleggen en accepteren dat ik dit nu eenmaal beb'.

\section{4 - De uiteindelijke definities}

De oplossingen die voor de categoriseringspoblemen zijn bedacht, hebben hun weerslag gekregen in de definities van de cognitieve strategieèn. In deze paragraaf wordt besproken hoe de definities zijn aangepast. De uiteindelijke definities zijn in een kader weergegeven.

\section{- Causale attributie (CA)}

De aanvankelijke definitie was: Een causale attributie verwijst naar een concrete gebeurtenis of periode die de patiënt als - mogelijke - oorzaak van haar ziekte noemt.

De volgende moeilijkheden deden zich voor. Aanvankelijk zijn uitspraken over pech en noodlot nogal willekeurig bij causale attributie, bij betekenisverlenende attributie of bij berusten ondergebracht. Vooral bij de laatste was dat dikwijls het gevolg van interpretatie. Er werd verondersteld dat uit een dergelijke uitspraak automatisch berusting sprak. Besloten is om alleen wanneer de uitspraak een duidelijk te onderscheiden deel bevat waaruit berusting blijkt, dat deel bij berusten onder te brengen en anders alleen als attributie te scoren. ' $1 k$ denk dat bet domme pech is' wordt alleen als attributie gescoord; want uit de uitspraak zelf blijkt geen berusting. Het zou kunnen, maar dat is dan interpretatie. De uitspraak ' $1 \mathrm{k}$ kan me er goed bij neerleggen. Zoiets is pecb en dan vragg ik me niet meer af uaarom moet mij dat overkomen' is 'op te knippen' in twee verschillende delen, waarbij het ene deel als attributie (Zoiets is pech) en het andere deel bij berusten wordt gescoord (lk kan me er goed bij neerleggen ... dan vraag ik me niet meer af waarom moet mij dat overkomen). 
Ook de afbakening tussen causale attributie (CA) en betekenisverlenende attributie (BA) was niet duidelijk. Het lag in de bedoeling een existentiele beschouwing als BA te categoriseren; concrete oorzaken zouden als CA worden opgevat. In de praktijk bleek dit onderscheid niet te handhaven. De benaming betekenisverlenende attributie stamt uit het onderzoek van Ten Kroode (1990). Hij onderscheidde een BA en een CA als volgt. Een causale attributie is het antwoord op de vraag 'Hoe kom ik er aan?' en een betekenisverlenende attributie is het antwoord op de vraag 'Waarom ik?'. Bij hem was dus eerder de vraag dan het antwoord of de uitspraak bepalend voor categorisering. In dit onderzoek is echter besloten gelijke uitspraken bij dezelfde strategie onder te brengen, ongeacht door welke vraag de uitspraak is uitgelokt. Daarom zijn alle pechof noodlotuitspraken, vooral omdat ze verwijzen naar de oorzaak, als causale attributie gescoord.

Een andere categorie uitspraken die, opnieuw op grond van de uitlokkende vraag, nogal willekeurig als CA of BA zijn gescoord, zijn de uitspraken waarin de patiènt haar kanker wijt aan de wijze waarop haar leven is verlopen (veel verdriet, verlating, zelfverwoesting). Ook hier is besloten ongeveer gelijke uitspraken bij één strategie, en wel bij CA onder te brengen.

Sommige attributies werden in de vorm van een sociale vergelijking (SV) geuit. In zo'n geval is er sprake van een dubbelstrategie en wordt de uitspraak zowel als attributie alsook als sociale vergelijking gescoord. De sociale vergelijking gelijkwaardig $\left(\mathrm{S}{ }^{\prime}\right)$ komt vaak voor in attributies over erfelijkheid ('mijn zus/moeder/tante had het ook, dus het zal wel erfelijk zijn') en in attributies over leeftijd en overgang ('het komt veel voor bij vrouwen tussen 45 en 60 , het zal dus wel met de overgang te maken hebben'). Ook uitspraken als 'ach, iedereen kan bet krijgen, $i k$ ben niet anders dan een ander, dus waarom ik niet!' zijn opgevat als een dergelijke dubbelstrategie (CA/S ").

Een vergelijking negatief naar boven die samenvalt met een attributie (CA/S - +), heeft vaak te maken met vatbaarder zijn dan een ander of een slechtere gezondheid hebben, zoals in het volgende voorbeeld: ' $I k$ denk dat ik bet beb gekregen omdat ik een oorlogskind ben; ik beb allemaal gekke dingen. Mijn oudste zus is vór de oorlog geboren, ik erin, en mijn jongste zusje erna. Ik bad een beel slecbt gebit, ik was zuak en mager. Mijn zusjes zagen er beel anders uit. Dus ik denk tocb dat ik een oorlogskind ben en dat je daardoor minder weerstand bebt voor van alles, ook voor dit.'

Wanneer we deze specifieke moeilijkheden rond de categorisering van causale attributies samenvatten, komen we tot de volgende oplossingen.

- Uitspraken die aanvankelijk als betekenisverlenende attributie waren gescoord, maar waarin naar een oorzaak wordt verwezen, zoals uitspraken over pech, noodlot of levensloop, zijn als causale attributie gecategoriseerd.

- Causale attributies in de vorm van een sociale vergelijking over de oorzaak zijn opgevat als dubbelstrategie. 
- Wanneer een causale attributie mogelijk ook iets anders uitdrukt, zoals 'berusten' in de uitspraak 'Het is domme pecb', wordt dit niet dubbel gescoord. Dit zou te veel een interpretatie zijn. Alleen wanneer de uitspraak afzonderlijk aan te wijzen woorden of elementen van andere strategieèn bevat, worden deze als zodanig ook gescoord.

- Omdat pech/noodlotattributies en uitspraken zoals 'ik ben niet anders dan een ander. iedereen kan bet kriggen', bij de causale attributies zijn ondergebracht, gaat het niet meer in alle gevallen om een concrete oorzaak, zoals in de aanvankelijke definitie was geformuleerd. De uiteindelijke definitie is daarom als volgt bijgesteld.

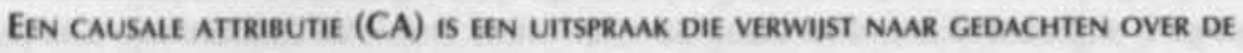 OORZMK.}

\section{- OntKennende atrributie (OKA)}

De aanvankelijke definitie leek eenduidig: $\mathrm{Er}$ is sprake van een ontkennende attributie wanneer de patiènt een concrete oorzaak noemt die niet op haarzelf van toepassing is en die dus nooit een verklaring voor haar ziekte kán zijn. Er is sprake van het neutraal wegstrepen van een eventuele verklaring.

Toch hoort ook hier een kanttekening bij. De naam van het begrip stamt uit het onderzoek van Ten Kroode (1990). In de definitie gaat het vooral om het neutraal wegstrepen van iets wat in werkelijkheid niet van toepassing is. De term 'ontkennen' is bij nader inzien niet zo'n goede keus. Ontkennen hoeft immers niet per se betrekking te hebben op iets wat je niet gedaan hebt of wat niet op jou van toepassing is. Het kan juist ook slaan op iets wat je wél gedaan hebt of wat wel van toepassing is, maar wat je ontkent. De term uitsluitende attributie (USA) past dan beter bij wat met deze strategie wordt bedoeld. Een voorbeeld van een uitsluitende attributie is: 'Ze zeggen dat bet erfelijk is, maar bet komt in onze familie niet voor:

Door de naamsverandering is meteen een ander probleem opgelost. Hierdoor werd de afbakening met een schuldontlastende attributie duidelijker. Tevens is de definitie enigszins aangescherpt.

ER IS SPRAKE VAN EEN UITSLUITENDE ATTRIBUTIE (USA) WANNEER DE PATIËNT EEN MOGELIIKE OORZAAK NOEMT EN CONCLUDEERT DAT DEZE NIET OP HAARZELF VAN TOEPASSING IS EN DUS NOOIT EEN VERKLARING VOOR HAAR ZIEKTE KÁN ZIIN. ER IS SPRAKE VAN HET NEUTRAAL WEGSTREPEN VAN EEN EVENTUELE VERKLARING. 


\section{- Schuldontlastende attributie (OLA)}

De aanvankelijke definitie was: $\mathrm{Er}$ is sprake van een schuldontlastende attributie wanneer een patiênt een oorzaak noemt die wel op haarzelf van toepassing is, maar die ze als verklaring voor de ziekte afwijst.

Ook deze definitie stamt uit het onderzoek van Ten Kroode (1990) en had toen vooral betrekking op longkankerpatiënten die rookten en verklaarden dat het absoluut niet zeker was dat roken de oorzaak van hun longkanker was. Vaak beriepen ze zich erop dat zij genoeg mensen kenden die hun hele leven hadden gerookt en geen kanker hebben gekregen.

Bij analyse van de uitspraken van de borstkankerpatiënten bleek dat een groot aantal uitspraken als schuldontlastend kan worden opgevat, hoewel ze niet aan de werkdefinitie voldoen. In deze uitspraken wordt niet zozeer aangegeven dat men iets wel gedaan heeft en dit als mogelijke oorzaak voor kanker afwijst, zoals bij roken, maar er wordt zeer nadrukkelijk aangegeven dat men iets juist altijd heel voortreffelijk heeft gedaan en desondanks toch kanker heeft gekregen. Het is een uiting van 'mij treft geen blaam'. Dit komt vooral voor bij uitspraken over leefgewoonten. 'We bebben tot mu toe altijd perfect geleefd. Heel gezond, beel sportief. En dan zeggen de mensen ook wel: "Jeetje, jij? Jij uas een gezondbeidsfreak. Onbegrijpelijk!" Het enige is dat je jezelf niets bebt te verwijten. Ik beb mijn kinderen op de Vrije Scbool, ik beb zelf brood gebakken, ik ben macrobiotisch, alles van bet reformbuis gegeten. Dus wat bad je nog meer moeten doen?'

Er zit vaak verbijstering of boosheid in dergelijke uitspraken. Patiënten begrijpen er helemaal niets van dat uitgerekend zij kanker hebben gekregen. De woorden 'altijd' en 'nooit' vallen daarbij op. Besloten is ook deze 'mij-treft-geen-blaam-uitspraken' als schuldontlastende attributie te scoren.

Veel vrouwen vertellen dat ze het knobbeltje echt niet eerder hadden kunnen ontdekken, bijna alsof ze zich moeten verdedigen. 'Toen ik bet voelde ben ik direct gegaan. Niet dat ik regelmatig aan borstonderzoek deed. Maar wie doet dat wel? Het was trouvens zo klein, dat je bet menselijkerwijs ook niet eerder bad kunnen voelen, ook al bad je jezelf regelmatig gecontroleerd'. Hoewel het hier niet gaat over de oorzaak van de kanker, is er wel sprake van schuldontlasting. Daarom zijn ook dergelijke uitspraken als schuldontlastende attributie opgevat.

Samenvattend, er zijn twee nieuwe categorieën uitspraken aan de schuldontlastende attributies toegevoegd. Dit zijn (1) uitspraken die gaan over het afwijzen van schuld aan iets wat algemeen maatschappelijk als oorzaak van kanker wordt aanvaard, waarbij de borstkankerpatiënt dan aangeeft dat ze haar best heeft gedaan zich daar juist niet aan te bezondigen en (2) uitspraken waarmee mogelijke schuld aangaande het tijdstip van het ontdekken van het knobbeltje wordt afgewezen. Dit heeft tot de volgende definitie geleid. 
VAN EEN SCHULDONTLASTENDE ATTRIBUTIE (OLA) IS SPRAKE ALS DE PATIËNT IETS DAT ZIJ WEL HEEF GEDAAN AFWIIST ALS OORZAAK VAN HAAR KANKER, ALS ZII EEN OORZAAK AFWIJST DIE ALGEMEEN MAATSCHAPPELIJKE GELDIGHEID HEEFT EN DAARBII LAAT WETEN ALTIDD HAAR BEST GEDAAN TE HEBBEN ZICH ER NIET AAN TE BEZONDIGEN EN ALS HET EEN UITSPRAAK BETREFT WAARMEE IEMAND AANGEEFT DAT ZE DE KANKER NIET EERDER HAD KUNNEN ONTDEKKEN.

\section{- Betekenisverlenende attributie (BA)}

De definitie was: Een betekenisverlenende attributie is een globale, existentiële beschouwing, die de vraag naar een concrete oorzaak overstijgt, maar wel betrekking heeft op het denken over een oorzaak. Het is vaak een beschouwing over de zin van ziekte.

In zijn proefschrift 'Het verhaal van kankerpatiënten: Oorzaakstoekenning en betekenisverlening' (1990) werd het antwoord op de vraag 'waarom ik?' door Ten Kroode een betekenisverlenende attributie genoemd. Omdat in dat onderzoek geen andere cognitieve strategieèn dan attributies werden onderzocht, bestond het probleem van overlapping of samenvallen dan ook niet. In eerste instantie is er mol deze oude definitie verder gewerkt en zijn uitspraken die eigenlijk beter onder een van de andere strategieèn gescoord hadden kunnen worden, anvankelijk toch bij BA terechtgekomen. Zoals eerder gemeld, is besloten de vraag als leidend criterium los te laten en de uitspraken op de inhoud te beoordelen. Dat had tot consequentie dat uitspraken over pech en noodlot, die aanvankelijk - omdat het antwoorden waren op de vraag 'waarom ik?' - als BA waren gescoord, in tweede instantie zijn geplaatst in de categorie waar ze in feite thuishoren, namelijk bij de causale attributies. Zo zijn de uitspraken over de levensloop als oorzaak van de kanker om dezelfde reden als CA gecategoriseerd.

Voorts bleek er heel veel overlapping met de strategie 'verleggen van prioriteiten' (VPR). Dat ligt voor de hand wanneer men beide definities vergelijkt. Bij VPR gaat het erom dat er dankzij de ziekte iets ten positieve is veranderd. Je kunt zeggen dat de ziekte daarmee zin of betekenis heeft gekregen. Veel VPR-uitspraken zouden dus net zo goed als BA kunnen worden gecategoriseerd. Omdat de definitie van VPR eenduidiger en concreter is dan die van BA, zijn alle uitspraken die als VPR-uitspraken zijn op te vatten, onder die strategie geplaatst.

Er zijn ook BA-uitspraken die een sterke overlapping vertoonden met de strategie 'in protest komen' (PR), zoals bijvoorbeeld 'Wij bebben al zo verscbrikkelijk veel meegemaakt. Dan word ik zo kuraad dat dit er ook nog eens bij komt'. Opnieuw vanwege de eenduidiger definitie is besloten in dergelijke gevallen de categorie PR te scoren.

Antwoorden op de vraag 'waarom ik?' worden vaak gegeven in termen van een 
sociale vergelijking. Met name de sociale vergelijking gelijkwaardig (S ") komt vaak voor, evenals de sociale vergelijking negatief naar boven (S $\left.{ }^{*}\right)$. Voorbeelden hiervan zijn respectievelijk 'Waarom ik? Ja uaarom ik niet? ledereen kan bet krijgen en tk ben niet anders dan een ander' en 'Het is absoluat niet eerlijk dat ik bet beb gekregen, zeker als je andere mensen ziet die er maar op los leven en er doorbeen mazzelen: Ook hier is gekozen deze uitspraken niet langer als BA te categoriseren.

Samenvattend: nagenoeg alle uitspraken die aanvankelijk als BA zijn gescoord, zijn beter onder te brengen bij de strategieën CA, SV, PR of VPR. Het lijkt erop dat betekenisverlening op zich geen afzonderlijke, goed af te bakenen strategie is. Betekenisverlening geschiedt klaarblijkelijk door middel van verschillende strategieenn. Daarom is besloten om de betekenisverlenende attributie als zelfstandige, van andere strategieèn af te bakenen strategie te laten vervallen.

\section{- VerLeggen Van prioriteiten (VPR)}

De aanvankelijke definitie was: $\mathrm{Er}$ is sprake van verleggen van prioriteiten wanneer de patiènt te kennen geeft dat zij dankzij de ziekte andere dingen belangrijk is gaan vinden, of dat er dankzij de ziekte positieve veranderingen bij haar zijn opgetreden.

Bij nadere analyse van de uitspraken die onder deze strategie zijn geplaatst, bleek dat het label 'verleggen van prioriteiten' niet helemaal de lading dekt. Het label 'een positieve wending geven' (PWG) lijkt passender. Met dit nieuwe label vallen niet alleen die uitspraken onder de definitie, waarin mensen aangeven dat zij andere keuzes zijn gaan maken, maar ook uitspraken waaruit blijkt dat men vindt dat de ziekte naast negatieve ook positieve gevolgen heeft gehad.

Je denkt wat meer over je leven na. Tot nu toe beeft bet leven alleen maar in bet teken van de zaak gestaan: werken, werken, werken. We besteden nu meer aandacbt aan bet gezin, en ik neem meer tijd voor mijzelf. Je beseft dat je je leven niet meer over kan doen, en dat er meer is dan materiële zaken.'

Je wordt met je neus op de feiten gedrukt. Je ogen gaan meer open over boe jezelf in bet leven stond. Dat kun je niet ongunstig noemen. De binnenkant van mijn arm, daar zit geen getoel meer in (door het okselkliertoilet; $\mathrm{MO}$ ). Het is eigenlijk een stukje memento mori, een stukje dood wat je bij je bebt. Maar dat is niet vervelend, dat kun je niet ongunstig noemen. Je wordt met dingen in contact gebracht wat je alleen maar verruimt, ondanks de beperkingen van je lichaam.'

Zoals al bij de beschrijving van de betekenisverlenende attributie aan de orde kwam, is besloten de BA-uitspraken die aan de definitie van PWG voldoen als PWG te scoren.

Samenvattend, de aanvankelijke definitie is niet wezenlijk veranderd. Wel is besloten tot een andere naam. Bovendien zijn uitspraken die oorspronkelijk zijn gescoord als BA en aan de definitie van PWG voldoen, overgeheveld naar deze strategie. 
EEN POSITIEVE WENDING GEVEN AAN DE ZIEKTE (PWG) WIL ZEGGEN DAT DANKZIJ DE ZIEKTE ANDERE DINGEN IN HET LEVEN BELANGRIJK ZIIN GEWORDEN, DAT DINGEN IN POSITIEVE ZIN ZIIN VERANDERD: DE ZIEKTE HEEFT IETS OPGELEVERD, HEEFT 'ZIN' GEHAD,

\section{- Sociale vergeljjking (SV)}

Over het algemeen is er aan de definities van de vijf verschillende sociale vergelijkingen niet veel veranderd. Zo hier en daar zijn wat kanttekeningen te plaatsen.

\section{- Sociale vergelijking positief naAr boven $\left(\mathbf{S}^{+*}\right)$}

De aanvankelijke definitie was: S * wil zeggen dat de patiënt zich vergelijkt met anderen waarmee het beter gaat en zich daaraan optrekt.

Er was geen aanleiding deze definitie aan te passen. Bij deze $\mathrm{S} \cdots$ komen vaak dubbelstrategieên voor, vooral in combinatie met het bagatelliseren (BAG) van de ziekte:

'Er zijn er die er dood aan gaan, maar die ben ik nog niet tegengekomen. $1 k$ ken er uel die er 25 jaar geleden of tien jaar geleden voor bebandeld zijn, en die leven allemaal nog. Er zijn er die bet nog

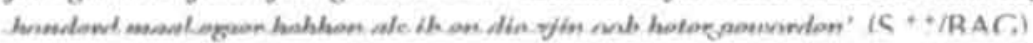

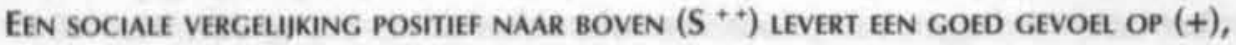 OMDAT DE PATIENT NAAR ANDEREN KIJKT MET WIE HET VOLGENS HAAR BETER GAAT $(+)$ EN AAN WIE ZIJ ZICH OPTREKT.}

\section{- Sociale vergelijking positief naAr beneden (S +- )}

De aanvankelijke definitie was: S * wil zeggen dat de patiënt zich vergelijkt met anderen met wie het slechter gaat en concludeert dat zij er beter vanaf komt.

Inhoudelijk lijkt deze strategie op relativeren (RL), de nieuwe naam voor 'erger bedenken' (zie verder). De uitspraken 'Als ik dan de buurvout zie met baar borstamputatie, dan kom ik er nog goed vamaf ( $\mathrm{S}^{*-}$ ) en 'lk ben blij dat bet geen amputatie is' ( $\mathrm{RL}$ ) hebben in feite dezelfde strekking. Om deze twee strategieën eenduidig te kunnen onderscheiden wordt een uitspraak als S +- gescoord wanneer er sprake is van een expliciete vergelijking met iemand anders. Bij een impliciete vergelijking wordt de uitspraak gescoord bij RL.

Wanneer een patiènt zich voorhoudt dat zij er direct of indirect vergeleken met anderen goed vanaf komt (respectievelijk S * of RL), kan dit op bagatelliseren van de ziekte (BAG) gaan lijken. Echter, een uitspraak wordt pas als BAG opgevat, wanneer de ernst van de ziekte of de gevolgen ervan kleiner worden gemaakt dan ze in werkelijkheid zijn; de werkelijkheid wordt in feite geweld aangedaan. Bij S * en RL gaat de patiënt uit van haar eigen, reële situatie, zonder daar afbreuk aan te doen; ze 
constateert dat het nog erger had kunnen zijn (RL), of dat het vergeleken met anderen meevalt $\left(S^{*}-\right)$. Met alle drie strategieën wordt de eigen situatie weliswaar minder erg voorgesteld, maar de manier waarop dat gebeurt is voor elk van de drie verschillend.

Samenvattend, de aanvankelijke definitie is niet wezenlijk veranderd. Om de afbakening met de strategie 'relativeren' te verbeteren is aan de definitie toegevoegd dat het om een expliciete vergelijking met anderen gaat.

EEN SOCIALE VERGELIJKING POSITIEF NAAR BENEDEN (S * - ) LEVERT EEN GOED GEVOEL OP (+), OMDAT DE PATIËNT NAAR ANDEREN KIJKT MET WIE HET VOLGENS HAAR SLECHTER GAAT

(-) EN CONSTATEERT DAT ZIJ ER ZELF BETER VANAF KOMT.

\section{- Sociale Vergelijking negatief naAr boven $\left(\mathbf{S}^{*+}\right)$}

De aanvankelijke definitie was: $\mathrm{S}^{-\cdots}$ wil zeggen dat de patiènt zich vergelijkt met anderen met wie het beter gaat en concludeert dat ze er slechter vanaf komt.

Hierbij komen ook vaak dubbelstrategieèn voor, vooral met causale attributies (CA) en 'in protest komen' (PR). Voorbeelden hiervan zijn respectievelijk te vinden bij de beschrijving van CA en PR. De definitie van $\mathrm{S}^{\cdots}$ blijft gehandhaafd.

EEN SOCIALE VERGELIJKING NEGATIEF NAAR BOVEN (S *+) LeVERT EEN VERVELEND GEVOEL OP (-), OMDAT DE PATIËNT NAAR ANDEREN KIJKT MET WIE HET VOLGENS HAAR BETER GAAT (+) EN CONSTATEERT DAT ZII ER ZELF SLECHT VANAF KOMT.

\section{- Sociale Vergelijking negatief naAr beneden (S - - $)$}

De aanvankelijke definitie was: $S^{--}$wil zeggen dat de patiënt zich vergelijkt met anderen met wie het slechter gaat en hun situatie als haar voorland ziet.

$\mathrm{Er}$ is een overlapping met causale attributies en de nieuwe strategie 'doemdenken' (DD), een strategie die is toegevoegd (zie verder). Dergelijke overlappende uitspraken zijn opgevat als dubbelstrategie S - /CA en S - /DD. Voorbeelden hiervan zijn respectievelijk te vinden bij de beschrijving van CA en DD. De aanvankelijke definitie van $\mathrm{S}^{\cdots}$ is vrijwel ongewijzigd.

EEN SOCIALE VERGELIJKING NEGATIEF NAAR BENEDEN ( ${ }^{*-}$ ) LEVERT EEN VERVELEND GEVOEL OP (-), OMDAT DE PATIËNT NAAR ANDEREN KIJKT MET WIE HET SLECHTER GAAT (-) EN CONSTATEERT DAT HUN SITUATIE HAAR VOORLAND IS.

\section{- Sociale Vergelijking GeliJKWAardig ( $\mathrm{S}$ ")}

De aanvankelijke definitie was: $S$ * wil zeggen dat de patiënt zich met anderen vergelijkt en tot de conclusie komt dat het met haar niet anders is dan met die anderen. 
Op vragen als 'Denkt $u$ wel eens boe kom ik eraan?' en 'Vraagt $u$ zicb trel eens af waarom ik? Waarom moet mij dit overkomen?' is nogal eens geantwoord met: 'Tja, waarom ik niet?. Afwijkend van de aanvankelijke definitie is besloten zulke uitspraken in de categorie $\mathrm{S}^{*}$ op te nemen, ook al is er van een expliciete vergelijking geen sprake.

Net als bij de pech-attributies lijkt uit een groot deel van de $\mathrm{S}$ * uitspraken berusting te spreken. De constatering dat je niet alleen bent lijkt troostrijk. Veel S "uitspraken waren aanvankelijk dan ook bij berusten (BR) ondergebracht. Ook hier is besloten niet te interpreteren maar alleen BR te scoren wanneer losse elementen van een uitspraak afzonderlijk bij die strategie zijn onder te brengen.

Zoals bij causale attributie (CA) is besproken, is er dikwijls sprake van de dubbelstrategie $5 \% / \mathrm{CA}$.

Samenvattend, er is afgeweken van de oorspronkelijke bedoeling om alleen expliciete vergelijkingen als S - te scoren. Ook impliciete vergelijkingen zijn bij deze strategie ondergebracht.

EEN SOCIALE VERGELIIKING GELIIKWAARDIG (S ") IS EEN UITSPRAAK WAARIN DE PATIENT ZICH AL OF NIET EXPLICIET VERGELIIKT MET ANDEREN EN DAN TOT DE CONCLUSIE KOMT DAT ZII NIET ANDERS IS DAN EEN ANDER.

\section{- Zichzelf een bijzondere patiënt VINDEN (SB)}

Deze strategie staat niet in de lijst met aanvankelijke definities. Er bleef namelijk een groep uitspraken over die eventueel is op te vatten als sociale vergelijking $\mathrm{S}^{+-}$, maar die zich daar ook van onderscheidt. Het zijn uitspraken waaruit blijkt dat de patiënt zichzelf een bijzonder geval vindt. Deze strategie is in feite de tegenhanger van $\mathrm{S}$ ": de patiënt vindt een duidelijk onderscheid tussen zichzelf en andere patiënten. Een deel van deze uitspraken bevat een expliciete vergelijking met anderen, maar evenals bij S* - berust een ander deel op impliciete vergelijkingen.

It beb daar ecbt een VIP-bebandeling gebad. Ik weet zeker dat ik de beste bebandeling beb gebad oudat de professor zicb er persoonlijk mee beeft bemoeid.'

ZICHZELF EEN BIJZONDERE PATIËNT VINDEN (SB) WIL. ZEGGEN DAT DE PATIËNT, AL OF NIET OP GROND VAN EEN EXPLICIETE VERGELIJKING MET ANDEREN, AANGEEFT DAT ZII EEN BIIZONDER GEVAL. IS OF DAT HAAR EEN BIJZONDERE BEHANDELING TEN DEEL IS GEVALLEN.

\section{- Erger bedenken (eB)}

De aanvankelijke definitie was: Wanneer een patiënt zichzelf voorhoudt dat haar situatie nog erger had kunnen zijn en dat ze relatief gezien nog boft, is er sprake van erger bedenken. 
De benaming 'erger bedenken' bleek verwarrend; ze lijkt teveel op 'doemdenken' (DD), een strategie die later is toegevoegd en uitspraken bevat waarin patiénten bedenken dat het allemaal nog erger kan worden (zie verder). Daarom is als nieuwe benaming relativeren (RL) gekozen.

Inhoudelijk is er veel overlapping tussen sociale vergelijking S +- en RL. Dezelíde onderwerpen komen aan de orde, alleen de vorm waarin dat gebeurt verschilt. Bij S*is er sprake van een expliciete vergelijking, bij RL juist niet.

RL en S*- onderscheiden zich van bagatelliseren (BAG) doordat bij de eerste twee strategieèn de patiënt van haar eigen, reële situatie uitgaat. $\mathrm{Bij}$ BAG maakt de patiènt de eigen situatie minder erg dan ze in werkelijkheid is. Er is dan sprake van het minimaliseren van de ernst.

Samenvattend, de benaming 'erger bedenken' is veranderd in 'relativeren'. Deze term dekt de lading beter en onderscheidt deze strategie duidelijker van doemdenken. De definitie is aangescherpt om RL beter af te bakenen van S*- en BAG.

\section{RELATIVEREN (RL) WIL ZEGGEN DAT DE PATIËNT BEDENKT DAT ZE NOG VAN GELUK MAG SPREKEN, OMDAT HET NOG ERGER HAD KUNNEN ZIJN: ZE KOMT ER NOG GOED VANAF. ER IS GEEN SPRAKE VAN EEN EXPLICIETE VERGELIJKING MET ANDEREN, EVENMIN VAN HET MINIMALISEREN VAN DE ERNST VAN HAAR SITUATIE.}

\section{- Bagatelliseren (BAG)}

De aanvankelijke definitie was: $\mathrm{Er}$ is sprake van bagatelliseren wanneer de patiènt de ernst van haar ziekte of de gevolgen ervan kleiner maakt.

Deze definitie is ongeveer gehandhaafd. Ter verduidelijking moeten eerst nog enkele opmerkingen worden gemaakt. BAG kan gemakkelijk worden afgebakend van relativeren ( $R L$ ) en sociale vergelijking $\left(S^{+-}\right)$, omdat bij BAG de ziekte minder erg wordt gemaakt of lichter wordt opgevat. Vaak zit dat in het gebruik van verkleinwoorden bij het beschrijven van de ziekte of de gevolgen ervan. Het was een dingetje van niks. Maar anderbalve centimeter. En de statistiek begint pas bij tuce. Dus dan valt bet renze mee.' of 'Het zat ietsje in de eerste klier. Maar dat geeft niets, want er waren er nog 24 die wel goed waren.' Er is ook sprake van BAG als er hyperbolische voorbeelden worden aangehaald waarin het goed is gegaan: ' $l k$ ken bele volksstammen die genezen zijn'. Voorts wanneer iemand zich vergelijkt met gezonde mensen en zegt dat zijzelf evenveel kans heeft opnieuw kanker te krijgen als deze gezonde mensen: 'Kijk, ik zeg altijd maar zo, jij kunt bet ook krijgen. Dat ik dit mu beb gebad wil in principe niets zeggen. Wat dat betreft ben ik even ver als jij en begin ik met een scbone lei'. In deze uitspraak wordt de kans op een metastase of recidief die er ondanks de behandeling toch altijd is - helemaal 'weggebagatelliseerd'. Uitspraken in de trant van 'ik weet zeker dat ik ben genezen' doen op de zelfde manier de werkelijkheid geweld aan en worden daarom ook als BAG opgevat. 
Niet altijd duidelijk was de afbakening tussen bagatelliseren (BAG) en 'cognitief vermijden' (CV), de nieuwe benaming voor 'vermijden van gedachten'. Ernst minimaliseren leunt immers aan tegen het verdringen van de ernst of het niet willen denken aan de ernst. De meeste verwantschap tussen BAG en CV komt tot uitdrukking in uitspraken als ' $/ k$ ben zeker genezen', die bij BAG, en 'de ziekte is afgesloten, bet is over', die bij CV wordt gescoord. Deze keuze is gemaakt omdat in de uitspraak 'ik ben zeker genezen' de ziekte vooral te licht wordt opgenomen, en wanneer iemand stellig zegt ' $I k$ beb kanker gebad, bet is klaarl Over en shitten!' het afsluiten en het er niet meer aan willen denken op de voorgrond staat.

Soms lijkt BAG op zichzelf toespreken (ZT): 'Nou, en borstkanker is nog de meest gunstige torm die je kunt bebben. Van alle soorten kanker is bet verreuveg de minst erge.' De ernst van de ziekte wordt kleiner gemaakt. Daarnaast kan de uitspraak ook worden opgevat als een impliciete vorm van zichzelf geruststellend toespreken. In feite zitten in alle BAGuitspraken geruststellende gedachten. Omdat dit impliciet gebeurt, is besloten de uitspraken niet als dubbelstrategie met ZT te scoren. Wanneer iemand expliciet zichzelf ervan probeert te overtuigen dat het zo erg nog niet is, en de nadruk dus ligt op het zich overtuigen, wordt de uitspraak als ZT gescoord. 'Ik zeg ook steeds tegen mezelf: kom op meid, je moet erin geloven dat je bent genezen!'

Zoals al bij sociale vergelijking positief naar boven ( ${ }^{* *}$ ) is besproken, is er overlapping tussen $\mathrm{S}^{*+}$ en BAG en kan er sprake zijn van de dubbelstrategie BAG/S * *

Samenvattend, bagatelliseren heeft raakvlakken met een aantal andere strategieën. Hierboven is aangegeven hoe BAG zich van deze strategieën onderscheidt. Met sociale vergelijking positief naar boven is er overlap; er kan sprake zijn van de dubbelstrategie $\mathrm{BAG} / \mathrm{S} *$.

\section{BAGATELLISEREN (BAG) IS HET KLEINER MAKEN VAN DE ERNST VAN DE ZIEKTE OF DE GEVOLGEN ERVAN. DE REALITEIT WORDT DAARBII GEWELD AANGEDAAN.}

\section{- ONTKENNING (OK)}

De definitie was: Van ontkenning is sprake als de patiënt denkt of zegt dat ze niet aan kanker lijdt.

Oorspronkelijk was het de bedoeling 'ontkenning' als zelfstandige categorie te benoemen. Er zijn echter geen uitspraken aangetroffen waarin sprake was van ontkenning van de ziekte in de strikte zin van het woord; soms wel van ontkennen van de ernst van gevolgen van ziekte of behandeling. Aangezien die uitspraken goed zijn te plaatsen onder bagatelliseren of 'cognitief vermijden' (CV), de nieuwe naam voor 'vermijden van gedachten' (VG), is besloten OK als aparte categorie te laten vervallen. 


\section{- Vermijden van gedachten (VG)}

De aanvankelijke definitie was: Onder vermijden van gedachten wordt verstaan het uit de weg gaan van cognities die met de ziekte te maken hebben.

Bij nadere analyse van de uitspraken werd duidelijk dat ook hier zowel de naam als de definitie de lading niet helemaal dekken. Er zijn veel uitspraken die aangeven dat de patiẻnt niet meer aan de ziekte of de gevolgen wil denken, zonder dat daarbij sprake is van het letterlijk vermijden van zaken of situaties die gedachten aan de ziekte kunnen oproepen. Er is eerder sprake van het afsluiten of stoppen van gedachten. ' $7 k$ moet bet geuoon vergeten en ik moet er verder niet meer aan denken. Het is gebeurd, en bopen dat je bet nooit meer terug krijgt.' Als de nieuwe naam is de term cognitief vermijden (CV) gekozen, waaronder zowel het letterlijke vermijden als het cognitief uitschakelen van gedachten wordt verstaan. Omdat patiënten vaak gedachten uitschakelen door afleiding te zoeken, is CV de enige categorie waar naast cognitieve coping ook een element van gedragsmatige coping is opgenomen. Echter in de uitspraken is steeds wel duidelijk dat het er om gaat niet aan de ziekte te denken: 'Dan sit ik op de bank en denk : kom op, ga een vriendin bellen en ga lekker de stad in. Het is niet goed toor een mens om te gaan zitten simmen. Dan kun je beter zorgen dat je iets leuks om banden bebt."

CV en het bagatelliseren van de ernst van de ziekte (BAG) zijn soms aan elkaar verwant. Welke oplossing hiervoor is gekozen is bij de beschrijving van bagatelliseren al aan de orde geweest.

De vermijdingsuitspraken bevatten vaak een opdracht of voornemen, zoals ' $i k$ vind dat $i k$ er niet meer aan moet denken' of 'ik wil bet nu vergeten'. Wanneer CV in deze vorm wordt geuit is zij opgevat als een dubbelstrategie met 'zichzelf toespreken' (ZT).

\section{COGNITIEF VERMIJDEN (CV) BEVAT VORMEN VAN ONTKENNING VAN DE ZIEKTE EN HAAR GEVOLGEN, ALSMEDE HET AFSLUITEN OF WEGHOUDEN VAN GEDACHTEN ERAAN.}

\section{- IN PROTEST KOMEN (PR)}

De aanvankelijke definitie was: Van in protest komen is sprake wanneer de patiènt in opstand komt tegen het feit dat zij kanker heeft, of tegen de gevolgen van de ziekte of behandeling.

Niet alle uitspraken die binnen deze strategie zijn gescoord, worden door deze benaming gedekt. Beter zou zijn 'niet accepteren en onrecht voelen'. Echter, vanwege de compactheid is toch voor de term 'protest' gekozen. De definitie is wel aangepast.

Zoals bij de bespreking van de betekenisverlenende attributie (BA) al aan de orde kwam, is in de eerste scoringsronde een groot deel van de uitspraken met de strekking 'bet is niet eerlijk, ik ben er boos over' als BA gescoord. Dit kwam omdat het antwoorden waren op de vraag 'Waarom ik?'. In die ronde gold nog het impliciete criterium dat wanneer een dergelijke uitspraak was gedaan in antwoord op de vraag 'Waarom ik?', 
de uitspraak als betekenisverlenende attributie werd gescoord, en wanneer zo'n uitspraak elders in het interview was gedaan, meestal als PR. Dit gemerkt hebbende is besloten alle uitspraken met een dergelijke strekking als PR te scoren.

Protest-uitspraken met de strekking 'oneerlijk' worden vaak gedaan in de vorm van een sociale vergelijking negatief naar boven $\left(S^{*}\right)$ : de patiēnt vindt dat ze er in vergelijking met anderen slechter vanaf komt.

'Maar je denkt wel bij jezelf: je ziet anderen bet een na bet ander aan vette troep naar binnen scbuiven, en bet gaat bun deur voorbij. En jij, die altijd zo op gezonde voeding let, jij krijgt bet wel!! Dat maakt je dan uel boos, boor' Hartstikke oneerlijk vind ik bet.'

'Ik dacbt: wat ontzettend oneerlijk, wat is dit vreselijk oneerlijk. Ik ben de laatste vier jaar al zo veel siek geweest. Drie jaar geleden beb ik een tweezifdige eileiderontsteking gebad waarvoor ik een maand in bet ziekenbuis beb gelegen. Ik beb drie maanden niet kumen uerken. Het jaar daarna zijn ue verbuisd. Tijdens de terbouuing ben ik overspannen geraakt. Daarna leek bet beter te gaan, maar ben ik tocb weer oterspannen geveest. Toen beb ik besloten dat dit zo niet kan doorgaan. Almaar overspannen zijn en zo. Ik ben toen een tijdje gestopt met werken. Toen ik er weer bovenop was gekomen dacbt ik: zo dat bebben we gelukkig acbter de rug en nu weer geuoon aan bet werk. En nu dit er bovenop. Ik vind bet gewoon een klotestreek, vooral als je ziet boe anderen overal doorbeen zuijmen. Ik vind dat ik onevenredig bard getroffen word. "

Dergelijke uitspraken zijn als dubbelstrategie S */PR gescoord, omdat de vergelijking en het protest erin niet van elkaar zijn te scheiden. Er zijn goede argumenten voor de bewering dat in feite alle $\mathrm{S}^{-+}$uitspraken elementen van protest bevatten. In vergelijking met een ander is de patiënt immers slechter af, en dat is oneerlijk. Besloten is dat er alleen sprake is van een dubbelstrategie wanneer de patiènt zelf expliciet aangeeft dat zij het oneerlijk vindt of er boos om is. Om deze reden wordt de S ' uitspraak 'mijn broer beeft ook kanker, maar bij beeft $90 \%$ kans dat bij bet oterleeft en ik $50 \%$, en dat is dus minder' niet als dubbelstrategie met PR, maar alleen als $\mathrm{S}$ *+ gescoord.

IN PROTEST KOMEN (PR) BEVAT UITSPRAKEN DIE WIIZEN OP HET NIET ACCEPTEREN VAN DE KANKER EN DE GEVOLGEN ERVAN. OOK BEVAT DEZE CATEGORIE UITSPRAKEN WAARUIT BUIJKT DAT DE PATIËNT HET ONRECHTVAARDIG VINDT DAT ZII KANKER HEEFT GEKREGEN; ZIJ IS ER BOOS OM.

\section{- Berusten (BR)}

De aanvankelijke definitie was: Er is sprake van berusten, wanneer een patiènt zich erbij neerlegt dat zij kanker heeft omdat het nu eenmaal niet anders is, maar niet bij de pakken neerzit. 
De toevoeging 'niet bij de pakken neerzitten' is vervallen. Uit de uitspraken is namelijk niet te beoordelen of daar sprake van is. Bijvoorbeeld, wanneer iemand zegt: 'Het is niet anders', kan dat betekenen dat zij er terneergeslagen en depressief van is, maar ook dat zij zich er niet door op haar kop laat zitten. Om interpretaties te voorkomen is besloten dit soort uitspraken allemaal onder de categorie BR te scoren. Toevoegingen waarmee een patiënt aangeeft dat ze niet bij de pakken wil neerzitten zijn afzonderlijk bij de categorie 'zichzelf toespreken' (ZT) ondergebracht. Toevoegingen daarentegen die aangeven dat iemand wel bij de pakken neerzit, zijn bij de nieuwe categorie 'doemdenken' (DD) gescoord.

BR-uitspraken zijn in te delen in uitspraken die duiden op accepteren bet is niet anders' en uitspraken waarin de patiènt zichzelf de opdracht geeft om het te (leren) accepteren. Voorbeelden van de laatste zijn: Het is op mijn ueg gekomen en mu moet ik daar render mee zien te komen' en ' $/ k$ moet ermee leren leven'. Deze laatste uitspraak is op te vatten als berusten in de vorm van een zelf-instructie of als een zelf-instructie om te berusten, en is daarom als dubbelstrategie BR/ZT gescoord. Dergelijke dubbelstrategièn bevatten vaak het werkwoord 'moeten'.

\section{Berusten (BR) BEVAT UITSPRAKEN WAAARMEE dE PATIÉNT AANGEeft DAT ZE HAAR HUIDIGE EN TOEKOMSTIGE SITUATIE ALS (EX-)KANKERPATIËNT ACCEPTEERT EN ER ZICH BI] NEERLEGT.}

\section{- Aggraveren van de ziekte (AGG)}

De aanvankelijke definitie was: Aggraveren is er bewust rekening mee houden dat het wel eens slecht kan aflopen, zodat het in ieder geval niet kan tegenvallen. AGG is de tegenpool van bagatelliseren.

$\mathrm{Na}$ scoring bleken slechts enkele uitspraken aan deze definitie te voldoen. Dat komt vooral door de toevoeging 'zodat het in ieder geval niet tegen kan vallen'. Uit de uitspraken zelf is namelijk moeilijk af te leiden of dat laatste het doel van de uitspraak is, zoals in 'Toen we bier de straat uit reden om foto's te laten maken, toen dacht ik: ik kom bier nooit meer terug. Gek, bè!? En ook op de dag dat ik opgenomen werd om die knobbel eruit te laten balen, die woensdagocbtend, toen bad ik dat gevoel weer, dat ik mijn buis niet meer terug zou zien.'

Er zijn zeer veel uitspraken gedaan met daarin angstige gedachten en doemscenario's. Aanvankelijk konden zij onder geen van de definities een plaats krijgen. Toen is besloten deze doemuitspraken met de oorspronkelijke uitspraken van aggraveren in één categorie te plaatsen en voor deze combinatie een andere naam en definitie te zoeken. Er is gedacht aan de benaming 'Zwaard van Damocles', maar ook onder deze term zijn niet alle uitspraken te verenigen. Uiteindelijk is gekozen voor doemdenken (DD). 
Nu bleek echter dat bijna alle uitspraken waarin een patiènt zich vergelijkt met iemand waarmee het slechter is gegaan en waaraan zo'n patiënt dan een negatief gevoel overhoudt ('dat is mijn voorland'), in feite DD-uitspraken zijn. Ze kunnen worden opgevat als DD in de vorm van S - of omgekeerd, als S - in de vorm van DD. Ze zijn daarom als dubbelstrategie (DD/S *-) gescoord.

'Mijn zus beeft bet ook gebad. Zij is er vorig jaar aan gestorven. Volgend jaar ben ik net zo oud als zij uas... Dat is bet nare eraan... Je weet te veel ... Je bent er belemaal niet gerust op. Ik denk vaak dat bet met mij ook zo zal gaan:

\section{DoEMdENKEN (DD) IS HET UITGAAN VAN EEN NEGATIEF SCENARIO: DE ZIEKTE OF DE GEVOLGEN ERVAN ROEPEN ANGSTIGE, NEGATIEVE GEDACHTEN OP.}

\section{- Zichzelf toespreken (ZT)}

De aanvankelijke definitie was: Van zichzelf toespreken is sprake als een patiënt zichzelf tot de orde roept, letterlijk of figuurlijk iets tegen zichzelf zegt of zichzelf iets voorhoudt.

Bij de exrse analyses bleek dat een groal aantal overeenkomstige uitşoraken bij andere strategieën was ondergebracht. Met name de zinsnede 'zichzelf iets voorhoudt' maakte de afbakening met andere strategieën moeilijk. Zichzelf iets voorhouden gebeurt impliciet bij veel strategieën. Bijvoorbeeld, bij relativeren (RL) en bagatelliseren (BAG) zegt de patiënt als het ware tegen zichzelf dat het nog erger had gekund, of dat het allemaal nog meevalt en het heus zo ernstig niet is. Ook bij S * houdt een patiënt zich impliciet voor dat ze er vergeleken met anderen nog goed vanaf komt. Bij het herindelen is besloten om uitspraken die slechts impliciet zijn op te vatten als 'zichzelf iets voorhouden', niet ook nog bij ZT in te delen, maar alleen bij de strategie waarover expliciet mededeling wordt gedaan.

Bij de afbakening van ZT van de strategieën berusten (BR) en cognitief vermijden $(\mathrm{CV})$ is nog iets anders aan de orde. Bij beide strategieën zijn er twee soorten uitspraken. Bij de ene soort is er alleen maar sprake van BR of CV. 'Ik kan geen zware buisboudelijke dingen meer doen zoals stofzuigen en zo. Mijn man doet dat nu. Ik vind dat uel beel vervelend, maar ja bet is niet anders' is een voorbeeld van zo' $n$ 'pure' BR en 'wat mij betreft is bet een afgesloten probleem. Ik ben weer aan bet werk, en denk er eigenlijk niet meer aan' een voorbeeld van een 'pure' CV. De andere soort bevat als het ware een zelf-instructie (ZT) om te berusten of cognitief te vermijden, een dubbelstrategie dus. De eigenaresse van een winkel in huishoudelijke apparatuur bracht de dubbelstrategie BR/ZT als volgt onder woorden: 'Ik mag nooit meer zuvar tillen met die arm. Dus er moet wel veel veranderen. Ik sleepte, zeg maar, geuoon een uasmacbine weg. of een formuis of zo. Dat kan nu niet meer. Dat zal ik moeten leren. Ook al zal dat niet meevallen. Ik zal dat moeten leren accepteren. " 
Een ander wilde daarentegen weer doorgaan als vroeger getuige haar dubbelstrategie CV/ZT: ' $1 k$ moet proberen om bet getwoon te tergeten. Dat is bet allerbeste toor jezelf. Gewoon weer de draad oppakken. Zo moet bet ook. Want als je dat niet doet, dan graafje je eigen graf. denk ik. Ik moet er zo min mogelijk bij stil staan:

$\mathrm{Er}$ is ook nog een grote groep uitspraken met als strekking 'je moet positief zijn' of 'je moet positief denken'. Deze uitspraken bevatten een nadrukkelijke zelf-instructie en zijn daarom bij ZT gecategoriseerd.

Tenslotte bleef er een groep uitspraken over die onder geen van de aanvankelijke definities viel. De gemeenschappelijke noemer voor die groep zou kunnen zijn 'het wegredeneren van angst en ongenoegen'.

'Ik raakte in paniek, dan denk je eroter en zeg tegen jezelf; ik ben goed bestraald, ik ben nog bezig met de cbemokuur, er kan dus geen gezuel zitten, dat kan geuvonueg niet!

Een maand voordat bet bij mij bekend werd is mijn zus eraan oterleden. Daar moet ik nog vaak aan denken. Maar zij bad er drie jaar mee gelopen. Die was al veel te ver been toen ze naar de dokter ging. Zij was 44 toen ze bet kreeg en 47 toen ze oterleed. Ik ben mu ook 44, maar ik was er veel vroeger bij. Zo'n gedacbte stelt me dan weer gerust.'

Besloten is deze groep uitspraken ook als ZT op te vatten.

Duidelijk is dat een geruststellende redenering soms op een sociale vergelijking is gebaseerd. Wanneer dat het geval is wordt de uitspraak als dubbelstrategie gescoord. Bij het laatste voorbeeld als S *-/ZT. De patiënt geeft aan in welk opzicht zij positief afsteekt bij haar zus; zij gebruikt de vergelijking om haar angst weg te redeneren.

\section{ZICHZELF TOESPREKEN WIL ZEGGEN DAT DE PATIËNT ZICHZELF INSTRUCTIES GEEFT DAT IETS MOET OF IUIST NIET MOET. OOK HET WEGREDENEREN VAN ANGST EN ONGENOEGEN WORDT ERONDER VERSTAAN.}

\section{5 - Samenvatting en conclusies}

Met behulp van een voorlopige lijst van veertien cognitieve strategieèn zijn de interviews geanalyseerd. Daarbij traden categoriseringsproblemen op, die voor het grootste deel konden worden opgelost door de werkdefinities verder te preciseren, af en toe een duidelijker benaming te kiezen, strategieën anders af te bakenen, een enkele strategie toe te voegen, opeenvolgende strategieën afzonderlijk te benoemen door een tekstfragment in stukken te knippen, en door interpretatie te vermijden. Ook het besluit om dezelfde uitspraken steeds hetzelfde te benoemen, ongeacht door welke vraag ze zijn uitgelokt, heeft bijgedragen aan een eenduidige indeling. 
Er bleef echter een fundamenteel probleem over dat niet zonder meer was op te lossen. Een aantal uitspraken bleek meer dan één strategie te bevatten maar kon toch niet worden opgeknipt in verschillende fragmenten. Gedeeltelijk komt dit omdat een en dezelfde uitspraak, vanuit de verschillende theorieën bezien, soms anders wordt benoemd. Wanneer er breder naar cognitieve strategieën wordt gekeken, zonder op één theorie terug te vallen kan dit een benoemingsprobleem opleveren. Bijvoorbeeld de uitspraak 'het is erfelijk want mijn zus heeft het ook' is zowel een causale attributie als een sociale vergelijking. De strategieẻn volgen elkaar niet op maar vallen samen. De uitspraak kan niet worden opgeknipt zonder haar betekenis te verliezen. Een andere oorzaak van het samenvallen van strategieèn wordt gegeven door van Zuuren (1995). Volgens haar kan een en hetzelfde fragment soms, los van het theoretisch kader, potentieel twee verschillende elementen in zich bergen, omdat psychische verschijnselen nu eenmal meervoudig gedetermineerd zijn en ook diverse functies tegelijk vervullen. $\mathrm{Zij}$ concludeert dat het daarom onvermijdelijk is dat verschillende beoordelaars dergelijke fragmenten verschillend zullen categoriseren. Zolang er maar genoeg fragmenten zijn die wel eenduidig zijn in te delen, zo vervolgt zij, hebben de elkaar overlappende categorieën toch elk bestaansrecht.

Echter door te onderkennen dat een bepaalde uitspraak twee mededelingen tegelijkertijd bevat zijn de uitspraken wel degelijk eenduidig in te delen. Immers wanneer hier overeenstemming over bestaat, en dit wordt vervolgens door beide strategieèn te benoemen in de categorisering tot uitdrukking gebracht, is er opnieuw sprake van eenduidigheid. Daarom is in dit onderzoek de term dubbelstrategie geintroduceerd voor een uitspraak die twee verschillende strategieën tegelijk bevat die zodanig met elkaar samenvallen, dat ze niet van elkaar zijn te scheiden.

$\mathrm{Na}$ herdefiniëring en aanscherpen van de definities zijn uiteindelijk zeventien strategieën in het onderzoek betrokken. Een overzicht met de bijbehorende definities vindt $u$ op de volgende pagina's. 


\section{- Causale attributie (CA)}

EEN CAUSALE ATTRIBUTIE IS EEN UITSPRAAK DIE VERWIIST NAAR GEDACHTEN OVER DE OORZAAK.

\section{- Uitsiuitende attributie (USA)}

ER IS SPRAKE VAN EEN UITSLUITENDE ATTRIBUTIE WANNEER DE PATIENT EEN MOGELIIKE OORZAAK NOEMT EN CONCLUDEERT DAT DEZE NIET OP HAARZELF VAN TOEPASSING IS EN DUS NOOIT EEN VERKLARING VOOR HAMR ZIEKTE KÁN ZIIN. ER IS SPRAKE VAN HET NEUTRAAL. WEGSTREPEN VAN EEN EVENTUELE VERKLARING.

\section{- Schuldontlastende attributie (OLA)}

VAN EEN SCHULDONTLASTENDE ATTRIBUTIE IS SPRAKE ALS DE PATIENT IETS DAT ZUI WEL HEEFT GEDAAN AFWIIST ALS OORZAAK VAN HAAR KANKER, ALS ZII EEN OORZAAK AFWIIST DIE ALGEMEEN MAATSCHAPPELIJKE GELDIGHEID HEEFT EN DAARBIJ LAAT WETEN ALTID HAAR BEST GEDAAN TE HEBBEN ZICH ER NIET AAN TE BEZONDIGEN EN ALS HET EEN UITSPRAAK BETRETT WAARMEE IEMAND AANGEEFT DAT ZE DE KANKER NIET EERDER HAD KUNNEN ONTDEKKEN.

\section{- POSITIEVE WENDING GeVEN AAN DE ZIEKTE (PWG)}

EEN POSITIEVE WENDING GEVEN AAN DE ZIEKTE WIL ZEGGEN DAT DANKZII DE ZIEKTE ANDERE DINGEN IN HET LEVEN BELANGRIIK ZIIN GEWORDEN, DAT DINGEN IN POSITIEVE ZIN ZIIN VERANDERD: DE ZIEKTE HEEFT IETS OPGELEVERD, HEEFT 'ZIN' GEHAD.

\section{- sociale Vergelijking positief naAr boven $\left(\mathrm{S}^{++}\right)$}

EEN SOCIALE VERGELIIKING POSITIEF NAAR BOVEN LEVERT EEN GOED GEVOEL OP $(+)$, OMDAT DE PATIENT ZICH MET ANDEREN VERGELIIKT MET WIE HET VOLGENS HAAR BETER GAAT $(+)$ EN AAN WIE ZII ZICH OPTREKT.

\section{- sociale vergelijking positief naAr beneden ( $\mathrm{S}^{+-}$)}

EEN SOCIALE VERGELIJKING POSITIEF NAAR BENEDEN LEVERT EEN GOED GEVOEL OP $(+)$, OMDAT DE PATIENT ZICH MET ANDEREN VERGELIIKT MET WIE HET VOLGENS HAAR SLECHTER GAAT (-) EN CONSTATEERT DAT ZIJ ER ZELF BETER VANAF KOMT.

\section{- sociale vergelijking negatief naAr boven $\left(\mathrm{S}^{-+}\right)$}

EEN SOCIALE VERGEL.IIKING NEGATIEF NAAR BOVEN LEVERT EEN VERVELEND GEVOEL OP (-), OMDAT DE PATIEENT ZICH MET ANDEREN VERGELIIKT MET WIE HET VOLGENS HAAR BETER GAAT $(+)$ EN CONSTATEERT DAT ZII ER ZELF SLECHT VANAF KOMT.

\section{- sociale vergelijking negatief naAr beneden (S - -)}

EEN SOCIALE VERGELUJKING NEGATIEF NAAR BENEDEN LEVERT EEN VERVELEND GEVOEL OP (-), OMDAT DE PATIENT ZICH MET ANDEREN VERGELIIKT MET WIE HET SLECHTER GAAT $(-)$ EN CONSTATEERT DAT HUN SITUATIE HAAR VOORLAND IS. 


\section{- sociale VergeliJKing GeLIJKWAardig ( $\mathrm{S}$ ")}

EEN SOCIALE VERGELIIKING GELIIKWAMRDIG IS EEN UITSPRAAK WAARIN DE PATIENT ZICH AL. OF NIET EXPLICIET VERCELIIKT MET ANDEREN EN DAN TOT DE CONCLUSIE KOMT DAT ZII NIET ANDERS IS DAN EEN ANDER.

\section{- ZICHZELF EEN BIJZONDERE PATIËNT VINDEN (SB)}

ZICHZELF EEN BIZZONDERE PATIENT VINDEN WIL ZEGGEN DAT DE PATIENT AL. OF NIET OP GROND VAN EEN EXPLICIETE VERGELIIKING MET ANDEREN AANGEEFT DAT ZII EEN BIJZONDER GEVAL IS OF DAT HAAR EEN BIIZONDERE BEHANDEIING TEN DEEL IS GEVALLEN.

\section{- Relativeren (RL)}

RELATIVEREN WIL ZEGGEN DAT DE PATIENT BEDENKT DAT ZE NOG VAN GELUK MAG SPREKEN, OMDAT HET NOG ERGER HAD KUNNEN ZIIN: ZE KOMT ER NOG GOED VANAF. ER IS GEEN SPRAKE VAN EEN EXPLICIETE VERGELIIKING MET ANDEREN, EVENMIN VAN HET MINIMULISEREN VAN DE ERNST VAN HAAR SITUATE.

\section{- Bagateluseren (BAG)}

Bagatelliseren is het kLEINER maken VAN de eRnst VAN de zIEkTE of DE Gevolgen ERVAN. DE REALTTEIT WORDT DAARBH GEWELD AANGEDAAN.

\section{- Cognitief vermijden (CV)}

COGNITIEF VERMIJDEN BEVAT VORMEN VAN ONTKENNING VAN DE ZIEKTE EN HAAR GEVOLGEN, ALSMEDE HET AFSLUITEN OF WEGHOUDEN VAN GEDACHTEN ERAAN.

\section{- In PROTEST KOMEN (PR)}

IN PROTEST KOMEN BEVAT UITSPRAKEN DIE WIIZEN OP HET NIET ACCEPTEREN VAN DE KANKER EN DE GEVOLGEN ERVAN. OOK BEVAT DEZE CATEGORIE UITSPRAKEN WAMRUIT BLIIKT DAT DE PATIENT HET ONRECHTVAARDIG VINDT DAT ZII KANKER HEEFT GEKREGEN; ZII IS ER BOOS OM.

\section{- Berusten (BR)}

BERUSTEN BEVAT UITSPRAKEN WAARMEE DE PATIENT AANGEEFT DAT ZE HAAR HUIDIGE EN TOEKOMSTIGE SITUATIE ALS (EX-)KANKERPATIENT ACCEPTEERT EN ER ZICH BIJ NEERLEGT.

\section{- Doemdenken (DD)}

DOEMDENKEN IS HET UITGAMN VAN EEN NEGATIEF SCENARIO: DE ZIEKTE OF DE GEVOLGEN ERVAN ROEPEN ANGSTIGE, NEGATIEVE GEDACHTEN OP.

\section{- ZiCHZELF TOESPREKEN (ZT)}

ZICHZELF TOESPREKEN WIL ZEGGEN DAT DE PATIENT ZICHZELF INSTRUCTIES GEEFT DAT IETS MOET OF IUIST NIET MOET. OOK HET WEGREDENEREN VAN ANGST EN ONGENOEGEN WORDT ER ONDER VERSTAAN. 


\section{COGNITIEVE STRATEGIEËN VAN BORSTKANKERPATIËNTEN}

In het vorige hoofdstuk is uiteengezet hoe de definities van de strategieèn tot stand zijn gekomen. In dit hoofdstuk zal eerst worden ingegaan op de onderwerpen die de patiënten in hun cognitieve strategieèn noemen en waarop deze strategieën betrekking hebben. Daarna wordt besproken hoe vaak de onderzochte strategieën in de interviews zijn aangetroffen, hoe ze onderling samenhangen en welke veranderingen er optreden in de loop van de tijd. Tenslotte wordt vermeld of, en zo ja in welke mate, subgroepen respondenten van elkaar verschillen in het gebruik van de strategieèn.

\section{1 - ONDERWERPEN VAN DE COGNITIEVE STRATEGIEËN}

De cognitieve strategieèn van de borstkankerpatiènten hangen niet in het luchtledige. Zoals uit de voorbeelden in hoofdstuk III blijkt, hebben ze betrekking op verschillende aspecten van de ziekte en haar gevolgen. De onderwerpen die in de strategieèn voorkomen laten zien wat borstkankerpatiënten bezighoudt; de strategieën maken duidelijk hoe zij hiermee omgaan. In deze paragraaf wordt hieraan gedetailleerd aandacht besteed.

Per strategie worden de te onderscheiden onderwerpen genoemd met de aantallen respondenten bij wie deze zijn aangetroffen. Daarbij staat $N_{1}$ voor het aantal patiènten dat een dergelijke uitspraak tijdens het eerste interview deed en $N_{2}$ en $N_{3}$ respectievelijk voor de aantallen patiënten tijdens het tweede en het derde interview $\left(N_{101}=46\right)$. Telkens zijn er voorbeelden van uitspraken gegeven.

Op verschuivingen in de aantallen uitspraken wordt in deze paragraaf niet expliciet ingegaan. Hieraan wordt in paragraaf 4 aandacht besteed. Hier en daar wordt vermeld dat een bepaalde strategie in combinatie met een andere voorkomt, of is er, met de inmiddels bekende afkortingen, aangegeven dat er sprake is van een dubbelstrategie. Dit samengaan van strategieën wordt verder uitgewerkt in paragraaf 6-1. 


\section{- Causale attributies}

In de causale attributies van deze groep borstkankerpatiènten zijn veertien verschillende oorzaken of onderwerpen te onderscheiden.

- I $\mathrm{k}$ ben niet anders dan een ander $\left(\mathrm{N}_{1}=34, \mathrm{~N}_{2}=27, \mathrm{~N}_{3}=20\right)$ 'I $k$ beb bet nu dan ook. Maar ik ben niet alleen. Er zitten bonderdduizend vroutuen mee.' (CAS *) 'Er zijn zoveel gezonde en jonge unouuen die bet kriggen. Zelfs kinderen krijgen bet. Dus waarom ik niet?' $\left(\mathrm{CAS} \mathrm{S}^{*}\right)$

- Psychologische verklaringen $\left(N_{1}=18, N_{2}=17, N_{3}=18\right)$

Th denk dat bet de laatste vier jaar zo gespookt beeft in mijn licbaam, dat op een gegeten moment tocb, boeuel ik juist dacbt dat alles weer wat rustiger was, dat dat tocb de ontstaansfactor is geueest. Die gespannenbeid, die onurede tbuis...'

'Het is wrok. Ik beb nog steeds een band met mijn ex, maar dat is een band san agressie. Daar ga ik dus niel goed mee om. En verder beb ik een jaar lang met tegenzin geuverkt en ik uoon bier niet met plezier. It mis de tuin. Dat zijn dingen die zitten niet lekker. Dat vreet tocb energie. Dat moet wel. Als ik zo doorga, vraag ik om een nieuue tumor. Dat klinkt misscbien beel bard, maar zo toel ik dat.'

\section{- Leefgewoonten $\left(N_{1}=17, N_{2}=11, N_{3}=21\right)$}

'Ik denk dat al die troep als conserveringsmiddelen, kleurstoffen en zo, dat kan geuoon niet gezond zijn toor een mens. Maar ja, je bent aan die maffia overgeleverd. En boe weet jij als eenvoudig mens nou uxt erin zit en of dat scbadelijk is of niet?'

'Vooral omdat mijn zus bet ook beeft denk ik: 'is bet iets van tbuis?' We bebben tbuis altijd samen van betzelfde gegeten. Hier in bet dorp is ook een gezin met veel kanker in de familie. Toen zeiden ze dat komt van vlees eten, want die grootvader bad een slachterij en er kuam daar altijd veel vlees op tafel. Dan denk ik uel eens... troeger bad mijn moeder een kennis die werkte bij een slacbtplaats en dan kregen wij wel eens afgekeurd vlees. Dat verbaal van dat vlees, dat beeft mij aan bet denken gezet. Ik beb dat vlees altijd met veel tegenzin gegeten. Je proefde dat die beesten ziek geweest waren.' $\left(\mathrm{CA} / \mathrm{S}^{*}\right)$

- Hormonen $\left(\mathrm{N}_{1}=13, \mathrm{~N}_{2}=10, \mathrm{~N}_{3}=11\right)$

'Ik beb ongeveer tien jaar de pil geslikt. In bet begin was-ie sterker dan nu. Toen badden ze bet misscbien nog niet zo goed onder controle. Viteindelijk legt dat tocb wat stil in je licbaam zo'n pil. Acbteraf denk je: dat is misscbien niet goed geureest."

Je bormoonbuisbouding verandert in de otergang. Dat beeft er vast iets mee te maken. Ik ken veel trouuen tussen de vilfenteertig en zestig, die dit bebben gekregen.' (CA/ $\left.{ }^{*}\right)$

'Ik ben een DES-docbter: mijn moeder beeft die bormonen gestikt toen ze in veruacbting was van mij. $1 \mathrm{k}$ dacbt.... ja boor, daar bebben ue bet dan! Bingo! Voor mij is bet duidelijk dat bet daarmee te maken beeft.' 
- Pech en noodlot $\left(N_{1}=11, N_{2}=17, N_{3}=19\right)$

'Ik vind bet beel jammer, maar ja, bet zal mijn lot wel geuvest aijn. Het is geuoon pech.'

Je kunt je wel afiragen uaarom dit en waarom dat? Maar dat beeft geen zin, want bet lot dat walt bij jou, bet valt niet bij een ander.'

- Aanleg en vatbaarheid $\left(\mathrm{N}_{1}=8, \mathrm{~N}_{2}=11, \mathrm{~N}_{3}=12\right)$

'Je leest dan wel eens over een snellere celdeling. Daar beb ik dan waarscbijnlijk uel aanleg voor.'

'Ik ben altijd al aan bet kuakkelen met mijn gezondbeid. Mijn zussen badden nooit iets. Er boefde maar een griepje over te waaien en ik uas bet baasje. Het zal wel iets met je algemene gestel te maken bebben.' $\left(\mathrm{CA} / \mathrm{S}^{-+}\right)$

- Erfelijkheid $\left(N_{1}=7, N_{2}=5, N_{3}=8\right)$

Mijn tader bad ook kanker en zijn moeder beeft ook borstkanker gebad. Dus nu je bet zelf ook bebt, denk je tocb aan je genen. Dat bet erfelijk is of zo. Daarom liet ik ook al jaarlijks een mammografie maken.' (CA/S")

- Milieufactoren $\left(N_{1}=7, N_{2}=6, N_{3}=11\right)$

'Er zueeft zoveel rommel in de lucht. Wij wonen in een agrarisch gebied. Er wordt veel gespoten.' Kanker is een ziekte van onze tijd, van de vervuiling aan ons milieu.'

- Magisch denken $\left(N_{1}=6, N_{2}=5, N_{3}=4\right)$

I $k$ beb wel eens geboord over jezelf iets aanpraten. Maar of dat nou ecbt zo is weet ik niet. Maar ik ben altijd wel een mens geweest van...: ik beb pijn in mijn buik, o jeetje! of ik beb bier of daar pijn: als ik DAT maar niet beb. Zo was ik altijd bezig.'

'Het klinkt misscbien beel gek. Ik beb altijd gezegd, veertig vind ik een stomme leeftijd. Dat beb ik altijd gevonden. Eenenveertig vind ik alweer beel anders. Negenendertig, okeel Maar veertig, gatverdamme!! En toen zei ik, en je zult zeggen dat bestaat niet, maar ik zei: zie je wel, veertig!'

- Eerdere problemen met die borst $\left(N_{1}=4, N_{2}=3, N_{3}=1\right)$

I $\mathrm{k}$ beb wel eens geboord dat vrouwen met zware borsten meer kans bebben. Het is ook de borst waaraan ik borstontsteking beb gebad. Ik beb namelijk kwalsterborsten. Dat zijn vleesborsten, dan zit er geen melkfabriek in. Daarom beb ik mijn kinderen ook nooit borstvoeding kunnen geven.'

'Ik beb altijd al zere borsten gebad: zere klieren en opgezet tijdens de menstruatie. Ik denk dat dit er mee te maken beeft.'

- Gestoten of druk $\left(N_{1}=4, N_{2}=3, N_{3}=2\right)$

'I $k$ denk dat bet door mijn docbter komt. Ze leunt altijd tegen mijn borst als we televisie kijken. Ik denk ook als de televisie niet daar bad gestaan maar daar, dat bet dan in de andere borst was geweest.' 
Het is misscbien gekomen omdat ik door een masseur werd gemasseerd toor mijn nek (patiënte lag daarbij op haar buik, M.0.). Ik denk dat bet geirriteend is geraakt door de druk op die tafel.'

- Beroepsmatig $\left(\mathrm{N}_{1}=2, \mathrm{~N}_{2}=0, \mathrm{~N}_{3}=0\right)$

'Ik beb wel gedacht dat bet van bet viliegen zou kunnen komen met al die stralen in de lucbt.' (patiènte is stewardess, M.O.)

'Ik beb vroeger op een laboratorium gewerkt. I $k$ beb toen meegewerkt aan een onderzoek met kankerverwekkende stoffen.'

$$
\text { - Straf van } \operatorname{god}\left(\mathrm{N}_{1}=1 \mathrm{~N}_{2}=1 \quad \mathrm{~N}_{3}=1\right)
$$

Het staat in de Bijbel: de kinderen zullen straf dragen voor de ouders. Als puntje bij paaltje komt ben ik geen kind van mijn eigen vader. Mijn ouders bebben zoveel kwaad gedaan, dat zal ik moeten ontgelden.'

\section{- Besmetting $\left(\mathrm{N}_{1}=1 \quad \mathrm{~N}_{2}=1 \quad \mathrm{~N}_{3}=0\right)$}

De tueede moeder van mijn moeder beeft bet gebad. Die beb ik verzorgd. Die bad bet op bet laatst ook aan de longen en gaf op. Toen bebben we wel getraagd kan dat kuaad. Ze zeiden tan niet maar tocb denk je er nu aan.'

\section{- Uitsluitende ATtributies}

De onderwerpen in de uitsluitende attributies komen allemaal ook bij de causale attributies voor.

\section{- Erfelijkheid $\left(\mathrm{N}_{1}=7 \quad \mathrm{~N}_{2}=7 \mathrm{~N}_{3}=3\right)$}

Ze vragen er wel naar of bet in je familie voorkomt of zo. Maar bij mij is dat niet zo. Niemand beeft bet. Het is terder een beel gezonde familie. Ik ben de enige uitzondering.' (USA/S $\left.{ }^{-+}\right)$

\section{- Aanleg en vatbaarheid $\left(\mathrm{N}_{1}=4 \mathrm{~N}_{2}=1 \mathrm{~N}_{3}=1\right)$}

'Ze veruacbten tocb altijd dat zoiets gebeurt in een licbaam wat tocb al ziekelijk is. Mensen die veel ditjes en datjes bebben gebad, zodat ze een lichaam bebben dat niet zo'n weerstand beeft. Maar, boe kan dat nou bij jou? Dat beb ik mij steeds afgerraagd. Ik ben nooit ziek, altijd kerngezond.' (CSA $\left./ 5^{\cdots+}\right)$

- Eerdere problemen met die borst $\left(\mathrm{N}_{1}=2 \mathrm{~N}_{2}=1 \quad \mathrm{~N}_{3}=2\right)$

'Ik beb voor mijzelf ook nooit de angst gebad tan: ik zal wel eens borstkanker krijgen. Ik beb zes kinderen, ik beb ze allemaal zelf gevoed. Die borsten bebben eigenlijk altijd goed gedaan wat ze moesten doen. Nooit eerder last gebad. ' 
- Psychologische verklaringen $\left(\mathrm{N}_{1}=2 \mathrm{~N}_{2}=1 \quad \mathrm{~N}_{3}=3\right)$

I $k$ beb eens iets gelezen over ontrede en kanker. Toen beb ik eens bij mijzelf nagegaan: is dat bij mij ook bet getal? Maar nee, ik zou niet weten uat dat zou moeten zijn. Nee, in alle eerlijkbeid, ik zou bet ecbt niet weten. Ik uas een gehkkig mens. Overal is wel eens uat, maar wij mocbten onze banden stiff dicbtknijpen.'

- Hormonen $\left(\mathrm{N}_{1}=1 \mathrm{~N}_{2}=1 \mathrm{~N}_{3}=1\right)$

'Ik beb nooit de pil geslikt. Dus dat kan bet niet aij.'

- Gestoten of druk $\left(\mathrm{N}_{1}=1 \mathrm{~N}_{2}=0 \mathrm{~N}_{3}=0\right)$

I $\mathrm{k}$ beb er al zo vaak over nagedacbt. Heb je misscbien je borst gestoten? Maar nee, dat geloof ik tocb ook niet. Zoiets zou je je berinneren.'

\section{- Schuldontlastende attributies}

Volgens de definitie zijn er drie groepen schuldontlastende attributies. Bij de eerste twee: 'afwijzen van schuld terwijl het (risico)gedrag wel is vertoond' en bij 'afwijzen van schuld terwijl het (risico)gedrag juist niet is vertoond' vinden we onderwerpen terug die ook voorkomen bij causale en uitsluitende attributies. De derde groep: 'schuldontlasting ten aanzien van het moment van ontdekken' is van een andere orde en komt als onderwerp niet voor bij CA en USA.

\section{Afwijzen van schuld terwijl het (risico)gedrag wel is vertoond}

- Leefgewoonten $\left(N_{1}=6 N_{2}=3 N_{3}=4\right)$

'Ik weiger om te denken dat bet iets in mijn leefivijze is. Dus ik wil er niet over denken dat bet kan komen omdat ik slecbt voor mezelf beb gezorgd. Hoewel dat wel zo is, boor.'

'Ik denk wel, als ik een stugge rookster was geweest, dat ik dan een aardig schuldcomplex bad gebad. Ik boef mij mu niets te verwijten, want ik rook maar een paar sigaretten per dag.'

- Hormonen $\left(\mathrm{N}_{1}=3 \mathrm{~N}_{2}=1 \mathrm{~N}_{3}=4\right)$

Ik slik al tien jaar niet meer de pil. Dan zou je tocb denken dat ik bet tien jaar eerder bad moeten krijgen. Je ueet bet niet. Ik kan niet meer doen dan mijn best. En trouwens, ook als je nooit de pil bebt geslikt kan je tocb borstkanker krijgen?! Dus eigenlijk lijkt bet mij sterk als bet met die pil te maken zou bebben.' 
- Overige $\left(\mathrm{N}_{1}=3 \mathrm{~N}_{2}=5 \mathrm{~N}_{3}=0\right)$

Deze groep bevat diverse uitspraken met als thema: afwijzen van schuld terwijl het (risico)gedrag wel is vertoond

Ik beb geboord dat als je je kind borstwoeding geeft, dat je dan je afialstoffen kuijt raakt en minder kans bebt op borstkanker. Ik beb mijn kind geen borst gegeven, want dat vond ik zielig. Ik moest weer aan bet werk en ik dacbt: als ze eerst weet wat borstwoeding is en ze moet daarna over op bet flesje.. dat vond ik zielig. Dus daarom beb ik expres geen borstvoeding gegeven, niet voor mij, maar juist voor baar. Je deed bet met de beste bedoelingen.'

\section{Afwijzen van schuld terwijl het (risico)gedrag niet is vertoond}

\section{- Leefgewoonten $\left(\mathrm{N}_{1}=26 \mathrm{~N}_{2}=21 \mathrm{~N}_{3}=21\right)$}

I $k$ ben altijd zo bezig geueest met uat goed voor me is. Ik zou niet weten wat ik verkeend beb gedaan. $1 \mathrm{k}$ beb altijd gezond geleefd. Niet otermatig, niet te dik. Je bent niet te dun, je bebt altijd gesport. Je drinkt dan wel eens een borreltje, maar ik rook niet. Dus uat beb je dan fout gedaan? Daarom is bet ook zo onbegrijpelijk en maakt bet me ook zo verscbrikkelijk kwaad. Het is absoluut oneerlijk.' (OLAPR)

\section{- Psychologische verklaringen $\left(N_{1}=9 N_{2}=7 N_{3}=6\right.$ )}

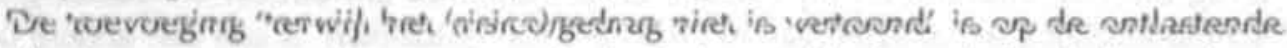
attributies met als onderwerp 'psychologische verklaringen' niet helemaal van toepassing. Het is althans niet zo duidelijk in de uitspraken terug te vinden. Wel is het duidelijk dat het afwijzen van schuld in deze uitspraken centraal staat.

Ye bebt die tbeorie over de persoonlijkbeidsstructuur: je bent er als bet ware zelf verantwoordelijk voor. Dat beb ik pas geboord. Maar daar ga ik niet in mee. Dat belast me veel te veel. Ik wil niet denken in termen van scbuld.'

'Ik geloof wel dat je allerlei ziekten kunt krijgen door psycbiscbe oorzaken en dat je je licbaam kunt beinvloeden door je geest. Dat geloof ik ecbt, boor. Maar ik geloof niet dat bet bij mij ... Nee, zo wil ik niet denken. Ik beb geen zin om mijzelf de scbuld ervan te geven.'

- Straf van God $\left(N_{1}=2 N_{2}=1 N_{3}=1\right)$

Net als hierboven is de toevoeging 'terwijl het (risico)gedrag niet is vertoond' niet helemaal van toepassing.

'Er zijn wel gemeenteleden die zeggen: bet kan een straf zijn. Eerst je docbter en nu jij. Maar zo denk ik niet. Het is niet iets dat van boven komt en je wordt toegedacbt. Ik geloof niet dat je op een dergelijke manier wordt gestraft en dat je bet dus aan jezelf te danken bebt. Ik geloof in een God van liefde.' 


\section{Schuldontlasting ten aanzien van het moment van ontdekken}

Deze groep uitspraken heeft maar één onderwerp, welke samenvalt met de titel.

- Moment van ontdekken $\left(\mathrm{N}_{1}=27 \mathrm{~N}_{2}=20 \mathrm{~N}_{3}=15\right)$

Bij de cbirurg kuam ik wat gerustgesteld vandaan. Die zei dat ik me niks te veruijten bad. Het zat zo diep dat ik bet nooit bad kumnen voelen. En inderdaad, toen ik wist waar bet zat roelde ik beel diep in mijn borst fets. Maar, ik beb er zoveel moeite voor moeten doen, dat de blauuv putten van mijn vingers zo ongeteer in mijn borst stonden."

In oktober zat er absoluut nog niets. En ik beb ook altijd goed aan zelfonderzoek gedaan. En dan opeens, dan ben je zo druk met allerlei dingen. Daardoor beb ik bet de laatste paar maanden dan niet gedaan... Misscbien dat je bet dan nog wel eender bad kunnen ontdekken... Maar bet was ook niet beel groot, boor. Dus veel eerder bad ik bet waarscbijnlijk tocb niet kumnen voelen. '

\section{- Een positieve Wending GeVEN}

In de uitspraken waarmee patiënten aangeven dat de ziekte hen ook iets positiefs heeft opgeleverd, zijn vijf onderwerpen te onderscheiden. Deze onderwerpen zijn niet aangetroffen bij andere strategieën, met uitzondering van uitspraken die gaan over 'minder haasten en jachten'. Deze komen ook voor bij de psychologische verklaringen van de strategieën die zich richten op een oorzaak (CA, USA en OLA).

- Bewuster leven $\left(N_{1}=36 N_{2}=38 N_{3}=23\right)$

De uitspraken wijzen op een positief veranderde levenshouding als gevolg van de ziekte en de confrontatie met de eigen sterfelijkheid.

Ik beb ook bet idee dat ik veel beuuster leef nu, veel rustiger, veel relaxter. Ook dat je je soms veel gehukkiger voelt. Als je zo een poosje buiten zit en er komt een vlinder op je boek. Ja, fijn dat bet zo is, of zo. Het is intenser. Ook van dingen die je nog wilt doen. Niet denken, nou dat doe ik later wel. Misscbien is er wel niet zo veel later, bè."

$7 k$ ben ecbt niet meer om zeven uur 's ocbtends op. I $k$ ga om een uur of negen pas m'n bed uit. Rommel wat rustig bierboven, doe meer aan bet gezin. Ik neem wat meer tijd voor mezelf. Ik denk bij mezelf: bet belangrijkste is niet meer alleen maar de zaak. Je denkt ook: straks is bet gebeurd, en dan beb je niet van je leven genoten. Tot nu toe beeft bet leven alleen maar in bet teken van de zaak gestaan: werken, werken, werken. Op een gegeven moment denk je: waar doe je bet eigenlijk voor? Je gaat wat meer over je leven nadenken en mijn man denkt er gelukkig net zo over.' 
- Minder haasten en jachten, minder werken $\left(N_{1}=13 N_{2}=20 N_{3}=15\right)$

Patiênten geven aan dat ze minder willen haasten en jachten, vaak omdat men beter naar de signalen van het lichaam wil luisteren en zich niet meer zo wil afmatten. In tegenstelling tot het vorige onderwerp, is er eerder sprake van een maatregel waarmee voorkomen moet worden dat er opnieuw kanker optreedt, dan dat het gaat om het genieten en positief waarderen. In de uitspraak wordt vaak verwezen naar stress als causale attributie.

Daarom beb ik ook bet getoel dat ik bet zelf in de band beb gehad. En dat op een gegeven moment de klok is stil gezet. Dat was niet voor niets. Het moet in bet vervolg ecbt anders. Ik neem me echt voor om bet straks anders aan te pakken. Ik ben blij met deze waarscbuwing en neem bem serieus!'

- De ziekte is aanleiding voor persoonlijke groei $\left(N_{1}=19 \quad N_{2}=22 \quad N_{3}=13\right)$

' $\mathrm{k}$ denk dat ik bet $\mathrm{nu}$ nog belangrijker vind de dingen te doen die ik zelf ecbt belangrijk vind. Ik uil niet langer bet verlengstuk tan mijn man zijn, maar dingen voor mijzelf doen. Ik ben dit weekeinde voor bet eerst tan mijn leven zonder mijn man weggeueest.'

'Dat ik meer en beuuster de dingen opzoek die voor mij belangrijk zijn. Vroeger dacbt ik altijd: leuk, leuk, ook leuk. Fn mu maak ik beter onderscbeid. Ik kies beunster voor wat ik ecbt leuk vind of voor uat ecbt belangrijk voor me is. Ik vind dat ik nu beter in evenuicbt ben.'

- Men is beter in staat anderen te begrijpen $\left(N_{1}=10 N_{2}=12 N_{3}=5\right)$

' $1 \mathrm{k}$ ben teranderd in mijn bouding jegens mensen die ook iets naars is overkomen. Ik denk ook dat ik straks patiënten anders zal benaderen. ' (patiënte is verpleegkundige, M.o.)

'Je merkt uel, dat nu je bet zelf bebt, dat je makkelijk op anderen afstapt die bet ook bebben. Ik wist nooit zo goed wat je moest zeggen. Je begrijpt anderen nu beter.'

- Relaties zijn verdiept $\left(\mathrm{N}_{1}=13 \mathrm{~N}_{2}=16 \mathrm{~N}_{3}=8\right)$

We praten nu veel meer dan vroeger. Vroeger was je druk en dan bad je er geen tijd voor. Maar nu wordt er meer opengelegd en besproken. Onze band is becbter geworden.'

- Overig $\left(\mathrm{N}_{1}=0 \mathrm{~N}_{2}=2 \mathrm{~N}_{3}=3\right)$

Deze groep bevat diverse uitspraken met als thema: de ziekte heeft ook positieve gevolgen.

'Ik wilde altijd al graag tan functie veranderen. En dat kon nooit. Nu bad PEO alle begrip en kreeg ik alle medeuverking. Nou dan beeft die kanker toch ook nog voordelen opgeleverd.

- Sociale vergelijking positief naAR boven

Aan deze sociale vergelijking kunnen twee onderwerpen worden onderscheiden. 
- Ik zal genezen $\left(\mathrm{N}_{1}=10 \mathrm{~N}_{2}=2 \mathrm{~N}_{3}=2\right)$

Maar ja, dan boor je verbalen van andere mensen, en ik beb er ook wel over gelezen, over mensen die tocb wel genezen. Ja ik wil weer beter worden, dacbt ik toen."

'Er zijn er die eram doodgaan, maar die ben ik nog niet tegengekomen. Ik ken er wel die er tien of zelfs vijfentuintig jaar geleden toor bebandeld zijn, en die leten allemaal nog. Kijk er zijn mensen die bet nog wel bonderdmaal erger bebben als ik, en die zijn er ook nog beter wan geuorden.' (S ' '/RAG)

- Leren van voorbeelden $\left(\mathrm{N}_{1}=9 \mathrm{~N}_{2}=3 \mathrm{~N}_{3}=1\right)$

'Het scboonzusje van een vriendin van mij, daar beb ik contact mee gezocbt. Dat was een beel nucbtere trouu. Ze beeft bet wel beel zuaar gebad, maar ze is tocb goed door de cbemo gekomen. Ik beb veel gebad aan dat gesprek.'

\section{- Sociale vergelijking positief naAr beneden}

De vergelijkingen waaruit de patiënten concluderen dat zij er zelf beter vanaf komen, richten zich vooral op de ernst van de ziekte en de gevolgen van ziekte en behandeling. Daarnaast zijn er nog enkele andere onderwerpen waarop deze vergelijkingen betrekking hebben.

\section{De ernst van de ziekte}

Deze groep uitspraken is nog verder in te delen. Bij de beschouwingen over de ernst van de ziekte komen vier verschillende onderwerpen aan de orde. De eerste drie daarvan treffen we ook aan bij de strategieën relativeren en bagatelliseren.

- Borstkanker in vergelijking met andere kankersoorten $\left(N_{1}=16 \quad N_{2}=11 N_{3}=2\right)$

'Het bad zat erger kunnen wezen. Als ik dan andere mensen zie denk ik: ik beb dit, maar bet bad ook dat of dat kunnen wezen. Dus ben je blij dat je dit bebt. Bij de bestraling uas er een man, zijn oog was eruit en zijn wang lag belemaal open. Dan denk ik: er zijn mensen die veel meer bebben als ik beb. Dat is makkelijk zat. Dan ben je ecbt blij dat je dit bebt.'

'Mijn tader, die bad bet aan zijn alvleesklier. Daar is veel moeilijker wat aan te doen. Dan bof ik dus nog.'

\section{- Uitzaaiingen $\left(N_{1}=4 N_{2}=4 N_{3}=3\right)$}

$7 k$ lag met een vrouw op de zaal en die bad bet ook nog in baar botten. Het speelt dan door je boofd van: dat bad mij ook kunnen overkomen. Bij baar vergeleken kom ik er natuurlijk beel goed vanaf.

- le had ook je doodvonnis te horen kunnen krijgen $\left(N_{1}=8 N_{2}=7 N_{3}=8\right)$

'En in dat plaatsje waar ons vakantiebuisje staat, daar is een vrouw van mijn leeftijd, die beeft ook kanker, maar die beeft niet lang meer te leven. Ze beeft nu al zuurstof. En dan zit je in je beerlijke tuin en dan denk je: bier vlakbij, daar is iemand en daar gaat bet beel anders mee. En dan besefje beel goed dat je je banden stijf dicht mag knijpen. Voor bet zelfde geld bad je te boren gekregen dat je niet lang meer bad te leven. 
- Met mij zal het beter gaan $\left(\mathrm{N}_{1}=8 \mathrm{~N}_{2}=6 \mathrm{~N}_{3}=4\right)$

'Die tante is uiteindelifk gestorven aan leverkanker. Maar ze begon ook met baar borst, net als ik nu. En daarom ben ik ook zo blij met die cbemokuur, die bad je in baar tijd nog niet. Ik weet dat ik veel meer kans beb dat ik over twintig jaar niet doodga aan leverkanker, zoals zij. Dat bedenk ik mij als ik weer eens in een dip zit.' $(S+\cdots / Z T)$

\section{De gevolgen van ziekte en behandeling}

Ook deze groep uitspraken is verder in te delen. Er zijn vijf onderwerpen die betrekking hebben op de gevolgen van de ziekte. Allemaal zijn ze ook terug te vinden bij de strategie relativeren. Uitspraken over de gevolgen van operatie, bestraling en chemokuur vinden we bovendien ook bij bagatelliseren en bij sociale vergelijkingen negatief naar boven ( $\mathrm{S}^{-+}$).

- Borstsparend behandeld $\left(\mathrm{N}_{1}=4 \mathrm{~N}_{2}=1 \mathrm{~N}_{3}=1\right)$

En dan troost ik mezelf en dan denk ik: wat ben je tocb een gelukstogel! Als ik dan boor, dat zelfs vroutuen die nog jonger zijn, al geamputeerd zijn.'

- Gevolgen van de operatie $\left(\mathrm{N}_{1}=5 \mathrm{~N}_{2}=2 \mathrm{~N}_{3}=2\right)$

'Daarna beb ik wel andere borsten gezien. En die zijn bijna allemaal lelijker geworden dan de mijne. Met van die deuken en zo en met zijstrepen. Zo 'n ritsshitinggetoel. Dat is bij mij gelukkig niet zo.'

- Gevolgen van de bestraling $\left(\mathrm{N}_{1}=5 \mathrm{~N}_{2}=2 \mathrm{~N}_{3}=5\right)$

'Het is ook niet kapot gegaan of zo. Een mevrouw die gelijk met mij bestraald werd, die moest verbonden uorden na de bestraling. Dat beb ik gelukkig niet gebad.'

- Gevolgen van de chemokuur of hormoontherapie $\left(\mathrm{N}_{1}=5 \mathrm{~N}_{2}=0 \mathrm{~N}_{3}=0\right)$

Want als je dan mijn vriendin meemaakt, dan denk je: als ik dat zou moeten doormaken, dat overleef ik niet, dat kan ik nooit opbrengen. Ik ben er niet ecbt doodziek tan en berstel na elke kuur gewoon goed.'

- Ik kan er goed mee om gaan $\left(\mathrm{N}_{1}=8 \mathrm{~N}_{2}=4 \mathrm{~N}_{3}=5\right)$

' $k$ ben ecbt niet gedeprimeerd of zo. Want als je dat wel eens in die wacbtkamers boort, dan denk je: er zijn ook mensen die er beel anders op reageren dan je zelf doet, die er belemaal door in de put zitten en bang zijn toor uitzaaiingen of dat bet terughomt. Maar ik sta daar beel anders tegenover. Ik ben gelukkig een optimistiscb mens. En dat scbeelt veel.' 


\section{Andere onderwerpen}

- Steun $\left(N_{1}=3 N_{2}=2 N_{3}=2\right)$

Uitspraken waarmee de patiënt aangeeft dat ze goed is opgevangen, komen ook voor bij relativeren.

Want ik denk dat onouuen die alleen zijn en dit meemaken, en die niet die scbouder bebben om op uit te builen, ob! lk denk dat die bet moeilijk bebben. Mijn man is een scbat: bij beeft aicb al die weken trijgemaakt om mij naar de bestraling te rijden. En bij gaat overal mee naar binnen. Nou, dan denk je tocb: zo'n man, dat is tocb bet einde, dat is tocb beerlijk' Anders moet je zelf naar Utrecbt of in een taxi en dan zit je acbter een vreemde man of vrouw waar je niet mee kan praten. Dat zou verscbrikbelijk noor mij aijn. Ik beb gewoon een toorrecbt, vind ik.'

- Leeftijd $\left(\mathrm{N}_{1}=6 \mathrm{~N}_{2}=1 \mathrm{~N}_{3}=1\right)$

Uitspraken over leeftijd vinden we ook terug bij sociale vergelijkingen negatief naar boven en relativeren.

'Als ik kleine kinderen zie of jonge mensen, dan denk ik: ob, mijn God, dat is pas engl'

'Oudere mensen, daar zie je aan dat ze bet beel moeilijk bebben, die zie je aftakelen. Dan kun je als je jonger bent er tocb beter tegen. Dat je licbaam tocb meer reserve beeft dan op oudere leeftijd'

- Controles $\left(\mathrm{N}_{1}=1 \quad \mathrm{~N}_{2}=1 \mathrm{~N}_{3}=0\right)$

Uitspraken over controles komen ook voor bij relativeren en bagatelliseren.

' $1 k$ ben $n u$ onder controle. Dat streepje beb ik weer voor op andere trouwen. Bij mij wordt bet gelijk ontdekt wanneer bet niet goed is. Dat zie ik als een groot voordeel.'

- Overige $\left(\mathrm{N}_{1}=2 \mathrm{~N}_{2}=5 \mathrm{~N}_{3}=1\right)$

Hieronder vallen diverse uitspraken waarin patiënten zich positief naar beneden vergelijken.

'Als je nou bijwoorbeeld over Prins Claus leest, die is bij een psycbiater die bem zijn eigen ik moet teruggeven. Ik geloof dat bij stiff staat van de pillen. Je weet nooit waar bet van komt, maar bet zal wel van zijn jeugd komen. Dan denk ik: kijk, ik beb gehukkig een goede jeugd gebad.'

\section{- Sociale Vergelijking negatief naAR boven}

De sociale vergelijkingen die een negatief gevoel opleveren omdat het met die ander beter gaat, zijn in zes onderwerpen onder te brengen.

- Vergelijkingen over de oorzaak

Alle vergelijkingen over de oorzaak zijn dubbelstrategieën met causale attributies en betreffen dus oorzaken die bij CA al zijn genoemd. De meeste S * /CA uitspraken gaan over erfelijkheid $\left(N_{1}=7 \quad N_{2}=7 \quad N_{3}=3\right)$ en vatbaarheid $\left(N_{1}=4 \quad N_{2}=1 \quad N_{3}=1\right)$. Daarnaast is er nog een kleine restcategorie $\left(N_{1}=3 \quad N_{2}=1 \quad N_{3}=1\right)$. Voorbeelden van uitspraken zijn bij de causale attributies terug te vinden. 
- Terwijl ik juist zo gezond leef $\left(\mathrm{N}_{1}=5 \mathrm{~N}_{2}=4 \mathrm{~N}_{3}=2\right)$

Deze vergelijkingen zijn vaak in de vorm van een schuldontlastende attributie. 'Maar je denkt wel bij jezelf: jij die altijd zo gezond mogelijk bebt geleefd, jij die altijd bezig was met gezonde voeding, jij krijgt bet. ' $\left(S^{-+} / O L A\right)$

- Ik heb het niet verdiend, ik ben een goed mens $\left(N_{1}=4 \quad N_{2}=3 \quad N_{3}=3\right)$

'Ik ken een vnouutje, die beeft voor mij al bet geluk van de wereld. Wat ze volgens mij niet verdient. Anderen in de buurt zeggen dat ook. Dan denk ik: waarom ik en zij niet? Ik tind niet dat ik bet verdien. Als th zag dat iemand bulp nodig bad, dan ging ik daar even kijken. Ik beb mij eigen eigenlijk altijd te veel weggecifferd. En dan krijg jij betI!' $\left(S^{-+} / P R\right)$

\section{- Leeftijd $\left(\mathrm{N}_{1}=7 \mathrm{~N}_{2}=5 \mathrm{~N}_{3}=3\right)$}

'En wat beel gek is: ik lees oterlijdensadvertenties. Dat deed ik nooit. En dan kijk ik boe oud ze zijn geuorden. En soms staat er dan 'na moedig gedragen ziekte' of zoiets. En dan denk ik: ob, die is zeventig of tacbtig, nou goed, dat is te accepteren. Maar op mijn leeftijd, daar klopt tocb belemaal niets tan!' ( $S^{*}$ 'PR $)$

- Uitspraken over de ernst van de ziekte $\left(N_{1}=4 N_{2}=3 \quad N_{3}=3\right)$

Gezien het geringe aantal S * uitspraken over dit onderwerp zijn deze niet, zoals bij de S *- uitspraken, verder ingedeeld.

'Ik ken een urouw, die bad ook wat in d'r borst en die moest even bellen voor de uitslag. Nou dat was allemaal goed. En ik uas in enen nijdig op dat mens. Waarom zij niet en ik wel? Dat beb je dan, bè.' $\left(S^{*+} / P R\right)$

- Uitspraken over de gevolgen van de ziekte $\left(N_{1}=6 N_{2}=9 N_{3}=4\right)$

Om dezelfde reden als hierboven zijn deze uitspraken niet verder onderverdeeld. Die laatste bestralingen, die vond ik een aanslag. I beb er ook met een andere mevrouw over gesproken, en die bad er totaal geen last van. Maar die zit misscbien ruimer in baar vet en in baar vlees. It beb al niet een enorme buste, en daar is dan ook nog iets uitgebaald. Mijn buid zit nu op de ribben tast en dat is beel pijnlijk.

- Steun $\left(N_{1}=0 N_{2}=7 N_{3}=5\right)$

'Kijk, de meeste mensen bebben een partner. Dan beb je tocb iemand om op terug te vallen. Als ik een partner bad gebad, was bet een stuk makkelijker getweest.' 


\section{- Sociale vergelijking negatief naAR beneden}

Twee onderwerpen zijn te onderscheiden in de vergelijkingen waarin de patiènt naar anderen kijkt met wie het slechter gaat en daaraan verbindt dat die situatie mogelijk haar voorland is.

- Een mogelijke negatieve afloop $\left(\mathrm{N}_{1}=27 \mathrm{~N}_{2}=17 \mathrm{~N}_{3}=30\right)$

De meeste van deze uitspraken zijn een dubbelstrategie met doemdenken (DD). Mijn broer bad longkanker. Die was opgegeven en is inmiddels ook overleden. En als je dan zo in de tuin bezig bent, dan denk je tocb: zou ik bet 't volgend jaar nog zien? Want ook toen ik belde toor de uitslag, dan denk je ecbt: ob, nu boor ik ook mijn doodionnis.' ( $\left.S^{--}-\mathrm{DD}\right)$

'Th dacbt altijd dat als je kanker bebt, dan is borstkanker bet beste uat je kunt bebben. Het uordt er uitgewipt en klaar. Maar zo is bet natuurlijk niet. Want ik las in de Volkskrant dat acbtduizend trouwen per jaar borstkanker krijgen en dat drieduizend overlijden.... En ik dacbt: boe kan dat eigenlijk? Maar ik bad nooit aan die bmfeklieren gedacbt. En ik beb ook positietve lymfeklieren. En dat maakt dat je er tocb lang niet gerust op bent. Die gedacbte laat mij niet los. ' ( $\left.\boldsymbol{S}^{--} \mathrm{DD}\right)$

- Gevolgen van de behandeling $\left(\mathrm{N}_{1}=4 \mathrm{~N}_{2}=0 \mathrm{~N}_{3}=4\right)$

Jee, nou moet ik betzelfde doorstaan als mijn vriendin doorstond. Dat is niet prettig, boor, dat je dat zo direct in je omgeving bebt meebeleefd. Zij was beel misselijk en uerd kaal.

\section{- Sociale vergelijking gelijKWAardig}

Er zijn vier groepen uitspraken te onderscheiden waarin de patiènt tot de conclusie komt dat zij uiteindelijk niet anders is dan een ander.

- Vergelijkingen over de oorzaak

Al deze uitspraken zijn dubbelstrategieën met causale attributies. De onderwerpen vallen dan ook samen met die van de causale attributies. Ze gaan over erfelijkheid $\left(N_{1}=4 N_{2}=4 N_{3}=1\right)$, hormonen $\left(N_{1}=6 N_{2}=0 N_{3}=0\right)$, of hebben de strekking 'ik ben niet anders dan een ander en kan dus ook kanker krijgen' $\left(N_{1}=36 \quad N_{2}=27 \quad N_{3}=20\right)$. Voorbeelden zijn te vinden bij de causale attributies.

- Ik heb weer evenveel kans op kanker als iemand die nog nooit kanker heeft gehad $\left(\mathrm{N}_{1}=9 \mathrm{~N}_{2}=5 \mathrm{~N}_{3}=5\right)$

' $\mathrm{k}$ weet wel dat ik bet misscbien wel terug kan krijgen. Maar een ander, die bet nog niet beeft gebad, kan bet ook krijgen. Van die gedacbte ga ik maar uit.'

En toen ik zei dat ik geen cbemo wilde doen, toen gaf de internist me groot gelijk. Vooral omdat ik er niet door overwoekerd ben; er waren maar een paar klieren niet goed, en dat zegt niets. Dus beb ik net zoveel kans als een gezond iemand.' ( $\left.S^{*} / B A G\right)$ 
- Mijn reactie is een normale reactie; het ligt niet aan mij; anderen hebben het ook $\left(N_{1}=8 \quad N_{2}=14 \quad N_{3}=7\right)$

Vandaag ben je zus en morgen ben je zo. Het is beel uisselend. Maar ik geloof dat iedereen dat beeft. Ik sprak een vrout en die zei dat ze dat ook bad.

- Overig $\left(\mathrm{N}_{1}=0 \mathrm{~N}_{2}=2 \mathrm{~N}_{3}=1\right)$

Hieronder vallen de $\mathrm{S}^{*}$ uitspraken die niet bij een van de eerder genoemde onderwerpen zijn onder te brengen.

\section{- Zichzelf een bijzondere patiént Vinden}

De uitspraken waarmee patiënten aangeven dat er in hun geval iets bijzonders aan de hand is, laten zich onderbrengen in drie onderwerpen.

- Bijzonder (medische) aandacht gekregen $\left(\mathrm{N}_{1}=8 \mathrm{~N}_{2}=1 \mathrm{~N}_{3}=2\right)$

Medepatiënten die zeiden ook al: gob, uat komt die dokter van jou vaak. Wat dat betreft beb ik uel uat extra aandacbt gebad gezien de voorgescbiedenis. Wij bebben geen standaard bebandeling gehad. En de afdelingsarts beeft zich ook wel eens iets laten ontrallen als: ik weet wel dat u onder de speciale zorg staat van dokter $S^{\prime}$

- Bijzondere kennis over de ziekte $\left(N_{1}=4 N_{2}=2 N_{3}=0\right)$

Maar ik ben tien jaar verpleegster geveest... dus ik begrijp er natuurlijk meer van dan een doorsnee patiënt.'

'Heel veel mensen kunnen zich niet voorstellen boe een tumor er uit ziet, maar wij juist wel.' (haar man is slachter, M.0.) 'Dat is een groot voordeel. Je begrijpt dan veel beter wat ze bedoelen met die moeilijke termen en ook boe dat er dus tan binnen bijje uit ziet.'

- Bijzonder in herstel of omgang met de ziekte $\left(N_{1}=12 N_{2}=14 N_{3}=5\right)$

'Die brieten, die beb ik toen zelf gepast. Meteen van de zaal af naar buiten, bet zonnetje in. Daar ben ik zelf nog verbaasd van. I $k$ liep toen langs dokter $P$, en die z'n mond viel open.'

'We gingen ook regelmatig op de fiets naar bet ziekenbuis voor die bestraling. Ik zag die mensen daar dan kijken, want bet was beel beet en jij kwam er dan met je korte broek aam. Dan zeiden die jongens van de bestraling: ze beeft alueer $25 \mathrm{~km}$ fietsen in de benen zitten. De andere patiënten geloofden bijna niet dat jij zelf ook een patiënt was.'

\section{- Relativeren}

De onderwerpen die respondenten aansnijden als zij hun ziekte relativeren, zijn nagenoeg dezelfde als bij sociale vergelijking positief naar beneden. Ook deze uitspraken gaan vooral over de ernst van de ziekte en de gevolgen van ziekte en behandeling. 


\section{De ernst van de ziekte}

In deze groep uitspraken zijn vier onderwerpen te onderscheiden. De eerste drie vinden we ook terug bij $\mathrm{S}^{*}$.

- Borstkanker in vergelijking met andere kankersoorten $\left(\mathrm{N}_{1}=5 \mathrm{~N}_{2}=2 \quad \mathrm{~N}_{3}=1\right)$

'Borstkanker is wat dat betreft een gunstig soort kanker om te bebben: er wordt zoreel onderzoek naar' gedaan. Goed onderzoek met grote aantallen.'

'Als ik bet in mijn boofd zou bebben of in mijn darmen, dan zou ik bet enger vinden. Ik vind dat ik nog gezegend ben, dat ik bet in zo'n torm beb.'

\section{- Uitzaaiingen $\left(\mathrm{N}_{1}=10 \mathrm{~N}_{2}=0 \mathrm{~N}_{3}=3\right.$ )}

'Toen al die onderzoeken gedaan moesten worden, toen realiseerde ik me opeens dat ik bet otval zou kunnen bebben. Dat bet ook engens anders zou kunnen zitten. Gelukkig kuam bet uit dat bet niet zo was.'

- Je had ook je doodvonnis te horen kunnen krijgen $\left(N_{1}=7 \quad N_{2}=5 \quad N_{3}=5\right)$

Voor betzelfde geld bad ik in bet ziekenbuis kunnen liggen met de boodscbap van: nou mevrouw, we proberen bet nog uat te rekken. Dan vind ik dat ik ongelooflijk ondankbaar ben als ik nu zou zeuren.'

- Op tijd ontdekt $\left(\mathrm{N}_{1}=11 \mathrm{~N}_{2}=5 \mathrm{~N}_{3}=7\right)$

'De cbirurg beeft ook tegen me gezegd dat bet nog wel een paar maanden bad kunnen duren voordat ik dat ding in mijn borst zelf bad kunnen voelen. Hij zei: wees jij maar blij dat jouw lymfestelsel zo aan bet werk was, omdat ik die ontstoken nagel van je vinger beb getrokken in januari; dat is nu misscbien je redding.' (patiènt had een opgezette lymfeklier in haar oksel, die aanleiding was voor verder onderzoek M.0.)

'Mijn buisarts beeft bet een balfjaar geleden ook met iemand van viffendertig meegemaakt. Dus ik beb geuoon mazzel gebad dat ik die ene voor me bad en dat de dokter bet zelf béél serieus nam en me gelijk beeft doorgestuurd. Er is absoluut geen tijd verloren gegaan.'

- Overig $\left(N_{1}=1 N_{2}=4 N_{3}=4\right)$

Diverse RL-uitspraken met als thema: de ernst van de ziekte valt mee.

\section{De gevolgen van ziekte en behandeling}

De vijf onderwerpen over de gevolgen van de ziekte vinden we ook terug bij $\mathrm{S}^{+-}$

- Borstsparend behandeld $\left(N_{1}=17 N_{2}=14 N_{3}=14\right)$

'Toen ik wakker werd, was bet eerste wat ik deed voelen, en ob gelukkig, mijn borst zit er nog aan!l Want ik ben nogal zwaar en als je bier niets meer bebt en daar wel, dan is bet zo ongelijk. En botendien dacbt ik: dan zit ik lekker ook niet met al dat gedoe van protbeses en zo.' 
- Gevolgen van de operatie $\left(N_{1}=10 N_{2}=9 N_{3}=5\right)$

'Ik beb een bét klein streepje; de cbirurg beeft bet zo keurig gedaan. Gelukkig maar, want we gaan veel naar de sauna. Stel je toor als bet niet zo moot gedaan was.'

'Mijn buisarts beeft mij deze cbirurg aangeraden. Hij zei: die man beeft ecbt liefde voor zijn vak. Nou dat was wel te merken. En dat is toch belangrijk, boor. Ook voor boe je geestelijk uit de strijd komt. Want wanneer je er een beel klein verschrompeld borstje aan overboudt, dan moet je ook daar weer mee in bet reine komen.'

- Gevolgen van de bestraling $\left(N_{1}=6 N_{2}=3 N_{3}=0\right)$

'Ik bad er niet echt teel last uan; de buid is niet stuk gegaan of zo. Daar ben je dan uel blij mee.'

'Ik zit op een koor. Gelukkig ben ik niet bees geworden van die bestraling. Dat zou ook kunnen, badden ze gezegd.'

- Gevolgen van de chemokuur of hormoontherapie $\left(N_{1}=6 N_{2}=4 N_{3}=5\right)$

'Gelukbig ben ik nog niet zo broodmager geuorden. De meeste mensen kunnen niets aan mij zien. Want als ze bet zo aan je af zouden kunnen zien, dat zou ik eng vinden.'

- Ik kan er goed mee om gaan $\left(\mathrm{N}_{1}=5 \mathrm{~N}_{2}=8 \mathrm{~N}_{3}=4\right)$

' $7 k$ beb eerst overal informatie ingewonnen. En toen ik alles zo goed mogelijk wist, ben ik weloverwogen die operatie ingegaan; wat rustiger. Ik bad bet getoel dat ik de dingen wat meer in eigen band bad. Niet dat er maar gedaan werd. En dat is acbteraf beel goed geweest. Het berstel ging beel voorspoedig en ik denk dat bet mede te danken is aan bet feit dat ik vooraf - bet was niet zoveel tijdmaar toch dat ik voor mezelf een bij mij passende manier bad gevonden. Omdat ik mijn leven tot nu toe vrij bewust beb willen doen en niet zo van: ik-onderga-alles-en-beb-er-dan-niet-veel-over-tezeggen. Daar ben ik beel eng blij om.'

Je bebt bet veel makkelijker als je kunt praten. Het is beel gunstig geveest dat ik dat kon, want als ik dicbtgeklapt was, dan uas bet niet zo goed gegaan.'

\section{Andere onderwerpen}

De onderwerpen die worden genoemd zijn dezelfde als bij S +-

- Steun $\left(N_{1}=6 \quad N_{2}=5 N_{3}=4\right)$

'Als je nu niemand om je been bad. Maar ik beb mijn man en uriendinnen en scboonzusjes, uaar ik allemaal beel goed mee kan praten. Ik ben gelukkig goed opgetvangen.'

- Leeftijd $\left(N_{1}=3 N_{2}=6 N_{3}=3\right)$

Misscbien is bet beter dat bet nu geconstateerd is dan wanneer je ouder bent. Want als je ziet boe bet nu met mijn arm gaat. Dat gaat beel snel tooruit.' 
- Controles $\left(\mathrm{N}_{1}=\mathrm{nvt} \mathrm{N}_{2}=1 \mathrm{~N}_{3}=0\right)$

'Ik ben blij met die controles, blij dat ze bestaan. Stel je noor dat ze er niet uaren, dan uns je teel ongeruster.'

\section{- Overig $\left(\mathrm{N}_{1}=3 \mathrm{~N}_{2}=6 \mathrm{~N}_{3}=7\right)$}

Diverse RL-uitspraken die niet in de genoemde onderwerpen zijn onder te brengen.

\section{- Bagatelliseren}

De uitspraken waarmee de ziekte minder ernstig wordt voorgesteld dan ze is, zijn als volgt ingedeeld. Sommige onderwerpen komen ook voor bij relativeren en bij de sociale vergelijkingen positief naar beneden.

\section{De ernst van de ziekte}

Onder te verdelen in:

- Borstkanker in vergelijking met andere kankersoorten $\left(N_{1}=6 N_{2}=5 \quad N_{3}=4\right)$

'Borstkanker zit aan de buitenkant. Dus als bet wondt weggebaald en bestraald, nou ja dan tvalt bet neuze mee. Dan is er eigenlijk niets meer aan de band. Het is in feite de allergunstigste soort kanker die je maar kunt bebben.'

- De ziekte stelt eigelijk niets voor $\left(N_{1}=16 N_{2}=17 N_{3}=21\right)$

'Nou, voor 99.99 procent ben ik er zeker van dat bet goed zal gaan. Dat ene kleine beetje is een onzekerbeid; die bebben we allemaal. Dat beb je ook als je een steenpuist bebt.'

'Zo'n operatie stelt niks voor. Niet veel anders dan je blinde darm.'

- Er waren maar een paar positieve klieren $\left(N_{1}=11 N_{2}=5 N_{3}=6\right)$

Er was één okselklier die wat aangedaan was. Maar dat geeft niet, want er zijn er nog minstens vierentuintig die goed waren.'

'Er zaten maar een paar uitzaaiinkjes. Maar die zaten nog vrij vooraan. Dat zijn de gunstigste klieren; dus dat zegt nog belemaal niets natuurlijk.'

- De chemotherapie is profylactisch $\left(N_{1}=8 N_{2}=2 N_{3}=3\right)$

Een aantal vrouwen 'gebruikt' het argument dat de chemokuur profylactisch wordt gegeven om daarmee de ernst van de ziekte kleiner te maken. Wanneer zij hier uitgebreid op ingaan, zoals in onderstaande voorbeelden, is dit opgevat als bagatelliseren. $7 \mathrm{k}$ kan bet opbrengen, omdat ik ook ergens in mijn boofd beb geprent dat bet ecbt preventief is, dat bet eigenlijk niet nodig geweest zou zijn. Want chemo, dat klinkt zo erg. En dit is dan eigenlijk geen echte chemokuur. Niet een die nodig is.'

'Ze zeiden toen: je mag nog een chemokuur doen, wit voorzorg mág je een chemokuur. Het was absoluut geen noodzaak boor. Want eigenlifk is die kut belemaal niet nodig. Ze scbieten met een kanon op een mug.' 
- In feite ben ik genezen (als de behandeling achter de rug is) $\left(N_{1}=31 \quad N_{2}=20\right.$ $\mathrm{N}_{3}=26$ )

' $k$ ben geplaatst in een groep vrouwen die ze, voorzoter er iets absoluut is in dit leven, bonderd procent genezing garanderen, maar die tocb ... (ze spreekt het woord chemotherapie niet uit, M.0.) Stel je toor dat er een klein celletje op de loop is gegaan, dat moeten we dan nog even pakken. Maar in feite ben ik dus volkomen genezen.'

'Ik ga er vanuit dat ik ben genezen, boor. Wat mij betreft ben ik weer net zover als ieder ander die bet krijgen kan. Die klieren uaren wel positief, maar verder ben ik scboon. En ze boeven geen eens viff jaar te wacbten om te weten dat ik genezen ben. Ik ben weer zo gezond als jij.' (BAG/S *)

\section{De gevolgen van ziekte en behandeling}

Gezien het beperkt aantal uitspraken is deze goep niet verder ingedeeld, in tegenstelling tot de $\mathrm{S}^{*}$ - en RL-uitspraken.

- De gevolgen van de behandeling vallen mee $\left(N_{1}=4 N_{2}=2 N_{3}=1\right)$

'Nou tan die bestraling merkte je eigenlijk niets. Je uas wel eens moe en ja, je voelde je treemd. Het is ook nog opengegaan onder mijn arm. Maar nee boor, bet was leuk daar. En die Noltadex acb, boeuvel je er ook best nadelige gevolgjes tan bebt, boor. Wat katterig en opviliegers. Maar acb, dat stelt eigenlijk niks toor:

\section{Andere onderwerpen}

- Ik ben nu onder controle $\left(N_{1}=n v t ~ N_{2}=11 N_{3}=8\right)$

Te bent nu onder controle; dus bet wordt ontzettend gauw ontdekt. Ik krijg gewoon de kans niet om ziek te worden, zeg ik wel eens. Dus daar lig ik ook ecbt niet wakker van. Ik ben volkomen safe.'

\section{- Cognitief vermijden}

De pogingen om gedachten aan de ziekte te vermijden of uit te bannen hebben betrekking op de volgende onderwerpen. Veel onderwerpen treffen we ook aan bij andere strategieèn.

\section{- Verdringen of ontkennen van de (ernst van de) ziekte $\left(N_{1}=12 \quad N_{2}=8 N_{3}=7\right)$}

Misscbien suf boor, maar nadat ze opgestuurd uaren, beb ik er geen moment aan gedacbt dat die klienen wel eens niet goed konden zijn. Misscbien wil je daar niet aan denken; maar nee, zelfs geen moment aan gedacbt!'

$7 k$ zal $u$ eerlijk zeggen: mijn tader ueet bet nog niet. Ik beb een zusje, die weet bet ook niet. En een broer, die weet bet niet. Als bet zoter komt dat ze bet moeten weten, is bet uroeg zat. Bij de bestraling beb ik beel vaak bet gevoel gebad tan: daar boor ik niet bij. Omdat ik me zo goed voel. En ik denk van: al die mensen bebben kanker en ja, ik eigenlijk ook. Maar ik beb ook bet gevoel dat ik bet niet beb. Dus uaarom paniek zaaien als bet belemaal niet nodig is.' 


\section{- Wegstoppen van de voortekenen $\left(\mathrm{N}_{1}=9 \mathrm{~N}_{2}=1 \mathrm{~N}_{3}=1\right)$}

Dit is het verdringen zoals dat vór de diagnose plaatsvindt. Er is misschien wel een vermoeden dat het niet goed zou kunnen zijn, maar die gedachte wordt niet toegelaten. 'Nooit meer zo aan gedacbt. Ik voelde bet uel, bet deed wel pijn. Het duurde wel twee jaar voordat ik naar de dokter ging. Het werd wel gnoter, en dan zei ik bet wel tegen mijn man, en die zei dan; ga er dan ook mee naar de dokter. Ik dacbt steeds: nou ja, bet stelt niets voor. Dit bericbt, daar bad ik nooit bij stil gestaan. Nou ja misscbien even, maar dat laat je dan ook weer meteen uegzakben. '

- Niet aan de ziekte willen denken; de ziekte is afgesloten $\left(N_{1}=30 N_{2}=18 \quad N_{3}=16\right)$ 'I $k$ moet bet getwoon vergeten en ik moet er verder niet meer aan denken. Het is gebeurd en klaar. Ik ben niet temand die acbterom kijkt. Ik wil vooruit kijken en ik wil er niet meer aan denken.' (CV/ZT)

- Niet aan de toekomst denken $\left(N_{1}=12 N_{2}=4 N_{3}=2\right)$

De toekomst is voor sommige patiënten zo bedreigend, dat zij daar helemaal niet aan willen of durven denken.

Toekomst? Daar denk ik liever niet aan. Mijn man maakt plannen, ja. En ik doe zogenaamd mee. of ikzelf plannen maak? Ik denk bet niet. Maar ik tind bet een moeilifk onderwerp. Ik merk dat ik geneigd ben om niet teveel over de toekomst te willen praten. Wilt u nog koffie?"

- Niet aan een ongunstig verloop willen denken $\left(N_{1}=32 \quad N_{2}=29 N_{3}=26\right)$

'Ik beb bet een paar keer in mijn leven meegemaakt; mijn moeder is aan kanker gestorven, mijn broer is ook aan kanker gestorven. $\left(S^{--}\right) \mathrm{I} k$ denk dat bet bet beste is er beel nucbter tegenover te staan en er maar niet te veel over te denken.'

'Ik moet er niet bij stil staan wat er allemaal zou kunnen gebeuren. Als ik dat zou doen, dan werd ik gek. Dus als ik in die ricbting denk, dan zeg ik tegen mijzelf: niet doen, niet aan denken.' (CV/LT)

- Afleiding zoeken $\left(\mathrm{N}_{1}=11 \mathrm{~N}_{2}=17 \mathrm{~N}_{3}=7\right)$

Je moet bezig zijn, zo snel mogelijk weer je oude leven bervatten, zodat andere dingen je bezig bouden in plaats van dat.'

'Als ik niets om banden beb, stort ik in. Ik probeer dus van alles te ondernemen.' 
- Vermijden van het woord $\left(\mathrm{N}_{1}=21 \mathrm{~N}_{2}=16 \mathrm{~N}_{3}=10\right)$

Een aantal patiěnten krijgt het woord kanker niet over de lippen. Ofwel omdat het woord veel angst oproept, ofwel omdat men niet bij 'die groep' wil horen. Dit gedrag is opgevat als een vorm van cognitief vermijden.

'Maar dan denk je DAT niet gelijk. ... terwijl ik er ecbt nog niet zo'n eng in bad dat bet misscbien DAT kon wezen. Die week was $1 k$ ontzettend zenuuacbtig, maar eigenlijk nog geen erg erin dat bet DAT zou wezen."

'Die beperkingen vind ik niet zo eng. Maar wat ik bet aller-allerergste vond, is... Het woord is voor mij zoiets verscbrikkelijks. Het tekentje, dat zat op de post van de deur of op je jas als je voor een collecte gegeten bad. Maar nu zat bet niet meer aan de buitenkant, maar aan de binnenkant. Nu bad ik bet. Bab, uat een naar woord!!' Ik kreeg de rillingen. En je zult bet mij nooit zo boren noemen. Ik zeg altijd ik bad iets in mijn borst en dat was niet goed.'

- Vermijden van angstige gedachten wanneer men iets voelt $\left(N_{1}=18 \quad N_{2}=14 N_{3}=8\right)$ Als ik iets in mijn licbaam voel, dan wil ik daar niet over denken. Nee boor, daar sta ik niet bij stil. Daar denk ik niet oter. Van de week bad ik pijn in mijn buik en meteen dacbt ik: bet zal tocb niet... Gelijk denk ik dan ook wel: nu moet je niet zeuren, anders beb je ook wel eens pijn in je buik. Dan moet je meteen bet weg gaan douten, anders zou je...' (CV/ZT)

- Informele informatie uit de weg gaan, met name andere patiënten en hun verhalen $\left(\mathrm{N}_{1}=15 \mathrm{~N}_{2}=7 \mathrm{~N}_{3}=0\right)$

' $k$ beb in bet ziekenbuis beel veel op bet balkon in de zon gezeten. Zo'n ziekenbuiskamer vind ik dan niks. Ik praat ook niet met andere mensen. Er lag nog een mevrouw met borstkanker, maar ik boefde niet nog een verbaal te boren.'

Die verbalen, daar word ik niet goed van. Ik neem mijn walkman mee en zet die meteen op mijn boofd. Die moet mee. Ik wil dat niet. Ik word er niet goed van. Dan vertellen ze boe misselijk ze uorden van de combinatie chemo en bestraling; ik wil dat niet weten. Dan denk ik: ja, dat kan natuurlijk ook nog. $O$ God nee, dat wil ik niet weten.'

- Formele informatie uit de weg gaan $\left(\mathrm{N}_{1}=19 \mathrm{~N}_{2}=16 \mathrm{~N}_{3}=10\right)$

'Misscbien bad ik de dokter ook meer moeten vragen. Maar ja, je denkt ook: bet is wel goed zo. Je wilt dan eigenlijk ook niet meer ueten.'

'Vroeger keek ik veel naar mediscbe programma's. Maar op dit moment moeten ze niet met iets over borsten aankomen. Want nou, op dit moment: borsten baat ik. Nee, zulke programma's daar kun je nu niet meer naar kijken, want dan ga je terug op je eigen.' 


\section{- In PROTEST KOMEN}

Er zijn verschillende onderwerpen waarop de boosheid van de kankerpatiēnten zich richt. Deze laten zich clusteren in drie groepen, waarbij de laatste groep nog verder is in te delen.

- Boos dat men kanker heeft $\left(N_{1}=14 N_{2}=12 N_{3}=10\right)$

De patiënt is simpelweg kwaad dat ze kanker heeft gekregen.

Ik was kuaad, razend, geuoon laaiend kuaad. Ik kon uel oteral tegenaan scboppen. Tegen de bele uereld eigenlijk.'

- Boos om de (fysieke) gevolgen van de ziekte en behandeling $\left(N_{1}=22 \quad N_{2}=28\right.$ $\mathrm{N}_{3}=26$ )

'Ik dacbt: dat gif, nee, dat wil ik niet! Dan bebben ze bier pas die cbemokar om al die zogenaamde gevaarlijke stoffen op te balen. Mif niet in die cbemokar, boor! Ob nee! Geen sprake van! Na de bestraling beb ik vier weken pauze genomen en toen ben ik tocb maar met die kuur begonnen. Maar bet is telkens wel een teleurstelling. Je begint je net weer goed te voelen en dan moet je weer iets doen uaar je ziek nan wondt. En ik denk ook telkens, ik geloof dat ik niet meer ga. Ik wil bet eigenlijk niet! Niet in MIJN licbaam.'

'En in bet begin, dan krijg je al die kaarten met van barte beterschap erop. Die gingen dus gelijk de prullenmand in. Alsof je beter wordt! Je wordt alleen maar zieker van die cbemo! En dan kuamen er allerlei vage bekenden met fruitmanden om je op te beuren en zo. En dan moest je telkens maar koffie zetten en dan dacbt ik: alsjeblieft, rot tocb op! $1 \mathrm{k}$ ging ecbt weg, ik vlucbtte bet buis uit en dan kwam ik terug en dan stond er weer zo'n rotte fruitmand bij de keukendeur en dan dacbt ik: gelukkig, die ben ik mooi misgelopen.'

- Oneerlijk dat ik het heb gekregen

De patiënten geven drie specifieke redenen aan waarom het oneerlijk zou zijn.

- Terwijl ik juist zo gezond leef $\left(N_{1}=13 N_{2}=12 N_{3}=11\right)$

Deze PR-uitspraken komen vaak als dubbelstrategie voor samen met schuldontlastende attributies (OLA).

Maar vooral in bet begin voelde ik mij zo terraden door mijn eigen lichaam. Ik vond bet zo oneerlijk dat jij die altijd oplet wat je eet, altijd goed voor je lichaam zorgt, dat jij bet krijgt.' (OLAPR) 
- Ik ben een goed mens, ik heb dit niet verdiend $\left(N_{1}=17 N_{2}=15 N_{3}=14\right)$

'Daar ben ik ook zo opstandig door. Dan denk ik: waarom moeten mijn kinderen dit mu tuee keer meemaken? (haar man heeft de ziekte van Hodgkin gehad, M.0.). En dan ben je opstandig, want dan denk je: ik beb altijd mijn best gedaan, en een ander leeft maar raak, en ja, waarom ik dan?' (PR/S $\left.{ }^{-+}\right)$ 'Dat ik bet niet eerlijk vind. $1 \mathrm{k}$ ben nooit zo met mezelf bezig geureest. Ik ben belemaal geen rot wijf. goed voor m'n ouders geveest, goed voor m'n man en voor m'n kinderen. Ik sla zelfs geen vlieg dood. Nou, wat is er overgebleven? Bitter weinig.

- Ik ben eigelijk te jong $\left(\mathrm{N}_{1}=7 \mathrm{~N}_{2}=6 \mathrm{~N}_{3}=6\right)$

Dan ga je om je been kijken op een verjaardag of zo, en dan denk je: er zijn er bier zoteel die al ouder zijn en die bebben niks, ja, uaarom ik dan? Dat is dan gewoon niet eerlijk.' (PR/s ${ }^{-+}$)

\section{- Berusten}

Alle uitspraken die als 'berusten' zijn aangemerkt zijn onder te brengen in een drietal onderwerpen.

- Acceptatie van de situatie $\left(\mathrm{N}_{1}=39 \mathrm{~N}_{2}=38 \mathrm{~N}_{3}=30\right)$

'Het is er. Het is nu eenmaal zo gelopen. Het is op je weg gekomen. Het beeft absoluut geen zin om te zeggen dat je bet liever niet bad gebad. Het feit ligt er nu eenmaal.'

'Je zegt tegen jezelf: je bebt bet er maar mee te doen. Zo is bet nu eenmaal. Ik moet bet leren accepteren; daar zit nu eenmaal niets anders op. Je kunt boog springen of laag springen, dat verandert tocb niets aan de feiten. Je zult je erbij neer moeten leggen. ' (BR/ZT)

- Uitspraken waaruit berusting of vertrouwen spreekt met het oog op de toekomst als (ex-)kankerpatiënt $\left(\mathrm{N}_{1}=20 \mathrm{~N}_{2}=21 \mathrm{~N}_{3}=17\right)$

Veel van deze uitspraken gaan impliciet over de ernst van de ziekte. Een onderwerp waarop ook andere strategieën zich richten.

'Eerst was ik doodsbang om kanker te krigen. Maar nu ik bet beb, ben ik er niet meer bang voor. Als bet moet gebeuren, dan gebeurt bet toch. Dus, unarom zou je je zorgen maken? Ik ben ook niet meer bang voor de toekomst. Ik zie wel wat er komt. Ik kan er tocb niets aan veranderen. Dus, waarom er dan zo mee bezig zijn? Ik beb er tertrouwen in dat ik er dan ook wel weer mee leer omgaan."

I I moet ermee leren leven. I vind bet beel moeilijk om te leven met bet besef dat alles zo betrekkelijk is. Maar ik zal op de een of andere manier voor mijzelf een oplossing moeten vinden. Ik zeg ook steeds als ik zit te somberen over de toekomst: kom op, je weet tocb niet boe bet zal lopen, komt tijd, komt raad. ' (BR/ZT) 
- Uitspraken die berusting, acceptatie aangeven met betrekking tot de behandeling

en de gevolgen van de behandeling $\left(N_{1}=27 N_{2}=29 N_{3}=15\right)$

'Het is iets waar je doorbeen moet. Daar ontkom je niet aan. Acb, je bebt geen keus. Er zijn mensen die dan zeggen: je bent zo flink. Maar dat getoel beb ik niet. Nee, ik onderga bet, vind bet niet leuk, maar bet is niet anders.'

Tk ben gautu moe. Maar ik denk dan: kom op, dat boort erbij. Dat moet ik accepteren, boe moeilijk dat ook is. Dat moet ik leren.' (BR/ZT)

\section{- Doemdenken}

De uitspraken waarmee mededeling wordt gedaan over een mogelijke slechte afloop zijn bij vier onderwerpen in te delen.

- Al bij de diagnose of het voelen van het knobbeltje uitgaan van het meest sombere scenario $\left(N_{1}=23 N_{2}=0 N_{3}=2\right)$

$7 \mathrm{k}$ ben toen bet ziekenbuis ingegaan met bet idee: bet is erop of eronder. In wezen bad ik al afscbeid genomen. In mijn fantasie groeide die knobbel met de snelbeid tan bet licbt.'

'En toen we bier de straat uitreden om foto's te laten maken, toen dacbt ik: acb, ik kom bier nooit weer terug. Gek is dat, be. Ik ben toen 's woensdags opgenomen. En toen die uoensdagocbtend, toen ik uit buis ging, toen bad ik dat getoel weer, tan: ik kom bier niet meer terug.'

- Bang zijn voor een slechte afloop $\left(N_{1}=29 N_{2}=35 N_{3}=37\right)$

In feite gaan deze uitspraken ook over de ernst van de ziekte. Het onderwerp dat we ook bij andere strategieën aantreffen.

'Daar ben ik erg van gescbrokken, van mifn bymfeklieren. Want je bele licbaam bestaat uit lymfeklier. En nou is bet maar afwacbten in boeverre de rest is aangetast en uanneer zicb dat zal openbaren.'

'Alleen op één ding krijg je geen antuoord. En dat boudt je onzeker. Is bet ecbt belemaal weg? En daar kunnen ze je geen zekerbeid over geven. Al geven ze je maar een bint. En dat spookt voortdurend door je boofd.

- Angst wanneer men iets voelt $\left(\mathrm{N}_{1}=32 \mathrm{~N}_{2}=36 \mathrm{~N}_{3}=40\right)$

'Het is een soort sluipmoordenaar, je weet bet niet. Die knobbel is weggebaald, maar bet kan in je teen zitten, in je boofd. Je weet niet wanneer bet eruit komt. Ook als ik wat pijn in $m$ ' $n$ boofd beb of in $m^{\prime} n$ arm, dan denk ik van: och, zou bet daar niet in zitten? Zou bet die kant op zijn gegaan? Dan bel ik de buisarts; die stelt me wel weer gerust. Dan is bet na één of twee dagen weer over. Maar die angst, die blijf je bouden. Je gaat er mee naar bed en je staat er 's ochtends mee op. Bij alles uat je voelt denk je: ik beb kanker.' 
- Angst rond controles $\left(\mathrm{N}_{1}=\mathrm{nvt} \mathrm{N}_{2}=23 \mathrm{~N}_{3}=28\right)$

'Die periode ervoor ben ik beel erg gespannen en voel ik elk pijntje. Het is telkens een spanningsteld als je er weer naartoe moet. Ja, ik ben er beel eng mee bezig. We slapen niet, die nacbt enoor. Ik ben zenuwacbtig, pijn in mijn maag. Heel eng veel spanning. Het is ook omdat ik mij vorig jaar, voordat ik bet knobbeltje ontdekte, ook steeds prima voelde. Dus als ik mij prima voel, is dat nog geen indicatie dat er niets aan de band is natuurlijk. En tedereen roept dan: job, dat is onzin, want je ziet er goed uit, je bent actief. Maar ik beb liever bevestiging van de foto's en van de dokter. Want toen riep ook iedereen dat ik er goed uitzag. Toen bad ik bet tócb! Dus, daar beb ik niets aan. Dat is toor mijgeen beuifs meer.'

\section{- Zichzelf toespreken}

Volgens de definitie zijn er twee groepen uitspraken te onderscheiden. Elk heeft betrekking op verschillende onderwerpen.

\section{Zelf-instructies}

Dit zijn uitspraken waarmee de patiènten aangeven wat zij allemaal van zichzelf wel of juist niet moeten. Vijf onderwerpen worden onderscheiden.

- Zelf-instructies met betrekking tot de behandeling of de gevolgen ervan $\left(N_{1}=21\right.$ $\left.\mathrm{N}_{2}=13 \mathrm{~N}_{3}=13\right)$

'Ik zag enorm op tegen de bestraling. Maar toen beb ik ook ecbt mijzelf onder banden genomen en gezegd tan: Iuister eens, die stralen zijn ervoor om tuat er nog is, om dat weg te nemen. Het is voor je eigen bestwil. Ik vatte bet ook op als mijn eigen Jibad. Als die toeter ging, dan beb ik beel sterk proberen te denken: o.k., maak kapot uat er kapot moet en laat zoteel mogelijk beel. Zo beb ik mijzelf maar toegesproken.'

'Soms ben ik belemaal verscbeurd en in de war. Maar van de andere kant ook steeds weer die zet die je jezelf geeft van: kom op, doorgaan' En natuurlijk beb je last van die arm en natuurlijk is die 's avonds dik en doet die zeer, maar kom op, je laat je niet kisten.'

- Ik moet erin geloven dat ik ben genezen $\left(N_{1}=12 \quad N_{2}=15 N_{3}=17\right)$

'We moeten verder, de kinderen zijn er ook nog. En de dokter beeft gezegd dat ik negenennegentig procent kans beb. Dus daar moet ik me dan maar aan vastbouden.'

'Ik wil alleen maar beter zijn. En je wilt dat bet nooit meer terug komt. Maar dat kunnen ze je nooit zeker zeggen. Ik weet bet niet, ik twijfel. Ik moet er tamuit gaan, maar dat vind ik beel moeilijk. Ik ga er vamuit en ik probeer zo te leven!! Want als ik nu zou moeten leven met fifty-fiffy, uat ik diep in mijn bart geloof, daar zou ik niet mee kunnen leven. Daar kun je niet mee leven. Dus ik zeg tegen mijzelf: kop op en geloof er in!' 
- Ik moet de situatie accepteren, ermee leren leven, het beste ervan maken $\left(N_{1}=36\right.$ $\mathrm{N}_{2}=22 \mathrm{~N}_{3}=18$ )

$j a$, maar ik moet bet tocb accepteren! Het is uel eens moeilijk boor. Maar bet feit ligt er. Het is geuoon een feit en daar moet ik mee leren omgaan. Dat moet ik geuoon accepteren. Dat moet ik leren en dat probeer ik zo goed mogelijk. Elke ocbtend zeg ik tegen mijzelf: dit is een nieuve dag en probeer er iets tan te maken.' (ZT/BR)

Ja, je moet ïberbaupt verder! Je moet bet je niet laten bebeersen en in zak en as gaan zitten. Gewoon goed voor jezelf zorgen. En ik moet de driffieer van bet gezin blijven, anders gaan ze er allemaal aan onderdoor:

- Ik moet niet aan de ziekte denken of aan de mogelijke slechte gevolgen; ik moet afleiding zoeken $\left(\mathrm{N}_{1}=25 \mathrm{~N}_{2}=21 \mathrm{~N}_{3}=14\right)$

' Ik moet bet gewoon vergeten en ik moet er verder niet meer aan denken. Het is gebeurd, en bopen dat je bet nooit meer terugkrijgt.' (ZT/CV)

'En ik vind de dood dus ook beel bedreigend geuorden. Daar ben ik wel mee bezig geuveest. En ik kan bet niet aan als je bedenkt dat je nog maar een paar jaar of zo te leven bebt. Daar raak je tan in paniek. Daar wil ik dus gewoon niet over denken. Dus dan zeg ik ook beel betust tegen mijzelf: kom. denk daar nu niet aan!' (ZT/CV)

- Positief denken; niet bij de pakken neerzitten; optimistisch zijn; uitgaan van een positieve toekomst $\left(\mathrm{N}_{1}=29 \mathrm{~N}_{2}=28 \mathrm{~N}_{3}=21\right)$

Positief denken is opgevat als een zelf-instructie, vooral omdat in bijna alle uitspraken het woord 'moeten' voorkomt.

'Vifftig procent beb je. Dan zal je voor die andere viiffig procent moeten knokken. Die beb je zelf in de band. Want als je in de put zit ben je veel verder van buis. Dus je moet positief blijven!"

'Altijd optimist blijven, niet bij de pakken neerzitten. Ik beb een oom die beeft longkanker, maar bij is nog steeds niet dood. Hij leeft nog, omdat bij niet bij de pakken neerzit en een blijmoedig mens is. I $k$ beb altijd veel bewondering voor bem gebad en ik wil bet op dezelfde manier doen. $\left(S^{+}{ }^{+}\right)$Ik geloof vast dat bet verschil maakt. Ik wil positief blijven.' 


\section{Wegredeneren van angst en ongenoegen}

De uitspraken uit deze tweede subgroep van 'zichzelf toespreken' hebben betrekking op drie onderwerpen.

- Wanneer je iets in je lichaam voelt $\left(N_{1}=17 N_{2}=14 N_{3}=13\right)$

'Af en toe bad ik ontzettende steken in die bestraalde borst. En bij die steken dacht ik: dat zijn uitzaaiingent Maar dan denk je ook: dat knobbeltje, daar beb je ook nooit last van gebad, dat beb je toevallig zelf getoeld, maar daar bad je ook nooit steken. Dus als ik nu weer eens een steek voel, ben ik ook belemaal niet bang'

Je voelt wel van alles en dat is best angstig. Maar je krijgt zoveel medicijnen, dus als ik dan mijn darmen voel, dan denk ik: dat is logisch natuurlijk. Ik gooi alles op die cbemokutur. Want die beeft allerlei uituerkingen natuurlijk. Dan denk ik: bet is de cbemo, bet zijn geen uitzaaiingen."

- Bij slechte voorbeelden aangeven waarom het bij jou beter zal gaan $\left(N_{1}=11 N_{2}=8\right.$ $\mathrm{N}_{3}=7$ )

Mifn broer kreeg vorig jaar oktober de mededeling dat bij nog maar een maand of drie bad... Hij is ook inderdaad gestorven... Kijk, bet is niet zo dat ik daar veel banger tan ben geworden. Hij uas al direct opgegeven. Ze bebben er ook niets meer aan gedaan. Bij mij bebben ze getvoon alles eraan gedaan wat ze eman konden doen. Ik ben geopereerd, bestraald en beb cbemokuren. Kijk, dat doen ze niet als ze niet denken dat je een beel goede kans maakt. Zoveel energie en geld stoppen ze beus niet in een bopeloos getval.' (ZT/ *)

- Jezelf voorhouden dat de gevolgen maar tijdelijk zijn $\left(N_{1}=16 N_{2}=10 \quad N_{3}=5\right)$

Dit jaar is een rot jaar. Maar in september niet meer. Dan begin ik aan de algebele restauratie. Dan ga t $k$ naar een scboombeidsboenderij en laat ik me belemaal opknappen. Ik geef dan een groot feest, want we zijn dan elf jaar getrouwd. Ik ga dan ook weer werken. Daar kijk ik allemaal naar uit en daar leef ik naar toe.'

I $\mathrm{k}$ ga wel van de veronderstelling uit dat alles weer wordt zoals bet was. Ik beb wat last tan die arm, met tillen en zo, maar terder... Ik ueet dat bet van tijdelijke aard is en bet is verklaarbaar, dus bet gaat ueer voorbij.'

Het voorgaande maakt duidelijk dat eenzelfde strategie wordt toegepast op meerdere aspecten van de ziekte en haar gevolgen. En ook dat een bepaald onderwerp niet exclusief bij één strategie hoort. Bij het denken over de oorzaak bijvoorbeeld, komen naast causale, uitsluitende en schuldontlastende attributies ook strategieën voor als een positieve wending geven, in protest komen, berusten en enkele vormen van sociale vergelijking. Een aantal specifieke oorzaken, zoals milieufactoren, besmetting, magisch denken en oorzaken die met het beroep te maken hebben, vinden we alleen 
maar bij CA. Andere oorzaken daarentegen, zoals psychologische verklaringen, erfelijkheid, leefgewoonten en hormonen zijn het onderwerp van meerdere strategieën. Behalve dat ze vooral als CA worden aangetroffen, worden psychologische verklaringen ook gevonden bij USA, OLA en PWG. Erfelijkheid is niet alleen een onderwerp van $C A$ en OLA, maar ook van $S^{-*}$ en $S^{-}$. Enzovoort, enzovoort. In tabel 4.1 is een samenvatting gegeven van de meest voorkomende onderwerpen die de patiënten aansnijden met de daarbij aangetroffen strategieën. Daaruit blijkt dat bij het denken over de ernst van de ziekte en de gevolgen van de behandeling de meeste strategieèn worden gebruikt.

- Tabel 4.1 - Veel voorkomende onderwerpen en bijbehorende strategieén

\begin{tabular}{|c|c|c|c|c|c|c|c|c|c|c|c|c|c|c|c|c|c|}
\hline & CA & USA & OLA & PWG & $S^{++}$ & $5+$ & $5 .+$ & $5 *$ & $5=$ & SB & $\mathrm{Rt}$ & BAG & cv & PR & BR & DD & $2 \pi$ \\
\hline OORZAKEN & - & · & - & - & & & . & - & · & & & & & . & . & & \\
\hline $\begin{array}{l}\text { MOMENT VAN } \\
\text { ONTDESEEN }\end{array}$ & & & . & & & 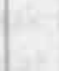 & F & 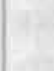 & 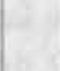 & & - & • & , & & f & , & \\
\hline ERNST VAN DE ZIEKTE & & & & & $\cdot$ & - & - & • & . & & • & - & . & . & . & - & $\cdot$ \\
\hline $\begin{array}{l}\text { GEVOLGEN VAN ZIETTE } \\
\text { S BEHNDELING }\end{array}$ & & & & • & $\cdot$ & • & $\cdot$ & - & . & , & • & - & $\cdot$ & $\cdot$ & - & • & $\cdot$ \\
\hline KENNS OVER DE ZIETTE & & & & & - & . & - & - & . & • & & & . & & & . & \\
\hline $\begin{array}{l}\text { PERSOONLLAKE } \\
\text { VERANDERING }\end{array}$ & & & & $\cdot$ & & 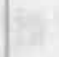 & 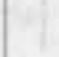 & $\sqrt{15}$ & . & - & & & 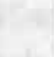 & . & . & & \\
\hline REATIES & & & & $\cdot$ & & * & & & & • & - & & . & - & & & \\
\hline LEtFIJD & • & & & & & • & $\cdot$ & * & • & & - & & & • & & & \\
\hline CONTROLES & & & & & & • & & & & & • & $\cdot$ & & & & $\cdot$ & \\
\hline
\end{tabular}




\section{2 - Welke VRAGEN ROEPEN WELKE COGNITIEVE STRATEGIË̈N OP?}

$\mathrm{Er}$ is onderzocht hoe de cognitieve strategieën samenhangen met de uitlokkende vragen'. In bijlage B is het volledige overzicht opgenomen. Van de opvallende bevindingen wordt in deze paragraaf verslag gedaan. Daar waar een vergelijking wordt gemaakt tussen de drie meetmomenten, wordt vooruitgelopen op paragraaf 4, waar nader wordt ingegaan op statistische verschillen tussen de meetmomenten.

\section{Over symptomen en diagnose}

Bij het eerste interview $\left(\mathrm{T}_{1}\right)$ luidde de openingsvraag: 'Kunt $u$ mij in bet kort vertellen, boe bet $u$ is vergaan vanaf de ontdekking van bet knobbeltje of bet eerste vermoeden dat er iets mis was?' Op $\mathrm{T}_{2}$ en $\mathrm{T}_{3}$ was dat: 'Kunt $u$ mij in bet kort vertellen boe bet $u$ is vergaan sinds bet vorige interview?' In de antwoorden komen vooral doemdenken (DD), relativeren (RL) en bagatelliseren (BAG) voor (respectievelijk bij $61 \%, 54 \%$ en $39 \%$ van de respondenten). RL en BAG worden bij de latere interviews minder gebruikt, DD daarentegen blijt tamelijk stabiel en komt op $\mathrm{T}_{3}$, ongeveer twee jaar na de diagnose, nog steeds vaak voor $(52 \%)$. Verder valt op dat er op $T_{1}$ relatief veel ontlastende attributies (OLA) in de antwoorden voorkomen $(28 \%)$. Blijkbaar bestaat kort na de diagnose bij veel respondenten de behoefte om al bij de openingsvraag spontaan te vertellen dat men zelf geen schuld heeft aan het ontstaan van de kanker, dan wel dat men de tumor niet eerder heeft kunnen ontdekken. Deze behoefte neemt in de loop van de tijd sterk af en is op $T_{3}$ zelís gereduceerd tot nul. Dit alles is in figuur 4.1 weergegeven.

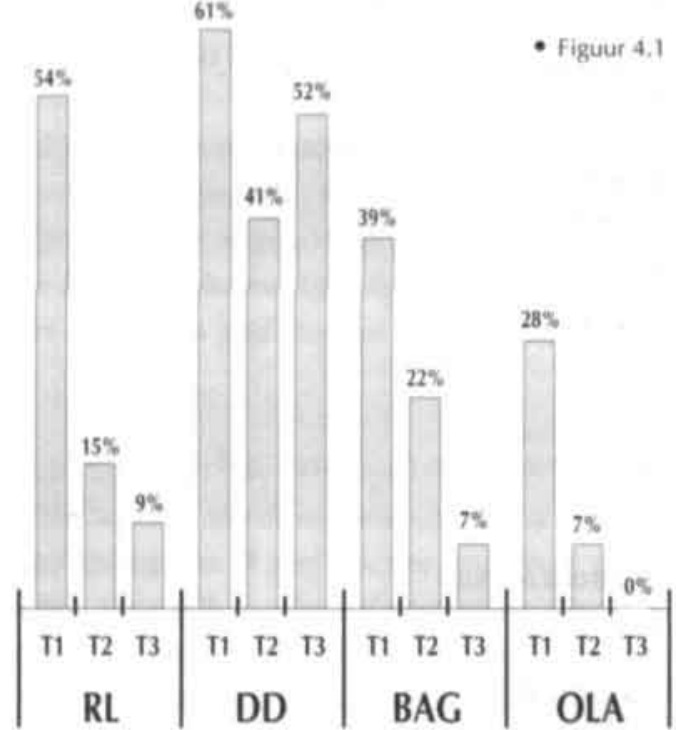

Percentage patiènten met de afgebeelde strategieen in antwoord op de vragen 'Kunt u mij in het kort vertellen hoe het $\mathrm{u}$ is vergaan vanaf de ontdekking of het eerste vermoeden?' (TI) en 'Kunt $\mathrm{u}$ mij in het kort vertellen hoe het $\mathrm{u}$ is vergaan sinds het vorige interview?' (T2 en T3)

\footnotetext{
' Hoe in de praktijk met deze vragen is omgegaan staat in hoofdstuk 11 paragraaf 2 - 2 beschreven.
} 
Daarna is in het eerste interview gevraagd wat de patiënt dacht toen haar de diagnose werd meegedeeld. Alhoewel DD ook dan de meest voorkomende strategie is $(28 \%)$, dacht toch bijna driekwart van de onderzoeksgroep niet onmiddellijk aan een doemscenario. Zo komt het zichzelf toespreken (ZT) in $22 \%$ van de antwoorden voor: 'I $k$ moet er uat tan maken' en 'Het is niet anders, maar ik zal mij niet klein laten krijgen'.

Op de vraag wat de patiënt denkt als ze iets in haar lichaam voelt, wordt op alle drie de meetmomenten erg vaak met DD gereageerd. Opvallend is dat het percentage patiènten met deze strategie in het antwoord in de loop van de tijd niet daalt, maar juist stijgt $(74 \%, 83 \%$, en $89 \%$ ). Ook worden in het antwoord nogal eens ZT, BAG en cognitief vermijden (CV) aangetroffen. De percentages zijn in figuur 4.2 weergegeven.

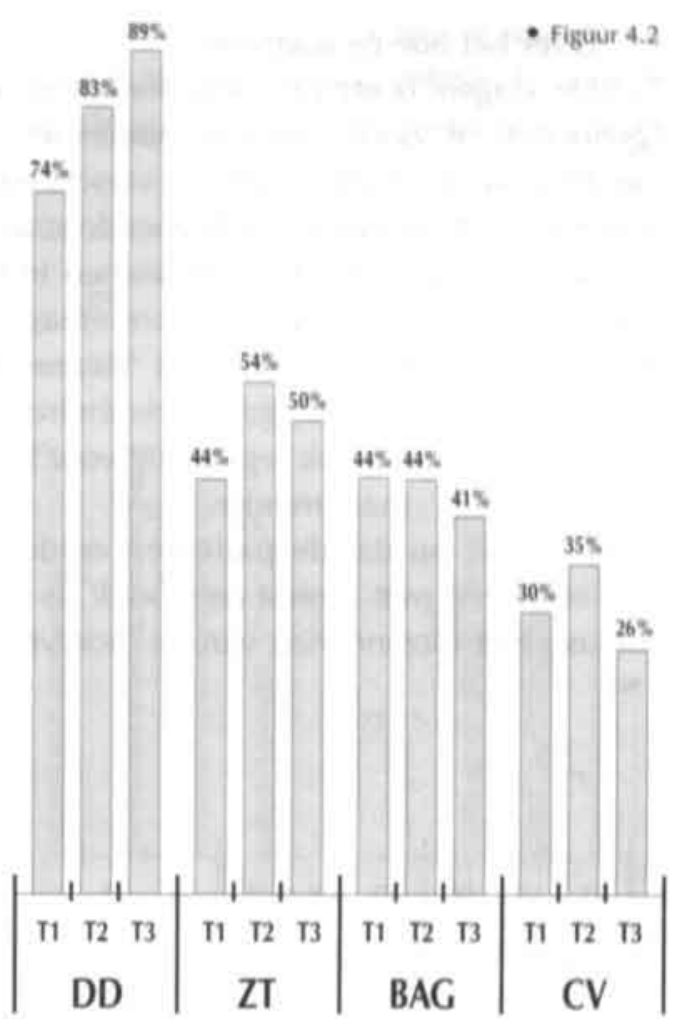

Percentage patiénten met de afgebeelde strategieén in het antwoord op de vraag 'Wat denkt $\mathrm{u}$ als $\mathrm{u}$ iets in uw lichaam voelt?"

Ook als de patiënten over de periode vlak vóór een medische controle vertellen, wat hen is gevraagd op $\mathrm{T}_{2}$ en $\mathrm{T}_{3}$, is er veel DD ( $83 \%$ en $\left.70 \%\right), \mathrm{CV}(44 \%$ en $37 \%), \mathrm{BAG}$ ( $22 \%$ en $15 \%)$ en ZT $(30 \%$ en $11 \%)$.

\section{Over de wachtkamer}

Op $T_{1}$ en $T_{2}$ is de vraag gesteld: 'Als $u$ in de wacbtkamer zit wat denkt $u$ dan?' De meest voorkomende strategieën zijn een sociale vergelijking positief naar beneden (S * -), respectievelijk bij $48 \%$ en $28 \%$, gevolgd door CV bij $28 \%$ en $26 \%$. Slechts bij enkele patiënten ( $15 \%$ en $4 \%$ ) roept de vergelijking met patiënten met wie het slechter gaat een negatief gevoel op (S - -). Borstkankerpatiènten vergelijken zich dus vooral met anderen waar het slechter mee gaat en komen dan tot de conclusie dat zij er zelf nog goed vanaf komen. Ruim een kwart van de respondenten sluit negatieve gedachten bewust af wanneer zij met andere kankerpatiënten worden geconfronteerd. 


\section{Over het hoe en waarom}

De vragen 'Denkt u wel eens: boe kom ik aan deze ziekte?' (in het vervolg 'de hoe-vraag' genoemd) en 'Denkt $u$ wel eens: waarom ik?' ('de waarom-vraag') roepen beide dezelfde strategieèn op. Maar er zijn ook verschillen (zie figuur 4.3). In de antwoorden op beide vragen is CA de meest voorkomende strategie, bij de 'hoe-vraag' nog meer dan bij de 'waarom-vraag'. OLA en USA komen in het antwoord op de 'hoe-vraag' ook relatief vaak voor, maar op de 'waarom-vraag' bijna niet. Deze laatste vraag wordt vaak beantwoord met uitspraken als 'Waarom ik niet!? $1 k$ ben tocb niet anders dan een ander??'. Overigens komt een dergelijke dubbelstrategie van een CA en een sociale vergelijking gelijkwaardig (S ") ook regelmatig voor in het antwoord op de vraag naar de oorzaak: de 'hoe-vraag', maar minder.

Het valt op dat de patiënten eerder boos dan berustend zijn: het percentage patiënten dat met protest antwoordt, is altijd hoger dan het percentage patiënten dat berust, met uitzondering van de 'hoe-vraag' op $T_{3}$. Uiteindelijk berusten er dus meer

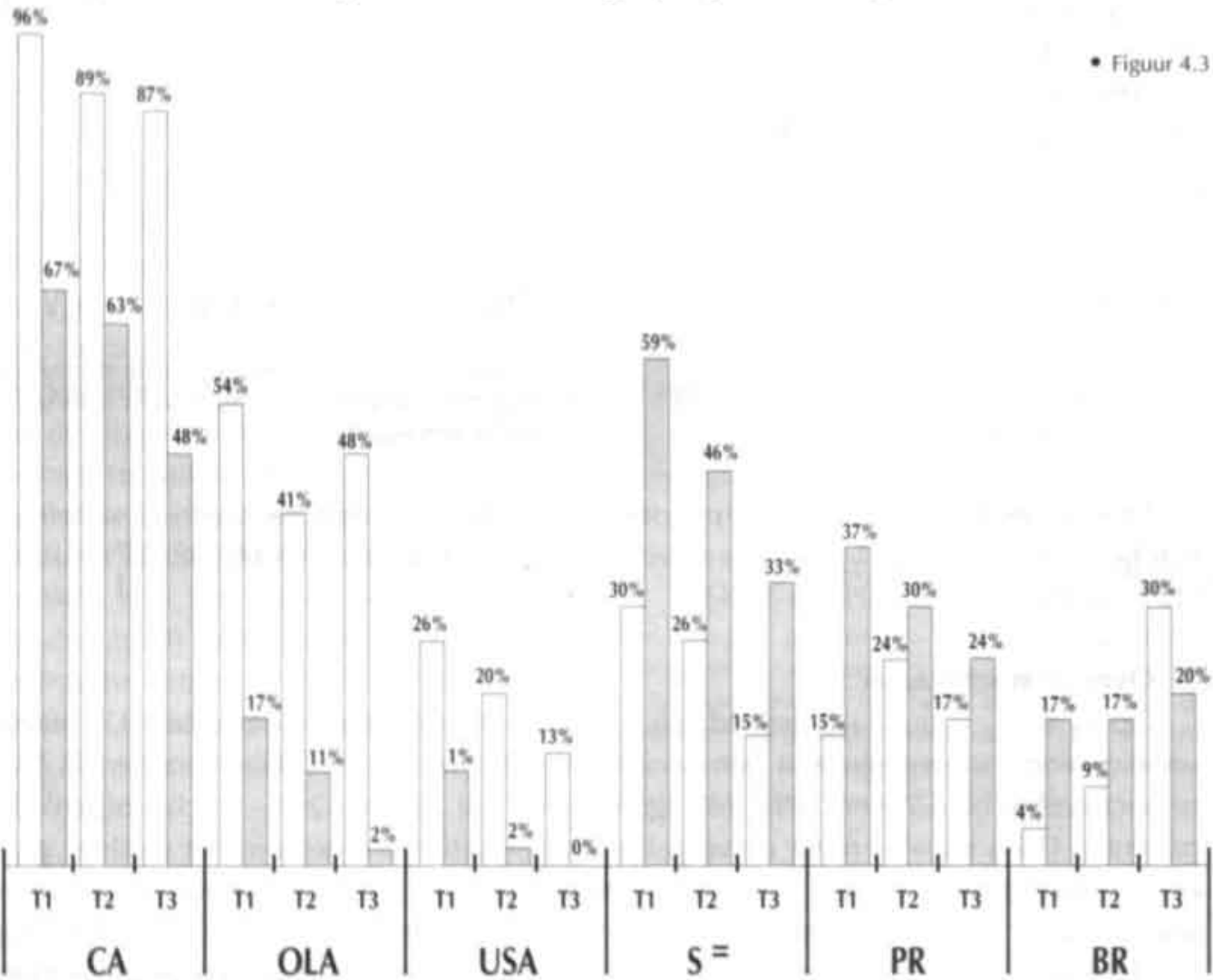

Percentage patiènten met de afgebeelde strategieèn in het antwoord op de vragen 'Denkt $u$ (nog) wel eens hoe kom ik aan deze ziekte?' ( $\square$ )

en 'Denkt u wel eens: Waarom ik? Waarom moet mij dit overkomen?' (ㅁ) 
patiēnten dan er protesteren wanneer het gaat om de vraag 'boe kom ik eraan?': zij antwoorden met uitspraken als: 'Acb, eigenlijk vind ik bet niet meer zo'n belangrijke traag. Je bebt bet nu eenmaal geknegen. Het is niet anders.' Maar de vraag 'uaarom ik?' roept ook nog op $\mathrm{T}_{3}$ bij meer patiënten protest op dan berusting.

\section{Over de toekomst}

Figuur 4.4 laat zien dat de vraag 'Toekomst, wat roept dat woord bij $u$ op?' vooral aanleiding geeft tot doemdenken (op de drie meetmomenten respectievelijk $41 \%$, $57 \%$ en $35 \%$ van de respondenten). Aanvankelijk is er ook relatief veel cognitief vermijden $(33 \%)$ : deze patiènten zeggen dat ze eigenlijk niet over de toekomst durven te denken. Dit vermijden neemt in de loop van de tijd af (via $26 \%$ naar 13\%). Verder komt er op $T_{1}$ en $T_{2}$ ook regelmatig de strategie 'een positieve wending geven' (PWG) in de antwoorden voor ( $24 \%$ en $30 \%)$. Dit is nauwelijks meer het geval op $\mathrm{T}_{3}(7 \%)$. Wordt er expliciet gevraagd of er door de ziekte iets aan de toekomst is veranderd, dan geven meer patiènten een antwoord met daarin PWG. Op $T_{3}$ zijn dat er zelfs

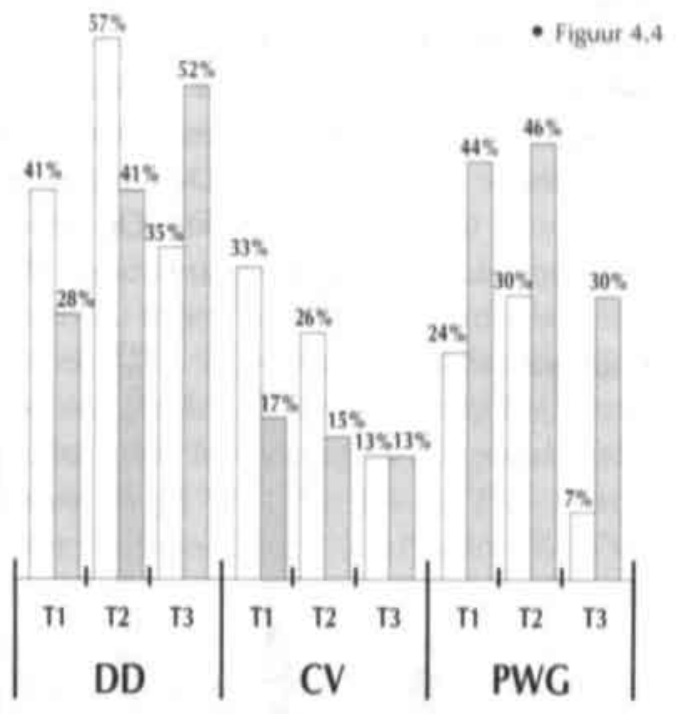

Percentage patiënten met de afgebeelde strategieèn in het antwoord op de vraag 'Toekomst, wat roep dat woord bij u op ?' ( $\square$ ) en 'Is daar door de ziekte iets aan veranderd?' ( $\square$ ) aanzienlijk meer (de percentages voor de drie meetmomenten zijn respectievelijk $44 \%, 46 \%$ en $30 \%$ ). Tegelijkertijd is ook het doemdenken op $T_{3}$ bij de vraag naar verandering hoger dan bij de algemene vraag naar toekomst (ook figuur 4.4). Met andere woorden, de vraag naar verandering genereert andere strategieën.

In de antwoorden op de vragen naar de toekomst en naar verandering in toekomstperspectief komt CA niet of nauwelijks voor (figuur 4.5). Wordt echter expliciet gevraagd 'Heeft $u$ zelf enige invloed op uw toekomst?', dan vinden we op $\mathrm{T}_{2}$ maar vooral op $\mathrm{T}_{3}$, causale attributies in de antwoorden (respectievelijk $30 \%$ en $57 \%$ ). De oorzaken waarnaar verwezen wordt, zijn meestal psychologische verklaringen zoals teveel stress en het gevoel dat men tot dan toe nooit een eigen leven heeft kunnen leiden. Ook zijn er vaak verwijzingen naar leefgewoonten. De patiënten hopen dat ze hun toekomst kunnen beïnvloeden door iets te veranderen aan de vermeende oorzaak. In de antwoorden komt ook 'het zichzelf toespreken' veel voor. Het zijn uitspraken als 
'Het belpt als je positief bliff. Je moet positief blijven denken, niet bij de pakken neerzitten maar doorgaan'. Anders dan bij CA neemt het percentage respondenten dat de ZT-strategie hanteert in de loop van de tijd af $(61 \%, 52 \%$ en $41 \%)$. Ook is gevraagd of de patiënt denkt zelf iets te kunnen doen om te voorkomen dat de ziekte terugkomt. Alhoewel dit in zekere zin eveneens een vraag is naar invloed op de toekomst, valt het op dat deze vraag niet vaak een CA- of ZT-strategie genereert. Blijkbaar worden attributies en het positieve denken wel nuttig geacht om invloed te hebben op de toekomst in algemene zin, maar niet wanneer het specifiek om het verloop van de ziekte gaat. In de antwoorden op beide vragen komen op alle drie de meetmomenten relatief veel ontlastende attributies voor. De hoogste percentages vinden we in het antwoord op de vraag naar invloed op de ziekte. Op deze vraag wordt eerder met een ontlastende dan met een causale attributie geantwoord. Dit alles staat eveneens in figuur 4.5.

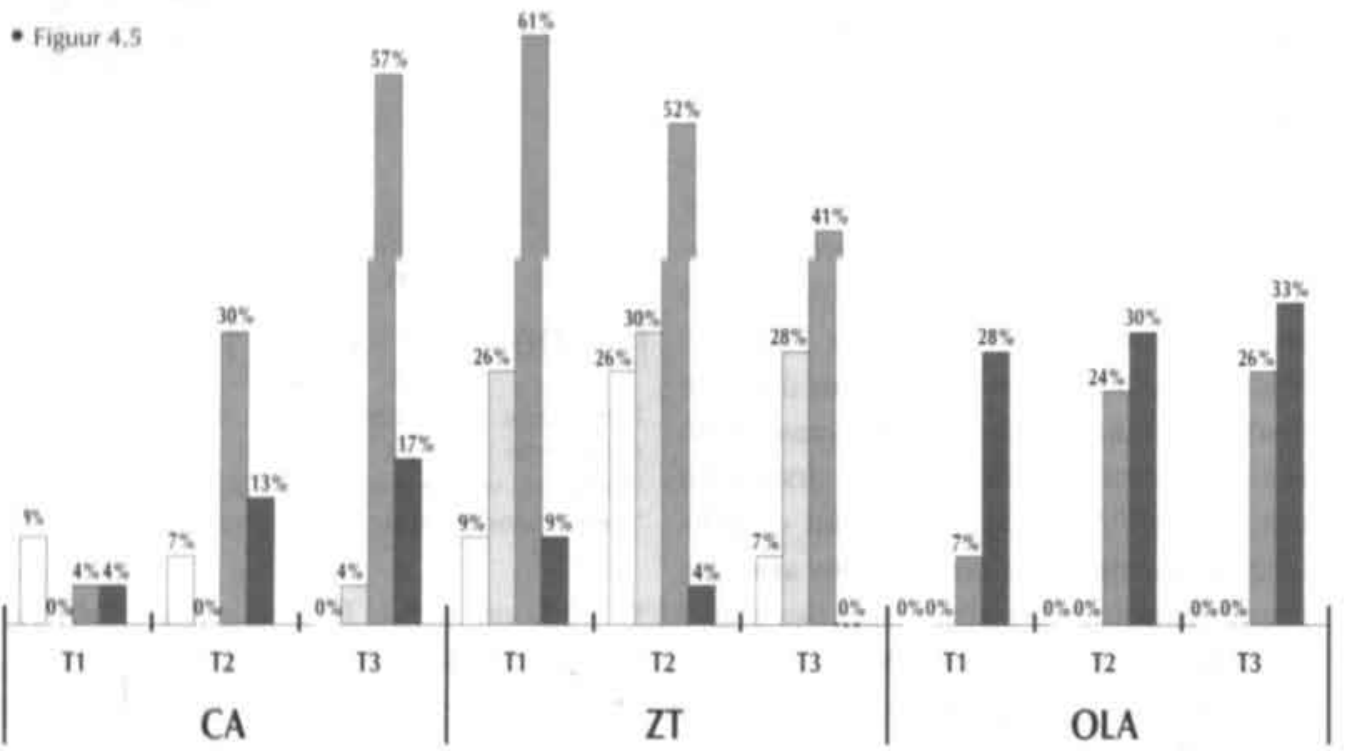

Percentage patiènten met de afgebeelde strategieén in het antwoord op de vraag 'Toekomst wat roept dat woord bij u op?' ( $\square$ ) 'Is daar door de ziekte iets aan veranderd?' ( $\square$ ) 'Heeft u zelf enige invloed op uw toekomst?' ( 1 ) en 'Is er iets dat u kunt doen of laten om te zorgen dat de ziekte niet terugkomt?' (모.

Tenslotte, op de vraag of men wel eens aan een negatieve afloop denkt, komt veel doemdenken in de antwoorden voor. Bovendien nemen de percentages DD in de loop van de tijd toe: $39 \%, 44 \%$ en $53 \%$. Naast DD is er vooral cognitief vermijden $30 \%$, $54 \%$ en $39 \%$ ) en bagatelliseren $(4 \%, 17 \%$ en $24 \%)$; ook bij deze strategieèn is er eerder een stijging dan afname van percentages patiènten die er gebruik van maken. 


\section{Praten over de ziekte}

In de antwoorden op vragen naar sociale steun en naar de vraag of men met anderen over de ziekte praat, komen weinig strategieën voor; cognitief vermijden relatief nog het meest (afhankelijk van de vraag en het tijdstip variẻrend van $11 \%$ tot $22 \%$ ). Dit betekent dat men anderen soms mijdt om niet over de ziekte te hoeven praten.

Bij de vraag 'Hoe noemt $u$ uv de ziekte?' valt op dat een groot deel van de patiënten het woord kanker liever vermijdt ( $28 \%, 33 \%$ en $24 \%)$. Zij geven antwoorden als ' $7 k$ zeg altijd bet was niet goed. Het woord zal ik nooit in mijn mond nemen, ocb nee! Van dat woord wond ik zo akelig. Nee, dat zul je mij nooit boren zeggen.'

\section{Over het zelfbeeld}

In de antwoorden op de vraag hoe patiënten nu tegen hun lichaam aankijken komt vooral relativeren (RL) voor: resp. $26 \%, 24 \%$ en $17 \%$. Bijvoorbeeld: ' $1 \mathrm{k}$ ben nog blij dat bet geen amputatie is geworden' of 'Het is wel een litteken, maar de cbirurg beeft bet zo verscbrikkelijk mooi gedaan. En daar ben ik blij mee. Dat maakt bet toor mij een stuk gemakkelijker'. Sociale vergelijkingen zijn er minder, het meest nog $\mathrm{S} *-(11 \%, 4 \%$ en $2 \%)$. Er komt slechts weinig berusten (BR) in de antwoorden voor (resp. bij $4 \%, 17 \%$ en $4 \%$ ). Deze laatste percentages stijgen echter wanneer expliciet gevraagd wordt 'Is dit nu anders dan voor de operatie en bebandeling?'. Dan vinden we bij 17\%, 22\% en $24 \%$ van de respondenten BR in het antwoord. Gering is het percentage respondenten dat protest laat horen in haar antwoord op deze vraag naar verandering in lichaamsbeeld $(4 \%$, $0 \%$ en $13 \%$ ). De vraag echter of er dingen zijn die zij door de ziekte of de behandeling niet meer kunnen en wat zij daar van vinden, roept meer protest op $(17 \%, 33 \%$ en $30 \%$ ). Vooral de beperkingen, de pijn en het lymfe-oedeem tengevolge van het okselkliertoilet worden genoemd en ook de vermoeidheid door de chemokuur. Het percentage antwoorden waarin berusting voorkomt, ligt wat lager $(17 \%, 22 \%$ en $20 \%$ ). Wanneer wordt gevraagd of men zelf is veranderd door het gebeurde, treffen we relatief veel PWG aan. Het percentage patiënten met deze strategie in het antwoord neemt in de loop van de tijd overigens wel af (van $67 \%$ via $63 \%$ naar $44 \%$ ).

\section{Over de balans opmaken}

Ter afsluiting van het interview is gevraagd de balans op te maken en aan te geven wat de hele periode de patiënt, emotioneel gezien, heeft gekost en of die periode misschien ook iets heeft opgeleverd. In de antwoorden komen allerlei cognitieve strategieën voor, het meest wordt een-positieve-wending-geven aangetroffen $(28 \%$, $35 \%$ en $17 \%$ ) en aanvankelijk ook berusten, maar de frequentie daarvan is op $\mathrm{T}_{2}$ en $\mathrm{T}_{3}$ gering $(22 \%, 7 \%$ en $4 \%)$. Cognitief vermijden, in de zin van niet meer aan de ziekte 
willen denken, wordt achtereenvolgens in $15 \%, 24 \%$ en $20 \%$ van de antwoorden gevonden. Protest komt er weinig in voor $(9 \%, 9 \%$ en $2 \%)$.

Uit het voorafgaande wordt duidelijk dat de vraag die wordt gesteld, zowel van invloed kan zijn op het soort strategieën dat in het antwoord voorkomt alsook op de mate waarin een strategie wordt gebruikt. Wanneer er naar heel verschillende aspecten van de ziekte wordt gevraagd, lijkt dat niet onlogisch. Er treden echter ook verschillen op in de antwoorden op vragen die ongeveer dezelfde strekking hebben, bijvoorbeeld bij de vragen: 'Denkt $u$ wel eens hoe kom ik eraan?' en 'Denkt $u$ wel eens: waarom moet mij dit overkomen?'. Maar ook vragen als 'Toekomst wat roept dat woord bij u op?' en 'Is daarin door deze ziekte iets veranderd?' leveren niet dezelfde strategieën op. Blijkbaar genereert de vraag naar de verandering andere cognitieve strategieèn dan de vraag naar de toestand van dat moment. Dit fenomeen is ook aangetroffen bij andere 'koppels' vragen.

Voorts is het opvallend dat in het antwoord op een groot aantal vragen relatief veel protest en doemdenken voorkomt en dat deze percentages in de loop van de tijd niet afnemen.

\section{3 - De mate waARIN de Cognitieve StrateGieËn ZiJn aANGetroffen}

In de vorige paragraaf zijn de strategieën besproken in relatie tot de vragen uit het interview. In deze en de hierna volgende paragrafen wordt, tenzij anders vermeld, verslag gedaan van de mate waarin de strategieën op de drie meetmomenten voorkomen, ongeacht in welk antwoord deze zijn aangetroffen. Daarbij worden drie verschillende indices voor de mate van strategiegebruik gehanteerd die eerst worden besproken.

\section{3 - 1 - Indices voor de mate van strategiegebruik}

Het percentage respondenten dat een bepaalde cognitieve strategie tenminste eenmaal gebruikt is één index voor het belang of de betekenis van die strategie. Een andere index is de frequentie waarin afzonderlijke respondenten die strategie gebruiken. Het gaat dus zowel om het aantal personen dat de strategie gebruikt (index 1) als om het gemiddeld aantal uitspraken waarin de strategie voorkomt (index 2). De laatste index is als volgt berekend. Eerst zijn voor elke respondent per vraag alle cognitieve strategieën die in het antwoord voorkomen, opgetekend. Vervolgens is beoordeeld op welk onderwerp de desbetreffende strategie betrekking 
heeft (zie paragraaf 1 voor de onderwerpen). Wanneer bijvoorbeeld een respondent te kennen geeft dat zij denkt dat kanker erfelijk is en daarbij óók zegt dat het ontstaan te maken had met haar leefgewoonten, zijn in dat antwoord twee causale attributies gescoord. Wordt echter in hetzelfde antwoord die opvatting over erfelijkheid meerdere keren geuit, dan is die causale attributie slechts eenmaal gescoord. Dit om te voorkomen dat breedsprakigheid zijn neerslag in de scores krijgt. Wanneer de erfelijkheid in een ander antwoord opnieuw ter sprake komt, dan is daar opnieuw een causale attributie gescoord. Een ander voorbeeld: wanneer een patiēnt in een bepaald antwoord aangeeft angstig te zijn over de toekomst en bovendien vertelt dat ze bang is blijvend klachten van haar arm te houden, is dit tweemaal als doemdenken gescoord. Maar, wanneer iemand in één antwoord enkele malen herhaalt angst te hebben voor de toekomst, is dit slechts eenmaal als doemdenken opgevat.

Voor elke respondent zijn deze scores per strategie over de vragen opgeteld. Zo is voor elke respondent een maat of index voor het gebruik van die strategie ontstaan. Wanneer in het vervolg van dit proefschrift wordt gesproken over de frequentie waarin een strategie voorkomt, dan wordt hiermee deze tweede index bedoeld. Is er bijvoorbeeld bij een respondent sprake van een hoge score van zichzelf toespreken, dan wil dat zeggen dat deze strategie in veel van haar antwoorden in relatie tot veel verschillende onderwerpen is aangetroffen.

Ten slotte is voor elke patiënt bepaald hoeveel verschillende strategieën zij gebruikt. Met andere woorden beperkt de patiënt zich tot slechts enkele strategieën of gebruikt zij juist een breed scala aan strategieën bij de verwerking van de ziekte en de gevolgen ervan. Dit is index 3.

\section{INDEX 1 PERCENTAGE RESPONDENTEN DAT DE STRATEGIE GEBRUIKT \\ INDEX 2 GEMIDDELDE FREQUENTIE WAARIN DE STRATEGIE WORDT GEBRUIKT \\ INDEX 3 MAAT VOOR DE DIVERSITEIT AAN GEBRUIKTE STRATEGIEËN}

\section{3 - 2 - Resultaten}

In tabel 4.2 is weergegeven hoeveel respondenten een bepaalde strategie gebruiken en met welke frequentie zij dat doen. In tabel 4.3 is daarin een rangorde aangebracht, waarmee duidelijk is welke de meest gebruikte strategieenn zijn. Zo blijkt dat van de zeventien onderzochte strategieèn er elf op alle meetmomenten door minstens de helft van de respondenten worden gebruikt. Slechts vijf strategieèn worden op elk van die tijdstippen bij minder dan de helft aangetroffen. Het zijn de uitsluitende attributie (USA) en de sociale vergelijkingen, met uitzondering van de vergelijkingen gelijkwaardig $\left(S^{*}\right)$ en positief naar beneden $\left(S^{*}{ }^{*}\right)$. Op $T_{1}$ staat de 
causale attributie op de eerste plaats; maar liefst $96 \%$ van de respondenten noemt er ten minste één. Op $T_{2}$ wordt deze eerste plaats gedeeld met doemdenken en cognitief vermijden; alle drie komen dan bij $89 \%$ van de respondenten voor. Op $\mathrm{T}_{3}$ worden doemdenken en zichzelf toespreken door de meeste respondenten gebruikt $(94 \%)$ en zijn de causale attributies naar de vierde plaats gezakt $(87 \%)$. Sociale vergelijking posi-

- Tabel 4.2 - Mate waarin de cognitieve strategieển voorkomen in de interviews

\begin{tabular}{|c|c|c|c|c|c|c|c|c|c|c|c|c|c|c|c|}
\hline \multirow[b]{2}{*}{$n=46$} & \multicolumn{5}{|c|}{$\mathrm{TI}$} & \multicolumn{5}{|c|}{ T2 } & \multicolumn{5}{|c|}{ T3 } \\
\hline & $n$ & $\%$ & $M$ & SD & $\operatorname{MAx}$ & $n$ & $\%$ & $M$ & SD & MAX & $n$ & $\%$ & $M$ & SD & MAX \\
\hline $\mathrm{CA}$ & 44 & 96 & 2.9 & 1.6 & 7 & 41 & 89 & 2.5 & 1.6 & 6 & 40 & 87 & 2.8 & 2.0 & 9 \\
\hline USA & 12 & 26 & 03 & 0.6 & 3 & 9 & 20 & 0.2 & 0.5 & 2 & 9 & 20 & 0.2 & 0.5 & 2 \\
\hline OLA & 38 & 83 & 17 & 1.6 & 8 & 34 & 74 & 1.5 & 1.2 & 4 & 32 & 70 & 1.4 & 1.4 & 7 \\
\hline PWG & 38 & 83 & 2.2 & 2.1. & 10 & 36 & 78 & 2.7 & 2.2 & 8 & 30 & 65 & 1.9 & 2.0 & 8 \\
\hline $5 *$ & 12 & 26 & 0.4 & 1.0 & 6 & 5 & 11 & Q.1 & 0.3 & 1 & 2 & 4 & 0.1 & 0.5 & 3 \\
\hline$s+\cdot$ & 35 & 76 & 1.6 & 1.5 & 5 & 28 & 61 & 1.1 & 1.3 & 5 & 23 & 50 & 0.9 & 1.1 & 4 \\
\hline s.+ & 22 & 48 & 0.9 & 1.2 & 5 & 19 & 41 & 0.9 & 1.4 & 6 & 15 & 33 & 0.6 & 1.0 & 4 \\
\hline $5 *$ & 19 & 41 & 0.7 & 1.1 & 4 & 15 & 33 & 0,4 & 0.8 & 4 & 20 & 44 & 0.7 & 1.1 & 4 \\
\hline $5=$ & 38 & 83 & 1.5 & 1.1 & 4 & 35 & 76 & 13 & 1.1 & 4 & 22 & 48 & 0.9 & 1.2 & 5 \\
\hline SB & 17 & 37 & 0.6 & 0.9 & 4 & 13 & 28 & 0.5 & 0.8 & 3 & 7 & 15 & 0.2 & 0.4 & 1 \\
\hline Rt & 39 & 85 & 2.0 & 1.6 & 8 & 33 & 72 & 1.6 & 1.5 & 6 & 32 & 70 & 1.4 & 1.7 & 9 \\
\hline$B A G$ & 28 & 61 & 1.7 & 1.8 & 6 & 28 & 61 & 1,4 & 1.6 & 6 & 31 & 67 & 1.5 & 1.5 & 6 \\
\hline $\mathrm{CV}$ & 43 & 94 & 3.7 & 2.5 & 10 & 41 & 89 & 3.5 & 3.1 & 15 & 41 & 89 & 3.1 & 2.8 & 13 \\
\hline PR & 28 & 61 & 1.8 & 2.2 & 7 & 28 & 61 & 1.7 & 2.2 & 8 & 24 & 53 & 1.6 & 2.1 & 9 \\
\hline$B R$ & 36 & 78 & 2.4 & 2.1 & 7 & 36 & 78 & 2.4 & 2.5 & 13 & 31 & 67 & 1.7 & 2.1 & 11 \\
\hline DD & 39 & 85 & 4.4 & 3.1 & 14 & 41 & 89 & 4.3 & 3.2 & 12 & 43 & 94 & 4.7 & 3.1 & 12 \\
\hline $2 T$ & 40 & 87 & 3.6 & 3.0 & 15 & 40 & 87 & 3.1 & 3.1 & 14 & 43 & 94 & 2.9 & 2.5 & 11 \\
\hline
\end{tabular}

Per meetmoment is in de kolommen 2 en 3 aangegeven bij hoeveel patiènten een strategie is aangetroffen. Daarbij staat in de kolom $n$ het aantal respondenten dat gedurende het interview ten minste eenmaal de genoemde cognitieve strategie heeft gebruikt. In de kolom $\%$ is dit aantal uitgedrukt als percentage van het totaal van 46 respondenten. In de daarop volgende drie kolommen staan gegevens over de frequentie waarin de strategiën voorkomen, $\mathrm{M}$ is het groepsgemiddelde en geeft dus het gemiddeld aantal malen weer, dat de strategie in de interviews is aangetroffen. De spreiding is uitgedrukt in de standaarddeviatie (SD). In de kolom MAX staat de maximale frequentie bij één patiênt. 
tief naar boven $\left(\mathrm{S}^{* *}\right)$ wordt op alle meetmomenten bij het minste aantal respondenten aangetroffen. Op $T_{1}$ is dit toch nog bij ruim een kwart van de respondenten het geval. $\mathrm{Op}_{2}$ en $\mathrm{T}_{3}$ is het aantal patiënten dat zich positief vergelijkt met anderen met wie het beter gaat sterk afgenomen ( $11 \%$ en $4 \%)$.

- Tabel 4.3-Rangorde van het strategiegebruik

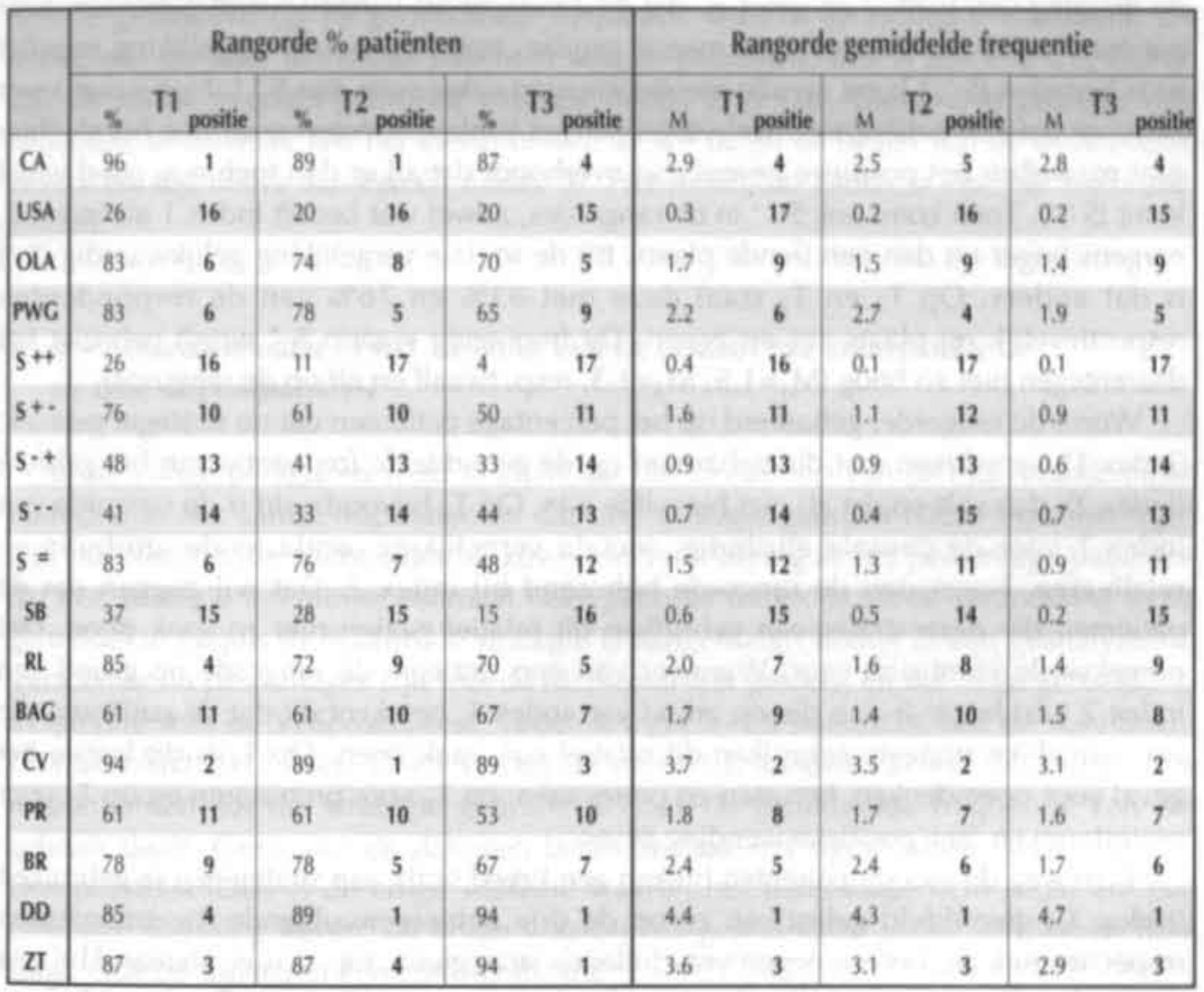

Het vetgedrukte cijfer verwijst naar de positie die de strategie ten opzichte van de overige strategieên inneemt. In de kolommen $2 \mathrm{t} / \mathrm{m} 4$ is deze rangorde gebaseerd op het percentage patienten dat de strategie tenminste eenmaal heeft gebruikt; in de laatste drie kolommen betreft het de gemiddelde frequentie waarin de strategieēn zijn aangetroffen. De bijbehorende percentages of gemiddelden staan eveens in de cel vermeld. 
De strategie die gemiddeld het meest frequent wordt gebruikt is doemdenken $\left(M_{1}=4.4, M_{2}=4.3\right.$ en $\left.M_{3}=4.7\right)$ De strategie met de laagste gemiddelde frequentie is op $T_{1}$ de uitsluitende attributie $\left(M_{1}=0.3\right)$ en op $T_{2}$ en $T_{3}$ de sociale vergelijking positief naar boven $\left(M_{2}, M_{3}=0.1\right)$.

Het is opvallend dat deze sociale vergelijking positief naar boven zo weinig voorkomt. Misschien komt dat omdat de respondenten maar weinig in aanraking komen met kankerpatiënten waaraan zij zich kunnen optrekken. Het kan ook zijn dat de dreiging van kanker zo groot is, dat de aandacht als vanzelf wordt getrokken naar patiënten waar het minder goed mee is gegaan. Immers, sociale vergelijking negatief naar beneden ( *) $^{-}$komt op alle meetmomenten vaker voor dan $\mathrm{S}^{*}$. Nog vaker komt het voor dat een patiënt zich wel vergelijkt met kankerpatiënten waarmee het slechter gaat maar daar het positieve gevoel aan overhoudt dat zij er dan toch nog goed vanaf komt ( $\mathrm{S}^{{ }^{+-}}$). Toch komt ook $\mathrm{S}^{*-}$ in de rangordes, zowel wat betreft index 1 als index 2 , nergens hoger uit dan een tiende plaats. Bij de sociale vergelijking gelijkwaardig (S ") is dat anders. Op $T_{1}$ en $T_{2}$ staat deze met $83 \%$ en $76 \%$ van de respondenten respectievelijk op plaats zes en zeven. De frequentie waarin $\mathrm{S}$ " wordt gebruikt ligt daarentegen niet zo hoog $\left(M_{1}=1.5, M_{2}=1.3\right.$, resp. twaalf en elf op de rangorde).

Wordt de rangorde, gebaseerd op het percentage patiënten dat de strategie gebruikt (index 1), vergeleken met die gebaseerd op de gemiddelde frequentie van het gebruik (index 2), dan valt op dat zij niet hetzelfde zijn. Op $T_{1}$ bijvoorbeeld is de rangorde van index 1 voor de causale attributie, sociale vergelijking, ontlastende attributie en relativeren, hoger dan de rangorde behorend bij index 2. Dat wil zeggen dat de patiënten die deze strategieèn gebruiken dit relatief gezien niet zo vaak doen. Het omgekeerde komt ook voor. Wanneer van een strategie de rangorde op grond van index 2 juist hoger is dan die op grond van index 1 , betekent dit dat de patiènten die een dergelijke strategie gebruiken dit relatief ook vaak doen. Op $T_{1}$ is dit laatste het geval voor doemdenken, berusten en protesteren; op $\mathrm{T}_{2}$ voor protesteren en op $\mathrm{T}_{3}$ voor protesteren en 'een positieve wending geven'.

Verreweg de meeste patiënten blijken een breed scala aan strategieën te gebruiken (index 3); gemiddeld gebruiken ze op de drie achtereenvolgende meetmomenten respectievelijk elf, tien en negen verschillende strategieèn. Op $T_{1}$ is er niemand bij wie er minder dan zes verschillende strategieën zijn aangetroffen, op $T_{2}$ en op $T_{3}$ is er steeds slechts één patiènt bij wie dit wel het geval is. Op $T_{1}$ zijn er zelfs twee personen die zestien van de zeventien strategièn gebruiken en op $T_{2}$ is dit het geval bij één respondent. Op $T_{3}$ ligt het maximum op veertien $(n=1)$.

Concluderend kan worden opgemerkt dat de meeste patiënten bij het verwerken van de ziekte een breed scala aan strategieën gebruiken. Daarbij zijn er strategieën die door 
bijna iedereen worden gebruikt, als ook strategieèn die slechts bij een klein percentage van de respondenten werden aangetroffen (de spreiding op $T_{1}$ is van $96 \%$ tot $26 \%$, op $T_{2}$ van $89 \%$ tot $11 \%$ en op $T_{3}$ van $94 \%$ tot $4 \%$ ). Ook zijn er grote verschillen in de frequentie waarin een strategie wordt gebruikt (de spreiding van de groepsgemiddelden is op $T_{1}$ van 4.4 tot 0.3 , op $T_{2}$ van 4.3 tot 0.1 , en op $T_{3}$ van 4.7 tot 0.1 ). Bovendien blijkt dat de positie die een strategie ten opzichte van andere strategieên inneemt, gebaseerd op het percentage respondenten dat een strategie gebruikt, niet altijd samenvalt met zijn positie gebaseerd op de gemiddelde frequentie waarin de strategie voorkomt. De strategieën die door de meeste patiënten worden gebruikt (index 1) zijn CA, CV, DD en ZT. De meest frequent gebruikte strategie (index 2) is DD. Gemiddeld gebruiken de patiënten, afhankelijk van het meetmoment, tussen de elf en negen van de onderzochte zeventien cognitieve startegieën (index 3). Het minimum aantal is zes, het maximum zestien.

\section{4 - VERANDERINGEN IN HET GEBRUIK VAN DE COGNITIEVE STRATEGIEËN OP DE DRIE MEETMOMENTEN}

In de vorige paragrafen werd al zichtbaar dat in de loop van de tijd veranderingen optreden in het aantal respondenten dat een strategie gebruikt. Deze veranderingen zijn statistisch onderzocht, waarbij zowel de verandering in het percentage patiënten dat een strategie ten minste eenmaal heeft gebruikt (index 1) als de verandering in de gemiddelde frequentie waarin de strategie is aangetroffen (index 2) zijn geanalyseerd. Verschillen in percentages zijn met de McNemar-test getoetst en die in de gemiddelde frequentie met de Wilcoxon-test. Tabel 4.4 geeft een overzicht van de resultaten. Daaruit blijkt dat tussen $T_{1}$ en $T_{2}$ bij de meeste strategieën zowel het percentage respondenten dat die strategie gebruikt als ook de gemiddelde frequentie van het gebruik daalt. Geen van de dalingen bereikt echter het significantieniveau van 05 . Doemdenken (DD) is de enige strategie waarbij het percentage licht stijgt, en 'een positieve wending geven' de enige waarbij het gemiddelde aantal uitspraken licht stijgt. Ook de stijgingen zijn niet significant.

De daling die tussen $T_{1}$ en $T_{2}$ is ingezet, zet bij de meeste strategieên door tussen $T_{2}$ en $T_{3}$. Bij de sociale vergelijking gelijkwaardig $\left(S^{*}\right)$ is de daling op beide indices significant. Daarnaast zijn er significante dalingen in de frequentie waarin 'een positieve wending geven' (PWG), 'zichzelf een bijzondere patiënt vinden' (SB) en berusten (BR) zijn aangetroffen. Ook tussen $T_{2}$ en $T_{3}$ is bij enkele strategieën sprake van een lichte, niet significante stijging in het gebruik van de strategieën. Dit geldt onder meer voor de sociale vergelijking negatief naar beneden $(+11 \%)$ en wederom DD $(+5 \%)$. 
Dit resulteert erin dat over de gehele periode tussen $T_{1}$ en $T_{3}$ bij de meeste strategieën zowel een daling optreedt in het aantal patiënten dat die strategie gebruikt (index 1) als in de frequentie van het gebruik (index 2). De daling op index 1 is bij ongeveer eenderde van de strategieën significant (PWG, $\mathrm{S}^{*}, \mathrm{~S}^{*}, \mathrm{~S}^{*}$ en $\mathrm{SB}$ ). Ook bij ongeveer eenderde van de strategieèn is er een significante daling op index 2 (OLA, $\mathrm{S}^{*}, \mathrm{~S}^{*}, \mathrm{SB}$ en BR). Geen van de gevonden stijgingen is significant.

Een aantal zaken valt op. Vier van de zes sociale vergelijkingen ( $\mathrm{S}$ *, $\mathrm{S}^{*}, \mathrm{~S}$ ** en $\mathrm{SB}$ ) komen op $T_{3}$ significant minder voor dan op $T_{1}$. De troostrijke gedachte dat je niet anders bent dan een ander en dat iedereen dit kan overkomen ( $\mathrm{S}$ "), kent de grootste daling $(-35 \%)$.

Tabel 4.4 - Veranderingen in het strategiegebruik

\begin{tabular}{|c|c|c|c|c|c|c|}
\hline$n=46$ & $\% \mathrm{~T} 2 . \% \mathrm{T1}$ & $\% \mathrm{~T} 3-\% \mathrm{~T} 2$ & $\% \mathrm{~T} 3-\% \mathrm{~T} 1$ & M2 - & $M 3-M 2$ & M3 \\
\hline $\mathrm{CA}$ & $.7 \%(89-96)$ & $-2 \%$ (67. - 69) & $-95 \quad(87+96)$ & $-0.4(2.5-2.9)$ & $+0.3(2.8-2.5)$ & $-0.1 \quad(2.8-2.9)$ \\
\hline USA & $-6 \%(20 \cdot-26)$ & $0 \%-20-20 \%$ & $.6 \% \quad 20.261$ & $-0.1 \quad 0.2 \cdot 0.31$ & ${ }^{0}(0.2-0.2)$ & $-0.1 \quad 10.2-0.3)$ \\
\hline ou & $.9 \% \quad 04.83$ & $.4 \% \quad 70-74$ & $-13 \% \quad 70-831$ & $-0.2(1.5-1.7)$ & $0.1(1.4 \cdot 1.5)$ & -0.3 常, $4-1,7$ \\
\hline $\mid$ PWG & $.5 \%, 384,433$ & $-13 \%, 365,28 \%$ & $-18 \% t^{\dagger}(65,293$ & $+0.5 \quad 227=223$ & $=0.8=97,9=2.77$ & -0.3 \\
\hline $\mathrm{st+}^{++}$ & $.15 \% \quad$ (II. 26$)$ & $.7 \%$ & $.22 \%^{\circ}(4-26)$ & $.0 .3[0.1$ & $0 \quad 0.1-0.1)$ & $\cdot 0.3(0.1-0.4)$ \\
\hline . & $-15 \%(61-76)$ & $.11 \% \quad 50-611$ & $.26 \%^{\circ}(50-76)$ & $-0.5(1.1-1.6)$ & $-0.2(0.9-1.1)$ & $-0.7^{\circ}(0.9-1.6)$ \\
\hline+ & $.7 \%(4) \cdot 48)$ & $.8 \% \quad(33.41)$ & $.15 \% \quad(33-48\}$ & $0 \quad(0.9-0.9)$ & $\cdot 0.3\{0.6-0.9\}$ & $.0 .3(0.6-0.9)$ \\
\hline $5 \cdots$ & $.8 \%[33.41]$ & $+11 \% \quad(44.33)$ & $+3 \% \quad(44.41)$ & $-0.3(0.4-0.7)$ & $+0.3[0.7 \cdot 0.4]$ & $0(0.7 .0 .7)$ \\
\hline$s=$ & $.7 \% \quad(76 \cdot 83)$ & $-28 \%{ }^{4}(48-76)$ & $.35 \%^{\circ}(48.83)$ & $-0.2(1.3-1.5)$ & $-0.4+(0,9-1,3)$ & $-0.6+(0.9-1.5)$ \\
\hline SB & $-9 \%(28-37)$ & $.13 \%(15-28)$ & $.22 \%^{\circ}(15.37)$ & $-0.1(0.5-0.6)$ & $-0.3^{4}(0.2-0.5)$ & $-0.4 \dddot{H}_{0.2-0.6)}$ \\
\hline RL & $.13 \% \quad(72.85)$ & $.2 \% \quad, 00.72$ & $-15 \%,(70.85)$ & $-0.4(1.6-2.0)$ & $-0.2(1.4-1.6)$ & $-0.6(1.4-2.0)$ \\
\hline BAG & $0 \%(61.61)$ & $.6 \% \quad(67-61)$ & $.6 \% \quad(67.61)$ & $-0.3(1.4-1.7)$ & $+0.1(1.5-1.4)$ & $-0.2(1.5-1.7)$ \\
\hline CV & $.5 \% \quad(89-94)$ & $0 \%$ (B9-89) & $.5 \% \quad(89.94)$ & $-0.2(3.5 \cdot 3.7)$ & $\cdot 0.4(3.1-3.5)$ & $.0 .6(3.1-3.7)$ \\
\hline PR & $0 \% \quad(61.61)$ & $.8 \% \quad(51.61)$ & $.8 \% \quad 153.611$ & $-0.1 \quad 1.7-1.8)$ & $-0.1(1.6-1.7)$ & $-0.2+1.6-1.80$ \\
\hline BR & $0 \% \quad(78-78)$ & $-11 \% \quad 67 \cdot 78$ & $-11 \% \quad(67-781$ & $0^{0}(2.4-2.4)$ & $-0.7(1.7-2.4)$ & $-0.7|1,-2.4|$ \\
\hline DD & $+4 \%(89-85)$ & $+5 \%(94-89)$ & $+9 \% \quad 194-851$ & $-0.1(4.3-4.4)$ & $+0.4(4.7-4.3)$ & $+0.3(4.7-4.4)$ \\
\hline $2 T$ & $0 \% \quad 18.87)$ & $+7 \% \quad(44-89]$ & $+7 \%(94-67)$ & $.0 .5(3.1-3.6]$ & -0.20 .9 .3 .11 & $0.7 \quad(2.9-3.6)$ \\
\hline
\end{tabular}

In de kolommen $2 \mathrm{t} / \mathrm{m} 4$ staan per strategie de verschillen in de percentages patiēnten die op de boven in de tabel vermelde tijstippen die strategie hebben gebruikt. In de volgende kolommen staan de verschillen in de gemiddelde frequentie van het gebruik. Tussen haakjes staan steeds de bijbehorende percentages, respectievelijk gemiddelden vermeld. De veranderingen in de percentages zijn met de McNemar-test getoetst op hun significantie, de verschillen in frequentie met Wilcoxontoetsen (tps.05 "ps.01 *ps.005). 
Sociale vergelijkingen lijken dus vooral aan het begin van het verwerkingsproces te worden gebruikt. Een verklaring kan zijn dat de sociale vergelijking als functie heeft informatie over de eigen situatie te verkrijgen. Het is een soort plaatsbepaling of inschatting van de eigen toestand en kansen. Vooral in het begin, wanneer de diagnose net is gesteld is er een grote behoefte aan informatie.

Ook het percentage patiënten met een PWG daalt tussen $T_{1}$ en $T_{3}$ significant $(-18 \%)$. Blijkbaar bestaat de behoefte de ziekte zin te geven vooral in de periode kort na diagnose en behandeling. Het gemiddeld aantal antwoorden met een PWG daalt nauwelijks. Dat wil zeggen dat terwijl het aantal patiënten daalt, bij die patiènten die de strategie op $T_{3}$ nog steeds hanteren, de frequentie waarin zij dat doen stijgt. Bij hen lijkt door de ziekte een wezenlijke verandering opgetreden en door het interview heen doen zij er meerdere malen gewag van dat de ziekte voor hen ook positieve gevolgen heeft gehad.

De gemiddelde frequentie van het gebruik van schuldontlastende attributies daalt in de loop van de tijd. Hieruit kan geconcludeerd worden dat schuldontlasting vooral in de beginfase aan de orde is, waarbij wel moet worden opgemerkt dat ook op $T_{3}$ nog bij $70 \%$ van de patiënten tenminste eenmaal een schuldontlastende attributie wordt aangetroffen.

Ook valt op dat berusten (BR) als strategie niet stijgt maar daalt. Dat is tegen de verwachting in. Het leek logisch dat in de loop van de tijd berusting zou toenemen. Uitgezocht is of er verschuivingen zijn van uitspraken waar het woord 'moeten' in voorkomt, zoals in 'ik moet me erbij neerleggen', naar uitspraken zoals 'ik beb me erbij neergelegd'. Hieruit zou voortgang in het proces van berusten blijken. Dat blijkt niet het geval te zijn. Het aandeel 'moeten' (ZT) blijft over de drie tijdstippen ongeveer gelijk.

Evenzeer valt op dat het protesteren (PR) nauwelijks afneemt en dat het cognitief vermijden (CV) onveranderd hoog blijft (rond $90 \%$ ), evenals het percentage respondenten dat zichzelf toespreekt (ZT: eveneens rond $90 \%$ ) of bagatelliseert (BAG: ruim $60 \%$ ).

Zoals eerder beschreven, laten DD en S - - in de loop van de tijd een lichte, zij het niet significante stijging zien. Het ligt in de verwachting dat, naarmate de ontdekking van de ziekte verder achter hen ligt, het aantal patiënten met negatieve gedachten zou afnemen evenals de mate waarin zij dit doen. Bij nadere analyse van de uitspraken blijkt dat op $T_{3}$ de twijfel toeslaat of de ziekte wel echt wegblijft. Eerder kon de patiént zichzelf nog geruststellen met de gedachte dat de behandeling nog maar net was afgelopen en eventuele kwaadaardige cellen nog geen kans hadden gehad om zich opnieuw te manifesteren. Een veel voorkomende uitspraak op $\mathrm{T}_{3}$ is: $\mathrm{Nu}$ moet bet licbaam bet weer op eigen kracbt doen. Het bescbermende effect van de bebandeling is nu uit mijn lifi. En ja, nu maar afwacbten of bet wegblijft. Maar je bent er nog niks gerust op.' Bovendien, konden patiënten wanneer ze ergens in hun lichaam iets voelden, dit aanvankelijk makkelijk 
toeschrijven aan bijwerkingen van de behandeling: 'Soms toel ik me nog wel moe. Maar dat is ook geen wonder, want de bestraling is nog maar net afgelopen.' Later kan dat niet meer en gaan normale lichamelijke sensaties, of je gewoon moe voelen, als (vals) alarm werken. Dit kan aanleiding zijn voor doemdenken en kan verklaren waarom S -- en DD op $\mathrm{T}_{3}(\mathrm{nog})$ niet dalen.

Samenvattend, het blijkt dat de verschillende vormen van sociale vergelijkingen vooral vlak na de diagnose worden gebruikt: bij vier van de zes treedt tussen $T_{1}$ en $T_{3}$ een significante daling op. Ook de frequentie waarin patiënten met schuldontlastende attributies antwoorden, daalt significant, evenals het aantal personen dat een positieve wending aan de ziekte geeft. Echter, de patiënten die deze laatste strategie blijven gebruiken, doen dit wel in toenemende mate: de gemiddelde frequentie van PWG neem niet af. Opvallend is dat het percentage patiënten dat berust niet toeneemt en dat de gemiddelde frequentie waarin de patiënten berusten zelfs significant daalt. Ook blijven zowel het percentage patiënten dat protesteert, cognitief vermijit, zichzelf toespreekt of bagatelliseert onverminderd hoog, evenals de frequentie waarin dit gebeurt. De frequentie waarin patiënten doemdenken en zichzelf negatief naar beneden vergelijken, stijgt zelfs iets, zij het niet significant. Dit alles wijst erop dat in de loop van de eerste twee jaar van de ziekte in de totale groep van patiënten niet zo heel veel verandert in hun strategiegebruik.

\section{5 - Stabiliteit van de Cognitieve strategieËN}

Ging het in de vorige paragraaf om veranderingen in het gebruik van de strategieèn, in deze paragraaf gaat het over de stabiliteit ervan. De vraag wordt immers vaak gesteld of het gebruik van een bepaalde strategie vooral voortvloeit uit iemands persoonlijkheid, en dus min of meer stabiel is, of dat het eerder situationeel wordt bepaald.

Eén van de twee indices voor het gebruik van de strategieèn is de frequentie waarin een respondent een strategie gebruikt. Het getal dat dit oplevert, weerspiegelt het aantal vragen en het aantal verschillende onderwerpen waarop een patiënt met een bepaalde strategie reageert. De aangetroffen minimumfrequentie is voor elk van de strategieèn nul, de aangetroffen maximumscores verschillen per strategie en zijn te vinden in tabel 4.2 in paragraaf 3.

Om inzicht te krijgen in de stabiliteit van een strategie zijn er Spearman-correlaties berekend tussen de frequenties van het strategiegebruik van de respondenten op de drie meetmomenten. Deze test-hertest-correlaties staan afgebeeld in tabel 4.5. Protesteren, bagatelliseren en doemdenken springen eruit. De test-hertest-correlaties 
- Tabel 4.5 - Stabiliteit van de strategieên

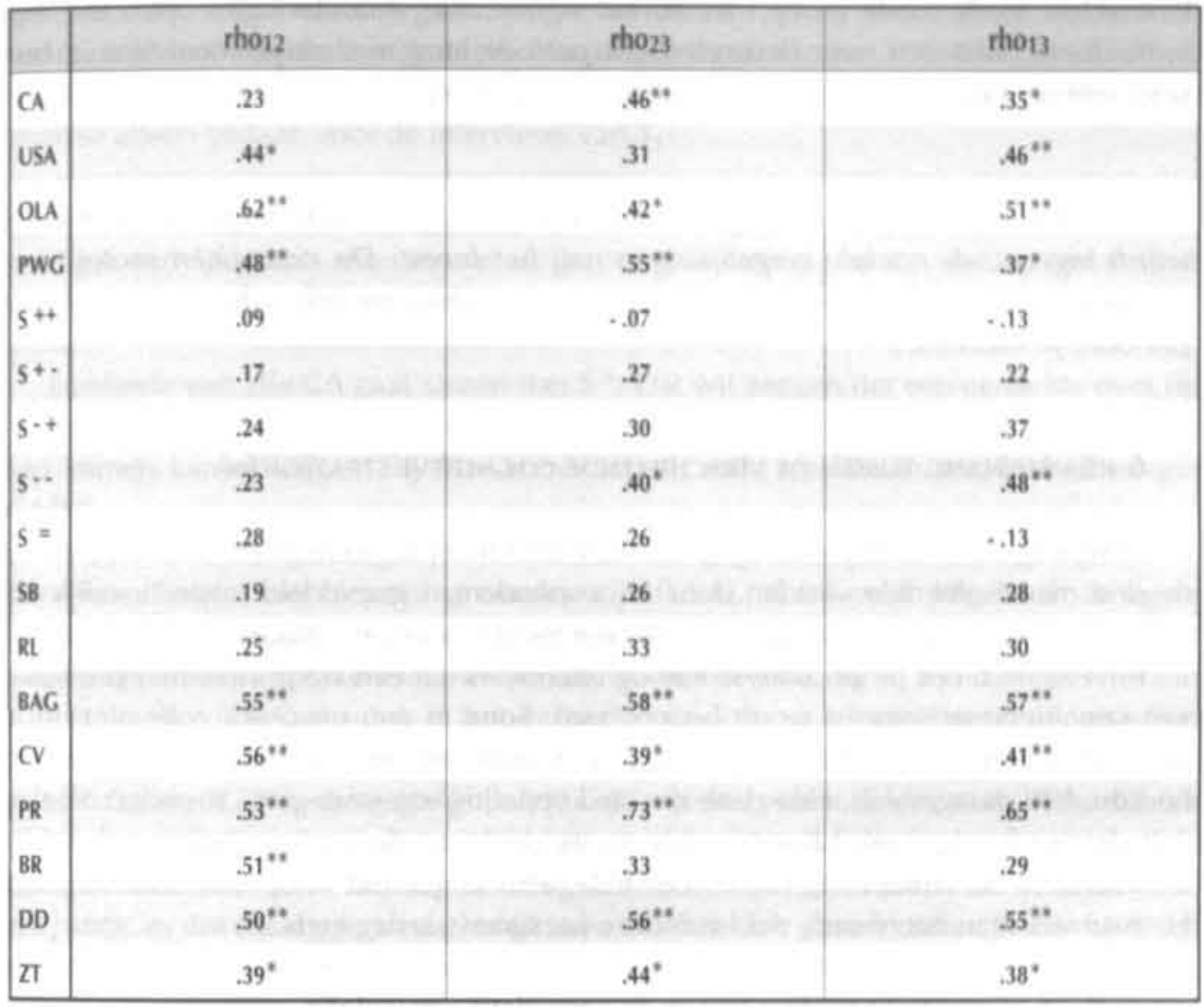

tho 12 is de correlatie-coefficiènt volgens Spearman tussen de frequentie van strategiegebruik op TI en T2; rho 23 geeft de correlatie weer tussen de frequentie van T2 en T3; rho 13 die tussen $\mathrm{T}_{1}$ en $\mathrm{T} 3$ ("ps.01 " "ps.001).

voor deze strategieën zijn behoorlijk, dat wil zeggen groter dan of gelijk aan .50. Patiënten die deze strategieën aan het begin direct na diagnose gebruiken, hebben blijkbaar de neiging dit te blijven doen. Daarentegen zijn de test-hertest-correlaties voor de sociale vergelijkingen positief naar boven, positief naar beneden, gelijkwaardig, negatief naar boven en zich bijzonder vinden, evenals die voor de strategie relativeren laag. Deze strategieën zijn dus niet stabiel in de loop van de tijd. Dit sluit aan bij de bevinding in de vorige paragraaf dat de sociale vergelijkingen met name in de periode vlak na de diagnose zijn aangetroffen. De meeste van de overige strategieën hebben test-hertest-correlaties die variëren van laag tot middelmatig, waarbij ontlastende en uitsluitende attributies, een positieve wending geven, cognitief 
vermijden en zichzelf toespreken een gemiddelde correlatie kennen van .40 of meer. Hoewel er in de totale groep niet zoveel significante veranderingen optreden, zijn individuele patiënten over de onderzoeksperiode lang niet altijd consistent in hun strategiegebruik.

Dit alles wijst erop dat een groot deel van de cognitieve strategieën situationeel wordt ingezet, de sociale vergelijkingen nog het meest. De strategieën protesteren, doemdenken en bagatelliseren zijn het meest stabiel en lijken het meest op een persoonlijkheidstrek.

\section{6 - Samenhang tussen de verschillende COGNitieve Strategië̈N}

Verreweg de meeste patiënten gebruiken verschillende strategieën door elkaar. Op de drie meetmomenten worden door de respondenten gemiddeld respectievelijk elf, tien en negen van de zeventien strategieèn ten minste éénmaal gebruikt (zie paragraaf 3 ).

Bovendien bleek bij de analyse van de interviews dat een vraag vaak met een keten van cognitieve strategieèn wordt beantwoord. Soms is een uitspraak zelfs niet op te delen in afzonderlijke strategieèn en is er sprake van een dubbelstrategie (zie ook hoofdstuk III paragraaf 2). Hoe deze directe koppeling van strategieën is onderzocht en wat dat heeft opgeleverd komt in het eerste deel van deze paragraaf aan de orde. Daarnaast is de samenhang tussen de strategieën uitgedrukt in Spearman-correlaties. Hiervan wordt in het tweede deel van deze paragraaf verslag gedaan.

\section{6 - 1 - Directe koppeling tussen de cognitieve strategieën}

Bij de interviews van het eerste meetmoment is geanalyseerd hoe vaak een cognitieve strategie in één antwoord direct met een andere samengaat. Wanneer bijvoorbeeld in hetzelfde antwoord zowel een schuldontlastende attributie (OLA) als een causale attributie (CA), doemdenken (DD) en een sociale vergelijking negatief naar boven $\left(\mathrm{S}^{-+}\right.$) samen voorkomen, is deze reeks opgesplitst in alle voorkomende tweetallen. Dit levert bij dit voorbeeld de volgende combinaties op: OLA met CA, OLA met DD, OLA met S $\cdots$, CA met DD, CA met $\mathrm{S}^{*+}$ en DD met S $\cdots$. Alle antwoorden zijn op deze manier geanalyseerd. Vervolgens is geteld hoe vaak op $T_{1}$ een bepaald tweetal samen is aangetroffen.

Daarna is het aantal malen dat een strategie in een bepaalde combinatie voorkomt, uitgedrukt in een percentage van het totaal aantal malen dat deze strategie op $\mathrm{T}_{1}$ voorkomt. Voor CA en S - betekent dit bijvoorbeeld dat $33 \%$ van alle CA op $\mathrm{T}_{1}$ wordt 
geuit in combinatie met $\mathrm{S}^{\text {* }}$ en $65 \%$ van alle $\mathrm{S}$ * in combinatie met CA. Dus het grootste deel $(67 \%)$ van CA gaat niet samen met S \%, maar komt alléén voor, of in combinatie met een andere strategie. Van alle S ${ }^{*}$ gaat slechts $35 \%$ niet direct samen met CA. Aangezien de procedure nogal arbeidsintensief is, is dit stuk van de interviewanalyse alleen gedaan voor de interviews van $T_{1}$.

\section{- Causale attributies}

Bijna eenvijfde van alle causale attributies gaat samen met ten minste één andere CA. Regelmatig noemden respondenten in een adem dus meerdere oorzaken voor hun ziekte.

Eenderde van alle CA gaat samen met S *. Dat wil zeggen dat een gedachte over de oorzaak dikwijls tot de conclusie leidt dat men niet anders is dan een ander: iedereen kan immers kanker krijgen. Bij deze combinatie is altijd sprake van een dubbelstrategie CA/S *

Het praten over een mogelijke oorzaak (CA) nodigt vaak uit tot mededelingen over oorzaken die niet van toepassing zouden zijn (USA). Ik beb wel de pil gebruikt. Ze zeggen dat dit er iets mee te maken kan bebben. Verder komt bet in onze familie niet voor. Dus erfelijk zal bet wel niet zijn.' Ook uitspraken waarin men aangeeft niet schuldig te zijn aan het ontstaan van de kanker (OLA) worden in het verhaal over de oorzaak regelmatig aangetroffen (16\%). 'Ik beb altijd gezond gegeten, altijd mijn eigen brood gebakken en veel in bet reformbuis gekocbt. Dat maakt bet zo onbegrijpelijk. Je bebt altijd zo je best gedaan, en dan mu dit. Natuurlijk beb $i k$ de laatste tijd wel een beel druk leven geleid, en misscbien dat je daar dan nu de rekening voor bebt gekregen. Want bet viel niet mee, drie kinderen, een baan, altijd gezond koken, dus nooit even snel een patatje, en dan ook nog verjaardagen bijbouden, en als bet kon speciale cadeautjes uitzoeken, zelf kleren maken, een goede moeder zijn. Dan ben je best eens afgedraaid. Dat is natuurlijk niet goed, uant je put jezelf uit.'

Tenslotte valt op dat CA in combinatie met alle andere strategieèn voorkomt, zij het soms maar zelden.

total aantal $=133$

$\begin{array}{rlrrrrrrr}9 \% & \text { alleen } & & 7 \% & \text { met } & S^{*} & 4 \% & \text { met } & \text { BAG } \\ 19 \% & \text { met andere CA } & 10 \% & \text { met } & S^{-*} & 2 \% & \text { met } & \text { CV } \\ 11 \% & \text { met } & \text { USA } & 9 \% & \text { met } & \mathrm{S}^{*} & 7 \% & \text { met } & \text { PR } \\ 16 \% & \text { met } & \text { OLA } & 33 \% & \text { met } & S^{*} & 7 \% & \text { met } & \text { BR } \\ 6 \% & \text { met } & \text { PWG } & 2 \% & \text { met } & \text { SB } & 10 \% & \text { met } & \text { DD } \\ 1 \% & \text { met } & \text { S*+ } & 7 \% & \text { met } & \text { RL } & 6 \% & \text { met } & \text { ZT }\end{array}$




\section{- UitsLuITENDE ATtRIBUTIES}

Een uitsluitende attributie wordt niet vaak gebruikt. Meestal gaat USA samen met CA $(82 \%)$, vaak ook met OLA $(41 \%)$. Het denken over de oorzaak roept dus vaak een combinatie van deze drie attributies op, waarbij er nooit meer dan één USA wordt genoemd.

De helft van USA gaat samen met $\mathrm{S} \cdots$. Het gaat dan om een uitspraak als: 'Het kan niet van bet roken komen. Ik beb namelijk nooit gerookt. En als je dan die mensen ziet die roken als een ketter en niets krijgen, nou dat maakt je dan wel kuaad. 'Het wegstrepen van een mogelijke oorzaak (USA) leidt tot een vergelijking met mensen die geen kanker hebben gekregen ondanks dat zij wel het vermeende risicogedrag hebben vertoond $\left(\mathrm{S}^{-{ }^{*}}\right.$ ). In deze uitspraak zit ook protest en is daarmee ook een voorbeeld van de combinatie USA en PR, die bij $18 \%$ van alle USA-uitspraken werd gevonden. De combinatie met S = loopt via het samengaan van USA met CA. Zoals eerder vermeld, is een deel van de CAuitspraken een dubbelstrategie met S".

\begin{tabular}{|c|c|c|c|c|c|c|c|c|}
\hline $5 \%$ & alleen & & $0 \%$ & met & s*. & $5 \%$ & met & BAG \\
\hline $0 \%$ & met andere & USA & $50 \%$ & met & $\mathrm{S}^{-+}$ & $0 \%$ & met & $\mathrm{CV}$ \\
\hline $82 \%$ & met & $\mathrm{CA}$ & $5 \%$ & met & S $\cdots$ & $18 \%$ & met & PR \\
\hline $41 \%$ & met & OLA & $18 \%$ & met & S* & $0 \%$ & met & BR \\
\hline $9 \%$ & met & PWG & $0 \%$ & met & SB & $5 \%$ & met & DD \\
\hline $0 \%$ & met & $\mathrm{S}^{*+}$ & $0 \%$ & met & RL. & $0 \%$ & met & ZT \\
\hline
\end{tabular}

\section{- Schuldontlastende attributies}

Een groot deel van alle ontlastende attributies komt alleen en niet in combinatie met andere strategieèn voor $(31 \%)$. Meestal zijn het dan uitspraken over het tijdstip van ontdekken en uitspraken over ongezonde leefgewoonten waar de respondent geen schuld aan wil hebben. Eerder is opgemerkt dat OLA vaak samengaat met CA $(27 \%)$. Het samengaan met $\mathrm{S}$ - heeft hier ook mee te maken: OLA gaat samen met CA, CA gaat samen met S :

De combinatie OLA en DD (13\%) komt voort uit het besef van de respondent, dat zij die toch al zo gezond leefde, niets meer aan haar leefgewoonten kan veranderen. Eigenlijk is er niets om de terugkeer van de kanker te voorkomen. De eerder geciteerde vrouw, die haar eigen brood bakte en haar levensmiddelen in het reformhuis kocht, verzucht: 'En wat moet je dan nog meer doen?' Ik beb altijd zo gezond mogelijk geleefd om zo goed mogelijk nare ziektes te voorkomen. En dan krijg je dit! Als je nou altijd ongezond gegeten bad, dan 
kon je nog zeggen: oke, nu ga ik bet anders doen. Dan bad je misscbien een kans dat je bet in de toekomst kunt toorkomen. Dan kun je misscbien nog iets goed maken. Maar ik beb bet gevoel dat ik niets kan doen om bet tegen te bouden. Het moet wel een agressieve kanker sijn als bet in bet zo'n gezond lichaam als dat wan mij een kans kriggt.

In de combinatie OLA met BAG (17\%) klinkt een heel ander effect door. In tegenstelling tot de combinatie met DD wordt de OLA juist gebruikt om aan te geven dat het allemaal niet zo erg kan zijn. 'Omdat je altijd zo gezond geleefd bebt, beeft je licbaam een goede ueerstand opgebouwd. En weerstand is bij kanker juist beel belangrijk. Dus uat dat betreft kun je niet anders zeggen dan dat ik de meest gunstige uitgangspasitie beb.' Ook bij OLA's over het tijdstip van ontdekken komt deze combinatie voor: 'Gelukkig maar dat ik zo goed aan zelfcontrole beb gedaan. Dan boef je jezelf niets te veruijten. Ik beb bet ontdekt mu bet nog maar beel klein uas. Het was een tumortje tan niks, nog maar een speldenprik. Ik maak me dan ook absoluut geen zongen.'

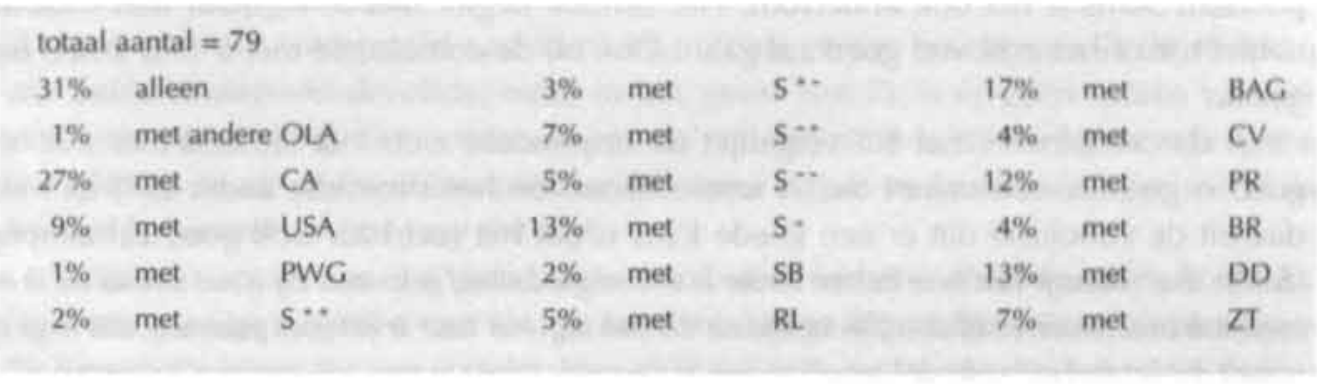

\section{- Een POSITIEVE WENDING GeVEn AAN DE ZIEKTE}

Meer dan de helft van 'een positieve wending geven' staat op zichzelf. Voor de rest wordt deze strategie in combinatie met elke andere strategie gebruikt, maar de percentages zijn laag.

\begin{tabular}{|c|c|c|c|c|c|c|c|c|}
\hline $57 \%$ & \multicolumn{2}{|c|}{ alleen } & $5 \%$ & met & s*. & $2 \%$ & met & BAG \\
\hline $8 \%$ & \multicolumn{2}{|c|}{ met andere PWG } & $4 \%$ & met & $\mathrm{S}^{\cdots}$ & $7 \%$ & met & $\mathrm{CV}$ \\
\hline $7 \%$ & met & CA & $1 \%$ & met & $5 *$ & $3 \%$ & met & PR \\
\hline $2 \%$ & met & USA & $5 \%$ & met & S & $6 \%$ & met & BR \\
\hline $1 \%$ & met & OLA & $2 \%$ & met & SB & $4 \%$ & met & DD \\
\hline $2 \%$ & met & $\mathrm{S}^{*+}$ & $2 \%$ & met & RL. & $7 \%$ & met & ZT \\
\hline
\end{tabular}




\section{- Sociale vergelijking positief naAR boven}

De sociale vergelijking positief naar boven komt niet zo vaak voor. De meeste S +* gaat samen met BAG (38\%). Een deel daarvan berust op een dubbelstrategie, zoals: ' $I k$ ken zoveel mensen die bet bebben gebad en er absoluut geen last meer van bebben. Ook met positieve klieren. Dat gaat nu ook goed. Dus, bet zegt belemaal niets dat je positieve klieren bebt.'

Bij een kwart van $\mathrm{S}^{*+}$ zegt de respondent tegen zichzelf dat ze moet kijken naar mensen waar het goed mee gaat. $\mathrm{Er}$ is dan sprake van een combinatie $\mathrm{S}^{++}$met $\mathrm{ZT}$ : 'Dan zeg ik tegen mijzelf: kom op, niet te negatiefl! Met dat vrouwtje twee straten verder is bet ook goed gekomen, dus dat kan ook! Niet aan die negatieve dingen denken!'. In de laatste zin van dit voorbeeld zit de combinatie S *+ met CV: de respondent verdringt negatieve gedachten door zich positieve voorbeelden voor de geest te halen.

De combinatie met DD (25\%) is opvallend en lijkt in eerste instantie onlogisch. Meestal volgt S ", op DD om als het ware iets van de negatieve gedachten weg te poetsen. Soms is het ook andersom. Het verhaal begint met $\mathrm{S}^{{ }^{*}}$, maar dan slaat de twijfel toe of het echt wel goed zal gaan. Ook bij de combinatie met S - ${ }^{-}$is zoiets het geval.

In de combinatie met $\mathrm{S}$ " vergelijkt de respondent zich met iemand met wie het goed is gegaan, constateert dat ze overeenkomsten heeft met die ander (S ") en trekt daaruit de conclusie dat er een goede kans is dat het met haar ook goed zal aflopen $\left(S^{+*}\right)$ : 'Dat vrouvtje van twee buizen verder is er beel goed vanaf gekomen. Zij is net zo oud als ik en beeft ook twee kinderen in dezelfde leeftijd als die van mij. Met baar is bet goed gekomen, dus ik ga er vamuit dat bet met mij ook goed komt:

\begin{tabular}{|c|c|c|c|c|c|c|c|}
\hline $4 \%$ & alleen & $4 \%$ & met & $5 \cdots$ & $38 \%$ & met & BAG \\
\hline $0 \%$ & met andere $\mathrm{S}$ *t & $13 \%$ & met & $\mathrm{S}^{* *}$ & $21 \%$ & met & CV \\
\hline $8 \%$ & met & $8 \%$ & met & $\mathrm{S}^{\cdots}$ & $4 \%$ & met & PR \\
\hline $0 \%$ & USA & $17 \%$ & met & S. & $4 \%$ & met & BR \\
\hline $8 \%$ & OLA & $0 \%$ & met & SB & $25 \%$ & met & DD \\
\hline $8 \%$ & PWG & $8 \%$ & met & RL. & $25 \%$ & met & ZT \\
\hline
\end{tabular}

\section{- Sociale vergelijking positief naAr beneden}

Bijna eenderde van deze sociale vergelijkingen staat op zichzelf: er komt geen andere cognitieve strategie in het antwoord voor. Een combinatie met bijna alle andere strategieẻn is aangetroffen; die met ZT komt relatief het meest voor. Opvallend is dat deze combinatie vaak verloopt via $\mathrm{S} \cdots:$ Mijn tante is nog niet zo lang geleden aan levermetastasen gestorven. Dat uas een lijdensueg. Die tante is ook met borstkanker begonnen, net als 
ik. Daar moet je dan niet aan denken. Dat moet je meteen nan je afzetten. Daarom ben ik ook zo blij met die cbemokuur. Die beeft zij niet gekregen. $1 \mathrm{k}$ beb bem nu al aan bet begin, al toordat bet eigenlijk nodig is. Daar ben $i k$ beel blij mee, want dan ueet ik tenminste zeker dat ik oter twintig jaar niet doodga aam leterkanker. Dat boud ik mijzelf ook steeds toor ogen, dat ik er wat dat betreft bét vél beter voor sta dan zij."

De uitspraak begint met de vergelijking met een tante waarmee het slecht is afgelopen (S - ). Dan houdt de patiënt zich voor (ZT) dat het bij haarzelf zo niet hoeft te verlopen, omdat zij een gunstiger uitgangspositie heeft (S * - ). Het gedeelte waarin zij zegt dat ze die nare gedachten van zich afzet, is bovendien nog als CV gescoord. De S*- wordt gebruikt om negatieve gedachten te verdringen. Tenslotte is in het voorbeeld ook sprake van een combinatie met BAG, omdat de patiènt zegt er zeker van te zijn dat ze geen metastasen zal krijgen. De S *- slaat dan in feite door en is de basis voor het bagatelliseren. Dit voorbeeld laat zien uit hoeveel cognitieve strategieèn een keten kan zijn opgebouwd.

Soms gaat S *- vergezeld van RL (13\%). Zoals eerder beschreven is de strekking van beide strategieèn dezelfde, maar in het geval van $\mathrm{RL}$ is er geen sprake van een expliciete vergelijking. Een voorbeeld van zo'n combinatie is: ' $1 k$ ben blij dat mijn borst er niet af boeft. En als ik dan die vrouten zie die cbemo krijgen en kaal worden, dan voel ik me belemaal bevoorrecbt dat dat bij mij niet boeft.'

Ruim een op de tien S *- uitspraken komt voor in het verhaal rondom oorzaakstoekenning en gaat samen met CA: Je boort bet vaak op deze leeftijd, zo nond de menopauze. Die bormonen schijnen dan mee te spelen. Maar als ik dan in de uacbtkamer zit en die jonge urouuen zie, dan denk ik tocb dat bet je beter op deze leeftijd kan overkomen. Nu ben je uit de kleine kinderen en in plaats dat je toor kleine kinderen moet zorgen, kunnen ze jou nu een bandje belpen."

\begin{tabular}{|c|c|c|c|c|c|c|c|}
\hline $30 \%$ & alleen & $1 \%$ & met & s*. & $10 \%$ & met & BAG \\
\hline $4 \%$ & met andere $5 .$. & $5 \%$ & met & $s^{\cdots \cdot}$ & $14 \%$ & met & $\mathrm{CV}$ \\
\hline $13 \%$ & met & $12 \%$ & met & $5 *$ & $8 \%$ & met & PR \\
\hline $0 \%$ & USA & $11 \%$ & met & s. & $10 \%$ & met & $B R$ \\
\hline $3 \%$ & OLA & $6 \%$ & met & SB & $11 \%$ & met & DD \\
\hline $6 \%$ & PWG & $13 \%$ & met & RL & $15 \%$ & met & ZT \\
\hline
\end{tabular}




\section{- Social.e Vergelijking negatief naAr boven}

Ruim eenderde van alle 'sociale vergelijkingen negatief naar boven' gaat samen met protest. Wanneer men zich vergelijkt met iemand die het beter gaat, kan dat leiden tot boosheid en een gevoel van oneerlijkheid: Ja, waarom ik en niet Sadam Hoessein? $J a$, dat vraag ik me beel veel af. Vanaf dat ik mezelf bewust ben, beb ik geleefd naar mijn geweten. Ik luister daarnaar, ik lieg niet, ik ga recht op de dingen af, ik boud beel veel van mijn man en mijn $k i n d, i k$ zorg goed voor ze. Ik beb goed voor $m$ 'n ouders gezorgd en ik vind bet beel erg oneerlijk. Ik sla nog geen viteg dood, ik vang bem en doe bem naar buiten. Dan vind ik bet gemeen dat ik dat beb.'

Een gedeelte van de combinatie S - en PR loopt via een OLA: de respondent vergelijkt zich met anderen die bijvoorbeeld wel ongezond hebben geleefd hebben en geen kanker hebben gekregen ( ( $^{-*}$ ), vervolgens benadrukt zij dat zij er wel alles aan heeft gedaan om kanker te voorkomen (OLA) en is boos dat dit niet is beloond (PR). 'Iedereen die bet boorde zei: zij?? boe is bet mogelijk! Daar begrijpen ze totaal niets van. Dat is van: boe moet je bet dán voorkomen??? Dat is bet eigenlijk, bè. Je leeft zo goed en gezond. Je doet er alles aan. Dat jou dat nu moet overkomen! Dat zijn een beleboel reacties geweest. Dat jij dat nu moet krijgen. Dat een ander dat nou met z'n levenspatroon ..., maar jij juist?! Dat boor ik ze gewoon nog zeggen. En dat maakt mij ook zo boos en verdrietig. Dat je er alles aan bebt gedaan en dan krijg je nu deze klap in je gezicht. En wat moet je dan nog? Zo zie je maar dat bet een ziekte is, waar geen kruid tegen is geurassen. Wat je ook doet, je verliest de strijd.' In dit voorbeeld zit ook nog de vaker voorkomende combinatie van $\mathrm{S} \cdots$ met doemdenken (18\%).

Een andere veel voorkomende combinatie is die met CA. Respondenten vergelijken zich met anderen om achter de oorzaak van hun kanker te komen. Deze vergelijking valt dan negatief voor hen uit. Zij komen er slechter vanaf, want zij hebben kanker gekregen en de ander niet. In het volgende voorbeeld is er sprake van een dubbelstrategie S - +/CA: 'Ik ben $m$ 'n leven lang al niet zo gezond. I $k$ beb alle mogelijke ziektes en kwaaltjes gebad. Dus ik denk dan: je bele afiveersysteem is je bele leven al bartstikke slecbt geweest en kanker is een ziekte waarbij er zeg maar verandering van celueefsel optreedt. Dat gebeurt ook bij alle gezonde mensen. Maar die bebben een natuurlijk afiveersysteem, en dat is bij mij al nooit zo goed geweest. Dus beb ik een grotere kans op kanker in vergelijking met mensen die een goed afueersysteem bebben:

Het samengaan met USA ( $22 \%$ ) loopt meestal via CA, omdat bij het zoeken naar een oorzaak vaak ook factoren worden genoemd die geen bijdrage hebben geleverd.

\begin{tabular}{|c|c|c|c|c|c|c|c|c|}
\hline \multicolumn{9}{|c|}{ totaal antal $=40$} \\
\hline $8 \%$ & alleen & & $6 \%$ & met & $\mathbf{S} *$ & $8 \%$ & met & BAG \\
\hline $0 \%$ & met andere & $S^{\cdots}$ & $10 \%$ & met & s* & $10 \%$ & met & $\mathrm{CV}$ \\
\hline $35 \%$ & met & $\mathrm{CA}$ & $2 \%$ & met & $S^{\cdots}$ & $35 \%$ & met & PR \\
\hline $22 \%$ & met & USA & $12 \%$ & met & S* & $4 \%$ & met & BR \\
\hline $14 \%$ & met & OLA & $2 \%$ & met & SB & $18 \%$ & met & DD \\
\hline $10 \%$ & met & PWG & $12 \%$ & met & RL. & $12 \%$ & met & $\mathrm{ZT}$ \\
\hline
\end{tabular}




\section{- Sociale vergelijking negatief naAr beneden}

Een sociale vergelijking negatief naar beneden komt zelden alleen voor en nooit samen met een andere $S^{\cdots}$.

Meer dan de helft vormt samen met doemdenken de dubbelstrategie DD/S * : 'Tuee zusjes, een nicbtje, een neef, plus nog een zuager zijn aan kanker overleden. In onze triendenkring komt bet ook beel eng voor. Je weet uat er speelt, wat er gebeuren kan. Ik durf geen plannen toor bet komende jaar te maken. Ik ben zo bang dat bet, net als bij ben. terugkomt en dat er dan niets aan te doen is. Je bele leven staat op losse scbroeven.

Ongeveer eenderde is gekoppeld aan een CA. Vaak gaat het dan om een attributie met erfelijkheid als oorzaak, waarbij het met het familielid slecht is afgelopen. Er is dan sprake van de dubbelstrategie CAVS --

Regelmatig gaat een S - samen met een strategie die het effect ervan weer wat moet afzwakken. Een kwart vormt als zodanig een combinatie met $\mathrm{S}^{*}$, zoals in het volgende voorbeeld: 'Een maand voordat bet bij mij bekend werd is mijn zus aan borstkanker overleden. Dus je bent reuzenbang dat bet met jou ook zo zal aflopen. Maar, zij bad er wel drie jaar mee gelopen. Die was al veel verder voordat ze naar de dokter ging. Zij was 44 toen ze bet kreeg en 47 toen ze oterleed. Ik ben mu ook 44. Maar ik was er unoeger bij, vél uroeger. Dus, dat is meteen ook een stuk gunstiger. Er waren wel meer verscbillen tussen ons. Ik beb drie kinderen gekregen en borstvoeding gegeven. Zij bad geen kinderen, dus geen borstvoeding. Dat is voor mij dus ook gunstiger,' De combinatie van S - en een gedachte dat het ook nog erger had kunnen zijn, en er dus ook gunstige kanten zijn aan te wijzen (RL), lijkt eveneens een poging het negatieve gevoel te verminderen. Zoiets lijkt ook te gebeuren in de combinatie met BAG en in de combinatie met CV: Je ziet bet tocb ook wel om je been, dat die vrouuen na een aantal jaren tocb weer iets bebben. Mijn scboonzus is eraan gestorven. Die is eenenvilftig geworden. Ze bad bet voor bet eerst toen ze in de dertig uas en bet kuam terug op baar acbtenveertigste. Toen bet terug kuam was baar bele bottenstelsel aangetast. Die beeft tocb wel een beel slecht einde gebad. Poeb! Maar daar wil ik niet aan denken. Ik betrek bet niet op mijzelf, boor. Want zij bad borstkanker en baarmoederkanker en bad bet toen al in baar botten natuurlijk. Nee, ikzelf ga beel monter verder'. Tweevijfde gaat samen met ZT. Eerst vergelijkt zo'n respondent zich met een ander die het slecht is vergaan en dan houdt zij zichzelf voor dat ze niet zo moet denken, dat ze afleiding moet zoeken, zich niet uit het veld moet laten slaan en dergelijke.

\begin{tabular}{|c|c|c|c|c|c|c|c|c|}
\hline $5 \%$ & alles & & $5 \%$ & met & $5 *$ & $14 \%$ & met & $B A C$ \\
\hline $0 \%$ & met & $\mathrm{S}$ & $25 \%$ & met & $S^{*}$ & $20 \%$ & met & CV \\
\hline $32 \%$ & met & $C A$ & $2 \%$ & met & $\mathbf{S}^{*+}$ & $7 \%$ & met & PR \\
\hline $2 \%$ & met & USA & $2 \%$ & met & S * & $11 \%$ & met & BR \\
\hline $11 \%$ & met & OLA & $5 \%$ & met & SB & $55 \%$ & met & DD \\
\hline $2 \%$ & met & PWG & $16 \%$ & met & $\mathrm{RL}$ & $39 \%$ & met & $Z T$ \\
\hline
\end{tabular}




\section{- Sociale vergelijking gelijkwaARdig}

Tweederde van de sociale vergelijkingen gelijkwaardig komt als dubbelstrategie voor met CA. Bij het zoeken naar de oorzaak concludeert de respondent dat zij op bepaalde punten overeenkomt met anderen die ook kanker hebben gekregen: Ja, één op de tien vrouten wordt er momenteel mee geconfronteerd; dat zijn de statistieken. Als bet één op de tien is, dan kan ik daar beel goed bij boren. Er zijn duizenden mensen die bet bebben. En ik boor daar nu bij.

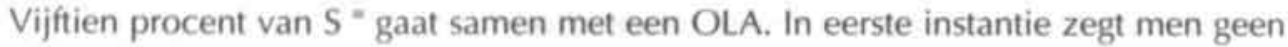
schuld te hebben aan het ontstaan van de kanker en staaft dit met de opmerking dat iedereen het kan krijgen waardoor er geen sprake kan zijn van persoonlijke schuld of nalatigheid.

Het samengaan van S - en DD is vooral gebaseerd op uitspraken waarin men na het noemen van angstige gedachten aangeeft dat het niet zo vreemd is zo te denken, omdat anderen in dezelfde situatie dat ook zouden doen: 'Dan lig ik in bed en dan gaat bet allemaal nog eens door mijn boofd, alles uat er kan gebeuren. Maar ik denk dat iedereen dat wel beeft."

Bij de combinatie met BAG gebruikt de respondent haar constatering 'niet anders te zijn dam een ander' om te onderstrepen dat ze naar haar eigen overtuiging is genezen. Met die ander worden dan niet-kankerpatiënten bedoeld. In de vergelijking wordt de ernst van de situatie gebagatelliseerd: 'En dan zijn er die bebben tegen mijn man gezegd: ja, maar als je ziet wat er allemaal gebeuren kan. En dan zeg ik: dat kan met jou ook gebeuren, net zo goed als met mij. Nee, ik beb ecbt bet idee dat ik genezen ben. Ik ben wat dat betreft weer net als ieder ander.

Wanneer S * met ZT samengaat, houdt de respondent zich hardop voor dat zij niet de enige is die in een dergelijke situatie verkeert. 'En dan denk je ook wel weer: kop op! Er zijn er zoteel die in betzelfde schuitje zitten. En dan verduijnt je zelfmedelijden als sneeuw voor de zon.'

Slechts bij tien procent van de S * uitspraken wordt de constatering, dat men niet anders is dan een ander, gevolgd door een uitspraak die als BR kon worden gescoord.

\begin{tabular}{|c|c|c|c|c|c|c|c|}
\hline $7 \%$ & alleen & $5 \%$ & met & $5 *$ & $14 \%$ & met & BAC \\
\hline $0 \%$ & met andere S - & $12 \%$ & met & $S^{*}$ & $7 \%$ & met & $\mathrm{CV}$ \\
\hline $65 \%$ & met & $7 \%$ & met & $S \cdots$ & $6 \%$ & met & PR \\
\hline $5 \%$ & USA & $4 \%$ & met & $\mathbf{s}^{\cdots}$ & $10 \%$ & met & $B R$ \\
\hline $15 \%$ & OLA & $1 \%$ & met & SB & $15 \%$ & met & DD \\
\hline $7 \%$ & PWG & $7 \%$ & met & RL & $14 \%$ & met & $Z T$ \\
\hline
\end{tabular}




\section{- Zichzelf eEN BIJZONDERE PATIËNT VINDEN}

Eenderde van 'zich bijzonder vinden' staat op zichzelf en gaat niet vergezeld van andere strategieèn. Ook eenderde gaat samen met ZT: En ik ben fussen de kuren door met mijn man naar een congres op Kreta getieest. Ik beb daar ook aan allerlei dingen megedaan. ledereen was er nogal verbaasd over dat ik daar zo goed mee om kon gaan. Gewoon mijn pruik op en meedoen. Maar zo ben ik. Niet zeuren' En tegen jezelf zeggen: kom op! Dat werkt bij mij bet beste.'

$\mathrm{Bij}$ ongeveer een kwart is er sprake van een combinatie met CV: De zondag toor ik werd opgenomen ben ik nog naar de kerk gegaan. En dan zijn ze stomverbaasd dat je nog zingt ook. Er uaren er die zeiden: knap dat je er bent. Misscbien is dat wel knap, maar bet belpt je ook om er niet de bele tijd aan te boeten denken. Anders loop je maar te malen en daar scbiet je ook niets mee op. Er niet aan denken en zoveel mogelijk proberen om in je getcone doen te zijn.'

Eenvijfde gaat samen met S *-, zoals in het volgende verhaal: 'Het is bij mij beel anders gegaan. De standaardoperatie is tumor uegbalen, en als die te groot is: de bele borst eraf. plus de klieren uegbalen toor onderzoek. Ik beb meteen gezegd: over mijn lijk. Die borst gaat er geuoon niet af, klaar! Ga eerst maar eens kijken wat voor 'n tumor bet is. En die klieren wil ik ook niet ueg. Straks is bet goedaardig en beb ik geen klieren meer. Ik ben geopereerd op de dagbebandeling. Dat uordt etgenlijk nooit gedaan. Maar ik kan niet tegen andere zieken en ik wilde niet opgenomen uorden. Dat bebben ze dus gedaan (de tumor bleek kwaadaardig; haar werd aangeraden de lymfeklieren toch weg te laten halen, voor onderzoek. M.0.). Toen duurde bet nog een paar dagen tot ik opgenomen kon worden. Dat tond ik niet erg. Ik wilde berstellen, wat lezen en bet goed tot mij door laten dringen wat er gebeurd uas. Er zijn beel veel vrouven die, nadat ze de diagnose geboord bebben, binnen een week bun borst en bun lymfeklieren kwijt zijn en zicb dan afuragen: wat overkomt me? Nou dat is zo'n gigantiscb trauma. Met mij is bet veel geleidelijker gegaan. Ik beb beel veel tijd gebad om te praten en mijn beslissing te nemen. Daar ben ik nog steeds blij om. Dat is een groot toordeel geueest.'

\begin{tabular}{|c|c|c|c|c|c|c|c|}
\hline $33 \%$ & alleen & $0 \%$ & met & s*. & $10 \%$ & met & BAG \\
\hline $0 \%$ & met andere SB & $20 \%$ & met & $\mathbf{S}^{+\cdots}$ & $23 \%$ & met & $\mathrm{CV}$ \\
\hline $10 \%$ & met & $3 \%$ & met & $\mathrm{s}^{-+}$ & $10 \%$ & met & PR \\
\hline $0 \%$ & USA & $10 \%$ & met & $\mathrm{s}^{\cdots}$ & $10 \%$ & met & BR \\
\hline $10 \%$ & OLA & $10 \%$ & met & S. & $10 \%$ & met & DD \\
\hline $10 \%$ & PWG & $13 \%$ & met & RL. & $33 \%$ & met & ZT \\
\hline
\end{tabular}




\section{- Relativeren}

Relativeren komt vooral alléén voor. Soms $(16 \%)$ is er een combinatie met ZT. De respondent houdt zichzelf voor dat ze niet mag mopperen, want het had veel ongunstiger kunnen zijn. 'En dan zeg ik ook tegen mijzelf dat ik niet zo moet somberen. De lymfeklieren, daar zat niets in, die waren belemaal scboon. Dat viel dus retzze mee. Voor betzelfde geld zeggen ze: sorry mevrouw, er is niets meer aan te doen. Dat bad toch ook gekund?

Opvallend is dat bijna eenvijfde in één adem met DD wordt genoemd. Als DD aan RL voorafgaat wordt het doemdenken door te relativeren afgezwakt. Wordt RL echter door DD gevolgd, dan blijft er onzekerheid hangen. Dergelijke opeenvolgingen laten de ambivalenties van deze borstkankerpatiënten zien.

\begin{tabular}{|c|c|c|c|c|c|c|c|}
\hline $41 \%$ & alleen & $2 \%$ & met & s* & $0 \%$ & met & BAG \\
\hline $7 \%$ & met andere RL & $10 \%$ & met & s*. & $8 \%$ & met & CV \\
\hline $10 \%$ & met & $5 \%$ & met & $s^{\cdots+}$ & $4 \%$ & met & PR \\
\hline $4 \%$ & OLA & $6 \%$ & met & $s^{*}$ & $3 \%$ & met & BR \\
\hline $0 \%$ & USA & $5 \%$ & met & s. & $18 \%$ & met & DD \\
\hline $3 \%$ & PWG & $3 \%$ & met & SB & $16 \%$ & met & 21 \\
\hline
\end{tabular}

\section{- Bagatelliseren}

Bagatelliseren gaat in ruim eenvijfde van de uitspraken hand in hand met CV: de werkelijkheid minder ernstig maken en niet aan nare dingen willen denken. I $k$ ga verder door eigenlijk geuoon mijn oude draad op te pakken en er niet bij na te denken. Ook omdat ik ergens in mijn boofd beb geprent dat bet ecbt preventief is, dat de bestraling en de chemo eigenlijk overbodig zijin geueest. Zo'n kleine tumor, dat moet baast wel goed aflopen.'

Bijna eenvijifde is in combinatie met ZT. Er zijn beel teel mensen die bet bebben. En je kunt er oud mee worden. Dus dan zie je dat er nog bél teel boop en kans is. In feite is borstkanker een beel gunstige torm tan kanker. Dan denk ik bij mijzelf ook van: nou, kom op, je bebt een kans, niet somberen, niet bij de pakken neerzitten, uant je bebt een goede kans. En dan zijn er allemaal mensen om je been met terbalen tan mensen die bet ook bebben gebad en uaar bet nu bél goed mee gaat. Nou daar trek je je dan aan op natuurlijk.' In dit voorbeeld is ook sprake van een combinatie met $\mathrm{S}^{*+}$.

Eveneens eenvijfde van de BAG-uitspraken gaat samen met DD. Je bent best beel erg bang voor wat de toekomst zal brengen. Door deze ziekte is er een grote onzekerbetd ingeslopen, en er bangt best wel een zuvarte wolk over de toekomst. Dan ben je focb blij dat bet maar borstkanker is. Want dat is een van de allengunstige kankers. Heel teel trouven krijgen bet en nagenoeg iedereen komt er goed tumaf.' Zoals al eerder werd opgemerkt, lijkt de ene strategie het effect van de andere af te zwakken. 
Bijna even vaak gaat BAG samen met OLA: Het uas maar zo groot als een speldenprik. Je zag bet amper. Je kunt bet nauuelijks een tumor noemen, laat staan kanker. Dus bet nalt allemaal reuse mee boor. Ik bad bet dus zelf nooit kunnen ontdekken, ook al zou ik aan zelfonderzoek gedaan bebben.

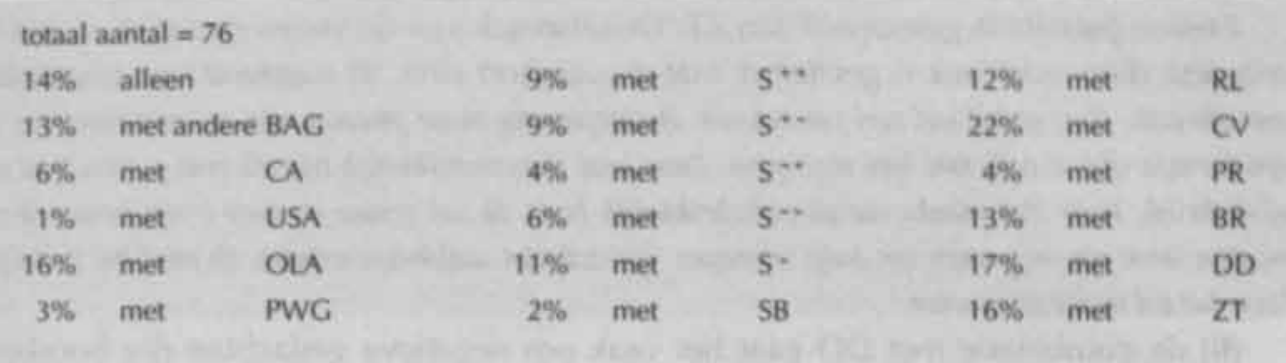

\section{- Cognitief vermijden}

Bijna eenderde van 'cognitief vermijden' komt zelfstandig voor. Bijna alle combinaties komen voor, maar de frequenties zijn laag. Uitzonderingen zijn die met ZT (15\%), DD $(13 \%)$ en BAG $(11 \%)$. Een voorbeeld van de laatste combinatie is te vinden bij bagatelliseren. Een voorbeeld van de combinatie met ZT is: Je betrapt jezelf erop dat je tocb onwillekeurig bij bet maken van plannen steeds denkt: als... Maar dan zeg ik ook tegen mijzelf: kom op, zo moet je niet denken, niet aan negatiete dingen denken! Dat poets ik dan zo gauv mogelijk uit mijn gedacbten. En eerlijk gezegd: daar weiger ik rekening mee te bouden, daar wil ik mijn leven niet door laten bebeersen.'

In deze uitspraak zit bovendien de combinatie met doemdenken. De patiënt begint met DD: Je betrapt jezelf erop dat je tocb onwillekeurig bij bet maken tan plannen steeds denkt: als... : Daarna volgt ZT: Maar dan zeg ik ook tegen mijzelf: kom op, zo moet je niet denken, niet aan negatieve dingen denkent' en CV: 'Dat poets ik dan zo gautv mogelijk uit mijn gedacbten. En eerlijk gezegd: daar weiger ik rekening mee te bouden.' Zij eindigt dan met een restje ZT: 'Daar wil ik mijn leven niet door laten bebeersen.

\begin{tabular}{|c|c|c|c|c|c|c|c|c|}
\hline \multicolumn{9}{|c|}{ totaal aantal $=168$} \\
\hline $32 \%$ & allet & & $2 \%$ & met & s* & $4 \%$ & met & RL. \\
\hline $4 \%$ & met & $\mathrm{CV}$ & $6 \%$ & met & s*- & $11 \%$ & met & BAG \\
\hline $2 \%$ & met & $\mathrm{CA}$ & $2 \%$ & met & $S^{\cdots}$ & $5 \%$ & met & PR \\
\hline $2 \%$ & met & OLA & $4 \%$ & met & $5 *$ & $8 \%$ & met & BR \\
\hline $0 \%$ & met & USA & $3 \%$ & met & 5* & $13 \%$ & met & DD \\
\hline $4 \%$ & met & PWG & $3 \%$ & met: & SB & $15 \%$ & met & ZT \\
\hline
\end{tabular}




\section{- Protesteren}

Eenderde van de protest-uitspraken komt zelfstandig voor. Daarnaast zijn er alle mogelijke combinaties met de overige strategieën. Zeventien procent gaat samen met een $\mathrm{S}^{* *}$. Meestal is er dan sprake van een dubbelstrategie. Deze relatie is eerder al beschreven bij de bespreking van deze sociale vergelijking.

Zestien procent is gekoppeld aan ZT. De uitspraak van de vrouw met een winkel in witgoed, die eerder ook is geciteerd, laat dit verband zien. 'Ik mag nooit meer zuaar tillen met die arm. Dus, er zal wel veel veranderen. Ik sleepte, zeg maar gewoon, een wasmacbine weg, of een formuis of wat ook. Dat kan niet meer. Daar baal ik verscbrikkelijk van. Ik voel me nu beel erg afbankelijk, bab!! Het maakt me zo verscbrikkelijk boos. Ik zal ermee moeten leren leven. Ik zal moeten leren om mijn man om bulp te tragen. Dat zal niet makkelijk worden, ik vind bet ureselijk. Maar bet zal tocb echt moeten.'

Bij de combinatie met DD gaat het vaak om negatieve gedachten die boosheid oproepen. 'En ik vind de dood dus ook beel bedreigend geworden. Daar ben ik wel mee bezig geueest. En ik kan bet niet aan, als je bedenkt dat je nog maar een paar jaar of zo te leven bebt. Mijn moeder is 81. Dan denk je: nou, misscbien baal ik dat wel nooit. Dat maakt je beel opstandig. Dat is zo vreselijk oneerlijk. Daar raak je van in paniek. Het is dus eigenlijk veel beter om daar maar niet over to denken, anders word je gek. Ik kan er ook niet meer tegen om overlijdensadvertenties te lezen. Dat doe ik dus maar niet meer.' In dit voorbeeld is bovendien sprake van CV. Een dergelijke combinatie komt bij ruim 10\% van het protesteren voor. Ook ruim $10 \%$ is gekoppeld aan een causale attributie en even vaak aan een schuldontlastende attributie. Het verhaal rond de oorzaak bevat regelmatig uitingen van boosheid.

Enigszins tegen de verwachting in, gaat ook ruim één op de tien protest-uitspraken samen met berusten: 'Het is allemaal zo moeilijk! Ik vind bet béel eng dat ik bet beb. Juist iemand als ik, die verder nog nooit ziek getweest is. Je gelooft bet niet, je snapt bet niet en bet maakt je zo woedend. Af en toe beb ik de neiging om alles kort en klein te slaan. Maar ja dat doe je natuurlijk niet. Je legt je er tocb maar bij neer. Wat moet je anders? Je kunt wel schelden en scbreeuwen, maar wat beeft dat voor een zin? Daar scbiet je ook niets mee op natuurlijk. Je bebt bet, en bet is nu eenmaal niet anders, en dan berust je er maar weer in. Maar dat gevoel van boosbeid, dat overvalt je regelmatig'. 
Opnieuw laat de combinatie van deze tegengestelde strategieën zien dat er bij de patiënten sprake is van ambivalentie en blijkt dat ogenschijnlijk tegenstrijdige strategieën elkaar niet uitsluiten.

\begin{tabular}{|c|c|c|c|c|c|c|c|}
\hline $33 \%$ & alleen & $1 \%$ & met & $s \cdots$ & $5 \%$ & met & Rt. \\
\hline $3 \%$ & met andere PR & $7 \%$ & met & $5 \cdots$ & $4 \%$ & met & BAG \\
\hline $1 \%$ & met & $17 \%$ & met & $S^{-t}$ & $11 \%$ & met & $\mathrm{CV}$ \\
\hline $4 \%$ & USA & $3 \%$ & met & $s^{\cdots}$ & $11 \%$ & met & $B R$. \\
\hline $11 \%$ & OLA & $5 \%$ & met & s. & $15 \%$ & met & DD \\
\hline $4 \%$ & PWG & $2 \%$ & met & SB & $16 \%$ & met & 21 \\
\hline
\end{tabular}

\section{- Berusten}

Ongeveer eenderde van het berusten komt zelfstandig voor. Ook ongeveer eenderde gaat samen met ZT. De respondent houdt zich voor dat het beter is om maar te berusten. $\mathrm{Er}$ is dan sprake van een dubbelstrategie ZT/BR. Vaak treffen we het woord moeten in een dergelijke uitspraak aan. 'Het is op mijn weg gekomen. Dus, ik moet ermee leren leven. Dat is absoluut niet makkelijk. Maar er blijft je geen keuze. Je maakt bet jezelf anders nog veel moeilijker. Ik moet me erbij neerleggen. Dat moet ik proberen.' BR gaat in ruim eentiende van de uitspraken samen met CV. De respondent berust in de situatie en wil er niet meer aan denken hoe het met haar zou kunnen aflopen. Ook één op de tien BR-uitspraken gaat gepaard met BAG en een even groot deel met DD. BR wordt dus met zeer uiteenlopende andere strategieën gecombineerd.

\begin{tabular}{|c|c|c|c|c|c|c|c|}
\hline $31 \%$ & alleen & $1 \%$ & met & $s^{\cdots}$ & $3 \%$ & met & RL. \\
\hline $7 \%$ & met andere BR & $7 \%$ & met & S* & $10 \%$ & met & BAG \\
\hline $9 \%$ & met & $2 \%$ & met & $s \cdots$ & $13 \%$ & met & $\mathrm{CV}$ \\
\hline $3 \%$ & OLA & $4 \%$ & met & $s^{*}$ & $9 \%$ & met & PR \\
\hline $0 \%$ & Usa & $6 \%$ & met & S- & $10 \%$ & met & DD \\
\hline $6 \%$ & PWG & $2 \%$ & met & SB & $34 \%$ & met & $2 T$ \\
\hline
\end{tabular}




\section{- Doemdenken}

Een kwart van doemdenken gaat niet gepaard met een andere strategie. De meeste directe samenhang is er met S - - Deze combinatie berust bijna altijd op een dubbelstrategie. Een andere veel voorkomende combinatie is met ZT: Ye voelt wel van alles, en op zicb is dat best angstig. Je vraagt je af wat er nu weer is. (DD) Maar dan denk ik ook: je krijgt zoveel medicijnen. Dus als ik dan mijn darmen voel, dan denk ik: dat is logiscb natuurlijk, dat is van de medicijnen, daar moet je je geen zorgen over maken. (ZT) En ik wil er ook niet teveel aan denken. Ik wil niet dat ik er de bele tijd mee bezig ben. Dan pak ik een boek of tijdscbrift en probeer er niet meer aan te denken.' Het voorbeeld eindigt met CV, een combinatie die bij ruim één op de tien DD-uitspraken voorkomt.

\begin{tabular}{|c|c|c|c|c|c|c|c|}
\hline $24 \%$ & alleen & $3 \%$ & met & $s^{*+}$ & $9 \%$ & met & RL \\
\hline $6 \%$ & met andere DD & $4 \%$ & met: & $s^{*-}$ & $8 \%$ & met & BAG \\
\hline $7 \%$ & met $\quad \mathrm{CA}$ & $4 \%$ & met & S*t & $12 \%$ & met & CV \\
\hline $5 \%$ & met $\mathrm{OLA}$ & $24 \%$ & met & $s^{*}$ & $6 \%$ & met & PR \\
\hline $0 \%$ & USA & $5 \%$ & met & S* & $5 \%$ & met & BR \\
\hline $2 \%$ & met PWG & $1 \%$ & met & $S B$ & $16 \%$ & met & ZT \\
\hline
\end{tabular}

\section{- Zichzelf TOESPREKEN}

Eenvijfde van 'zichzelf toespreken' komt zelfstandig voor. Voor de rest zijn er alle mogelijke combinaties met de andere strategieën. De combinaties met BR, DD en CV zijn het meest aangetroffen. Voorbeelden daarvan zijn al gegeven bij de bespreking van die strategieën.

\begin{tabular}{|c|c|c|c|c|c|c|c|c|}
\hline $21 \%$ & alleen & & $3 \%$ & met & s*t & $9 \%$ & met & $\mathrm{RL}$ \\
\hline $15 \%$ & met andere & $2 T$ & $7 \%$ & met & s*. & $8 \%$ & met & BAG \\
\hline $4 \%$ & met & CA & $3 \%$ & met & $s^{*}$ & $15 \%$ & met & $\mathrm{CV}$ \\
\hline $3 \%$ & met & OLA & $8 \%$ & met & $S^{\cdots}$ & $8 \%$ & met & PR \\
\hline $0 \%$ & met & USA & $5 \%$ & met & s * & $20 \%$ & met & BR \\
\hline $4 \%$ & met & PWG & $5 \%$ & met & SB & $19 \%$ & met & DD \\
\hline
\end{tabular}




\section{6 - 2 - Correlaties tussen de cognitieve strategieën}

Zoals vermeld is de samenhang tussen de strategieën ook uitgedrukt in Spearmancorrelaties. Deze zijn voor elk van de drie meetmomenten berekend en hebben betrekking op de frequenties waarin de strategieèn voorkomen. Daarbij is de directe koppeling tussen de strategieën losgelaten en is simpelweg geteld hoe vaak een respondent een strategie heeft gebruikt, ongeacht de plek in het interview waar dit gebeurde (index 2 zoals beschreven in paragraaf 3-1). De correlaties zijn weergegeven in tabel 4.6. Over het algemeen zijn deze niet erg hoog en bij slechts drie paren is op elk van de drie meetmomenten een redelijke correlatie gevonden. Het zijn PR met $\mathrm{S}^{-+}$ $\left(\mathrm{rho}_{1}=.51^{* *}\right.$, $\mathrm{rho}_{2}=.52^{* *}$ en $\left.\mathrm{rho}_{3}=.61^{* *}\right)$, DD met $\mathrm{S}^{\cdots}\left(\mathrm{rho}_{1}=.46^{*}, \mathrm{rho}_{2}=.40^{*}\right.$ en $\left.\mathrm{rho}_{3}=.54^{* *}\right)$ en CA met $\mathrm{S}^{\prime}\left(\mathrm{rho}_{1}=.45^{* *}, \mathrm{rho}_{2}=.39^{*}\right.$ en $\left.\mathrm{rho}_{3}=.45^{* *}\right)$. Al deze correlaties berusten gedeeltelijk op een dubbelstrategie. Ook het koppel USAS $\cdots$, waarbij in de dubbelstrategie het uitsluiten van een oorzaak samenvalt met de constatering dat men er slechter vanaf komt dan een ander, laat significante correlaties zien op $T_{1}$ en $T_{2}$ $\left(r_{h}{ }_{1}=.44^{*}\right.$ en $\left.r^{\circ} o_{2}=.52^{* *}\right)$, niet op $T_{3}$. Bij de andere koppels met dubbelstrategieèn vinden we op geen van de meetmomenten een significante correlatie.

Tussen strategieẻn die geen dubbelstrategie kennen, zijn eveneens enkele correlaties gevonden. Geen van deze koppels laat op alle drie meetmomenten een significante samenhang zien, een tweetal wel op twee meetmomenten namelijk BAG met BR ( $\mathrm{rho}_{1}=.47^{* *}$ en $\mathrm{rho}_{2}=.46^{* *}$ ) en BAG met S*- $\left(\mathrm{rho}_{1}=.38^{*}\right.$ en $\left.\mathrm{rho}_{2}=.45^{* *}\right)$. Daarnaast is er een grotere groep die slechts op één van de drie meetmomenten met elkaar samenhangt: vijf paren op T1, acht op T2 en twee op T3. Gezien het grote aantal correlaties dat is berekend, is de kans op een toevalsbevinding echter vrij groot. Alleen de combinaties CA met PWG en RL met BAG bereiken een correlatie van boven de .50 (respectievelijk $\mathrm{rho}_{2}=.60^{* *}$ en $\mathrm{rhO}_{2}=.52^{* *}$ ). Het is opvallend dat er maar twee significante negatieve correlaties zijn gevonden, die bovendien ook nog zwak zijn (DD en BAG $\mathrm{rho}_{2}=-.35^{*}$, DD en PWG $\mathrm{rho}_{3}=-.38^{*}$ ). Blijkbaar zijn er geen koppels strategieën waarbij veelvuldig gebruik van de ene samengaat met gering gebruik van de andere.

Tenslotte is het opmerkelijk dat op geen van de meetmomenten een significante samenhang bestaat tussen de strategieën relativeren (RL) en sociale vergelijking positief naar beneden ( $\mathrm{S}^{*-}$ ). Zoals uit de definities blijkt, lijken beide strategieèn erg op elkaar. Het enige verschil is dat er bij S *- sprake is van een expliciete vergelijking met een ander en bij RL juist niet. Blijkbaar worden deze strategieën niet als synoniemen door elkaar gebruikt, maar zijn het te onderscheiden strategieën die elk door andere patiënten worden gebruikt. 
- Tabel 4.6 - Samenhang tussen de cognitieve strategieën

\begin{tabular}{|c|c|c|c|c|c|c|c|c|c|c|c|c|c|c|c|c|}
\hline & CA & USA & OLA & PWG & $S^{++}$ & $s^{+\cdots}$ & $5 .+$ & $5 \cdots$ & $5=$ & SB & RL & BAG & CV & PR & BR & DD \\
\hline & & & & & & & & T1 & & & & & & & & \\
\hline USA & .19 & . & . & . & . & . & . & - & - & . & - & . & . & . & . & . \\
\hline OLA & 32 & 10 & $\therefore$ & - & 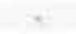 & $=$ & . & + & $=$ & . & $\cdot$ & $\cdot$ & $=$ & . & $=$ & - \\
\hline PWG & .97 & .16 & .19 & . & . & . & s. & - & - & - & . & - & - & - & - &. \\
\hline $5+4$ & 19 & .96 & 10 & -97 & 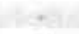 & 20 & , & - & . & 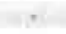 & + & rafi & - & rin & + & 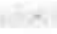 \\
\hline $5+$ & 33 & .08 & 31 & .11 & 31 & * & - & . & - & $\therefore$ &. & $=$ & - & . & . & 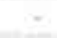 \\
\hline $5 \cdot+$ & .12 & $44^{\circ}$ & 28 & .10 & .08 & 30 & . & 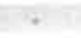 & - & . & 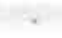 &. & : & . & . & F \\
\hline $5 \cdots$ & .18 & .16 & .25 & .05 & 04 & $39^{\circ}$ & .06 & $\Rightarrow$ & $=$ & $=$ & . & . & 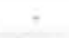 & . & . & - \\
\hline $5=$ & $A 5 * *$ & 17 & .25 & .08 & .29 & 27 & .05 & .01 & . & r. & - & - & $=$ & $=$ & , & . \\
\hline 58 & .07 & .09 & -10 & .00 & .09 & .05 & .07 & -.01 & .19 & $\therefore$ &. & . & - & . & - & . \\
\hline RL & .02 & .21 & .17 & .08 & $.43^{\circ}$ & .12 & .07 & .03 & .11 & .09 & . & . & $=$ & . . & - & . \\
\hline$B A G$ & 26 & .24 & 27 & .12 & .16 & $38^{\circ}$ & .25 & 28 & 17 & 27 & .19 & . & $=$ & $\therefore$ & $=$ & $=$ \\
\hline $\mathrm{CV}$ & .06 & 10 & .13 & .09 & .24 & 33 & .29 & .01 & 12 & .09 & .06 & $A 1^{\circ}$ & 6 & $=$ & . & . \\
\hline PR & .03 & .16 & .20 & .01 & .07 & .24 & $.51 *$ & .07 & .01 & .02 & -13 & -02 & .22 & . & . & . \\
\hline BR & .01 & .00 & .12 & .10 & .08 & .06 & .07 & 22 & .06 & .09 & .16 & $47^{* \prime}$ & .08 & .25 & . & - \\
\hline DD & .03 & .24 & .21 & .10 & .17 & .20 & .27 & $46^{\circ *}$ & .04 & -30 & .01 &. .14 & .09 & $47^{\prime \prime}$ & .16 & . \\
\hline \multirow[t]{2}{*}{$\pi$} & .26 & $\sqrt{13}$ & .28 & .02 & .27 & 32 & .20 & .18 & .13 & .13 & .15 & .12 & .25 & 21 & 31 & .16 \\
\hline & & & & & & & & $\mathrm{T} 2$ & & & & & & & & \\
\hline USA & 13 & . &. & 4 &. & . & . & . & - & . & . & - & - & . & . & - \\
\hline OLA & $40^{\circ}$ & .10 &. & . & - & 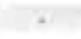 & $\cdot$ & $\cdot$ & . & $=$ & $=$ & . & . & . & . &. \\
\hline PWG & $.60^{* *}$ & .00 & .05 & . & $=$ & . & . & - & - & - & . & . & - & . & . & . \\
\hline $5+t$ & .06 & 11 & .24 & .06 & . & . & , & - & . & . & 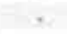 & - & - & - & . & . \\
\hline 5,4 & -06 & $28^{\circ}$ & $x, 07^{*}$ & $.17^{*}$ & $18^{-}$ & . & . &. & - & - & 2 & $=$ & - & $=$ &. & - \\
\hline $5 .+$ & .05 & $52 *$ & .20 & .19 & +12 & 10 & 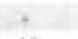 & + & . & . & . & - & ? & . & $=$ & . \\
\hline s.. & .14 & .25 & .11 & .24 & -10 & .28 & 10 & . & - & - & . & 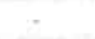 & $=$ & & $=$ & $=$ \\
\hline $5=$ & $39^{\circ}$ & .23 & .10 & .17 & .09 & .15 & .20 & -04 & " & $\cdots$ & - & . & $=$ & . & - & $\cdot$ \\
\hline SB & .20 &, 05 & .08 & 04 & .15 & .14 & .09 & .21 & 24 & - & . & . & - & . & - & $\ldots$ \\
\hline RL & .08 & .20 & .00 & .10 & .04 & .26 & .03 & .22 & $36^{\circ}$ & 22 & $\therefore$ & . & $=$ & . & . & - \\
\hline BAG & 18 & .29 & .29 & .15 & .05 & $.45 *$ & .18 & .22 & .33 & .24 & $.40^{\circ}$ & - & - & . & $=$ & . \\
\hline $\mathrm{CV}$ & .06 & .05 &, 06 & .12 & .01 & $=06$ & .08 & $=$ & .07 & .19 & .26 & .03 & - & . & - & $=$ \\
\hline PR & .06 & 13 & $15^{\circ}$ & -18 & -04 & 02 & $52^{\circ}$ & $\Leftrightarrow$ & .04 & 0 & -.06 & .16 & 15 & . & " & - \\
\hline$B R$ & .04 & .11 & 02 & .24 & .12 & .32 & .09 & .18 & .24 & 16 & $36^{\circ}$ & $46 * 0$ & .02 &. .14 & - & I. \\
\hline DD & 12 & 25 & .09 & -14 & .10 & .11 & 14 & $.40^{\circ}$ & 19 & .17 & -.23 & $35^{*}$ & 19 & .10 & .04 & i. \\
\hline \multirow[t]{2}{*}{$z$} & 10 & $40^{\circ}$ & .13 & .06 & -.00 & .22 & .27 & .19 & .23 & .09 & .14 & .13 & 33 & .33 & .18 & 33 \\
\hline & & & & & & & & $\mathrm{T} 3$ & & & & & & & & \\
\hline USA & 03 & & . &. & - & - & . & . & - & . & . & - & . & . & . & . \\
\hline OLA & .18 & .10 & - & . & . & $\%$ & , & . & . & * & * & , & - & $n$ & . & $\pi$ \\
\hline PWG & 10 & .15 & 18 & z & $v$ & $=$ & - & - & - & - & $\therefore$ & - & . & . & - & . \\
\hline $\mathrm{St+}^{++}$ &., 25 & .00 & .16 & 513 & i. & . & $=$ & . & . & $\approx$ & . & - & + & . & - & $\Rightarrow$ \\
\hline $5+\cdots$ & .09 & 04 & -.04 & .23 & -.11 & & - & & - & - & - & . & . & . & - & . \\
\hline $50+$ & 23 & .29 & .10 & .00 & .04 & .04 & $=$ & $=$ & . & $=$ & $a$ & $=$ & $*$ & $=$ & - & $=$ \\
\hline $5 \%$ & .27 & 31 & .09 & .08 & $-2,13$ & .04 & .27 & . & . & . & . & . & - & . & . & . \\
\hline $5=$ & $.45=$ & .02 & .24 & .25 & $\sqrt{10}$ & .21 & .01 & .08 & . &. & + & - & + & . & * & . \\
\hline 58 & .02 & .08 & .03 & .16 & 32 & .09 & -18 &, 18 & -10 & 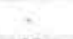 & . & - & - & - & - & - \\
\hline RL & .02 & .04 & .05 & .22 & .05 & .20 & $\$ .05$ & .06 & .05 & .19 & : & - & . & $=$ & - & $=$ \\
\hline BAG & -.03 & -.10 & .17 & .14 & .13 & .24 & -12 & -13 & .08 & .10 & .22 & . & $\therefore$ & . & $=$ & . \\
\hline CV & .06 & 417 & 20 &, 05 & 418 & .01 & .07 & $\$ .04$ & .03 &., 17 & -.04 & 07 & . &. & . & . \\
\hline PR & -03 & 31 & 27 & $\sqrt{13}$ & .00 & .11 & $.61^{*}$ & 10 & .20 & 2.03 &, 00 & .13 & .12 & . & . & - \\
\hline BR &, 03 & .04 & -.02 & .13 & .05 & 29 & $\rightarrow 19$ & -.07 & .25 & 17 & .13 & .10 & .10 & .06 & - & $=$ \\
\hline DD & .27 & .05 & 11 & $38^{4}$ & .11 & .27 & 33 & $54 *$ & 10 & .10 & .09 & .26 & .17 & 34 & -11 & $\therefore$ \\
\hline $2 \pi$ & 22 & .05 & .17 & 21 & .08 & .13 & .22 & .18 & 23 & .06 & .21 & .23 & 30 & 27 & 29 & 32 \\
\hline
\end{tabular}

Spearman-correlaties per meetmoment, gebaseerd op de frequentie waarin de strategieèn voorkomen ("ps.01 "-ps.001). 
Uit het eerste deel van deze paragraaf is gebleken dat cognitieve strategieein vaak in reeksen voorkomen. Van de zeventien komen er zes nauwelijks zelfstandig voor, te weten: $S^{* *}(4 \%)$, USA $(5 \%), S^{\cdots}(5 \%), S=(7 \%), S^{*}(8 \%)$ en CA $(9 \%)$. Elf strategieèn blijken regelmatig in hetzelfde antwoord meer dan één keer voor te komen. Dit zijn dan geen herhalingen van dezelfde uitspraak. Het betreft steeds eenzelfde strategie die zich op verschillende onderwerpen richt. Dit komt vooral voor bij causale attributies, wanneer er verschillende oorzaken worden opgesomd. Ook bij de strategieën zichzelf toespreken en bagatelliseren is dit verschijnsel relatief vaak aangetroffen.

Uit het tweede deel kan worden geconcludeerd dat ondanks deze directe koppelingen er niet veel robuuste en consistente correlaties zijn. Dit duidt erop dat hoewel strategieën in reeksen voorkomen er toch vaak wisselende combinaties worden gemaakt. Maar er is ook nog sprake van een ander fenomeen. Zo gaat bijvoorbeeld op $T, 82 \%$ van de uitsluitende attributies (USA) samen met een causale attributie (CA). Toch is hun onderlinge correlatie erg laag $\left(r h_{1}=19\right)$. Dit komt omdat er veel minder USA's worden gebruikt dan CA's, slechts $11 \%$ van de CA's heeft een directe koppeling met een USA. Dus de meeste USA's gaan wel samen met CA's maar lang niet alle CA's gaan samen met een USA. Dit laatse heeft negatieve gevolgen voor de onderlinge correlatie.

Niet alle significante correlaties berusten erop dat de betreffende strategieën in directe relatie tot elkaar worden gebruikt. Bijvoorbeeld op $T_{1}$ gaat slechts $6 \%$ van DD direct samen met $P R$, terwijl er toch een substantiële correlatie tussen beide strategieën is (rho ${ }_{1}=.47^{* *}$ ). Met andere woorden patiënten die protesteren blijken ook relatief veel te doemdenken en andersom. Echter ze doen dit op verschillende plekken in het interview, naar aanleiding van verschillende onderwerpen.

Tenslotte blijkt uit beide delen van deze paragraaf dat er bij patiënten vaak sprake is van ambivalentie. Deze komt tot uitdrukking in het regelmatig samengaan van ogenschijnlijk tegenstrijdige strategieën. 


\section{7 - StrategiegebruIK DOOR VERSCHILLENDE SUBGROEPEN RESPONDENTEN}

Van de volgende vijf demografische en medische variabelen is nagegaan of deze van invloed zijn op het strategiegebruik of de mate van aanpassing aan de ziekte:

- ernst van de ziekte

- aard van de behandeling

- leeftijd

- opleiding

- verloop van de ziekte

De invloed van deze variabelen op aanpassing komt in hoofdstuk $\mathrm{V}$ aan de orde. Over de invloed op het strategiegebruik wordt hier verslag gedaan.

Voor elk van de meetmomenten is onderzocht of de volgens de genoemde variabelen onderscheiden subgroepen verschillen in het percentage respondenten dat een strategie gebruikt (index 1), of dat er verschillen zijn in de gemiddelde frequentie van het strategiegebruik (index 2). De percentageverschillen zijn met de $\mathrm{X}^{2}$-toets op significantie onderzocht; de verschillen in frequentie met de Mann-Whitney-toets. Een volledig overzicht van de resultaten is te vinden in de tabellen 4.7 tot en met 4.12. Deze tabellen zijn opgenomen in bijlage $C_{\text {; }}$ de significante bevindingen worden hieronder besproken.

\section{Ernst van de ziekte (tabel 4.7)}

De ernst van de ziekte blijkt uit de stagering. Daarbij is het met name van belang of er kankercellen in de lymfeklieren van de nabijgelegen oksel zijn aangetroffen. In dat geval spreekt men van positieve okselklieren en is het vooruitzicht minder gunstig. De onderzoeksgroep is gesplitst in patiènten met positieve okselklieren $(n=33)$ en die met negatieve okselklieren $(n=13)$.

Het percentage respondenten dat op $T_{1}$ een positieve wending aan de ziekte geeft (PWG) of berust (BR), is significant hoger onder patiënten met positieve klieren. Bovendien is de gemiddelde frequentie waarin wordt berust (index 2) bij hen significant hoger. De frequentie waarin patiënten zich op $T_{1}$ gelijkwaardig vergelijken $(S=)$ is juist hoger voor patiënten met negatieve klieren. Op de andere meetmomenten is voor geen enkele strategie een significant verschil gevonden, noch in het percentage patiënten dat de strategie gebruikt, noch in de gemiddelde frequentie van het gebruik.

De invloed van de ernst van de ziekte op het strategiegebruik is dus niet erg groot. 


\section{Behandeling (tabel 4.8 en 4.9)}

In hoofdstuk II is beschreven welke behandelingsmodaliteiten in de respondentengroep te onderscheiden zijn. Sommige patiènten hebben alleen chirurgie en radiotherapie ondergaan $(n=13)$. De patiènten met positieve okselklieren kregen ook nog chemotherapie $(n=23)$ of hormoontherapie $(n=10)$. Chemotherapie is over het algemeen ziekmakend. Bovendien heeft het een zeer negatieve klank en staat als het ware symbool voor de verschrikkingen van kanker. $\mathrm{Bij}$ hormoontherapie is dat niet het geval. De bijwerkingen zijn over het algemeen milder, hoewel patiënten soms vervroegd in de menopauze geraken. De hormoontabletten moeten echter wel gedurende twee jaar dagelijks worden ingenomen, waardoor de patiënt nog lang met de ziekte wordt geconfronteerd.

Onderzocht is of er verschillen zijn in gebruik van strategieèn tussen patiènten die wel en die niet zijn behandeld met chemotherapie $(n=23$ versus $n=23$ ) en ook of er verschillen zijn tussen patiënten behandeld met chemotherapie $(n=23)$ en patiènten behandeld met hormoontherapie $(n=10)$.

Gebleken is dat de aard van de behandeling invloed heeft op het strategiegebruik. Zo is er op $T_{3}$ significant meer protest (PR) in de groep die is behandeld met chemotherapie dan bij de andere patiënten. Dit betreft zowel index 1 als index 2 . Wordt de groep met chemotherapie vergeleken met patiënten die een hormoonkuur ondergingen, dan is het percentage patiënten met protest zelfs op alle drie de meetmomenten hoger. Op $T_{1}$ komt dit ook tot uitdrukking in een significant hogere gemiddelde frequentie van het gebruik van deze strategie.

Bovendien blijkt dat patiënten behandeld met chemotherapie minder gebruik maken van de sociale vergelijking gelijkwaardig. Op $T_{1}$ geldt dit voor zowel het percentage respondenten dat de strategie gebruikt alsook voor de frequentie waarmee zij dit doen. Beide indices zijn significant lager dan bij de overige patiènten. Op $T_{2}$ is dat nog steeds het geval voor het percentage patiènten met S ". Blijkbaar komen patiënten die met chemotherapie worden behandeld, in de vergelijken met anderen minder gemakkelijk tot de conclusie dat zij niet van die ander verschillen.

\section{Leeftijd (tabel 4.10)}

De onderzoeksgroep is gesplitst in een groep met patiënten in de leeftijd van 29 tot en met 47 jaar $(n=24)$ en een met patiënten van 48 tot en met 60 jaar $(n=22)$. De ouderen maken in het algemeen meer gebruik van cognitieve strategieèn dan de jongeren. Zo zijn er op $T_{1}$ en $T_{2}$ niet alleen meer ouderen die berusten (index 1), maar van diegenen die berusten gebruiken de ouderen deze strategie ook vaker dan de jongeren (index 2). Op $\mathrm{T}_{2}$ en $\mathrm{T}_{3}$ geldt hetzelfde voor de uitsluitende attributies. Ook gebruiken ouderen de verschillende sociale vergelijkingen meer. Op verschillende 
meetmomenten zijn er significante verschillen in ofwel index 1, ofwel index 2, ofwel in beide. Voorts is op $T_{3}$ de mate waarin ouderen doemdenken (DD) groter. Tenslotte is ook de mate waarin zij schuldontlastende attributies (OLA) gebruiken zowel op $T_{1}$ en $\mathrm{T}_{3}$ groter. Op $\mathrm{T}_{3}$ ligt bovendien het percentage ouderen dat deze strategie gebruikt hoger.

De enige strategie die bij meer jongeren is aangetroffen is 'een positieve wending geven aan de ziekte', en dan nog alleen maar op $\mathrm{T}_{2}$.

\section{Opleiding (tabel 4.11)}

Onderscheid is gemaakt in een groep tot en met het niveau van middelbaar beroepsonderwijs $(n=31)$ en een groep die daarboven zit $(n=15)$. Het blijkt dat opleiding niet veel invloed heeft op strategiegebruik. Wel bedienen meer hoger opgeleiden zich op $\mathrm{T}_{1}$ van ontlastende attributies (index 1), en ligt de gemiddelde frequentie van het gebruik van OLA in deze groep (index 2) hoger op zowel $T_{1}$ als $T_{2}$. Op $\mathrm{T}_{2}$ zijn er meer lager opgeleiden die relativeren en op $\mathrm{T}_{3}$ zijn er onder hen meer respondenten die causale attributies (CA) noemen.

\section{Verloop van de ziekte (tabel 4.12)}

Als laatste is onderzocht of een hernieuwde confrontatie met kanker door een metastase of recidief het strategiegebruik beïnvloedt. Op $\mathrm{T}_{3}$ waren zes respondenten opnieuw met de ziekte geconfronteerd, de andere veertig waren op dat moment ziektevrij. Het strategiegebruik verschilt niet zoveel. Relatief gezien zijn er onder die zes minder respondenten die ontlastende attributies noemen. Ook is de gemiddelde frequentie waarin ze zich een bijzondere patiënt noemen, de ziekte relativeren of zichzelf toespreken hoger.

De subgroepen blijken niet veel van elkaar te verschillen in hun strategiegebruik.

Chemotherapie-patiënten protesteren significant meer en vergelijken zich minder vaak gelijkwaardig dan de anderen. Daarnaast is gebleken dat wanneer de ouderen een bepaalde strategie gebruiken, de frequentie waarmee ze dat doen over het algemeen hoger is dan bij de jongeren. Dit geldt voor alle strategieën met uitzondering van 'een positieve wending geven'. Tenslotte bedienen de hoger opgeleiden zich wat meer van ontlastende attributies. Met andere woorden de behandeling en de leeftijd hebben enige invloed op het strategiegebruik.

Ernst en verloop van de ziekte zijn in deze onderzoeksgroep nauwelijks van invloed gebleken op het strategiegebruik. Wat dit laatste betreft, is echter wel enige voorzichtigheid geboden. Door het geringe aantal patiënten met een recidief of 
metastasen $(n=6)$ en door het feit dat er over deze subgroep alleen op $T_{3}$ gegevens zijn, kunnen er geen harde conclusies worden getrokken.

\section{8 - Samenvatting en conclusies}

Uit de interviews met borstkankerpatiënten blijkt dat zij bij het verwerken van hun ziekte en de gevolgen daarvan een scala aan cognitieve strategieèn gebruiken: gemiddeld, afhankelijk van het meetmoment, tussen de negen en elf verschillende strategieèn. Causale attributies, cognitief vermijden, zichzelf toespreken en doemdenken komen het meest voor; de sociale vergelijkingen positief naar boven, negatief naar beneden, negatief naar boven en zich bijzonder vinden, evenals de uitsluitende attributies het minst. Ogenschijnlijk tegenstrijdige strategieën worden vaak in combinatie met elkaar gebruikt. Hienuit blijkt dat bij veel patiènten sprake is van ambivalentie over hun ziekte en de gevolgen ervan.

De sociale vergelijkingen worden vooral vlak na de diagnose gebruikt: bij vier van de zes treedt tussen $T_{1}$ en $T_{3}$ een significante daling op. Ook de frequentie waarin patiënten met schuldontlastende attributies antwoorden, daalt significant, evenals het aantal personen dat een positieve wending aan de ziekte geeft. Echter, de patiénten die deze laatste strategie blijven gebruiken, doen dit wel in toenemende mate: de gemiddelde frequentie van PWG neemt niet af. Opvallend is dat het percentage patiënten dat berust niet toeneemt en dat de gemiddelde frequentie waarin de patiënten berusten zelfs significant daalt. Ook blijven zowel het percentage patiënten dat protesteert, cognitief vermijdt, zichzelf toespreekt en bagatelliseert onverminderd hoog, evenals de frequentie waarin dit gebeurt. De frequentie waarin patiènten doemdenken en zichzelf negatief naar beneden vergelijken, stijgt zelfs iets, zij het niet significant. Dit alles wijst erop dat in de loop van de eerste twee jaar na de diagnose in de in de totale groep van patiënten niet zo heel veel verandert wat hun strategiegebruik betreft. Toch is het strategiegebruik van de individuele patiènt gedurende de onderzoeksperiode lang niet altijd stabiel. De test-hertest-correlaties varièren over het algemeen van zeer laag tot middelmatig. Dit wijst erop dat een groot deel van de cognitieve strategieën situationeel wordt ingezet, de sociale vergelijkingen nog het meest Een uitzondering vormen de strategieén protesteren, bagatelliseren en doemdenken. Patiënten die deze strategieën aan het begin direct na diagnose gebruiken, hebben de neiging dit te blijven doen. Deze strategieèn zijn het meest stabiel. 
Cognitieve strategieën komen vaak in reeksen voor, ongeveer eenderde treffen we zelfs nauwelijks zelfstandig aan. Desondanks zijn er niet veel robuuste en consistente correlaties gevonden tussen de strategieèn. Blijkbaar worden steeds wisselende combinaties gemaakt. De lage test-hertest correlaties wijzen eveneens in deze richting. $\mathrm{Er}$ is nog een andere verklaring voor de lage onderlinge correlaties. Regelmatig zijn er combinaties van een strategie die weinig voorkomt met een strategie die veel frequenter wordt gebruikt, bijvoorbeeld USA en CA. Verreweg de meeste USA's gaan samen met een CA. Op grond hiervan zou men een hoge correlatie verwachten. Maar omdat er veel meer CA's voorkomen gaat een groot deel van de CA's niet met een USA samen, waardoor de onderlinge correlatie veel lager uitvalt.

Er zijn niet veel verschillen gevonden in het strategiegebruik van de onderscheiden subgroepen patiënten. De behandeling en de leeftijd hebben enige invloed: chemotherapie-patiënten protesteren significant meer en vergelijken zich minder vaak gelijkwaardig dan de anderen. Daarnaast is gebleken dat wanneer de ouderen een bepaalde strategie gebruiken, de frequentie waarmee ze dat doen over het algemeen hoger is dan bij de jongeren. Dit geldt voor alle strategieën met uitzondering van 'een positieve wending geven'. Tenslotte bedienen de hoger opgeleiden zich wat meer van ontlastende attributies. De ernst van de ziekte is in deze onderzoeksgroep nauwelijks van invloed gebleken op het strategiegebruik. 


\section{AANPASSING AAN BORSTKANKER}

\section{1 - OpERATIONALSERING VAN AANPASSING}

Voor de operationalisering van aanpassing aan borstkanker is van de volgende indicatoren uitgegaan (zie hoofdstuk II paragraaf 2-3-3);

- toekomstperspectief

- gevoel van controle

- zelfbeeld

- schaamte

Een patiënt zou zich aan haar ziekte hebben aangepast als zij zich, ondanks de dreiging en de onzekerheid die van borstkanker uitgaan, toch een zinvol toekomstperspectief weet te scheppen, enig gevoel van controle over haar leven ervaart, een positief zelfbeeld heeft en niet gebukt gaat onder schaamte voor de ziekte. De interviews bevatten open vragen die een beeld geven van de aanpassing ten aanzien van de genoemde indicatoren. Kwantitatieve gegevens zijn verkregen met Visueel Analoge Schalen (VAS) die steeds gekoppeld waren aan deze vragen. Daarop kon de patiènt aangeven hoe groot de invloed van de ziekte was. Bij een groot aantal vragen volgde een tweede VAS, waarmee is gevraagd naar de waardering van hetgeen daarvóor geantwoord was. Immers, niet altijd is de verandering op zich, maar de beleving of waardering ervan, een afspiegeling van aanpassing aan de ziekte. Met andere woorden, hoe gaat de patiënt ermee om en welke plaats heeft de ziekte in haar leven? Hoe de VAS-sen in het interview waren ingebed, evenals de beschrijving van het apparaat waarmee de gegevens zijn verkregen, staat in paragraaf 2-3-2 van hoofdstuk II beschreven.

Elke VAS heeft een lengte van tien centimeter. Wanneer de respondent de schuif van het VAS-apparaat tussen 0 en $1 \mathrm{~cm}$ plaatste, werd daaraan de score 0 toegekend; tussen 1 en $2 \mathrm{~cm}$ de waarde 1, en zo verder. Op die manier leverde de VAS een tienpuntsschaal op met waarden van 0 tot en met 9.

Met het oog op de noodzakelijke datareductie is onderzocht of de scores van verschillende VAS-sen op een zinvolle manier kunnen worden opgeteld. Daartoe zijn logische groeperingen gemaakt. Deze zijn opgevat als apriori-schalen voor de indicatoren van aanpassing. Om na te gaan of deze items inderdaad de veronderstelde samenhang vertonen, zijn verschillende exploratieve methoden zoals factoranalyse en betrouwbaarheidsberekeningen uitgevoerd. Daarbij bleken de VAS-sen die in de apriori-schalen voor toekomstperspectief en controle waren opgenomen, zich over drie groepen te verdelen, met als gemeenschappelijke noemers toekomstperspectief, angst 
en eigen invloed. Dit heeft er toe geleid dat de indicator controle is vervangen door eigen invloed, en angst als vijfde indicator is toegevoegd.

\section{UITEINDELIJKE INDICATOREN VOOR AANPASSING}

\section{TOEKOMSTPERSPECTIEF}

ANGST

EIGEN INVLOED

ZELFBEELD

SCHAAMTE.

Slechts voor drie van de vijf indicatoren is een betrouwbare schaal gevonden. Het criterium was een gemiddelde Chronbach's alfa van .70 of meer. De alfa-coëfficiënten staan in tabel 5.1 aan het eind van deze paragraaf.

Hieronder is beschreven hoe de schalen zijn samengesteld. De VAS-sen die in een schaal zijn opgenomen zijn cursief weergegeven. Waar nodig zijn de vragen vermeld die aan de VAS voorafgingen. Daar waar geen betrouwbare schaal is ontstaan, is aangegeven met welke losse VAS-sen de betreffende indicator is gemeten. Ook deze zijn cursief afgedrukt.

\section{- TOEKOMSTPERSPECTIEF}

Voor de indicator toekomstperspectief is een betrouwbare schaal gevonden. Deze bestaat uit de volgende twee VAS-sen:

- Toekomst..., wat roept dat woord nu bij u op? In welke mate is er door de ziekte iets veranderd?

Wat vindt u daarvan? dat vind ik beel erg _ dat vind ik belemaal niet eng

- Hoe ziet u uw toekomst? beel optimistiscb — beel pessimistiscb

\section{- ANGST}

Ook voor de indicator angst is een betrouwbare schaal gevonden. Deze bestaat uit de volgende vier VAS-sen:

- Denkt u dat u bent genezen? Kunt $\mathrm{u}$ aangeven hoe zeker $\mathrm{u}$ daar over bent? $i k$ ben er zeker ran dat ik ben genezen __ ik ben er zeker tan dat ik niet ben genezen 
- Als u nu ergens in uw lichaam iets voelt, reageert $u$ dan anders dan voordat $u$ ziek werd?

Bent $\mathrm{u}$ dan angstiger?

ik ben erg veel angstiger —_ ik ben belemaal niet angstiger

- In hoeverre beheerst de ziekte uw leven?

volledig _ belemaal niet

- Denkt u wel eens aan een minder gunstige afloop?

Is dat een angstig idee?

beel beangstigend — belemaal niet beangstigend

\section{- EIGEN INVLOED}

De drie VAS-sen bedoeld om een schaal te vormen voor de indicator eigen invloed bleken onvoldoende met elkaar samen te hangen. Besloten is ze op te vatten als afzonderlijke items, die elk een verschillend terrein beschrijven waarop een patiènt invloed op haar ziekte of situatie ervaart.

- Denkt u dat u op enigerlei wijze iets kunt doen om te voorkomen dat de ziekte terugkomt?

Kunt $\mathrm{u}$ aangeven in welke mate $\mathrm{u}$ invloed denkt te hebben? $i k$ beb beel veel invloed _ $i k$ beb belemaal geen invloed

- Heeft u verandering aangebracht in uw leefgewoonten?

Kunt $\mathrm{u}$ aangeven in welke mate $\mathrm{u}$ daarmee invloed denkt te hebben op het verloop van uw ziekte?

$i k$ beb beel veel invloed _ $i k$ beb belemaal geen invloed

- In hoeverre vindt u dat u uw toekomst zelf kunt beïnvloeden?

$i k$ beb zelf beel veel invloed op mijn toekomst _— ik beb zelf absoluut geen invloed op mijn toekomst

\section{- Zelfbeeld}

Zelfbeeld is de derde indicator waarvoor een betrouwbare schaal gevonden is. Deze bestaat uit de volgende vijf VAS-sen:

- Kunt u weer alles doen wat u voor de ziekte en behandeling kon? Wat vindt u daarvan? daar ben ik beel eng tevreden over __ daar ben ik beel eng ontevreden over

- Vindt u dat $\mathrm{u}$ bent veranderd door wat $\mathrm{u}$ heeft meegemaakt? Kunt $u$ aangeven in hoeverre $u$ bent veranderd?

Wat vindt u daarvan? daar ben ik beel eng tevreden over ___ daar ben ik beel eng ontevreden over 
- Kijkt u nu anders tegen uw lichaam aan ten gevolge van de ziekte en de behandeling?

Kunt $u$ aangeven in hoeverre dat is veranderd?

Wat vindt u daarvan?

dat vind ik beel positief __ dat vind ik beel negatief

- Sommige mensen zeggen wel eens: 'Het is net of die borst niet meer van mij is.' Denkt $\mathrm{u}$ iets dergelijks ook wel eens?

dat denk ik dikwijls _ dat denk ik nooit

- Alles bij elkaar genomen, in hoeverre voelt u zich door de operatie en de behandeling beschadigd?

beel erg — belemaal niet

\section{- SchaAmte}

De VAS-sen die bedoeld waren voor de indicator schaamte bleken eveneens geen betrouwbare schaal op te leveren. Ze worden daarom als twee afzonderlijke items opgevat.

- Er zijn mensen die zeggen: 'Diep in mijn hart schaam ik me er wel eens voor dat ik deze ziekte heb.' Heeft u dat wel eens?

dat beb ik nooit — dat beb ik vaak

- Er zijn mensen die zeggen: 'Ik praat er liever niet met anderen over, omdat ik bang ben dat ze me met andere ogen zullen bekijken.' Heeft u dat wel eens? dat beb ik tuak — dat beb ik nooit

- Tabel $5.1 \alpha$-Coefficiènten van de onderzochte aanpassingschalen

\begin{tabular}{|c|c|c|c|}
\hline Indicator & $\alpha \mathrm{TH}$ & $\alpha \mathrm{T} 2$ & $\alpha{ }_{3}$ \\
\hline Toekomsperspectief : & .61 & .76 & .79 \\
\hline Angs: & 73 & $\pi$ & $\pi$ \\
\hline Eigen invloed & 53 & 27 & 42 \\
\hline Zelibeeld & 74 & .73 & $n$ \\
\hline Schaamte & .23 & .66 & .65 \\
\hline
\end{tabular}

De betrouwbare schalen zijn aangegeven met *

Er zijn betrouwbare schalen gevonden voor drie van de vijf indicatoren van aanpassing. Het betreft toekomstperspectief, angst en zelfbeeld. De items van de indicatoren eigen invloed en schaamte blijken onvoldoende samen te hangen om een schaal te vormen. Derhalve zullen deze indicatoren op basis van enkele losse items in kaart worden gebracht. 


\section{2 - DE DRIE AANPASSINGSCHALEN}

\section{2-1 - Samenhang tussen de schalen}

Met behulp van Spearman-correlaties is de onderlinge samenhang tussen de drie schalen onderzocht.

- Tabel 5.2 - Samenhang tussen de schalen

\begin{tabular}{|c|c|c|c|c|c|c|c|c|c|c|}
\hline \multirow{2}{*}{$\begin{array}{l}n=46 \\
\text { Schaal }\end{array}$} & & \multicolumn{3}{|c|}{ Toekomstperspectief } & \multicolumn{3}{|c|}{ Angst } & \multicolumn{3}{|c|}{ Zelfibeid } \\
\hline & & $\pi$ & $\mathrm{T} 2$ & T3 & $\pi$ & 12 & I3 & II & $\mathbf{1 2}$ & 13 \\
\hline \multirow[t]{3}{*}{ Toriumiperyectied } & $n$ & & & & $75 *$ & $51^{*}$ & 28 & $57 * 4$ & 14 & .25 \\
\hline & $\mathbf{n}$ & & & & $\because$ & $59 \%$ & $35^{\circ}$ & . & 30 & .26 \\
\hline & $\mathbf{B}$ & & & & & . & $30 \%$ & $*$ & $*$ & $34^{\circ}$ \\
\hline \multirow[t]{3}{*}{ Angt } & $\mathbf{n}$ & $75 *$ & $33^{* *}$ & $53^{* 4}$ & & . & & site & 28 & $.35^{\circ}$ \\
\hline & 12 & : & $59 * 0$ & $44^{*}$ & & & & * & 34 & .26 \\
\hline & T3 & 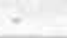 & - & $30^{* 4}$ & & & & * & - & 27 \\
\hline \multirow[t]{3}{*}{ Zelloetd } & $n$ & $57^{* 4}$ & .27 & 29 & $.51 *$ & 13 & .10 & & & \\
\hline & $\mathbf{1 2}$ & . & 30 & 28 & z & 34 & .19 & 1 & & \\
\hline & $\mathbf{T}$ & - & $=$ & $39^{*}$ & - & $\therefore$ & .27 & & & \\
\hline
\end{tabular}

Weergegeven zijn correlaties volgens Spearman (*p $\leq .01 \quad * p \leq .001)$.

Uit de correlaties blijkt dat toekomstperspectief, angst en zelfbeeld als afzonderlijke indicatoren kunnen worden opgevat, maar ze zijn niet onafhankelijk van elkaar. Op T, is de onderlinge samenhang tussen de drie schalen het sterkst. Later neemt deze af. Vooral die tussen angst en toekomstperspectief is substantieel $\left(\mathrm{rho}_{1}=.75, \mathrm{rho}_{2}=.59 \mathrm{en}\right.$ $\mathrm{rho}_{3}=.50$ ). De correlaties met zelfbeeld zijn op $T_{1}$ nog noemenswaardig (angstzelfbeeld $r_{h} o_{1}=.51$, toekomstperspectief-zelfbeeld $r_{1} o_{1}=.57$ ) maar worden vanaf $T_{2}$ verwaarloosbaar klein. 


\section{2 - 2 - Het verloop van de aanpassing}

Voor elk van de drie aanpassingschalen is de gemiddelde score van de groep met de standaarddeviatie berekend, evenals het percentage respondenten dat hoog of laag scoort op de schaal. Dit is weergegeven in tabel 5.3. Hoog-scoorders scoren op of boven het theoretisch middelpunt, laag-scoorders eronder. Een hogere score op de aanpassingsschaal voor angst betekent meer aanpassing, dus minder angst.

- Tabel 5.3 - Aanpassing op de drie schalen

\begin{tabular}{|c|c|c|c|c|c|c|c|c|c|c|c|c|c|}
\hline \multirow{2}{*}{$\begin{array}{l}n=46 \\
\text { Schaal }\end{array}$} & \multirow{2}{*}{$\begin{array}{l}\text { Theoretisch } \\
\text { maximum } \\
\text { van de schaal }\end{array}$} & \multicolumn{3}{|c|}{$\begin{array}{l}\text { Cemiddeide } \\
\text { score }\end{array}$} & \multicolumn{3}{|c|}{$\begin{array}{l}\text { Standaard- } \\
\text { deviatie }\end{array}$} & \multicolumn{3}{|c|}{$\begin{array}{l}\text { Percentage } \\
\text { laag-scoorders }\end{array}$} & \multicolumn{3}{|c|}{$\begin{array}{c}\text { Percentage } \\
\text { hoog-scoorders }\end{array}$} \\
\hline & & II & 12 & $\mathrm{~B}$ & $\mathrm{TI}$ & $\mathrm{r} 2$ & T3 & $\mathrm{rt}$ & $\mathrm{T} 2$ & 13 & $\mathrm{TI}$ & $\mathrm{n} 2$ & $\mathrm{~T} 3$ \\
\hline Tockomstperspectief & 18 & 12.4 & 13.0 & 12.0 & 5.2 & 5.0 & 5.5 & 24 & 15 & 28 & & 85 & 72 \\
\hline Angu & 36 & 19.5 & 20.5 & 20.2 & 9.8 & 10.0 & 9.7 & 46 & 37 & 44 & 54 & 63 & 56 \\
\hline Zelibeeld & 45 & 33.3 & 33.6 & 34.0 & 10.3 & 10.5 & 10.6 & 13 & 13 & 15 & 87 & 87 & 85 \\
\hline
\end{tabular}

Weergegeven zijn het theoretisch maximum van de schaal en het groepsgemiddelde met de standaarddeviatie op T1, T2 en T3. Ook is het percentage patiènten dat laag of hoog scoort vermeld.

Met behulp van de Wilcoxon-toets is onderzocht of in de loop van de tijd significante verschillen optreden in de groepsgemiddelden. Dit bleek bij geen van de schalen het geval. Vervolgens is geanalyseerd of er toch veranderingen zijn in de individuele scores van de respondenten. Per aanpassingsschaal zijn Spearman-correlaties berekend tussen de scores behorend bij de drie meetmomenten. Deze test-hertest-correlaties zijn over het algemeen niet zo hoog, wat inderdaad wijst op individuele veranderingen.

- Tabel 5.4 - Test-hertest-correlaties

\begin{tabular}{|c|c|c|c|c|c|c|c|c|c|c|}
\hline \multirow{2}{*}{$\begin{array}{l}n=46 \\
\text { Schaal }\end{array}$} & & \multicolumn{3}{|c|}{ Toekomstperspectief } & \multicolumn{3}{|c|}{ Angt } & \multicolumn{3}{|c|}{ Zelfbeeld } \\
\hline & & $\mathrm{TI}$ & $\mathrm{T} 2$ & $\mathrm{T3}$ & $\mathrm{TH}$ & $\mathrm{T} 2$ & 13 & $\pi$ & $\mathrm{T} 2$ & T3 \\
\hline \multirow[t]{3}{*}{ Tockomstperpectiel } & $\pi$ & i & $46^{* *}$ & $39^{\circ}$ & & & & & & \\
\hline & $\mathbf{n}$ & $\therefore$ & - & $59 *$ & & & & & & \\
\hline & $\mathrm{B}$ & . & $\because$ & * & & & & & & \\
\hline \multirow[t]{3}{*}{ Anger } & $n$ & & & & - & $m * *$ & $58 *$ & 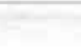 & & 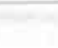 \\
\hline & $\mathrm{n} 2$ & & & & - & . & $49 *$ & & & \\
\hline & $\mathbf{n}$ & & & & . & 4 & . & & 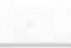 & \\
\hline \multirow[t]{3}{*}{ Zelibeeld } & $\mathrm{TI}$ & & & & & & & . & $50^{\circ *}$ & $48^{\circ \prime}$ \\
\hline & $\mathrm{n} 2$ & & & & & & & $=$ & . & $52 \%$ \\
\hline & T3 & & & & & & & . & - & + \\
\hline
\end{tabular}

Weergegeven zijn de test-hertest correlaties uitgedrukt in correlaties volgens Spearman (*p $\leq .01$ "ps.001). 
De individuele veranderingen zijn nog verder onderzocht. Daartoe zijn per respondent verschil-scores berekend. Deze zijn als volgt tot stand gekomen. De schaalscore op een bepaald meetmoment is afgetrokken van die op het eerdere meetmoment. Zo ontstond het rekenkundig verschil tussen de schaalscores van opeenvolgende meetmomenten. Omdat de drie schalen uit een verschillend aantal items bestaan, is voor de onderlinge vergelijkbaarheid de verschil-score gedeeld door het aantal schaal-items. Dit betekent dat de maximale positieve verschil-score van negen wordt behaald wanneer een patiènt op alle items van een schaal van nul naar negen is gestegen. Is deze daarentegen op alle items van negen naar nul gedaald, dan bedraagt de maximaal negatieve verschil-score min negen. De verschil-scores zijn afgerond op hele getallen. Verschillen vanaf min negen tot en met min drie zijn als een verslechtering ten opzichte van het vorige meetmoment opgevat, die vanaf min twee tot en met plus twee als niet of nauwelijks veranderd en die vanaf plus drie als een verbetering in aanpassing. In tabel 5.5 zijn de percentages respondenten weergegeven van wie, volgens deze definitie, de aanpassing is verbeterd, slechter geworden of gelijk gebleven. Omdat het klinisch niet zo relevant is of iemand van een hoge score naar een nog hogere score is gestegen, of gedaald is van heel hoog naar nog steeds hoog, zijn er bovendien kruistabellen gemaakt die zijn gebaseerd op de verdeling in hoog-en laag-scoorders, zoals aan het begin van deze paragraaf is beschreven. Op die manier werd inzichtelijk hoeveel procent van de patiènten op twee achtereenvolgende momenten hoog scoort (hoog-blijvers), welk percentage op twee achtereenvolgende momenten laag scoort (laag-blijvers), welk percentage daalt van hoog naar laag en welk percentage stijgt van laag naar hoog. Dit was een derde manier waarmee de scores op de verschillende tijdstippen met elkaar zijn vergeleken. De resultaten hiervan zijn eveneens in tabel 5.5 te vinden.

- Tabel 5.5 - Verandering in aanpassing

\begin{tabular}{|c|c|c|c|c|c|c|c|c|c|c|c|c|c|c|c|c|c|c|c|c|c|}
\hline \multirow{2}{*}{$\begin{array}{l}n=46 \\
\text { Schaal }\end{array}$} & \multicolumn{7}{|c|}{$\begin{array}{l}\text { T2 ten oprichte van II } \\
\text { Percentage patiènten }\end{array}$} & \multicolumn{7}{|c|}{$\begin{array}{l}\text { T3 ten opxichte van } 12 \\
\text { Percentage patienten }\end{array}$} & \multicolumn{7}{|c|}{$\begin{array}{l}\text { T3 ten oprichte van } I I \\
\text { Percentage patiénten }\end{array}$} \\
\hline & -1 & $=$ & + & II & $\mathrm{HH}$ & $\mathrm{LH}$ & $\mathrm{HL}$ & - & $=$ & + & II & $\mathrm{HH}$ & IH & $\mathrm{HI}$ & 2 & $=$ & + & 11 & $\mathrm{HH}$ & IH & $\mathrm{HI}$ \\
\hline Toeknonsperspectied & 13 & 70 & 17 & 7 & & 17 & 9 & 22 & b3 & 15 & 11 & & 4 & 17 & 17 & 65 & 17 & 13 & 61 & 11 & 15 \\
\hline Angs & 7 & 80 & 13 & 28 & 46 & 17 & 9 & 17 & $n$ & II & 24 & 4 & 13 & 20 & 13 & 65 & $n$ & 28 & 39 & 17 & 15 \\
\hline Zelitberid & 11 & 76 & 13 & 9 & 83 & 4 & 4 & 11 & 74 & 15 & 9 & 80 & 4 & 7 & 11 & 74 & 15 & 4 & 80 & 4 & 7 \\
\hline
\end{tabular}

Per aanpassingschaal is in de kolom (-) het percentage patienten weergegeven dat tussen de aangegeven meetmomenten in aanpassing achteruit is gegaan (verschil-scores vanaf $-9 \mathrm{~V} / \mathrm{m}-3$ ), in de kolom $(\Rightarrow)$ het percentage dat gelijk is gebleven (verschil-scores vanaf $-2 \mathrm{t} / \mathrm{m}+2$ ) en in de kolom $(+)$ het percentage dat is verbeterd (verschil-scores vanaf +3 ). In de kolom LL is het percentage patiênten aangegeven dat op de beide meetmomenten laag scoort (onder het theoretisch middelpunt van de schaal), in de kolom $\mathrm{HH}$ het percentage dat op beide meetmomenten hoog scoort (op of boven het theoretisch middelpunt). Het percentage patiénten dat van laag naar hoog is gegaan staat weergegeven in de kolom L.H en dat van hoog naar laag ging in de kolom $\mathrm{HL}$. 
Wat betekent dit alles? Per aanpassingsschaal zullen de belangrijkste bevindingen de revue passeren.

\section{- TOEKOMSTPERSPECTIEF}

De toekomst wordt door de patiënten over het algemeen positief ingeschat. Het theoretisch maximum ligt op 18. De gemiddelde scores van de gehele groep op de drie meetmomenten zijn respectievelijk 12.4, 13.0 en 12.0. Er is een scheve verdeling naar de hoge kant van de schaal. In de loop van de tijd treden geen significante veranderingen op in de groepsgemiddelden. Toch zijn de correlaties tussen de scores op de verschillende meetmomenten, met name die van $T_{1}$ en $T_{3}$, niet zo hoog ( $\left(h_{0_{13}}=.39\right.$ ). Dit wijst erop dat individuele scores wel veranderen.

De verschil-scores laten zien dat op $\mathrm{T}_{3} 17 \%$ van de respondenten negatiever tegen de toekomst aankeek dan op $\mathrm{T}_{1}$. Eveneens $17 \%$ is positiever geworden over de toekomst. Ruim de helft $(61 \%)$ ziet zowel op $\mathrm{T}_{1}$ als op $\mathrm{T}_{3}$ de toekomst met vertrouwen tegemoet en scoort op beide meetmomenten in de categorie 'hoog'. Toch ervaart een substantieel deel van de respondenten de toekomst als bedreigend. Op de drie achtereenvolgende meetmomenten scoort respectievelijk $24 \%, 15 \%$ en $28 \%$ in de categorie 'laag'. Ongeveer één op de tien onderzochte vrouwen (13\%) geeft op $T_{1}$ aan dat ze de toekomst bedreigend vindt, en vindt dat op $\mathrm{T}_{3}$ nog steeds.

\section{- ANGST}

De scores op de aanpassingsschaal voor angst zijn min of meer normaal verdeeld. Het theoretisch maximum, dat wil zeggen geen angst, ligt op 36 . Het groepsgemiddelde is op de achtereenvolgende meetmomenten respectievelijk 19.5, 20.5 en 20.2. Deze gemiddelde angstniveaus verschillen niet significant van elkaar.

Over het algemeen wordt vrij veel angst gerapporteerd. Op de achtereenvolgende meetmomenten valt respectievelijk $46 \%, 37 \%$ en $44 \%$ van de respondenten in de categorie laag aangepast. Ruim een kwart van de groep $(28 \%)$ is op $\mathrm{T}_{1}$ angstig en is dat op $T_{3}$ nog steeds. Ruim eenderde van de respondenten (39\%) valt zowel op $T_{1}$ als $T_{3}$ met hun score in de categorie hoog aangepast: zij geven zowel vlak na bestraling als ongeveer twee jaar na diagnose aan niet zo angstig te zijn.

De correlatie tussen de scores op $T_{1}$ en $T_{2}$ is hoog $\left(r_{h} o_{12}=.77\right)$. De score op $T_{1}$ is dus een redelijke voorspeller voor de score op $T_{2}$. De samenhang tussen de scores op $\mathrm{T}_{2}$ en $\mathrm{T}_{3}$ is minder sterk, evenals die op $\mathrm{T}_{1}$ en $\mathrm{T}_{3}$, maar toch nog aanmerkelijk $\left(\mathrm{rho}_{23}=.49\right.$ en $\left.\mathrm{rho}_{13}=.58\right)$. De samenhang is terug te vinden in de verschil-scores. Ook deze laten zien dat steeds het grootste deel van de groep ongeveer gelijk blijft in haar score $\left(80 \%\right.$ tussen $\mathrm{T}_{1}$ en $\mathrm{T}_{2}, 72 \%$ tussen $\mathrm{T}_{2}$ en $\mathrm{T}_{3}$ en $65 \%$ tussen $\mathrm{T}_{1}$ en $\mathrm{T}_{3}$ ). De tijd heeft klaarblijkelijk niet veel invloed op het angstniveau. 


\section{- Zelfbeeld}

De zelfbeeldschaal heeft, evenals de schaal voor toekomstperspectief, een scheve verdeling naar de hoge kant. Het theoretische maximum is 45 en het groepsgemiddelde ligt respectievelijk op 33.3, 33.6 en 34.0. Ook hier ontstaan in de loop van de tijd geen significante verschillen. Verreweg het grootste deel van de respondenten $(83 \%)$ valt zowel op $\mathrm{T}_{1}$ als op $\mathrm{T}_{3}$ in de categorie hoog-scoorder. Op de achtereenvolgende meetmomenten is respectievelijk slechts $13 \%, 13 \%$ en $15 \%$ van de respondenten een laag-scoorder en maar $9 \%$ van de respondenten scoort zowel op $\mathrm{T}_{1}$ als op $\mathrm{T}_{3}$ laag.

De correlaties geven aan dat er een zekere samenhang bestaat tussen de scores op verschillende meetmomenten (de waarden van tho liggen tussen .48 en .52). De verschil-scores bevestigen dit beeld.

Samenvattend kan het volgende worden geconcludeerd. Ziekte en behandeling lijken op het zelfbeeld van de patiënten geen noemenswaardig effect te hebben gehad. Bovendien ziet een groot deel van hen de toekomst positief tegemoet en voelt zich niet erg angstig.

Toch vindt op $T_{3}$, twee jaar na de diagnose, $28 \%$ van de patiënten de toekomst als gevolg van de ziekte bedreigend en zegt $44 \%$ angstig te zijn. Deze percentages verschillen nauwelijks van die op $T_{1}$. Er zijn dan ook geen veranderingen gevonden in de gemiddelde scores van de totale onderzoeksgroep. Het spreekwoord de tijd heelt alle wonden' gaat voor een groot deel van de onderzoeksgroep dus niet op, althans niet gedurende de eerste twee jaar na de diagnose.

Op individueel niveau zien we het volgende beeld: $13 \%$ van de patiënten vindt zowel op $T_{1}$ als op $T_{3}$ de toekomst bedreigend en $28 \%$ is en blijft angstig. Er zijn patiènten die vooruit zijn gegaan in aanpassing (respectievelijk 11\% en $17 \%$ ) en er zijn er die achteruit zijn gegaan (respectievelijk 15\% en 16\%). De overigen, respectievelijk $61 \%$ en $39 \%$, hebben zich vanaf het begin relatief goed aangepast en hebben dit vast kunnen houden.

Aanvankelijk is er een tamelijk sterke samenhang tussen de drie aanpassingschalen. Er is dan een redelijke kans dat een respondent die op één van de schalen hoog dan wel laag scoort, dit ook doet op de andere schalen. De samenhang wordt in de loop van de tijd minder sterk. 


\section{3 - EIGEN INVLOED EN SCHAAMTE}

Voor de aanpassingsindicatoren eigen invloed en schaamte zijn geen betrouwbare schalen in het onderzoeksmateriaal aangetroffen. Daarom worden beide aan de hand van scores op afzonderlijke items besproken. De gemiddelde scores van de onderzoeksgroep en de standaarddeviaties zijn berekend, evenals het percentage patiënten dat hoog of laag scoort op het item. Deze VAS-scores lopen van 0 tot en met 9. Net als bij de schalende indicatoren in de vorige paragraaf is het criterium voor hoogscoorders, dat zij op of boven het theoretisch middelpunt van de VAS scoorden (score 5 of hoger). Laag-scoorders zitten daaronder. Ook hier duidt een hogere score op betere aanpassing. Bijvoorbeeld, een hogere score op de items voor schaamte betekent een betere aanpassing en dus minder schaamte. Met behulp van Wilcoxon-toetsen is onderzocht of in de loop van de tijd significante verschillen optreden in de gemiddelde scores van de groep. Een overzicht staat in tabel 5.6 aan het eind van deze paragraaf. Ook zijn voor elk item de test-hertest-correlaties berekend en is nog onderzocht welke samenhang er is met de drie aanpassingsschalen. Significante correlaties vanaf .40 zijn steeds vermeld. Per indicator worden de belangrijkste resultaten besproken.

\section{- EIGEN INVLOED}

- Invloed op de ziekte

Op de vraag 'Denkt u dat u op enige wijze iets kunt doen om te voorkomen dat de ziekte terugkomt?' antwoordden de meeste respondenten dat zij geen of weinig invloed op de ziekte kunnen uitoefenen. Respectievelijk $59 \%, 67 \%$ en $78 \%$ van de groep behoort tot de categorie laag-scoorder. Het groepsgemiddelde daalt van 3.9 op $T_{1}$, via 3.1 op $T_{2}$, naar 2.6 op $T_{3}$. De daling tussen $T_{1}$ en $T_{3}$ is significant $(p=.02)$. Er is een redelijke correlatie tussen de scores op $\mathrm{T}_{2}$ en $\mathrm{T}_{3}\left(\mathrm{rho}_{23}=.62\right)$ : patiënten die op $\mathrm{T}_{2}$ van mening zijn dat zij invloed hebben, behouden dat gevoel en andersom. Op geen van de meetmomenten is een samenhang gevonden met de aanpassingsschalen.

- Invloed door leefgewoonten

Het overgrote deel van de respondenten denkt niet dat door verandering van leefgewoonten invloed op de ziekte kan worden uitgeoefend. Onder leefgewoonten worden zowel voedingsgewoonten alsook roken en omgaan met stress verstaan. Op $T_{1}$ scoorde $87 \%$ van de respondenten laag op dit item. Op $\mathrm{T}_{2}$ was dit $83 \%$ en op $\mathrm{T}_{3}$ zelfs $91 \%$. Het groepsgemiddelde gaat van 1.7 op $T_{1}$, via 1.8 op $T_{2}$, naar 1.1 op $T_{3}$. De daling tussen $T_{2}$ en $T_{3}$ is net niet significant $(p=.06)$. Er is een matige correlatie tussen de scores op $\mathrm{T}_{2}$ en $\mathrm{T}_{3}\left(\mathrm{rho}_{23}=40\right) \mathrm{Er}$ is geen samenhang met een van de aanpassingsschalen. 


\section{- Invloed op de toekomst}

Ongeveer de helft van de respondenten vindt dat zij op de een of andere manier invloed hebben op de toekomst. Op de drie meetmomenten scoorde respectievelijk $59 \%, 43 \%$ en $48 \%$ van de respondenten hoog. De gemiddelde scores van de groep zijn respectievelijk 4.5,3.8 en 4.3. De verschillen zijn niet significant. $\mathrm{Er}$ is een redelijke correlatie tussen de scores op $\mathrm{T}_{1}$ en $\mathrm{T}_{2}$ (rho $\mathrm{s}_{12}=.52$ ). De mate waarin patiénten op $T_{1}$ invloed op hun toekomst ervaren blijkt, tot op zekere hoogte, samen te hangen met de angstscores op $\mathrm{T}_{3}(\mathrm{~h} /=.46)$. De patiënten die meer invloed ervaren zijn minder angstig.

\section{- SChaAmTe}

- Schaamte over de ziekte

Er is weinig schaamte over de ziekte. Zowel op $\mathrm{T}_{1}$ als op $\mathrm{T}_{2}$ geeft slechts $4 \%$ van de respondenten aan zich te schamen kankerpatiént te zijn. Op $T_{3}$ is dit $7 \%$. De meeste respondenten zijn op dit punt dus zeer aangepast. Het gemiddelde van de groep is dan ook hoog, respectievelijk 8.4, 8.6 en 8.5. Deze gemiddelde scores veranderen niet significant in de tijd. $\mathrm{Er}$ is een matige correlatie tussen de scores van $\mathrm{T}_{2}$ en $\mathrm{T}_{3}$ $\left(\mathrm{rho}_{23}=.43\right)$. Schaamte voor de ziekte blijkt op sommige meetmomenten samen te hangen met angst en zelfbeeld en heeft voor beide indicatoren ook enige voorspellende waarde (rho $=.49$ voor schaamte en angst op $T_{3}$, rho $=.40$ voor schaamte op $T_{1}$ en angst op $T_{3}$, rho $=.58$ voor schaamte en zelfbeeld op $T_{1}$, rho $=.54$ voor schaamte en zelfbeeld op $T_{3}$, rho $=.45$ voor schaamte op $T_{1}$ en zelfbeeld op $T_{3}$ ).

\section{- Bang om met andere ogen te worden bekeken}

De meeste respondenten waren niet bang dat ze met andere ogen worden bekeken nu ze voor kanker zijn behandeld. Zij scoorden dus hoog op deze aanpassingsindex. De gemiddelde score van de groep ligt wel iets lager dan bij de directe vraag naar schaamte. Ze zijn respectievelijk 7.1, 7.3 en 7.6 en er treden geen significante veranderingen op. De percentages respondenten die in de categorie laag aangepast vallen, zijn op de drie meetmomenten respectievelijk 15\%, 20\% en 15\%. Er zijn redelijke correlaties tussen de scores op de verschillende meetmomenten $\left(\mathrm{rho}_{12}=.56\right.$, $\mathrm{hho}_{13}=.62$, $\mathrm{rho}_{23}=.57$ ). Bovendien is er met elk van de drie aanpassingsschalen enige samenhang gevonden: met toekomstperspectief op alle meetmomenten ( $h_{h} o_{1}=40$, rho $_{2}=.43$, en hoo $_{3}=.49$ ), met het zelfbeeld op $T_{1}$ en op $T_{3}\left(r h o_{1}=.40\right.$ en $\left.r o_{3}=.51\right)$, met angst alleen op $\mathrm{T}_{3}\left(\mathrm{rho}_{3}=, 48\right)$. Ook zijn er onder de patiënten die op $\mathrm{T}_{2}$ bang zijn dat ze met andere ogen worden bekeken op $\mathrm{T}_{3}$ relatief gezien meer angstige vrouwen (rho=.44). 
- Tabel 5.6 - Eigen invloed en schaamte

\begin{tabular}{|c|c|c|c|c|c|c|c|c|c|c|c|c|}
\hline \multirow{2}{*}{$\begin{array}{l}n=46 \\
\text { Item }\end{array}$} & \multicolumn{3}{|c|}{$\begin{array}{c}\text { Gemiddelde } \\
\text { score }\end{array}$} & \multicolumn{3}{|c|}{$\begin{array}{l}\text { Standaard- } \\
\text { deviatie }\end{array}$} & \multicolumn{3}{|c|}{$\begin{array}{l}\text { Percentage } \\
\text { laag-scoorders }\end{array}$} & \multicolumn{3}{|c|}{$\begin{array}{c}\text { Percentage } \\
\text { hoog-scoorders }\end{array}$} \\
\hline & T1 & $\mathrm{T2}$ & $\mathrm{T3}$ & $\mathrm{TH}$ & 12 & 13 & $\mathrm{T1}$ & $\mathrm{T} 2$ & T3 & $\mathrm{II}$ & $\mathrm{T2}$ & T3 \\
\hline Invioed op zielde & 3.9 & 3.1 & 26 & 3.5 & 3.2 & 2.8 & 59 & 67 & 78 & 41 & 33 & 22 \\
\hline Invloed door lexigewoonten & 17 & 18 & 1.1 & 24 & 27. & 2.1 & 87 & 83 & 91 & 13 & 17 & 9 \\
\hline Invioed op toekomst & 4.5 & 3.8 & 4.3 & 3.2 & 3.3 & 2.8 & 41 & 57 & 52 & 59 & 43. & 48 \\
\hline Schasamte voor de ziekte & 8.4 & 8.6 & 85 & 1.8 & 1.9 & 1.7 & 4 & 4 & 7 & 96 & 96 & 93 \\
\hline Met andese ogen beleken & 7.1 & 7.3 & 7.6 & 3,0 & 3.0 & 2.8 & 15 & 20 & 15 & 85 & 80 & 85 \\
\hline
\end{tabular}

Weergegeven zijn het groepsgemiddelde en de standaarddeviatie van de scores op de Vasitems voor eigen invloed en schaamte op T1, T2 en T3. Ook is het percentage patienten vermeld dat laag dan wel hoog scoort. 'Laag-scoorders' hebben een score van $0 \mathrm{t} / \mathrm{m} 4$, 'hoogscoorders' van $5 \mathrm{t} / \mathrm{m} 9$.

Samenvattend, veel patiënten vinden dat zij weinig invloed hebben op het verloop van hun borstkanker. Dit gevoel is er vanaf het begin en wordt in de loop van de tijd eigenlijk alleen maar sterker. Bij de items invloed op de ziekte en invloed door leefgewoonten treedt een (bijna) significante daling op in het groepsgemiddelde; dit

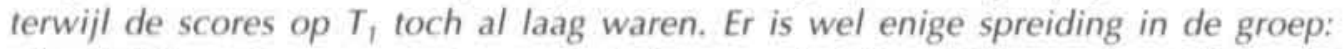
athankelijk van item en meetmoment vindt tussen de $9 \%$ en $59 \%$ van de patiënten dat zij in meerdere of mindere mate zelf invloed hebben, het meest nog op hun toekomst. De mate waarin patiënten al dan niet invloed ervaren, blijkt niet samen te hangen met hun beleving van de toekomst, het zelfbeeld en de mate van angst van de patiënt.

Slechts weinig patiënten schamen zich voor de ziekte $(4 \%$ tot $20 \%)$. Omdat de aantallen zo klein zijn is deze aanpassingsindex niet in de verdere statistische analyses meegenomen. Wel is gebleken dat patiënten die zich schamen, over het algemeen ook angstiger zijn, minder toekomstperspectief ervaren en een lager zelfbeeld hebben. Vanuit klinisch perspectief is schaamte dus wel degelijk een factor die aandacht verdient.

\section{4 - NOGMAALS VERANDERING IN AANPASSING: REKENKUNDIGE VERSCHILLEN VERSUS PATIËNTENOORDELEN}

Het rekenkundig verschil tussen de schaalscores van twee opeenvolgende meetmomenten is een van de manieren waarop verandering in aanpassing is gerationaliseerd (zie paragraaf 2). Echter, tijdens het tweede en derde interview is elke patiént, na het scoren van de actuele situatie, bij een aantal schaal-items gevraagd ook 
te scoren in welke mate er volgens haarzelf verandering was opgetreden sinds het vorige interview. Deze toegevoegde vragen luidden als volgt: 'Kunt u aangeten in boeverre dat is verandend ten opzicbte van bet torige intervieu?' met als VAS: beel teel — belemaal niets, en 'Gaat bet om een positieve of negatieve verandering?' Zo ontstond er naast een rekenkundige maat het 'patiēntenoordeel' over de mate van verandering.

Dit patiëntenoordeel is toegevoegd, aangezien uit de literatuur bekend is dat de interne standaard waarop mensen hun waardering voor bepaalde onderwerpen afmeten, kan veranderen onder invloed van allerlei gebeurtenissen en interventies. Dit verschijnsel is ook wel bekend onder de term response shift. Dat wil zeggen dat, wanneer een patiënt op twee verschillende momenten zijn situatie bijvoorbeeld met een zeven beoordeelt, dit niet per se betekent dat er niets is veranderd. Het kan zijn dat de patiěnt twee keer een zeven heeft gegeven omdat het op beide momenten onder de gegeven omstandigbeden zo gek nog niet ging. Bij de beoordeling heeft zij als het ware de situatie verdisconteerd en heeft haar zeven in beide gevallen vanuit een ander perspectief gegeven. Het kan dus zo zijn dat ondanks dezelfde score, het op het tweede meetmoment toch beter of slechter gaat dan op het eerste meetmoment. Een dergelijke verandering blijkt niet uit een gewone verschil-score (Sprangers 1988 en 1999, Heyink 1993).

Voor toekomstperspectief is, op de manier zoals hiervoor beschreven, bij een van de twee schaal-items gevraagd de mate van verandering ten opzichte van het vorige interview te scoren. Het betreft het item 'In boeverre is er door de ziekte iets veranderd aan boe u tegen ut toekomst aankijkt?'. Hetzelfde is gedaan bij drie van de vier items van de angstschaal. En wel bij 'Denkt $u$ dat $u$ bent genezen?', 'Als $u$ nu ergens in uw licbaam iets voelt, reageert $u$ dan angstiger dan voordat $u$ ziek werd?' en 'In boeverre bebeerst de ziekte uw leven?'. Bij de zelfbeeldschaal is bij twee van de vijf items gevraagd naar de mate van verandering ten opzichte van het vorige interview. Het ene item gaat over het lichaamsbeeld: Alles bij elkaar genomen, in boeverre voelt u zicb door de operatie en de bebandeling beschadigd?', het andere over hoe men tegen zichzelf als persoon aankijkt: 'In boeverre bent $u$ teranderd door wat $u$ beeft meegemaakt?:

Analoog aan de indeling van de rekenkundige verschil-scores (zie paragraaf 2-2), zijn de patiëntenoordelen als volgt ingedeeld: VAS-scores vanaf drie tot en met negen. waarbij de patiënt heeft aangegeven dat het een positieve verandering betrof, zijn opgevat als verbetering, die waarbij het om een negatieve verandering ging als verslechtering. De scores van nul tot en met twee zijn, ongeacht de richting van de verandering, opgevat als gelijk gebleven. 
In de tabellen $5.7 \mathrm{a}$ en $5.7 \mathrm{~b}$ staan de percentages patiënten die naar eigen zeggen zijn vooruit gegaan, gelijk gebleven of achteruit gegaan, alsook de percentages patiënten waarvan het rekenkundige verschil in hun scores dit aangeeft. Voor elk van deze veranderingsmaten is met een $\mathrm{X}^{2}$-toets onderzocht of de verandering die tussen $T_{1}$ en $T_{2}$ heeft plaatsgevonden, significant afwijkt van die welke plaatsvond tussen $T_{2}$ en $T_{3}$. In tabel 5.7a is weergegeven waar dit het geval is. Om een indruk te krijgen of de verdeling over de categorieën 'verslechterd', 'gelijk gebleven' en 'verbeterd' bij de patiěntenoordelen significant afwijkt van die bij de rekenkundige verschillen, zijn eveneens $\mathrm{X}^{2}$-toetsen uitgevoerd. Tabel 5.7b laat zien voor welke items dit inderdaad zo is. Deze tabel bevat verder dezelfde gegevens als tabel 5.7 a maar ze zijn wat anders gerangschikt.

Tenslotte is de samenhang tussen patiëntenoordelen en rekenkundige verschillen onderzocht door de Pearson-correlatie-coëfficiënten te berekenen. Deze zijn staan in tabel 5.8 .

- Tabel 5.7a - Patientenoordelen en rekenkundige verandering: het verloop in tijd

\begin{tabular}{|c|c|c|c|c|c|c|c|c|c|c|c|c|}
\hline \multirow{2}{*}{$\begin{array}{l}n=46 \\
\text { Item }\end{array}$} & \multicolumn{6}{|c|}{ ratientenoorodiè } & \multicolumn{6}{|c|}{ 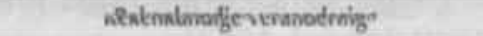 } \\
\hline & \multicolumn{3}{|c|}{$P_{12} \%$} & \multicolumn{3}{|c|}{$P_{2} \%$} & \multicolumn{3}{|c|}{$R_{n} \%$} & \multicolumn{3}{|c|}{$\mathbf{R}_{21} \%$} \\
\hline lockoms & 11 & 50 & 39 & 20 & 54 & 26 & 15 & 70 & 15 & 15 & 76 & 9 \\
\hline Beheers door de ziekte & 11 & 50 & $39 * *$ & 26 & 57 & $17 * *$ & 4 & 57 & $39+++$ & 17 & 63 & $20+1+$ \\
\hline Zekerheid genezen & 7 & 74 & 20 & 11 & 67 & 21 & 9 & 70 & $22+++$ & 24 & 59 & $17++$ \\
\hline Angr bif lichaamignalen & 24 & 59 & 17 & 25 & 61 & 13 & 20 & 76 & $4++$ & 13 & 39 & $28+++$ \\
\hline Zeli veranderd & 7 & 63 & 30 & 13 & 64 & 22 & 18 & 76 & 11 & is & 78 & 7 \\
\hline Beschadigd & 2 & 77 & $21 * 0$ & 14 & 83 & $3 * *$ & 20 & 74 & 7 & 13 & 74 & 13 \\
\hline
\end{tabular}

Weergegeven zijn de percentages patiënten die in aanpassing zijn achteruitgegaan (-), gelijk gebleven $(a)$ of verbeterd $(+)$. Bij de patiëntenoordelen over de verandering $(P)$ en de rekenkundige verandering $(R)$ is aangegeven of dit de verandering tussen $T_{1}$ en $T_{2}$ betreft of die tussen $T_{2}$ en $T_{3}$. Significante verschillen zijn voor de patiëntenoordelen gemarkeerd met het symbool ${ }^{2}$ en voor de rekenkundige veranderingeringen met + . De verschillen zijn getoetst met een $X^{2}$-toets (* en + ps.05, $\cdots$ en ++ ps.01, $\cdots$ en +++ ps.005). 
- Tabel 5.7b-Patiëntenoordelen en rekenkundige verandering: verschillen tussen beide maten

\begin{tabular}{|c|c|c|c|c|c|c|c|c|c|c|c|c|}
\hline \multirow{3}{*}{$\begin{array}{l}1 \mathrm{~s}=46 \\
\text { liem }\end{array}$} & \multicolumn{6}{|c|}{ Verandering tussen $\mathrm{T} 1$ en $\mathrm{T} 2$} & \multicolumn{6}{|c|}{ Veranderiag tussen $\mathrm{R}$ en $\mathrm{T3}$} \\
\hline & \multicolumn{3}{|c|}{$P_{n} \leqslant$} & \multicolumn{3}{|c|}{$R_{12} \%$} & \multicolumn{3}{|c|}{$P_{n}=8$} & \multicolumn{3}{|c|}{$R_{21}=$} \\
\hline & - & $=$ & + & - & $=$ & + & - & $=$ & + & - & $=$ & + \\
\hline Jodumst & 11 & 50 & $390 *$ & 15 & 70 & $15 * 4$ & 20 & 54 & $26 * *$ & 15 & 76 & $9 * n$ \\
\hline Beleeset door de zielse & if & 50 & 39 & 4 & 37 & 39 & 26 & 57. & 17 & 17 & 63 & 20 \\
\hline Zisenteid grnezen & 7 & 74 & 20 & 9 & 70 & 22 & 11 & 67 & $21^{*}$ & 24 & 59 & 17 \\
\hline Anget bi lichamsignalen & 24 & 59 & $17 *$ & 20 & 76 & 4 & 25 & 61 & $B^{m+*}$ & 13 & 59 & $28+4$ \\
\hline Zetf verandend & 7 & 63 & $30^{\circ *}$ & 13 & 76 & $11 *$ & 13 & 64 & 22 & 15 & 78 & $r$ \\
\hline Bestudigd & 2 & 7 & $21 * *$ & 20 & 74 & $7 * 4$ & 14 & 83 & 3 & 13 & 74 & $13^{*}$ \\
\hline
\end{tabular}

Weergegeven zijn de percentages patiênten die in aanpassing zijn achteruitgegaan $(-)$, gelijk gebleven $(\Leftrightarrow)$ of verbeterd $(+)$. Bij de patiêntenoordelen over de verandering $(P)$ en de rekenkundige verandering $(R)$ is aangegeven of dit de verandering tussen $T_{1}$ en $T_{2}$ betreft of die tussen $T_{2}$ en $T_{3}$. De verschillen tussen patièntenoordelen en rekenkundige veranderingeringen zijn getoetst met een $X^{2}$-toets ("ps.05 *ps.01 **ps.005).

- Tabel 5.8 - Correlaties tussen patiènten-oordelen en rekenkundige verandering

\begin{tabular}{|c|c|c|}
\hline $\begin{array}{l}n=46 \\
\text { liten }\end{array}$ & $\mathrm{r}_{n} \mathrm{T2}$ ten oprichte van $\mathrm{I1}$ & $\mathrm{I}_{n} \mathrm{~B}$ ten oprichte van $\mathrm{R}$ \\
\hline Torioms & 26 & $45^{*}$ \\
\hline Beherst door zielte. & 34 & $x_{1}^{3}=2$ \\
\hline Zetertheid genezen & .00 & 31 \\
\hline Anga bij licharnsignalen & $.01+$ & 32 \\
\hline Zeff veranderd & .99 & 12 \\
\hline Beschadigd & 29 & 24 \\
\hline
\end{tabular}

Weergegeven zijn de Pearson product-moment correlaties ( $r$ ) tussen de patièntenoordelen $(P)$ over de verandering en de verandering op basis van de rekenkundige verschillen (R) ("ps.01 " "ps.001).

Het valt op dat de patiënten over het algemeen anders oordelen over de verandering die zij hebben doorgemaakt, dan uit de rekenkundige verschil-scores naar voren komt. Dit blijkt zowel uit de zwakke correlaties tussen beide veranderingsmaten als uit de vele significante verschillen in de verdeling over de categorieèn 'verslechterd', 'gelijk gebleven' en 'verbeterd'. Wanneer de patiênten rechtstreeks wordt gevraagd of er een verandering heeft plaats gevonden, kiezen zij meestal duidelijker positie: de categorie 'gelijk gebleven' is bij het patiëntenoordeel bijna overal minder gevuld. Bij de vragen over de toekomst en of men zelf is veranderd, resulteert dit erin dat de categorie 'verbeterd' bij de patiëntenoordelen meer is gevuld. Dit geldt zowel voor de verandering tussen $T_{1}$ en $T_{2}$, als voor die tussen $T_{2}$ en $T_{3}$. Er zijn dus meer patiënten die zelf vinden dat zij vooruit zijn gegaan dan uit de verschilscores is af te lezen. Gedeeltelijk zou dit ook verklaard kunnen worden uit een 
zogenaamd plafond-effect. Door de scheve verdeling op de betreffende schalen kon een deel van de patiënten rekenkundig niet veel vooruit gaan, aangezien zij al bovenin de schaal zaten, met het patiëntenoordeel hadden zij wel de mogelijkheid een vooruitgang aan te geven. Maar er lijkt meer aan de hand, want bij de vragen of men angstiger is geworden wanneer men iets voelt en of men vindt dat men door de operatie of behandeling is beschadigd, gebeurt het volgende. Aanvankelijk is het percentage patiënten dat vooruit is gegaan bij de patiëntenoordelen hoger dan bij de rekenkundige verandering, maar dit draait later om: de patiëntenoordelen over de verandering die plaatsvond tussen $T_{2}$ en $T_{3}$ steken juist negatief af bij de rekenkundige verandering. Ook op de vraag 'denkt $u$ dat $u$ bent genezen' antwoorden meer patiënten dat zij onzekerder zijn geworden tussen $T_{2}$ en $T_{3}$ dan de verschil-scores aangeven.

Alles met elkaar lijkt het erop dat de patiënten in principe geneigd zijn aan te geven dat ze vooruit zijn gegaan, zelfs meer dan de rekenkundige verschil-scores doen vermoeden. In die zin zou er dus sprake kunnen zijn van een response shift, zoals aan het begin van deze paragraaf is beschreven. Echter voor een aantal onderwerpen treedt hierin tussen $T_{2}$ en $T_{3}$ een verandering op. Dit blijkt ook wanneer de patiëntenoordelen over de verandering die heeft plaats gevonden tussen $T_{1}$ en $T_{2}$, wordt vergeleken met hun oordeel over de verandering tussen $T_{2}$ en $T_{3}$ (zie tabel 5.7a). Op $\mathrm{T}_{3}$ geven meer patiënten aan dat een negatieve verandering heeft plaats gevonden dan op $\mathrm{T}_{2}$. Voor de items 'In boeterre wordt $u$ bebeerst door de ziekte' en 'in boeverre voelt $u$ zich bescbadigd' zijn de verschillen zelfs hoog significant. Dit alles wijst erop dat voor een niet onaanzienlijk deel van de patiënten de impact van de ziekte niet afneemt, maar misschien zelfs groter wordt.

Uit de verhalen van de patiënten blijkt dat naarmate de tijd verstrijkt, zij zich minder beschermd voelen door de behandeling die zij hebben ondergaan. 'Mijn licbaam moet bet nu zelf weer doen en bet beeft me al eerder in de steek gelaten.' Ook speelt mee dat allerlei klachten en klachtjes niet langer kunnen worden afgedaan als een gevolg van de bestraling of medicamenteuze therapie. Daardoor wordt de alarmwaarde ervan groter. Medische controles kunnen deze gevoelens niet bij iedereen wegnemen. Op de vraag 'Geven de controles in bet ziekenbuis $u$ op enige wijze een veilig gevoel?' antwoordt ongeveer een kwart van de patiënten ontkennend $\left(26 \%\right.$ op $\mathrm{T}_{2}, 20 \%$ op $\left.\mathrm{T}_{3}\right)$. Ongeveer een derde put er wel zekerheid uit ( $30 \%$ op $\mathrm{T}_{2}$ en $33 \%$ op $\mathrm{T}_{3}$ ). De rest kiest een neutrale positie (respectievelijk $44 \%$ en $49 \%$ ).

Ook blijkt uit de verhalen dat men er aanvankelijk alles voor over heeft om te genezen. Mogelijke gevolgen van de behandeling worden in het licht van de dreiging van kanker op de koop toe genomen. Later gaan diezelfde gevolgen toch zwaarder wegen. Het gaat dan om beperkingen in het gebruik van de arm ten gevolge van het verwijderen van de okselklieren, aanhoudende moeheid en het vroegtijdig in de 
overgang raken door de chemotherapie. Drie jongere vrouwen vertellen dat zij ten gevolge van de chemotherapie geen kinderen meer kunnen krijgen, terwijl zij dat nog graag zouden willen.

Samenvattend kan worden geconcludeerd, dat, wanneer aan de patiënten expliciet werd gevraagd of er veranderingen waren opgetreden ten opzichte van een vorig interview, zij meer veranderingen aangaven dan blijkt uit de rekenkundige verschillen tussen de VAS-scores op de betreffende meetmomenten. De categorie 'gelijk gebleven" bevat bij de patièntenoordelen bijna overal een lager percentage patiënten. Bovendien wordt duidelijk dat de impact van de ziekte naar het oordeel van een substantieel deel van de patiënten niet afneemt in de tijd. Het percentage patiènten dat aangeeft dat er een negatieve verandering is opgetreden ten opzichte van het vorige meetmoment is op $T_{3}$ overal hoger dan op $T_{2}$. Bij de items beheerst door de ziekte' en 'beschadigd door ziekte en behandeling' zijn deze verschillen zelís uitgesproken significant.

\section{5 - AANPASSING BI] VERSCHILLENDE SUBGROEPEN}

Van de volgende vijf demografische en medische variabelen is nagegaan of deze van invloed zijn op het strategiegebruik of de mate van aanpassing aan de ziekte:

- ernst van de ziekte

- aard van de behandeling

- leeftijd

- opleiding

- verloop van de ziekte

De invloed van deze variabelen op het strategiegebruik is in hoofdstuk IV paragraaf 7 aan de orde geweest. Over de invloed op aanpassing aan de ziekte wordt hier verslag gedaan.

Voor elk van de meetmomenten is, met behulp van Mann-Whitney-toetsen, onderzocht of de volgens de genoemde variabelen te onderscheiden subgroepen verschillen in hun scores op een van de aanpassingsschalen voor toekomst, angst en zelfbeeld. De resultaten hiervan zijn te vinden in de tabellen 5.9 tot en met 5.14 van bijlage $D$. Op dezelfde wijze is onderzocht of de subgroepen verschillen in de mate waarin zij invloed ervaren. Omdat voor deze laatste aanpasingsindex geen goede schaal is gevonden zijn de verschillen voor elk van de drie bedoelde schaal-items afzonderlijk onderzocht. Het betreft de items: invloed op de ziekte in algemene zin, invloed op de ziekte specifiek door leefgewoonten en invloed op de toekomst. De resultaten van deze analyses staan in de tabellen 5.15 tot en met 5.20, eveneens in bijlage D. De opvallende bevindingen worden hierna besproken. 


\section{Ernst van de ziekte (tabel 5.9 en 5.15)}

De groep respondenten is ingedeeld in een subgroep patiënten met positieve okselklieren $(n=33)$ en een subgroep met negatieve okselklieren $(n=13)$. Ondanks de slechtere prognose schatten patiënten met positieve klieren hun toekomst vlak na de bestraling $\left(T_{1}\right)$ significant hoger in dan patiēnten bij wie geen positieve okselklieren zijn aangetroffen.

\section{Behandeling (tabellen 5.10, 5.11, 5.16 en 5.17)}

Er zijn geen verschillen gevonden in de scores op de aanpassingsschalen tussen patiënten die wel en patiënten die niet zijn behandeld met chemotherapie $(n=23$ versus $n=23$ ) en ook niet tussen patiënten behandeld met chemotherapie $(n=23)$ versus patiënten behandeld met hormoontherapie $(n=10)$, behalve dat op $T_{1}$ het zelfbeeld van de patiënten die behandeld zijn met chemotherapie significant lager is dan van patiènten behandeld met hormoontherapie. Wel zijn significante verschillen gevonden in de invloed die men ervaart op het verloop van de ziekte. De met chemotherapie behandelde patiënten ervaren op $T_{1}$, dat wil zeggen tijdens of vlak na de kuren, meer invloed op hun ziekte dan de andere patiënten. Ook wanneer zij vergeleken worden met patiënten die hormoontherapie kregen, is dit verschil gevonden.

\section{Leeftijd (tabel 5.12 en 5.18)}

De onderzoeksgroep is gesplitst in een groep met patiënten in de leeftijd van 29 tot en met 47 jaar $(n=24)$ en een met patiënten van 48 tot en met 60 jaar $(n=22)$. Gevonden is dat vlak na de bestraling $\left(\mathrm{T}_{1}\right)$ de jongere patiënten hun toekomstperspectief significant ongunstiger beoordelen dan hun oudere lotgenoten.

\section{Opleiding (tabel 5.13 en 5.19)}

Onderscheid is gemaakt in een groep met opleiding of werkervaring tot en met het niveau van middelbaar beroepsonderwijs $(n=31)$ en een groep die daarboven zit $(n=15)$. Het niveau van opleidingen of werkervaring blijkt niet van invloed op de scores op de aanpassingsschalen. Wel ervaren de patiênten met de hoogste opleiding zowel op $\mathrm{T}_{1}$ als op $\mathrm{T}_{2}$ significant meer invloed op hun toekomst.

\section{Verloop van de ziekte (tabel 5.14 en 5.20 )}

Als laatste is onderzocht of een hernieuwde confrontatie met kanker door een metastase of recidief de mate van aanpassing beïnvloedt. Op $\mathrm{T}_{3}$ waren zes respondenten opnieuw met de ziekte geconfronteerd, de andere veertig waren op dat moment ziektevrij. De patiënten die te maken kregen met een metastase of recidief zijn op $\mathrm{T}_{3}$ aanmerkelijk angstiger en zien hun toekomst veel somberder in dan de anderen die op dat moment ziektevrij waren. 
De subgroepen blijken niet veel van elkaar te verschillen in de mate waarin zij zich aan de ziekte hebben aangepast. Logischerwijs zijn de patiënten die op $T_{3}$ zijn geconfronteerd met metastasen of een recidief, angstiger en ook somberder over hun toekomst dan de anderen. Verder blijkt dat patiènten die hoger zijn opgeleid over het algemeen wat meer invloed ervaren (op $T_{1}$ en $T_{2}$ ). Tenslotte zijn er nog enkele verschillen gevonden die alleen gelden op $T_{t}$ : jongere patiënten zijn direct na de diagnose somberder over hun toekomst dan oudere patiënten en de patiënten die een chemokuur ondergaan ervaren tijdens de kuur meer invloed op hun ziekte dan hun lotgenoten die niet met chemotherapie worden behandeld. Hun zelfbeeld is op dat moment wel wat negatiever. Vanaf $T_{2}$, na beeindiging van de kuur zijn deze verschillen niet meer gevonden.

\section{6 - ERVAREN SteUn en AanPASSING}

De invloed van sociale steun op aanpassing aan de ziekte is onderzocht. Alvorens in te gaan op die resultaten wordt eerst aangegeven hoe het begrip 'ervaren steun' is geoperationaliseerd en in welke mate de patiênten zich gesteund voelen.

\section{6 - 1 - Operationalisering van het begrip en de mate van steun}

In het interview zijn vragen naar steun opgenomen die op de eerder beschreven manier werden afgesloten met een VAS. De patiënt scoorde hoe tevreden ze was met de steun die ze had gekregen van haar partner, familie, vrienden en kennissen. Verondersteld werd dat deze VAS-vragen samen een indicatie zouden opleveren voor 'steun uit de omgeving'. Daarnaast is gevraagd naar de steun die de patiènt had ervaren van artsen en andere zorgverleners in het ziekenhuis. Ook hier was het de bedoeling dat er een schaal zou ontstaan voor 'steun vanuit het ziekenhuis'.

De veronderstelde samenhangen zijn met behulp van factor- en schaalanalyse onderzocht. De items uit de apriori-schaal voor 'steun uit de omgeving' blijken echter niet voldoende met elkaar samen te hangen. De gemiddelde alfa voor de drie meetmomenten is slechts .52. De items zullen daarom afzonderlijk worden besproken.

De apriori-schaal voor 'steun vanuit het ziekenhuis' viel uiteen in twee vragen naar informatieve steun, die overigens samen wel een schaal vormen, gemiddeld is alfa . 85 , alsmede een losse vraag naar emotionele steun. 


\section{$6-1$ - 1 - Steun van de omgeving}

De steun uit de omgeving is met de volgende vragen en VAS-sen geïnventariseerd:

\section{Steun van partner}

Drieënveertig patiënten hadden een partner. Aan hen zijn de volgende vragen gesteld:

- Vindt u dat uw partner $u$ tot steun is?

- Waar uit zich dat in?

- Kunt u met uw partner spreken over de dingen die u bezighouden?

De vragen werden afgesloten met de volgende VAS-vraag:

Alles bij elkaar genomen, in hoeverre voelt u zich dan gesteund? beel erg — absoluut niet

De VAS-vragen voor de andere bronnen van steun werden als volgt ingeleid:

- Je merkt wel eens bij mensen met deze ziekte dat de omgeving het moeilijk vindt om contact te zoeken. Heeft u dat ook wel eens gemerkt?

- Je hoort zelfs dat patiènten zeggen dat ze door mensen uit hun omgeving in de steek zijn gelaten. Is u dat ook overkomen?

- Het omgekeerde hoor je ook: mensen van wie je het niet verwacht, tonen juist belangstelling en zijn tot steun. Is u dat ook overkomen?

De bijbehorende VAS-sen zijn:

\section{Steun van familie}

Alles bij elkaar genomen, zijn uw ervaringen met uw familie dan naar tevredenheid?

zeer naar teuredenbeid __ absoluut niet naar tetredenbeid

Steun van vrienden

Alles bij elkaar genomen, zijn uw ervaringen met uw vrienden dan naar tevredenheid?

$$
\text { zeer naar terredenbeid —_ absoluut niet naar tevredenbeid }
$$

\section{Steun van kennissen}

Alles bij elkaar genomen, zijn uw ervaringen met uw kennissen dan naar tevredenheid?

zeer naar terredenbeid __ absoluat niet naar tetredenbeid 
- Tabel 5.21 - Ervaren steun uit de omgeving

\begin{tabular}{|c|c|c|c|c|c|c|c|c|c|c|c|c|c|}
\hline \multirow{2}{*}{\multicolumn{2}{|c|}{ Bronnen vas steun }} & \multicolumn{3}{|c|}{$\begin{array}{c}\text { Gemiddelde } \\
\text { score }\end{array}$} & \multicolumn{3}{|c|}{$\begin{array}{l}\text { Standaand- } \\
\text { deviatie }\end{array}$} & \multicolumn{3}{|c|}{$\begin{array}{l}\text { Percentage } \\
\text { Lag-scoerden }\end{array}$} & \multicolumn{3}{|c|}{$\begin{array}{l}\text { Rercentage } \\
\text { hoogsscoorden }\end{array}$} \\
\hline & & 11 & $\mathrm{~T} 2$ & $\mathrm{I3}$ & TI & $\mathbf{1 2}$ & $\mathbf{B}$ & 11 & I2 & 13 & $\mathrm{TI}$ & $\mathrm{IZ}$ & 13 \\
\hline Pather: & $n=43$ & 189 & 8.1 & 8.9 & 2.2 & 30 & 3.0 & 13 & 16 & 24 & at & 84 & 76 \\
\hline Fandile & $n=46$ & 84 & 80 & 80 & 27 & 29 & 30. & 17 & 22 & 22 & 23 & 70 & 76 \\
\hline Vienden & $n=46$ & 9.4 & 8.8 & 92 & 15 & 20 & 1.8 & 2 & 11 & 4 & 98 & 89 & 96 \\
\hline Kenvisen: & $n=46$ & 89 & 83 & 6.7. & 1.6 & 21 & 2.1 & 4 & 15 & 11 & 96 & 18 & B9 \\
\hline
\end{tabular}

Weergegeven zijn groepsgemiddelde en standaarddeviatie van de scores voor de verschillende bronnen van steun op T1, T2 en T3. Ook is vermeld welk percentage van de patiènten laag dan wel hoog scoort. Laag-scoorders hebben een score van $0 \mathrm{t} / \mathrm{m} 4$, hoog-scoorders van $5 \mathrm{t} / \mathrm{m} 9$.

Het blijkt dat de patiènten over het algemeen veel steun ervaren (tabel 5.21). De gemiddelde scores liggen voor alle bronnen en op alle tijdstippen op of boven 8.0 , terwijl het maximum van de schaal op 9.0 ligt. Tussen $T_{1}$ en $T_{2}$ neemt weliswaar de steun van partner, vrienden en kennissen (bijna) significant af (Wilcoxon-test: partner $p=.04$, vrienden $p=.01$, kennissen $p=.06$ ), maar de scores blijven hoog.

Desondanks vindt op $\mathrm{T}_{3}$ bijna een kwart van de groep zich niet voldoende gesteund door partner en familie (respectievelijk $24 \%$ en $22 \%$ ). De meest gehoorde klacht over de partner is diens moeite om over de ziekte en de daarmee gepaard gaande emoties te praten. Met name op $T_{3}$ vindt de partner dikwijls dat het nu allemaal alweer zo ver achter hen ligt, dat het niet meer logisch is om er nog over te praten. Een van de patiênten verwoordde dit als volgt:

In de periode dat ik bestraald moest worden beeft bij enorm zijn best gedaan. Ecbt waar boor. Maar bij begrijpt bet niet dat ik soms zomaar ineens stil toor me uit kan zitten kijken en er tocb nog aan denk. Voor bem is bet acbter de rug. Hij is beel eng blij dat we er zo goed vanaf gekomen zijn, en toor bem is bet terleden tijd. Hij is toch nooit een prater geuvest, boor. Hij kan bet beste belpen door iets te doen. Maar, ik zou tocb graag bebben dat bij eens zou zeggen: "Meid, ik snap bet dat je soms bang bent. "En dan alleen maar eten een arm om me been slaan, meer boeft belemaal niet." 


\section{6-1 - 2 - Steun vanuit het ziekenhuis}

De apriori-schaal 'steun vanuit het ziekenhuis' viel uiteen in twee vragen naar informatieve steun die samen een schaal vormen, alsmede een losse vraag naar emotionele steun.

\section{Informatieve steun}

De inleidende vragen voor informatieve steun en de twee bijbehorende VAS-sen luidden als volgt:

Op welke wijze bent $u$ op de hoogte gesteld van wat $u$ had?

Kon u de vragen stellen die voor $\mathrm{u}$ van belang waren?

Bent u iemand die graag alles wil weten over uw ziekte en wilt u graag betrokken worden bij de beslissingen die er genomen worden over uw behandeling?

- Vindt $u$, alles bij elkaar genomen, dat $u$ voldoende informatie en uitleg heeft gekregen over uw ziekte en de behandeling ervan?

absoluut voldoende — absoluut onvoldoende

- Vindt u dat u voldoende bent betrokken bij de beslissingen over uw behandeling?

absoluut voldoende —absoluut onvoldoende

\section{Emotionele steun}

- Hoe tevreden bent u met de aandacht die er voor u was? Met andere woorden, vindt $\mathrm{u}$ dat $\mathrm{u}$ goed bent opgevangen en begeleid in het ziekenhuis? beel erg teureden —— beel erg onteureden

- Tabel 5.22 - Ervaren steun vanuit het ziekenhuis

\begin{tabular}{|c|c|c|c|c|c|c|c|c|c|c|c|c|c|c|c|}
\hline \multirow[t]{2}{*}{$\begin{array}{c}n=46 \\
\text { ltem }\end{array}$} & \multicolumn{3}{|c|}{$\begin{array}{l}\text { Gemiddelde } \\
\text { score }\end{array}$} & \multicolumn{3}{|c|}{$\begin{array}{l}\text { Standaard- } \\
\text { deviatie }\end{array}$} & \multicolumn{3}{|c|}{$\begin{array}{l}\text { Theoretisch } \\
\text { maximum }\end{array}$} & \multicolumn{3}{|c|}{$\begin{array}{l}\text { Percentage } \\
\text { laas-scoorders }\end{array}$} & \multicolumn{3}{|c|}{$\begin{array}{c}\text { Percentage } \\
\text { hoog-scoorders }\end{array}$} \\
\hline & $\pi$ & 12 & B & $\pi$ & 12 & T3 & $\pi$ & 12 & 13 & $\pi$ & 12 & B & $\pi$ & 12 & T3 \\
\hline Informatieve strun & 16.0 & 15.2 & 16.2 & 3.0 & 29 & 2.5 & 18 & 18 & 18 & 20 & 26 & 13 & 30 & 74 & 87 \\
\hline Emotioncle strun & 700 & 73 & 7.7 & 3.6 & 3.0 & 2.6 & 9 & 9 & 9 & 33 & 28 & 26 & 67 & 72 & 74 \\
\hline
\end{tabular}

Weergegeven zijn het gemiddelde, de standaarddeviatie en de maximumscore op T1, T2 en T3, evenals het percentage patiēnten dat laag dan wel hoog scoort. Laag-scoorders scoren onder, hoog-scoorders op of boven het theoretisch middelpunt van de schaal.

Tabel 5.22 laat zien dat zowel de informatieve als de emotionele steun vanuit het ziekenhuis tamelijk hoog is gewaardeerd. $\mathrm{Er}$ is nog wel een kanttekening te plaatsen. Borstkankerpatiënten hebben zowel met chirurgen als radiotherapeuten te maken. Degenen die daarnaast aanvullend zijn behandeld met chemo- of hormoontherapie, hebben ook nog contact met een internist. De oordelen over hun behandelaars zijn 
dus samengestelde oordelen. Alle behandelaars tezamen hebben één score gekregen. Uit de commentaren bij de scoring blijkt dat de radiotherapeuten en internisten er wat de emotionele steun betreft beter af komen dan de chirurgen. Ongeveer $70 \%$ ( 32 van de 46 patiënten) geeft ongevraagd aan dat er weinig tijd, maar vooral weinig aandacht voor ze is tijdens de controles bij de chirurg. Een patiēnt gaf het als volgt weer:

De verpleegster liet me in een kamertje en zei dat ik me tan boven vast moest uitkleden. Daar zit je dan met je blote borsten op de rand van zo'n onderzoektafel. Na even uacbten kuam de cbinurg binnenstormen. Hij bad zijn jas open en de panden nan zijn jas uappenden acbter bem aan. Hij voelde aan mijn borst, zei dat bet er pracbtig uitzag en met dat bij ahueer naar de deur liep vnoeg bij boe bet tender met me ging. Ja uat zeg je dan..? Ik was te perplex voor woorden, stamelde iets van wel goed, en met de woorden "nou dat is dan prima" was bij weer weg."

Dat de gemiddelde scores desondanks hoog zijn, komt omdat de zorg van de andere specialisten zeer hoog is gewaardeerd. Voor de meeste patiènten heeft die zwaar meegewogen in hun eindoordeel. Ook de bestralingslaboranten delen in deze lof. Bovendien zijn natuurlijk niet alle chirurgen negatief beoordeeld. Over het algemeen is er veel waardering voor het werk dat zij hebben verricht zoals blijkt uit de volgende uitspraak:

Tk beb een béel klein streepje. De chirurg beeft bet zó keurig gedaan. Gelukkig maar, uant we gaan veel naar de sauna. Stel je toor als bet niet zo mooi gedaan uas. Mijn buisarts beeft mij deze cbirung aangeraden. Hij zei: die man beeft ecbt liefde voor zijn vak. Nou dat was wel te merken. En dat is tocb belangrijk, boor. Ook voor boe je geestelijk uit de strijd komt.'

Uiteindelijk komt respectievelijk $33 \%, 28 \%$ en $26 \%$ van de patiēnten op de achtereenvolgende meetmomenten tot een negatief oordeel en scoort lager dan vijf. Met behulp van Wilcoxon-toetsen is onderzocht of in de loop van de tijd significante verschillen optreden in de groepsgemiddelden. Dit bleek niet het geval.

\section{6 - 2 Relatie tussen steun en aanpassing}

Er zijn rangordecorrelaties volgens Spearman berekend tussen de scores voor ervaren steun en de schaalscores op de aanpassingindices toekomstperspectief, angst en zelfbeeld. De resultaten hiervan staan in tabel 5.23. Slechts enkele correlaties zijn significant ( $p \leq .01)$. Al deze correlaties zijn positief, dat wil zeggen dat meer steun samengaat met meer aanpassing in de vorm van meer vertrouwen in de toekomst, minder angst en een hoger zelfbeeld, maar de relaties zijn over het algemeen zwak en niet consistent over de tijd. 
- Tabel 5.23 - Samenhang tussen ervaren steun en aanpassing

\begin{tabular}{|c|c|c|c|c|c|c|c|c|c|c|}
\hline \multicolumn{2}{|c|}{ Bronnen van steun } & \multicolumn{3}{|c|}{ Tockomstperspectief } & \multicolumn{3}{|c|}{ Angst } & \multicolumn{3}{|c|}{ Zelfbeeid } \\
\hline & & $\pi$ & 12 & 13 & $\mathrm{II}$ & $\mathrm{I} 2$ & $\mathrm{~T}$ & T1 & $\mathrm{T} 2$ & 13 \\
\hline Parther & $n=43$ & .03 & $38^{\circ}$ & .20 & .20 & 22 & .16 & .10 & .17 & 26 \\
\hline Familie & $n=46$ & .28 & 25 & .05 & 28 & 31 & .01 & .18 & 37 & .03 \\
\hline Vienden & $n=46$ & .21 & $39^{\circ}$ & .12 & $36^{\circ}$ & $38^{\circ}$ & -01 & $35^{\circ}$ & $41^{*}$ & .21 \\
\hline Kennissen & $n=46$ & 31 & $38^{\circ}$ & .14 & 29 & $35^{\circ}$ & .05 & 30 & 37 & H \\
\hline $\begin{array}{l}\text { Informaticve stran } \\
\text { ziekenhuis }\end{array}$ & $n=46$ & .29 & .28 & -.02 & .11 & .15 & .10 & .09 & .09 & .23 \\
\hline $\begin{array}{l}\text { finotionele steun } \\
\text { ziekenhuis: }\end{array}$ & $n=46$ & $36^{\circ}$ & .16 & -.03 & of & .11 & -21 & -.06 & -64 & .12 \\
\hline
\end{tabular}

Weergegeven zijn de correlatie-coeificienten volgens Spearman tussen ervaren steun en aanpassing. Ervaren steun is opgesplitst naar de verschillende bronnen voor steun; aanpassing is uitgedrukt in de scores op de aanpassingschalen ("ps.01 " "ps.001).

Samenvattend kan worden geconcludeerd dat de patiënten over het algemeen veel steun ervaren. In de loop van de tijd neemt deze wel wat af, maar blijft gemiddeld hoog. De afname betreft vooral de emotionele steun van de partner, die vaak sneller

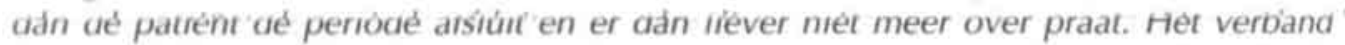
tussen de mate waarin de patiënten steun ervaren en hun aanpassing aan de ziekte is over het algemeen tamelijk zwak en niet consistent over de tijd. Daarom is besloten 'ervaren steun' niet bij de verdere analyses naar de relatie tussen cognitieve coping en aanpassing te betrekken.

\section{7 - Discrepantie tussen VerhaAl en SCORE}

In de loop van de interviews viel op dat sommige vrouwen heel anders op de VASsen scoren dan hun verhaal deed vermoeden. Een voorbeeld: een vrouw in wier kennissenkring onlangs iemand uitzaaiingen had gekregen, vertelt dat ze erg bang is en dat er geen dag voorbij gaat of ze denkt er aan dat haar dit ook kan overkomen. Als haar vervolgens wordt gevraagd om te scoren hoe zeker ze is dat ze is genezen, zegt ze: 'Als ik zeg uan fifty-fifty, wat ik diep in mijn bart denk, dan word ik gek. Dus dat zeg ik niet. Nee. ik ben een optimist, want als je dat niet bent... Nee, ik zet bem bier.' Ze zet de schuif met een klap helemaal op het uiteinde van de lijn, bij: 'Ik ben er zeker van dat ik ben genezen.'

Het leek van belang dit fenomeen nader te onderzoeken om inzicht te krijgen of het toevallige observaties betreft of dat er sprake is van een systematisch verschijnsel waar mogelijk rekening mee moet worden gehouden bij de interpretatie van de resultaten. 
De interviews, inclusief het scoren en de commentaren daarbij, zijn integraal op band opgenomen. Daardoor was het mogelijk de scoring met het verhaal te vergelijken. Per aanpassingsschaal is door wisselende koppels van twee beoordelaars bij elk van de schaal-items aangegeven of de score in overeenstemming is met het verhaal ( $=$ ), of in termen van aanpassing evident hoger $(+)$ dan wel evident lager (-). De toevoeging 'in termen van aanpassing' is van belang. Immers, bij de VAS-sen over angst geeft een score die lager is dan verwacht (dat wil zeggen, minder angst gescoord) een overschatting van de aanpassing (+) aan, omdat meer angst synoniem is aan minder aanpassing.

Het ging nadrukkelijk om duidelijke discrepanties tussen verhaal en score. De VAS van een patiènt met een ontkennend, afwerend verhaal en een overeenkomstige score is met een = beoordeeld: het verhaal is in lijn is met de score. Interpretaties zoals de redenering dat de score eigenlijk te laag is omdat de patiënt waarschijnlijk veel angstiger is dan zij durt toe te geven, zijn vermeden.

Per aanpassingsschaal is geinventariseerd welk percentage van de onderzoeksgroep over- of onderscoorde. Als vuistregel is aangehouden dat bij ongeveer de helft van de schaal-items sprake moet zijn van een discrepantie om iemand als zodanig aan te merken. In tabel 5.24 zijn deze percentages weergegeven.

- Tabel 5.24 - Discrepantie tussen verhaal en VAS-score

\begin{tabular}{|c|c|c|c|c|c|c|}
\hline \multirow{2}{*}{$\begin{array}{l}n=46 \\
\text { Schaal. }\end{array}$} & \multicolumn{2}{|c|}{$\pi$} & \multicolumn{2}{|c|}{$\mathrm{T} 2$} & \multicolumn{2}{|c|}{$\mathrm{TH}$} \\
\hline & $\%$ & \% & $\%$ & 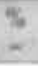 & of & $\%$ \\
\hline $\begin{array}{l}\text { Torkomsperyectiel } \\
11 \text { ian } 21\end{array}$ & 26 & 2 & 35 & 0 & 26 & 0 \\
\hline $\begin{array}{l}\text { Anget } \\
\mid 2 \text { van } 41\end{array}$ & 22 & 0 & 20 & 0 & 13 & 0 \\
\hline $\begin{array}{l}\text { Zetibeeid } \\
{[2 \text { van } 5]}\end{array}$ & 2 & 2 & 2 & 0 & 2 & 0 \\
\hline
\end{tabular}

Weergegeven is het percentage patiěnten dat op een aanpassingschaal hoger $(+)$ dan wel lager $(-)$ scoorde dan op grond van het verhaal werd verwacht. Tussen haakjes staat het aantal items vermeld van waaraf een patiênt als zodanig is geclassificeerd.

Bij een substantieel deel van de patiënten blijkt sprake te zijn van overscoring op de aanpassingschalen voor toekomstperspectief en angst. Dit wijst op een systematisch verschijnsel. Op de zelfbeeldschaal komt overscoring eigenlijk niet voor.

Onderscoring blijkt op geen van de schalen voor te komen. In hoofdstuk VI, waar de relatie tussen strategieën en aanpassing wordt besproken, wordt nader op dit verschijnsel ingegaan. 
Een substantieel deel van de patiënten scoort anders op de VAS dan uit het verhaal logisch lijkt. Systematisch wordt op de aanpassingsschalen voor toekomstperspectief en angst hoger gescoord, dat wil zeggen, in de richting van meer aanpassing dan past bij de uitlatingen over de ziekte en de gevolgen. Op de zelfbeeldschaal komt een dergelijke systematische overscoring niet voor. Op geen van de schalen is sprake van onderscoring, dat wil zeggen in de richting van minder aanpassing dan in het verhaal wordt vermeld.

\section{8 - SAmenvatting en COnclusies}

Om het zeer ruime begrip 'aanpassing aan kanker' te kunnen onderzoeken, is dit begrip verdeeld in vijf gebieden die door de ziekte kunnen worden verstoord en waarop borstkankerpatiënten zich moeten aanpassen. Voor drie ervan, toekomstperspectief, angst en zelfbeeld, zijn betrouwbare schalen ontwikkeld. Voor de overige twee, eigen invloed en schaamte, bleken de beoogde schaal-items onvoldoende met elkaar samen te hangen. Daarom zijn deze met enkele losse items in kaart gebracht. De scores op de drie aanpassingsschalen en op de losse items zijn vervolgens opgevat als indicatoren voor aanpassing aan borstkanker.

De aanpassingsgebieden zijn conceptueel goed van elkaar te onderscheiden, maar niet geheel onafhankelijk van elkaar. De relatie tussen angst en toekomstperspectief is het sterkst (rho is tussen .75 en .50 afhankelijk van het meetmoment). Ook is gebleken dat patiënten die zich schamen, over het algemeen angstiger zijn, minder toekomstperspectief ervaren en een lager zelfbeeld hebben. Zelfbeeld en 'eigen invloed' staan het meest op zichzelf en hebben weinig of geen relaties met de overige indicatoren.

De scores van de zesenveertig patiënten uit dit onderzoek geven het volgende beeld van hun aanpassing. De meeste patiënten zijn van mening dat zij weinig invloed hebben op het verloop van hun borstkanker. Desondanks is het grootste deel ven hen niet angstig en ziet de toekomst positief tegemoet. Ook lijken ziekte en behandeling niet noemenswaard van invloed op het zelfbeeld en blijken slechts weinig vrouwen zich te schamen voor hun ziekte. Afgezien van de index 'eigen invloed', is het gemiddelde aanpassingsniveau van de borstkankerpatiënten uit deze onderzoeksgroep, op alle aanpassingsindices en op alle meetmomenten, dan ook hoog tot tamelijk hoog. Hierin treden gedurende de onderzoeksperiode geen significante veranderingen op. Ondanks dit in het algemeen positieve beeld, vindt $28 \%$ van de patiënten twee jaar na diagnose $\left(\mathrm{T}_{3}\right)$ de toekomst als gevolg van de ziekte toch bedreigend en zegt $44 \%$ angstig te zijn. Voor respectievelijk $13 \%$ en $28 \%$ was dit vlak 
na de diagnose ook al zo, de overigen zijn sindsdien somberder en/of angstiger geworden. Nog eens $11 \%$ en $17 \%$ hebben de omgekeerde weg doorgemaakt, zij zijn sinds $T_{1}$ vooruitgegaan in hun scores. De rest scoorde zowel op $T_{1}$ als op $T_{3}$ hoog.

Wanneer patiènten rechtstreeks wordt gevraagd naar de verandering die tussen de verschillende interviewmomenten heeft plaats gevonden, nemen zij over het algemeen een duidelijker positie in dan uit de rekenkundige verschil-scores blijkt. Bij de vragen over de verandering van de toekomst, en of men zelf is veranderd, resulteert dit erin dat de categorie 'verbeterd' bij de patiëntenoordelen telkens meer is gevuld dan bij de rekenkundige verandering. $\mathrm{Bij}$ de vragen of men angstiger is geworden wanneer men iets voelt en of men vindt dat men door de operatie of behandeling is beschadigd, zijn de patièntenoordelen aanvankelijk eveneens positiever, maar tussen $T_{2}$ en $T_{3}$ draait dit om; de patiënten geven aan dat zij angstiger zijn geworden en zich meer beschadigd zijn gaan voelen dan uit de verschil-scores blijkt. Bovendien is het percentage patiënten dat aangeeft dat er een negatieve verandering is opgetreden ten opzichte van het vorige meetmoment op $T_{3}$ overal hoger dan op $T_{2}$. Bij de items 'beheerst door de ziekte' en 'beschadigd door ziekte en behandeling' zijn deze verschillen zelfs uitgesproken significant.

Uit dit alles blijkt dat de impact van de ziekte naar het oordeel van een substantieel deel van de patiënten toch niet afneemt. Uit hun verhalen komt naar voren dat, naarmate de tijd verstrijkt, zij zich minder beschermd voelen door de behandeling, die dan inmiddels achter hen ligt. Uitspraken als 'mijn lichaam moet het nu zelf weer doen en het heeft me al eerder in de steek gelaten' geven hier blijk van. Bovendien kunnen allerlei algemene lichamelijke klachten en klachtjes niet langer meer worden geduid als een gevolg van de behandeling. Hierdoor wordt de alarmwaarde ervan groter. De medische controles kunnen deze gevoelens niet bij iedereen wegnemen. Ook blijkt dat men er aanvankelijk alles voor over heeft om te genezen. Mogelijke gevolgen van de behandeling worden op de koop toe genomen. Later gaan diezelíde gevolgen, zoals beperkingen in het gebruik van de arm ten gevolge van het verwijderen van de okselklieren, aanhoudende moeheid en het vroegtijdig in de overgang raken door de chemotherapie zwaarder wegen.

Van een aantal variabelen is de invloed op aanpassing onderzocht. Logischerwijs zijn de patiënten die op $T_{3}$ zijn geconfronteerd met metastasen of een recidief, angstiger en somberder over hun toekomst. Verder blijkt dat patiënten die hoger zijn opgeleid over het algemeen wat meer invloed ervaren (op $T_{1}$ en $T_{2}$ ). Tenslotte zijn nog enkel verschillen gevonden die alleen gelden op $T_{1}$ : jongere patiënten zijn direct na de diagnose somberder over hun toekomst dan oudere patiènten en de patiènten die een chemokuur ondergaan, ervaren tijdens de kuur meer invloed op hun ziekte dan hun 
lotgenoten die niet met chemotherapie worden behandeld. Hun zelfbeeld is op dat moment wel wat negatiever. Vanaf $T_{2}$, na beëindiging van de kuur, zijn deze verschillen er niet meer.

De meeste patiènten hebben over het algemeen veel steun ervaren. In de loop van de tijd neemt deze wel wat af, maar blijft gemiddeld hoog. De afname betreft vooral de emotionele steun van de partner, die vaak sneller dan de patiënt de periode afsluit en er dan liever niet meer over praat. Het verband tussen de mate waarin de patiënten steun ervaren en de verschillende aanpassingsindices is over het algemeen tamelijk zwak en niet consistent. 


\section{RELATIES TUSSEN COGNITIEVE STRATEGIEËN EN AANPASSING}

In de vorige hoofdstukken is aandacht besteed aan de cognitieve strategieën van borstkankerpatiënten en de mate waarin deze patiënten zich aan hun ziekte hebben aangepast. In dit hoofdstuk komen beide onderwerpen samen in de vraag 'welke invloed hebben de cognitieve strategieën van de patiënt op het aanpassingsproces?'. Om deze vraag te beantwoorden zijn de verbanden tussen de cognitieve strategieèn en aanpassingsindices statistisch geanalyseerd. Bovendien is getoetst of vrouwen die over een rijk coping-repertoire beschikken beter zijn aangepast dan zij die zich slechts van enkele cognitieve strategieën bedienen, hetgeen volgens verschillende auteurs het geval zou zijn (Heim et al 1987, Glanz \& Lerman 1992, Jarrett et al 1992, Carver et al 1993 en 1994). Ook is geanalyseerd of causale attributies waarin sprake is van zelfbeschuldiging een grotere aanpassende waarde hebben (Janoff-Bulman1979, Malcamer \& Compas 1990).

Uit het onderzoeksmateriaal kwamen nog twee onderwerpen naar voren waaraan in dit hoofdstuk aandacht wordt besteed. Ten eerste ontstond tijdens het interviewen de indruk dat vrouwen die veel nadruk legden op bet boe en uaarom van hun ziekte slechter af waren dan de anderen. Daarnaast bleek dat een substantieel deel van de patiënten zich anders uitten in het interview dan in hun score op de aanpassings. schaal (zie hoofdstuk V paragraaf 7). De vraag rees of deze discrepantie was terug te voeren op de cognitieve strategieën van de patiënt. Beide hypotheses zijn eveneens nader onderzocht.

Dit alles heeft geleid tot de volgende onderzoeksvragen:

1 Zijn er directe relaties tussen de cognitieve strategieèn van borstkankerpatiènten en de mate waarin zij op dat moment zijn aangepast aan hun ziekte?

2 Zijn er strategieën met een voorspellende waarde voor de mate van aanpassing op latere meetmomenten?

3 Zijn er relaties tussen het gebruik van bepaalde cognitieve strategieèn en verandering in aanpassing? Dat wil zeggen, zijn er strategieën die samengaan met een stiging of daling in het aanpassingsniveau?

4 Treden er in de loop van de tijd veranderingen op in de werking van de cognitieve strategieẻn? Met andere woorden zijn er strategieën die in het begin, vlak na de diagnose, van invloed zijn en later niet meer, of waarvan de werkzaamheid in de loop van de tijd misschien zelfs omdraait in het tegendeel?

5 Is de relatie tussen een cognitieve strategie en aanpassing voor de verschillende aanpassingsmaten hetzelfde? Anders geformuleerd: zijn er strategieèn die voor een bepaalde aanpassingsindex wel werkzaam zijn en voor een andere niet of zelfs negatief uitpakken? 
6 Bestaat er een positieve samenhang tussen het aantal cognitieve strategieën waarvan een patiënt zich bedient en de mate waarin zij zich aan de ziekte heeft aangepast?

7 Wat is de relatie tussen causale attributies, zelfbeschuldiging en aanpassing?

8 is er een negatieve relatie tussen de behoefte aan een antwoord op de vraag naar bet boe en uaarom van de ziekte en aanpassing?

9 Kunnen de discrepanties tussen interviewgegevens en aanpassingscores verklaard worden uit het gebruik van bepaalde cognitieve strategieën?

Eerst komen de vragen een tot en met vijf aan bod. Daarna zal in paragraaf 2 worden ingegaan op de vragen zes tot en met acht. Aan de bespreking van vraag negen is een aparte paragraaf gewijd.

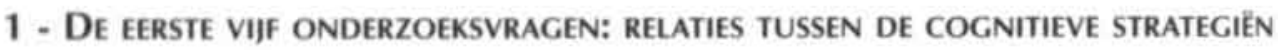 EN DE AANPASSINGSINDICES}

Voor het beantwoorden van de onderzoeksvragen één tot en met vijf is als volgt te werk gegaan:

\section{1 - 1 - Werkwijze, analyses en beslisregel}

De volgende drie soorten verbanden zijn onderzocht:

a het strategiegebruik van een patiènt in relatie tot de mate van aanpassing op datzelfde meetmoment;

b het strategiegebruik van een patiënt in relatie tot de mate van aanpassing op volgende meetmomenten;

c het strategiegebruik van een patiënt in relatie tot de verandering van aanpassing tussen twee meetmomenten;

Als maat voor bet strategiegebruik van een patiènt is per cognitieve strategie voor elk meetmoment de frequentie bepaald waarin die strategie in het betreffende interview is aangetroffen. In hoofdstuk IV paragraaf 3 is beschreven hoe dit is gedaan.

De mate van aanpassing is bij de drie aanpassingsindices waarvoor een goede schaal is gevonden - toekomstperspectief, angst en zelfbeeld - uitgedrukt in de score op de bijbehorende schaal (zie hoofdstuk V paragraaf 2). Bij 'eigen invloed', de index waarvoor geen bevredigende schaal is gevonden, is teruggevallen op de losse items 'invloed op de ziekte in het algemeen', 'invloed op de ziekte specifiek door leefgewoonten' en 
'invloed op de toekomst'. De relatie met de vijfde aanpassingsindex, schaamte, is niet verder uitgewerkt, aangezien in de onderzochte patièntengroep weinig schaamte is aangetroffen (zie hoofdstuk $V$ paragraaf 3 ).

De verandering tan aampassing is op drie manieren uitgedrukt. Op de eerste plaats is deze berekend door op de gebruikelijke wijze per aanpassingsindex de score van het ene meetmoment af te trekken van die van een eerder meetmoment. Naast deze rekenkundige maat voor verandering is ook het subjectieve patiëntenoordeel over de verandering als uitkomstmaat gebruikt'. Ten slotte is het beloop van de aanpassing nog op een derde manier geoperationaliseerd. De patiènten zijn per aanpassingsindex op elk van de meetmomenten ingedeeld in de categorie hoog dan wel laag aangepast; de hoog-aangepasten hebben een score op of boven het groepsgemiddelde, de laagaangepasten een score daaronder. Vervolgens zijn de patiènten gecategoriseerd als laagblijver, hoogblijver, laag-hoogstijger of hoog-laagdaler.

De verbanden zijn als volgt statisch geanalyseerd:

a strategiegebruik en aanpassing op hetzelfde meetmoment met

- Spearman-correlaties tussen de frequentie waarin een strategie is aangetroffen en de aanpassingsscores van dat moment,

- T-toetsen, waarbij per strategie en per aanpassingsindex is getoetst of het gemiddelde strategiegebruik van de hoog-aangepasten verschilt van de laagaangepasten;

b strategiegebruik als voorspeller voor aanpassing op volgende meetmomenten met

- Spearman-correlaties tussen de frequentie waarin een strategie op een bepaald moment is aangetroffen en de aanpassingsscores op een later meetmoment,

- T-testen waarbij voor de hoog- en laag-aangepasten van een bepaald meetmoment is onderzocht of zij verschillen in het strategiegebruik op de daaraan voorafgaande meetmomenten;

c strategiegebruik en verandering van aanpassing, zowel voor de rekenkundige verandering als voor het patièntenoordeel met

- Spearman-correlaties tussen strategiegebruik en de grootte van de verandering, waarbij rekening is gehouden met de richting van de verandering,

- univariate variantieanalyses (F-testen) tussen het strategiegebruik en verandering in aanpassing, waarbij de verandering is opgedeeld in drie categorieèn namelijk 'achteruit gegaan', 'gelijk gebleven' en 'vooruitgegaan' (zie voor criteria hoofdstuk V paragraaf 2 ).

\footnotetext{
${ }^{1}$ Als aanvulling op de score voor de actuele situatie hebben de patiénten middels een VAS-score ook zelf aangegeven in welke mate zij een verandering ervaren ten opzichte van het vorige meetmoment Dit patiêntenoordeel is bij de drie schalen ingevoerd om rekening te houden met een mogelijke response shift (zie paragraaf 4 in hoofdstuk $v$ ).
} 
Voor de rekenkundige verandering bovendien nog:

- univariate variantieanalyses tussen de mate van strategiegebruik en verandering in aanpassing, waarbij is getoetst of laag-blijvers, hoogblijvers, laag-hoogstijgers en hoog-laagdalers van elkaar verschillen in hun strategiegebruik.

Daar waar de F-test aangaf dat de groepen van elkaar verschillen is middels T-toetsen verder onderzocht op welke groepen de verschillen zijn terug te voeren.

Omdat er veel toetsen zijn uitgevoerd, is de kans op toevalsbevindingen groot. Om die reden is de volgende beslisregel gehanteerd: er is sprake van een verband wanneer er een significante relatie bestaat die bij dezelfde aanpassingsindex is aangetroffen bij meerdere analyses en/of op hetzelfde meetmoment is aangetroffen bij meerdere indices.

\section{1 - 2 - Resultaten}

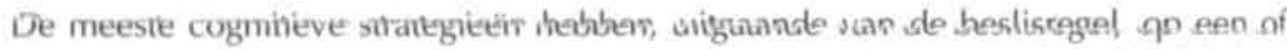
andere wijze een verband met aanpassing aan borstkanker. De verbanden bleken onafhankelijk van leeftijd, opleiding, ernst van de ziekte, aard van de behandeling en het verloop van de ziekte. De covariantie-analyses (waarvan de resultaten niet zijn opgenomen) lieten in alle gevallen een significant hoofdeffect zien. In paragraaf 1-2-1 wordt eerst beschreven welke verbanden er zijn gevonden. Vervolgens worden deze resultaten in paragraaf $1-2-2$ vertaald in een antwoord op de bijbehorende onderzoeksvragen.

\section{$1-2-1$-Verbanden tussen afzonderlijke strategieën en aanpassingsindices}

Zoals vermeld hebben de meeste van de onderzochte cognitieve strategieën een verband met de aanpassing aan borstkanker. Per strategie wordt beschreven welke dit zijn. Bij elke beschrijving staan de bijbehorende statistische gegevens. Deze zijn per aanpassingsindex gegroepeerd. Steeds wordt eerst genoemd over welke relatie het gaat. Daarbij is het meetmoment vermeld waarop de strategie betrekking heeft, evenals van de aanpassing c.q. de verandering in aanpassing. Wanneer het een verandering in aanpassing betreft, is dit aangegeven met het teken delta $(\Delta)$. Daar waar het om het patiëntenoordeel over de verandering gaat, is dit expliciet aangegeven. In de overige gevallen betreft het de rekenkundige verandering. De significante rhowaarden zijn vermeld evenals de significanties van T- en F-testen. Testen waarmee patiënten zijn vergeleken die in hun score zijn gedaald (D), gelijk gebleven (G) of 
gestegen (S), zijn gemarkeerd door de toevoeging DCS, de testen waarmee een vergelijking is gemaakt tussen hoog $(\mathrm{H})$ en laag (L) aangepasten door Ht. Tenslotte zijn nog de p-waarde van de test en het gemiddelde strategiegebruik $(M)$ van de verschillende groepen vermeld.

\section{- Causale attributies}

Er zijn geen relaties gevonden tussen het gebruik van causale attributies en aanpassing.

\section{- Uitsluitende atTributies}

Patiënten met relatief veel uitsluitende attributies weten over het algemeen niet wat de oorzaak van de ziekte zou kunnen zijn. Dit 'niet weten' terwijl de behoefte er klaarblijkelijk wel is, blijkt uit te monden in het eigen oordeel van de patiënt dat het op $\mathrm{T}_{2}$ slechter met haar gaat dan op $\mathrm{T}_{1}$. Dit geldt zowel voor het toekomstperspectief, de angst en het zelfbeeld. Er zijn geen relaties gevonden met de rekenkundige verandering in aanpassing.

\section{Toekomst (Toe)}

USA-T, en pat-oordeel $\Delta$ Toe- $_{12}$

tho $=-44$;

F-testocs $p=001, M_{0}=1.2, M_{c}=0.3, M_{s}=0.2$

\section{Zelfbeeld (ZB)}

USA-T, en pat-oordeel $\triangle Z B-\mathrm{T}_{12}$

mo= -47 ;

F-testocs $p=005, M_{p}=1.5, M_{c}=0.5, M_{3}=0.1$

\section{Angst}

USA-T, en pat-oordeel $\Delta$ Angst- $T_{12}$

tho $=-.40$;

F-testios $p=05, M_{0}=0.6, M_{C}=0, M_{3}=0.2$

\section{- Schuldontlastende attributies}

Schuldontlastende attributies hebben een positieve invloed op het zelfbeeld van een patiënt, tegelijkertijd is er een negatief effect voor de beleving van de toekomst. Patiènten die zich op $T_{1}$ relatief veel bezig houden met schuldontlasting blijken tussen $T_{1}$ en $T_{3}$ te stijgen op de zelfbeeldschaal en te dalen op de schaal voor toekomstperspectief. Deze tegengestelde werking is als volgt te verklaren. Wanneer iemand tot de conclusie komt zelf geen schuld te hebben aan hetgeen haar is overkomen, kan dit heilzaam zijn voor het zelfbeeld. Maar het betekent tegelijkertijd dat er zomaar weer iets ernstigs kan gebeuren, zonder dat dit te voorkomen is. Deze notie kan bedreigend zijn voor het toekomstbeeld. De volgende uitspraak is hiervan een voorbeeld. 
'Ik ben altijd zo bezig geweest met wat goed voor me is. I $k$ zou niet weten wat ik verkeerd beb gedaan. I $k$ beb altijd gezond geleefd. Niet overmatig, niet te dik. Je bent niet te dun, je bebt altijd gesport. Je drinkt dan wel eens een borreltje, maar ik rook niet. Dus wat beb je dan fout gedaan? Gelukkig beb ik mijzelf niets te verwijten, maar daarom is bet ook zo onbegrijpelijk. Wat kun je nog doen? Niemand geloofde dat dit mij zou kunnen overkomen.

Opvallend genoeg hebben OLA's geen negatieve relaties met één van de indices voor eigen invloed of met angst, hetgeen uit het bovenstaande wel viel te verwachten.

\section{Toekomst}

OLA-TI en $\Delta$ Toe- $_{13}$

F-testocs $p=05, M_{0}=1.7, M_{c}=1.3, M_{5}=0.5$

\section{Zelfbeeld}

OLA-T, en $\triangle Z B-T_{13}$

F-testocs $p=.003, M_{0}=3.3, M_{G}=1.5, M_{5}=4.5$

\section{- Een positieve wending Geven (PWG)}

Als de patiënt in staat is een positieve wending te geven aan de gevolgen van de ziekte heeft dit een sterk positieve invloed op de beleving van de toekomst, het zelfbeeld en het gevoel zelf invloed te hebben op de ziekte. De 'hoogblijvers' en 'stijgers' gebruiken deze strategie vaak. De consequente laag-scoorders en de dalers doen dit significant minder. Dit vermogen van patiënten om ondanks de nare kanten van de ziekte er toch iets positiefs uit te halen, heeft geen invloed op het angstniveau.

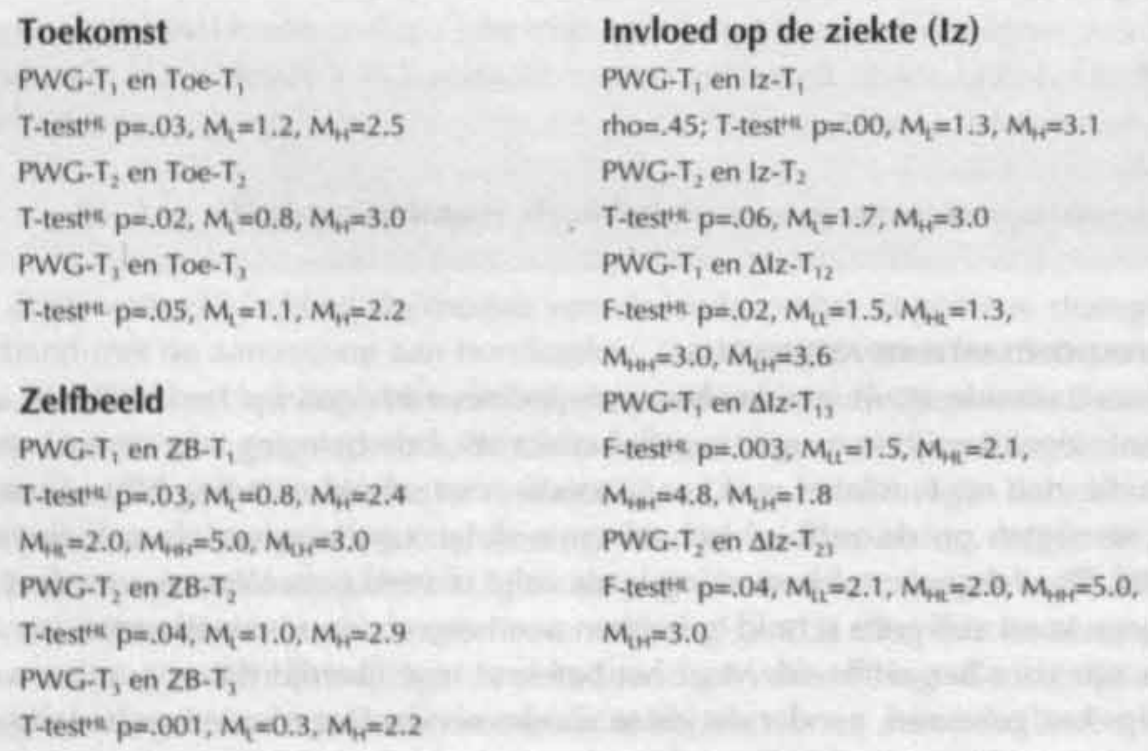

\section{Zelfbeeld}

PWG-T, en ZB-T,

T-tespic $p=03, \mathrm{M}_{\mathrm{L}}=0.8, \mathrm{M}_{\mathrm{H}}=2.4$ 


\section{- Sociale vergelijking positief naAr boven}

De vergelijking waarin patiënten zich optrekken aan anderen met wie het beter gaat, is vooral gunstig voor het gevoel zelf invloed te hebben. Patiènten die relatief veel $S^{*}$ " gebruiken, zijn op elk van de drie items voor 'eigen invloed' significant vaker hoogblijvers of stijgers. In sommige van de $\mathrm{S}^{+*}$ uitspraken komt deze relatie heel direct tot uitdrukking: 'En als ik dan die triendin zie - bet gaat zo goed met baar en zij is zo'n sterke trout - dan denk ik: ja, dat wil ik ook! Zo wil ik er ook mee omgaan. I weet zeker dat bet belpt'. Ook het zelfbeeld van de patiënt wordt positief beïnvloed. Voor deze index geldt eveneens dat hoogblijvers en de stijgers zich significant meer positief naar boven vergelijken.

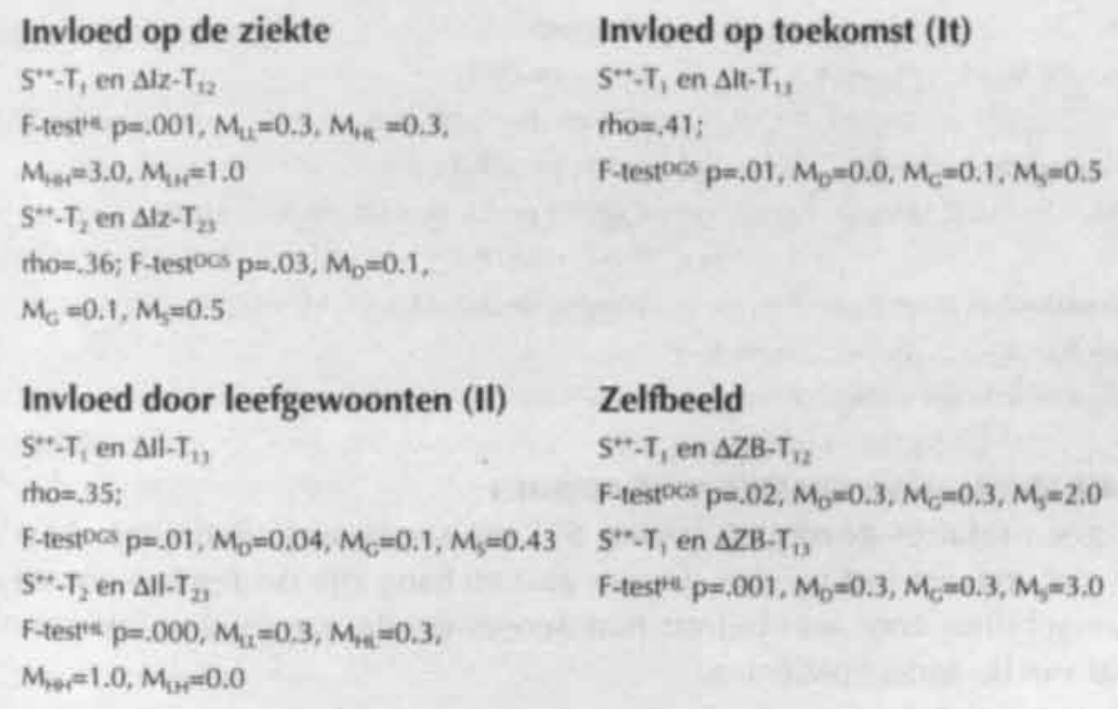

\section{- Sociale vergelijking positief naAR beneden}

Er zijn slechts enkele positieve relaties met aanpassing. Patiènten die zich op $\mathrm{T}_{2}$ vergelijken met anderen met wie het slechter gaat en vervolgens tot de conclusie komen dat ze het zelf zo slecht nog niet treffen, blijken op dat moment hun toekomstperspectief gunstig in te schatten en relatief weinig angst te ervaren. Er zijn geen relaties gevonden met het zelfbeeld.

\section{Toekomst}

S*- $\mathrm{T}_{2}$ en Toe- $\mathrm{T}_{2}$

tho=,41: T-testes $p=002, M_{2}=0.3, M_{Y}=1.3$

\section{Angst}

$S^{*}-T_{2}$ en Angst $T_{2}$

T-testes $p=.006, M_{2}=0.5, M_{4}=1.5$ 


\section{- Sociale vergeljjking negatief naAr boven}

Deze vergelijking, waarin patiënten zich slechter af voelen dan anderen met wie het beter gaat, heeft op verschillende manieren een negatieve invloed op het toekomstperspectief en het zelfbeeld. Laag-scoorders evenals laag-blijvers en dalers gebruiken de strategie significant meer dan hoog-scoorders, hoogblijvers of stijgers. Er zijn geen relaties gevonden met angst of eigen invloed.

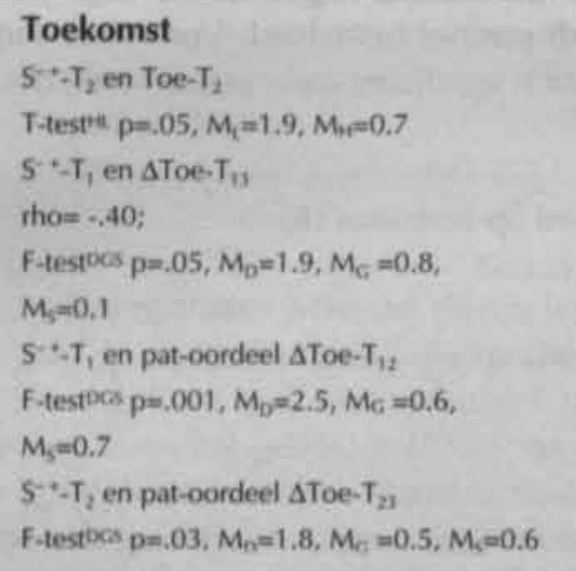

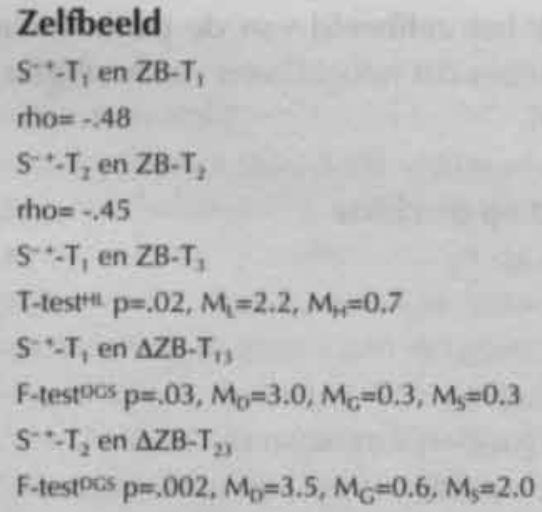

\section{- Sociale vergelijking negatief naAr beneden}

Er zijn geen relaties gevonden tussen $\mathrm{S}^{--}$en aanpassing. Patiënten die zich vergelijken met anderen met wie het slechter gaat en bang zijn dat het hen ook zo zal vergaan, verschillen voor wat betreft hun scores op de aanpassingsindices niet aantoonbaar van de andere patiënten.

\section{- Sociale vergelijking geljjkwaARdig}

De mate waarin patiënten zich vergelijken met anderen en daarbij tot de conclusie komen dat zij niet anders zijn, heeft enige invloed op aanpassing. Deze invloed is er alleen op $T_{3}$. Het blijkt negatief te zijn voor angst - 'wat die ander overkomt kan mij ook overkomen' - maar positief voor het zelfbeeld - 'het ligt in ieder geval niet aan mijzelf".

\section{Angst}

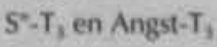

T-testh $p=04, M_{1}=1.4, M_{4}=0.6$

\section{Zelfbeeld}

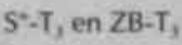

$T$-test th $p=05, M_{2}=0.3, M_{H}=1.0$ 


\section{- Zichzelf een bijzondere patiént vinden}

De mate waarin patiënten zichzelf bijzonder vinden of zich bijzonder behandeld voelen, heeft geen aantoonbare invloed op aanpassing.

\section{- Relativeren}

Relativeren heeft effect op het toekomstperspectief, op angst en op het zelfbeeld.

De.directe uitwerking op elk van deze drie aanpassingsindices is positief - hoogaangepasten relativeren significant meer dan de laag-aangepasten -, maar op de langere termijn is de uitwerking negatief. Patiènten die in de loop van de tijd achteruit zijn gegaan in hun aanpassingscores blijken op de daaraan voorafgaande meetmomenten significant meer te relativeren dan patiënten die gelijk zijn gebleven of vooruit zijn gegaan.

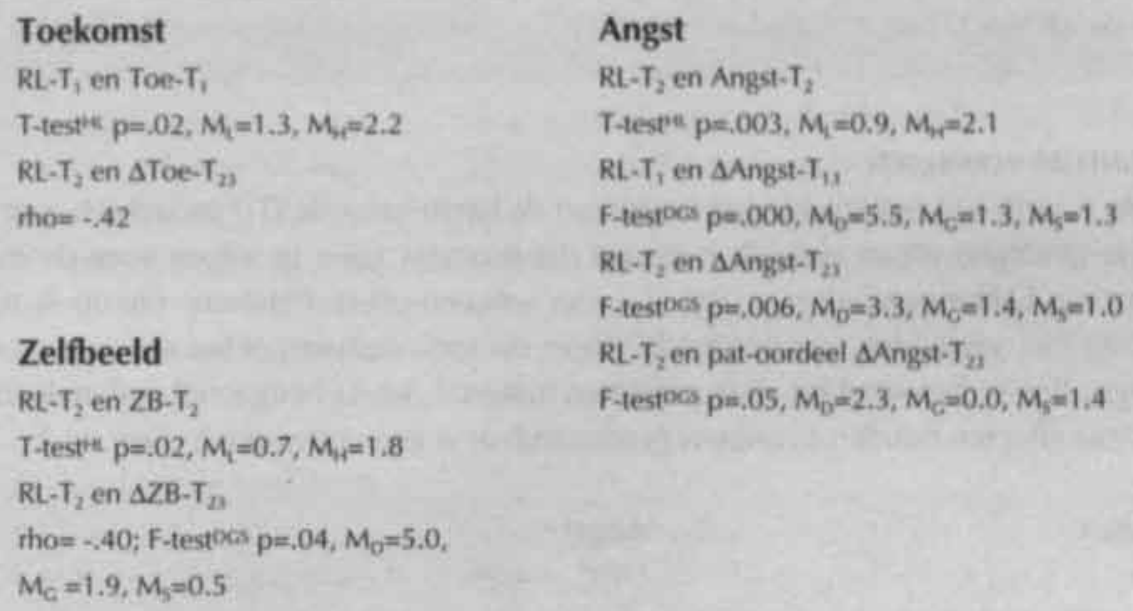

\section{Toekomst}

RL-T, en Toe-T,

T-testik $\mathrm{p}=.02, \mathrm{M}_{2}=1.3, \mathrm{M}_{2}=2.2$

$R L-T_{2}$ en $\Delta T_{\text {oe }} \mathrm{T}_{23}$

iho $=-.42$

\section{Zelfbeeld}

$R L-T_{2}$ en $Z B-T_{2}$

T-testet $\mathrm{p}=.02, \mathrm{M}_{2}=0.7, \mathrm{M}_{\mathrm{t}}=1.8$

$\mathrm{RL}-\mathrm{T}_{2}$ en $\triangle \mathrm{ZB}-\mathrm{T}_{D}$

tho= $-.40 ; \mathrm{F}$-testors $\mathrm{p}=.04, \mathrm{M}_{\mathrm{O}}=5.0$,

$M_{\mathrm{C}}=1.9, \mathrm{M}_{\mathrm{s}}=0.5$

\section{Angst}

$\mathrm{RL}-\mathrm{T}_{2}$ en Angst- $\mathrm{T}_{2}$

T-tespe $p=, 003, M_{2}=0.9, M_{4}=2.1$

$R L-T_{1}$ en $\Delta$ Angst $-T_{11}$

F-testocs $p=, 000, M_{0}=5.5, M_{c}=1.3, M_{s}=1.3$

$R L-T_{2}$ en AAngst- $T_{2}$

F-testocs $p=, 006, M_{0}=3.3, M_{c}=1.4, M_{6}=1.0$

$R L-T_{2}$ en pat-oordeel $\Delta$ Angst- $T_{23}$

F-testocs $p=05, M_{0}=2.3, M_{G}=0,0, M_{5}=1.4$

\section{- Bagateluseren}

Patiënten die hoog scoren op de aanpassingsschalen voor toekomst, angst en zelfbeeld bagatelliseren hun ziekte significant vaker dan de laag-scoorders. In die zin heeft bagatelliseren een positieve invloed op aanpassing. Voor het angstniveau is bagatelliseren ook op de lange termijn positief: hoogblijvers en stijgers - in termen van aanpassing - bagatelliseren op voorafgaande meetmomenten significant meer. Daarentegen is er een negatief lange-termijneffect gevonden voor het toekomstperspectief en het zelfbeeld. Op beide indices gaan de bagatelliserende patiënten juist achteruit in hun scores. 


\author{
Toekomst \\ BAG-T, en Toe-T, \\ T-testrel $p=.007, \mathrm{M}_{1}=0.7, \mathrm{M}_{\mathrm{H}}=1.9$ \\ $B A G-T_{2}$ en Toe- $T_{2}$ \\ rho=.50; T-testh $p=.000, M_{2}=0.1, M_{H}=1.6$ \\ BAG-T, en $\triangle T_{0 e}-T_{13}$ \\ rho $=-.42$; \\ F-testocs $p=.04, M_{0}=1.9, M_{C}=1.0, M_{s}=0.1$

\section{Zelfbeeld} \\ BAG-T, en ZB-T, \\ T-testith $p=000, M_{2}=0.0, M_{H}=1.8$ \\ BAG-T, en $\triangle Z B-T_{13}$ \\ F-testocs $p=03, M_{0}=3.7, M_{c}=1.2, M_{s}=1.8$
}

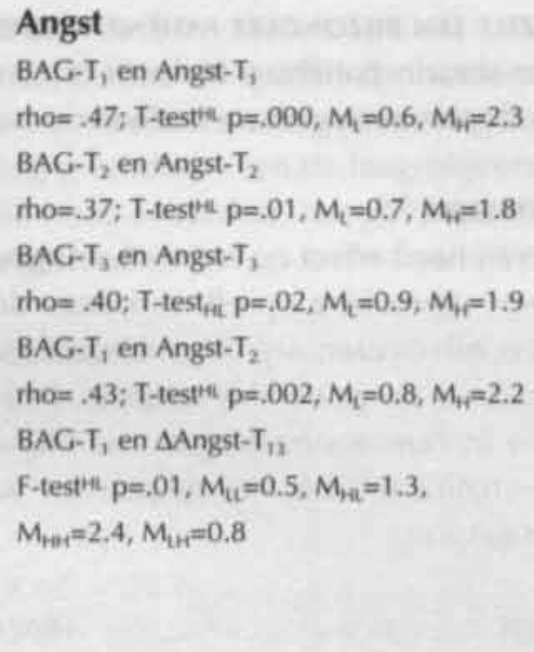

\section{- Cognitief vermijden}

De mate waarin een patiënt aan het begin van de herstelperiode $\left(\mathrm{T}_{1}\right)$ gedachten over de ziekte of de gevolgen ervan afweert, heeft op dat moment geen gevolgen voor de mate van aanpassing. Echter een half jaar later $\left(\mathrm{T}_{2}\right)$ is er wel een effect. Patiënten die op $T_{1}$ relatief veel cognitief vermijden, scoren op $T_{2}$ hoger op toekomstperspectief en rapporteren minder angst. Bovendien stijgt bij deze patiënten tussen $T_{1}$ en $T_{2}$ het gevoel zelf invloed te hebben. Deze effecten houden overigens geen stand: er is geen uitwerking meer op $T_{3}$.

\section{Toekomst \\ CV.T, enToe- $T_{2}$ \\ T-test'e $p=001, M_{2}=1.7, M_{H}=4.0$}

\section{Invloed op de ziekte}

$C V-T_{1}$ en $\Delta \mathrm{lz}_{2}-\mathrm{T}_{12}$

F-testil $\mathrm{p}=.05, \mathrm{M}_{\mathrm{L}}=3.2, \mathrm{M}_{\mathrm{hu}}=3.8$,

$M_{t a r}=8.0, M_{u r}=4.5$

\author{
Angst \\ CV-T, en Angst- $T_{2}$ \\ T-testre $p=005, M_{1}=2.5, M_{4 i}=4.4$
}

\section{Invloed op de toekomst}

$C V-T_{1}$ en $\Delta l t-T_{12}$

F-testocs $p=04, M_{0}=2.7, M_{c}=2.6, M_{s}=4.5$

\section{- Protesteren}

Van alle onderzochte strategieën blijkt de invloed van protesteren het meest uitgesproken en consistent. Naarmate patiënten meer protesteren blijken zij zich moeilijker aan te passen. Zij zijn angstiger en negatiever over hun toekomstperspectief dan de andere patiënten en hun zelfbeeld is lager. De mate van protest op het ene meetmoment blijkt bovendien een voorspeller voor aanpassing op latere meetmomenten. Zowel de 
rekenkundige verandering als het patiëntenoordeel laten zien dat patiënten die tegen de ziekte en haar gevolgen protesteren in de loop van de tijd achteruit gaan in aanpassing. Naarmate patiënten meer protesteren, ervaren zij bovendien op volgende meetmomenten minder invloed op hun toekomst dan de anderen.

\section{Toekomst}

PR-T, en Toe- $T_{1}$

tho= -35

PR-T, en Toe-T,

tho= $-.50 ;$ T-teste $p=.01, \mathrm{M}_{\mathrm{L}}=3.3, \mathrm{M}_{\mathrm{r}}=0.9$

PR-T, en Toe-T,

tho $=-\checkmark 43$

PR-T $\mathrm{T}_{2}$ en Toe- $\mathrm{T}_{3}$

tho= $-.45 ;$ - test't $p=.03, M_{2}=2.9, M_{4}=1.1$

PR-T, en $\Delta$ Toe- $_{13}$

tho= -36;

F-teste $\mathrm{p}=.05, \mathrm{M}_{\mathrm{n}}=3.5, \mathrm{M}_{\mathrm{re}}=2.4$.

$\mathrm{M}_{\mathrm{mer}}=1.3, \mathrm{M}_{\mathrm{Lr}}=0.4$

PR-T, en pat-oordeel $\Delta$ Toe $_{13}$

F-testocs $p=.003, M_{0}=4.5, M_{C}=1.4, M_{s}=1.3$

PR-T $T_{2}$ en pat-oordeel $\Delta$ Toe $_{23}$

F-testocs $p=.02, M_{0}=3.3, M_{C}=1.2, M_{5}=1.1$

\section{Invloed op de toekomst}

$P R-T_{1}$ en It-T

T-testre $p=0.01, M_{1}=2.8, M_{4}=1.1$

PR-T en It-T,

tho= $-.34 ;$ T-tespe $p=.03, M_{2}=2.8, M_{M}=1.0$

\section{Angst}

PR- $T_{\text {, }}$ en Angst-T,

thois - 38; T-testh pw.02, $M_{1}=2.8, M_{4}=1.1$

PR-T, en Angst-T,

tho= -41 ; T-teste $p=02, \mathrm{M}_{\mathrm{i}}=2.6, \mathrm{M}_{4}=0.9$

$P R-T_{1}$ en Angst- $T_{3}$

thou= -36

$P R-T_{1}$ en $\Delta$ Angst- $T_{13}$

F-testit $p=02, M_{n}=3.6, M_{m-1}=1.9$,

$\mathrm{M}_{\text {Mer }}=1.3, \mathrm{M}_{\mathrm{UH}}=0.9$

PR-T, en pat-oordeel $\triangle$ Angst- $T_{12}$

F-testocs $p=05, M_{0}=2.9, M_{c}=1.4, M_{5}=1.3$

PR- $\mathrm{T}_{2}$ en pat-oordeel Alingst- $\mathrm{T}_{21}$

F-testos $p=002, M_{0}=3.1, M_{C}=0.9, M_{3}=0.4$

\section{Zelfbeeld}

PR-T, en ZB-T,

tho $=-.63$

PR-T $\mathrm{T}_{2}$ en ZB-T

tho $=-48$

PR-T, en ZB-T,

tho= -.57: T-testre $p=.01, \mathrm{M}_{2}=4.8, \mathrm{M}_{\mathrm{r}}=1.1$

PR-T, en ZB-T,

tho= -.39; T-testel $p=.02, M_{1}=4.3, M_{4}=1.4$

PR-T $T_{2}$ en ZB-T,

tho= $=.45$; T-testet $p=.02, M_{2}=5.2, M_{4}=1.1$

PR-T, en DZB-T 13

F-testocs $p=.001, M_{0}=6.1, M_{C}=1.3, M_{5}=0.5$;

F-teste $p=005, M_{u}=5.7, M_{H u}=3.0, M_{i e r}=1.4$,

$M_{14}=1.0$

PR-T, en pat-oordeel $\triangle Z B-T_{15}$

F-testocs $p=.001, M_{0}=6.0, M_{c}=0.6, M_{s}=2.4$

PR-T $T_{2}$ en $\triangle Z B-T_{21}$

F-testocs $p=01, M_{0}=6.0, M_{C}=1.5, M_{3}=0.0$ 


\section{- Berusten}

De mate waarin patiënten in hun situatie berusten heeft invloed op het toekomstperspectief, de angst en het zelfbeeld. De directe effecten zijn positief: angstige vrouwen, vrouwen met een negatief toekomstperspectief en vrouwen met een laag zelfbeeld berusten significant minder dan de vrouwen die blijkens deze aanpassingsindices goed zijn aangepast. Het effect op de langere termijn ligt gecompliceerder. Er zijn twee tegengestelde bewegingen. Enerzijds is er een negatieve relatie tussen berusten en aanpassing: patiënten die achteruit zijn gegaan in hun scores - de dalers blijken op daaraan voorafgaande momenten significant meer te berusten dan de stijgers. De negatieve correlaties met de rekenkundige verandering in de aanpassingsscores laten eenzelfde beeld zien. Daar tegenover staat het positieve effect: ook hoogblijvers berustten op voorafgaande momenten significant meer dan laagblijvers. De positieve relaties tussen de mate van berusting en het niveau van aanpassing dat daarop volgt - berusten als positieve voorspeller voor latere aanpassing laten eveneens een positief lange-termijneffect zien. Met andere woorden, berusten helpt op het moment zelf. Voor de lange termijn is er zowel een groep patiënten die er baat bij heeft als ook een groep die achteruit gaat in haar aanpassingsscores.

\section{Toekomst}

BR-T. en Tne-T.

rho $=.72 ;$ T-testh $p=.000, M_{L}=0.6$,

$M_{H}=2.9$

BR-T $\mathrm{T}_{2}$ en Toe- $\mathrm{T}_{2}$

tho $=.44 ; \mathrm{T}$-test $\mathrm{t}+\mathrm{p}=000, \mathrm{M}_{\mathrm{L}}=0.6$,

$M_{M}=2.7$

BR-T, en Toe-T,

rho= .37; T-testrit $p=002, \mathrm{M}_{\mathrm{L}}=1.0$,

$M_{H}=2.6$

$B R-T$, en Toe- $T$,

T-tespit $\mathrm{p}=.03, \mathrm{M}_{\mathrm{L}}=1.4, \mathrm{M}_{\mathrm{H}}=2.8$

$B R-T_{1}$ en $\Delta T_{0 e}-T_{12}$

tho $=-41 ; F$-testocs $p=.03, M_{0}=2.3$,

$\mathrm{M}_{\mathrm{c}}=2.9, \mathrm{M}_{\mathrm{s}}=0.6$

BR-T, en $\Delta T_{0 e}-T_{1 s}$

F-testocs $p=006, M_{0}=3.1, M_{c}=2.7$.

$M_{5}=0.1$;

Ftest's $p=.002, M_{2}=1.0, M_{42}=1.7$.

$M_{\text {Yer }}=3.3, M_{L H}=0.2$

\section{Angst}

BR-T, en Anest-T.

Tho $=.58 ;$ T-testit $p=.000, M_{1}=1.1, M_{H}=3.3$

$B R-T_{2}$ en Angst- $T_{2}$

T-testit $p=.004, M_{L}=1.2, M_{r}=3.1$

$B R-T_{1}$ en Angst- $T_{2}$

tho= .43; T-test't $p=.002, M_{2}=1.3, M_{\mathrm{H}}=3.0$

$B R-T_{1}$ en $\Delta$ Angst- $T_{13}$

F-testit $p=.004, M_{L}=1.0, M_{\text {hit }}=3.1$,

$M_{\text {Pet }}=3.3, M_{G H}=1.1$

$B R-T_{2}$ en $\Delta$ Angst- $T_{23}$

rho $=-41$;

F-testocs $p=.01, M_{0}=5.0, M_{C}=2.0, M_{5}=1.3$

\section{Zelfbeeld}

$B R-T_{1}$ en ZB-T,

T-test $p=01, M_{2}=0.5, M_{4}=2.6$

$B R-T_{2}$ en ZB-T

T-test the $p=000, M_{1}=0.5, M_{2}=2.7$

$B R-T_{3}$ en ZB-T,

T-test th $p=03, M_{2}=0.8, M_{4}=1.9$

$B R-T_{1}$ en ZB-T

T-testik $p=04, M_{2}=1.2, M_{4}=2.6$ 


\section{- Doemdenken}

De mate van doemdenken heeft negatieve gevolgen voor het toekomstperspectief en vooral voor het angstniveau. Op $T_{1}$ zijn er geen directe gevolgen aangetoond. Klaarblijkelijk is de mate waarin een patiènt aan het begin van de herstelperiode doemdenkt nog niet van invloed op de aanpassing. Later, op $T_{2}$ en $T_{3}$, is dit wel het geval. Meer doemdenken gaat dan samen met minder toekomstperspectief en meer angst. De mate van doemdenken heeft bovendien een duidelijke voorspellende waarde voor het angstniveau op latere meetmomenten. De relatie met de rekenkundige verandering laat zien dat patiènten die doemdenken in de loop van de tijd zelís angstiger worden. Het valt op dat doemdenken geen voorspellende waarde heeft voor het toekomstperspectief.

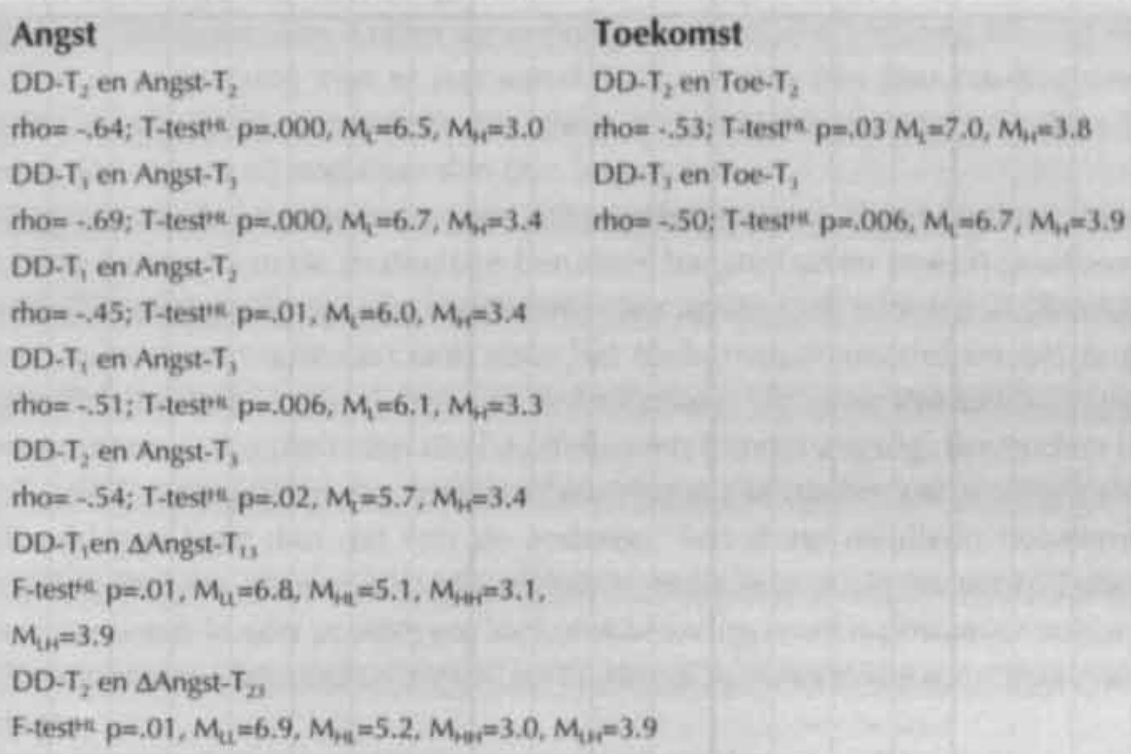

\section{Angst}

DD- $T_{2}$ en Angst- $T_{2}$

rho= - .64; T-testit $\rho=.000, M_{2}=6.5, M_{4}=3.0$

DD-T, en Angst- $T_{\text {, }}$

tho= -69; T-testre $\rho=.000, M_{2}=6.7, M_{1}=3.4$

DD- $T_{1}$ en Angst- $T_{2}$

tho= $-.45 ;$ t-teste $p=.01, M_{2}=6.0, M_{4}=3.4$

DD- $T_{1}$ en Angst- $T_{3}$

tho=-.51; T-test" $p=.006, M_{1}=6.1, M_{r}=3.3$

DD- $T_{2}$ en Angst- $T_{3}$

ho=-.54; T-testr $p=02, M_{2}=5.7, M_{H}=3.4$

DD- $T_{1}$ en $\Delta$ Angst- $T_{13}$

F-tester $p=01, M_{U}=6.8, M_{4 t}=5.1, M_{4 u}=3.1$.

$\mathrm{M}_{\mathrm{LH}}=3.9$

DD $-T_{2}$ en $\Delta$ Angst $-T_{2}$

F-testh $p=01, M_{u}=6.9, M_{p a}=5.2, M_{4 a r}=3.0, M_{u r}=3.9$

\section{Toekomst}

DD- $\mathrm{T}_{2}$ en $\mathrm{Toe}_{-} \mathrm{T}_{2}$

tho= $-.53 ;$ T-testa $\rho=, 03 \mathrm{M}_{1}=7.0, \mathrm{M}_{4}=3.8$

DD-T, $\mathrm{T}_{3}$ en Toe- $\mathrm{T}_{3}$ tho= $-50 ;$ T-testh $p=006, M_{1}=6.7, M_{4}=3.9$

\section{- ZiCHZELF tOESPREKEN}

Er is een geringe positieve invloed van 'zichzelf toespreken' op aanpassing. De mate waarin patiënten deze strategie op $T_{1}$ toepassen is gunstig voor het toekomstperspectief en het angst-niveau.

\section{Toekomst}

ZT-T, en Toe-T,

T-testre $p=008, M_{1}=1.9, M_{1}=4.2$

\section{Angst}

ZT-T, en Angst-T,

T-testet $p=04, M_{1}=2.6, M_{1}=4.3$

ZT-T, en Angst-T,

T-teste $p=002, M_{2}=2.1, M_{4}=4.6$ 
Dit alles is schematisch weergegeven in tabel 6.1. Hierin wordt een overzicht geboden van de cognitieve strategieën en de aanpassingsindices waarmee een verband is gevonden.

- Tabel 6.1 - Overzicht van de verbanden tussen strategieèn en aanpassing

\begin{tabular}{|c|c|c|c|c|c|c|c|c|c|c|c|c|c|c|c|c|c|c|c|c|c|c|}
\hline \multirow[b]{3}{*}{ Strat } & \multicolumn{4}{|c|}{$\begin{array}{c}\text { Toekomst- } \\
\text { perspectief (T) }\end{array}$} & \multicolumn{4}{|c|}{$\begin{array}{l}\text { Angst } \\
\text { (A) }\end{array}$} & \multicolumn{5}{|c|}{$\begin{array}{c}\text { Zelfbeeld } \\
\text { (ZB) }\end{array}$} & \multicolumn{9}{|c|}{$\begin{array}{ccc}\begin{array}{c}\text { op de } \\
\text { ziekte }\end{array} & \begin{array}{c}\text { op de } \\
\text { toekomst }\end{array} & \begin{array}{c}\text { door leef- } \\
\text { gewoonten }\end{array} \\
\text { (IZ) } & \text { (II) } & \text { (IL) } \\
\end{array}$} \\
\hline & \multicolumn{2}{|c|}{$\mathbf{T}$} & \multicolumn{2}{|c|}{$\Delta \mathbf{T}$} & \multicolumn{2}{|c|}{ A } & \multicolumn{2}{|c|}{$\Delta \mathbf{A}$} & \multicolumn{3}{|c|}{ ZB } & \multicolumn{2}{|c|}{$\triangle \mathrm{ZB}$} & \multicolumn{2}{|c|}{ IZ } & \multirow{2}{*}{$\begin{array}{ll}\Delta \mathrm{IZ} \\
\mathrm{R}\end{array}$} & \multicolumn{2}{|c|}{ IT } & \multirow{2}{*}{ AIT } & \multicolumn{2}{|c|}{ II. } & \multirow{2}{*}{ All } \\
\hline & $\mathrm{ZM}$ & VM & R & $\mathbf{P}$ & ZM & VM & R & $\mathbf{P}$ & $\mathrm{ZA}$ & v & & R & $P$ & ZM & VM & & $\mathrm{ZM}$ & VM & & ZM & VM & \\
\hline$\overline{C A}$ & & & & & & & & & & & & & & & & & & & & & & \\
\hline USA & & & & - & & & & - & & 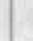 & & & - & & & & & & & & & \\
\hline OLA & & & - & & & & & & & & & + & & & & & & & & & & \\
\hline PWG & + & & & & & . & & . & + & & & & & + & & + & & & & & & \\
\hline $\mathrm{s}^{*+}$ & & & & & & & & & & & & + & & & & + & & & + & & & + \\
\hline $\mathbf{S}^{*-}$ & + & & & & + & & & & & & & & & & & & & & & & & \\
\hline $\mathrm{S}^{-+}$ & - & & - & - & & & & & - & - & & - & & & & & & & & & & \\
\hline $5^{--}$ & & & & & & & & & & & & & & & & & & & & & & \\
\hline $5^{*}$ & & & & & - & & & & + & & & & & & & & & & & & & \\
\hline SB & & & & & & & & & & & & & & & & & & & & & & \\
\hline RL. & + & & - & & + & & - & - & + & & & - & & & & & & & & & & \\
\hline BAG & + & & - & & + & + & + & & + & & & - & & & & & & 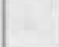 & . & & & \\
\hline $\mathrm{CV}$ & & + & & & & + & & & & & & & & & & + & & & + & & & \\
\hline PR & - & - & - & - & - & - & - & - & - & - & & - & - & & & & & - & & & & \\
\hline BR & + & + & +- & & + & + & +- & & + & + & & & & & & & & & & & & \\
\hline DD & - & & & & - & - & - & & & & & & & & & & & & & & & \\
\hline ZT & + & & & & $1+$ & + & & & & & & & & & & & & & & & & \\
\hline
\end{tabular}

Per strategie is weergegeven met welke aanpassingsindex een verband bestaat. Een + wijst op een positief verband, een - op een negatief verband. Er is een onderscheid gemaakt in verbanden tussen strategieèn en aanpassing van het zelfde meetmoment (ZM), en die tussen strategiegebruik van een bepaald moment en aanpassing op volgende meetmomenten (VM). Verbanden die betrekking hebben op verandering in aanpassing staan in de kolommen met het delta-teken $(\Delta)$. Deze laatste kolom is opgedeeld in de rekenkundige verandering (R) en het patièntenoordeel over de verandering ( $\mathrm{P}$ ). 


\section{1 - 2 - 2 - Vertaling naar de onderzoeksvragen}

Wat betekent het voorafgaande in het licht van de eerste vijf onderzoeksvragen? Per vraag wordt dit uitgewerkt.

- Zijn er directe relaties tussen de cognitieve strategieën van borstkankerpatiënten en de mate waarin zij op dat moment zijn aangepast aan hun ziekte? (vraag 1)

Het antwoord op deze vraag luidt: ja! Verschillende strategieën hebben een uitgesproken invloed op de aanpassing van dat moment. Het meest negatief is protesteren: patiënten die zich boos of verontwaardigd uiten over de ziekte en haar gevolgen, denken negatiever over hun toekomst, zijn angstiger en hebben een lager zelfbeeld. Dit geldt voor de gehele onderzoeksperiode. Ook doemdenken heeft negatieve consequenties. Echter de doemdenkers onderscheiden zich niet direct. Verschillen in aanpassing zijn er pas vanaf $\mathrm{T}_{2}$, ongeveer één jaar na diagnose. Op het tweede en derde meetmoment zijn deze vrouwen negatiever over hun toekomstperspectief en zijn zij angstiger dan hun lotgenoten.

Tegenover de negatieve invloed van protesteren en doemdenken staat de sterk positieve invloed van de strategieèn berusten, bagatelliseren en een positieve wending geven. Berusten werkt op alle meetmomenten positief uit voor het zelfbeeld en op de eerste twee meetmomenten ook voor het toekomstperspectief en het angstniveau. Bagatelliseren heeft vooral een positief effect op de gerapporteerde angst: op alle meetmomenten zijn patiënten die bagatelliseren minder angstig. Bovendien hebben zij op $T_{1}$ en $T_{2}$ een positievere toekomstbeleving en is op het eerste meetmoment hun zelfbeeld gunstiger dan dat van de anderen. Ten slotte resulteert het vermogen om ondanks de nare kanten van de ziekte er toch iets positiefs uit te halen op alle meetmomenten in een positievere toekomstbeleving en een positiever zelfbeeld. Deze patiënten ervaren bovendien zowel op $T_{1}$ als op $T_{2}$ meer invloed op hun ziekte dan de anderen.

Naast de hierboven genoemde strategieën is voor de sociale vergelijking positief naar beneden evenals voor de strategieèn relativeren en zichzelf toespreken een beperkte positieve invloed op aanpassing gevonden, en voor de sociale vergelijking negatief naar boven een beperkt negatieve. Deze strategieën hebben slechts op een enkel meetmoment of met een enkele index een verband.

\section{- Zijn er strategieën met een voorspellende waarde voor de mate van aanpassing op latere meetmomenten? (vraag 2)}

Deze vraag kan eveneens bevestigend worden beantwoord, hoewel minder voorspellende verbanden zijn aangetoond dan tussen strategiegebruik en aanpassing op hetzelfde meetmoment. 
Wederom is de relatie tussen protest en aanpassing het sterkst. Ook deze voof spellende verbanden houden gedurende de gehele periode van het onderzoek stand de mate van protest op $T_{1}$ heeft een voorspellende waarde voor het aanpassingsniveat twee jaar later op $\mathrm{T}_{3}$. Er zijn negatieve relaties met toekomstbeleving, angst, zelfbeeli en de ervaren invloed. Ook doemdenken heeft langdurige negatieve consequenties maar dan alleen voor angst.

De mate waarin patiënten berusten heeft in positieve zin de meest voorspellendt waarde. De verbanden zijn als volgt: diegenen die op $T_{1}$ meer berusten dan de anderen hebben op $\mathrm{T}_{2}$ een positievere toekomstbeleving, zijn minder angstig en hebben eer positiever zelfbeeld. Op $\mathrm{T}_{3}$ bestaat nog steeds een effect voor de toekomstbeleving niet meer voor de andere indices. De mate waarin patiënten aan het begin van hur herstelperiode in staat zijn gedachten over de ziekte en de nare gevolgen te vermijden heeft eveneens een half jaar later een gunstig effect op de beleving van de toekomst er het angstniveau.

Tenslotte is er een aantal strategieën met een beperkte invloed op latere aanpassing Zo heeft de sociale vergelijking negatief naar boven een beperkte negatieve invloed of het zelfbeeld en hebben zowel bagatelliseren als zichzelf toespreken enige positievt invloed op het angstniveau.

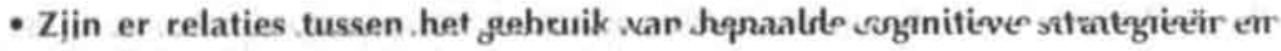 verandering in aanpassing? (vraag 3)}

Opnieuw luidt het antwoord op deze vraag ja en opnieuw blijkt dat protesteren de grootste impact heeft. Dit komt tot uitdrukking in een negatiever wordende kijk op de toekomst, in een toename van de angst en in een negatiever wordend zelfbeeld. Op elk van deze indices is er sprake van een gestage achteruitgang. Zowel de rekenkundige veranderingen alsook de patiëntenoordelen laten dit beeld zien. Protesteren is overigens de enige strategie waarbij de rekenkundige veranderingen en de patiëntenoordelen helemaal met elkaar overeenkomen, maar daarover later meer.

Ook het gebruik van de sociale vergelijking negatief naar boven, van uitsluitende en schuldontlastende attributies en van de strategieën relativeren en doemdenken gaat gepaard met een daling op een of meerdere van de aanpassingsindices.

Het aantal strategieën met positieve gevolgen voor de verandering in aanpassing ligt beduidend lager. In feite hebben alleen de sociale vergelijking positief naar boven - die waarin patiënten zich optrekken aan anderen met wie het goed gaat - en 'een positieve wending geven' een eenduidig positieve uitwerking. Het effect van de sociale vergelijking positief naar boven komt tot uitdrukking in een stijging van het zelfbeeld en een sterker wordend gevoel zelf invloed te hebben op ziekte en toekomst. Een positieve wending geven bevordert alleen het van invloed. 
Bagatelliseren en berusten hebben een gemengde uitwerking. Patiènten die de ziekte en haar gevolgen bagatelliseren zijn ongeveer twee jaar na diagnose somberder geworden over hun toekomst en negatiever over zichzelf. Daartegenover staat dat hun angst wel is afgenomen. Bij berusten ligt het anders. Hier komt de tegengestelde werking tot uitdrukking binnen dezelfde aanpassingsindex. In de vorige paragraaf bleek reeds dat patiënten die op voorafgaande meetmomenten meer berusten, significant vaker dalen dan stijgen op de scores voor toekomst en angst, maar dat patiënten die berusten ook significant vaker hoogblijvers zijn dan de laag-blijvers. Er is dus een groep patiènten die ook op termijn baat heeft bij berusten en er is een groep voor wie berusten op termijn negatief uitpakt.

Van de tien strategieën die de verandering in aanpassing beïnvloeden, hebben er zes alleen maar invloed op de rekenkundige verandering (OLA, PWG, S $\cdots, B A G, B R$ en ZT). Uitsluitende attributies beïnvloeden alleen het patiëntenoordeel over de verandering en protesteren, relativeren en de sociale vergelijking negatief naar boven behalve de rekenkundige verandering ook dikwijls het patiëntenoordeel.

\section{- Treden er in de loop van de tijd veranderingen op in de werking van de cognitieve strategieën? (vraag 4)}

De beantwoording van deze vraag kent twee invalshoeken. Ten eerste gaat het erom of de momentane effecten van de cognitieve strategieën in de loop van de tijd veranderen. Het betreft dan de relatie tussen een cognitieve strategie en aanpassing van eenzelfde meetmoment. De vraag is vervolgens hoe deze relatie zich in de loop van de tijd gedraagt. Het kan bijvoorbeeld zo zijn dat op een bepaald moment een relatie bestaat tussen een strategie en een van de aanpassingsindices, terwijl dit op een ander moment nog niet of niet meer het geval is. Ook kan de werking van een strategie omslaan van positief naar negatief of andersom. Op de tweede plaats betreft het de vraag of de momentane effecten verschillen van de effecten op de lange termijn. Zo is het mogelijk dat het gebruik van een strategie op $T_{1}$ aanvankelijk voor dat moment positief uitwerkt, maar negatieve consequenties heeft voor latere aanpassing op $T_{2}$ of $T_{3}$. In een dergelijk geval verschilt het korte-termijneffect van het lange-termijneffect.

Over de verandering in de momentane effecten van de strategieèn is het volgende op te merken. Het komt niet voor dat een strategie op het ene meetmoment een positieve en op een ander meetmoment een negatieve invloed heeft op een bepaalde aanpassingsindex. Met andere woorden, de richting van de directe verbanden draait in de loop van de tijd niet om. Wel verschillen de strategieèn in de fase waarin zij werkzaam zijn. Veel van de onderzochte cognitieve strategieën lijken in de loop van de tijd hun werking te verliezen. De relaties met aanpassing zijn er vooral op $T_{1}$ en $T_{2}$. 
Uitzonderingen zijn protesteren en een positieve wending geven. Beide strategieën be houden hun werking op alle betreffende indices ook op $\mathrm{T}_{3}$. Bagatelliseren en beruste? nemen een tussenpositie in. Deze twee strategieën hebben relaties met toekomst, ang en zelfbeeld. Over het algemeen zijn alleen verbanden aangetroffen op $T_{1}$ en $T_{2}$, maa de relatie tussen bagatelliseren en angst en die tussen berusten en zelfbeeld is er oo' op $T_{3}$. De strategieën doemdenken en cognitief vermijden wijken op een tegenover gestelde manier af van het patroon dat een strategie met name het eerste jaar werkzaar is. De werking van deze strategieën begint juist pas vanaf $\mathrm{T}_{2}$; een jaar na diagnose.

Kijken we vanuit de tweede invalshoek naar de verandering in de werking van d cognitieve strategieën dan blijken er geen verschillen tussen het onmiddellijke en he lange-termijneffect van protesteren, doemdenken, de sociale vergelijking negatief naa boven en 'een positieve wending geven'. De eerste drie strategieën hebben uitsluiten negatieve consequenties voor aanpassing, de laatste uitsluitend positieve. De korte- ef lange-termijneffecten van relativeren, bagatelliseren en berusten zijn wel verschillend Relativeren heeft voor toekomst, angst en zelfbeeld op het moment zelf een positie effect, maar gaat tevens gepaard met een daling in deze aanpassingscores op volgend meetmomenten. Bagatelliseren is zowel op de korte als op de lange termijn gunstif voor het angstniveau, maar voor het toekomstperspectief en het zelfbeeld draait he onmiddellijke positieve effect om, met als resultaat een daling op volgend

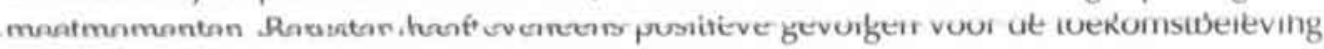
en de angst van dat moment, maar voor de lange termijn zijn voor deze indices zowel negatieve als positieve effecten gevonden. De overige cognitieve strategieën hebben geen enkele relatie met aanpassing (CA, $\mathrm{S}^{--}, \mathrm{SB}$ ), alleen een onmiddellijk effect ( $\mathrm{S}^{*-}$, $\mathrm{S}^{*}, \mathrm{ZT}$ ) of alleen een lange-termijneffect (USA, OLA, $\mathrm{S}^{++}, \mathrm{CV}$ ). Voor deze strategieën is derhalve de vraag naar de verschillen tussen korte- en lange-termijn-effecten niet van toepassing.

\section{- Is de relatie tussen een cognitieve strategie en aanpassing voor de verschillende aanpassingsindices hetzelfde? (vraag 5)}

$\mathrm{Er}$ is gebleken dat de onderzochte cognitieve strategieën over het algemeen niet op dezelfde wijze op de vier onderscheidden aanpassingsmaten uitwerken. Zo pakt de sociale vergelijking gelijkwaardig positief uit voor het zelfbeeld en negatief voor angst, en hebben schuldontlastende attributies eveneens een positieve uitwerking voor het zelfbeeld maar een negatieve voor de toekomstbeleving. Bagatelliseren heeft een positieve uitwerking op de momentane aanpassing voor zowel toekomst, zelfbeeld als angst, terwijl het lange-termijneffect voor angst positief is en voor de andere twee indices juist negatief. De overige strategieën kennen geen tegengestelde werking voor verschillende indices. Toch is ook hun effect op de afzonderlijke aanpassingsindices in 
zekere zin specifiek te noemen, aangezien zij op sommige indices wel, en op andere geen effect blijken te hebben.

\section{2 - De Onderzoeksvragen zes tot en Met ACHT}

\section{- Invloed van een rijk versus arm coping-repertoire (vraag 6)}

Op verschillende manieren is geanalyseerd of de diversiteit van het copingrepertoire invloed heeft op aanpassing. Dit kon niet worden aangetoond. Zo zijn bijvoorbeeld correlatie-coëfficiënten berekend tussen het aantal strategieèn dat een patiënt op een meetmoment gebruikt en haar scores op de verschillende aanpassingsindices. De gevonden correlaties zijn laag tot zeer laag en geen van alle significant. Ook T-toetsen tussen de extremen - patiënten met relatief weinig en met relatief veel verschillende strategieèn - leveren op geen enkel meetmoment significante verschillen op. Hoewel geen bevestiging is gevonden voor de opvatting van Heim et al (1987). Glanz \& Lerman (1992), Jarrett et al (1992) en Carver et al (1993 en 1994) is wel gebleken dat de patiènten gemiddeld tien van de zeventien onderzochte strategieèn gebruiken. Het minimum aantal dat op elk van de drie meetmoment is aangetroffen bedraagt zes (zie hoofdstuk IV paragraaf 3). In feite bevat de onderzoeksgroep dus geen patiënten met een heel beperkt repertoire. Dit impliceert dat aanpassing aan borstkanker het gebruik van meerdere strategieèn vraagt. In die zin zijn de bevindingen niet in tegenspraak met die van genoemde auteurs.

\section{- Causale attributies, zelfbeschuldiging en aanpassing (vraag 7)}

In paragraaf 1-2-1 werd duidelijk dat het gebruik van causale attributies in zijn algemeenheid geen invloed heeft op aanpassing aan borstkanker. De literatuur geeft aanwijzingen dat causale attributies waarin sprake is van zelfbeschuldiging een grote aanpassende waarde zouden hebben vooral wanneer de zelfbeschuldiging is gebaseerd op gedrag. Dergelijke attributies bieden de patiënt de mogelijkheid tot verandering waardoor, in ieder geval in haar eigen beleving, de kans op herhaling zou verkleinen. Echter niet elke zelfbeschuldiging, ook al verwijst die naar gedrag, biedt de mogelijkheid tot verandering, zoals blijkt uit de volgende uitspraak: 'Ik beb beel lang de pil geslikt. Ik wist dat bet niet goed was en bad er diep in mijn bart ook een grote weerstand tegen. Acbteraf denk ik: wat ontzettend stom dat ik toen niet beter naar mijn gevoel beb geluisterd. $1 \mathrm{k}$ bad die rotzoot nooit moeten slikken'. Andersom, niet alle attributies met mogelijkheid tot verandering zijn gebaseerd op zelfbeschuldiging. Een patiènt die zegt: 'Ik denk dat bet komt door bet voedsel. Ik leefde altijd al beboorlijk gezond, maar nu let ik nog beter op al die E-nummers', beschuldigt zichzelf niet, maar denkt toch iets te kunnen veranderen. In uitspraken als 
'Tk beb een beel ongeregeld leven geleid, gerookt, junk-food, laat naar bed en noem bet maar op. Dat kon natuurlijk niet goed gaan. Daar moest wel narigbeid vam komen. 'vallen zelfbeschuldiging en mogelijkheid tot verandering wel samen.

Om deze reden is voor de analyses zowel een onderscheid gemaakt in attributies die al dan niet aangrijpingspunten opleveren voor verandering alsook in attributies waarin al dan niet sprake is van zelfbeschuldiging. Met behulp van de Mann-Whitneytoets is onderzocht of veranderbaarheid of zelfbeschuldiging verschillen in aanpassing aan borstkanker verklaren.

Dit leverde het volgende op. Patiënten die op $T_{1}$ een oorzaak voor hun ziekte noemen, die aangrijpingspunten levert voor verandering $(n=20)$, vinden op $T_{1}$ en $T_{2}$ meer dan de anderen $(n=26)$ dat zij invloed hebben op hun ziekte $\left(p_{1}=.006 ; p_{2}=.02\right)$. De groepen onderscheiden zich niet van elkaar in hun scores op toekomstperspectief, angst en zelfbeeld. Patiënten die zichzelf op $T_{1}$ beschuldigen in hun attributie $(n=18)$, ervaren op elk van de drie meetmomenten meer invloed op hun ziekte $\left(p_{1}=.001\right.$ : $\left.\mathrm{p}_{2}=.02 ; \mathrm{p}_{3}=.01\right)$ dan de anderen $(\mathrm{n}=28)$. Opnieuw zijn geen verschillen in toekomstperspectief, angst en zelfbeeld gevonden.

Het lijkt er dus op dat met name causale attributies waarin sprake is van zelfbeschuldiging, en in iets mindere mate de causale attributies die de mogelijkheid tot verandering bieden, positief uitwerken op het gevoel zelf invloed te hebben op ziekte. Echter, dit gevoel vertaalt zich vervolgens niet in een positievere kijk op de toekomst, evenmin leidt dit tot minder angst of een positiever zelfbeeld. De theorie van JanoffBulman en de resultaten van Malcamer \& Compas zijn derhalve maar gedeeltelijk bevestigd.

\section{- De behoefte aan een antwoord op de vraag naar het hoe en waarom van de ziekte (vraag 8)}

De patiënten is verzocht om bij de vragen 'Denkt $u$ wel eens boe kom ik aan deze ziekte' (de hoe-vraag) en 'Denkt $u$ wel eens waarom ik, waarom moet mij dit overkomen?' (de waaromvraag) eveneens aan te geven of het $(\mathrm{nog})$ een belangrijke vraag voor hen was. Vervolgens is met behulp van de Mann-Whitney-toets geanalyseerd of er verschillen in aanpassing zijn tussen de patiënten voor wie genoemde vragen (nog) wel belangrijk waren en de patiënten die aangaven het geen belangrijke vragen (meer) te vinden.'

Op $T_{1}$ vond ongeveer tweederde ( 28 van 46$)$ het belangrijk een antwoord te hebben op de vraag naar de oorzaak van de ziekte (de hoe-vraag). Maar op dat eerste meetmoment is geen relatie met aanpassing gevonden. Het aantal patiënten voor wie de vraag belangrijk was, daalt tussen $T_{1}$ en $T_{2}$ behoorlijk. De acht patiënten die op $T_{2}$ aangeven dat het voor hen nog steeds een belangrijke vraag is, blijken in hun aanpas-

I De patiènten die geen causale attributie hadden $\left(n_{1}=2, n_{2}=5, n_{3}=6\right)$ gaven allen aan dat de vragen naar hoe en waarom van hun ziekte voor hen niet belangrijk waren. Zij zijn opgenomen in de groep 'niet belangrijk'. 
sing te verschillen van de anderen. Zij ervaren weliswaar meer invloed op de ziekte $\left(\mathrm{p}_{2}=.03\right)$, maar tegelijkertijd beoordelen zij hun toekomstperspectief negatiever $\left(p_{2}=.05\right)$ en zijn zij ook angstiger $\left(p_{2}=, 05\right)$. Op $T_{3}$ vinden nog steeds acht mensen het antwoord op die vraag van belang maar de relatie met aanpassing is er niet meer.

Patiènten die de waarom-vraag belangrijk vinden, onderscheiden zich op een aantal aanpassingsmaten en op een aantal meetmomenten van patiènten die deze

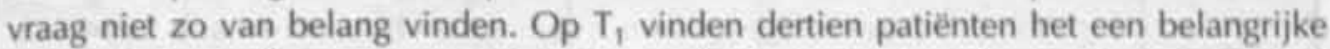
vraag. Deze patiënten ervaren niet alleen minder invloed op hun toekomst $\left(p_{1}=, 02\right)$ maar zijn ook angstiger $\left(p_{1}=.000\right)$ dan de anderen. Op $T_{2}$ en $T_{3}$ zijn zij nog steeds angstiger $\left(p_{2}=.01, p_{3}=.001\right)$ en schatten zij eveneens hun toekomst negatiever in $\left(p_{2}=.05, p_{3}=.005\right)$. Op $T_{2}$ zijn er nog maar vier patiënten die de waarom-vraag nog steeds belangrijk vinden; zij onderscheiden zich niet van de anderen. Maar op $\mathrm{T}_{3}$ is het aantal patiènten dat de vraag naar het waarom van hun ziekte belangrijk vindt weer tot tien toegenomen. Deze tien patiënten ervaren minder invloed op de toekomst $\left(p_{3}=.005\right)$, zijn angstiger $\left(p_{3}=.001\right)$ en zien hun toekomst somberder in $\left(p_{3}=, 02\right)$.

Concluderend, patiënten die zich bezighouden met de vraag naar het boe en meer nog met de vraag naar het waarom van hun ziekte zijn slechter af dan de anderen. De onderzochte relatie staat helemaal los van de cognitieve strategieën die de patiënt gebruikt. Er is namelijk op geen van de meetmomenten een noemenswaardige correlatie gevonden tussen de mate waarin de patiënt belang hecht aan deze vragen en het gebruik van welke strategie dan ook, inclusief causale, ontkennende of schuldontlastende attributies.

\section{3 - Discrepantie tUSSEN VERHAAL EN SCORE (VRAAG 9)}

Bij een deel van de patiënten bleek het verhaal dat zij over hun ziekte vertelden niet in overeenstemming met de score die zij vervolgens gaven (zie hoofdstuk V paragraaf 7). Afhankelijk van het meetmoment scoorden 26 tot $35 \%$ van de patiènten beter op de schaal voor toekomstperspectief dan op grond van het interview werd verwacht. Voor de score op de aanpassingsschaal voor angst bleek dit het geval voor 13 tot $22 \%$ van de respondenten. Met behulp van de Mann-Whitney-toets is nagegaan of degenen die beter scoorden dan verwacht, significant verschillen van de andere patiènten wat betreft hun strategiegebruik (onderzoeksvraag 9). De belangrijkste resultaten worden besproken. Tabel 6.2 geeft een overzicht. 
- Tabel 6.2 - Overscoring en strategiegebruik

\begin{tabular}{|c|c|c|c|c|c|c|}
\hline \multirow[b]{2}{*}{ strategie } & \multicolumn{3}{|c|}{ Toekomstperspectief } & \multicolumn{3}{|c|}{ Angst } \\
\hline & tijdtip & richting & p-waarde & tijdstip & richting & p-waarde \\
\hline $5 \%$ & • & $\cdot$ & $\cdot$ & $T_{1}$ & + & 78 \\
\hline $\mathrm{cV}$ & - & • & - & $I_{2}$ & + & so \\
\hline PR & $T_{2}$ & + & $\infty$ & $\bar{T}_{2}$ & + & on \\
\hline BR & - & - & - & $b_{3}$ & - & 02 \\
\hline Do & - & - & - & $\begin{array}{l}T_{2} \\
T_{1}\end{array}$ & + & $n$ \\
\hline $2 \pi$ & $T_{2}$ & + & s5 & $\mathrm{I}_{3}$ & + & or \\
\hline
\end{tabular}

Strategieèn waarbij overscoring is aangetroffen zijn weergegeven. Daarbij is af te lezen op welk meetmoment het verschil is aangetroffen evenals de richting van het verschil $1+$ is meer strategiegebruik bij de 'overscoorders', - is minder strategiegebruik bij 'overscoorders'). De p-waarden hebben betrekking op de Mann-Whitney-test waarmee de verschillen tussen de groepen zijn getest.

Patiěnten die op de angstscbaal beter scoorden dan op grond van hun verhaal werd verwacht, blijken in hun strategiegebruik op een aantal punten te verschillen van de patiēnten van wie het verhaal congruent is met hun score. Op $T_{1}$ vergelijken zij zich vaker negatief naar beneden ( $\left.\mathrm{S}^{--}\right)$. Op $\mathrm{T}_{2}$ blijken zij meer cognitief te vermijden (CV), te protesteren (PR), te doemdenken (DD) en zichzelf toe te spreken (ZT). Ook op $T_{3}$ doen zij meer aan cognitief vermijden en doemdenken. Bovendien berusten zij op $\mathrm{T}_{3}$ minder dan de andere patiënten. Patiënten bij wie een discrepantie is geconstateerd tussen het verhaal en de score op 'toekomstperspectief protesteren meer en spreken zichzelf meer toe. Op het tweede meetmoment is het verschil met de 'congruente scoorders' significant.

Hoe is dit te verklaren? Bij het scoren wordt men gedwongen het verhaal samen te vatten en een vaste positie in te nemen. In tegenstelling tot het vertellen van een verhaal, waarin gemakkelijker de ambivalentie doorklinkt, biedt het scoren minder mogelijkheid tot nuancering en tot enerzijds- anderzijds-argumenten. Dit leidt tot twee parallelle verklaringen voor een discrepantie tussen verhaal en score. De patiënten die cognitief vermijden of zichzelf toespreken lijken dit ook te doen tijdens het scoren, waardoor de scoring gunstiger uitpakt dan het meer genuanceerde verhaal, waarin ook de andere kant doorklinkt. Dergelijke 'overscoorders' zetten als het ware hun voorkeurstrategie door tijdens het scoren. De patiẻnten die relatief veel de negatieve cognitieve strategieën doemdenken, protesteren en de sociale vergelijking negatief naar beneden, gebruiken of juist weinig berusten, zouden - indien zij conform hun verhaal scoren - uitkomen op een lage score. Aangezien dit nogal confronterend is, treedt er dissonantie-reductie op. Hierdoor wordt de negatieve score opgewaardeerd en wordt hoger dan een toehoorder op grond van het verhaal van de patiënt verwacht. 
Deze wijze van dissonatie-reductie lijkt op het fenomeen dat in hoofdstuk IV paragraaf 6-2 is besproken. Daar werd geconstateerd dat ogenschijnlijk tegenstrijdige strategieën door de patiënt vaak in een adem genoemd worden, waarbij in veel gevallen de impact van een negatieve strategie werd afgezwakt door direct daarop met een positieve strategie te vervolgen. Dit patroon zet zich door in de scoring.

De scoring is klaarblijkelijk voor een deel van de patiënten zo'n confronterende daad dat daarin dezelfde cognitieve mechanismen tot uitdrukking komen als de patiënt gebruikt in andere confronterende situaties. Doordat de interviews integraal op band staan, inclusief het scoren, werd dit duidelijk. Een voorbeeld treffen we aan in het volgende fragment waarvan een deel ook in hoofdstuk $\mathrm{V}$ is geciteerd. Het betreft een vrouw in wier kennissenkring onlangs bij iemand uitzaaiingen van kanker waren geconstateerd. Dit heeft haar bang gemaakt. Er gaat geen dag voorbij of ze denkt eraan dat dit haar ook zou kunnen overkomen. Ze vertelt:

Ik wil alleen maar beter zijn. En je wilt dat bet nooit meer terugkomt. Maar dat kunnen ze je nooit zeker zeggen. Ik weet bet niet, ik tuiffel. $1 \mathrm{k}$ moet er vanuit gaan, maar dat vind ik beel moeilijk. Ik ga er namuit en ik probeer zo te leven!l Want als ik nu zou moeten leven met fifty-fifty, wat ik diep in mijn bart geloof, daar zou ik niet mee kunnen leten. Daar kun je niet mee leven. Dus ik aeg tegen mijzelf: kop op en geloof er in! Nee, daar wil ik niet aan denken'.

Als haar wordt gevraagd met een score aan te geven hoe zeker ze is dat ze is genezen, zegt ze terwijl ze zit te dubben waar ze het wijzertje van het VAS-aparaat zal zetten: Als ik zeg van fifty-fifty, wat ik dus diep in mijn bart denk, dan word ik gek. Dus dat zeg ik niet. Nee, ik ben een optimist, want als je dat niet bent... Nee, ik zet bem bier'. Ze zet de schuif met een klap helemaal op het uiteinde van de lijn bij 'ik ben er zeker tan dat ik ben genezen'. Deze vrouw wisselt in haar verhaal doemdenken af met zichzelf toespreken en cognitief vermijden. Ook tijdens het scoren spreekt zij zichzelf toe en vermijdt de confronterende score die eigenlijk hoort bij wat ze denkt. In haar verhaal kan ze de twijfel nog toelaten, bij het scoren durft zij dat niet aan.

\section{4- SAMENVATting en CONCLUSIES}

Vijftien van de zeventien onderzochte strategieèn hebben op enige wijze invloed op de aanpassing aan borstkanker. Uitzonderingen zijn de sociale vergelijking negatief naar beneden en 'zich een bijzondere patiènt vinden'; voor deze twee cognitieve strategieën zijn geen relaties met aanpassing gevonden. Over het algemeen 'werken' de strategieên vooral in het eerste jaar na de diagnose en verliezen ze vanaf $T_{2}$ hun effect. Dit geldt niet voor protesteren (uitwerking ook nog op $T_{3}$ ), en doemdenken en cognitief vermijden (uitwerking pas vanaf $\mathrm{T}_{2}$ ). 
Protesteren heeft verreweg de meeste gevolgen voor de mate van aanpassing. Hoe meer de patiënt tegen de ziekte en haar gevolgen in protest komt, des te moeizamer verloopt het aanpassingsproces. Niet alleen hebben deze patiënten een negatiever beeld over hun toekomst, maar ook is hun zelfbeeld lager en zijn zij angstiger. De invloed is bovendien langdurig en houdt over de gehele onderzoeksperiode stand, dus tot ten minste twee jaar na de diagnose. Protesteren heeft geen invloed op de mate waarin patiënten invloed op de ziekte ervaren.

Ook doemdenken en de sociale vergelijking negatief naar boven hebben substantiële, negatieve consequenties voor het aanpassingsniveau. Beide strategieën beĩnvloeden het toekomstperspectief in negatieve zin en respectievelijk ook de mate van angst en het zelibeeld.

Daartegenover staat dat patiënten die berusten, bagatelliseren of in staat zijn een positieve wending te geven aan hetgeen hun is overkomen, in het algemeen beter af zijn dan de anderen, hoewel de effecten van berusten en bagatelliseren op de lange termijn niet bij iedereen stand houden.

De overige negen strategieën hebben allemaal een beperkte invloed op aanpassing; hun effect is veel minder uitgesproken. Ofwel zijn er slechts op een enkel meetmoment relaties met aanpassing gevonden, ofwel deze relaties beperken zich tot slecht een enkele aanpassingsindex. Positieve effecten zijn gevonden van cognitief vermijden, zichzelf toespreken, relativeren en de sociale vergelijkingen positief naar boven en positief naar beneden. Uitsluitende attributies hebben een negatieve invloed en het effect van schuldontlastende attributies en sociale vergelijking gelijkwaardig zijn, afhankelijk van de aanpassingsindex waarop het effect is onderzocht, zowel positief als negatief. Voor causale attributies ligt het iets ingewikkelder. In algemene zin zijn zij niet van invloed op aanpassing. Maar die attributies waarin sprake is van zelfbeschuldiging, en in iets mindere mate de attributies die de mogelijkheid bieden tot verandering, blijken positief in te werken op het gevoel zelf invloed te hebben op de ziekte. Echter, dit gevoel vertaalt zich vervolgens niet in een positievere kijk op de toekomst. Evenmin leidt dit tot minder angst of een positiever zelfbeeld.

Patiënten die zich erg bezighouden met de vraag naar het hoe en het waarom van hun ziekte zijn slechter af dan de anderen. De onderzochte relatie staat los van de cognitieve strategieèn die de patiënt bij de beantwoording van deze vragen gebruikt.

Uit het voorgaande blijkt dat protesteren, doemdenken, zich negatief vergelijken met anderen en het zich blijven bezighouden met de vragen naar het hoe en waarom, aanpassing in de weg staan. Het lijkt van belang patiënten te helpen deze strategieën los te laten en op te schuiven in de richting van berusten en bagatelliseren en ze daarbij aan te moedigen om te onderzoeken of de situatie hun ondanks alles ook nog 
iets heeft opgeleverd. Hoewel geen verschillen zijn gevonden tussen patiěnten die een zeer uitgebreid scala aan strategieën aanwenden bij de aanpassing aan de ziekte en patiēnten met een relatief beperkter coping-arsenaal, lijkt het toch van belang om over een uitgebreid coping-arsenaal te beschikken. Geen van de patiënten gebruikte minder dan zes verschillende strategieèn, gemiddeld zelis tien van de zeventien. Dit wijst erop dat de aanpassing aan een veelomvattende situatie, zoals de confrontatie met borstkanker, het gebruik van meerdere strategieèn vraagt.

Tenslotte nog enkele opmerkingen met een wat meer theoretische en methodologische strekking. Er is gebleken dat de meeste van de onderzochte strategieén niet op elke aanpassingsindex in gelijke mate of op dezelfde wijze van invloed zijn. Soms is de invloed op verschillende indices zelis tegengesteld. Het lijkt derhalve van belang bij het onderzoek naar het effect van copingstrategieèn het algemene begrip 'aanpassing aan kanker' op te splitsen in concrete te onderscheiden domeinen, zoals bijvoorbeeld toekomstperspectief, angst en zelfbeeld.

Ook is gebleken dat de discrepantie tussen het verhaal en de scoring, die bij 13-35\% van de patiènten is aangetroffen, in ieder geval gedeeltelijk wordt verklaard uit de cognitieve strategieèn van de patiënt. De ambivalentie die het verhaal wel toelaat kan niet tot uitdrukking komen in de scoring. De score wordt dan, via twee verschillende mechanismen, in positieve zin bijgesteld. Diegenen die tijdens het interview cognitief vermijden of zichzelf toespreken, zetten deze strategie voort tijdens het scoren. Patiënten die relatief veel protesteren, doemdenken en zich negatief naar beneden vergelijken, en diegenen die relatief weinig berusten, zwakken de confronterende score die dit zou opleveren af door tijdens het scoren als het ware met een positieve strategie te vervolgen. Dit heeft consequenties voor de interpretatie van de scores. 


\section{VAN ONDERZOEK NAAR THEORIE EN VAN THEORIE NAAR PRAKTIJK}

\section{1 - Probleemstelling en Onderzoeksvragen}

Er zijn veel publicaties over aanpassing aan kanker, maar er zijn weinig consistente resultaten gevonden. Zowel wat betreft het proces van aanpassing, coping genoemd, als over de mate van aanpassing die wordt bereikt, is geen eenduidigheid. Beide zijn het gevolg van een veelheid aan methodologische problemen.

In de copingliteratuur zien we een wildgroei aan containerbegrippen en factoranalytische samenvoegsels, die vervolgens copingstrategieèn zijn genoemd. Het is onduidelijk wat deze precies inhouden en hoe zij zich tot elkaar verhouden. Ook is het effect van coping dikwijls onderzocht in verschillende fasen van het aanpassingsproces en zijn er verschillende uitkomstmaten gebruikt. Bovendien is er het fundamentele methodologische probleem of mensen eigenlijk wel in staat zijn over hun copinggedrag te rapporteren ${ }^{1}$.

Over de mate waarin kankerpatiënten slagen zich aan hun ziekte aan te passen, merkt Spiegel (1997) op dat de wijze waarop de onderzochte problematiek is gedefinieerd van groot belang is voor het onderzoeksresultaat. Wanneer aanpassing wordt uitgedrukt in algemene kenmerken van angst en depressie, zouden de specifiek aan kanker gerelateerde problemen niet zichtbaar en daardoor onderschat worden (Nelson et al 1994). Naast de definiëring is de onderzoeksmethode van invloed op de resultaten. Studies gebaseerd op diepgaande interviews geven een genuanceerder beeld van de problematiek en laten meer problemen zien dan die waarin louter vragenlijsten zijn gebruikt (Breedveld \& Van Dam 1991, Heyink \& Tijmstra 1991 , Shedler et al 1993). Zo kan het gebeuren dat enerzijds het beeld naar voren komt dat kankerpatiënten er psychologisch gezien niet slechter aan toe zijn dan een gezonde populatie, terwijl de meeste auteurs het er toch wel over eens zijn dat kanker, méér dan de meeste andere ziekten, vanaf de aanvang het psychisch evenwicht ontregelt (Schrameijer \& Brunenberg 1992). De alledaagse ervaringen van artsen, verpleeg. kundigen en andere hulpverleners wijzen eveneens in deze richting.

Hoewel in het effect van coping op aanpassing aan kanker weinig consistente resultaten zijn aangetroffen, lijkt het copingconcept wel bruikbaar. Immers, zowel uit de klinische praktijk als op basis van common sense blijkt dat mensen een bedreigende situatie proberen te beheersen, op te heffen, te reduceren of te tolereren, op een wijze zoals in de copingtheorie wordt beschreven. Tevens is het evident dat sommige copingstrategieën vaker tot succes leiden dan andere. Bij de opzet van deze studie is

\footnotetext{
${ }^{1}$ Zie ook Coyne 2000 voor een inventarisatie van de problemen in het copingonderzoek
} 
daarom aan het copingconcept vastgehouden, maar is tegelijk gezocht naar een oplossing voor de genoemde problemen.

Het onderzoek heeft zich toegespitst op cognitieve coping, omdat tegen de feitelijke aantasting of bedreiging van de gezondheid slechts beperkt actie kan worden ondernomen. Veeleer zou er een vorm van psychologische beheersing plaatsvinden, die zich niet zozeer richt op het veranderen van de situatie, maar op de beleving ervan. De beoordeling van wat de situatie betekent, en de inschatting van de eigen vaardigheden, spelen een cruciale rol, meer nog dan de objectieve aspecten ervan. Daarom bestaat aanpassing aan kanker, en andere ernstige ziekten, voor een belangrijk deel uit de cognitieve component van het copingproces. Onderzoek naar bijvoorbeeld kwaliteit van leven wijst eveneens in deze richting (Filipp et al 1990, De Haes et al 1991, Dunkel-Schetter et al 1992, Boer et al 1992, Edgar et al 1992, Glanz \& Lerman 1992, Carver et al 1993, Heyink 1993, Sensky 1997).

Uit de literatuur bleek duidelijk dat onderscheid gemaakt moest worden tussen de verschillende fasen van het aanpassingsproces. Daarom is gezocht naar een homogene onderzoeksgroep bestaande uit patiënten die aan het begin van hun aanpassingsproces stonden en die vanwege het longitudinale design tevens een goede medische prognose hadden. De keuze is gevallen op vrouwen met borstkanker omdat hun ziekte-stadium goed is vast te stellen, hun behandeling uniform en geprotocolleerd is, zij over het algemeen een tamelijk goede prognose hebben en de incidentie van deze vorm van kanker hoog is (in Nederland krijgt ongeveer één op de tien vrouwen deze ziekte).

Gezien deze overwegingen werd de centrale vraag van dit proefschrift: Wat is de relatie tussen cognitieve coping en aampassing aan borstkanker? Deze vraag is opgesplitst in de volgende deelvragen:

- Welke cognitieve strategieën gebruiken borstkankerpatiënten gedurende de eerste twee jaar na hun behandeling?

- Treden er in de loop van de tijd veranderingen op in het strategiegebruik?

- Wat is de relatie tussen de cognitieve strategieën en aanpassing?

- Is deze relatie onafhankelijk van de tijd die sinds de diagnose is verstreken? Met andere woorden, is de relatie tussen cognitieve strategie en aanpassing op de verschillende meetmomenten dezelfde?

De antwoorden op de onderzoeksvragen zijn gezocht in de openhartige verhalen van uiteindelijk zesenveertig vrouwen. Vanaf het beëindigen van de bestraling - het moment waarop het fysieke en emotionele herstel begint en de patiënten hun rollen en sociale activiteiten weer moesten oppakken - hebben zij gedurende de eerste twee jaar na de diagnose, op drie verschillende meetmomenten, verteld wat hen bezighield en hoe het hen is vergaan. In de komende paragrafen worden de resultaten belicht 
vanuit drie verschillende perspectieven: allereerst vanuit een methodologische invalshoek, vervolgens worden de resultaten gekoppeld aan de theorieèn over aanpassing en tenslotte volgen enkele aanbevelingen voor de praktijk.

\section{2 - Methodologische Reflecties}

'Mensen doen niet wat ze zeggen en zeggen niet wat ze doen'. Deze uitspraak deed Piet Vroon ooit in een radioprogramma van de VPRO. Een variant hierop is 'mensen zeggen niet wat ze echt vinden en vinden niet wat ze zeggen'. Naarmate het meer gaat om wezenlijke onderwerpen zijn beide uitspraken des te meer waar. Meerdere oorzaken liggen ten grondslag aan deze discrepanties. Gedeeltelijk hebben ze betrekking op de methode van gegevensverzameling, bijvoorbeeld dat men zich niet herkent in de voorgeschreven vragen en antwoordcategorieēn, of zich niet voldoende uitgenodigd voelt het achterste van zijn tong te laten zien. Daarnaast zijn er redenen van meer algemene aard, zoals de neiging sociaal-wenselijk dan wel egodefensief te antwoorden. Ook zijn er enkele argumenten die specifiek betrekking hebben op het onderzoek naar coping. Vooral is van belang of mensen eigenlijk wel in staat zijn over hun eigen copinggedrag te rapporteren (Lazarus 1993, Jarrett et al 1992). Tenslotte speelt nog het verschijnsel response sbift. De 'vertekening' ligt dan niet bij de onderzochte - deze rapporteert wel degelijk wat hij er echt van vindt - maar ligt in de rekenkundige benadering van de onderzoeker, die ervan uitgaat dat de standaard waartegen de ondervraagde zijn ervaring afzet niet verandert in de loop van het onderzoekstraject, terwijl dit dikwijls wel het geval zou zijn (Sprangers 1999, Heyink 1993 en Breedveld \& Van Dam 1991).

Toch is de psycholoog-onderzoeker voor het verzamelen van zijn gegevens in hoge mate aangewezen op de mededelingen van de personen die hij onderzoekt. Dit is een van de belangrijkste redenen waarom onderzoek naar psychologische processen vaak zo lastig is en er dikwijls tegenstrijdige resultaten worden gevonden.

\section{2 - 1 - Onderzoeksmethode}

Bij de opzet van de onderhavige studie is een serieuze poging gedaan voor de methodologische problemen zoveel mogelijk oplossingen te vinden. Essentieel is dat zo dicht mogelijk wordt aangesloten bij de belevingswereld van de patiënt, maar dat er tegelijkertijd methodisch te werk wordt gegaan, en dat de methode liefst ook de mogelijkheid tot kwantificering en statistische bewerking biedt. Daarom is het persoonlijke verhaal over de ervaringen, angsten, twijfels, en de wijze waarop er is omgegaan met de diagnose borstkanker en de gevolgen daarvan, niet alleen als 
onderwerp van studie genomen, maar tegelijkertijd ook als de methode waarlangs de gegevens zijn verzameld (zie ook Bonarius 1988). Er is een combinatie gemaakt van een diepte-interview en een vragenlijst, waarbij de kankerspecifieke vragenlijst-items in de vorm van een Visueel Analoge Schaal (VAS) zodanig in het interview zijn verweven, dat deze met elkaar een eenheid vormen. Zo is getracht de onvruchtbare dichotomie tussen kwantitatief en kwalitatief onderzoek te vermijden, terwijl $\mathrm{\epsilon}$ tegelijkertijd naar is gestreefd de kloof tussen onderzoek en klinische praktijk $\mathrm{e}$ overbruggen, door inzichten en vaardigheden uit deze verschillende achtergronden $\mathrm{e}$ combineren. Met behulp van dit interview zijn de cognitieve strategieën van de patiènten geïnventariseerd, en is de mate van aanpassing aan de ziekte vastgesteld.

\section{2-1 - 1- Inventarisatie en definiëring van de cognitieve strategieën}

Het verhaal over de ziekte geeft een inkijk in de wijze waarop de patiënt met haar ziekte omgaat. De citaten in dit proefschrift laten heel duidelijk zien hoe persoonlijk en idiosyncratisch de gedachten van de patiënten dikwijls zijn. Juist vanwege dt idiosyncratische karakter is het onmogelijk om deze gegevens met een voorgestructureerde copingvragenlijst naar boven te halen. Bovendien zijn veel mensen zich niet bewust dat zij bagatelliseren wanneer ze de ziekte een 'tumortje' noemen, of dat zij zich negatief met anderen vergelijken wanneer zij verzuchten dat hun zus aan de ziekte is overleden. Het is niet voor niets dat Lazarus in 1993, na een indrukwekkende carrière als copingonderzoeker, voorstelt om precies te beschrijven wat een persoon denkt en doet, om vervolgens door een 'professional observer' te laten benoemen van welke copingstrategie er sprake is. Deze opmerking van Lazarus sluit aan bij onze klinische ervaring dat alleen op basis van concrete uitspraken, waarvan duidelijk is wat de persoon er precies mee bedoelt, inzicht kan worden verkregen in de wijze waarop deze persoon probeert de situatie het hoofd te bieden. Dit was een belangrijke overweging om de cognitieve strategieën uit het interview te destilleren.

Omdat een antwoord is gezocht op de brede vraag 'welke cognitieve strategieën gebruiken borstkankerpatiënten?', zijn heel veel uitspraken tegen het licht gehouden. Deze waren niet gemakkelijk eenduidig in te delen, aangezien voor de meeste cognitieve strategieèn geen goede definitie voor handen was. Aan de definities is derhalve veel aandacht besteed. Gaandeweg bleek dat een aantal strategieèn elkaar zodanig overlapte dat zij definitorisch niet waren te scheiden. Ook Van Zuuren (1995) merkte op dat psychische verschijnselen nu eenmaal meervoudig gedetermineerd zijn en dikwijls meerdere functies tegelijk kunnen vervullen, waardoor één en hetzelfde fragment potentieel twee elementen in zich kan bergen. Zij verbond hieraan de conclusie dat dergelijke fragmenten per definitie niet eenduidig zijn in te delen, maar dat dit aan het bestaansrecht van de afzonderlijke categorieën geen afbreuk doet, 
zolang er ook fragmenten bestaan die voor slechts één van beide categorieèn representatief zijn en als zodanig door verschillende beoordelaars worden herkend. Het laatste deel van haar conclusie lijkt redelijk, maar aan het eerste deel is wel iets af te dingen. Immers, wanneer overeenstemming bestaat dat een bepaalde uitspraak een 'dubbele functie' heeft, en deze beide functies kunnen expliciet worden benoemd, dan kan dit ook in de categorisering tot uitdrukking worden gebracht. De uitspraak is vervolgens wél eenduidig in te delen, wat een van de eisen is voor herhaalbaarheid en daarmee voor betrouwbaarheid van de methode. Daarom is in dit onderzoek het begrip dubbelstrategie geïntroduceerd. Hiermee is een oplossing gevonden voor dit fundamentele probleem. De 'ontdekking' van dubbelstrategieèn heeft overigens veel te maken met de gevolgde iteratieve methode. Namelijk door de letterlijke uitspraken op inhoudelijke argumenten steeds opnieuw te ordenen, totdat er een bevredigende oplossing was gevonden.

Op basis van de uitspraken uit de eerste interviewronde is een lijst van zeventien cognitieve strategieèn ontstaan, die door borstkankerpatiënten worden gebruikt. Hoewel de uitspraken uit de vervolginterviews vanzelfsprekend niet letterlijk gelijk waren aan die uit de eerste ronde, konden ook deze uitspraken goed in de lijst worden ondergebracht en waren er geen verdere aanpassingen nodig. Zo diende de analyse van het tweede en derde interview als een validering van de definities en scoringsafspraken. Op grond van deze ervaring lijkt de conclusie gerechtvaardigd dat de werkwijze bruikbaar en valide is en dat met de zeventien benoemde cognitieve strategieèn voor een belangrijk deel de cognitieve arbeid van de patiënten in kaart is gebracht.

Over het begrip 'cognitieve strategie' moet nog worden opgemerkt dat deze is gebruikt voor alle cognitieve arbeid die een vrouw verricht bij de aanpassing aan haar borstkanker. Daarbij is geen onderscheid gemaakt tussen appraisals en cognitieve coping. In theorie begint het copingproces bij de inschattingen van de situatie - de zogenaamde primary appraisals - en volgt daarna de copingstrategie, waarna het resultaat wordt geèvalueerd - de secondary appraisals. Echter, sommige inschattingen zijn tevens een strategie. Immers, wanneer bijvoorbeeld de situatie te licht wordt ingeschat, is de coping al begonnen, want er wordt tijdens de inschatting ook meteen gebagatelliseerd. Wanneer daarna het resultaat van de actie wordt geèvalueerd, en de conclusie wordt getrokken dat men het in vergelijking met anderen nog niet zo slecht heeft gedaan, is er sprake van een sociale vergelijking. Ook bij de evaluatie kunnen dus appraisals en coping door elkaar lopen. Het bleek in de praktijk niet mogelijk beide concepten goed van elkaar te scheiden.

De term 'strategie' impliceert dat het een bewuste, intentionele actie betreft. Dit is niet altijd het geval. De strategieèn zijn te plaatsen in een continuüm, waarbij zichzelf toespreken het meest bewust gebeurt en een aantal vormen van cognitieve vermijding 
en bagatelliseren het minst bewust plaatsvindt. Hier bleek het in de praktijk eveneens niet mogelijk een eenduidige scheiding aan te brengen tussen bewuste, intentionele coping en de meer onbewuste, niet-intentionele vormen. Derhalve is ook de minder 'strategische' cognitieve arbeid cognitieve 'strategie' genoemd.

\section{2 - 1 - 2 - Operationalisering van aanpassing en hoe scoren mensen?}

Het bleek niet storend het interview op gezette tijden te onderbreken om de patiënt een VAS-score te laten toekennen aan hetgeen ze zojuist had verteld. Deze werkwijze leverde voor drie van de vijf aanpassingsindicatoren een betrouwbare schaal op. Met behulp van deze schalen is gekwantificeerd in hoeverre de patiënt in staat was zichzelf ondanks de ziekte een toekomstperspectief te scheppen, haar zelfbeeld te handhaven en de angst tengevolge van de diagnose te pareren. De beoogde schaalitems voor de twee overige aanpassingsindices, namelijk het gevoel zelf invloed te hebben op de ziekte - betiteld als eigen invloed - en de mate waarin er sprake is van schaamte over de ziekte, bleken onvoldoende samen te hangen. Deze indicatoren zijn derhalve met enkele losse VAS-items in kaart gebracht.

Om rekening te houden met een eventuele response shift is bij een aantal belangrijke items in het tweede en derde interview gevraagd ook te scoren in hoeverre er iets was veranderd ten opzichte van het vorige interviewmoment. Vervolgens is dit patiëntenoordeel over de mate van verandering vergeleken met de rekenkundige verandering.

Door deze methode van gegevensverzameling konden kwantitatieve vragenlijstgegevens en kwalitatieve interviewgegevens in hun onderlinge samenhang worden onderzocht en begrepen. Daardoor werd tevens duidelijk waar de verschillen in resultaten, zoals in de literatuur aangetroffen, aan zijn toe te schrijven. Een drietal thema's bleek daarbij van belang.

\section{Eerste thema: discrepantie tussen verhaal en score}

Al eerder in dit proefschrift is de vrouw opgevoerd die vertelde erg bang te zijn voor uitzaaiingen. Toen haar werd gevraagd de bijbehorende VAS te scoren, koos zij het uiteinde van de schaal bij 'ik ben er zeker van dat ik ben genezen', terwijl ze daarbij zei: 'als ik zeg tan fifty-fifty, wat ik diep in mijn bart denk, dan word ik gek. Dus dat zeg ik $n i e t$. Nee, ik ben een optimist, want als je dat niet bent... Nee, ik zet bem bier boor'. Haar score kwam als kwantificering geenszins overeen met hetgeen ze daarvoor had verteld. $\mathrm{Zij}$ bleek geen uitzondering te zijn. Afhankelijk van het meetmoment blijkt op de aanpassingsschaal voor toekomstperspectief tussen 16 en $35 \%$ van de patiènten beter te scoren, dat wil zeggen in de richting van meer aanpassing, dan past bij hun 
uitlatingen in het interview. Voor de angstschaal is dit het geval bij 13 tot $22 \%$ van de patiënten. Op de zelfbeeldschaal kwam een dergelijke systematische overscoring niet voor. Op geen van de schalen was sprake van onderscoring, i.e. minder aanpassing dan verwacht. De gevonden discrepanties zijn in lijn met de constatering van Breedveld en Van Dam (1991) en Heyink en Tijmstra (1991) dat diepgaande interviews een ander beeld opleveren dan vragenlijsten - ongeacht of deze vragenlijsten specifiek zijn voor aan kanker gerelateerde problematiek - en dat in de vragenlijstscores sprake is van een onderrapportage van klachten, i.e. een overscoring van aanpassing. Eveneens lijken er parallellen met het verschijnsel dat Shedler $\boldsymbol{t} t$ al (1993) beschreven in hun artikel 'The illusion of mental health'. Zij selecteerden een groep personen die allen zodanig scoorden op een aantal vragenlijsten voor angst en depressie, dat zij in de categorie 'geen problemen' vielen. Vervolgens lieten zij ervaren clinici op grond van een diagnostisch gesprek een oordeel vellen. Deze concludeerden dat een deel van de respondenten, in tegenstelling tot de score op de lijsten, wel degelijk angstig waren of tekenen van depressie vertoonden. Interessant is dat een aantal fysiologische parameters, zoals huidweerstand en hartslag tijdens het verrichten van een stressvolle taak, hoog bleek te correleren met het oordeel van de clinici. Dit was niet het geval wanneer een willekeurige groep studenten de respondenten beoordeelden. Met andere woorden, de clinici zouden met een diagnostisch interview in staat zijn de vals negatieven (geen problemen op de vragenlijst, maar in werkelijkheid waarschijnlijk wel) te scheiden van de echte negatieven (geen problemen), waarbij hun oordeel gesteund werd door de wijze waarop de patiënten fysiologisch op stress reageerden. Analoog aan het onderzoek van Shedler lijken de borstkankerpatiènten met een goede score op de schalen voor toekomstperspectief en angst, uiteen te vallen in een deel dat werkelijk is aangepast en een deel waarbij dit op zijn minst twijfelachtig is.

Hoe is de discrepantie tussen score en verhaal te begrijpen? Nader onderzoek wees uit dat de over-scoorders zich significant onderscheiden wat betreft hun strategiegebruik. In hun verhaal werd relatief veel cognitief vermijden, zichzelf toespreken, doemdenken, protesteren en de sociale vergelijking negatief naar beneden, aangetroffen. De interviews staan integraal op band, inclusief het scoren en de afwegingen die daarbij werden geuit. Daaruit bleek dat voor het ontstaan van een discrepantie in ieder geval twee verklaringsmechanismen zijn, die naast elkaar voorkomen. Ze vloeien voort uit het feit dat men bij het scoren wordt gedwongen het verhaal samen te vatten en een vaste positie in te nemen; het scoren biedt geen mogelijkheid tot nuancering of tot enerzijds-anderzijds-argumenten. Dit in tegenstelling tot het vertellen van een verhaal, waarin gemakkelijker de ambivalentie doorklinkt, zeker wanneer 
deze goed wordt uitgevraagd. Welke van de twee verklaringsmechanismen optreec, hangt af van de cognitieve strategieën van de patiënt. Patiënten die relatief vel cognitief vermijden of zichzelf toespreken, gebruiken deze strategieën niet alleen ? hun verhaal, maar zetten deze voort tijdens het scoren. Hierdoor pakt de scorig gunstiger uit dan hun verhaal, dat een genuanceerder beeld laat zien. Bij patiënten de relatief veel negatieve cognitieve strategieèn gebruiken, zoals doemdenken, prtesteren en de sociale vergelijking negatief naar beneden, ontstaat de discrepantie $\bar{\sigma}$ volgt. Wanneer deze patiënten conform hun verhaal scoren, zouden zij uitkomen o een slechte score. Omdat dit nogal confronterend is, treedt bij een deel van dez patiënten een soort dissonantie-reductie op: de score wordt opgewaardeerd e daardoor beter dan op grond van het verhaal wordt verwacht. Deze dissonantireductie vertoont verwantschap met een andere bevinding uit deze studie, namelik dat ook in het verhaal ogenschijnlijk tegenstrijdige cognitieve strategieën vaak in ée adem worden genoemd, waarbij in veel gevallen de impact van een negatiee strategie werd afgezwakt door direct daarop met een positieve strategie te vervolgen.

De discrepantie tussen scoring en verhaal is dus gebaseerd op cognitiee strategieën die tijdens het scoren optreden. Dit is niet vreemd, want ook het scoren va een problematische situatie kan op zichzelf stressvol zijn. Zeker wanneer men wort gedwongen te onderkennen hoe problematisch deze in werkelijkheid is. Logischerws treden ook dan copingstrategieèn op, die gericht zijn op stressreductie en eg. defensie. Dit is een groot probleem bij de interpretatie van vragenlijstgegevens en verklaart waarom de scores vaak niet in overeenstemming zijn met resultaten uit interviews.

\section{Tweede thema: response shift, cognitieve strategie of aanpassing?}

Het bleek dat de patiënten over het algemeen meer vooruitgang rapporteren dan uit het verschil tussen twee opeenvolgende scores was af te lezen. Dit kwam vooral voor bij de items over toekomst en bij sommige items van de zelfbeeldschaal. Daaraan is de conclusie verbonden dat mogelijk een response shift is opgetreden. Maar wat is response shift nu eigenlijk? Breedveld en Van Dam (1991) noemen twee soorten. De eerste is de zogenaamde beta-change en zou het gevolg zijn van een herijking van de 'eigen interne schaal'. Mensen zijn geen machines en de onderlinge afstand tussen twee opeenvolgende scores ligt niet vast zoals de afstand tussen de centimeters op een liniaal. Daardoor kan de ene keer een zeven worden gescoord en de andere keer, zonder dat er wezenlijk iets is veranderd, een zes of een acht. De tweede soort response shift is de zogenaamde gamma-change. Bij een gamma-change is er sprake van een herdefiniëring van het te meten onderwerp. Daardoor verandert de waardering: iets dat eerst als onbelangrijk werd ervaren kan in waarde stijgen, of 
andersom, en wordt om die reden anders gescoord. Er is dan sprake van een wezenlijke verandering. Een mooi voorbeeld vinden we bij Sprangers (1988), die constateerde dat sommige cursisten na het volgen van een training zichzelf een lagere score voor een bepaalde vaardigheid gaven; niet omdat de cursus averechts had gewerkt en zij minder vaardig waren geworden, maar omdat zij inzagen dat ze niet zo goed waren als zij aanvankelijk dachten. Er was dus iets veranderd aan hun 'standaard'.

Hoe is de response shift bij de borstkankerpatiënten te verklaren? Bij analyse van de interviews viel op dat, wanneer naar de actuele situatie werd gevraagd, andere strategieën naar voren kwamen dan wanneer werd gevraagd of er iets was veranderd ten opzichte van een vorig meetmoment. In dat laatste geval is relatief vaak geantwoord dat ondanks alles, de ziekte toch ook positieve gevolgen heeft gehad. Met andere woorden, de strategie 'een positieve wending geven' werd vooral gebruikt bij het beantwoorden van de vraag naar verandering. Hetzelíde gold voor berusten, erger bedenken en de sociale vergelijking positief naar beneden. Er werden dus positieve cognitieve strategieèn ingezet.

Het is niet onlogisch dat, wanneer in de herstelperiode na een ingrijpende gebeurtenis expliciet naar een verandering wordt gevraagd, dit uitnodigt tot een sociaal wenselijk antwoord. De onderzoeker moet immers niet denken dat er helemaal niets is veranderd. Het antwoord kan ook ego-defensief zijn: 'nou ja, het was natuurlijk niet allemaal slecht'. Het kan ook zijn dat een herdefiniëring heeft plaatsgevonden, in de zin van de gamma-change. Het gebruik van de cognitieve strategieèn wijst in die richting. Als dat zo is, dan rijst vervolgens de vraag of deze vorm van gamma-change eigenlijk niet een uiting is van een geslaagde aanpassing ten gevolge van positieve cognitieve strategieèn. Dit is tevens een verklaring voor de tegen-intuitieve bevinding, die uit bijna al het 'kwaliteit-van-leven'-onderzoek naar voren komt, namelijk dat de kwaliteit van leven van allerlei ernstig zieke mensen niet lager is dan die van gezonden. Dat verschillende auteurs dit terugvoeren op het fenomeen response shift en dit vervolgens verklaren met behulp van adaptatie-theorieèn (Breedveld \& Van Dam 1991, de Haes et al 1992, Sprangers 1999, Gibbons 1999, Carver 2000) en daarbij termen als cognitieve reconstructie, coping, persoonlijke groei, sociale vergelijking en dergelijke in het verklaringsmodel gebruiken, kan worden gezien als een ondersteuning voor deze opvatting. Methodologisch is dit wel een probleem. Het impliceert namelijk dat de mate van aanpassing niet zonder meer is te achterhalen door vragenlijstscores van achtereenvolgende meetmomenten te vergelijken. Immers, juist ten gevolge van de aanpassing is de interne standaard veranderd en daarmee zijn de scores dus onvergelijkbaar geworden. Ook hierin ligt een verklaring waarom vragenlijstgegevens kunnen afwijken van hetgeen in een interview naar voren komt, of niet sporen met wat in de klinische praktijk wordt geconstateerd. 
De Haes en haar collega's liet zien dat niet alle dimensies van aanpassing even gevoelig zijn voor response shift. Zij maakt onderscheid tussen een cognitieve en een affectieve dimensie. De affectieve dimensie zou door een ernstige gebeurtenis meer en langduriger uit balans raken en zich minder lenen voor herdefiniëring. De cognitieve dimensie heeft als uitkomst een mate van tevredenheid over de ontstane situatie. Daarbij kan onderscheid worden gemaakt in tevredenheid over het feit dat ondanks de nare situatie, toch is behaald wat men voor ogen had, en tevredenheid die het gevolg is van berusting omdat verwachtingen zijn bijgesteld. Deze laatste vorm van tevredenheid berust op een geslaagde herdefiniëring; er is derhalve sprake van response shift. Het onderscheid tussen cognitief en affectief biedt een verklaring waarom bij de borstkankerpatiënten wel een response shift lijkt te zijn opgetreden $q p$ items over toekomst en zelfbeeld, maar niet op die over angst, waarvan de items het meest affectief geladen zijn.

\section{Derde thema: hoe onafhankelijk is de onafhankelijke variabele?}

De belangrijkste onderzoeksvraag luidt: wat is de relatie tussen cognitieve coping en aanpassing aan borstkanker. Daarbij wordt impliciet verondersteld dat de onafhankelijke variabele zijnde cognitieve coping - opgesplitst in zeventien cognitieve strategieën - goed is te onderscheiden van de afhankelijke variabele zijnde aanpassing aan borstkanker - opgesplitst in vijf verschillende indicatoren.

inmidideis is duidefijk dat daarbij kanttekeningen zijn te plaatsen. Uit het voorgaande is gebleken dat ook tijdens het scoren cognitieve strategieën worden ingezet die als het ware zelf onderdeel worden van de aanpassingsscore. Bovendien bleek dat wanneer verandering in aanpassing wordt gemeten, er sprake kan zijn van een response shift, waarbij deze response shift niet alleen wordt beïnvloed door cognitieve strategieẻn, maar misschien zelfs een uiting is van aanpassing. Dit leidt tot de fundamentele vraag: waar eindigt coping en begint aanpassing? Vele onderzoekers worstelden hiermee, en zo kan het gebeuren dat wat in het ene onderzoek als maat van aanpassing is gepresenteerd, in het andere onderzoek onder copingstrategie is terug te vinden (Coyne' 2000). Sommige onderzoekers plaatsen strategie en uitkomst binnen één definitie en omzeilen zo het probleem enigszins. Bijvoorbeeld de onderzoeksgroep rond Taylor en die rond Buunk hebben de verschillende sociale vergelijkingen afgebakend door niet alleen de richting van de vergelijking aan te geven, maar tevens te benoemen of het een positief of negatief gevoel oplevert. Zo scheiden ze bijvoorbeeld $\mathrm{S}^{+-}$van $\mathrm{S}^{--}$. Beide zijn vergelijkingen met mensen met wie het slechter gaat, maar bij $\mathrm{S}^{+-}$wordt de conclusie getrokken dat men nog boft en bij $\mathrm{S}$ - leidt het tot het idee 'dit is mijn voorland'. Op zich is dit een zinnig onderscheid, immers beide strategieën bewerkstelligen wezenlijk iets anders. Om die reden zijn hun 
definities overgenomen, in het besef dat er wel sprake is van enige tautologie, zeker als vervolgens wordt onderzocht of deze strategieèn een verschillende invloed hebben op bijvoorbeeld angst of toekomstperspectief.

Ook Lazarus (1991) roert dit probleem aan, als hij terugblikt en uitlegt dat hij indertijd in zijn model coping doelbewust heeft opgevat als een inspanning (effort) die onafhankelijk is van haar uitkomst. Dit was nodig om de effectiviteit van een copingstrategie te kunnen onderzoeken, zonder coping te verwarren met haar resultaat. Maar, zo constateert ook hij, in de werkelijkheid zijn een copingstrategie, het doel van de strategie en de uitkomst ervan meer met elkaar vervlochten dan met het theoretische model wordt verondersteld, om vervolgens op te merken dat dit een verwarrend idee is voor eenieder die de Aristotelische wet aanhangt dat concept A niet tegelijk concept B kan zijn.

Toch komen we dit fenomeen in de realiteit, en dus ook in de psychologie, geregeld tegen. Er is vaak sprake van niet-lineaire processen die circulair of spiraalvormig verlopen. Daarbij is de uitkomst van de ene ronde het begin van de volgende, wat het moeilijk maakt afhankelijke en onafhankelijke variabele volledig van elkaar te scheiden. In het verlengde hiervan ligt de vraag naar de causaliteit. Bepaalt de mate van aanpassing welke cognitieve strategieën men hanteert, of bepaalt de strategie die wordt gebruikt in welke mate de aanpassing zal slagen? Met andere woorden, ben je angstig omdat je veel doemdenkt of doe je aan doemdenken omdat je zo angstig bent (zie ook Lazarus 1993 en Coyne 2000).

De oplossing voor dit probleem is er niet. Het is de vraag of dat erg is. Zolang maar duidelijk wordt gedefinieerd wat met een bepaald concept wordt bedoeld en wordt geëxpliciteerd welke keuzes er zijn gemaakt. In dit onderzoek zijn, in navolging van Lazarus, coping en aanpassing zo goed mogelijk van elkaar gescheiden door zorgvuldig gedefinieerde copingstrategieën op te vatten als coping-inspanning en de scores op de vijf aanpassingsindicatoren als aanpassing te beschouwen. Berusten, een positieve wending geven en de andere strategieèn zijn dus niet opgevat als een uiting van aanpassing, maar als middel om te bereiken dat men minder angstig is, toch nog toekomst ervaart, enzovoort. Wat betreft de richting van de causaliteit is eveneens aangesloten bij de copingtheorie. Het model begint bij inschattingen en strategieën, die vervolgens leiden tot aanpassing. Maar ook als clinicus is het logisch om op dit punt in de spiraal te stappen. In die hoedanigheid wordt immers getracht om aanpassing te beïnvloeden door beïnvloeding van cognitieve strategieën en appraisals, heel goed wetende dat de mate van aanpassing eveneens de cognitie beïnvloedt. Met de longitudinale opzet van deze studie is onderzocht hoe cognitieve strategieén, die op een bepaald meetmoment worden gebruikt, aanpassing van daarop volgende meetmomenten beïnloeden. Daarmee kon iets over de causaliteit worden gezegd. Wat dit heeft opgeleverd komt later aan de orde. 


\section{2 - 3 - Selectie-bias en andere invloeden}

Ruim een kwart van de vrouwen weigerde deelname (23 van 79). Ongeveer de helft van de weigeraars liet weten niet meer over de ziekte te willen praten; zij wilden alles het liefst zo snel mogelijk zien te vergeten. Van de overigen is het argument voor weigering niet bekend. Door deze selectie hebben de meest vermijdende en meest angstige vrouwen niet aan het onderzoek meegedaan.

Gemiddeld duurden de interviews drie uur, waarbij de sfeer over het algemeen vertrouwelijk was en geen 'interviewmoeheid' optrad. Er was dan ook weinig uitval. Blijkbaar voorzagen de interviews in een behoefte, want toen bij de derde interviewronde enige achterstand dreigde te ontstaan, namen verschillende vrouwen zelf contact op met de vraag of ze niet werden vergeten. Dit komt mogelijk omdat tijdens het derde interview ongeveer een kwart van de patiënten aangaf dat zij in afnemende mate een luisterend oor vonden om over hun zorgen en de gevolgen van hun ziekte te spreken, terwijl zij daar soms nog behoefte aan hadden. Tijdens het interview werd die mogelijkheid wel geboden. Er bestaat een kans dat de interviews onbedoeld een interventie in zich droegen, waardoor de aanpassing van deze onderzoeksgroep in positieve zin is beinvloed.

Eerder is al aangegeven dat bij een deel van de vrouwen een systematische 'overscoring' is geconstateerd op een aantal aanpassingsindices en dat er sprake was van een onderrapportage van de klachten. Voorts bestond de onderzoeksgroep uit vrouwen met een goede prognose, die binnen het scala aan behandelingsmogelijkheden relatief gezien niet de zwaarste behandeling hebben ondergaan. Dit alles maakt het aannemelijk dat de geconstateerde problematiek eerder is onder- dan overbelicht.

\section{3 - THEORETISCHE REFLECTIES EN BELANGRIJKSTE RESULTATEN}

De meeste vrouwen zijn in staat na de behandeling hun leven weer redelijk goed op te pakken. Toch blijkt op elk van de drie meetmomenten ten minste een kwart van de patiënten problemen te ervaren. Een dergelijk getal vinden we vaker terug. Bijvoorbeeld bij Schrameijer en Brunenberg (1992), die zich baseren op een grootschalig onderzoek onder Nederlands (ex)kankerpatiënten. Tegen de verwachting in, treedt op groepsniveau gedurende de onderzoeksperiode, i.e. de eerste twee jaren na de diagnose, geen significante verbetering op. Patiënten geven zelfs aan, dat de ziekte hen eerder méér dan minder is gaan beheersen. De onzekerheid over hoe het lichaam zich na het beëindigen van de behandeling zal houden, lijkt hierin een belangrijke rol te spelen. Medische controles kunnen deze gevoelens niet bij iedereen wegnemen. Op 
de vraag 'geven de controles in het ziekenhuis $\mathrm{u}$ op enige wijze een veilig gevoel?' antwoordt ongeveer een kwart van de patiênten ontkennend, ongeveer een derde put er wél zekerheid uit. De rest neemt een neutrale positie in. Ook in de literatuur zijn er aanwijzingen dat er in de loop van de eerste jaren niet veel verbetering optreedt (Irvine et al 1991, Edgar et al 1992, Glanz \& Lerman 1992, Nelson et al 1994, Moyer \& Salovey 1996), of zelfs dat de problemen juist waren toegenomen (Ell et al 1989. Mahon et al 1990 in Heim et al 1997 en Rappaport 1993 eveneens in Heim et al 1997). Vinokur (1989) toonde aan dat het schanierpunt ongeveer vijf jaar na de diagnose ligt en dat daarna het vertrouwen in het lichaam groeit. Ook in de interviews gaven veel vrouwen spontaan aan, de voor artsen belangrijke en voor de patiënten magische grens van de vijfjaarsoverleving, als een ijkpunt te zien. De onderzoeksperiode was echter te kort om dit verder te kunnen nagaan.

Deze studie bevestigt het beeld dat aanpassing aan borstkanker over het algemeen goed verloopt, maar dat, wanneer specifieker wordt gekeken en er geen standaard vragenlijsten worden gebruikt, wel degelijk nuanceringen zijn aan te brengen. De resultaten per aanpassingsindex laten zien welke nuanceringen dit zijn en hoe de cognitieve strategieên hierop inwerken.

\section{3-1 - Resultaten per aanpassingsindex}

Ziekte en behandeling lijken op het zelfbeeld van de patiënten geen noemenswaardig effect te hebben gehad. Op de vraag, of zij zelf vinden dat ze zijn veranderd, antwoordt meer dan de helft van de patiënten zelfs in positieve zin. De antwoorden zijn in de trant van: 'ik weet nu dat ik een moeilijke situatie aankan, ik ben er sterker uit gekomen' of 'ik kom mu meer voor mijzelf $o p^{\prime}$ '. Dit soort uitspraken hoort bij de strategie 'positieve wending geven' en blijkt het zelfbeeld gunstig te beïnvloeden. Ook 'berusten', ontlastende attributies en de sociale vergelijking positief naar boven hebben een gunstige uitwerking op het zelfbeeld. Naast dit positieve beeld blijkt wel, dat in de loop van de tijd de gevolgen van de behandeling zwaarder gaan wegen. Worden aanvankelijk klachten ten gevolge van lymfe-oedeem, vermoeidheid of het vervroegd in de overgang raken door de chemotherapie, in het licht van de dreiging van kanker op de koop toegenomen, aan het eind van de onderzoeksperiode rapporteert eenderde van de patiënten hiervan fysiek en/of mentaal tamelijk veel hinder te ondervinden. De dan, of eerder, gehanteerde strategieën protesteren en de vergelijking negatief naar boven, hebben een sterk negatieve invloed op het zelfbeeld.

Ruim de helft van de patiënten houdt vertrouwen in de toekomst. Daar staat tegenover dat ongeveer één op de tien vrouwen al vanaf de diagnose de toekomst 
somber inziet en niet in staat is zich daar overheen te zetten. Daarnaast is er een grcep patiënten die in de loop van de tijd het vertrouwen verliest. $\mathrm{Zij}$ voelen zich langzamerhand minder beschermd door de behandeling. Dit resulteert erin, dat thee jaar na de diagnose een kwart van de patiènten vindt dat hun toekomst door de ziekte wordt bedreigd. Protesteren en de sociale vergelijking negatief naar boven versterken, zowel op de korte als op de langere termijn, dit gevoel.

Het grootste probleem is angst. Ruim veertig procent van de vrouwen is twee jaar na diagnose angstig. Meer dan een kwart is dit al vanaf het begin; de overigen zijn naarmate de behandeling verder achter hen ligt angstiger geworden. Vooral het verlies aan vertrouwen in het eigen lichaam komt in veel van de interviews naar voren. Geen van de vrouwen had lichamelijke klachten toen het knobbeltje in hun borst werd ontdekt. De ervaring dat je een levensbedreigende ziekte als kanker hebt en je tóch gezond voelt, heeft veel vrouwen in de war gebracht en heeft de beleving van het begrip gezondheid danig op zijn kop gezet: 'Als ik niets voel, betekent bet niet dat ik niets keb. Waar kan ik nog op vertrouuen?'. Een groot deel van hen vindt alles wat zij in hun lichaam voelen alarmerend. Dit is in de loop van de tijd eerder sterker geworden dan afgenomen. Met name protesteren en doemdenken bevorderen de angst. Maar bagalelliseren heeft een gunstige invloed. Ook hier zijn er zowel korte als lange termijn effecten.

Slechts zeven procent van de vrouwen zegt zich voor de ziekte te schamen. Toch is rond vijftien procent bang dat zij nu met andere ogen worden bekeken, en vermijdt eenderde van de patiënten het woord kanker, deels omdat dit te veel angst oproept en deels omdat men niet bij 'die groep' wil horen. Schaamte is een belangrijke aanwijzing dat het psychologisch gezien niet goed gaat. Deze aanpassingsindex correleert hoog met angst, toekomst en zelfbeeld. Vrouwen die zich schamen ervaren ook op deze gebieden problemen.

De meeste patiënten vinden dat ze weinig tot geen invloed hebben op hun ziekte en de gevolgen ervan. Dit gevoel is er vanaf het begin en wordt in de loop van de tijd alleen maar sterker. De vrouwen die een positieve wending geven aan de ziekte, ervaren relatief gezien de meeste invloed, evenals de vrouwen die zich optrekken aan positieve voorbeelden $\left(\mathrm{S}^{++}\right)$. Eigen invloed is de enige aanpassingsmaat die geen samenhang vertoont met de overige aanpassingsindices. Bovendien is het in het geval van borstkanker reëel te veronderstellen dat men het beloop van de ziekte niet zelf in de hand heeft. Het is dan ook de vraag of 'eigen invloed' wel kan worden opgevat als een onderdeel van 'aanpassing'. Toch wordt in de literatuur aan begrippen als invloed en controle veel waarde gehecht. Een belangrijke functie van de causale attributie zou dan ook zijn dat zij aanknopingspunten biedt voor verandering, en daardoor tot controle zou leiden. Dit laatste kon worden aangetoond: causale attributies die een 
mogelijkheid tot veranderen in zich houden, bleken inderdaad positief uit te werken op het gevoel zelf invloed te hebben op de ziekte. Echter, dit resulteerde vervolgens niet in een lager angstniveau, een positievere kijk op de toekomst of een positiever zelibeeld. Ook daarin staat 'eigen invloed' los van 'aanpassing'.

\section{3-2 - Wat is er gevonden over cognitieve coping?}

Het onderzoek heeft duidelijk laten zien, dat aanpassing aan borstkanker een flexibel proces is, waarbij de patiēnt gebruik maakt van een groot aantal cognitieve strategieën die zij in wisselende reeksen inzet. Gemiddeld worden tien van de zeventien onderzochte strategieën door één patiënt gebruikt. Daarbij worden ogenschijnlijk tegenstrijdige strategieĕn dikwijls in één adem genoemd. Dit laatste wijst erop dat ziekte en behandeling zijn omkleed met een flinke dosis ambivalentie. Ook andere onderzoekers hebben geconstateerd, dat er over het algemeen niet één voorkeursstrategie is aan te wijzen en dat bij het verwerken van de gevolgen van kanker veel verschillende strategieën door elkaar worden gebruikt waarbij patiënten gemakkelijk van strategie wisselen (Heim 1991, Dunkel-Schetter et al 1992, Glanz \& Lerman 1992, Taylor \& Brown 1994). Protesteren, bagatelliseren en doemdenken zijn het meest stabiel en worden door de patiënten het meest consistent gebruikt. De testhertestcorrelaties van de overige strategieèn waren lager dan .50.

Hoewel de individuele patiênt nogal flexibel is in haar strategiegebruik, treden er in de loop van de tijd op groepsniveau maar weinig veranderingen op. Het is daarom des te opmerkelijker dat het aantal berustende uitspraken significant daalt, vooral omdat het percentage patiënten dat cognitief vermijdt, protesteert, bagatelliseert of zichzelf toespreekt, onverminderd hoog blijft. Het lag in de verwachting dat juist deze strategieën zouden afnemen en er meer berusting zou optreden. Deze bevinding is overigens in lijn met de constatering dat ook op de aanpassingsindices, althans op groepsniveau, geen veranderingen ten positieve plaatsvinden.

Protesteren is zonder twijfel de belangrijkste determinant voor een minder geslaagde aanpassing en heeft een grote negatieve uitwerking. Vrouwen die protesteren zijn niet alleen angstig maar ook pessimistisch over hun toekomst en hebben vaker problemen met een veranderd zelfbeeld: zij voelen zich het meest door de ziekte beperkt en 'aangetast'. Dit blijft zo gedurende de gehele onderzoeksperiode. Daarbij heeft de mate waarin de vrouw vlak na de behandeling protesteert, een grote voorspellende waarde voor haar aanpassing twee jaar later. Patiènten die de vraag 'waarom ik?' belangrijk vinden, zijn eveneens slechter aangepast dan de anderen, ongeacht of dit samengaat met protest. Tenslotte bleken ook doemdenken en de 
sociale vergelijking negatief naar boven niet goed voor aanpassing. Daar stat tegenover dat patiënten die berusten, bagatelliseren, of in staat zijn een positiere wending te geven aan hetgeen hen is overkomen, over het algemeen beter af zijn din de anderen, hoewel de effecten van berusten en bagatelliseren op de lange termin lang niet altijd stand houden.

Gedeeltelijk komt dit overeen met in de literatuur genoemde resultaten. Hoevel deze geen eenduidig beeld laten zien, blijken strategieën met als noemer 'emotioral ventilation' en 'anger', die lijken op protesteren, en een strategie als 'thought intrusion', die wel iets weg heeft van doemdenken, in veel studies gepaard te gaan met een slechtere aanpassing. Van strategieën zoals 'fighting response', 'optimisn', 'positive reframing' en 'focussing on the positive' ontstaat uit de literatuur de indrik dat zij positief uitwerken op aanpassing. Deze strategieën hebben verwantschap met 'een positieve wending geven'.

Doemdenken, cognitief vermijden, zichzelf toespreken en causale attributies zijn in de interviews het meest aangetroffen. De sociale vergelijkingen, met uitzondering vin de sociale vergelijkingen 'gelijkwaardig' en 'positief naar beneden' worden het mirst gebruikt, maar toch nog door ten minste een kwart van de patiënten. Bovendien is er een significante daling in het gebruik van vier van de zes sociale vergelijkingen. Lit wijst erop dat sociale vergelijkingen vooral in het begin, dus vlak na de diagnos, worden dangewend.' Dat' is mèt verwondèriljk omaát' er juist dán veel 'onzekerheid ' is, en door de vergelijking met anderen gepoogd wordt inzicht te krijgen in de eigen situatie. Het valt op dat de sociale vergelijkingen eerder zijn gericht op zelfversterking dan op het verkrijgen van accurate informatie. Dit blijkt uit het relatief hoge percentage vergelijkingen waarin patiënten er zelf gunstig vanaf komen ( $\mathrm{S}^{+-}$). Zo zijn er oudere patiënten die zeggen blij te zijn dat zij niet meer zo jong zijn, bijvoorbeeld omdat zij niet meer de zorg voor een gezin hebben. Daarentegen menen sommige jonge patiënten juist te boffen dat zij nog niet zo oud zijn. Daarvoor voeren zij verschillende argumenten aan, bijvoorbeeld dat hun vitaliteit het herstel in gunstige zin zal bevorderen. Kortom, patiënten kiezen een voor hen gunstig vergelijkingsobject en zijn daar creatief in. Desondanks konden er weinig relaties met aanpassing worden aangetoond.

Het hoge percentage patiënten dat al bij de openingsvraag spontaan benadrukt zelf geen schuld te hebben aan het ontstaan van de ziekte of ongevraagd laat weten dat zij het echt niet eerder had kunnen ontdekken, wijst eveneens op de behoefte aan zelfbescherming. Ook Ten Kroode (1990) wees op dit verschijnsel. Anders dan in zijn onderzoek, richt een groot deel van de schuldontlastende attributies van de vrouwen met borstkanker zich niet op oorzaken, waaraan zij zich objectief gezien wel schuldig 
hebben gemaakt. Deze vrouwen verwijzen juist naar zaken die ze goed deden en geven daarbij de boodschap af: mij treft geen blaam. Het gaat dan om maatschappelijke opvattingen over oorzaken van kanker, zoals sommige leefgewoonten of over zaken die je hoort te doen, zoals zelfonderzoek om eventuele kanker vroegtijdig te ontdekken. De publiekscampagnes die erop zijn gericht om mensen op hun verantwoordelijkheid te wijzen, roepen blijkbaar ook de behoefte op jezelf van schuld vrij te pleiten wanneer de ziekte je toch overkomt. Vooral de vrouwen die altijd erg met hun gezondheid bezig waren, voelen zich bedrogen en zijn boos omdat de impliciete belofte, dat door gezond gedrag kanker kan worden voorkomen, niet is uitgekomen.

Al met al kan worden geconcludeerd dat cognitieve coping van invloed is op aanpassing aan kanker en dat het copingmodel, ondanks de theoretische en methodologische problemen, voldoende aanknopingspunten biedt om het aanpassingsproces te onderzoeken. Vijftien van de zeventien onderzochte strategieën hebben op enige wijze invloed op aanpassing aan borstkanker. Over het algemeen is in het eerste jaar na de diagnose de invloed het grootst. Toch worden, met uitzondering van de sociale vergelijkingen, de strategieèn ook daarna nog veelvuldig gebruikt.

De meeste relaties zijn aangetroffen tussen strategieèn en aanpassing van hetzelíde meetmoment, het betreft dus rechtstreekse verbanden. Maar bij elf van de zeventien strategieën zijn tevens één of meerdere voorspellende verbanden aangetoond. Dit laatste wijst erop dat de causaliteit in ieder geval ook in de richting gaat van cognitieve strategie naar aanpassing en dat cognitieve strategieën aanpassing beïnvloeden.

De strategieën blijken niet op elke aanpassingsindex in gelijke mate of op dezelfde wijze van invloed te zijn. Soms is de invloed op verschillende indices zelís tegengesteld, zoals bijvoorbeeld bij de ontlastende attributie, die positief is voor het zelfbeeld en negatief voor de toekomstbeleving. Het is derhalve van belang gebleken het algemene begrip 'aanpassing aan kanker' op te splitsen in concrete, van elkaar te onderscheiden onderdelen.

\section{3 - 3 - Hoe verhouden de resultaten zich tot de overige aanpassingstheorieën?}

In dit onderzoek is het begrip coping breed opgevat en zijn 'zelfstandige' aanpassingstheorieën, zoals bijvoorbeeld de sociale vergelijkingstheorie, gezien als specifieke onderdelen van een meer algemene theorie over aanpassing. De belangrijkste resultaten die onder een van die specifieke theorieën vallen, worden nog even apart belicht. Sommige daarvan kwamen in de voorgaande paragrafen al aan de orde. 
Voor wat betreft de 'sociale vergelijkingstheorie' werd duidelijk dat - zoals veel onderzoekers beweren - in bedreigende omstandigheden sociale vergelijkingen vooral gericht zijn op zelfversterking (Buunk et al 1990, Helgeson \& Taylor 1993, Hagopagian et al 1994, Van der Zee 1996). Deze bevinding lijkt robuust. Patiënten blijken creatief in het kiezen van hun vergelijkingsobject, en de sociale vergelijking positief naar beneden, die waarin de patiënt vindt dat ze vergeleken met anderen nog boft, is dan ook frequent aangetroffen. Daamaast gebruiken veel patiënten de gelijkwaardige vergelijking: 'ik ben niet anders dan een ander'. Sociale vergelijkingen worden vooral in het begin, kort na de diagnose aangewend. De invloed op aanpassing is er wel, maar is over het algemeen niet erg groot. De richting van de invloed is zoals in de definities van Buunk et al wordt gesuggereerd, met dien verstande dat de sociale vergelijking gelijkwaardig het angst-niveau negatief beïnvloedt, maar positief uitwerkt op het zelibeeld.

Vrijwel alle patiènten (steeds rond de $90 \%$ ) hadden één of meer causale attributies over de oorzaak van hun ziekte. Ook andere onderzoekers komen tot dergelijke percentages (zie Ten Kroode 1990 en Sensky 1997). Hoewel dit wijst op behoefte aan een verklaring, kon geen invloed op aanpassing worden aangetoond. Het kan zijn dat, omdat bijna iedereen deze strategie gebruikt, het onderscheidend vermogen wegvalt. Dergelijke 'nulbevindingen' zijn lastig te interpreteren. Onbekend is hoe de aanpassing zou zijn verlopen wanneer de strategie niet was gebruikt. Het lijkt erop, dat het niet veel uitmaakt welke specifieke attributies de 'denkarbeid' oplevert, maar dat het denkproces op zichzelf helpt bij de verwerking (conform Taylor \& Brown 1994, Wolf et al 1995, Sensky 1997). Wel bleken causale attributies die tot verandering leiden, het gevoel zelf invloed te hebben te versterken, wat zich overigens niet vertaalde in een hoge aanpassing op de overige indices.

Het bleek zinvol om naast causale attributies schuldontlastende attributies te benoemen (zie Ten Kroode 1990). Voor de borstkankerpatiënten bleek schuldontlasting een belangrijk thema te zijn. De door Ten Kroode geïntroduceerde 'betekenisverlenende attributie' kon niet worden gehandhaafd, hoewel het thema wel van belang lijkt. Juist omdat er theorie-overstijgend is gekeken, bleek dat op meerdere manieren betekenis wordt verleend aan de situatie, en dat dit zich niet beperkt tot een specifieke, te isoleren, cognitieve strategie.

In de literatuur over defensie-mechanismen zijn twee stromingen aan te wijzen, die van mening verschillen over de aanpassende waarde ervan. De resultaten uit dit onderzoek ondersteunen de opvatting dat bij kanker en andere ernstige ziekten, waarbij het niet mogelijk is iets aan de situatie te veranderen, allerlei vormen van 
ontkennen en verdringen positief zijn voor aanpassing, mits er geen sprake is van een volledige ontkenning van de ziekte (Cohen \& Lazarus 1979, Orr \& Meyer 1990, Peterson 1991, Greer 1992, Heyink 1993). De auteurs merken daarbij op dat van echte ontkenning nauwelijks sprake is. Ook in dit onderzoek is geen echte ontkenning aangetroffen, in de zin dat een patiënt gewoonweg ontkende dat ze borstkanker had. Wel deden veel vrouwen (steeds rond de $90 \%$ ) op een of andere manier aan cognitieve vermijding. Hiervan kon geen negatieve invloed op aanpassing worden aangetoond, eerder een licht positieve.

Er zijn vooral veel aanwijzingen gevonden die passen in de 'just world theorie'. Het ziet het er naar uit dat bij de vrouwen die het minst goed zijn aangepast, de illusies van veiligheid, rechtvaardigheid, onaantastbaarheid en voorspelbaarheid ernstig zijn aangetast. Deze vrouwen blijken vervolgens niet in staat de gebeurtenis zodanig cognitief te manipuleren dat deze weer past in de oude schema's, dan wel hun vroegere opvattingen zodanig aan te passen dat deze stroken met de nieuwe ervaring. Zij blijven vast zitten in protest en het gevoel dat het oneerlijk is wat hen is overkomen. De vraag 'waarom ik?' is een belangrijke vraag voor hen, en blijft dat ook, zonder dat zij een bevredigend antwoord vinden. Patiënten die in staat zijn de vraag om te buigen in de richting van 'waarom ik niet?' zijn beter af. In termen van de attributietheorie zijn zij in staat het gevoel van persoonlijke hulpeloosheid te vervangen door een gevoel van universele hulpeloosheid: 'iedereen kan dit overkomen, zo zit het leven nu eenmaal in elkaar. Ik ben niet anders dan een ander'. Abramson toonde al in 1978 aan dat deze laatste attributie tot veel minder negatieve gevoelens leidt. Patiënten die het lukt om ondanks alles zin te geven aan de gebeurtenis door een positieve wending te geven aan hetgeen hen is overkomen, blijken het beste af. In dit onderzoek is dat bij meer dan de helft van de patiènten het geval (conform Schaefer \& Moos 1998, Kleber 2000, Stiegelis 2003).

\section{3 - 4 - Zijn er verschillen tussen subgroepen van patiënten?}

Er zijn geen noemenswaardige verschillen gevonden in strategiegebruik of in de mate van aanpassing, die zijn terug te voeren op leeftijd, opleiding of ernst van de ziekte. Dit laatste is opvallend. De ernst van de ziekte blijkt uit het al dan niet aanwezig zijn van positieve okselklieren, en dit is medisch gezien een belangrijk verschil. De aanwezigheid van positieve klieren heeft namelijk negatieve consequenties voor de prognose en de behandeling. Toch blijkt dit niet van invloed te zijn op de toekomstbeleving van de patiënten of op de mate waarin zij zich angstig voelen. Wel hebben patiënten die aanvullend een chemokuur moesten ondergaan, tijdens die kuur, 
een wat lager zelfbeeld dan de vrouwen die aanvullend met hormonen werden behandeld, of geen aanvullende behandeling kregen en slechts werden bestraald. $\mathrm{Na}$ het beeindigen van de kuur verdween het verschil. Deze bevinding is conform die van een aantal andere onderzoekers (Wainstock 1991, Berglund et al 1991, Carver et al 1993, Nelson et al 1994, Hürny et al 1996) en is in lijn met onderzoeken waaruit blijkt dat, tegen de verwachting in, patiënten die borstsparend zijn behandeld, er psychologisch gezien niet anders aan toe zijn dan patiënten die een borstamputatie hebben ondergaan (Fallowfield \& Hall 1991, Goldberg et al 1992, Omne-Ponten et al 1994). Dit alles wijst erop dat de problemen van (borst)kankerpatiënten eerder voortvloeien uit het feit dat men kanker heeft, dan uit specifieke gevolgen van een bepaalde behandeling (zie ook Schroevers 2002).

\section{4 - VAN THEORIE NAAR PRAKTIJK}

Welke inzichten levert dit onderzoek op voor de praktijk?

Duidelijk werd dat ongeveer een kwart van de borstkankerpatiënten in meer of mindere mate kampt met negatieve gevoelens ten gevolge van de ziekte of behandeling. Daarin treedt in de eerste twee jaar na diagnose niet vanzelf verbetering op. Er is dus een groep patiënten die baat zou kunnen hebben bij extra ondersteuning. Hoe zijn deze patiènten te herkennen?

Patiènten die tegen de ziekte en de gevolgen ervan protesteren, zijn het meest 'at risk'. Deze cognitieve strategie heeft een grote negatieve invloed op bijna alle aanpassingsindices, zowel op de korte als op de langere termijn. Ook diegenen die worstelen met de vraag 'waarom ik?' en patiënten die veel doemdenken, zijn angstiger en somberder over hun toekomst. Daarnaast is schaamte een belangrijk signaal. Wanneer patiënten zich voor hun ziekte schamen, zijn zij over het algemeen ook angstiger. Bovendien zien zij hun toekomst somberder in en hun zelfbeeld is meer verstoord. In de screening voor hulpverlening, en vervolgens in de begeleiding zelf, zouden deze thema's aan bod moeten komen.

Een ander belangrijk thema is het verlies van vertrouwen in het eigen lichaam. Veel vrouwen zijn er van in de war dat zij aan borstkanker bleken te lijden, terwijl ze zich gezond voelden. Dit betekent voor hen dat wanneer je niets bijzonders voelt, je er niet zonder meer vanuit kunt gaan dat je niets ernstigs onder de leden hebt. Daardoor is bij deze borstkankerpatiënten het begrip 'gezondheid' op zijn kop gezet. Dat maakt hen erg onzeker over hun lichaam, een onzekerheid die soms gegeneraliseerd wordt naar allerlei andere situaties in hun leven. 
Ook schuldontlasting blijkt van belang. Veel vrouwen hechten eraan zichzelf en anderen er van te overtuigen, dat hun geen blaam treft. Zij wijzen nadrukkelijk op hun gezonde leefwijze en merken op dat zij de kanker niet eerder hadden kunnen ontdekken, al deed lang niet iedereen aan zelfonderzoek. Met name de vrouwen die naar eigen zeggen erg gezond geleefd hebben, zijn extra boos en voelen zich soms door de gezondheidsvoorlichting bedrogen. Dit lijkt de keerzijde van de publiekscampagnes die pleiten voor gezond gedrag en eigen verantwoordelijkheid. Het is aan te bevelen dat in dergelijke campagnes nadrukkelijker wordt vermeld, dat het niet zeker is dat daarmee de ziekte altijd wordt voorkomen. Hieraan moet ook in de begeleiding van patiënten aandacht worden besteed.

Alles bij elkaar ziet het er naar uit dat, zoals in de 'just world theory' wordt beschreven, bij de vrouwen die het minst goed zijn aangepast, de illusies van veiligheid, rechtvaardigheid, onaantastbaarheid en voorspelbaarheid ernstig zijn aangetast. Deze vrouwen blijken niet in staat de gebeurtenis zodanig cognitief te manipuleren dat deze weer past in de oude schema's, dan wel hun vroegere opvattingen zodanig aan te passen dat deze stroken met de nieuwe ervaring. De begeleiding en - indien nodig - de psychologische behandeling zou zich hierop moeten richten. Wanneer het lukt om de vraag 'waarom ik?' om te buigen in de richting van 'waarom ik niet?', is de kans groot dat er meer berusting optreedt, dat de patiënt minder angstig wordt en dat zij zich meer kan richten op datgene waar zij wél invloed op heeft, namelijk 'wat maak ik er desondanks van'. Patiënten die in staat zijn een positieve wending te geven aan hetgeen hun is overkomen, zijn over het algemeen beter af dan de anderen. Ook de cognitieve strategieën berusten en bagatelliseren hebben een gunstige invloed op het aanpassingsproces.

Veel vrouwen doen aan cognitieve vermijding en een deel - aanvankelijk zelfs ruim veertig procent - geeft aan niet meer over de ziekte te willen weten dan strikt noodzakelijk is. Zo'n houding staat aanpassing niet in de weg en lijkt daarom geen ongezonde copingstrategie, vooral omdat deze vrouwen niet zover gaan dat ze hun ziekte ontkennen. Bij de meeste vrouwen is er sprake van gezonde ambivalentie. Zij blijken goed in staat te switchen tussen reële hoop en reële vrees. Daardoor volgen ogenschijnlijk tegenstrijdige cognitieve strategieën elkaar vaak in hoog tempo op. Dit is geen teken van slechte aanpassing en behoeft geen interventie. Hoogstens verdient het aanbeveling om met het verstrekken van informatie het tempo en de behoefte van de patiènt te volgen.

Een ingrijpende gebeurtenis, zoals borstkanker, vergt een grote hoeveelheid cognitieve arbeid; er komt een proces van oorzaaktoekenning en betekenisverlening op gang (Ten Kroode 1990). De interviews hebben laten zien dat de vrouwen daarbij 
veel verschillende cognitieve strategieën gebruiken. De citaten in dit proefschrift torn aan dat de inhoud van de cognities over het algemeen zeer idiosyncratisch is en beist op persoonlijke constructen. Met behulp van deze cognities ontstaat een verhal waarmee de gebeurtenis wordt ingebed in het eigen levensverhaal. In de Engelstabe literatuur wordt dit fenomeen 'narrative reconstruction' genoemd. Ook Kleber (200) wijst op het belang van het verhaal en formuleert het als volgt: 'verwerken is et verhaal vertellen'. Door de verwarrende gebeurtenis in een talige structuur te brenç zou deze worden georganiseerd. Volgens Kleber zou Pennebaker (1995) en ek anderen overtuigend hebben aangetoond dat het vertellen van het verhaal en de darbij optredende emotionele expressie, aanzienlijke effecten hebben op de geestelijken biologische gezondheid. Het is dus van belang om patiënten die in hun direte omgeving niet terecht kunnen of willen, een gelegenheid te bieden 'vertellenderws' de gebeurtenis te verwerken. Dit proefschrift laat zien welke thema's voor borstkankrpatiënten van belang zijn. Een dergelijk gesprek kan bijvoorbeeld door een oncolopeverpleegkundige worden opgepakt. Daarnaast zijn er in de meeste regio's gespresgroepen voor kankerpatiënten. Wanneer dit niet voldoende blijkt te zijn kunnen ret behulp van psychotherapeutische technieken genoemde processen worden oncsteund. Omdat de cognitieve component van het copingproces van belang is bije aanpassing, sluit bijvoorbeeld een methode als de Rationele Emotieve Therapie daaij goed aan.

Tevens verdient het aanbeveling aandacht te besteden aan de verstoole lichaamsbeleving. Dit kan door intormatie te geven over de tysieke gevolgen van de behandeling. Ook door ontspannings- en ademtherapie is het mogelijk gewone lichaamssensaties en de lichamelijke component van spanning te leren herkennen en te beinvloeden. Hierdoor verliezen deze lichaamssensaties hun onterechte alarmwaarde en wordt voorkomen dat een patiënt in een negatieve angstspiraal terechtkomt. Zo kan preoccupatie met lichaamssignalen plaatsmaken voor een gezonde waakzaamheid. De patiënt krijgt een instrument in handen om haar gevoelens van onzekerheid te pareren (Ferrell et al 1998, Somerfield et al 1999). Recentelijk is in toenemende mate aandacht voor de ontwikkeling en implementatie van revalidatieprogramma's, waarbij er niet alleen wordt gewerkt aan emotioneel, maar ook aan fysiek herstel, en aan herstel van de verstoorde lichaamsbeleving. Deze ontwikkeling doet recht aan de problematiek van kankerpatiënten.

Ter afsluiting nog een laatste opmerking. Het is zowel voor clinici als voor onderzoekers van groot belang zich te realiseren dat met vragenlijsten andere resultaten naar voren komen dan wanneer er interviews worden gebruikt (Breedveld en Van Dam 1991, Heyink \& Tijmstra 1991, Shedler et al 1993). In dit onderzoek werd dat 
opnieuw bevestigd. Het in score brengen van een problematische situatie is op zichzelf weer een stressvolle gebeurtenis. Er treden dan ook tijdens het invullen van de vragenlijst copingstrategieèn op, die gericht zijn op stressreductie en ego-defensie. Hierdoor valt de score bij een deel van de patiènten gunstiger uit dan uit hun verhaal blijkt, temeer omdat het verhaal de mogelijkheid biedt uiting te geven aan ambivalentie, of enerzijds-anderzijds argumenten te gebruiken. Deze wetenschap is van belang bij het interpreteren van vragenlijstgegevens en is tevens een pleidooi om zowel in de onderzoekspraktijk alsook in de praktijk van de hulpverlening niet blind te varen op vragenlijstgegevens alleen. 


\section{SAMENVATTING}

Dat kankerpatiënten op heel verschillende manieren met hun ziekte omgaan, was mij vijfentwintig jaar geleden als beginnend bestralingslaborant al opgevallen. Sindsdien heeft de vraag 'hoe lukt het mensen zich aan te passen aan een bedreigende ziekte?' mij niet meer losgelaten. Ook als medisch psycholoog ben ik mij met deze vraag blijven bezighouden. Hoewel er naar dit onderwerp veel studies zijn verricht, is er nog steeds geen eenduidig antwoord gevonden. Een subsidie van het NWO maakte het mogelijk mij verder in dit onderwerp te verdiepen. Met dit onderzoek heb ik mijn bijdrage willen leveren aan het vinden van een antwoord.

Uit het literatuuroverzicht in hoofdstuk I blijkt dat er niet alleen weinig consensus bestaat over het proces van aanpassing; 'wat doen mensen?', maar ook over de uitkomst ervan; 'wat levert het hun op?'. Duidelijk werd dat de tegenstrijdige resultaten zijn terug te voeren op een opeenstapeling van methodologische problemen. Eén ervan is dat aanpassing vaak is onderzocht in niet-homogene groepen van patienten met verschillende ziekten, die zich soms ook nog in verschillende fasen van het aanpassingsproces bevonden. Om die reden is in dit onderzoek gekozen voor een homogene onderzoeksgroep, te weten vrouwen in een beginstadium van borstkanker, die net klaar waren met hun bestraling.

In de literatuur lopen de meningen uiteen over de mate en tijd, waarin het deze vrouwen lukt zich aan hun ziekte aan te passen. Ze variëren van 'na ongeveer een jaar zijn de meeste vrouwen weer in balans en hebben de belangrijkste gevolgen van hun borstkanker overwonnen' tot 'een belangrijke minderheid $(20 \%$ tot $30 \%)$ kampt na enkele jaren nog steeds met problemen'. Deze verschillen blijken vooral terug te voeren op de wijze waarop de problemen zijn gedefinieerd: in algemene termen zoals angst en depressie, of in kankerspecifieke termen zoals bijvoorbeeld angst voor terugkeer van de ziekte. Ook de wijze waarop de problemen zijn geïnventariseerd, met behulp van vragenlijsten of interviews, blijkt van invloed op de resultaten. Dit zijn nog twee factoren die bijdragen aan het gebrek aan eenduidigheid.

Bovendien, het aanpassingsproces is vanuit verschillende theoretische modellen onderzocht. In hoofdstuk I zijn enkele belangrijke theorieèn besproken. Deze vullen elkaar gedeeltelijk aan, overlappen elkaar of spreken elkaar tegen. Ook dit maakt het lastig resultaten te vergelijken. Een van die theorieèn is de copingtheorie. Deze bleek geschikt om andere aanpassingstheorieèn, zoals bijvoorbeeld de sociale vergelijkingstheorie en de attributietheorie, in onder te brengen, waarbij deze zijn opgevat als specifieke uitwerkingen van de copingtheorie. Zo konden inzichten uit verschillende 
theorieën in hun onderlinge samenhang worden onderzocht. Op basis van een aaral definities uit de literatuur, is het begrip coping als volgt gedefinieerd: coping isle cognitieve en gedragsmatige inspanning die een persoon levert om bet boofd te bieden aan eisenlie door anderen, de situatie of zicbzelf aan bem worden gesteld, en waarvan bij inscbat dat deze ijn vermogens op de proef stellen of misscbien zelfs te boten gaan. Deze inspanning is erop gerichide stressuolle situatie te bebeersen, op te beffen, te reduceren of te tolereren.

Omdat uit de literatuur tevens duidelijk werd, dat omgaan met kanker en andre ernstige ziekten vooral bestaat uit de cognitieve component van het aanpassinsproces, heeft het onderzoek zich toegespitst op de relatie tussen cognitieve coping n aanpassing.

Binnen het coping-onderzoek heeft men al snel de factoranalyse als leiderle onderzoeksmethode omarmd. Dit heeft een berg aan copingvragenlijsten opgeleved, bestaande uit factoranalytisch gegroepeerde items die vervolgens als een copigstrategie zijn opgevat. Zelden wordt duidelijk wat deze precies inhouden. Er zijn an ook zeer veel tegenstrijdige of onduidelijke resultaten gevonden.

Hoewel het copingmodel bruikbaar lijkt, heeft het in zijn uitwerking nog geen enduidige resultaten opgeleverd. Nog een laatste en niet onbelangrijke reden hiervoo is terug te voeren op de fundamentele vraag: in hoeverre zijn mensen in staat om oer hun eigen copinggedrag te rapporteren? Met andere woorden, is het mogelijk ret behulp van vragenlijsten de copingstrategieën van de respondent boven waterte krijgen?

In hoofdstuk II is het onderzoeksdesign, de methode en de onderzoeksgroep beschreven.

Vanwege het gebrek aan eenduidige resultaten uit eerder onderzoek - vooral als gevolg van methodologische problemen - is veel aandacht besteed aan design en methode. $\mathrm{Er}$ is een semi-gestructureerd interview ontwikkeld, waarmee de cognitieve strategieën van de borstpatiënten in kaart zijn gebracht. De letterlijke uitspraken van de patiënten over hun omgang met de ziekte en de gevolgen ervan vormden het basismateriaal voor verdere analyse. Zo is geprobeerd de problemen tengevolge van zelfrapportage over het eigen coping-gedrag op te heffen, en konden ook minder bewuste strategieën zoals cognitieve vermijding en bagatelliseren worden onderzocht door bijvoorbeeld een uitspraak als 'bet was maar een tumortje' als uiting van bagatelliseren te scoren.

De mate van aanpassing is bepaald door kankerspecifieke vragenlijst-items in de vorm van Visueel Analoge Schalen (VAS) door het interview heen te weven. Steeds werd een onderwerp ermee afgesloten. Zo werd het mogelijk om kwantitatieve en kwalitatieve gegevens te verzamelen, en deze in hun onderlinge samenhang te analyseren en te begrijpen. 
Op deze wijze is een antwoord gezocht op de volgende vragen:

- welke cognitieve strategieên gebruiken borstkankerpatiënten gedurende de eerste twee jaar na hun behandeling?

- in welke mate komen deze cognitieve strategieèn op drie achtereenvolgende meetmomenten voor?

- wat is de relatie tussen de cognitieve strategieèn en aanpassing?

- is deze relatie afhankelijk van de tijd die sinds de diagnose is verstreken?

Het interview is driemaal afgenomen. De eerste maal $\left(T_{1}\right)$ was zeven weken na beëindigen van de bestraling, $T_{2}$ was acht maanden daarna, en $T_{3}$ een jaar later, i.e. ruim twee jaar na de diagnose. Vanwege het longitudinale design was het nodig dat er door medische redenen weinig uitval zou zijn. Daarom is gekozen voor vrouwen met borstkanker in een gunstig stadium $\left(\mathrm{T}^{1,2} \mathrm{~N}^{0-2} \mathrm{M}^{0}\right)$. Gedurende ruim een jaar zijn de dossiers van borstkankerpatiënten die op de afdeling Radiotherapie van het Academisch Ziekenhuis in Utrecht werden bestraald, gescreend op patiènten die aan dit selectiecriterium voldeden. Exclusie-criteria waren: ernstige bijkomende ziekten en een leeftijd boven 60 jaar. Dit laatste omdat werd ingeschat dat toekomstverwachting en beperkingen ten gevolge van ziekte en behandeling bij oudere vrouwen een andere betekenis kunnen hebben dan bij jongere vrouwen. Voorts moesten de vrouwen de Nederlandse taal beheersen en een Westerse culturele achtergrond hebben, omdat ziektebeleving en reactie op ziekte bij vrouwen uit andere culturen dikwijls anders zijn.

Van de 79 vrouwen die in aanmerking kwamen, hebben 56 aan het onderzoek meegewerkt. Deze vrouwen zijn tussen 1991 en 1994 gedurende de eerste twee jaar na hun diagnose gevolgd. Bij de analyses zijn uiteindelijk 46 borstkankerpatiënten betrokken. Van de overige tien ontbraken om verschillende redenen gegevens. Vier van hen zijn in de loop van de onderzoeksperiode overleden. Bij aanvang was de gemiddelde leeftijd 46,9 jaar (standaarddeviatie 8,0 jaar): de jongste patiènt was 29 en de oudste zestig. Alle vrouwen zijn borstsparend behandeld. Dat wil zeggen dat zij, na het chirurgisch verwijderen van de tumor, zijn bestraald. Voor vrouwen met negatieve okselklieren was dit de volledige behandeling $(n=13)$. De vrouwen met positieve okselklieren hebben een aanvullende behandeling ondergaan. Diegenen die nog niet aan de menopauze voorbij waren, zijn aanvullend behandeld met adjuvante chemotherapie $(n=23)$ en de vrouwen van na de menopauze met een hormonale therapie $(n=10)$. Bij zes vrouwen was ten tijde van het derde interview de ziekte teruggekeerd. 
In hoofdstuk III is het proces van definiëring van de cognitieve strategieèn beschreven. Omdat een antwoord is gezocht op de brede vraag 'welke cognitieve strategieèn gebruiken borstkankerpatiënten?', zijn heel veel uitspraken tegen het licht gehouden. Deze waren niet gemakkelijk eenduidig in te delen, aangezien voor de meeste cognitieve strategieën geen goede definitie voorhanden was. Bovendien bleek dat sommige strategieën, die hun oorsprong hebben in verschillende theorieën, zodanig overlappen dat ze definitorisch niet volledig van elkaar zijn te scheiden. Daarom is begrip dubbelstrategie geïntroduceerd, zijnde een uitspraak die tegelijkertijd twee verschillende strategieën bevat en niet is op te delen zonder dat de betekenis ervan verdwijnt.

Op basis van de uitspraken uit de eerste interviewronde is een lijst van zeventien cognitieve strategieèn ontstaan die door borstkankerpatiënten worden gebruikt. Hoewel de uitspraken uit de vervolginterviews vanzelfsprekend niet letterlijk gelijk waren aan die uit de eerste ronde, konden ook deze uitspraken goed in de lijst worden ondergebracht en waren er geen verdere aanpassingen nodig. Zo diende de analyse van het tweede en derde interview als een validering van de definities en scoringsafspraken. Op grond van deze ervaring lijkt de conclusie gerechtvaardigd dat de gevolgde werkwijze bruikbaar en valide is, en dat met de zeventien cognitieve strategieèn voor een belangrijk deel de cognitieve arbeid van de patiënten in kaart is gebracht. Op de pagina's 93 en 94 van dit boek staat de lijst met de zeventien cognitieve strategieen en hun definities afgedrukt.

Hoofdstuk IV gaat verder in op de cognitieve strategieën van de borstkankerpatiënten uit dit onderzoek. Eerst is uiteengezet welke onderwerpen in de cognitieve strategieën zijn aangetroffen. Hieruit wordt duidelijk wat borstkankerpatiënten bezig houdt en hoe zij er mee omgaan. Het bleek dat de vraag die wordt gesteld van invloed is op de soort strategieën die in het antwoord voorkomen, alsook op de frequentie waarin een strategie wordt aangetroffen. Opvallend is dat vragen naar de status quo, respectievelijk die naar de mate van verandering die door de ziekte is opgetreden, verschillende strategieën uitlokken, hoewel het in principe om dezelfde onderwerpen gaat.

In het tweede deel van dit hoofdstuk zijn de kwantitatieve gegevens gepresenteerd. Aangetoond wordt dat de meeste patiënten bij het verwerken van de ziekte een breed scala aan strategieèn gebruiken, gemiddeld tien van de zeventien onderzochte strategieën. Deze strategieën worden in wisselende reeksen ingezet, waarbij ook ogenschijnlijk tegenstrijdige strategieën elkaar opvolgen. Daarbij zijn er strategieën die door bijna iedereen worden gebruikt (steeds tussen $97 \%$ en $85 \%$ van de vrouwen), zoals causale attributies, cognitief vermijden, doemdenken en zichzelf toespreken, en 
strategieèn die slechts door een enkeling worden gebruikt (afhankelijk van het meetmoment, tussen $4 \%$ en $26 \%$ van de vrouwen), zoals uitsluitende attributies, zichzelf bijzonder vinden en de sociale vergelijking positief naar boven. In de loop van het onderzoek zijn op groepsniveau weinig significante veranderingen gevonden. Tegen de verwachting in, neemt het percentage patiënten dat berust niet toe en stijgt ook de frequentie niet waarmee deze strategie wordt gebruikt (op de eerste twee meetmomenten berust $78 \%$ van de patiënten, op het derde meetmoment is dit, niet significant, teruggelopen naar $67 \%$ ). Daarbij blijft het percentage patiënten dat protesteert, cognitief vermijdt, doemdenkt, bagatelliseert of zichzelf toespreekt onverminderd hoog. Wel dalen vier van de zes sociale vergelijkingen significant in gebruik, wat er op wijst dat sociale vergelijkingen vooral in het begin van het aanpassingsproces worden aangewend.

Hoewel in de totale groep niet veel verandert, blijkt uit de test-hertest- correlaties dat individuele patiënten lang niet altijd consistent zijn in hun strategiegebruik. Protesteren, doemdenken en bagatelliseren zijn nog het meest stabiel.

Er zijn weinig verschillen in strategiegebruik gevonden tussen subgroepen van patiënten. Patiënten die een chemokuur moesten ondergaan, protesteren significant meer en vergelijken zich minder vaak gelijkwaardig dan de anderen. Ook is gebleken dat, wanneer ouderen een bepaalde strategie gebruiken, de frequentie waarmee zij dat doen meestal hoger is dan bij de jongeren. Hoger opgeleiden gebruiken meer schuldontlastende attributies. Er zijn geen samenhangen gevonden tussen strategiegebruik en de objectieve ernst van de ziekte.

De mate waarin de borstkankerpatiënten zich hebben aangepast aan hun ziekte, is het onderwerp van hoofdstuk V. De VAS-items uit het interview zijn opgevat als apriori-schalen voor de vijf indicatoren waarmee aanpassing is geoperationaliseerd. Voor drie ervan, namelijk toekomstperspectief, angst en zelfbeeld kon een betrouwbare schaal worden geconstrueerd. Aangezien de beoogde schaal-items voor de twee overige indices, schaamte en eigen invloed, onvoldoende samenhang vertoonden, zijn deze met enkele losse items in kaart gebracht.

De aanpassingsgebieden bleken conceptueel goed van elkaar te onderscheiden, maar niet geheel onafhankelijk van elkaar. De relatie tussen angst en toekomstperspectief bleek het sterkst: de correlatiecoëfficiënten waren op de opeenvolgende meetmomenten .75, .59 en .50. Zelfbeeld en eigen invloed bleken het meest op zichzelf te staan. 'Eigen invloed' was zelfs zo onafhankelijk dat moet worden betwijfeld of het wel een onderdeel van aanpassing is.

De patiënten vonden over het algemeen dat zij weinig invloed hadden op het verloop van hun borstkanker. Ruim de helft van de patiênten was niet angstig en 
driekwart zag de toekomst positief tegemoet. Ziekte en behandeling bleken niet noemenswaard van invloed op het zelfbeeld en slechts weinig vrouwen schaamden zich voor hun ziekte. Afgezien van 'eigen invloed' was het gemiddelde aanpassingsniveau van de borstkankerpatiënten uit deze onderzoeksgroep op alle aanpassingsindices en op alle meetmomenten hoog tot tamelijk hoog. Hierin traden gedurende de onderzoeksperiode geen significante veranderingen op. Toch vond $28 \%$ van de patiënten twee jaar na diagnose $\left(\mathrm{T}_{3}\right)$ de toekomst als gevolg van de ziekte bedreigend en zei $44 \%$ angstig te zijn. Voor respectievelijk $13 \%$ en $28 \%$ was dit vlak na de diagnose ook al zo, de overigen zijn sindsdien somberder en angstiger geworden. Dergelijke percentages worden in de literatuur meer aangetroffen.

Naast het rekenkundige verschil tussen de scores van opeenvolgende meetmomenten, de gebruikelijke maat voor verandering, is tevens een andere maat voor verandering geanalyseerd. Daartoe hebben de patiènten op een VAS aangegeven in hoeverre zij vonden dat er ten opzichte van het vorige interview iets was veranderd. Deze patiënten-oordelen over de verandering lieten zien dat volgens de patiënten meer was veranderd dan uit de rekenkundige verschillen viel af te lezen. Bovendien werd duidelijk dat naar het oordeel van een aanzienlijk deel van de patiënten, in de loop van de tijd de impact van de ziekte niet afnam, maar eerder groter werd. Uit de verhalen van de patiênten kwam naar voren dat zij zich steeds minder door de behandeling beschermd gingen voelen: 'mijn licbaam moet bet mu zelf weer doen en bet beeft me al eerder in de steek gelaten.' Bovendien ging meespelen dat lichamelijke klachten en klachtjes niet langer konden worden afgedaan als een gevolg van de bestraling of medicamenteuze therapie. Dat vergrootte de 'alarmwaarde'. Medische controles konden deze gevoelens lang niet bij iedereen wegnemen. Ook kwam uit de verhalen naar voren dat men er aanvankelijk alles voor over had om te genezen. Mogelijke gevolgen van de behandeling werden in het licht van de dreiging van kanker op de koop toe genomen. Later gingen ze toch zwaarder wegen. Het ging dan om beperkingen in het gebruik van de arm ten gevolge van het verwijderen van de okselklieren, aanhoudende moeheid en het vroegtijdig in de overgang raken door de chemotherapie.

Behalve deze discrepantie tussen de patiënten-oordelen en de rekenkundige verandering werd er een discrepantie geconstateerd tussen de indruk die uit het verhaal ontstond en de scores op de VAS-items. Met andere woorden, er werd een discrepantie geconstateerd tussen kwalitatieve en kwantitatieve data. Gebleken is dat op de aanpassingsschalen voor toekomstperspectief en angst systematisch hoger werd gescoord, dus in de richting van meer aanpassing, dan past bij de uitlatingen over de ziekte en de gevolgen. Op de zelfbeeldschaal komt een dergelijke systematische overscoring niet voor. Op geen van de schalen was sprake van onderscoring; i.e. in de richting van minder aanpassing dan in het verhaal wordt vermeld. 
Tussen subgroepen van patiënten zijn weinig verschillen in aanpassingsniveau gevonden die over de drie meetmomenten standhielden. Vanzelfsprekend zijn degenen die op $\mathbf{T}_{3}$ zijn geconfronteerd met metastasen of een recidief, angstiger en somberder over hun toekomst dan de anderen. Verder bleek dat op $\mathrm{T}_{1}$ en $\mathrm{T}_{2}$ patiènten die hoger zijn opgeleid, meer invloed dachten te hebben op de ziekte en de gevolgen ervan. Ook patiënten die een chemokuur ondergingen ervoeren meer invloed op hun ziekte, maar dan alleen in de periode van de kuur. Bovendien was hun zelfbeeld op dat moment wat negatiever. Na beèindiging van de kuur (vanaf $\mathrm{T}_{2}$ ) zijn deze verschillen niet meer aangetroffen.

Tenslotte is de invloed van sociale steun op aanpassing onderzocht. Er kon worden geconcludeerd dat de patiènten over het algemeen veel steun ervoeren. In de loop van de tijd nam deze wel wat af, maar bleef gemiddeld hoog. Daarom is 'ervaren steun' niet bij de verdere analyses naar de relatie tussen cognitieve coping en aanpassing betrokken.

In hoofdstuk VI zijn de resultaten uit de twee voorafgaande hoofdstukken met elkaar in verband gebracht. In dit hoofdstuk wordt de centrale vraag van dit proefschrift behandeld: wat is de relatie tussen de cognitieve strategieën en aanpassing?. De meeste cognitieve strategieèn bleken op een of andere wijze een relatie te hebben met aanpassing aan borstkanker. De verbanden bleken onafhankelijk van leeftijd, opleiding, objectieve ernst van de ziekte en aard van de behandeling. Bij ruim tweederde van de strategieën zijn tevens een of meerdere voorspellende verbanden aangetoond. Daaruit is de belangrijkste conclusie van dit onderzoek getrokken, namelijk dat cognitieve strategieën aanpassing beinnloeden.

Protesteren is zonder twijfel de belangrijkste determinant voor een minder geslaagde aanpassing. Vrouwen die protesteren waren niet alleen angstig, maar ook pessimistisch over hun toekomst en hadden vaker problemen met een veranderd zelfbeeld: zij voelden zich het meest door de ziekte beperkt en aangetast. Dit bleef zo gedurende de gehele periode van het onderzoek. Daarbij heeft de mate waarin de vrouw vlak na de behandeling protesteert, een grote voorspellende waarde voor een gebrekkige aanpassing twee jaar later. Patiënten die de vraag 'waarom ik?' belangrijk vinden, passen zich eveneens minder goed aan, ongeacht of zij daarbij ook protesteren. Tenslotte bleek dat ook doemdenken en de sociale vergelijking negatief naar boven slecht zijn voor aanpassing. Daar staat tegenover dat patiënten die berusten, bagatelliseren, of een positieve wending geven aan hetgeen hun is overkomen, over het algemeen beter af waren dan de anderen, hoewel de effecten van berusten en bagatelliseren op de lange termijn niet altijd stand hielden.

Het is van belang gebleken het algemene begrip 'aanpassing aan kanker' op te splitsen in concrete, van elkaar te onderscheiden onderdelen. In dit onderzoek waren 
dat de vijf indicatoren toekomstperspectief, angst, zelfbeeld, eigen invloed el schaamte. De strategieën bleken niet op elke aanpassingsindex in gelijke mate of op dezelfde wijze van invloed te zijn. Soms was de invloed op verschillende indices zels tegengesteld, zoals bijvoorbeeld bij de ontlastende attributie, die positief is voor he zelfbeeld en negatief voor de toekomstbeleving.

De discrepantie tussen verhaal en scoring, die in hoofdstuk $V$ werd gesignaleerd bleek, in ieder geval gedeeltelijk, te verklaren uit de cognitieve strategieën van d patiènt. De ambivalentie die het verhaal wél toelaat, kan niet tot uitdrukking komen i) een score. Diegenen die tijdens het interview cognitief vermijden of zichzef toespreken, bleken deze strategie voort te zetten tijdens het scoren, waardoor d? nuancering uit het verhaal wegviel en de score positiever uitviel dan uit het verhad zou mogen worden verwacht. Patiënten die relatief veel protesteren, doemdenken el zich negatief naar beneden vergelijken, alsmede diegenen die relatief weinig berusten zwakken de confronterende score die dit zou opleveren af, door tijdens het scoren ab het ware met een positieve strategie te vervolgen, waardoor de score in positieve zi) werd bijgesteld. Hiermee is tevens een verklaring gegeven waarom de onderzoeks resultaten uit vragenlijstonderzoek dikwijls afwijken van die uit interviews.

In hoofdstuk VII tenslotte, zijn de resultaten uit dit onderzoek afgezet tegen die ut de literatuur. Opnieuw is veel aandacht besteed aan de bespreking van methodo logische problemen in onderzoek naar psychologische processen en zijn oplossings richoingen besproken.

Afsluitend zijn de resultaten vertaald naar de klinische praktijk. Het onderzoek biedt aanknopingspunten voor de screening van patiënten die in aanmerking komen voor extra begeleiding. Duidelijk werd dat de mate waarin de patiënt tegen de ziekte en de gevolgen ervan protesteert, een zeer belangrijke indicator is voor een slechte aanpassing. Met patiënten die worstelen met de vraag 'waarom ik?' en met patiënten die veel doemdenken, gaat het over het algemeen ook niet goed. Daarnaast is schaamte een belangrijk signaal. Alles bij elkaar ziet het er naar uit dat bij de vrouwen die het minst goed zijn aangepast, de illusies van veiligheid, rechtvaardigheid, onaantastbaarheid en voorspelbaarheid ernstig zijn aangetast. De begeleiding en, indien nodig, de psychologische behandeling zou zich hierop moeten richten. Wanneer het lukt om de vraag 'waarom ik?' om te buigen in de richting van 'waarom ik niet?', is de kans groot dat er meer berusting optreedt, dat de patiënt minder angstig wordt en dat zij zich meer kan richten op datgene waar zij wél invloed op heeft, namelijk 'wat maak ik er desondanks van'. Patiënten die in staat zijn een positieve wending te geven aan hetgeen hun is overkomen, zijn over het algemeen beter af dan de anderen. Ook de cognitieve strategieën berusten en bagatelliseren hebben een gunstige invloed op het aanpassingsproces en zouden bevorderd kunnen worden. 
Een ander belangrijk thema is het verlies van vertrouwen in het eigen lichaam. Veel vrouwen hadden borstkanker, terwijl ze zich gezond voelden. Dat maakt hen erg onzeker over hun lichaam, een onzekerheid die soms gegeneraliseerd wordt naar allerlei andere situaties in hun leven. Het verdient aanbeveling aandacht te besteden aan de verstoorde lichaamsbeleving. Dit kan door informatie te geven over de fysieke gevolgen van de behandeling. Ook door ontspannings- en ademtherapie is het mogelijk gewone lichaamssensaties en de lichamelijke component van spanning te leren herkennen en te beïnvloeden. Hierdoor verliezen deze lichaamssensaties hun onterechte alarmwaarde en wordt voorkomen dat een patiënt in een negatieve angstspiraal terechtkomt.

Schuldontlasting bleek een belangrijk onderwerp. Veel vrouwen wezen er nadrukkelijk op dat ze gezond hebben geleefd of dat zij de kanker niet eerder hadden kunnen ontdekken, al deed lang niet iedereen aan zelfonderzoek, zoals in publiekscampagnes wordt gepropageerd. Met name de vrouwen die naar eigen zeggen erg gezond geleefd hebben, waren extra boos en voelden zich soms door de gezondheids. voorlichting bedrogen. Dit lijkt de keerzijde van dergelijke campagnes die pleiten voor gezond gedrag en eigen verantwoordelijkheid. Het is aan te bevelen dat bij zulke campagnes nadrukkelijker wordt vermeld, dat het niet zeker is dat daarmee de ziekte altijd wordt voorkomen. In de begeleiding van patiènten moet ook hieraan aandacht worden besteed.

De citaten in dit proefschrift tonen aan dat de inhoud van de cognities over het algemeen zeer idiosyncratisch is en berust op persoonlijke constructen. Met behulp van deze cognities ontstaat een verhaal waarmee de gebeurtenis wordt ingebed in het eigen levensverhaal. Door de verwarrende gebeurtenis in een talige structuur te brengen wordt deze georganiseerd. Het lijkt van belang om patiënten die in hun directe omgeving niet terecht kunnen of willen, een gelegenheid te bieden 'vertellenderwijs' de gebeurtenis te verwerken. Dit proefschrift heeft laten zien welke thema's daarbij voor borstkankerpatiënten van belang zijn. 


\section{COGNITIVE STRATEGIES OF BREAST CANCER PATIENTS IN RELATION TO THEIR ADAPTATION PROCESS: A LONGITUDINAL STUDY}

\section{SUMMARY}

Starting out as a radiographer twenty-five years ago, I wondered at the variety of ways in which cancer victims coped with their disease, and the question of how people adapt to a life-threatening disease has never let me go. Today, as a medical psychologist I am still exploring this question. Although many studies have already been carried out, there is little generally agreed knowledge about the subject. Thanks to a grant from the Netherlands Research Organization (NWO), I was able to study this matter more deeply This thesis, a result of our research, will, I hope, shed more light on this issue.

Chapter I gives an overview of the literature on coping, which reveals a lack of consensus about both the adaptation process, 'i.e. what people do', and the outcome, i.e. 'what is their return'. The conflicting results clearly arise from successive methodological problems. One such problem is that adaptation is often studied in non-homogeneous groups of patients with different diseases who might also have been in different stages of the adaptation process. For that reason, we have used a homogeneous study sample in our research, namely women with early stage breast cancer who have just completed radiotherapy.

Another aspect which contributes to the lack of consensus is related to the different views about the degree in which these women adapt to their disease, and the time they require to do so. Some researchers state that 'after about a year, most women have regained their equilibrium and have conquered the greatest impacts of breast cancer' while others report 'a sizeable group of patients (20 to $30 \%$ ) still experiencing problems after several years". These differences can be attributed primarily to the way in which the concept of problem is defined: in general terms such as fear and depression, or in cancer-specific terms such as the fear of recurrence. Next to this, the way in which problems are surveyed, using questionnaires or interviews, also influences results.

In addition, different theoretical models have been used over time to study the process of adaptation. The most important theories are discussed in chapter I. In some cases these theories complement each other, but they may also overlap or even conflict with each other. This also contributes to the confusion and makes a comparison of research results difficult or even impossible. The coping theory of 
Lazarus and Folkman is an important theory in adaptation research, and in our opinion is a suitable umbrella for other adaptation theories such as social comparison theory and attribution theory. By placing these theories under one umbrella, we were able to study aspects of the different theories in relation to each other. On the basis of various definitions in the literature, we defined the overall concept of coping as follows: coping is the wbole of a person's cognitize and bebatioural efforts to deal witb the demands - set by otbers, by the situation or by berself - ubicb are felt to challenge or even exceed ber capacities. The person's efforts are aimed at controlling, ending, alleviating or generating tolenance to the stressful situation.

There was strong evidence in the literature that dealing with cancer and other serious diseases mainly involves the cognitive component of the adaptation process. This research therefore examines the relationship between cognitive coping and adaptation.

In coping research, factor analysis has become the research method of choice. This has resulted in a virtual mountain of coping questionnaires made up of factor-analytical groups of items which are subsequently assumed to represent coping strategies. These coping strategies are rarely, however, defined and substantiated. Consequently, many research results have been conflicting or ambiguous.

Thus, although the coping model has potential, there are many reasons why it has as yet never produced clear-cut results. One last, not unimportant reason for this can be found in the basic premise underlying coping research, that people are capable of reporting on their own coping behaviour. The question is, to what extent this presumption is correct. In other words, can respondents' coping strategies really be revealed using questionnaires?

Chapter II describes the research design, method and sample used in this study. We aimed to answer the following research questions:

- Which cognitive strategies do breast cancer patients use the first two years after cancer treatment?

- What is the intensity and frequency of these cognitive strategies at the three consecutive measurement periods?

- What is the relationship between cognitive strategies and adaptation?

- Does this relationship depend on the time passed since diagnosis?

Because of the methodological problems in coping research, we paid special attention to research design and method. Patients' own words formed the raw material for analysis in order to avoid the problems associated with self-reports on coping behaviour and also to bring sub-conscious strategies to the surface, such as cognitive avoidance and minimization. Therefor we developed a semi-structured interview to chart the cognitive strategies of breast cancer patients. 
The degree of adaptation was determined with Visual Analog Scales for cancespecific items scattered tbrougbout the interview. Discussion of a topic always ended wh one of these scales. In this way, we obtained a coherent set of both quantitative ad qualitative data which we could analyse and understand separately and togethe. Subjects were interviewed three times. The first interview $\left(T_{1}\right)$ was taken seven wees after the completion of radiotherapy, the second $\left(T_{2}\right)$ eight months after $T_{1}$ and te third $\left(T_{3}\right)$ one year after $T_{2}$, i.e. more than two years after diagnosis. Because of ths longitudinal design, it was important to ensure a low drop-out rate for mediol reasons. For this reason, our study sample was made up of women with favourabtstage breast cancer $\left(\mathrm{T}^{1,2} \mathrm{~N}^{0-2} \mathrm{M}^{0}\right)$. Exclusion criteria were: severe secondary diseass and age over 60 years. We set an age limit because we expected that the outlook ad limitations caused by the disease and the treatment would have different implicatios for younger women. Women in the sample also had to speak Dutch fluently and hae a Western cultural background, since disease perception and disease response oftn differ between people from different cultures.

Seventy-nine women were eligible for inclusion, and of these 56 participated n our study. All patients were treated at the Radiotherapy section of Academiscb Medis Centrum Utrecbt (Utrecht University Hospital). We followed these women in the tw years after diagnosis, in the period between 1991 and 1994. In the end, our analys included 46 breast cancer patients. We had missing data for ten subjects, four if whom had died in the course of our research. At the start of the study, the mean age if the sample was 46.9 years (standard deviation 8.0 years), with ages ranging from 29 to 60. Conservative surgery was performed on all women in the sample, i.e. the tumour was excised and women then received radiation treatment. This comprised the full treatment for women with negative lymph nodes $(n=13)$. Women with positive lymph nodes received additional treatment: those who had not yet reached menopause were given adjuvant chemotherapy $(n=23)$, while post-menopausal women had hormonal therapy $(n=10)$. At the time of the third interview, the disease had recurred in six women.

Chapter III describes the process of defining cognitive strategies. We had set ourselves a broad question ('which cognitive strategies do breast cancer patients use?'), which meant examining a huge number of statements. In many cases, a clear-cut division into one or other category was made difficult by the fact that for most cognitive strategies there was no definition at hand, so that we had to draw up our own definitions. Some strategies, stemming from different theories, overlapped to such a degree that it was impossible to make a strict conceptual division between them. We therefore introduced the concept of double strategy to refer to statements which 
simultaneously contained two different strategies which could not be split up without resulting in a loss of meaning.

The statements collected in the first series of interviews produced a list of seventeen cognitive strategies used by breast cancer patients. The statements made in the follow-up interviews naturally differed in wording from the statements of the first series, but they could still be classified quite easily using this list. We did not have to adapt the list further. The analysis of the second and third series of interviews thus served to validate the definitions and the scoring procedure. On the basis of these results, we concluded that the method developed is both feasible and valid, and successfully charts most of patients' cognitive coping efforts. The list of seventeen cognitive strategies and their definitions are presented at the end of this summary.

Chapter IV gives an in-depth presentation of the cognitive strategies used by breast cancer patients in this study. First, the subjects of the cognitive strategies are described. These reveal the issues that occupy breast cancer patients and how they deal with these. We found that bow we asked a question influenced which types of strategies were used in patients' answers as well as the frequency in which a strategy occurred. For example, asking about patients' status quo as opposed to the degree of change caused by the disease elicited different strategies, while in effect the questions concern the same subject.

Quantitative data are presented in the second part of chapter IV. Most patients used a wide range of strategies to come to terms with the disease, an average of ten out of the seventeen strategies defined in this study. These strategies were deployed in changing sequences, so that one strategy might be followed by a seemingly conflicting strategy. Some strategies were used by nearly all women (between $85 \%$ and $97 \%$ of the women throughout the study), namely causal attributions, cognitive avoidance, doom-and-gloom thinking and self-admonishment. Other strategies were used by only a few women (between $4 \%$ and $26 \%$ depending on the time of the interview). These were: cancel-out attributions, believing self to be a unique patient and positive upward social comparison. In the course of the study, few significant changes occurred at group level. Contrary to our expectations, the percentage of patients that had resigned themselves to the disease did not grow, nor did the frequency that this strategy was used $(78 \%$ of patients expressed resignation at $\mathrm{T} 1$ and $\mathrm{T} 2$, compared to $67 \%$ at the time of the final interview, but the change was not significant). Protest, cognitive avoidance, doom-and-gloom thinking, minimization and self-admonishment on the other hand were used by a consistently high percentage of patients. The use of four of the six social comparisons did decline significantly over time, suggesting that social comparison is used primarily in the early stages of the adaptation process. 
Although there were few changes in the sample as a whole, individually patient were by no means consistent in the strategies they used, as shown by the test-retest correlations. The use of protest, doom-and-gloom thinking and minimization was the most stable.

We did not find many differences in strategy deployment between patient subgroups. Patients who had to take chemotherapy protested significantly more ofter and were less likely to compare themselves as equal to others (equal social comparison). We also found that, once a strategy had been chosen, older patients would use it mort often than younger patients. Patients with a higher level of education used more guilt relieving attributions. We found no relationship between strategy deployment and the objective severity of the disease.

Chapter $\mathbf{V}$ is about the degree in which breast cancer patients have adapted to their illness. The VAS items were postulated as a priori scales for the five indicators with which we operationalised the concept of adaptation. The scales for three of these indicators, namely future outlook, fear and self-image, were found to be reliable scale with Cronbach alphas greater than 0.70 . The associations between the intended scale items of the other two indices, shame and own influence, were too weak to form t scale, so we decided instead to measure these indicators using a few single items.

The different conceptual components of adaptation were sufficiently distinct, bul also to some extent interdependent. The strongest relationshin was found hetween foaf and future outlook, with correlation coefficients of $.75, .59$ and .50 at the three consecutive times of measurement. The most independent indicators were self-image and own influence. Own influence was so independent that it might not be a component of adaptation at all.

In general, the breast cancer patients in our sample felt they had little influence on the course of their disease. More than half of the patients were not afraid and threequarters were confident about their future outlook. The disease and its treatment did not particularly affect patients' self-image and very few women felt ashamed about their illness. In our study sample, the scores for all indicators except 'own influence' reflected a high or fairly high degree of adaptation at all three times of measurement. Significant changes did not occur in the course of the study. Nevertheless, two years after diagnosis (T3), $28 \%$ of patients felt their future was threatened by the disease and $44 \%$ felt afraid. These percentages agree with the results of other studies. For $13 \%$ and $28 \%$ of the sample, respectively, this had already been the case shortly after diagnosis. Apparently, the other patients had become less optimistic and more afraid in the course of time.

The quantitative differences between scores at different times of measurement is only one measure of change. Patients' own reports of change are another and were 
also used in this study. Patients were asked to indicate on a VAS to what extent they felt something had changed since the previous interview. Patients reported a greater degree of change than we had measured quantitatively. Apparently, a large group of patients felt that the impact of the disease actually increased, not decreased, over time. In their narratives, patients spoke of feeling more vulnerable after cancer therapy: 'Now it's all up to my own body again, and it's let me down before'. Also, once the therapy had stopped, physical complaints and ailments could no longer be shrugged off as side effects of radiation or chemotherapy. This lowered the threshold for alarm for these complaints, and medical check-ups could not always alleviate the resulting feelings of anxiety. Patients also told us how, initially, they had been willing to do anything to be cured of cancer. Possible secondary effects of treatment were accepted in the light of the danger posed by the cancer. At a later stage, however, these secondary effects started to carry more weight. The main concerns were functional limitations of the arm due to the removal of underarm lymph nodes, persistent fatigue and an earlier menopause induced by the chemotherapy.

Next to this discrepancy between patients' perceptions of change and quantitatively measured change, we also found a discrepancy between the overall impression given by patients in their own reports of the event and the ratings on the VAS items. There was, in other words, a discrepancy between qualitative and quantitative data. Scores on adaptation scales for future outlook and fear were consistently higher, suggesting greater adaptation, than one would expect on the basis of patients' own statements about the disease and its consequences. This did not apply to the self-image scale. Under-rating, i.e. suggesting less adaptation than indicated in patients' own reports, did not occur on any of the scales.

A comparison of patient subgroups revealed very few differences in the degree of adaptation which persisted throughout the study. Naturally, those with metastases or recurrence at $\mathrm{T}_{3}$ were more fearful and pessimistic about their future than others. Patients with a higher level of education believed they had more control over the disease and its consequences at $T_{1}$ and $T_{2}$. Patients taking chemotherapy also experienced greater control over their disease, but only for the duration of the chemotherapy. At the same time, they had a more negative self-image. These differences disappeared after the chemotherapy was completed (i.e. from $\mathrm{T}_{2}$ on).

Finally, we examined the effect of social support on adaptation. In general, patients received a lot of support. This declined somewhat over time, but remained high overall. We therefore decided not to include 'received social support' in our further analyses of the relationship between cognitive coping and adaptation. 
In Chapter VI the results presented in the previous two chapters are brought together. An answer is given to the main research question, concerning the nature of the relationship between cognitive strategies and adaptation. Most cognitive strategies were in some way associated with patients' adaptation to breast cancer. The relationships were independent of age, level of education, objective severity of the disease and the type of treatment followed. We established one or more predictive associations for more than two-thirds of the strategies. On the basis of these results, the main conclusion of this study is that cognitive strategies do influence the adaptation process.

Protest is clearly the most important determinant of a less successful adaptation. Women who protested had more feelings of fear and were more pessimistic about their future. They also had more problems accepting their altered self-image. Of the women in our sample, they felt strongest that the disease limited and debilitated them. This remained consistent for the duration of the study. The degree in which a woman protests was, moreover, found to have a high predictive value for insufficient adaptation to the disease after two years. Patients for whom the question 'Why me?' was important were also less well adapted to the disease, regardless of whether or not they protested. Finally, doom-and-gloom thinking and a negative upward social comparison also had a negative influence on adaptation. By contrast, patients who resigned themselves to the disease, who minimized it or who gave a positive turn to this life event were generally better off than the others. The effects of resignation and minimization were not always sustained in the long run, however.

Our research showed that it is necessary to divide the general concept 'adapting to cancer' into concrete, distinct components. In our study, we used five indicators of adaptation: future outlook, fear, self-image, own influence and shame. We found that these indicators were affected in different ways and at different intensities by the coping strategies defined in this study. A certain strategy could even have an opposite effect on different indicators. For example, the guilt relieving attribution had a positive effect on self-image but affected the patient's future outlook negatively.

The discrepancy between patients' own narratives and objective measurements, observed in chapter V, could be explained at least in part by the cognitive strategies used by patients. In relaying one's own story and experiences, there is scope for ambivalence which cannot be caught by so-called objective measures. Patients who used the cognitive avoidance or self-admonishment strategies during the interview continued to do so when rating the VAS items. The nuances expressed in their own words were lost, so that the ratings were more positive than the narrative would lead one to expect. On the other hand, patients who tended to protest, express doom-andgloom thinking and make negative downward social comparisons would use a positive 
strategy for rating the VAS, thus toning down what would otherwise have been a confrontational rating. In other words, the rating was adjusted for the better. This explains why the results of questionnaire surveys often differ from those obtained by interviews.

In chapter VII the research results are discussed in relation to the literature. Again, considerable attention is paid to the methodological problems encountered in research into psychological processes and possible solutions are discussed.

Lastly, the results are transposed to clinical practice. Our research provides additional ideas for screening patients who qualify for supplementary counselling. Our study results clearly show that the intensity of a patient's protests about the disease and its consequences is a very important indicator for poor adaptation. Adaptation difficulties can also be expected when the question 'Why me?' and doom-and-gloom thinking prey on a patient's mind. Shame is also an important indicator of poor adaptation.

Our results suggested that the least adapted women suffered severe blows to their illusions of safety, justice, invulnerability and predictability. This should be the focus of counselling, and if necessary psychological treatment. If the question 'Why me?' can be turned around to 'Why not me?', there is a good chance that the patient will become more resigned to her situation, less fearful and better able to focus on the things that she can influence, finding ways to make the best of things despite the disease. Patients who can give a positive turn to the disease are generally in a better state than other patients. The cognitive strategies resignation and minimization also enhance the adaptation process and could be promoted.

Another important theme is women's loss of confidence in their bodies. Many women found out they had breast cancer while they felt healthy. This makes them feel very insecure about their health, and this feeling is sometimes generalized to other areas of their lives. We recommend paying attention to this matter, for example by giving patients detailed information about the physical consequences of cancer treatment, so that they know what they can expect. Relaxation or breathing exercises can also help women to distinguish normal body sensations and the physical expression of tension and fear, and can enable them to alleviate this tension. As a result, these physical sensations lose their false power of alarm, preventing patients from falling in a downward spiral of fear.

Guilt relief was also an important theme. Many women explicitly pointed out that they had healthy lifestyles or that they could not have discovered the cancer earlier, even though not all women conducted routine breast examinations as recommended in public health campaigns. Women who said they had always lived 
healthily were especially angry and sometimes felt misled by the public heath campaigns. This might be the downside of campaigns promoting healthy behaviour and taking responsibility for your own health. Perhaps these campaigns should communicate more clearly that taking the right measures cannot always prevent disease. This subject should also be addressed in patient counselling.

The quotations in this dissertation reveal the idiosyncratic nature of patien's' cognitions, and show that they are based on personal constructs. These cognitions help patients generate a coherent narrative about what has happened so that the event can be embedded in the patient's own life history. Expressing the emotionally confusing episode in words helps patients to structure the event. Patients who canrot find a receptive ear in their own environment might benefit from an opportunity to tell their story to help them deal with the event. This dissertation shows which themes should be raised in the counselling of breast cancer patients. 


\section{LIST OF COGNITIVE STRATEGIES AND THEIR DEFINITIONS}

\section{- Causal attribution}

A CAUSAL. ATTRIBUTION IS A STATEMENT THAT REVEALS THE PATIENT'S THOUGHTS ABOUT THE CAUSE OF THE DISEASE.

\section{- Cancel-out attribution}

A PATIENT CONSIDERS A POSSIBLE CAUSE OF THE DISEASE, BUT CONCLUDES THAT IT DOES NOT APPLY TO HERSELF AND THUS COULD NEVER BE AN EXPLANATION FOR HER ILLNESS. THE POSSIBLE EXPLANATION IS RULED OUT IN A NEUTRAL MANNER.

\section{- Guilt relieving attribution}

THE PATIENT RELIEVES HERSELF OF FEELINGS OF GUILT BY REIECTING SOMETHING THAT SHE ACTUALIY DIO AS BEING THE CAUSE OF THE DISEASE, OR EMPHASIZES THAT SHE HAS ALWAYS LIVED A HEALTHY LUFE ESPECIALLY TO PREVENT CANCER AND THEREFORE REIECTS RESPONSIBILITY FOR CAUSING THE DISEASE, OR DECLARES THAT SHE COULD NOT HAVE DISCOVERED THE CANCER ANY EARLIER.

\section{- Giving a positive meaning}

THE PATIENT GIVES A POSTIVE TURN TO A NEGATIVE EVENT. THE DISEASE HAS MADE OTHER THINCS IN THE PATIENT'S LIFE IMPORTANT: THE ILLNESS HAS EFFCTED SOMETHING, II HAS HAD A 'PURPOSE'.

\section{- Positive upward social comparison}

A POSITIVE UPWARD SOCIAL COMPARISON PRODUCES A POSITIVE EMOTION BECAUSE THE PATIENT COMPARES HERSELF TO OTHERS WHO SHE PERCEIVES ARE DOING BETTER OR WHOSE CIRCUMSTANCES ARE BETTER, AND THIS GIVES HER HOPE THAT THINGS WILL IMPROVE.

\section{- Positive downward social comparison}

A POSITIVE DOWNWARD SOCIAL COMPARISON PRODUCES A POSITIVE EMOTION BECAUSE THE PATIENT COMPARES HERSELF TO OTHERS WHO SHE PERCEIVES ARE DOING WORSE OR WHOSE CIRCUMSTANCES ARE WORSE, AND CONCLUDES THAT THINCS AREN'T GOING TOO BADLY FOR HER.

\section{- Negative upward social comparison}

A NEGATIVE UPWARD SOCIAL COMPARISON PRODUCES AN UNPLEASANT EMOTION BECAUSE THE PATIENT COMPARES HERSELF TO OTHERS WHO SHE PERCEIVES ARE DOING BETTER OR WHOSE CIRCUMSTANCES ARE BETTER, AND CONCLUDES THAT THINGS ARE NOT GOING AS WELL FOR HER.

\section{- Negative downward social comparison}

A NEGATIVE DOWNWARD SOCIAL COMPARISON PRODUCES AN UNPLEASANT EMOTION BECAUSE THE PATIENT COMPARES HERSELF TO OTHERS WHO SHE PERCEIVES ARE DOING WORSE OR WHOSE CIRCUMSTANCES ARE WORSE, AND CONCLUDES THAT THERE IS A REAL. THREAT THAT SHE WILL END UP IN THE SAME SITUATION. 


\section{- Equal social comparison}

IN AN EQUAL SOCIAL COMPARISON STATEMENT, A PATIENT CONCLUDES THAT SHE IS NO DIFFERENT FROM ANYONE ELSE AND THAT WHAT HAS HAPPENED TO HER COULD HAVE HAPPENED TO ANYONE.

\section{- Considering self to be a unique patient}

CONSIDERING ONESELF A UNIQUE PATIENT MEANS THAT THE PATIENT FEELS HER CASE OR HER TREATMENT TO BE EXCEPTIONAL.

\section{- PUTtING things into PeRSPECtive}

THE PATIENT WHO PUTS THINGS INTO PERSPECTIVE FEELS SHE OUGHT TO BE LUCKY THAT THINGS AREN'T ANY WORSE: SHE CONSIDERS HERSELF FORTUNATE. SHE DOES NOT COMPARE HERSELF EXPLICITLY TO OTHERS, NOR DOES SHE DOWNPLAY THE SERIOUSNESS OF THE SITUATION.

\section{- Minimization}

MINIMIZATION MEANS DOWNPLAYING THE SERIOUSNESS OF THE DISEASE OR ITS EFFECTS. THE PATIENT HAS A WARPED PERSPECTIVE OF REALITY.

\section{- Cognitive avoidance}

CogNiTIVE AVOIDANCE INCLUDES FORMS OF DENIAL OF THE DISEASE AND ITS CONSEQUENCES, AS WELL AS BLOCKING OUT THOUGHTS ABOUT THE DISEASE.

\section{- Protest}

PROTEST STATEMENTS INDICATE THAT THE PATIENT DOES NOT ACCEPT THE DISEASE OR ITS CONSEQUENCES. THIS CATEGORY ALSO INCLUDES STATEMENTS ABOUT IT BEING UNFAIR THAT SHE HAS GOTTEN CANCER; THE PATIENT IS ANGRY.

\section{- Resignation}

STATEMENTS OF RESIGNATION ARE THOSE IN WHICH A PATIENT EXPRESSES ACCEPTANCE OF HER CURRENT AND FUTURE SITUATION AND HER STATUS AS A CANCER PATIENT OR CANCER SURVIVOR; SHE RECONCILES HERSELF TO THESE FACTS.

\section{- GLOOM AND DOOM THINKING}

GLOOM AND DOOM STATEMENTS PAINT A VERY NEGATIVE PICTURE: THE DISEASE AND ITS CONSEQUENCES RAISE FEARFUL, NEGATIVE THOUGHTS.

\section{- Self-ADMONISHMENT}

SELF-ADMONISHMENT MEANS THE PATIENT URGES HERSELF BY SELF-TALK TO DO OR NOT TO DO SOMETHING. SELF-ADMONISHMENT ALSO REFERS TO SELF-TALK IN WHICH THE PATIENT PERSUADES HERSELF NOT TO BE AFRAID OR NEGATIVE. 


\section{BIILAGE A: ONDERWERPEN UIT HET INTERVIEW}

De onderwerpen zijn in vraagvorm weergegeven. Hoe met deze vragen is omgegaan, is te lezen in hoofdstuk II paragraaf 2-2. Tenzij anders vermeld zijn alle onderwerpen op de drie meetmomenten aan de orde geweest.

- 1- Kunt u mij in het kort vertellen, hoe het $\mathrm{u}$ is vergaan vanaf de ontdekking of het eente vermoeden? (T1) Kunt u mij in het kort vertellen hoe het $\mathrm{u}$ is vergaan sinds het vorige interview? (T2 en T3)

- 2 - Wat dacht $u$ toen u hoorde wat u had? (T1)

- 3-Vindt u dat u er op tijd bij was?

- 4- Als u voor een behandeling of controle in de wachtkamer zit wat denkt u dan?

- 5- Hoe ervaart u de periode voor een controle? (T2 en T3)

- 6-Denkt u nog wel eens hoe kom ik aan deze ziekte?

- 7-Bent u nog op zoek naar een verklaring?

- 8- Denkt u nog wel eens 'Waarom ik? Waarom moet mij dit overkomen?'

- 9 - Toekomst, wat roept dat woord bij u op?

- 10 - is daar door de ziekte iets aan veranderd?

- 11. Praat u met uw naasten over wat u ten aanzien van de ziekte bezig houdt? Wordt u door hen voldoende gesteund?

- 12 - Denkt u wel eens over een negatieve afloop?

- 13- Heeft u zelf enige invloed op uw toekomst?

- 14- In hoeverre kunt u accepteren wat u is overkomen?

- 15 - Hoe vult u op dit moment uw tijd in? (dagelijkse bezigheden, werk, hobbies)

- 16 - Is daarin iets veranderd door de ziekte?

- 17- Zijn er (nu nog) dingen die u door de ziekte of de behandeling niet meer kunt doen?

- 18 - Bent u zelf veranderd?

- 19 - Sommige mensen zeggen van zichzelf ik ben een vechter. Zou u dat van uzelf zeggen? (T1 en T2)

- 20 - Heeft u voldoende steun ervaren van uw familie, uw vrienden en uw kennissen?

- 21 - Praat u makkelijk over uw ziekte?

- 22 - Hoe noemt u de ziekte?

- 23 - Als er iets op TV is over uw ziekte, of u ziet iets in een krant of tijdschrift, wat doet u dan?

- 24- Wat denkt u als u ergens iets in uw lichaam voelt?

- 25 - Als u voor de spiegel staat en u ziet uzelf, wat denkt u dan?

- 26 - Is dit anders dan voor de behandeling?

- 27 - Is er iets dat u kunt doen of laten om te zorgen dat de ziekte niet terugkomt?

- 28 - Hoe is uw stemming de laatste weken?

- 29. Hoe vindt u dat u zich er doorheen slaat?

- 30 - Hoe tevreden bent u over de situatie op dit moment?

- 31 - Als u nu de balans opmaakt, hoe wilt u dan de afgelopen periode samenvatten? 


\section{BIJLAGE B: VRAGEN UIT HET INTERVIEW MET DE AANTALLEN PATIËNTEN DIE MET EEN BEPAALDE STRATEGIE HEBBEN GEANTWOORD. TABELLEN BEHOREND BIJ HOOFDSTUK IV PARAGRAAF 2}

Per vraag is schematisch weergegeven bij hoeveel respondenten in het antwoord een bepaalde strategie is aangetroffen. $\mathrm{T} 1, \mathrm{~T} 2$, en $\mathrm{T} 3$ verwijzen naar de drie tijdstippen waarop de interviews zijn gehouden. Enkele vragen zijn niet op alle drie de tijdstippen gesteld, omdat ze niet op alle meetmomenten relevant waren.

- 1 - Kunt u mij in het kort vertellen, hoe het $\mathrm{u}$ is vergaan vanaf de ontdekking of het eerste vermoeden? (T1) Kunt $u$ mij in het kort vertellen hoe het $u$ is vergaan sinds het vorige interview? (T2 en T3)

\begin{tabular}{|c|c|c|c|}
\hline $\begin{array}{l}\text { AANTAL } \\
\text { ppn in=46) }\end{array}$ & STRATEGIEËN II & STRATEGIEËN 12 & STRATEGIEËN T3 \\
\hline 0 & USA & USA & USAOLASt+ \\
\hline $1 .-3$ & $5++5+5=5+2$ PR PWG BR & CAOLAS + SBS $* 5+5=5+=$ & CASBS - -5 $+5=$ RL PWC BAG \\
\hline $5 \cdot 10$ & SBCACVS & RL PR PWC BR & $S+-P R B R$ \\
\hline $10-15$ & ZTOA & CVBAC & $\mathrm{CV}$ \\
\hline $15 \cdot 20$ & BAG & - & 21 \\
\hline $20 \cdot 25$ & $=$ & DDZT & DO \\
\hline $25-30$ & $\mathrm{RL} D \mathrm{DO}$ &. & . \\
\hline
\end{tabular}

- 2. Wat dacht u toen u hoorde wat u had?

\begin{tabular}{|c|c|c|c|}
\hline $\begin{array}{c}\text { AANTAL } \\
\text { ppn (n=46) }\end{array}$ & STRATEGIEËN TI & STRATEGIEEN T2 & STRATEGIEËN T3 \\
\hline 0 & PWG & & \\
\hline 1.5 & CAUSAOUAS++ $585++5=B R$ & & \\
\hline 5.10 & $5 \sim-5+-R L$ PR BACCV & & \\
\hline 10.15 & $\mathrm{DDZT}$ & & \\
\hline
\end{tabular}

- 3 - Vindt u dat u er op tijd bij was?

\begin{tabular}{|c|c|c|c|}
\hline $\begin{array}{c}\text { ANTAL } \\
\text { ppn }(n=46)\end{array}$ & STRATEGIEENNI & STRATEGIEENT2 & STRATFGIEENN T3 \\
\hline 0 & SBS- $5 *-P W G$ & CASt+\$BS $-5=$ PWC & CAst+s85 $=5 *+$ PWC \\
\hline 1.5 & CAUSASt+5*ts = PR BRCV & USAS*+st-RL PR BR CVZI & USA S*-5*+PRBRCVZI \\
\hline $5 \cdot 10$ & RL DOBAGZT & DD & RL DOBAG \\
\hline 10.15 & $*$ & BAG & ou \\
\hline 15.20 & OL & OLA & + \\
\hline
\end{tabular}


- 4 - Als u voor een behandeling of controle in de wachtkamer zit wat denkt u dan?

\begin{tabular}{|c|c|c|c|}
\hline $\begin{array}{c}\text { MNTAL } \\
p p o n(n=46)\end{array}$ & STRATEGIEËN TI & STRATEGIEËN D2 & STRATEGIEEN DB \\
\hline 0 & USAOAAWC & USAOLAS*+585-*FR PWC BR & USAOUS* $+585 *+P R$ \\
\hline 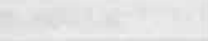 & & ta & FWG BR CAS*-5 *21 \\
\hline 1.5 & CASt+ SAS = RL PR BR RT & CAS"-5 = $212 \pi$ & RL BAG \\
\hline 5.10 & $5 *-5 *+0 D B A C$ & DDBAC & Do \\
\hline $10 \cdot 15$ & $\mathrm{cv}$ & st. $\mathrm{CV}$ & $\mathrm{Cus}^{+}+\mathrm{t}$ \\
\hline $15 \cdot 20$ & 2 & . & $-x+1=0$ \\
\hline $20-25$ & ste & . & . \\
\hline
\end{tabular}

- 5 - Hoe ervaart u de periode voor een controle?

\begin{tabular}{|c|c|c|c|}
\hline $\begin{array}{c}\text { AANTAL } \\
\text { ppn (n=46) }\end{array}$ & STRAIEGIELN TI & STRATEGIËEN T2 & STRATEGILÉND \\
\hline 0 & & USAS* $+s *$ PWG & OASHSBAWG \\
\hline 1.5 & & 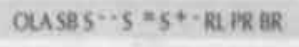 & CAUSAS- $5 *+5=5 *-$ PR BR RQ \\
\hline $5 \cdot 10$ & & a & $\operatorname{Bac} 2 \pi$ \\
\hline 10.15 & & BAGZI & . \\
\hline 15.20 & & . & c v \\
\hline $20 \cdot 25$ & & c & . \\
\hline 30.35 & & . & DO \\
\hline 35.40 & & $D D$ & . \\
\hline
\end{tabular}

- 6. Denkt u nog wel eens hoe kom ik aan deze ziekte?

\begin{tabular}{|c|c|c|c|}
\hline $\begin{array}{c}\text { AANTAL } \\
\text { ppn }(n=46)\end{array}$ & STRATEGIEEN TI & STRATEGILEN T2 & STRATEGIEEN $D$ \\
\hline 0 & $\mathrm{~s}+\mathrm{CV}$ & $5+585 *$ & $5 * 58 \mathrm{RL}$ \\
\hline 1.5 & SB5+-RL. PWC BR BACGZI & $5+\cdot R L$ DD FWG BR BACCVZI & S*-s+-DDPWC BACZII \\
\hline 5.10 & $S \sim P R D D$ & usA & USAS- + $=\mathrm{PRCV}$ \\
\hline $10-15$ & USAS $=$ & $5=+5=18$ & BR \\
\hline $15-20$ & . & ou & . \\
\hline $20-25$ & Ous:- & $\cdot$ & ou \\
\hline 25.30 & . & - & . \\
\hline$>40$ & a & A & $a$ \\
\hline
\end{tabular}

-7 - Bent u nog op zoek naar een verklaring?

\begin{tabular}{|c|c|c|c|}
\hline $\begin{array}{c}\text { MNTAL } \\
\text { Ppn }(n=46)\end{array}$ & STRATEGIEẼN $\mathrm{n}$ & STRATEGIEIN 12 & STRATEGIEEN T3 \\
\hline 0 & $5+585++$ PRPWG BAG & Usast+sos $=0$ & St+595-RA DD FWG BAG CVZI \\
\hline 1.5 & USAOUS $-5=5 *: R 2 D D B R$ & 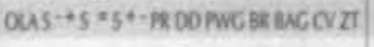 & USAFEs $=5+-5 *+8 R$ \\
\hline 5.10 & cicrat & a & CAOL \\
\hline
\end{tabular}


- 8- Denkt u nog wel eens 'Waarom ik? Waarom moet mij dit overkomen?'

\begin{tabular}{|c|c|c|c|}
\hline $\begin{array}{c}\text { ANTAL } \\
\text { Ppn }(n=46)\end{array}$ & STRATEGIEËN TI & STRATEGIEËN I2 & STRAIEGIEE"N T3 \\
\hline 0 & $5+5 B S \cdots D O$ & $s^{++}$ & USAS* + SBS $\cdots$ DDCV \\
\hline 1.5 & USARLPWGBAGCVZI & USAOLASBS--s+:-DDPWGCVZI & OUAS ${ }^{-+}+S^{+-R L}$ PWG BAGZT \\
\hline $5 \cdot 10$ & OLAS+- $5+$ +BR & $S \cdots+R L B R B A G$ & BR \\
\hline $10 \cdot 15$ & - & PR & $P R$ \\
\hline $15 \cdot 20$ & $P R$ & - & $s=$ \\
\hline 20.25 & . & $5=$ & CA \\
\hline $25 \cdot 30$ & $5=$ & $\mathrm{CA}$ & - \\
\hline 30.35 & $\mathrm{CA}$ & - & - \\
\hline
\end{tabular}

- 9 - Toekomst, wat roept dat woord bij u op?

\begin{tabular}{|c|c|c|c|}
\hline $\begin{array}{c}\text { AANTAL } \\
\text { ppn }(n=46)\end{array}$ & STRATEGIEËN TI & STRATEGIEẼN T2 & STRATEGIEEN T3 \\
\hline 0 & USAOUASBS $=5^{-+}$ & USAOUASBS $=S+-R I$ & CAUSAOLASBS $\cdots S=S+-R L P R$ \\
\hline 1.5 & CA $5+t 5=5+-R L$ PR BAGZI & $\mathrm{CAS}+5 \cdots 5+B A G$ & $s+s *+$ PWC BR BAG ZI \\
\hline $5 \cdot 10$ & $B R$ & PR BR & $\mathrm{CV}$ \\
\hline 10.15 & PWG & PWC CV ZT & $\therefore$ \\
\hline $15 \cdot 20$ & DDCV & . & $\mathrm{DD}$ \\
\hline $20 \cdot 25$ & 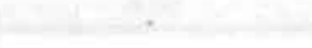 & $\rightarrow$ & $\therefore$ \\
\hline $25 \cdot 30$ & . & DD & - \\
\hline
\end{tabular}

- 10 - Is daar door de ziekte iets aan veranderd?

\begin{tabular}{|c|c|c|c|}
\hline $\begin{array}{c}\text { AANTAL } \\
\text { ppn }(n=46)\end{array}$ & STRATEGIEEN TI & STRATEGIEËN 72 & STRATEGIEẼN T3 \\
\hline 0 & CAUSAOLAS+- & CAUSAOLASHS & USAOLASBS $\cdots R L$ \\
\hline 1.5 & $5+585-5 *+5=R L B A C$ & $58 S^{*+}+5=5+-R L P R B A G$ & CASt+5 $-5+-P R B A G S=$ \\
\hline $5 \cdot 10$ & PRBRCV & BRCV & $\mathrm{BRCV}$ \\
\hline 10.15 & DDZI & $2 \pi$ & PWGZI \\
\hline 15.20 & - & DO & - \\
\hline 20.25 & PWG & PWG & $\mathrm{DD}$ \\
\hline
\end{tabular}

- 11- Praat u met uw naasten over wat u ten aanzien van de ziekte bezig houdt? Wordt u door hen voldoende gesteund?

\begin{tabular}{|c|c|c|c|}
\hline $\begin{array}{c}\text { ANNTAL } \\
\text { ppon }(n=46)\end{array}$ & STRATEGIEEN TI & STRATEGIEZENT2 & STRATEGIEẼN T3 \\
\hline 0 & USAOLAS $+\$ B S \cdots P R$ & CAUSAOLAS ${ }^{++} 585=P R$ & CAOUS $+58 S \cdots 5=5+-P R B R Z I$ \\
\hline 1.5 & CA $5 *+5=5 *-R L$ PWG BR BAG $2 T$ & $5^{*}-5^{*}+5+-R L$ PWG BR BAC & USAS + RL DD PWG BAC \\
\hline 5.10 & DoCV & DocrzI & CV \\
\hline
\end{tabular}


- 12 - Denkt u wel eens over een negatieve afloop?

\begin{tabular}{|c|c|c|c|}
\hline $\begin{array}{c}\text { ANTAL } \\
\operatorname{ppn}(n=46)\end{array}$ & STRATEGIEL̈N TI. & STRATEGIELN T2 & STRATEGIEEN T3 \\
\hline 0 & USASB $5^{*+}$ RL PWG & ISAOUAS * & USAst+58 \\
\hline 1.5 & CAOUSt+5 =st+ PRBAC & 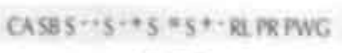 & CAOASt RI RREWGS"t \\
\hline $5-10$ & $5 * B R Z T$ & BR BAG & $5 \cdots 5 * B R Z T$ \\
\hline $10 \cdot 15$ & $\mathrm{CV}$ & 21 & $B A C$ \\
\hline $15 \cdot 20$ & DD & $\therefore$ & $\mathrm{CV}$ \\
\hline 20.25 & 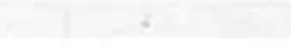 & DO & DO \\
\hline 25.30 & . & $\mathrm{cV}$ & $=$ \\
\hline
\end{tabular}

- 13 - Heeft u zelf enige invloed op uw toekomst?

\begin{tabular}{|c|c|c|c|}
\hline $\begin{array}{l}\text { AMNTAL } \\
\text { ppn }(n=46)\end{array}$ & STRATEGIEEN $\mathrm{TI}$ & STRATEGIEẼNT 12 & STRATEGIEEN T3 \\
\hline 0 & USASB $5=5 *+C V$ & USAS* $+5 *+5=P R$ & $5+585 \cdots 5=8 L$ IWG BAC \\
\hline 1.5 & CA st+s-'s+- RL FR DOFWGBREAG & $585 * 5+-R L$ PWC BR BAGCV & USAS*--St-PR BRCV \\
\hline 5.10 & ou & Do & Do \\
\hline 10.15 & . & OLA & OLA \\
\hline $15 \cdot 20$ & - & $\mathrm{CA}$ & $2 \pi$ \\
\hline $20 \cdot 25$ & . & 2ा & . \\
\hline $25 \cdot 30$ & . & . & $\mathrm{CA}$ \\
\hline $30 \cdot 35$ & $2 \pi$ & , & , \\
\hline
\end{tabular}

- 14 - In hoeverre kunt u accepteren wat $\mathrm{u}$ is overkomen?

\begin{tabular}{|c|c|c|c|}
\hline $\begin{array}{c}\text { AMNTAL } \\
\operatorname{Ppn}(n=46)\end{array}$ & STRATEGIEËN TI & STRATEGIEEN T2 & STRATEGIEENT \\
\hline 0 & 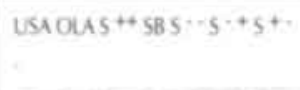 & $\begin{array}{l}\text { ZT BAG PWGPK Ra } 5 * 56 \\
5 * 5 * 5=5 * \text { OLAUSACA }\end{array}$ & CAUSAOLAS"tsas * \\
\hline $1 \cdot 5$ & CA $S=$ RL DDFWG BAGCV & CVODBR & $5 * 5 *+5 *-R L P R B R$ \\
\hline $5 \cdot 10$ & $P R$ & & DOPWGBAGCVZT \\
\hline $10 \cdot 15$ & $2 T$ & . & $=$ \\
\hline $15 \cdot 20$ & - & 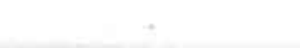 & . \\
\hline 20.25 & . & . & $a_{2}$ \\
\hline 25.30 & $B R$ & . & \\
\hline
\end{tabular}

- 15 - Hoe vult u op dit moment uw tijd in? (dagelijkse bezigheden, werk, hobbies)

\begin{tabular}{|c|c|c|c|}
\hline $\begin{array}{c}\text { AANTAL } \\
\text { ppn }(n=46)\end{array}$ & STRATEGEEEN TI & STRATEGIEẼNT2 & STRATEGIEẼNT3 \\
\hline \multirow[t]{2}{*}{0} & CAUSAOLAS + SA & CAUSAOLAS* & CAUSAOLAS* SBS $* 5 *$ \\
\hline & $5 \cdots 5 \cdots+5=5+-B A G$ & $s=s+\cdots R D D$ BR BAG & $5=P K$ DD PWC BMG \\
\hline 1.5 & RL PR DD PWG BR CV & RaCV & $s+\cdot R L B R C V Z F$ \\
\hline $5 \cdot 10$ & $2 \pi$ & PWC ZI & $\therefore$ \\
\hline
\end{tabular}


- 16-15 daarin iets veranderd door de ziekte?

\begin{tabular}{|c|c|c|c|}
\hline $\begin{array}{c}\text { A ANTAL } \\
\text { ppn }(n=46)\end{array}$ & STRATECIEENTI & STRATEGIËN 12 & STRATEGIËN T3 \\
\hline \multirow[t]{2}{*}{0} & USAOUSt+ SBS $=5+$ BAC & CAUSAOASt+58 & CAUSAOLAS + SB \\
\hline & & s- $-s-+R L D O B A C$ & $5 * 5 x+5=5+-R L B A C$ \\
\hline 1.5 & $5+5+R L P R D O B R C V Z T$ & $s=s+-P Q B R C V Z T$ & PRDDBRZT \\
\hline 5.10 & . & $=$ & $\mathrm{cv}$ \\
\hline 10.15 & PWC & - & - \\
\hline 15.20 & 8 & . & PWG \\
\hline 20.25 & $=$ & PWG & - \\
\hline
\end{tabular}

- 17 - Zijn er (nu nog) dingen die u door de ziekte of de behandeling niet meer kunt doen?

\begin{tabular}{|c|c|c|c|}
\hline $\begin{array}{c}\text { ANNIAL } \\
\text { ppn (nn46) }\end{array}$ & STRAIEGIEẼN II & STRATEGIEËN T2 & STRATEGIEÉN T3 \\
\hline 0 & 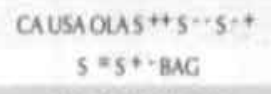 & $\begin{array}{c}\text { USAOLAS }{ }^{+*} \\
5 * \text { RL PWC BACCV }\end{array}$ & CAUSAOAS + SB PWC BAC \\
\hline 1.5 & SARL DD PWGCV & CAs8s $=+5=5+=00 Z T$ & $5 \cdot-5=+5=5+-00 C V$ \\
\hline $5 \cdot 10$ & PR BR ZT & - & RL BR ZT \\
\hline $10=15^{*}$ & * & BR & PR \\
\hline $15 \cdot 20$ & $\therefore$ & PR & . \\
\hline
\end{tabular}

- 18- Bent u zelf veranderd?

\begin{tabular}{|c|c|c|c|}
\hline $\begin{array}{c}\text { ANTIA } \\
\text { ppn (n=46) }\end{array}$ & STRATEGIEEN $\mathrm{TI}$ & STRATEGIEÉN $\mathrm{n}$ & STRATEGIEËN T3. \\
\hline \multirow[t]{2}{*}{0} & USAOUA + SB & USAOUASt+\$B & CaUSHOLASt \\
\hline & $5 * 5 \cdot+5=B R$ BACCVZT & $s \cdots s=\mathrm{RLCV}$ & $s * s=s+\cdot c v 2 \pi$ \\
\hline 1.5 & CAST-RLPRDD & CASt+5*+5*-PR BRBACZI & SBS++5+-RL PR DD BR BAC \\
\hline 5.10 & - & DD & . \\
\hline 10.15 & . & . & . \\
\hline $15 \cdot 20$ & . & 47 & . \\
\hline 20.25 & - & - & PWG \\
\hline $25 \cdot 30$ & ? & PWC & . \\
\hline 30.35 & PWG & . & - \\
\hline
\end{tabular}


- 19 - Sommige mensen zeggen van zichzelf ik ben een vechter. Zou u dat van uzelf zeggen?

\begin{tabular}{|c|c|c|c|}
\hline $\begin{array}{c}\text { ANTIAL } \\
\text { ppa }(n=46)\end{array}$ & STRAIEGIEEN T1 & STRATEGIEEN T2 & STRAIEGItEN T3 \\
\hline 0 & Caustoust+5*-5*t5 = & 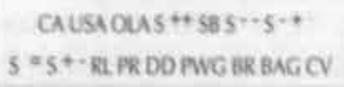 & 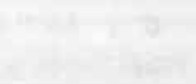 \\
\hline 1.5 & SBS?-RL DD FWG BR BAC & 21 & \\
\hline $5 \cdot 10$ & PRCV & . & \\
\hline $10 \cdot 15$ & $*$ & - & \\
\hline $15 \cdot 20$ & - & - & \\
\hline 20.25 & ; & = & \\
\hline $25 \cdot 30$ & 21 & $=$ & 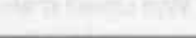 \\
\hline
\end{tabular}

- 20 - Heeft u voldoende steun ervaren van uw familie, uw vrienden en uw kennissen?

\begin{tabular}{|c|c|c|c|}
\hline $\begin{array}{c}\text { AANTAL } \\
\text { Ppa }(n=46)\end{array}$ & STRATEGIEENTI & STRATEGIË̈N T2 & STRATEGIEN T3 \\
\hline$x$ & $2 T R L 5-585+$ OLAUSACA & PWGS- st+OANUSACA & $\begin{array}{l}\text { CAUSAOUSBS-"s*t } \\
\text { s=DOFWCBRBAC }\end{array}$ \\
\hline 1.5 & $\begin{array}{c}\text { PWCKRS }+2=5 *-\text { GR } \\
\text { CVBACDO }\end{array}$ & $\begin{array}{c}\text { BR OD RL PRS }=+2 T B A C \\
5+-5=98\end{array}$ & $s+5+\cdots P R Z$ \\
\hline $5 \cdot 10$ & $\therefore$ & cr & $\mathrm{RLCV}_{\mathrm{C}}$ \\
\hline
\end{tabular}

- 21 - Praat u makkelijk over uw ziekte?

\begin{tabular}{|c|c|c|c|}
\hline $\begin{array}{c}\text { AANTAL } \\
\text { ppen }(n=46) \text { ) }\end{array}$ & STRATEGIEËN TI & STRATEGIEÉN T2 & STRAIEGHENT3 \\
\hline 0 & CAUSAOUA & Causaoustos.t & Causagusth \\
\hline & is $-s+s=s+-D D B R B A C$ & & $5^{-}+$RL PRPWG BRZT \\
\hline $1+5$ & St+SBRL PR.PWG ZT & $\begin{array}{c}S B 5 \cdots 5=5+\cdots R \text { PR DD } \\
\text { PWG BR BAGZI }\end{array}$ & $585:-5 * 5+: D D B A C$ \\
\hline $5 \cdot 10$ & $\mathrm{cr}$ & . & . \\
\hline 10.15 & 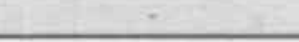 & cV & $\mathrm{cv}$ \\
\hline
\end{tabular}

- 22 - Hoe noemt u de ziekte?

\begin{tabular}{|c|c|c|c|}
\hline $\begin{array}{c}\text { ANTML } \\
\text { ppa }(n=46)\end{array}$ & SRATEGIEẼN TI & STRATEGIEEN T2 & STRATEGIEKN 13 \\
\hline 0 & $\begin{array}{c}\text { USAS }+ \text { SBS } * 5 *+ \\
\text { Rt PR DDPWC }\end{array}$ & CAUSA $5++5 *+5=$ PR BR PWG & $\begin{array}{c}\text { CAUSHOLAS }+5 B \\
5 \sim 5 *+5=R L \text { PRPWC BR }\end{array}$ \\
\hline 1.5 & CAOLA $=5+-B R$ BACZI & Quses"-s+-R2 DD BACZI & $5+=$ DDBAC \\
\hline s. 10 & - & . & . \\
\hline 10.15 & cv & cy & $c$ \\
\hline
\end{tabular}


- 23 - Als er iets op TV is over uw ziekte, of u ziet iets in een krant of tijdschrift wat doet u dan?

\begin{tabular}{|c|c|c|c|}
\hline $\begin{array}{c}\text { MNTAL } \\
\text { ppm }(n=46)\end{array}$ & STRATEGEEN TI & STRATECIËN 12 & STRATEGIEËN TS \\
\hline 0 & USASE 5 - +s $=5+-$ PWG BRC & USHOUSBS + R1 PK BR & USASt+st- RI PWCBGZI \\
\hline 1.5 & CACLASHS-RL PR DOBRZZ & CAS*s*s $=5+-$ DDPWG BAG ZI & CAOUSB5--5 = PRDOBR5.- \\
\hline 5.10 & - & . & $\mathrm{cv}$ \\
\hline 10.15 & cy & $c$ & . \\
\hline
\end{tabular}

- 24 - Wat denkt $u$ als $u$ ergens iets in uw lichaam voelt?

\begin{tabular}{|c|c|c|c|}
\hline $\begin{array}{c}\text { AANTAL } \\
\text { ppn (ne46) }\end{array}$ & STRATEGIEEN TI & STRATEGIEEN T2 & STRATEGIËN T3 \\
\hline 0 & . & USA S* SB PR PWG & USASB RI PWG \\
\hline \multirow[t]{2}{*}{1.5} & CAUSAOUSHSB & CAOLAS $\cdot 5 \cdot+5=5+\cdots R L$ RR & 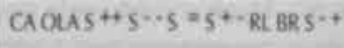 \\
\hline & $5 *-5 \cdots+5+-R L$ PR PWG BR & & \\
\hline $5 \cdot 10$ & $s=$ & ? & . \\
\hline 10.15 & $\mathrm{cv}$ & $\therefore$ & cr \\
\hline $15 \cdot 20$ & - & $\mathrm{cr}$ & BAG \\
\hline 20.25 & BAGZT & BAC & $Z \pi$ \\
\hline 25.30 & $x^{2}$ & $2 z^{2}=$ & - \\
\hline $30-35$ & Do & $\cdot$ & . \\
\hline 35.40 & . & DD & . \\
\hline$>40$ & $=$ & . & $D O$ \\
\hline
\end{tabular}

- 25 - Als u voor de spiegel staat en u ziet uzelf, wat denkt u dan?

\begin{tabular}{|c|c|c|c|}
\hline $\begin{array}{c}\text { MNIAL } \\
\text { ppn (n:46) }\end{array}$ & STRATEGIEẼN TI & STRATEGIEÊN T2 & STRATEGIEẼN T3 \\
\hline 0 & $\begin{array}{l}\text { CAUSAOUS +t SB } \\
5 * 5+5=\text { PWG }\end{array}$ & $\begin{array}{c}\text { CAUSAOUA"H } \\
\text { S"DDPWGBAGCVZT }\end{array}$ & $\begin{array}{c}\text { CAUSAOUASt+SB } \\
5 * 5=\text { PR DO PWGCVZT }\end{array}$ \\
\hline 1.5 & PRDOBR BAGCVZT & $585+5=5+-P R$ & S+-BR BAG \\
\hline 5.10 & s*- & BR & RL \\
\hline 10.15 & RL & Ri & . \\
\hline
\end{tabular}

- 26 - Is dit anders dan voor de behandeling?

\begin{tabular}{|c|c|c|c|}
\hline $\begin{array}{c}\text { AANTAL } \\
\text { ppn }(n=46)\end{array}$ & STRATEGIEẼN TI & STRATEGIIẼN I2 & STRATEGIEËN T3 \\
\hline 0 & CAuSAS++585:-5*+ PWGCV & $\begin{array}{c}\text { CAUSAOUAS }+\$ 8 B \\
5 * 5 * 5=5+-P R \text { PWG BAGCV }\end{array}$ & Causnoust+ses"- \\
\hline 1.5 & OAAS $=S+: P R D D B A G Z T$ & 00 & $5^{*+5}=5^{*-D D P W C B A G C V Z T}$ \\
\hline 5.10 & $B R$ & $2 \pi$ & $P R$ \\
\hline 10.15 & Ri & $\mathrm{RL}$ 䁌 & $\mathrm{RQ} B \mathrm{BR}$ \\
\hline
\end{tabular}


- 27 - Is er iets dat u kunt doen of laten om te zorgen dat de ziekte niet lerugkomt?

\begin{tabular}{|c|c|c|c|}
\hline $\begin{array}{c}\text { MNTAL } \\
\text { ppn (n=46) }\end{array}$ & SIRATEGIEEN TI & STRATEGIEEN 12 & STRATECHËNT3 \\
\hline 0 & 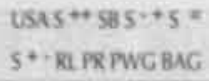 & 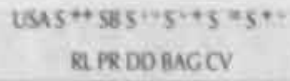 & $\begin{array}{l}\text { USAS*585*5*t5*5* } \\
\text { RL DDPWGBAGI }\end{array}$ \\
\hline 1.5 & CAs-D06RCVZT & PWC BR ZT & FRUR CV \\
\hline 5.10 & . & CA & a \\
\hline 10.15 & ou & on & $\alpha A$ \\
\hline
\end{tabular}

- 28 - Hoe is uw stemming de laatste weken?

\begin{tabular}{|c|c|c|c|}
\hline $\begin{array}{c}\text { MNTAL } \\
\text { ppn (net6) }\end{array}$ & STRATEGIEENTI & STRAIEGIEEN 12 & STRATEGIEEN T3 \\
\hline 0 & $\begin{array}{l}\text { CAusioust+58 } \\
5-5-5+-846\end{array}$ & CAUSAOUS & $\begin{array}{l}\text { CAUSAOUASt+SB } \\
\text { S"PWGBC }\end{array}$ \\
\hline 1.5 & $S=R L$ DO PWG AR CVZT & $s=s=s+\cdot R L$ PRPWCCV & $5=-5$ +st- RLPR BRCVZI \\
\hline $5 \cdot 10$ & PR. & DD BR ZT & DD \\
\hline
\end{tabular}

- 29- Hoe vindt u dat u zich er doorheen slaat?

\begin{tabular}{|c|c|c|c|}
\hline $\begin{array}{c}\text { AANTAL } \\
\text { Ppn }(n=46)\end{array}$ & STRATEGIELN TI & STRATLGIEEN 22 & STRAIEGIEÉN TI \\
\hline 0 & $\begin{array}{c}\text { USACUAS }+58 \\
5 * 5 *+5=\text { PR DOPWG BACG }\end{array}$ & USAOCASt+ SB5*- $5^{\circ}+$ PWC & USAOUSt+5*-5 =PR \\
\hline 1.5 & CARL DD BR CVZI & CAS = proobaGst-beCV & 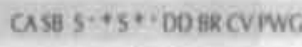 \\
\hline 5.10 & st: & Ra & $\operatorname{Rin} \pi$ \\
\hline 10.15 &. & ZI & - \\
\hline
\end{tabular}

- 30 - Hoe tevreden bent u over de situatie op dit moment?

\begin{tabular}{|c|c|c|c|}
\hline $\begin{array}{c}\text { MNTAL } \\
\text { ppn }(n=46)\end{array}$ & STRATEGIEẼN TI & STRAIEGIËN 12 & SRATECIEENT3 \\
\hline 0 & & $\begin{array}{l}\text { CAUSACUS }+58 \\
5 * 5+5+2 R 2 P R\end{array}$ & $\begin{array}{c}\text { CAUSAOLAS*5B } \\
5-\cdot 5 * 5=5+\text { PRPWCBAGCV }\end{array}$ \\
\hline 1.5 & & 5 = DDPWGBR BAC CVRT & RL DDARZI \\
\hline
\end{tabular}

- 31 - Als u nu de balans opmaakt, hoe wilt u dan de afgelopen periode samenvatten?

\begin{tabular}{|c|c|c|c|}
\hline $\begin{array}{c}\text { ANTAL } \\
\operatorname{ppn}(n=46)\end{array}$ & STRATEGIEËNTI & STRATFGIEINT 2 & STRATEGIEENTB \\
\hline 0 & USAOUAS + S $+S=$ & USAs+t. $+\cdot 5=$ & 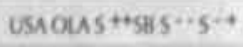 \\
\hline 1.5 & CASBS $\cdots 5+-18$ BAC & CAOUASBS*+PRERBAGZ & CAS F PRDDBR \\
\hline $5 \cdot 10$ & RL $00 \mathrm{CV} Z T$ & $5+\cdots R D$ & 5*- RPWCBAGCVZT \\
\hline 10.15 & PWGAR & WWGCV & + \\
\hline
\end{tabular}


- Tabel 4.7 - Verschillen in het gebruik van cognitieve strategieen tussen patienten met negatieve okselklieren $\left(n_{\mathrm{N}}=13\right.$ ) versus patienten met posistieve okselklieren $\left(n_{p}=33\right)$

\begin{tabular}{|c|c|c|c|c|c|c|c|c|c|c|c|c|c|c|c|c|c|c|c|c|c|}
\hline \multirow{3}{*}{$\begin{array}{l}n=46 \\
\text { strategie }\end{array}$} & \multicolumn{7}{|c|}{ II } & \multicolumn{7}{|c|}{12} & \multicolumn{7}{|c|}{$\mathrm{T} 3$} \\
\hline & \multicolumn{3}{|c|}{ necrotuce } & \multicolumn{4}{|c|}{ monevar } & \multicolumn{3}{|c|}{ neseviag } & \multicolumn{4}{|c|}{ 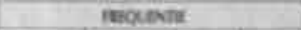 } & \multicolumn{3}{|c|}{ nersiva } & \multicolumn{4}{|c|}{ moguevie } \\
\hline & $\mathrm{HN}$ & $\% p$ & p & contuth & Contitit & U & $\mathrm{P}$ & $8 \mathrm{~N}$ & \%p & $p$ & Condets & $C$ & U & p & $\mathrm{g}_{\mathrm{N}}$ & sp & p & 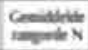 & Condtit & $\mathrm{U}$ & P \\
\hline $\mathrm{CA}$ & 92 & 97 & 57 & 20667 & 21.85 & 1700 & .46 & 92 & 88 & .66 & 19.63 & -24.23 & 157.5 & 29 & 92 & B7 & 50 & 22.08 & 2.33 & 187.0 & $\pi$ \\
\hline USA & 23 & 27 & 77 & 21.58 & 23.52 & 181,0 & .56 & 0 & 24 & 20 & 19.00 & 24.45 & 130.0 & .06 & a & 21 & 65 & 20.83 & 23.79 & 172.0 & 32 \\
\hline OLA & 69 & 80 & 13 & 18.21 & 24.74 & 1405 & .13 & $\pi$ & 73 & 77 & 228 & 2305 & 1965 & 97 & 69 & 70 & 97 & $21 \geq 1$ & 21.47 & 182.5 & .68 \\
\hline PWG & 58 & 91 & $.02^{t}$ & 20.83 & 23.79 & 1720 & .50 & 83 & 79 & .89 & 21.29 & 2362 & 1775 & 59 & 58 & 20 & 31 & 20.96 & 23.74 & 173.5 & .52 \\
\hline$s+1$ & 23 & 27 & $n$ & 21.00 & 23.73 & 1740 & 41 & 8 & 12 & .66 & 2238 & 2323 & 1903 & 72 & 8 & bs & 49 & 23.83 & 22.70 & 188.0 & 47 \\
\hline$s+\cdots$ & 67 & 79 & 49 & 18.92 & 24.48 & 149.0 & 19 & 67 & 58 & 47 & 24.63 & 22.41 & 178.5 & 60 & 58 & 45 & 33 & 25.17 & 22.21 & 172.0 & 47 \\
\hline $5 .+$ & 42 & $4 a$ & 89 & 2204 & 2335 & 186.5 & 75 & 25 & 45 & 36 & 19.08 & 24.42 & 151.0 & 17 & 33 & 30 & 60 & 2250 & 23,18 & 192.0 & .85 \\
\hline $5 \cdots$ & 33 & 42 & 81 & 21.08 & 23.70 & 175.0 & .50 & 33 & 33 & 87 & 23.25 & 22.91 & 195.0 & 93 & 33 & 45 & 66 & 21.13 & 23.68 & 1755 & .52 \\
\hline$S=$ & 92 & 79 & 28 & 30.71 & 20.20 & 105.5 & $.01^{*}$ & 83 & 73 & 39 & 23.71 & 2274 & 1895 & 82 & 58 & 52 & 89 & 2258 & 23.15 & 193.0 & 89 \\
\hline SB & 25 & 42 & .22 & 20.08 & 24.06 & 163.0 & .30 & 25 & 30 & .62 & 21.75 & 23.45 & 183.0 & 63 & 1 & 21 & .07 & 19.50 & 24.27 & 156.0 & .09 \\
\hline Rt & 183 & 85 & 98 & 19.83 & 24.15 & 160.0 & 31 & 75 & 70 & .62 & 21.79 & 23,44 & 183.5 & 70 & 75 & 67 & 50 & 22.04 & 23.35 & 186.5 & .76 \\
\hline BAG & 58 & 61 & 95 & 20.46 & 23.92 & 167.5 & 42 & 75 & 55 & .16 & 26.63 & 21.68 & 154.5 & .24 & 83 & 61 & .12 & 26.17 & 21,85 & 160.0 & 31 \\
\hline $\mathrm{CV}$ & 92 & 94 & $B 4$ & 25.67 & 22.03 & 166.0 & 41 & 92 & 88 & 66 & 25.38 & 22.14 & 169.5 & 46 & 100 & 85 & 54 & 24.42 & 2248 & 181.0 & 66 \\
\hline PR & 58 & 61 & 95 & 22.67 & 23.12 & 194.0 & 92 & 58 & 61 & 95 & 20.96 & 2374 & 1735 & 51 & 33 & 58 & 24 & 18.33 & 24.70 & 142.0 & .13 \\
\hline$B R$ & 50 & 88 & $010^{\circ}$ & 15.58 & 25.70 & 109.0 & $.02^{\dagger}$ & 73 & 92 & .15 & 2200 & 25.75 & 165.0 & 38 & 67 & 70 & 60 & 20.71 & 23.83 & 170.5 & 47 \\
\hline DD & 92 & 82 & 37 & 23.13 & 22.95 & 196.5 & .97 & 99 & 85 & .14 & 27.04 & 21.53 & 149.5 & .21 & 100 & 91 & .26 & 23.29 & 22.89 & 194.5 & .93 \\
\hline $2 \pi$ & 75 & 71 & 21 & 16.92 & 25.21 & 1250 & .06 & 92 & 85 & 30 & 21.79 & 23,44 & 183.5 & 71 & 83 & 97 & 13 & 1838 & 24.68 & 142.5 & 14 \\
\hline
\end{tabular}

Per meetmoment staat in de kolommen $2 \mathrm{v} / \mathrm{m} 4$ steeds het percentage patiënten met negatieve okselklieren dat een strategie ten minste eenmaal gebruikt (\%:N), het percentage patienten met positieve okselklieren dat dit doet $(\% \mathbf{P})$ en de p-waarde behorend bij de $X^{2}$-test waarmee het onderlinge verschil is getoetst. In de volgende vier kolommen staan steeds gegevens die betrekking hebben op de frequentie van het strategiegebruik. De gemiddelde rangorde van beide patiëntengroepen is weergegeven, evenals de U-waarde en p-waarde behorend bij de Mann-Whitney-test waarmee het onderlinge verschil is getoetst ( $t p \leq .05 \leq{ }^{*} p \leq .01$ ). 
- Tabet 4.8 - Verschillen in het gebruik van cognitieve strategieen tussen patienten behandeld met chemotherapie $\left(n_{\mathrm{C}}=23\right)$ versus patiènten niet behandeld met chemotherapie $\left(\mathrm{n}_{\mathrm{c}_{0}}=23\right)$

\begin{tabular}{|c|c|c|c|c|c|c|c|c|c|c|c|c|c|c|c|c|c|c|c|c|c|}
\hline \multirow{3}{*}{$\begin{array}{l}n=46 \\
\text { strategie }\end{array}$} & \multicolumn{7}{|c|}{$\mathrm{TI}$} & \multicolumn{7}{|c|}{12} & \multicolumn{7}{|c|}{$\overline{T 3}$} \\
\hline & \multicolumn{3}{|c|}{ nacinag } & \multicolumn{4}{|c|}{ mosevia } & \multicolumn{3}{|c|}{ mecerica } & \multicolumn{4}{|c|}{ mogente } & \multicolumn{3}{|c|}{ merpotua } & \multicolumn{4}{|c|}{ Ingotweili } \\
\hline & $\mathrm{qC}^{+}$ & $\% \mathrm{C}^{\circ}$ & P & t. & 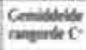 & $U$ & P & ${ }^{* C^{+}}$ & $s c$ & $\mathrm{P}$ & . & Conse & u & P & $\mathrm{scc}^{+}$ & \%C & P & & conitc & U & \\
\hline$C A$ & 96 & $\pi$ & N & & 24 & 2585 & 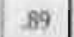 & & 96 & .16 & 3.67 & 2333 & 2605 & 93 & & 00 & 30 & 2.54 & 4,46 & 242.3 & a. \\
\hline USA & 26 & 26 & 00 & 24 & 76 & 2585 & .86 & 1 & & 27 & 1.87 & 25.13 & 2270 & .23 & 17 & 22 & 21 & 283 & 4.17 & 249.0 & \\
\hline OL & 9 & 73. & .12 & 1.65 & 2235 & 0 & s & 70 & 78 & 5 & 65 & 3.35 & 261.0 & .94 & 70 & 70 & 1.00 & 104 & 3.96 & 2540 & At \\
\hline PWG & 96 & 7 & 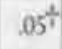 & 24.52 & 22.48 & .0 & .60 & 83 & 74 & .47 & 4.59 & 41 & 239.5 & .58 & 7 & 57 & .22 & 6.33 & 67 & 199. & 87 \\
\hline & 7 & 26 & 0 & $\approx$ & & 261.0 & 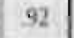 & 1 & & .64 & $\infty$ & .00 & 253.0 & .64 & 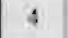 & 4 & 1.00 & 3.52 & 3.48 & 264.0 & 9 \\
\hline & 74 & 78 & & 43 & 57 & 263.0 & 97 & 6 & 61 & 1.00 & 1.22 & 23.78 & 258.0 & .88 & 46 & 52 & $\pi$ & 2.37 & 4.63 & 23 & 54 \\
\hline s. & 57 & 3 & & & 22.15 & 2335 & .46 & 43 & & 77 & 24.22 & 8 & 9 & 6. & 35 & 30 & .75 & 24.22 & 8 & 24 & \\
\hline s. & 43 & 39 & & & & 0 & 74 & s & & .75 & 24.00 & .00 & 33.0 & 0 & 5 & 48 & $\infty$ & 65 & 4.35 & 245 & 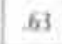 \\
\hline $5=$ & 7 & 96 & .0 & & & 3 & .0 & 61 & 91 & $04^{\prime}$ & 20.28 & 72 & 90.5 & .09 & 5. & 52 & 1.00 & 23.59 & 23.41 & 262.5 & 90 \\
\hline SB & 43 & 3 & 3 & & & 9.5 . & 2 & 3 & & 74 & & 22.87 & 250.0 & 69 & 17 & 13 & .68 & 100 & 0 & 25 & 69 \\
\hline RL & 78 & 91 & 2 & 22.24 & 24.76 & I & 3 & 7 & 74 & 74 & & 9 & 2510 & 76 & 57 & 83 & $.05^{7}$ & 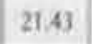 & 557 & 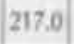 & 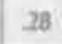 \\
\hline BAG & 70 & 52 & & & & & 25 & 48 & & . 07 & & & 10000 & $\dagger$ & 61 & 74 & 35 & 202 & 24,48 & 2420 & 01 \\
\hline $\mathrm{CV}$ & 91 & 96 & & & & 3. & .69 & 67 & & fol & & 9 & 262.5 & 97 & as & 96 & If & 54 & 46 & 24 & 39 \\
\hline PR & 74 & 4 & $\theta$ & 26 & 20.37 & 192.5 & 1 & 74 & & .07 & 26.48 & 20.52 & 19 & .12 & 70 & 35 & $92^{t}$ & 50 & 50 & 172.5 & \\
\hline Bg & 87 & $\pi$ & .15 & & 2 & 247.0 & .7 & 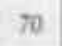 & 87 & . & 20.15 & 26.85 & 1208 & .08 & 70 & 65 & the & 年 & 2.20 & $2=0$ & 30 \\
\hline 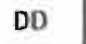 & 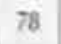 & . & . & & 24.43 & $x \rightarrow 0$ & 64 & 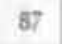 & 91 & . & 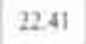 & (N) & Dons & 301 & 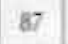 & 91 & 교 & 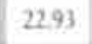 & 07 & 20 & 77 \\
\hline ZII & 96 & 78 & .08 & 4.20 & 1002 & 2223 & 36 & 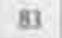 & 11 & $3 d$ & 2100 & 2014 & 24.5 & דיר & 90 & $n$ & 55 & 24,78 & 22.22 & 235.0 & 31 \\
\hline
\end{tabular}

Per meetmoment staat in de kolommen 2 t/m 4 steeds het percentage patiênten behandeld met chemotherapie dat een strategie ten minste eenmaal gebruikt $\left(\% \mathrm{C}^{+}\right)$, het percentage patiënten niet behandeld met chemotherapie dat dit doet $\left(\% \mathrm{C}-\mathrm{C}^{-}\right.$en de p-waarde behorend bij de $\mathrm{X}^{2}$-test waarmee het onderlinge verschil is getoetst. In de volgende vier kolommen staan steeds gegevens die betrekking hebben op de frequentie van het strategiegebruik. De gerniddelde rangorde van beide patièntengroepen is weergegeven, evenals de U-waarde en p-waarde behorend bij de Mann-Whitney-test waarmee het onderlinge verschil is getoets (ث) $\mathrm{p} \leq .05$ ) 
- Tabet 4.9 - Verschillen in het gebruik van cognitieve strategieên tussen patiēnten behandeld met chemotherapie $\left(n_{c}=23\right)$ versus patiênten behandeld met hormoontherapie $\left(n_{H}=10\right)$

\begin{tabular}{|c|c|c|c|c|c|c|c|c|c|c|c|c|c|c|c|c|c|c|c|c|c|}
\hline \multirow{3}{*}{$\begin{array}{l}a=33 \\
\text { strategie }\end{array}$} & \multicolumn{7}{|c|}{ T1 } & \multicolumn{7}{|c|}{$\mathrm{T} 2$} & \multicolumn{7}{|c|}{$\mathrm{T} 3$} \\
\hline & \multicolumn{3}{|c|}{ mexiva } & \multicolumn{4}{|c|}{ feoctant } & \multicolumn{3}{|c|}{ mocista } & \multicolumn{4}{|c|}{ magever } & \multicolumn{3}{|c|}{ nectiva } & \multicolumn{4}{|c|}{ Fequen } \\
\hline & $\because C$ & $\% \mathrm{H}$ & P & Conctc & Conth & U & P & $s$ & $\approx \mathrm{H}$ & $p$ & $\stackrel{c}{\longrightarrow}$ & Cantisk & $U$ & $p$ & $\because \mathrm{C}$ & S.H & P & contc & $C_{\operatorname{lol}}^{C}$ & U & p \\
\hline $\mathrm{CA}$ & 96 & 100 & 50 & 16.91 & 1720 & 113,0 & 94 & 83 & 100 & 16 & 6.17 & 18.90 & 96.6 & .45 & 83 & 90 & 59 & 16.13 & 19.00 & 95.0 & 43 \\
\hline USA & 26 & 27 & 82 & 16.67 & 1775 & 107.5 & 21 & 13 & 50 & $02^{\dagger}$ & 15.92 & 21.55 & 69.5 & $.02^{\dagger}$ & 16 & 30. & 42 & 16.28 & 18.65 & 98.5 & 36 \\
\hline OLA & 91 & 80 & 36 & 16.87 & 1730 & 1120 & 90 & 70 & a0 & 54 & 17.20 & 16.55 & 110.5 & 86 & 70 & 70 & 98 & 16.65 & 1780 & 107.0 & 74 \\
\hline PWG & 96 & BO & .15 & 17.13 & 16.70 & 1120 & 90 & 83 & 70 & .17 & 17.07 & 16.85 & 113.5 & .95 & 74 & 60 & .16 & 17.02 & 16.95 & 114.5 & 98 \\
\hline $5^{++}$ & 26 & 30 & 82 & 16.83 & 17.40 & 111.0 & .84 & 13 & 10 & .81 & 17.15 & 16.65 & 111.5 & 81 & 4 & 0 & 50 & 17.22 & 16.50 & 110.0 & 51 \\
\hline $5+\cdot$ & 74 & 90 & 30 & 16.13 & 19.00 & 95.0 & 42 & 61 & 50 & 56 & 17.28 & 16.35 & 108.5 & 79 & 48 & 40 & 68 & 15.52 & 20.40 & 81.0 & .17 \\
\hline $5=4$ & 57 & 30 & .16 & 18.07 & 1455 & 90.5 & 30 & 43 & 50 & 23 & 16.87 & 17.30 & 112.0 & 90 & 35 & 20 & 40 & 16.78 & 17.50 & 110.0 & .83 \\
\hline s. & 43 & 40 & 85 & 17.00 & 17.00 & 115.0 & 1.00 & 35 & 30 & 79 & 1730 & 16.30 & 108.0 & .74 & 39 & 60 & 27 & 16.04 & 19.20 & 99.5 & .45 \\
\hline $5=$ & 70 & 100 & $.05^{\dagger}$ & 14.74 & 22.20 & 63.0 & $.03^{4}$ & 61 & 100 & $.02^{*}$ & 1509 & 21.40 & 71.0 & .07 & 52 & 50 & 90 & 16.89 & $17: 25$ & 112.5 & 91 \\
\hline SB & 43 & 40 & 85 & 17.52 & 15.80 & 103.0 & .60 & 30 & 30 & .98 & 17.02 & 16.95 & 114.5 & 98 & 17 & 30 & 42 & 16.37 & 18.45 & 100.5 & 42 \\
\hline RL & 78 & 100 & .11 & 15.35 & 20.80 & 77.0 & 12 & 70 & 70 & 98 & 16.37 & ${ }^{2} 18.45$ & 100.5 & 56 & 57 & 90 & .06 & 19.02 & 12.35 & 68.5 & .06 \\
\hline$B A G$ & 70 & 40 & .11 & 18.00 & 1470 & 92.0 & 35 & 48 & 70 & 24 & 15.67 & 20.05 & 84.5 & 21 & 61 & 60 & .96 & 17.83 & 15.10 & 96.0 & .45 \\
\hline CV & 91 & 100 & 34 & 18.24 & 14.15 & 86.5 & .25 & 87 & 90 & 81 & 17.76 & 15.25 & 97.5 & .49 & 83 & 90 & 59 & 16.93 & 17.15 & 113.5 & 95 \\
\hline PR & 73 & 30 & $02^{t}$ & 19.13 & 12.10 & 66.0 & $.05^{\dagger}$ & 70 & 30 & $.02^{\dagger}$ & 18.80 & 12.85 & 73.5 & .09 & 70 & 30 & $04 \hat{\circ}$ & 16.80 & 17.45 & 110.5 & .86 \\
\hline BR & 87 & 90 & .81 & 15.63 & 20.15 & 83.5 & .21 & 70 & 80 & 34 & 15.43 & 20.60 & 79.0 & .15 & 70 & 70 & .98 & 17.24 & 16.45 & 109.5 & .82 \\
\hline DD & 78 & 90 & 42 & 16.33 & 18.55 & 99.5 & 34 & 87 & 80 & 61 & 17.04 & 16.90 & 114.0 & 97 & 87 & 100 & .23 & 18.28 & 14.05 & 85.5 & 24 \\
\hline$Z T$ & 96 & Bo & .15 & 16.65 & 17.80 & 107.0 & 75 & 83 & 90 & 59 & 15.76 & 19.85 & 86.5 & .26 & 96 & 100 & .50 & 6.50 & 6.50 & 16.0 & 1.00 \\
\hline
\end{tabular}

Per meetmoment staat in de kolommen $2 \mathrm{t} / \mathrm{m} 4$ steeds het percentage patiènten behandeld met chemotherapie dat een strategie ten minste eenmaal gebruikt $(\% \mathbf{C})$, het percentage patienten behandeld met hormoontherapie dat dit doet $(\% \mathbf{H})$ en de $\mathrm{p}$-waarde behorend bij de $\mathrm{X}^{2}$-test waarmee het onderlinge verschil is getoetst. In de volgende vier kolommen staan steeds gegevens die betrekking hebben op de frequentie van het strategiegebruik. De gemiddelde rangorde van beide patiëntengroepen is weergegeven, evenals de U-warde en p-warde behorend bij de Mann-Whitney-test waarmee het onderlinge verschil is getoetst (†p $\leq .05)$ 
- Tabel 4.10 - Verșchillen in het gebruik van cognitieve strategieen lussen jonge patiênten $\left(n_{1}=24\right)$ versus oude patiënten $\left(n_{0}=22\right)$

\begin{tabular}{|c|c|c|c|c|c|c|c|c|c|c|c|c|c|c|c|c|c|c|c|c|c|}
\hline \multirow{3}{*}{$\begin{array}{l}n=\text { th } \\
\text { strategie }\end{array}$} & \multicolumn{7}{|c|}{ I1 } & \multicolumn{7}{|c|}{$\mathrm{T} 2$} & \multicolumn{7}{|c|}{$\mathrm{T3}$} \\
\hline & \multicolumn{3}{|c|}{ necivtea } & \multicolumn{4}{|c|}{ movasm } & \multicolumn{3}{|c|}{ nacivisa } & \multicolumn{4}{|c|}{ tacomit } & \multicolumn{3}{|c|}{ masiva } & \multicolumn{4}{|c|}{ mอนที } \\
\hline & $\% 1$ & $\% 0$ & $\mathrm{P}$ & Comidutel & Condutle & U & P & $\% 1$ & $\% 0$ & p & Cendutit & Coniste & U & $p$ & 71 & $\% 0$ & p & Consistith & Comitito & $\mathrm{U}$ & P \\
\hline CA & 96 & 96 & .95 & 23.50 & 23.50 & 264.0 & 1.00 & 83 & 96 & .19 & 22.81 & 24.25 & 247.5 & 71 & 83 & 91 & 45 & 20.67 & 26.59 & 196.0 & .13 \\
\hline USA & 17 & 36 & .13 & 21.4 & 25.75 & 2145 & -16 & 59 & 100 & $002^{* *}$ & 19,00 & 28.41 & 156.0 & $.001 \%$ & 4 & 46 & $02^{\dagger}$ & 19.92 & 27.41 & 178.0 & $006^{\circ}$ \\
\hline OLA & 79 & 86 & 52 & 19.10 & 2830 & IS8.5 & $.02 \hat{\imath}$ & 6? & 82 & 24 & 20.52 & 26.75 & 192.5 & II & 54 & 86 & $04^{\hat{t}}$ & 18.19 & 29.30 & 136.5 & $.004^{*}$ \\
\hline PWG & 87 & 77 & 36 & 23.65 & 23.34 & 260.5 & .94 & 92 & 64 & $02^{t}$ & 25.67 & 21.14 & 212.0 & 25 & 73 & 55 & .13 & 25.63 & 21.18 & 213.0 & .25 \\
\hline$S++$ & 25 & 27 & .86 & 22.88 & 24.18 & 249.0 & 67 & 13 & 9 & 71 & 23.88 & 23.09 & 255.0 & 72 & 4 & 4 & .94 & 23.44 & 23.57 & 262.5 & 93 \\
\hline$S^{4}$. & 71 & 82 & 38 & 2171 & 25.45 & 221.0 & .33 & 67 & 54 & .40 & 24.29 & 22.64 & 245.0 & 66 & 36 & 55 & 56 & 23.19 & 23.84 & 256.5 & 86 \\
\hline $5 \cdot+$ & 46 & 50 & 78 & 22.58 & 24,50 & 2420 & .60 & 17 & 62 & 0000. & 17,44 & 30.11 & 118.5 & $000^{\circ}$ & 29 & 36 & 60 & 21.06 & 23.98 & 2535 & 78 \\
\hline $5 \cdots$ & 37 & 45 & .58 & $22: 58$ & 24.50 & 242.0 & 59 & 33 & 32 & 91 & 23.63 & 23.36 & 261.0 & 94 & 29 & 59 & $04 \hat{t}$ & 20.06 & 27.25 & 181.5 & $.04^{t}$ \\
\hline $5=$ & 71 & 96 & $0^{\hat{r}}$ & 20.25 & 27.05 & 186.0 & 07 & 71 & 82 & 38 & 21.15 & 26.07 & 207.5 & 19 & 36 & 59 & 37 & 2152 & 25.66 & 216.5 & .26 \\
\hline SB & 42 & 32 & 49 & 24.65 & 22.25 & 236.5 & 46 & 17 & 4) & .07 & 20.50 & 26.77 & 192.0 & $.05^{\frac{4}{3}}$ & 4 & $v$ & $.03^{t}$ & 20.96 & 26.27 & 203.0 & $.03^{\dagger}$ \\
\hline $\mathbf{R L}$ & 83 & 86 & 78 & 23.42 & 23.59 & 262.0 & 96 & 75 & 68 & 6) & 22.65 & 24.43 & 243.5 & 64 & 63 & $\eta 7$ & .28 & 22.06 & 25.07 & 229.5 & 43 \\
\hline BAG & 58 & 64 & 21 & 2217 & 24.95 & 232.0 & 47 & 58 & 64 & 21 & 21,79 & 2536 & 223.0 & 35 & 67 & 68 & 91 & 23,40 & 23.61 & 261.5 & 96 \\
\hline $\mathrm{CV}$ & 92 & 96 & .60 & 2429 & 22.64 & 245.0 & 67 & 92 & 86 & 56 & 2306 & 2138 & 253.5 & 82 & 92 & 86 & 56 & 26.69 & 20.02 & 107.5 & 09 \\
\hline PR & 67 & 54 & 40 & 24.46 & 22.45 & 241.0 & 60 & 58 & 64 & 71 & 2217 & 24.95 & 232.0 & 46 & 46 & 59 & 37 & 21.94 & 25.20 & 226.5 & 38 \\
\hline BR: & 67 & 91 & $.05^{\frac{1}{t}}$ & 19.04 & 28.36 & 157.0 & $.02^{\frac{1}{x}}$ & 67 & 91 & cot & 18.96 & 28.45 & 155.0 & $\operatorname{cog}^{t}$ & 67 & 68 & .91 & 23.10 & 23,93 & 2545 & 83 \\
\hline DI & 83 & 86 & 78 & 20.44 & 46,48 & 1905 & 10 & 92 & 86 & 56 & 21.42 & 25.77 & 214.0 & $m$ & 92 & 96 & .60 & 19.83 & 2750 & 176.0 & $.05^{+}$ \\
\hline $2 \pi$ & 87 & $\Delta 6$ & 91 & 2039 & 26.45 & 199.0 & 15 & 79 & 96 & 10 & 21.79 & 2536 & 221.0 & 35 & 97 & 100 & 09 & 2171 & 25.45 & 2210 & 33 \\
\hline
\end{tabular}

Per meetmoment staat in de kolommen $2 \mathrm{t} / \mathrm{m} 4$ steeds het percentage jonge patiènten dat een strategie ten minste eenmaal gebruikt $(\%)$, het percentage oude patienten dat dit doet $(\% 0)$ en de $p$-waarde behorend bij de $x^{2}$ waarmee het onderlinge verschil is getoetst. In de volgende vier kolommen staan steeds gegevens die betrekking hebben op de frequentie van het strategiegebruik. De gemiddelde rangorde van beide patièntengroepen is weengegeven, evenals de $U$-waarde en p-waarde behorend bij de Mann-Whitney-test waarmee het onderlinge verschil is getoetst (tp $\leq .05$ " $p \leq .01$ * "p $\leq .005$ ) 
- Tabel 4.11 - Verschillen in het gebruik van cognitieve strategieen tuss in laagopgeleide patienten $\left(n_{t}=31\right)$, versus hoogopgeleide patiènten $\left(n_{H}=15\right)$.

\begin{tabular}{|c|c|c|c|c|c|c|c|c|c|c|c|c|c|c|c|c|c|c|c|c|c|}
\hline \multirow{3}{*}{$n=46$} & \multicolumn{7}{|c|}{ T1 } & \multicolumn{7}{|c|}{$\overline{\mathrm{T} 2}$} & \multicolumn{7}{|c|}{ T3 } \\
\hline & \multicolumn{3}{|c|}{ nechica } & \multicolumn{4}{|c|}{ Noveste } & \multicolumn{3}{|c|}{ ruxives } & \multicolumn{4}{|c|}{ Iaposeves } & \multicolumn{3}{|c|}{ mucintaca } & \multicolumn{4}{|c|}{ Heg INII } \\
\hline & st & $\% \mathrm{H}$ & $P$ & cint & coliditit & $\mathrm{u}$ & P & \&1 & $\mathrm{SH}$ & P & wet & comple & U & p & 81 & 54 & $p$ & Contut & Conth & U & $\mathrm{F}$ \\
\hline $\mathrm{CA}$ & 94 & 100 & 31 & 23.68 & 22.82 & 2145 & 95 & 87 & 93 & 52 & 21.94 & 25.36 & 1840 & 41 & 94 & $\pi$ & $.0 \hat{t}^{2}$ & 24.06 & 20.64 & 184.0 & 41 \\
\hline USA & 29 & 20 & 51 & 23.63 & 21.61 & 1975 & 54 & 26 & 7 & .11 & 4.19 & 2036 & 180.0 & .19 & 26 & 7 & 13 & 24.34 & 20.04 & 175.5 & 14 \\
\hline OLA & 74 & 100 & $.05^{4}$ & 20.16 & 2929 & 129.0 & $.03^{4}$ & 68 & a) & .17 & 2040 & 28.73 & 136.5 & .04 & 71 & 67 & $\pi$ & 22.77 & 23.50 & 210.0 & 86 \\
\hline PWG & 81 & 86 & b) & 21.45 & 26.43 & 169.0 & 23 & 7 & 86 & 34 & .21 & 26.96 & 1625 & 1 & 61 & 71 & 4 & 22.32 & 0 & 96.0 & 60 \\
\hline $\mathrm{S}^{++}$ & 26 & 27 & 95 & 227 & 23.50 & 210.0 & 82 & 13 & r & 52 & 23.40 & 22.11 & 2045 & 57 & 8 & 0 & II & 23,45 & 2200 & 201.0 & 34 \\
\hline$s^{+}$. & 81 & 64 & 30 & 24.71 & 19.21 & 164.0 & 18 & 58 & 64 & 58 & 15 & 2268 & 2125 & 91 & 58 & 15 & 12 & 23.90 & 2082 & 186.5 & 42 \\
\hline $5 \cdot+$ & 48 & 50 & 91 & 23.11 & 2275 & 2135 & 93 & 42 & 43 & 90 & 2356 & 21.75 & 1925 & 6 & 42 & 12 & $\omega^{3}$ & 24.77 & 19.07 & 162.0 & 11 \\
\hline $5 \cdots$ & 39 & 43 & 61 & 23.02 & 22.96 & 216.5 & 99 & 26 & 43 & 16 & 22.00 & 25.21 & 1860 & 35 & 42 & 43 & 76 & 2306 & 22.86 & 215.0 & 96 \\
\hline $5=$ & 87 & 71 & 25 & 23.97 & 20.86 & 1870 & 44 & 81 & 64 & 30 & 24.21 & 20.32 & 1795 & 34 & 55 & 50 & 62 & 23.03 & 22.93 & 216.0 & 98 \\
\hline 58 & 35 & 43 & 77 & 22.63 & 23.82 & 205.5 & 74 & 35 & 14 & 12 & 24.40 & 19.89 & 173.5 & .18 & 16 & 15 & 80 & 23,13 & 2271 & 213.0 & 88 \\
\hline RL & 84 & 85 & 80 & 11 & 96 & 1 ag 5 & 48 & 51 & 57 & $.05^{\dagger}$ & 2460 & 19.46 & 167.5 & 21 & $\pi$ & 50 & 10 & 2421 & 20.32 & 179.5 & 34 \\
\hline BAC & 68 & 5 & .17 & 15 & 0 & 75.0 & 13 & 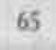 & 57 & 47 & 23.27 & 22.39 & 208.5 & .83 & 74 & 57 & 16 & 8 & 20.39 & 5 & 36 \\
\hline $\mathrm{CV}$ & 94 & 93 & -98 & 24.52 & 19.64 & 170.0 & 24 & 87 & 93 & 52 & 24.44 & 19.02 & 102 & 27 & 94 & 79 & 'n & 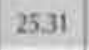 & 9 & 5 & 08 \\
\hline$P R$ & 65 & 53 & .47 & 23.32 & 22.29 & 207.0 & .80 & 61 & 64 & .93 & 23.26 & 22,43 & $\cos \theta$ & 204 & 30 & 30 & .00 & 23.28 & 22.39 & 208.5 & 83 \\
\hline $\mathrm{BR}$ & $\pi$ & 79 & 84 & 22.98 & 23.04 & 216.5 & 93 & 81 & 79 & 57 & 21,98 & 25 & 185.5 & .43 & 65 & 71 & 55 & 21.61 & 25.64 & 180.0 & 35 \\
\hline $\mathrm{DD}$ & 81 & 93 & 26 & 23.98 & 20.82 & 186.5 & .45 & 90 & 86 & 31 & 24.48 & 19.71 & 171.0 & 25 & 94 & 92 & 96 & 24.60 & 19.46 & 167.5 & 22 \\
\hline 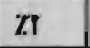 & 87 & 86 & 97 & 2273 & 23.61 & 208.5 & 183 & 90 & 79 & 33 & $23.4 ?$ & 21.96 & 2025 & 72 & 97 & 86 & .19 & 22.16 & 24.86 & 1910 & $5 i$ \\
\hline
\end{tabular}

Per meetmoment staat in de kolommen $2 \mathrm{t} / \mathrm{m} 4$ steeds het percentage laagopgeleide patiënten dat een strategie ten minste eenmaal gebruikt $(\% \mathbf{L})$, het percentage hoogopgeleide patiēnten da dit doet $(\% \mathrm{H})$ en de $\mathrm{p}$-waarde behorend bij de $\mathrm{X}^{2}$-test waarmee het onderlinge verschil is getoetst. In de volgende vier koloinmen staan steeds gegevens die betrekking hebben op de frequentie van het strategiegebruik. De gemiddelde rangorde van beice patiëntengroepen is weergegeven, evenals de U-waarde en p-waarde behorend bij de Mann-Whitney-test waarmee het onderlnge verschil is getoetst (tp $\leq .05)$ 
- Tabel 4.12 - Verschillen in het gebruik van cognilieve strategievin tussen patienten die opnieuw met de ziekte zijn geconfronteerd $\left(n_{z^{-}}=6\right)$ versus patienten die niet opnieuw met de ziekte zijn geconfronteerd $\left(n_{2^{*}}=40\right)$

\begin{tabular}{|c|c|c|c|c|c|c|c|c|c|c|c|c|c|c|c|c|c|c|c|c|c|}
\hline \multirow{3}{*}{$\begin{array}{l}n=4 \text { d } \\
\text { strategie }\end{array}$} & \multicolumn{7}{|c|}{ T1 } & \multicolumn{7}{|c|}{12} & \multicolumn{7}{|c|}{$\mathrm{T} 3$} \\
\hline & \multicolumn{3}{|c|}{ maceviag } & \multicolumn{4}{|c|}{ friquevili } & \multicolumn{3}{|c|}{ mareniag } & \multicolumn{4}{|c|}{ Foquent } & \multicolumn{3}{|c|}{ nucevita } & \multicolumn{4}{|c|}{ izoupre } \\
\hline & $\approx Z^{*}$ & $\pi z$ & p & 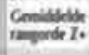 & Cominte & U & $\beta$ & $\% Z^{+}$ & $\approx Z^{\circ}$ & P & Comitutert & Conitut & U & $p$ & $\% z^{*}$ & $\% z^{*}$ & $p$ & Gencult & Contr & U & $p$ \\
\hline $\mathrm{CA}$ & - & . & . & . & . & - & - & . & - & . & . & . & - & - & 83 & 87 & 61 & 17,25 & 24.44 & 825 & .21 \\
\hline USA & $=$ & . & . & - & - & . & - & . & : & . & . & - & $\because$ & . & 80 & 80 & 67 & 22.67 & 23.63 & 115.0 & B1 \\
\hline OLA & - & . & a & - & . & . & . & . & - & - & - & - & . & . & 50 & 73 & $.02^{t}$ & 17.92 & 2434 & 865 & 26 \\
\hline PWG & - & . & . & . & . & . & - & . & - & - & . & - & - & - & 67 & 30 & 96 & 17.25 & 24,44 & 82.5 & 21 \\
\hline$s^{++}$ & - & . & $=$ & . & . & . & - & . & - & . & . & s. & 8 & $\therefore$ & 100 & 65 & 67 & 26.42 & 23.06 & 1025 & 11 \\
\hline st. & - & . & - & - & . & . & - & . & . & . & . & . & . & 2 & 33 & 52 & 66 & 31,42 & 22.31 & 725 & .10 \\
\hline$S \cdot+$ & . & . &. & . & . & . & . & . & - & . & - & . & $\therefore$ & . & 67 & 67 & 45 & 22.50 & 2365 & 1140 & 81 \\
\hline$s \cdots$ & . & , &. & . & . & . & - & . & . & . & . & . & . & . & 67 & 55 & 64 & 21.67 & 23.77 & 109.0 & 69 \\
\hline$s=$ & . & $b$ & - & $=$ & . & . & - & . & . & . & . & $=$ & 5 & . & 33 & 90 & 23 & 28.67 & 22,73 & 89.0 & 27 \\
\hline SB & $=$ & ? & 5 & . & . & $=$ & $=$ & . & - & . & . & . & $\therefore$ & is & 50 & 10 & 11 & 31,50 & $22 \times 0$ & 72.0 & $.91^{\circ}$ \\
\hline $\mathbf{R L}$ & - & 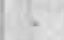 & 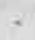 & 2 & $\div$ & . & - & . &. & . & . & $=$ & . & 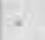 & 100 & 65 & 27 & 3835 & 2127 & 31.0 & $.003 \cdot$ \\
\hline BAG & - & $\rightarrow$ & 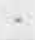 & $=$ & $=$ & - & $=$ & $\therefore$ & - & - & - & - & - & . & 17 & 35 & 76 & 28.08 & 2281 & 92.5 & 35 \\
\hline $\mathrm{CY}$ & . & - & - & - & . & . & - & $=$ & - & - & - & . & - & . & 83 & 90 & 49 & 19.83 & 24.06 & 98.0 & 47 \\
\hline PR & n & . & . & $=$ & . & . & - & . & . & . & . & . & , & $=$ & 67 & 50 & 76 & 26.50 & 23.05 & 102.0 & 53 \\
\hline BR & . & . & . & $=$ & . & . & . & . & . & . & 2 & $=$ & - & $\therefore$ & 100 & 63 & 46 & 32.42 & 22.16 & 66.5 & 07 \\
\hline Do & . & - & - & . & . & : & - & . & $\rightarrow$ & . & 2 & . & - & . & 100 & 92 & 27 & 30.08 & 2251 & Ba.s & 20 \\
\hline $2 T$ & $=$ & . & $\therefore$ & . & $=$ & . & - & . & . & . & . & $=$ & $\therefore$ & $\because$ & 100 & 92 & 30 & 31.58 & 22.0 & 60.0 & $n 5^{4}$ \\
\hline
\end{tabular}

Voor meetmoment 13 staat in de kolommen $2 \mathrm{~V} / \mathrm{m} 4$ het percentage patienten dat opnieuw met de ziekte is geconfronteerd en een strategie ten minste eenmaal gebruikt $\left(* z^{*}\right)$, het percentage patienten dat niet opnieuw met de ziekte is geconfronteerd dat dit doet (s:-) en de p-waarde behorend bij de $\mathrm{X}^{2}$-test waarmee hel onderlinge verschil is getoetst. In de volgende vier kolommen staan gegevens die betrekking hebben op de frequentie van het strategiegebruik. De gemiddelde rangorde van beide patiëntengroepen is weergegeven, evenals de U-waarde en p-waarde behorend bij de Marnn-Whitney-test waarmee het onderlinge verschil is getoetst (t $p \leq .05$ ) 
BIJLAGE D: DE MATE VAN AANPASSING BII VERSCHILLENDE SUBGROEPEN RESPONDENTEN. TABELLEN BEHOREND BIJ HOOFDSTUK $V$ PARAGRAAF 5

- Tabel 5.9 - Verschillen in aanpassing tussen patiènten met negatieve okselklieren $\left(n_{N}=13\right)$ versus patiënten met positieve klieren $\left(n_{p}=33\right)$.

\begin{tabular}{|c|c|c|c|c|}
\hline Aanpassingsschaal $n=46$ & $\begin{array}{l}\text { Gemiddelde } \\
\text { rangorde } \mathrm{N}\end{array}$ & $\begin{array}{l}\text { Gemiddelde } \\
\text { rangorde P }\end{array}$ & U & p \\
\hline & & $\mathrm{T1}$ & & \\
\hline Toekomstperspectief & 14.17 & 26.21 & 92.0 & $.01^{\circ}$ \\
\hline Angst & 21.67 & 23.48 & 182.0 & .68 \\
\hline Zelibeeld & 20.50 & 23.91 & 168.0 & .44 \\
\hline & & $\mathrm{T} 2$ & & \\
\hline Toekomstperspectief & 24.46 & 22.47 & 180.5 & .65 \\
\hline Angst & 21.83 & 23.42 & 184.0 & 72 \\
\hline Zeltbeeld & 27.25 & 21.45 & 147.0 & .19 \\
\hline & & $\mathrm{T} 3$ & & \\
\hline Toekomstperspectief & 26.50 & 21.73 & 156.0 & .28 \\
\hline Angst & 25.17 & 22.21 & 172.0 & .50 \\
\hline Zelibeeld & 27.50 & 21.36 & 144.0 & .17 \\
\hline
\end{tabular}

Per meetmoment staan per aanpassingsschaal achtereenvolgens de gemiddelde rangorde van de aanpassingsscores van patiênten met negatieve okselklieren $(\mathrm{N})$ en die van patiěnten met positieve okselklieren (P), evenals de U- en p-waarde behorend bij de Mann-Whitney-test waarmee de onderlinge verschillen zijn getoetst ( $p \leq .05 * p \leq .01 * p \leq .005)$. 
- Tabel 5.10 - Verschillen in aanpassing tussen patiènten behandeld met chemotherapie $\left(\mathrm{n}_{\mathrm{C}+}=23\right)$ versus patiênten niet behandeld met chemotherapie $\left(n_{\mathrm{c} \cdot=23)}\right.$

\begin{tabular}{|c|c|c|c|c|}
\hline Aanpassingsschaal $n=46$ & $\begin{array}{l}\text { Gemiddeide } \\
\text { rangorde } \mathrm{C}^{+}\end{array}$ & $\begin{array}{l}\text { Gemiddelde } \\
\text { rangorde C }\end{array}$ & u & P \\
\hline \multicolumn{5}{|c|}{ T1 } \\
\hline Toekomstperspectief & 24.57 & 22.43 & 240.0 & .59 \\
\hline Angst & 22.59 & 24.41 & 243.5 & .64 \\
\hline Zelibeeld & 20.87 & 26.13 & 204.0 & .18 \\
\hline \multicolumn{5}{|c|}{$\mathrm{T} 2$} \\
\hline Toekomstperspectief & 21.39 & 25.61 & 216.0 & .28 \\
\hline Angst & 22.63 & 24.37 & 244.5 & .66 \\
\hline Zelitheeld & 20.22 & 26.78 & 189.0 & 10 \\
\hline \multicolumn{5}{|c|}{ T3 } \\
\hline Toekomstperspectief & 22.20 & 24.80 & 234.5 & .51 \\
\hline Angst & 23.13 & 23.87 & 256.0 & .85 \\
\hline Zelifbeeld & 20.04 & 26.96 & 185.0 & .08 \\
\hline
\end{tabular}

Per meetmoment staan per aanpassingsschaal achtereenvolgens de gemiddelde rangorde van de aanpassingsscores van patiënten behandeld met chemotherapie $\left(C^{+}\right)$en die van patiènten niet behandeld met chemotherapie $\left(C^{-}\right)$, evenals de $U$ - en p-waarde behorend bij de Mann-Whitney-test waarmee de onderlinge verschillen zijn getoetst to $\leq .05$ " $p \leq .01$ " $p \leq .005$ ). 
- Tabel 5.11 - Verschillen in aanpassing tussen patiënten behandeld met chemotherapie $\left(n_{c}=23\right)$ versus patiénten behandeld met hormoontherapie $\left(n_{H}=10\right)$

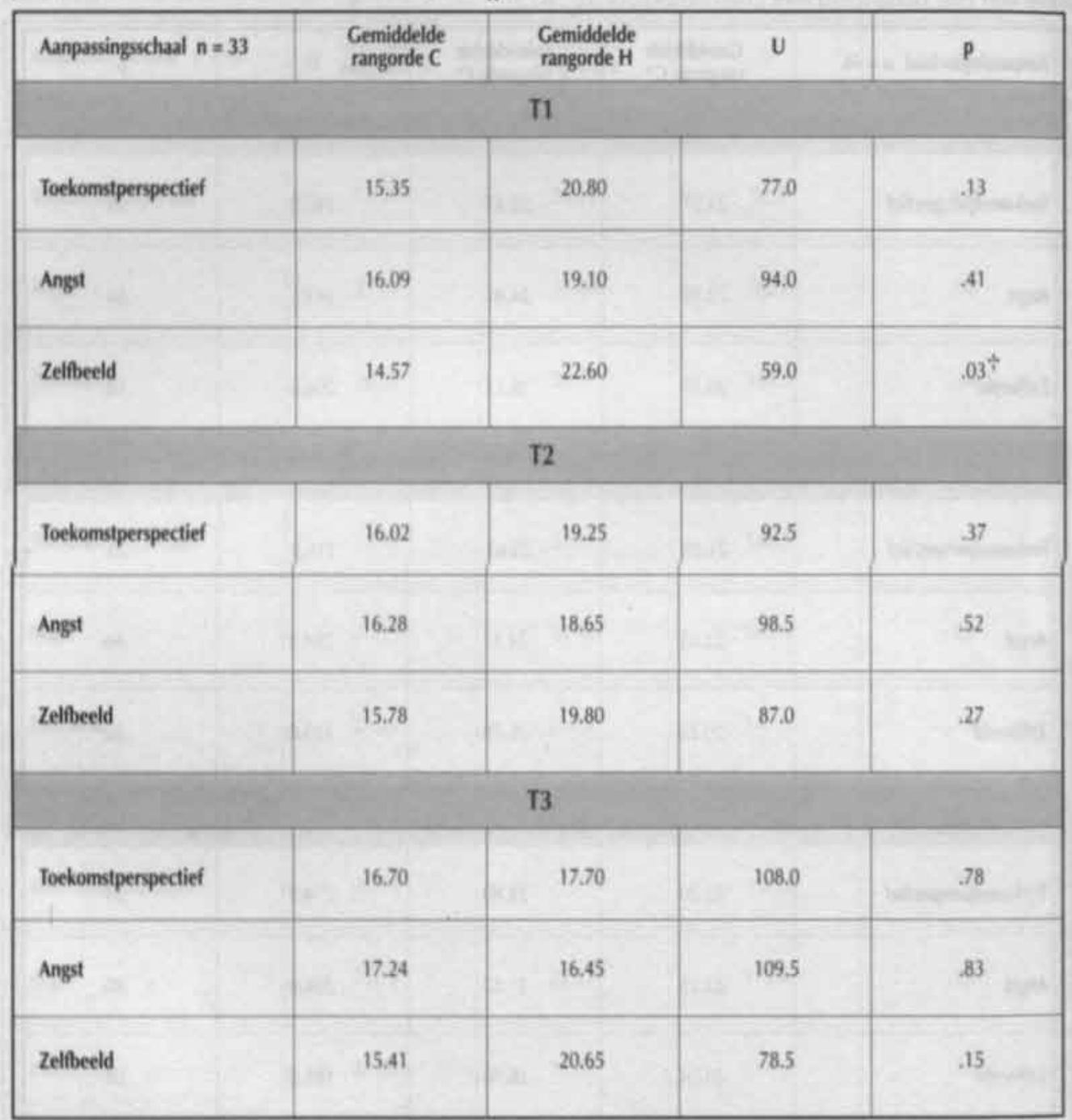

Per meetmoment staan per aanpassingsschaal achtereenvolgens de gemiddelde rangorde van de aanpassingsscores van patiènten behandeld met chemotherapie (C) en die van patiënten behandeld met hormoontherapie (H), evenals de U- en p-waarde behorend bij de Mann-Whitney-test waarmee de onderlinge verschillen zijn getoetst (t" $\leq \leq .05 " p \leq .01 \quad$ " $p \leq .005)$. 
- Tabel 5.12 - Verschillen in aanpassing tussen jonge patiènten $\left(n_{1}=24\right)$ versus oude patiénten $\left(\mathrm{n}_{\mathrm{o}}=22\right)$

\begin{tabular}{|c|c|c|c|c|}
\hline Aanpassingsschaal $n=46$ & $\begin{array}{l}\text { Gemiddelde } \\
\text { rangorde I }\end{array}$ & $\begin{array}{l}\text { Gemiddelde } \\
\text { rangorde } 0\end{array}$ & u & $p$ \\
\hline \multicolumn{5}{|c|}{$\mathrm{T1}$} \\
\hline Toekomstperspectief & 19.50 & 27.86 & 168.0 & $.03^{t}$ \\
\hline Angst & 22.21 & 24.91 & 233.0 & 30 \\
\hline Zelibeeld & 22.90 & 24.16 & 249.5 & 75 \\
\hline \multicolumn{5}{|c|}{$\mathrm{r} 2$} \\
\hline Toekomstperspectief & 23.58 & 23.41 & 262.0 & .96 \\
\hline Angst & 23.13 & 23.91 & 255.0 & .84 \\
\hline Zelifbeeld & 24.56 & 22.34 & 238.5 & 57 \\
\hline \multicolumn{5}{|c|}{13} \\
\hline Toekomstperspectief & 24.54 & 22.36 & 239.0 & 58 \\
\hline Angst & 26.31 & 20.43 & 196.5 & .14 \\
\hline Zelibeeld & 22.40 & 24.70 & 237.5 & $56=$ \\
\hline
\end{tabular}

Per meetmoment staan per aanpassingsschaal achtereenvolgens de gemiddelde rangorde van de aanpassingsscores van jonge patiënten (I) en die van oude patiënten $(0)$, evenals de $U$ - en pwaarde behorend bij de Mann-Whitney-test waarmee de onderlinge verschillen zijn getoetst (†p $\leq .05$ " $\mathrm{p} \leq .01 \cdots \mathrm{p} \leq .005)$. 
- Tabel 5.13 - Verschillen in aanpassing tussen laagopgeleide patiënten $\left(n_{t}=31\right)$ versus hoogopgeleide patienten $\left(n_{\mathrm{H}}=15\right)$.

\begin{tabular}{|c|c|c|c|c|}
\hline Aanpassingsschaal $n=46$ & $\begin{array}{l}\text { Gemiddelde } \\
\text { rangorde L }\end{array}$ & $\begin{array}{l}\text { Gemiddelde } \\
\text { rangorde H }\end{array}$ & $u$ & $\mathbf{p}$ \\
\hline \multicolumn{5}{|c|}{$\mathrm{T1}$} \\
\hline Toekomstperspectief & 22.92 & 23.18 & 214.5 & 95 \\
\hline Angst & 22.90 & 23.21 & 214.0 & .94 \\
\hline Zelfbeeld & 22.94 & 23.14 & 215.0 & 96 \\
\hline \multicolumn{5}{|c|}{ T2 } \\
\hline Toekomstperspectief & 22.79 & 23.46 & 210.5 & 87 \\
\hline Angst & 22.77 & 23.50 & 210.0 & .86 \\
\hline Zelfbeeld & 22.73 & 23.61 & 208.5 & .84 \\
\hline \multicolumn{5}{|c|}{ T3 } \\
\hline Toekomstperspectief & 23.45 & 22.00 & 203.0 & 73 \\
\hline Angst & 22.16 & 24.86 & 191.0 & .52 \\
\hline Zelifbeeld & 23.00 & 23.00 & 217.0 & 1.00 \\
\hline
\end{tabular}

Per meetmoment staan per aanpassingsschaal achtereenvolgens de gemiddelde rangorde van de aanpassingsscores van laagopgeleide patiënten $(\mathbf{L})$ en die van hoogopgeleide patiênten $(\mathbf{H})$, evenals de $U$ - en p-waarde behorend bij de Mann-Whitney-test waarmee de onderlinge verschillen zijn getoetst ( $p \leq .05$ " $p \leq .01 * p \leq .005$ ). 
- Tabei 5.14 - Verschillen in aanpassing tussen patiènten die opnieuw met de ziekte zijn geconfronteend $\left(n_{2}=6\right.$ ) versus patiênten die niet opnieuw met de ziekte zijn geconfronteerd $\left(n_{2}=40\right)$.

\begin{tabular}{|c|c|c|c|c|}
\hline Aanpassingsschaal $n=46$ & $\begin{array}{l}\text { Gemiddelde } \\
\text { rangorde } \mathrm{Z}^{+}\end{array}$ & $\begin{array}{l}\text { Gemiddelde } \\
\text { rangorde Z' }\end{array}$ & U & p \\
\hline \multicolumn{5}{|c|}{ T1 } \\
\hline Toekomstperspectief & . & & $=$ & $=$ \\
\hline Angt & & & & $=$ \\
\hline Zelibeeld & . & $=$ & $=$ & . \\
\hline \multicolumn{5}{|c|}{$\mathrm{T} 2$} \\
\hline Toekomstperspectief & . & & . & \\
\hline Angst & . & . & . & \\
\hline Zelifbeeld & . & . & - & . \\
\hline \multicolumn{5}{|c|}{ T3 } \\
\hline Toekomstperspectief & 8.50 & 25.75 & 30,0 & $.00^{4 *}$ \\
\hline Angst & 8.92 & 25.69 & 32.5 & $.00^{* *}$ \\
\hline Zelibeeld & 21.75 & 23.76 & 109.5 & .73 \\
\hline
\end{tabular}

Voor meetmoment T3 staan per aanpassingsschaal achtereenvolgens de gemiddelde rangorde van de aanpassingsscores van patiènten die opnieuw met de ziekte zijn geconfronteerd $\left(z^{*}\right)$, en die van patienten die niet opnieuw met de ziekte zijn geconfronteerd $(z-)$, evenals de U-en p-waarde behorend bij de Mann. Whitney-test waarmee de onderlinge verschillen zijn getoetst ( $\left.{ }^{+} p \leq 05 * 0 \leq .01 \quad " p \leq .005\right)$. 
- Tabet 5.15 - Verschillen in 'gevoel van eigen invloed' tussen patiënten met negatieve okselklieren $\left(n_{N}=13\right)$ versus patiènten met positieve klieren $\left(n_{p}=33\right)$.

\begin{tabular}{|c|c|c|c|c|}
\hline$n=46$ & $\begin{array}{l}\text { Gemiddeide } \\
\text { rangorde } N\end{array}$ & $\begin{array}{c}\text { Gemiddelde } \\
\text { rangorde P }\end{array}$ & U & p \\
\hline \multicolumn{5}{|c|}{ T1 } \\
\hline Invloed op de ziekte & 21,08 & 24.45 & 183.0 & 37 \\
\hline Invloed op de toekomst & 24.15 & 23.24 & 206.0 & 81 \\
\hline Invloed door leefgewoonten & 24,04 & 23.29 & 207.5 & 77 \\
\hline \multicolumn{5}{|c|}{$\mathrm{T} 2$} \\
\hline Invloed op de ziekte & 23,08 & 23.67 & 209.0 & 87 \\
\hline Invloed op de tockomst & 20.58 & 24.65 & 176.5 & 28 \\
\hline Invloed door leefgewoonten & 23.04 & 23.68 & 208.5 & 82 \\
\hline \multicolumn{5}{|c|}{ T3 } \\
\hline Invloed op de ziekte & 25.58 & 22.68 & 187.5 & 36 \\
\hline Invloed op de toekomst & 24.88 & 22.95 & 196.5 & .61 \\
\hline Invloed door leefgewoonten & 25.04 & 22.89 & 194.5 & 32 \\
\hline
\end{tabular}

Per meetmoment staan per item achtereenvolgens de gemiddelde rangorde van de VAS-scores van patiênten met negatieve okselklieren $(\mathbf{N})$ en die van patiēnten met positieve okselklieren ( $\mathbf{P}$ ), evenals de U- en p-waarde behorend bij de Mann-Whitney-test waarmee de onderlinge

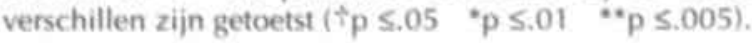


- Tabel 5.16 - Verschillen in 'gevoel van eigen invloed' tussen patienten behandeld met chemotherapie $\left(n_{C}=23\right)$ versus patiênten niet behandeld met chemotherapie $\left(n_{C}=23\right)$

\begin{tabular}{|c|c|c|c|c|}
\hline$n=46$ & $\begin{array}{l}\text { Gemiddelde } \\
\text { rangorde } \mathrm{C}^{*}\end{array}$ & $\begin{array}{l}\text { Gemiddelde } \\
\text { rangorde } \mathrm{C}^{-}\end{array}$ & u & p \\
\hline \multicolumn{5}{|c|}{$\mathrm{T1}$} \\
\hline Invloed op de ziebte & 28.00 & 19.00 & 161.0 & $.00^{* *}$ \\
\hline Invloed op de toekomst & 24.00 & 23,00 & 253.0 & .77 \\
\hline Invloed door leetgewoonten & 23.50 & 23.50 & 264.5 & 1.00 \\
\hline \multicolumn{5}{|c|}{$\mathrm{T} 2$} \\
\hline Invloed op de ziekte & 24,00 & 23.00 & 253.0 & .76 \\
\hline Invloed op de toekomst & 26.50 & 20.50 & 195.5 & .08 \\
\hline Invloed door leeigewoonten & 24.50 & 22.50 & 241.5 & .44 \\
\hline \multicolumn{5}{|c|}{13} \\
\hline Invloed op de ziekte & 23.50 & 23.50 & 264.5 & 1.00 \\
\hline Invloed op de toekomst & 22.50 & 24.50 & 241.5 & .56 \\
\hline Invloed door leeigewoonten & 22.50 & 24.50 & 241.5 & 30 \\
\hline
\end{tabular}

Per meetmoment staan per item achtereenvolgens de gemiddelde rangorde van de VAS-scores van patiènten behandeld met chemotherapie $\left(\mathrm{C}^{+}\right)$en die van patiènten niet behandeld met chemotherapie (C-), evenals de U- en p-waarde behorend bij de Mann-Whitney-test waarmee de onderlinge verschillen zijn getoetst ( ${ }^{+} \mathrm{p} \leq .05$ " $\mathrm{p} \leq .01 \quad$ " $\left.\mathrm{p} \leq .005\right)$. 
- Tabel 5.17 - Verschillen in 'gevoel van eigen invloed' tussen patiènten behandeld met chemotherapie $\left(n_{C}=23\right)$ versus patiénten behandeld met hormoontherapie $\left(n_{H}=10\right)$

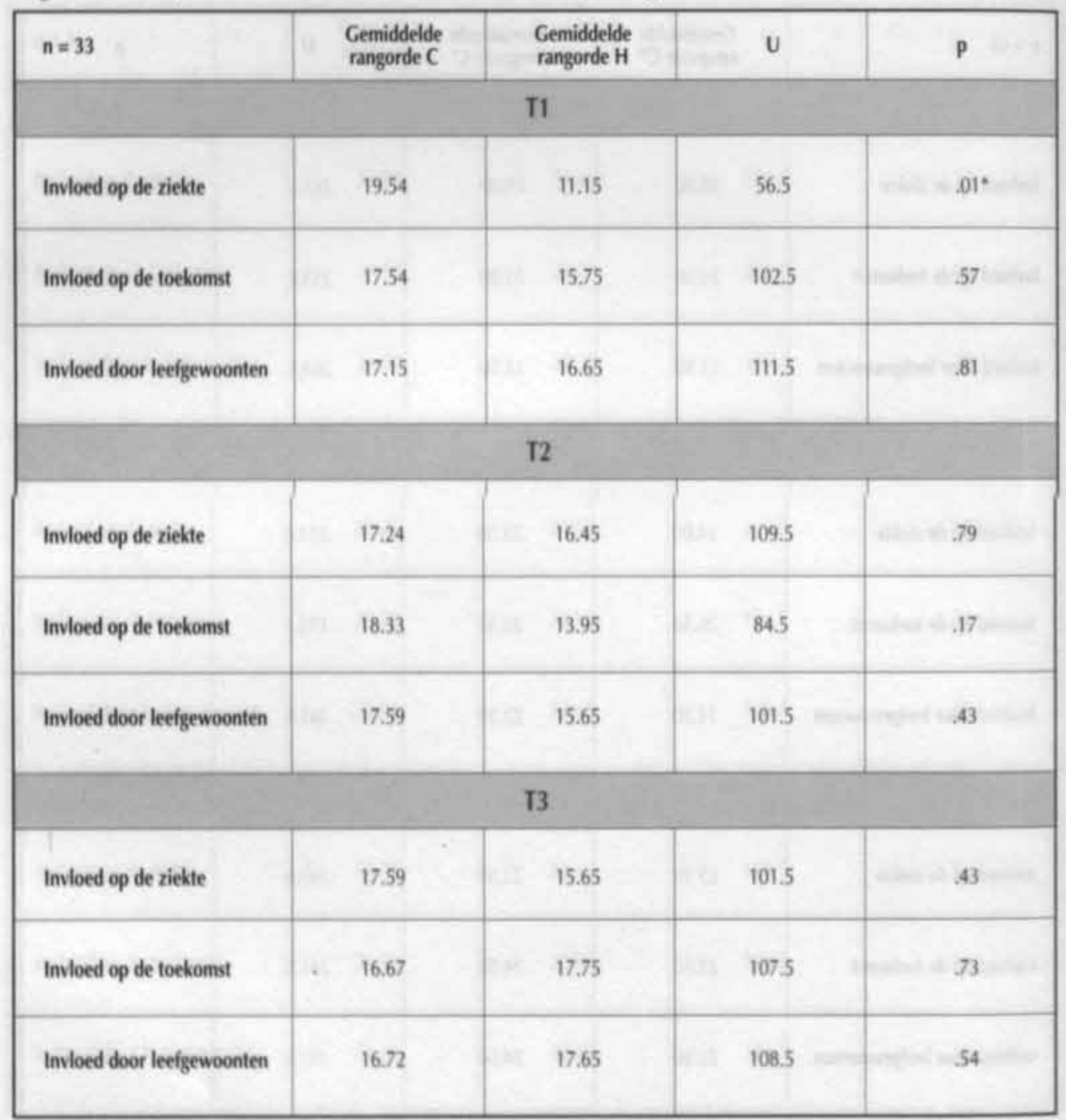

Per meetmoment staan per item achtereenvolgens de gemiddelde rangorde van de VAS-scores van patiênten behandeld met chemotherapie (C) en die van patiènten behandeld met hormoontherapie (H), evenals de $U$ - en p-waarde behorend bij de Mann-Whitney-test waarmee de onderlinge verschillen zijn getoetst (" $\mathrm{p} \leq .05$ " $p \leq .01 \quad * p \leq .005)$. 
- Tabel 5.18 - Verschillen in 'gevoel van eigen invloed' tussen jonge patiènten $\left(n_{1}=24\right)$ versus oude patiènten $\left(\mathrm{n}_{0}=22\right)$

\begin{tabular}{|c|c|c|c|c|}
\hline$n=46$ & $\begin{array}{l}\text { Gemiddelde } \\
\text { rangorde I }\end{array}$ & $\begin{array}{l}\text { Gemiddelde } \\
\text { rangorde } 0\end{array}$ & $u$ & p \\
\hline \multicolumn{5}{|c|}{$\mathrm{T1}$} \\
\hline Invioed op de ziekte & 25.50 & 21.32 & 216.0 & .22 \\
\hline Invloed op de toekomst & 24.38 & 22.55 & 243.0 & $\begin{array}{r}59 \\
\times 1-59\end{array}$ \\
\hline Invloed door leefgewoonten & 24.33 & 22.59 & 244.0 & .45 \\
\hline \multicolumn{5}{|c|}{$\mathrm{T} 2$} \\
\hline Invloed op de ziekte & 23.67 & 23.32 & 260.0 & 91 \\
\hline Invloed op de toekomst & 25.00 & 21.86 & 228.0 & 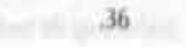 \\
\hline Invloed door leefigewoonten & 24.29 & 22.64 & 245.0 & $1=.53$ \\
\hline \multicolumn{5}{|c|}{ T3 } \\
\hline Invloed op de ziekte & 24.25 & 22.68 & 246.0 & .58 \\
\hline Invloed op de toekomst & 23.04 & 24.00 & 253.0 & 78 \\
\hline Invloed door leefigewoonten & 22,46 & 24.64 & 239.0 & 1.26 \\
\hline
\end{tabular}

Per meetmoment staan per item achtereenvolgens de gemiddelde rangorde van de VAS-scores van jonge patiênten (j) en die van oude patiénten ( 0 ), evenals de $U$ - en p-waarde behorend bij de Mann-Whitney-test waarmee de onderlinge verschillen zijn getoetst ( $p \leq .05$ " $p \leq .01$ "*p s.005). 
- Tabel 5.19 - Verschillen in 'gevoel van eigen invloed' tussen laagopgeleide patiènten $\left(n_{l}=31\right)$ versus hoogopgeleide patiènten $\left(n_{\mathbf{H}}=15\right)$.

\begin{tabular}{|c|c|c|c|c|}
\hline$n=46$ & $\begin{array}{l}\text { Gemiddelde } \\
\text { rangorde L }\end{array}$ & $\begin{array}{l}\text { Gemiddelde } \\
\text { rangorde H }\end{array}$ & $u$ & $p$ \\
\hline \multicolumn{5}{|c|}{$\mathrm{T} 1$} \\
\hline Invloed op de ziekte & 22.90 & 24.73 & 214.0 & .61 \\
\hline Invloed op de toekomst & 21.13 & 28.40 & 159.0 & $.04^{+}$ \\
\hline Invloed door leefgewoonten & 22.73 & 25.10 & 208.5 & .34 \\
\hline \multicolumn{5}{|c|}{$\mathrm{T} 2$} \\
\hline Invloed op de ziekte & 21.94 & 26.73 & 184.0 & .16 \\
\hline Invloed op de toekomst & 20.92 & 28.83 & 152.5 & $.03^{\dagger}$ \\
\hline Invloed door leefgewoonten & 22.47 & 25.63 & 200.5 & .25 \\
\hline \multicolumn{5}{|c|}{ T3 } \\
\hline Invloed op de ziekte & 22.95 & 24.63 & 215.5 & .58 \\
\hline Invloed op de toekomst & 22.15 & 26.30 & 190.5 & .26 \\
\hline Invloed door leefgewoonten & 23,73 & 23.03 & 225.5 & 74 \\
\hline
\end{tabular}

Per meetmoment staan per item achtereenvolgens de gemiddelde rangorde van de VAS-scores van laagopgeleide patiënten ( $\mathbf{L}$ ) en die van hoogopgeleide patiēnten $(\mathbf{H})$, evenals de $\mathrm{U}$ - en p-waarde behorend bij de Mann-Whitney-test waarmee verschillen zijn getoetst (tp $\leq .05$ " $p \leq .01 *$ * $\leq .005$ ). 
- Tabel 5.20 - Verschillen in 'gevoel van eigen invloed' tussen patiènten die opnieuw met de ziekte zijn geconfronteerd i $n_{z^{+}}=6$ ) versus patienten die niet opnieuw met de ziekte zijn geconfronteerd $\left(n_{2}=40\right.$ ).

\begin{tabular}{|c|c|c|c|c|}
\hline$n=46$ & $\begin{array}{l}\text { Gemiddelde } \\
\text { rangorde } \mathrm{Z}^{+}\end{array}$ & $\begin{array}{l}\text { Gemiddelde } \\
\text { rangorde Z }\end{array}$ & u & p \\
\hline \multicolumn{5}{|c|}{$\mathrm{T} 1$} \\
\hline Invioed op de ziekte & . & . & . & - \\
\hline Invloed op de toekomst & . & $=$ & & \\
\hline Invloed door leefgewoonten & " & - & $=$ & . \\
\hline \multicolumn{5}{|c|}{$\mathrm{T} 2$} \\
\hline Invloed op de ziekte & - & - & . & $\therefore$ \\
\hline Invloed op de toekomst & - & . & & ₹ \\
\hline Invloed door leefgewoonten & - & - & . & - \\
\hline \multicolumn{5}{|c|}{ T3 } \\
\hline Invloed op de ziekte & 22.33 & 23.67 & 113.0 & .75 \\
\hline Invloed op de toekomst & 20.17 & 24.00 & 100.0 & .45 \\
\hline Invloed door leefgewoonten & 25.33 & 23.23 & 109.0 & .46 \\
\hline
\end{tabular}

Voor meetmoment T3 staan per item achtereenvolgens de gemiddelde rangorde van de VAS-scores van patiènten die opnieuw met de ziekte zijn geconfronteend $\left(z^{*}\right)$, en die van patiënten die niet opnieuw met de ziekte zijn geconfronteend ( $\mathbf{z}$ ), evenals de U-en p-waarde behorend bij de Mann-Whitney-test waarmee de onderlinge verschillen zijn getoetst ( $\mathrm{t} p \leq .05 * \mathrm{p} \leq .01 * \mathrm{p} \leq .005)$. 


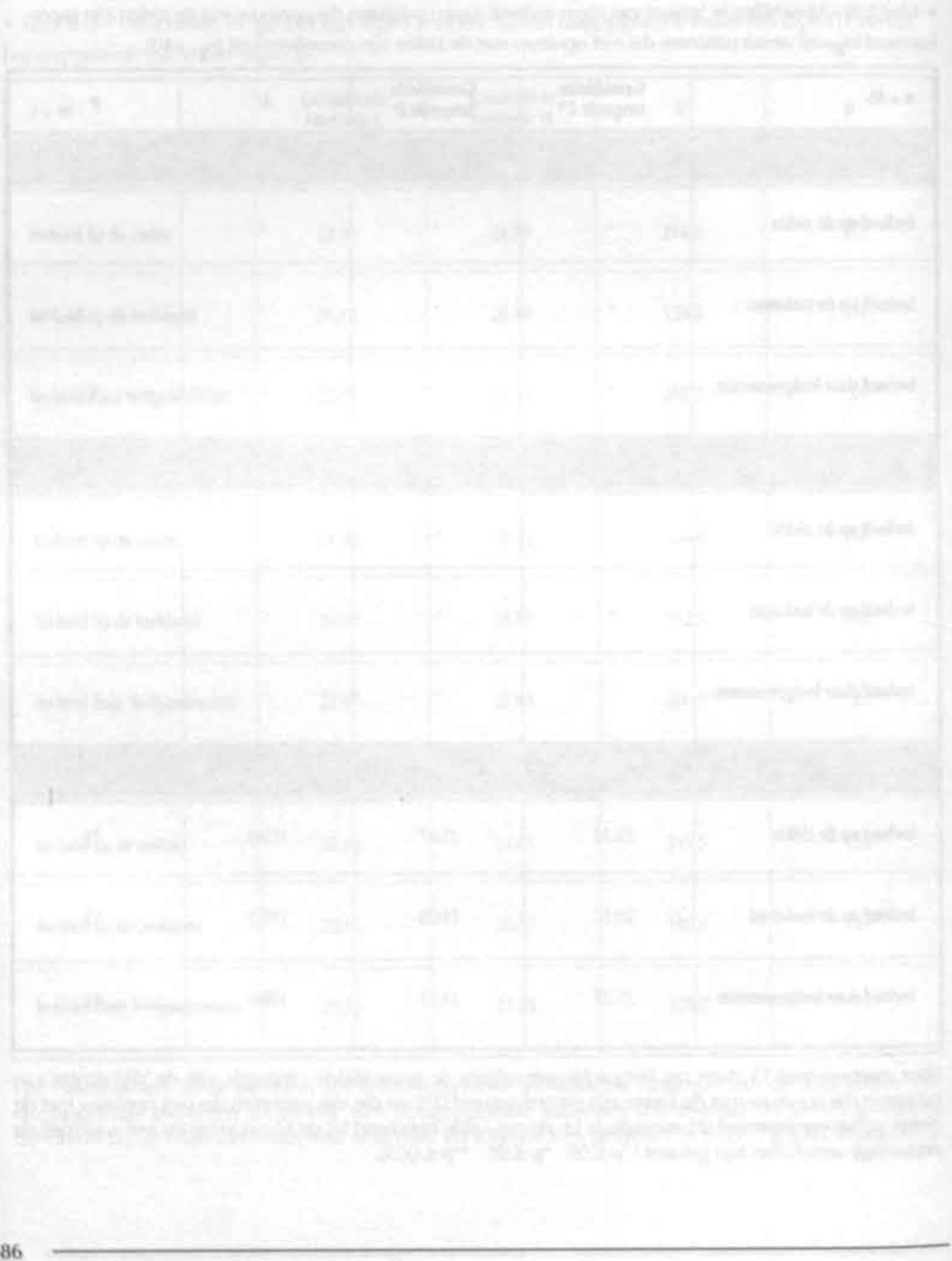




\section{LITERATUUR}

Abramson LY, Seligman MEP. Leamed helplessness in humans: critique and reformulation.

IAtnorm Psychol 1978;87(1):49-74

Afileck G. Tennen H. Social comparison and coping with major medical problems. In: I Suls, TA Wills (eds). Social comparison; contemporary theory and research. Hillsdale: Lawrence Erlbaum 1991:369-393

Aitken RCB. A growing edge of measurement in feelings. Proc Roy Soc Med: section measurement in medicine 1969:62:989-993

Andrews FM, McKennell AC. Measurement of self-reported well-being: their affective, cognitive and other coponents. Soc Indicators Res 1980;8:127-155

Andrykowski MA, Curran St., Studts JL, Cunningham L, Carpenter IS, McGrath PC, Sloan DA, Kenady, DE. Psychosocial adjustment and quality of life in women with breast cancer and benign breast problems: a controlled comparison. I Clin Epidem 1996;49(8):827-34

Audrain I. Schwartz MD, Lerman C, Hughes C, Peshkin BN. Psychological distress in women seeking genetic counseling for breast-ovarian cancer risk: the contributions of personality and appraisal. Ann Behav Med $1997 ; 19(4): 370-377$

Baider L, Sarell M. Perceptions and causal attributions of Israeli women with breast cancer concerning their illness: the effects of ethnicity and religiosity. Psychother Psychosom 1983:39:136-143

Beisecker A, Cook MR, Ashworth I. Hayes I, Brecheisen M, Heimig L, Hyland S, Selenke D. Side effects of adjuvant chemotherapy: perceptions of node-negative breast cancer patients. Psycho-Oncol 1997;6(2):85-93

Beisser AR. Denial and affirmation in illness and health. Am / Psychiat 1979;136(8):1026-1030

Benedict S, Williams RD, Baron PL. Recalled Anxiety: from discovery to diagnosis of a benign breast mass. Oncol Nurs Forum 1994;21(10):1723-1727

Berckman KL, Austin JK. Causal attribution, perceived control, and adjustment in patients with lung cancer. Oncol Nurs Forum 1993;20(1):23-30

Berglund G, Bolund C, Fornander T, Rutqvist LE, Sjodén P. Late effects of adjuvant chemotherapy and postoperative radiotherapy on quality of life among breast cancer patients. Eur / Cancer 1991;27(9):1075-1981

Boer H, Seydel ER, Rijn K van, Boekema AG, Mak ACA. Psychosociale problemen van recent gediagnostiseerde borstkankerpatiènten. Gedrag \& Gezondheid 1992;20(6):297-305

Bonarius H. Het verhaal van de persoonlijkheid. Ned Tijdschr Psychol 1988;43:145-158

Bome HW van den. Pruyn FA. Angst en onzekerheid bij kanker. Tijidschr Ziekenverp/ 1987;41(11):339-345

Breetvelt 15, Dam FSAM van. Underreporting by cancer patients: the case of response shift. Soc Sci Med 1991;32(9):981-987

Brickman P, Rabinowitz VC, Karuza I, Coates D, Cohn E, Kidder L. Models of helping and coping. Am Psychologist 1982;37:368-384 
Bruder-Mattson SF, Hovanitz CA. Coping and attributional styles as predictors of depression. I Clin Pyschol $1990: 46(5): 557-565$

Buddeberg VC. Bergant A, Wolf Ch. Wie erleben Brustkrebspatientinnen die Teilnahme an einer psychoonkologischen Verlaufsstudie? Zsch Psychosom Med 1991;37:172-184

Budin WC. Psychosocial adjustment to breast cancer in unmarried women. Res in Nurs Health 1998;21:155-166

Burgess C, Morris T, Pettingale KW. Psychological response to cancer diagnosis. II. Evidence for coping styles (coping styles and cancer diagnosis). I Psychosom Res 1988;32(3):263-272

Bury M. The sociology of chronic illness: a review of research and prospect. Soc Health \& Illness 1991;13(4);451-466

Butts Stahly G. Psychosocial aspects of stigma of cancer: an overview. J Psychosocial Onc 1988;6(3/4):3-27

Buunk BP, Collins RL, Taylor SE, Yperen NW van, Dakof GA. The affective consequences of social comparison: either direction has its ups and downs. J Pers Soc Psychol 1990;59(6):1238-1249

Carver CS, Pozo C, Harris SD, Noriega V, Scheier MF, Robinson DS, Ketcham AS, Moffat FL, Clark KC. How coping mediates the effect of optimism on distress: a study of women with early stage breast cancer. I Pers. Soc Psychol $1993 ; 65(2) ; 375-390$

Carver CS, Pozo-Kaderman C, Harris SD, Noriega V, Scheier MF, Robinson DS, Ketcham AS, Mofíat FL, Clark KC. Optimism versus pessimism predicts the quality of women's adjustment to early stage breast cancer. Cancer $1994 ; 73(4): 1213-1220$

Carver CS, Scheier MF. Scaling back goals and recalibration of the affect system are processes in normal adaptive self-regulation: Understanding 'response shift' phenomena. Soc Sci Med 2000;50:1715-1722

Cella FD, Perry SW. Reliability and concurrent validity of three visual-analogue mood scales, Psychol Rep 1986: $59: 827 \cdot 833$

Chodoff P, Friedman S, Hamburg D. Stress, defenses and coping behavior; observation in parents of children with malignant disease. Am I Psychiat 1964:120:743-749

Classen C, Koopman C, Angell K, Spiegel D. Coping styles associated with psychological adjustment to advanced breast cancer. Health Psychol 1996;15(6):434-437

Cohen F, Lazarus RS. Coping with the stress of illness. In: GC Stone, F Cohen, NE Adler (eds). Health Psychology-a handbook: theories, applications and challenges of a psychological approach to the healthcare system. San Francisco: lossey Bass 1979:217-254

Colvin CR, Block I. Do positive illusions foster mental health? An examination of the Taylor and Brown formulation. Psychol Bull 1994:116:3-20

Couzijn AL, Ros WIG, Winnubst IAM. Patiènten met levensbedreigende ziekte: kanker. In A Kaptein, H. van de Ploeg, B. Garssen, P. Schreurs (eds),Behavioral medicine: psychologische behandeling van lichamelijke aandoeningen, Alphen aan de Rijn: Samson Stafleu 1986:221-235

Coyne $\mathrm{KC}$. Never the twain shall meet? Closing the gap between coping research and clinical intervention research. Am Psychologist 2000:55(6):655-664 
Dunkel-Schetter C. Bennet TL. Differentiating the cognitive and behavioral aspects of social support. In: B Sarason. I Sarason, G Pierce (eds). Social stupport: an interactional view. New York: Wiley 1990

Dunkel-Schetter C, Feinstein LG, Taylor SE, Falke RL. Patterns of coping with cancer. Health Psychol 1992;11(2):79-87

Edgar L. Rosberger Z, Nowlis D. Coping with cancer during the first year after diagnosis. Cancer 1992;69(3):817. 828

Ell KO, Mantell JE, Hamovitch MB, Nishimoto RH. Social support, sense of control, and coping among patients with breast, lung, or colorectal cancer. I Psychosocial Oncol 1989;7(3):63-89

Epping-tordan JE, Compas BE, Osowiecki DM. Oppedisano G. Gerhardt C. Primo K. Krag DN. Psychological adjustment in breast cancer: processes of emotional distress. Health Psychol 1999:18(4):315.326

Fallowfield L. Hall A. Psychosocial and sexual impact of diagnosis and treatment of breast cancer. Brit Med Bull $1991 ; 47(2): 388-399$

Felton BI, Revenson TA, Hinrichsen GA. Stress and coping in the explanation of psychological adjustment among chronically ill adults. Soc Sci Med 1984:18(10):889-898

Ferrell BR, Grant MM, Funk B, Otis-Green S, Garcia N. Quality of life in breast cancer survivors: implications for developing support services. Onc Nurs Forum 1998;25:887-895

Filipp S, Klauer T, Freudenberg E, Ferring D. The regulation of subjective well-being in cancer patients: an analysis of coping effectiveness. Psychol Health 1990;4:305-317

Folkman S, Lazarus RS. Manual for the ways of coping questionnaire. Palo Alto Californié: Consulting Psychologist Press 1988.

Friedman LC, Nelson DV, Baer PE, Lane M, Smith FE. Adjustment to breast cancer: a replication study. I Psychosocial Oncol 1990;8(4):27.40

Gibbons FX. Social comparison as a mediator of response shift. Soc Sci Med 1999;48:1517-1530

Glanz, K, Lerman C. Psychosocial impact of breast cancer: a critical review. Ann Behav Med 1992;14(3)204:212

Gleitman H. Psychology. New York/London: WW Nonton 1986 (2) $^{\text {nd }}$ ed

Goldberg IA, Scott RN, Davidson PM, Murray GD, Stallard S, George WD, Maguire GP. Psychological morbidity in the first year after breast surgery. Eur / Surg Oncol 1992;18:327-331

Gotay CC. Why me? Atributions and adjustment by cancer patients and their mates at two stages in the disease process, Soc Sci Med 1985;20(8):825-831

Greer S. The management of denial in cancer patients. Oncol 1992;6112t:33-36

Greer S, Moorey 5, Baruch IDR. Watson M. Robertson BM, Mason A, Rowden L. Law MG, Bliss JM. Adjuvant psychological therapy for patients with cancer: a prospective randomised trial. Brit Med / 1992;304:675-680

Greer S, Moory S. Watson M. Patients adjustment to cancer: the mental adjustment to cancer (MAC) scale vs clinical ratings. I Psychosm Res 1989:33(3):373-377 
Greer S, Silberfarb PM. Psychological concomitants of cancen current state of research. Psychol Med 1982;12:563-573 Hart O van der. Trauma: dissociatie en hypnose. Amsterdam: Swets \& Zeitlinger 1991

Hackett TP, Cassem NH. Devolepment of a quantitative rating scale to assess denial. J Psychosom Res 1974;18:93-100

Haes JCIM de, Knippenberg FCE van, Trijsburg RW, Een theorie over kwaliteit van leven bij patiēnten. Ned Tijdschr Psychol 1991;46:146-150

Haes JCIM de, Ruiter JH de, Tempelaar R, Pennink BIW. The distinction between affect and cognition in the quality of life of cancer patients - sensitivity and stability, Quality of Life Res 1992;1:315-322

Hagopian GA, Lowery B], Jacobsen B. Adjustment to breast cancer using downward comparison. Cancer Pract $1994 ; 2(5): 359-364$

Heim E. Coping and adaptation in cancer. In: CL Cooper, M Watson (eds), Cancer and stress: psychological, biological and coping studies, New York: John Wiley 1991: 197-235

Heim E, Augustiny KF, Blaser A, Bürki C, Kuhne D, Rothenbühler M, Schaffner L, Valach L. Coping with breast cancer - a longitudinal prospective study. Psychother Psychosom 1987;48:44-59

Heim E, Augustiny KF, Schaffiner L, Valach L. Coping with breast cancer over time and situation. I Psychosom Res $1993 ; 37(5) ; 523-542$

Heim E, Valach L. Schaffiner L. Coping and psychosocial adaptation: longitudinal effect over time and stages in breast cancer. Psychosom Med 1997;59:408-418

Helgeson VS, Taylor SE. Social comparisons and adjustment among cardiac patients.

IApplied Soc Psychol 1993:23:1171-1195

Heyink 1. Adaptation and well-being. Psychol Rep 1993;73:1331-1342

Heyink \}. Tijmstra T. Kwalitatief onderzoek en onderzoek naar kwaliteit van leven. Ned Tijdschr Psychol $1991: 46: 123-130$

Hofstee WKB. De vragenlijstsituatie. Ned Tijdschr Psychol 1965:20:592-602

Houldin AD, Jacobsen B, Lowery B]. Seli-blame and adjustment to breast cancer. Oncol Nurs forum $1996 ; 23(1): 75.9$

Hamy C, Bemhard J, Coates AS, Castiglione-Gertsch M, Peterson HF, Gelber RD, Forbes IF, Rudenstam C, Simoncini E, Crivellari D, Goldhirsch A, Senn H. Impact of adjuvant therapy on quality of life in women with node-positive operable breast cancer. Lancet 1996;347(9011):1279-1284

Irvine D. Brown B, Crooks D, Roberts I, Browne G. Psychosocial adjustment in women with breast cancer. Cancer 1991;67(4):1097-1117

Janoif-Bulman, R. Characterological versus behavioral selfblame: inquiries into depression ande rape. I Pers Soc Psychol 1979:37:1798-1809

lanoff-Bulman R. A theoretical perspective for understanding reactions to victimization. / Soc Issues 1983;39(2):1-17 Janoff-Buiman, R. Shattered assumptions. Towards a new psychology of trauma. New York: Free Press 1992. 
fanoff-Bulman R. Wortman CB. Attributions of blame and coping in the "Real World"; severe accident victims react to their lot. J Pers Soc Psychol 1977;35(5):351-363

Jarret SR, Ramirez AJ. Richards MA, Weinman J. Measuring coping in breast cancer. fPsychosom Res 1992:36(6):593-602

Jenkins RA, Pargament KI. Cognitive appraisals in cancer patients. Soc Sci Med 1988;2616):625-633

Kessler RC, Price RH, Wortman CB. Social factors in psychopathology: stress, social suppont, and coping processes. Ann Rev Psychal 1985;36:531-72

Kleber R. Het trauma voorbij: over de grenzen van de psychotraumatologie. Psycholoog 2000; 35(1):8-14

Komproe IH, Rijken M, Ros WIG, Winnubst JAM, Hart H t. Available support and received support: different effects under stressful circumstances. I Soc and Pers Relationships 1997;14(1):59-77

Ksoode HFI ten. Het verhaal van kankerpatiènten; oorzaakstoekenning en betekenisverlening. Een onderzoek naar het verband tussen attributies en zelirespect. Utrecht 1990 (diss)

Kroode HFJ ten, Oosterwijk MH, Bonarius $\mathrm{H}$. Kankerpatiënten zoeken zelf naar verklaringen voor hun ziekte en situatie. Kanker 1988;12:6-8

Lavery If, Clarke VA. Causal attributions, coping strategies, and adjustment to breast cancer, Cancer Nurs $1996 ; 19(1) ; 20-28$

Lazanus RS. Progress on a cognitive-motivational-relational theory of emotion.

Am Psychologist 1991;:46(8);819-834

Lazarus RS. Coping theory and researc: past, present, and future. Psychosom Med 1993;55:234-247

Lazarus RS, Folkman S. Stress, appraisal, and coping. New York: Springer 1984.

Lazarus RS, Launier R. Stress-related transactions between person and environment. In: LA Pervin, M Lewis (eds). Perspectives in Interact Psychology. New York: Plenum 1978:287-214

Lerman C, Rimer B, Blumberg B. Effects of coping style and relaxation on cancer chemotherapy side effects and emotional responses. Cancer Nurs 1990;13:308-315

Lerner MJ. Observer's evaluation of a victim: justice, guilt, and veridical perception. J Pers Soc Psychol $1971 ; 20: 127-135$

Leventhal H, Easterling DV, Coons HL, Luchterhand CM, Love RR. Adaptation to chemotherapie treatments, In BL Andersen (ed). Women with cancer; psychological perspectives, Berlin: Springer 1986:172-203

Loveys 81, Klaich K. Breast cancer: demands of illness. Oncol Nurs Forum 1991;18(1):75-80

Lowery BI, Jacobsen BS, DuCette I. Causal attribution, control and adjustment to breast cancer, J Psychosocial Oncol 1993;10(4):37-53

Luria RE. The validity and reliability of the visual analogue mood scale. J Psychiat Res 1975;12:51-57

Mages NL, Mendelsohn GA. Effects of cancer on patients' lives: a personological approach. In: GC Stone, F Cohen, NE Adler (eds). Health Psychology-a handbook: theories, applications and challenges of a psychological approach to the healthcare system. San Francisco: Jossey Bass 1979: 255-284 
Manne SL, Sabbioni M, Bovbjerg DH, Jacobsen PB, Taylor KL, Redd WH. Coping with chemotherapy for breast cancer. I Behav Med 1994:17(1):41-55

McCann IL. Sakheim DK, Abrahamson DJ. Trauma and victimization: A model of psychological adaptation. Couns Psychologist 1988;16:531.559

Mendelsohn GA. Psychosocial adaptation to illness by women with breast cancer and women with cancer at other sites. I Psychosocial Oncol 1990;8(4):1-25

Meyerowitz BE. Postmastectomy coping strategies and quality of life. Health Psychol 1983;2(2):117-132

Molleman E, Pruyn I, Knippenberg A van. Social comparison processes among cancer patients. Brit / Soc Psychol $1986 ; 25: 1-13$

Morris T, Blake S, Buckley M. Development of a method for rating cognitive responses to a diagnosis of cancer. Soc Sci Med 1985;20(8):795-802

Morris T, Buckley M, Blake SM. Defining psychological responses to a diagnosis of cancer. In: M Watson, T Morris (eds). Psychological aspect of cancer 1986:55-64

Moyer A, Salovey P. Psychosocial sequelae of breast cancer and its treatment. Ann Behav Med 1996;18(2):110-125 Muris $\mathrm{P}$, Merckelbach $\mathrm{H}$. Ironische en minder ironische effecten van gedachte-onderdrukking. Psycholoog $19972138-143$

Neison DV, Friedman LC, Baer PE, Lame M, Smith FE. Subtypes of psychosocial adjustment to breast cancer. J Behav Med 1994;17(2):127-141

Northouse L. A longitudinal study of the adjustment of patients and husbands to breast cancer. Oncol Nurs forum $1989: 16(4): 511.516$

Northouse L4, Swain MA. Adjustment of patients and husbands to the initial impact of breast cancer. Nurs Res $1987 ; 36(4): 221-225$

Omne-Ponten M, Holmberg L, Bums T. Determinants of the psycho-social outcome after operation for breast cancer, Results of a prospective comparative interview study following mastectomy and breast conservation. Eur J Cancer 1992:28A:1062-1067

Omne-Ponten M, Holmberg L, Sjoden PO. Psychosocial adjustment among women with breast cancer stages I and II: six-year follow-up of consecutive patients. J Clin Oncol 1994;12:1778-1782

Orr E. Open communication as an effective stress management method for breast cancer patients. I Human Stress $1986 ; 12(4) ; 175-185$

Orr E, Meyer 1. Disease appraisals as a coping strategy with cancer threat. Isr I Pychiat Relat Sciences $1990 ; 27(3): 145-159$

Otten W. Onrealistisch optimisme. Pyycholoog 1998:46-53

Pearlin L.I, Scooler C. The structure of coping. I Health Soc Behav 1978;19:2-21

Pennings L, Cohen L. Ploeg $\mathrm{H}$ van der. Predictions for sensitivity in measuring change: visual analogue scales compared to rating scales in a Likert format. Psychol Rep 1995;77:475-480 
Peterson C, Bossio LM. Health and optimism. New York: The Free Press 1991

Ray C. Lindop I. Gibson S. The concept of coping. Psychol Med 1982;12:385-395

Razavi D. Psychosocial and psychiatric interventions in patients with cancer. Oncol in prac 1994:5-10

Rooij I van. Attributie: een kritische analyse van de attributie-theorie. Ned Tijdschr Psychol 1986;41:201-207.

Ros WIG. Sociale steun bij kankerpatienten. Utrecht 1989 (diss)

Schaefer IA, Moos RH. The context for posturaumatic growth. Life crises, individual and social resources and coping. In: RG Tedeschi, CL. Park, LG Calhoun (eds). Posttraumatic growth. Positive changes in the aftermath of crises. Mahwah: Lawrence Erlbaum 1998:99-126

Schrameijer F, Brunenberg W. Psychosociale zorg bij kanker. Utrecht: NeGv-reeks 1992;22

Schroevers M. Short- and long-term adaptation to cancer. Groningen 2002 (diss)

Scott J. Huskinson EC. Graphic representation of pain. Pain 1976;2:175-184

Sensky T. Causal attributions in physical iliness. J Psychosom Res 1997;43(6):565-573

Shapiro DE, Boggs SR, Rodrigue IR, Urry HL, Algina II. Hellman R, Ewen F, Stage II breast cancer: differences betweet four coping patterns in side effects during adjuvant chemotherapy. I Psychosom Res 1997;43(2):143-157

Shedler 1, Mayman M, Manis M. The illusion of mental health. Am Psychologist 1993;48(11):117-1131

Somerfield M, Curbow B. Methodological issues and research strategies in the study of coping with cancer. Soc SciMed 1992;34(11):1203-1216

Somerfield MR, Steanek ME, Smith TI, Padberg II. A system model for adaptation to somatic distress among Cancer survivors. Psycho-oncology 1999;8: 334-343

Spiegel D. Psychosocial aspects of breast cancer treatment. Seminars Oncol 1997;24(1):S1-36-SI-47

Sprangers MA. Response shift and the retrospective pretest- posttest. On the usefulness of retrospective pretestposttest designs in detecting training related response shift. Den Haag 1988 (diss)

Sprangers MA, Schwartz CE. The challenge of response shift for quality-of-life-based clinical oncology research. Ann Oncol 1999;10(7):747-9.

Stiegelis HE. A life less ordinary; cognitive adaptation and psychological functioning among cancer patients treated with radiotherapy. Groningen 2003 (diss)

Taylor SE. Adjustment to threatening events, Am Psychologist 1983:1161-1173

Taylor SE, Brown ID. Illusion and well-being: a social psychological perspective on mental health. Psychol Bull $1988 ; 103: 193-210$

Taylor SE, Brown JD. Positive illusions and well-being revisited: separating fact from fiction. Psychol Bull 1994:116(1):21-27

Taylor SE, Lichtman RR, Wood N. Attitudes and social cognition. Attributions, beliefs about control, and adjustment to breast cancer. I Pers Soc Psychol 1984;46(3):489-502 
Taylor SE, Lichtman RR, Wood NV, Bluming AZ, Dosik GM, Leibowitz RL. Illness-related and treatment-related factors in psychological adjustment to breast cancer. Cancer 1985;55:2506-2513

Taylor SE, Lobel M. Social comparison activity under threat: downward evaluation and upward contacts. Psychol Rev 1989;96(4):569-575

Taylor SE, Wood IV, Lichtman RR. It could be worse: selective evaluations as a response to victimization. I Soc Issues 1983:39(2):19-40

Thompson S. Will it hurt less if I can control it ? A complex answer to a simple question. Psychol Bull 1981;90:89-101 Timko C, Janoff-Bulman R. Attributions, vulnerability, and psychological adjustment: the case of breast cancer. Health Psychol 1985;4(6):521-544

Vinokur AD, Threatt BA, Caplan RD, Zimmerman BL. Physical and psyhosocial functioning and adjustment to breast cancer. Cancer 1989;63:394-405

Vinokur AD, Threat BA, Vinokur-Kaplan D, Satariano WA. The process of recovery from breast cancer for younger and older patients: changes during the first year. Cancer 1990;65:1242-1254

Wainstock JM. Breast cancer: psychosocial consequences for the patient. Seminars Oncol Nurs 1991;7(3):207-215

Watson, M. Greer S, Blake S, Shrapnell K. Reaction to a diagnosis of breast cancer. Relationship between denial. delay and rates of psychological morbidity, Cancer 1984;53:2008-2012

Watson M. Greer S. Rowden L. Gorman C, Robertson B, Bliss IM, Tunmore R. Relationships between emotional control, adjustment to cancer and depression and anxiety in breast cancer patients. Psychol Med 1991;21:51-57

Weisman AD, Sobel HI. Coping with cancer through self-instruction: a hypothesis. I Human Stress 1979:3-8

Weisman AD, Worden IW. The existential plight in cancer: significance of the first 100 days. Psychiat in Med 1976 . $77: 7(1): 1-15$

Wheeler L. A brief history of social comparison theory. In: I Suls, TA Wills (eds). Social comparison; contemporan? theory and research. Hillsdale: Lawrence Eribaum 1991:3-21

Williams $\mathrm{GH}$. The genesis of chronic illness: narrative reconstruction. Sociol, Health and Illness 1984;6:175-200

Wills TA. Similarity and self-esteem in downward comparison. In: I Suls, TA Wills (eds). Social comparison; contemporary theory and research. Hillsdale: Lawrence Erlbaum 1991:51-77

Wolf $\mathrm{CH}$ von, Meyer PC, Richter D, Riehl-Emde A, Ritter-Landolt C, Sieber M, Steiner R, Buddeberg C. Kausalattribution und Krankheitsverarbeitung bei Brustkrebspatientinnen: Ergebnisse einer Langsschniftuntersuchung. Zeitschr Psychosom Med und Psychoanal 1995;41(4):356-369

Wortman CB. Coping with victimization: conclusions and implications for future research. I Soc lssues $1983 ; 39(2): 195-221$

Zee K van der. For better or for worsel Social comparison and coping with health problems. Groningen 1996 (diss: Zuuren Fl, van. Kwalitatief onderzoek: het belang van kwalitatieve benadering bij onderzoek in de sociale gezondheidzorg. Tijochr Soc Gezondheidsz 1995;5:315-321 


\section{CURRICULUM VITAE}

Mieke Oosterwijk werd op 26 mei 1956 geboren te Zwolle. Daar deed zij in 1974 eindexamen Gymnasium B aan het Thomas à Kempis Lyceum. Na enige jaren werkzaam te zijn geweest als radiodiagnostisch laborant in het Zuiderziekenhuis te Rotterdam (diploma 1978) en daarna als radiotherapeutisch laborant in de Daniel den Hoedkliniek, eveneens te Rotterdam (diploma 1980), begon zij in 1981 met de studie psychologie aan de Universiteit van Utrecht. Naast vakken op het gebied van de klinische en gezondheidspsychologie volgde zij verschillende modules in de arbeidsen organisatiepsychologie. In maart 1987 slaagde zij cum laude af met het doctoraal examen klinische psychologie met als nevenrichting persoonlijkheidsleer. Tijdens de doctoraalstudie was zij werkzaam als docent psychologie aan de opleiding tot radiotherapeutisch laborant van de Daniël den Hoedkliniek.

Kort voor het afronden van haar studie trad zij als wetenschappelijk medewerker in dienst bij de Afdeling Medische Psychologie van de Faculteit Geneeskunde in Utrecht. Daar werkte zij mee aan het promotieonderzoek van Herman ten Kroode, dat uitmondde in diens dissertatie 'Het verhaal van kankerpatiënten: oorzaakstoekenning en betekenisverlening'. Ook gaf zij er onderwijs aan studenten geneeskunde. Daarnaast was zij vanaf 1983 bij de Afdeling Radiotherapie van het Academisch medisch Centum Utrecht, betrokken bij de begeleiding van patiënten en hun naasten. In 1990 verwierf zij, samen met Herman ten Kroode een subsidie van NWO voor het onderzoek naar cognitieve strategieën van borstkankerpatiènten. Uiteindelijk heeft dit tot deze dissertatie geleid. Naast deze werkzaamheden voor de Afdeling Medische Psychologie werkte zij als freelancer werkzaamheden voor het bureau 'Markant' op het gebied van trainingen aan diverse beroepsgroepen en volgde een opleiding imaginatietherapie bij drs. Jan Taal.

In 1993 trad zij in dienst bij de Afdeling Medische Psychologie van de Vrije Universiteit in Amsterdam (VU). Haar werkzaamheden bestonden uit een combinatie van onderzoek, onderwijs en patiëntenzorg. Dat laatste ten behoeve van patiènten van het VU-ziekenhuis, vooral die van de verschillende oncologische afdelingen en de Afdeling Klinische Genetica. Daar deed zij onder meer onderzoek naar de psychosociale gevolgen bij jonge mannen en hun partners na behandeling voor een testiscarcinoom en startte en coachte zij een intervisiegroep voor oncologieverpleegkundigen. In die periode was zij actief lid van de Nederlandse Vereniging van Psychosociale Oncologie.

Vanaf 1995 is zij werkzaam in het Revalidatie Centum Beatrixoord te Haren (Gr), dat sinds 1 januari 2000 deel uitmaakt van het Academisch Ziekhuis Groningen onder de naam Centrum voor Revalidatie AZG. Aanvankelijk was zij psycholoog in het hartrevalidatie-team (HR) en op de tuberculose-afdeling en vanaf 1996 psycholoog en 
lid van de teamleiding HR. Samen met dr. Johan Brügemann, cardioloog en eveneens lid van de teamleiding HR, publiceerde zij over hartrevalidatie. Tevens is zij lid van enkele landelijke werkgroepen op dit terrein. Sinds 1 juni 2003 maakt zij deel uit van het Bestuur van het Centum voor Revalidatie als manager patiëntenzorg chronisch zieken. Hieronder vallen de teams voor de revalidatie van hart-, kanker-, long-, reumaen diabetespatiënten. 



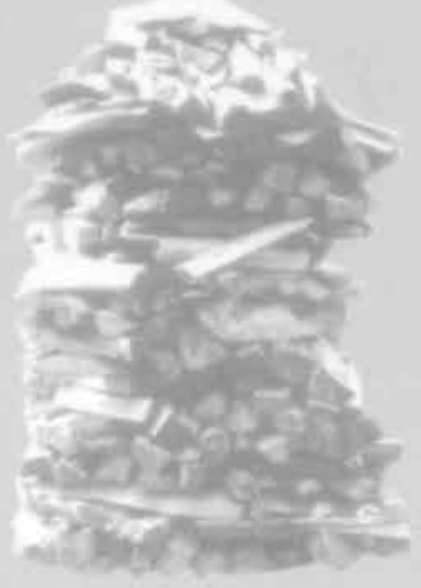

